DANIELE MARIA PILLA JUNQUEIRA CAFANGE

ESTUDO DE MÉTODOS E MEDIDAS AUXILIARES PARA O CONTROLE DA RESISTÊNCIA À CARBONATAÇÃO DE CONCRETOS ESTRUTURAIS DE CIMENTO PORTLAND 
DANIELE MARIA PILLA JUNQUEIRA CAFANGE

\section{ESTUDO DE MÉTODOS E MEDIDAS AUXILIARES PARA O CONTROLE DA RESISTÊNCIA À CARBONATAÇÃO DE CONCRETOS ESTRUTURAIS DE CIMENTO PORTLAND}

Dissertação apresentada à Escola Politécnica da Universidade de São Paulo para obtenção do Título de Mestre em Engenharia Civil

Área de Concentração:

Engenharia de Construção Civil e Urbana

Orientadora: Prof. Drª . Silvia Maria de Souza Selmo 
Este exemplar foi revisado e alterado em relação à versão original, sob responsabilidade única do autor e com a anuência de seu orientador.

São Paulo, 22 de fevereiro de 2011.

Assinatura do autor

Assinatura do orientador

FICHA CATALOGRÁFICA

Cafange, Daniele Maria Pilla Junqueira

Estudo de propriedades auxiliares no controle tecnológico dos concretos de cimento Portland com vistas à resistência à carbonatação / D.M.P.J. Cafange. -- ed.rev. -- São Paulo, 2011. $375 \mathrm{p}$.

Dissertação (Mestrado) - Escola Politécnica da Universidade de São Paulo. Departamento de Engenharia de Construção Civil.

1.Concreto armado (Durabilidade) 2.Carbonatação

3.Concreto fresco (Teor de ar) 4.Controle tecnológico

5.Análise de Imagem I.Universidade de São Paulo. Escola Politécnica. Departamento de Engenharia de Construção Civil II.t. 
"A confiança em si mesmo é o primeiro degrau para subir pela escada do sucesso".

RALPH WALDO EMERSON, escritor (1803-1882). 


\section{AGRADECIMENTOS}

Os agradecimentos são muitos, afinal como não me afastei de minhas atividades profissionais, sempre conciliei o mestrado com meu trabalho, precisei do apoio direto e indireto de muitas pessoas...

À Escola Politécnica da Universidade de São Paulo através do Departamento de Engenharia Civil, pela oportunidade e infra-estrutura para obtenção do título de Mestre em Engenharia Civil.

A Deus, por toda força, serenidade e fé, pois neste caminho percorrido, muitos foram os obstáculos, problemas e dificuldades superadas para continuar e jamais desistir.

À Prof. Dra ${ }^{a}$ Silvia Maria de Souza Selmo, pela ajuda, apoio, amizade, orientação, dedicação, seriedade, ensinamentos de vida e por acreditar tanto neste trabalho. Meu muito obrigado acima de tudo pela compreensão com minhas disponibilidades de horários com reuniões à noite, aos sábados e domingos na USP, no Mc'Donalds, no cafezinho da Praça Panamericana, afinal foram tantas as vezes que nos reunimos.

Aos professores Paulo Helene e Elton Bauer, pela participação no exame de qualificação e contribuições importantes para o desenvolvimento desta dissertação.

Aos professores Selmo Kupperman, Antônio Figueiredo, Kai Uemoto, Rafael Pileggi, pelos conhecimentos adquiridos no curso de pós-graduação.

Aos funcionários e colaboradores dos laboratórios da USP, pela colaboração em algumas etapas dos ensaios desta pesquisa, em especial ao Mário e ao Adilson.

A todos os amigos da Engemix pelo apoio, troca de idéias, auxílio na parte experimental e que tantas vezes me ajudaram e compreenderam meu excesso de tarefas. Meus agradecimentos para Josué Ardnt e Eliron Maia Souto Jr. Aos amigos do laboratório da central do Jaguaré, que ajudaram com os preparativos e execução dos ensaios, Adelino Boaventura, Daniela Carvalho, Carlos Henrique e Heriberto. Meus agradecimentos para Carlos E. Xavier Regattieri por toda colaboração e apoio para o desenvolvimento e conclusão desta dissertação.

Aos amigos da Holcim, pela ajuda no tempo em que trabalhei nesta empresa, ao José Vanderlei de Abreu e à Renata D'Agostino.

Aos amigos da Lenc Laboratório de Engenharia, pelo apoio no início do mestrado, meus agradecimentos ao Álvaro Sérgio Barbosa Jr e à amiga Pâmela Soares. 
Ao amigo Antônio Nereu Cavalcanti Filho, por toda amizade desde o início do curso, pelo apoio nas horas difíceis e de desânimo, pelo auxílio nos ensaios realizados e por sempre estar pronto a ajudar.

Aos meus irmãos queridos, Júlio Cézar e Vanessa, meus agradecimentos pela amizade, às conversas pelo msn, sobre o mestrado, sobre o futuro, sobre a distância e a ausência pelo principal motivo de sempre - "estudar".

Ao meu marido Alexandre Cafange pelo apoio incondicional em todas as minhas idéias e sonhos, por compartilhar e incentivar a concretização destes. A ele que suportou muitas ausências de dias e noites, feriados, férias e finais de semana, para que eu pudesse desenvolver este trabalho. Esteve sempre ao meu lado motivando e compreendendo a falta de tempo.

Ao Carlos Pilla e à Maria, meus queridos pais, pelo carinho, apoio, compreensão, e que com toda simplicidade de vida, me ensinaram muitos conhecimentos importantes em que o estudo é a única coisa "sua" e ninguém pode tirar... São exemplos de luta, perseverança, trabalho, honestidade, dignidade, amor e humildade.

Aos amigos Dyetry Miranda e Marcelo Matar pela ajuda com os ensaios de laboratório. Muito obrigada ao Dyetry pelo empenho nos ensaios, nas análises de imagens e análises estatísticas.

Ao Prof. Dr. Henrique Kahn por nos ajudar com os ensinamentos em análises de imagens.

Ao colaborador Nalso, pela ajuda com as pesagens dos corpos-de-prova e toda parte operacional. Sozinha seria muito difícil... 
CAFANGE, D.M.P.J. Estudo de métodos e medidas auxiliares para o controle da resistência à carbonatação de concretos estruturais de cimento Portland. 2011. Dissertação (Mestrado em Engenharia Civil) - Programa de Pós-Graduação em Engenharia Civil da Universidade de São Paulo, São Paulo, 2011.

\section{RESUMO}

A durabilidade das estruturas de concreto armado deve ser alcançada, entre outros fatores, pela adequação do concreto frente ao meio ambiente para proteger as armaduras pelas características da camada de cobrimento. Assim, concretos precisam ser corretamente especificados no projeto estrutural e ter a sua qualidade controlada durante a produção e aplicação. Pela ABNT NBR 6118 (2007), os concretos passaram a ser especificados por classes de $f_{c k}$ associadas a outras variáveis de dosagem e produção, como relação água/cimento máxima e consumo mínimo de cimento por metro cúbico. Mas, continuam invariavelmente controlados apenas por ensaios de abatimento no estado fresco e de resistência à compressão $\left(f_{c j}\right)$, para desforma ou verificação do $f_{c k}$ (28 dias, nas obras comuns). Logo, a propriedade em uso para controlar indiretamente a resistência à carbonatação do concreto deveria ser o $\mathrm{f}_{\mathrm{cj}}$, já que os concretos se diferenciam, de fato, é pelos materiais constituintes, método de dosagem e pela variabilidade de produção. Mas, na prática o controle da resistência à carbonatação dos concretos vem ocorrendo apenas pela especificação e aceitação do $f_{c k}$ e uma das razões para isto pode ser a falta de métodos mais avançados para a predição de propriedades físicas mais complexas, como é a resistência à carbonatação. Assim, este trabalho visou contribuir para a evolução do controle tecnológico dessa propriedade em concretos estruturais, e o programa experimental teve por objetivos principais: testar o teor de ar no concreto fresco por quatro diferentes métodos, como variável auxiliar de controle; b) comparar três métodos acelerados de carbonatação; c) comparar área relativa e espessura de carbonatação, em seção diametral de corpos-de-prova cilíndricos de $10 \mathrm{~cm} \times 20 \mathrm{~cm}$, através de dois programas de análise de imagem e medida linear tradicional. Como concreto de estudo foi escolhido um da classe 30 , pré-misturado e bombeável, de abatimento de $10 \pm 2 \mathrm{~cm}$, de relação água/cimento 0,60 e consumo de cimento igual a $300 \mathrm{~kg} / \mathrm{m}^{3}$. Em uma dada central dosadora, foram então amostrados, aleatoriamente, as misturas de seis caminhões betoneira de $8 \mathrm{~m}^{3}$, produzidas em uma só data, de um dado lote de produção do citado concreto e para fornecimento a uma obra muito próxima. Cada mistura foi caracterizada no estado fresco, por oito diferentes propriedades e seguiu-se à moldagem de cilindros de $10 \mathrm{~cm} \times 20 \mathrm{~cm}$. A maior parte dos corpos-de-prova foi submetida à cura acelerada por imersão em tanque de água em temperatura amena $\left(35 \pm 5^{\circ} \mathrm{C}\right)$, entre 1 e 3 dias, por adaptação do método $\mathrm{A}$ da ASTM C684, seguida de um resfriamento natural e cura a temperatura ambiente, no mesmo tanque, entre 3 e 7 dias. As propriedades no estado endurecido foram medidas a 8, 35, 63, 91 e 203 dias. As propriedades no estado fresco que melhor se relacionaram às medidas de carbonatação das seis misturas foram o teor de ar por método pressométrico e a medida de compactabilidade do concreto adensado, método adaptado da BS EN 12350-4 (2009). O teor de ar das misturas no estado fresco resultou com valor médio de $1,7 \%$ e mostrou correlações fortes e inversas com a resistência à compressão, resistência à tração por compressão diametral e com as medidas de profundidade de carbonatação. É recomendável prosseguir estudos sobre esse concreto, para elucidar as causas e os limites da correlação inversa, pois tanto podem ter resultado de efeitos do ar na interface pasta/agregados, quanto de sedimentação do concreto no estado plástico. A 203 dias, a espessura média de carbonatação pelos três métodos de envelhecimento acelerado resultou entre 4 e $5 \mathrm{~mm}$, com coeficiente de variação entre $13 \%$ e $21 \%$ para oito dos nove grupos de doze corpos-de-prova (dois por mistura), no caso diferenciados pelo método de envelhecimento ou de medida da carbonatação. Por análise de variância para três fatores nessa idade, foram observadas equivalência entre as medidas de carbonatação, por dois dos métodos acelerados - um de secagem contínua a $40^{\circ} \mathrm{C}$ em estufa ventilada e outro de um dia de exposição a $\mathrm{CO}_{2}\left(5 \%\right.$ e U.R. $75 \%$ ) alternado por 27 dias de secagem a $40^{\circ} \mathrm{C}$ em estufa ventilada, mas ambos não mostraram semelhança com o terceiro método, que foi de um dia de imersão em água alternada por 27 dias de secagem a $40^{\circ} \mathrm{C}$ em estufa ventilada. As medidas de carbonatação em corpos-de-prova submetidos a este terceiro método, envolvendo apenas imersão em água e secagem, resultaram com ótimo contraste com o indicador de fenolftaleína e foram as que mostraram maiores probabilidades de igualdade de médias, independente do método de medida. Espera-se que o prosseguimento de pesquisas com esses métodos possa trazer avanços no controle da resistência carbonatação de concretos, por valores médios ou característicos, e um melhor domínio tecnológico das variáveis de verificação da vida útil de projeto de armaduras e das estruturas em geral.

Palavras-chave: concreto armado; teor de ar no estado fresco; carbonatação; análise de imagem; durabilidade; controle tecnológico. 
CAFANGE, D.M.P.J. Study of auxiliary methods and measurements to control carbonation resistance of Portland cement structural concrete. 2011. Master's thesis (MSc in Civil Engineering) - Graduate Program in Civil Engineering of Universidade de São Paulo, São Paulo, 2011.

\section{ABSTRACT}

Durability of reinforced concrete structures should be obtained, among other factors, by adapting the concrete to the environment to protect the steel reinforcements depending on the characteristics of the cover layer. Therefore, concrete must be properly specified in the design structural and have its quality controlled during production and placing. After ABNT NBR 6118 (2007), concretes began to be specified according to $f_{c k}$ classes in association with other mixture proportion and production variables, such as maximum water/cement ratio and minimum cement content per cubic meter. However, concretes are invariably controlled only through slump tests of fresh concrete and compressive strength tests $\left(f_{\mathrm{cj}}\right)$ for stripping or assessment of $f_{c k}$ (28 days, in common construction sites). As a result, the property in use to indirectly control concrete carbonation resistance should be $f_{c j}$, since what actually differentiates the concretes are the constituent materials, the mix design and production variability. However, in practice, control of concrete carbonation resistance usually occurs through specification and acceptance of $f_{c k}$ and one of the reasons for that may lie in the lack of more advanced methods to predict more complex physical properties, as in the case of carbonation resistance. Therefore, this study aimed to contribute to the evolution of technological control of this property in structural concrete and the experimental program had as its main goals: a) to test air content of fresh concrete by four different methods as auxiliary control variable; b) to compare three methods of accelerated carbonation; c) to compare relative area and carbonation thickness, in the diametral section of cylindrical specimens measuring $10 \mathrm{~cm} \times 20 \mathrm{~cm}$, through two image analysis softwares and traditional linear measurement. The concrete chosen for the purposes of this study was a class 30 , ready mixed and pumped concrete, slump test of $10 \pm 2 \mathrm{~cm}$, water/cement ratio of 0.60 and cement content of $300 \mathrm{~kg} / \mathrm{m}^{3}$. In a given batch plant, random samples were taken from the mixtures of six $8-\mathrm{m}^{3}$ truck mixers that had been produced on the same date, from a given production batch of that concrete and for the supply of a nearby construction site. Each mixture was characterized in the fresh state, according to eight different properties, and then $10 \mathrm{~cm} \times 20 \mathrm{~cm}$ cylinders were molded. Most specimens were submitted to accelerated curing by immersion in water tank at mild temperature $\left(35 \pm 5^{\circ} \mathrm{C}\right)$, between 1 and 3 days, in an adaptation of method A of ASTM C684, followed by natural cooling and curing at room temperature, in the same tank, between 3 and 7 days. The properties in the hardened state were measured at $8,35,63,91$ and 203 days. The properties in the fresh state that best related to the carbonation measurements of the six samples were air content by the pressure method and compactability of compacted concrete, in a method adapted from BS EN 12350-4 (2009). Air content of the mixtures in the fresh state resulted in mean value of $1.7 \%$ and showed strong and inverse correlations with compressive strength, splitting tensile strength and with the measurements of carbonation depth. Further studies about this concrete are recommended to clarify the causes and limits of the inverse correlation, since they may result from effects of the air on the transition zone between paste and aggregates, or from concrete settlement in the fresh state. At 203 days, mean carbonation thickness in the three accelerated ageing methods resulted in between 4 and $5 \mathrm{~mm}$, with coefficient of variation between $13 \%$ and $21 \%$ for eight out of nine groups of twelve specimens (two per mixture), which were differentiated according to the ageing method or the carbonation measurement. After an analysis of variance for three factors at this age, equivalences were observed in the carbonation measurements in two of the accelerated methods - one of continuous drying at $40^{\circ} \mathrm{C}$ in ventilated oven and the other of one-day exposure to $\mathrm{CO}_{2}(5 \%$ and R.H. $75 \%)$ alternated with 27 days of drying at $40^{\circ} \mathrm{C}$ in ventilated oven, but neither showed similarity with the third method, which consisted in one-day water immersion alternated with 27 days of drying at $40^{\circ} \mathrm{C}$ in ventilated oven. Carbonation measurements in specimens submitted to the third method, involving only water immersion and drying, resulted in optimum contrast with the phenolphthalein indicator and showed higher probabilities of equality of means, regardless of the measurement method. It is expected that further research about these methods can bring advances in the control of concrete carbonation resistance, by mean or characteristic values, and better technological knowledge of the variables in verifying the design service life of steel reinforcement and structures in general.

Keywords: Reinforced concrete; fresh air content; carbonation; image analysis; durability; technological control. 
SUMÁRIO

AGRADECIMENTOS___ II

RESUMO _IV

ABSTRACT_ V V

SUMÁRIO_ VI

LISTA DE FIGURAS __ XI

LISTA DE TABELAS___XVII

1 INTRODUÇÃO _ 24

1.1 JUSTIFICATIVAS GERAIS _ 26

1.1.1 No âmbito da qualidade das estruturas de concreto armado ___ 26

1.1.2 No âmbito da predição de vida útil das armaduras de aço carbono___ 27

1.2 OBJETIVOS_ 30

1.3 PESQUISAS SOBRE O TEMA ___ 31

1.4 ESTRUTURA DA DISSERTAÇÃO 37

2 A CARBONATAÇÃO DO CONCRETO E A VIDA ÚTIL DE PROJETO DAS ARMADURAS_ 38

2.1 A PREVISÃO DA VIDA ÚTIL DE ARMADURAS POR TAXA DE CARBONATAÇÃO DO CONCRETO

2.1.1 A durabilidade e a deterioração de estruturas __ 39

2.1.2 A corrosão de armaduras __ 43

2.1.3 Conceitos básicos sobre a carbonatação do concreto de cimento Portland ___ 46

2.1.4 Modelos de previsão da carbonatação __ 51

A) O modelo clássico e outros em pesquisa ___ 51

B) Modelo do CEB (1996)

C) Modelo de Izquierdo (2003)__ 55

D) Modelo de Andrade et al. (2006)__ 56

E) Modelo de Helene (1997) __ 57

Outros exemplos em ábacos 60

2.2 VARIÁVEIS AMBIENTAIS INFLUENTES na CARBONATAÇÃO __ 62

2.2.1 Diferenciação entre clima regional, local e microclima___ 62

2.2.2 As variáveis ambientais nas normas de projeto brasileira e européia __ 65

2.2.3 Critérios simplificados de projeto das estruturas a partir das classes de agressividade ambiental 69

2.3 VARIÁVEIS INTRÍNSECAS AO CONCRETO INFLUENTES NA CARBONATAÇÃO

2.3.1 Porosidade 74

A) Importância _ 74

B) Classificação dos poros ___ 79

C) Qualificação da porosidade por critérios de índices de vazios ou de absorção de água

2.3.2 Efeitos da natureza e dosagem dos materiais constituintes____ 82

A) Cimento Portland ___ 83

B) Água

C) Aditivos

D) Agregados _ 86

E) Adições 88

F) Método de dosagem e proporção de uso dos materiais _ 90

2.4 VARIÁVEIS DA CONCRETAGEM INFLUENTES NA CARBONATAÇÃO_____ 92

A) Adensamento __ 92

B) Cura nas primeiras idades__ 94 
B.1) Cura úmida normal 95

B.2) Cura acelerada 97

2.5 MÉTOdOS DE CONDICIONAMENTO E MEDIDAS DE CARBONATAÇÃO __ 99

A) Estado da arte quanto aos métodos empregados___ 99

B) Determinação da espessura de carbonatação __ 103

C) Concentração de $\mathrm{CO}_{2}$

D) Umidade relativa no ensaio ___ 111

E) Precondicionamento dos corpos-de-prova __ 115

F) Temperatura__ 116

2.6 CONCLUSÕES SOBRE O ESTADO DA ARTE ___ 117

3 PROGRAMA EXPERIMENTAL

3.1 OBJETIVOS 120

3.2 METODOLOGIA PARA A DEFINIÇÃO DO LOTE DE CONCRETO

3.2.1 Definições da classe de resistência, cidade e central dosadora do lote __ 121

3.2.2 Seleção e visita preliminar à obra __ 122

3.2.3 Plano básico de amostragem do lote em estudo __ 123

3.2.4 Caracterização dos materiais constituintes e dosagem do concreto __ 125

3.3 AMOSTRAGEM E CARACTERIZAÇÃO DO CONCRETO

3.3.1 Ensaios no concreto fresco ___ 126

3.3.2 Moldagem de corpos-de-prova e ensaios no concreto endurecido ___ 131

3.3.3 Procedimentos de cura dos corpos-de-prova __ 135

3.3.4 Condições de envelhecimento acelerado dos corpos-de-prova___ 137

3.3.5 Ensaios no concreto endurecido ___ 138

A) Ensaios de compressão simples, tração por compressão diametral, módulo de elasticidade e ultrassom _ 139

A.1) Ensaios de ultrassom 140

B) Ensaios indicadores de porosidade__ 141

C) Ensaios acelerados quanto à profundidade de carbonatação __ 142

C.1) Ensaios acelerados de resistência à carbonatação por exposição em câmara de $\mathrm{CO}_{2}$ alternada com secagem (AE1)___ 142

C.2) Ensaios acelerados de resistência à carbonatação por ciclagem de 24h de imersão em tanque de água alternada com secagem (AE2). 143

C.3) Ensaios acelerados de resistência à carbonatação por secagem contínua (AE3). 144

D) Métodos de medidas de profundidade de carbonatação __ 145

4 APRESENTAÇÃO E DISCUSSÃO DOS RESULTADOS__ 149

4.1 RESULTADOS E ANÁLISE COMPARATIVA ENTRE OS CONCRETOS AMOSTRADOS _ 149

4.1.1 Propriedades no estado fresco ___ 149

A) Informações e composição nominal do concreto fornecido __ 149

B) Abatimento do tronco de cone (slump) _ـ 150

C) Densidade de massa aparente do concreto fresco___ 152

D) Teor de ar 1154

D.1) Teor de ar pelo método pressométrico __ 154

D.2) Teor de ar pelo método gravimétrico _ 155

E) Compactabilidade de concreto fresco _ 157

E.1) Compactabilidade do concreto adensado _ـ 157

E.2) Compactabilidade do concreto não-adensado___ 160

F) Umidade do concreto fresco ___ 163

G) Teor de finos total $<75 \mu \mathrm{m}$ no concreto fresco___ 165

4.1.2 Propriedades do concreto endurecido __ 166

A) Resistência à compressão ___ 166

A.1) Resistência à compressão a 1 dia por cura acelerada de 1 dia $\left(\mathrm{fc}_{1-\text { acel } 0 / 1}\right) \_166$

A.2) Resistência à compressão a 2 dias por cura acelerada de 1 a 2 dias ( $f_{c 2-\text { acel.1/2) }}$ - 167

A.3) Resistência à compressão a 3 dias por cura acelerada de 1 a 3 dias $\left(f_{c 3-a c e l .1 / 3}\right)$ _ 168

A.4) Resistência à compressão a 7 dias por cura acelerada de 1 a 3 dias $\left(f_{c 7 a c e l .}\right)$ __ 169 
A.5) Resistência à compressão por cura normal de 1 a 28 dias $\left(f_{c 28 n}\right)$ 170

A.6) Análise conjunta das resistências à compressão, nas idades com cura acelerada e normal

B) Análise da evolução da resistência relativa à cura normal de 28 dias ___ 174

C) Cálculo da resistência característica estimada à compressão ___ 175

D) Controle de massa dos corpos-de-prova em condições de exposição por envelhecimento acelerado

D.1) Grau de saturação - cura acelerada $24 / 72$ horas seguida por imersão em água até 7 dias e ciclos de exposição por 24 horas em câmara de carbonatação e 27 dias de secagem em estufa a $(40 \pm 1 \stackrel{\circ}{ } \mathrm{C})$. (AE1)

D.2) Grau de saturação - cura acelerada 24/72 horas seguida por imersão em água até 7 dias e ciclos de 24 horas de imersão em água e 27 dias de secagem em estufa a $\left(40 \pm 1^{\circ} \mathrm{C}\right)(\mathrm{AE} 2)$.

D.3) Grau de saturação - cura acelerada de $24 / 72$ horas seguida por imersão em água até 7 dias e ciclos de secagem contínua em estufa ventilada a $\left(40 \pm 5^{\circ} \mathrm{C}\right)$ (AE3). ${ }_{184}$

E) Resistência à tração por envelhecimento acelerado 187

E.1) Cura acelerada 24/72 horas seguida por imersão em água até 7 dias e ciclos de 24 horas em câmara de carbonatação e 27 dias de secagem (AE1).

E.1a) Resistência à tração a 8 dias por cura acelerada de 1 a 3 dias $\left(\mathfrak{f}_{\mathrm{cttsp}} 8 \mathrm{acel.AE} 1\right)$ _ 187

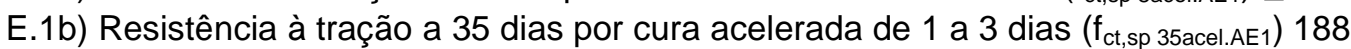

E.1c) Resistência à tração a 63 dias por cura acelerada de 1 a 3 dias $\left(f_{c t, s p} 63 a c e l . A E 1\right) 188$

E.1d) Resistência à tração a 91 dias por cura acelerada de 1 a 3 dias ( $f_{\text {ct,sp } 91 \text { acel.AE1 } 1)} 189$

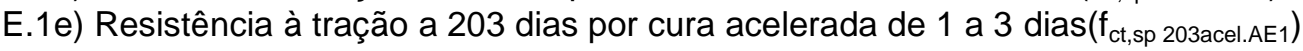

E.2) Cura acelerada 24/72 horas seguida por imersão em água até 7 dias e ciclos de 24 horas de imersão em tanque com água seguidos por 27 dias de secagem (AE2). 191

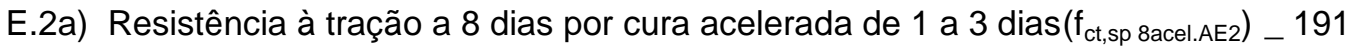

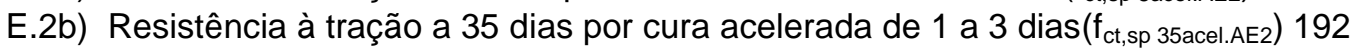

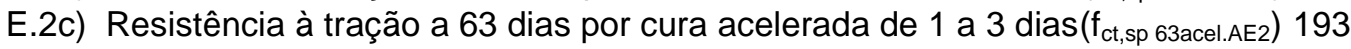

E.2d) Resistência à tração a 91 dias por cura acelerada de 1 a 3 dias $\left(f_{\text {ct,sp } 91 \text { acel.AE2 } 2}\right) 194$

E.2e) Resistência à tração a 203 dias por cura acelerada de 1 a 3 dias $\quad\left(f_{c t, s p}\right.$ 203acel.AE2)

E.3) Cura acelerada 24/72 horas seguida por imersão em água até 7 dias e ciclos de 28 dias de secagem contínua (AE3).

E.3a) Resistência à tração a 91 dias por cura acelerada de 1 a 3 dias $\left(f_{c t, s p} 91\right.$ acel.AE3 $) 196$

E.3b) Resistência à tração a 203 dias por cura acelerada de 1 a 3 dias $\quad\left(f_{c t, s p}\right.$

203acel.AE3)

E.4) Análise conjunta da resistência à tração para todas as idades e condições de envelhecimento acelerado 197

F) Absorção de água

F.1) Cura acelerada 24/72 horas seguida por imersão em água até 7 dias e ciclos de 24 horas em câmara de carbonatação e 27 dias de secagem em estufa (AE1).

F.1a) Absorção de água a 8 dias

F.1b) Absorção de água a 35 dias

203

F.1c) Absorção de água a 63 dias

204

F.1d) Absorção de água a 91 dias

204

F.1e) Absorção de água a 203 dias

205

F.2) Cura acelerada de 24/72 horas seguida por imersão em água até 7 dias e ciclos de 24 horas de imersão em tanque com água seguida por 27 dias de secagem em estufa (AE2).

F.2a) Absorção de água a 8 dias

F.2b) Absorção de água a 35 dias

F.2c) Absorção de água a 63 dias

F.2d) Absorção de água a 91 dias

210

F.2e) Absorção de água a 203 dias 211

F.3) Cura acelerada de 24/72 horas seguida por imersão em água até 7 dias e ciclos de 28 dias de secagem contínua (AE3). 
F.3a) Absorção de água a 91 dias

F.3b) Absorção de água a 203 dias 213

F.4) Análise conjunta da absorção de água, para todas as idades e condições de envelhecimento acelerado

G) Índice de vazios

G.1) Cura acelerada 24/72 horas seguida por imersão em água até 7 dias e ciclos de 24 horas em câmara de carbonatação e 27 dias de secagem em estufa (AE1).__ 217

G.1a) Índice de vazios a 8 dias

G.1b) Índice de vazios a 35 dias

G.1c) Índice de vazios a 63 dias

G.1d) Índice de vazios a 91 dias 218

G.1e) Índice de vazios a 203 dias

G.2) Cura acelerada 24/72 horas seguida por imersão em água até 7 dias e ciclos 24 horas de imersão em tanque com água seguida por 27 dias de secagem em estufa (AE2).

G.2a) Índice de vazios a 8 dias

G.2b) Índice de vazios a 35 dias 222

G.2c) Índice de vazios a 63 dias 222

G.2d) Índice de vazios a 91 dias 223

G.2e) Índice de vazios a 203 dias 224

G.3) Cura acelerada 24/72 horas seguida por imersão em água até 7 dias e ciclos de 28 dias de secagem contínua (AE3).

G.3a) Índice de vazios a 91 dias 226

G.3b) Índice de vazios a 203 dias 227

G.4) Análise conjunta do índice de vazios em todas as idades e condições de envelhecimento acelerado

H) Absorção de água por capilaridade___ 231

I) Profundidade de carbonatação ___ 232

I.1) Cura acelerada de $24 / 72$ horas seguida por imersão em água até 7 dias e ciclos de 24 horas em câmara de carbonatação e 27 dias de secagem em estufa (AE1). _ 233

I.1A) Profundidade de carbonatação a 8 e 35 dias__ 233

I.1b) Profundidade de carbonatação a 63 dias_ 233

I.1c) Profundidade de carbonatação a 91 dias 235

I.1d) Profundidade de carbonatação a 203 dias__ 237

1.2) Cura acelerada de $24 / 72$ horas seguida por imersão em água até 7 dias e ciclos de 24 horas de imersão em tanque com água e 27 dias de secagem (AE2). _ 240

I.2a) Profundidade de carbonatação a 63 dias __ 240

I.2b) Profundidade de carbonatação a 91 dias 242

I.2c) Profundidade de carbonatação a 203 dias __ 244

I.3) Cura acelerada de 24/72 horas seguida por imersão em água até 7 dias e ciclos de 28 dias de secagem contínua (AE3).

I.3a) Profundidade de carbonatação até 91 dias 247

I.3b) Profundidade de carbonatação a 203 dias 247

I.4) Análise conjunta da profundidade de carbonatação, para todas as idades e condições de envelhecimento acelerado __ 250

J) Comparação dos resultados de carbonatação com a predição pelo modelo de Helene (1997) 253

L) Módulo de elasticidade __ 255

M) Ultrassom 257

4.2 ANÁLISES ESTATÍSTICAS

4.2.1 Correlações entre as propriedades___ 260

A) Estudo da matriz de correlações das propriedades analisadas em relação às medidas de profundidade de carbonatação _ـ 260

A.1) Concreto Fresco _ 262

A.2) Concreto Endurecido - Resistência à compressão __ 263

A.3) Concreto Endurecido - Resistência à tração por compressão diametral ___ 266

A.4) Concreto Endurecido - Índice de vazios __ 269 
A.5) Concreto Endurecido - Absorção de água por capilaridade e total 270

A.6) Concreto Endurecido - Carbonatação

4.2.2 Teste de hipótese e normalidade quanto às propriedades__ 272

A) Concreto fresco _ 273

B) Análise conjunta das propriedades do concreto no estado endurecido __ 275

4.2.3 Análise de Variância (ANOVA) __ 281

A) Testes ANOVA das propriedades analisadas (Fator duplo) ___ 282

B) Testes ANOVA por comparações múltiplas (fator quádruplo) __ 283

B.1) Análise complementar pelo método de Tukey ___ 283

B.2) Análise de resultados por fator triplo ou quádruplo e método de Tukey ___ 285

5. CONSIDERAÇÕES E CONCLUSÕES FINAIS__ 290

5.1 QUANTO AO PROGRAMA EXPERIMENTAL _ 290

5.1.2 Sobre a cura acelerada em temperatura amena __ 291

5.1.2 Correlações entre propriedades do estado fresco e endurecido __ 292

5.1.3 Quanto aos métodos e medidas de carbonatação estudados e suas correlações com outras propriedades _ـ 297

5.2 SUGESTÕES PARA FUTURAS PESQUISAS _ 301

5.3 TRANSFERÊNCIAS AO MEIO TÉCNICO _ 303

6 REFERÊNCIAS BIBLIOGRÁFICAS_ 304

APÊNDICE A - Caracterização dos materiais coletados nas centrais dosadoras de concreto

APÊNDICE B - Resultados completos de ensaios __ 322

APÊNDICE C - Relatório fotográfico- ensaios de carbonatação e frente de secagem _ 344

APÊNDICE D - Tabelas de análises de fator duplo com repetição ___ 368

APÊNDICE E - Tutorial dos softwares utilizados para medidas de carbonatação ___ 371

APÊNDICE F - Matriz de correlações __ 374 


\section{LISTA DE FIGURAS}

Figura 1- Comparativo entre relação água/ cimento e teor de ar do concreto fresco. Dados de Regattieri (1998) interpretados por esta autora.

Figura 2- Comparativo entre relação água/cimento e teor de ar do concreto fresco. Dados de Cunha (2001), interpretados por esta autora.

Figura 3 - Comparativo entre relação água/cimento e teor de ar. Dados de Regattieri (1998) e Cunha (2001), interpretados por esta autora.

Figura 4 - Comparativo entre consumo de cimento e teor de ar do concreto fresco. Dados de Regattieri (1998), interpretados por esta autora.

Figura 5 - Comparativo de espessura carbonatada por tipo de cimento e por relação a/c. Dados de Cunha (2001), interpretados por esta autora.

Figura 6 - Durabilidade e desempenho do concreto (CEB 1989 adaptado por SILVA, 1995)..... 40

Figura 7 - Um modelo holístico da deterioração do concreto a partir dos efeitos ambientais mais freqüentes (MEHTA; MONTEIRO, 2008).

Figura 8 - Modelo de vida útil de Tuutti $^{4}$ (citado por ANDRADE, 1992)...... 43

Figura 9 - Célula simplificada de corrosão (ANDRADE, 2001).

Figura 10 - Corrosão numa fissura (FIGUEIREDO et al. 1994).

Figura 11 - Difusão de $\mathrm{CO}_{2}$ através do elemento de controle. SONG (2006) et al. adaptado por SIMAS (2007).. 47

Figura 12 - Processo de carbonatação (CEB apud isaia, 2005). 48

Figura 13 - Lei da conservação de massa e modelos constituintes da carbonatação (Ishida; Maekawa, 2000). . 50

Figura 14 - Profundidade de carbonatação em função do tempo, por previsão simplificada e endossada no modelo de vida útil das armaduras de Tuutti ${ }^{4}$ (SIMAS, 2007).

Figura 15 - Ábaco para obtenção da espessura de cobrimento com relação à carbonatação em função do tipo de concreto (C10 a C50) e da vida útil de projeto desejada (1 a 100 anos) (HELENE, 1997).

Figura 16 - Relação entre o tipo de concreto e $\mathrm{k}_{\mathrm{cO} 2}$ em função do tipo de concreto, segundo interpretação de Carmona (2005), nos ábacos de helene (1997).

Figura 17 - Profundidade de carbonatação em 50 anos, em função do tipo de concreto segundo os modelos de Tuutti, papadakis, ceb, helene e thomas.

Figura 18 - Ábaco para estimar a profundidade de carbonatação (MEYER, 1987 apud SILVA, 1995)...............61

Figura 19 - Efeito das condições de exposição na carbonatação (Modelo de MEYER, 1969).

Figura 20 - Representação gráfica dos mecanismos de penetração em função da porosidade (HELENE, 1993).

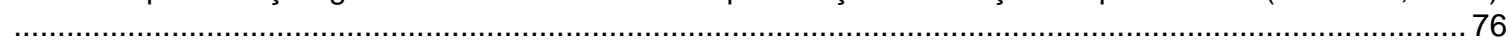

Figura 21 - Fatores que interferem na porosidade e no transporte de massa (SATO, 1998)..........................77

Figura 22- Distribuição do tamanho dos poros em pastas de cimento hidratado. (MEHTA; MONTEIRO, 1994). . 78

Figura 23 - Influência da relação água/cimento e do grau de hidratação sobre a resistência e a permeabilidade (mehta; monteiro, 1994).

Figura 24 - Distribuição do tamanho de poros na pasta de cimento endurecida (CASCUDO, 1997 adaptado por POLITO, 2006).

Figura 25 - Efeito do ar incorporado na durabilidade de concretos, por ação de gelo e degelo. (MINDESS; YOUNG, 1981 adaptado por MARTIN, 2005). 
Figura 26 - Representação esquemática de exsudação no concreto fresco. (MEHTA; MONTEIRO, 1994, 2008).

Figura 27 - Influência do tipo de cimento e sua quantidade por $\mathrm{m}^{3}$ de concreto sobre a profundidade de carbonatação. HO; LEWIS, 1987 (adaptado por POLITO, 2006).

Figura 28 - Profundidade de carbonatação acelerada a 10\% aos 91 dias ( $t=4$ semanas de exposição), para os concretos das classes 20,30, 35 e 40 para os três diferentes tipos de materiais cimentícios (COSTA JUNIOR et al. 2005).

Figura 29 - Profundidade de carbonatação de concreto com diferentes porosidades (GONEN; YAZICIOGLU, 2007).

Figura 30 - Influência da cura úmida inicial e sequência de exposição do concreto em ambiente seco, na profundidade de carbonatação em câmara de carbonatação acelerada (umidade relativa de $65 \%$, teor de $\mathrm{CO}_{2}$ de $5 \%$ e temperatura de $23^{\circ} \mathrm{C} \pm 2^{\circ} \mathrm{C}$ ), durante quatro semanas (Battagin et al., 2002).

Figura 31- Esquema do estado da arte das pesquisas de carbonatação acelerada no Brasil (PAULETTI et al. 2007).

Figura 32 - Câmara de carbonatação para ensaio acelerado com aumento da concentração de $\mathrm{CO}_{2}$ (JERGA, 2004)......

Figura 33 - Medidas de profundidade de carbonatação (CHANG; CHEN, 2006). ...................................... 106

Figura 34 - Medida da profundidade de carbonatação (GONEN; YAZICIOGLU, 2007). 106

FIGURA 35 - As imagens de a) a b) ilustram o método de análise de imagem adotado por Pauletti (2004). As medidas da maior e menor profundidade de carbonatação para cada uma das laterais estão representadas por linhas pretas pontilhadas.

Figura 36 - Influência do teor de $\mathrm{CO}_{2}$ no coeficiente de carbonatação (UEMOTO; TAKADA, 1993).

Figura 37 - Profundidade de carbonatação em relação à umidade relativa e o teor de $\mathrm{CO}_{2}($ Ceukelaire e Nieuwenburg ${ }^{36}, 1993$ citados por Possan, 2004).

Figura 38 - Profundidade carbonatada em relação à umidade relativa, para diferentes classes de concreto (ROY et al., 1999).

Figura 39 - Porosidade versus coeficiente de carbonatação para atmosfera normal e acelerada, em função da umidade relativa de ensaio (GONEN; YAZICIOGLU, 2007).

Figura 40 - Fluxograma de amostragem do lote de concreto analisado.

Figura 41- Resumo das características dos materiais utilizados nos concretos amostrados para o lote analisado.

Figura 42- Fluxograma de amostragem e dos ensaios no concreto fresco de cada caminhão-betoneira integrante da amostra constituída para representar o lote analisado.

Figura 43- Preparo para recebimento do concreto, descarga do caminhão-betoneira e homogeneização para realização dos ensaios e suas repetições.................................................................................... 127

Figura 44- Aparelho medidor de ar no concreto, por método pressométrico ............................................ 129

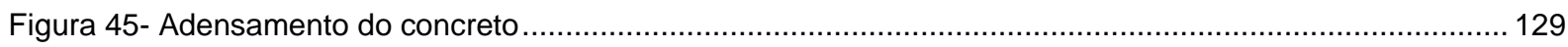

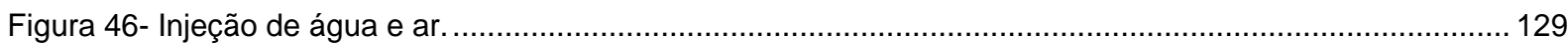

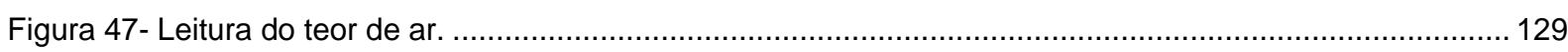

Figura 48 - Ensaios do concreto no estado fresco - a) abatimento, b) densidade de massa específica e teor de ar pressométrico, c e d) compactabilidade, e) e f) ensaio de umidade e de finos total $<75 \mu \mathrm{m}$ do concreto realizado no laboratório. 
FIGURA 49 - Moldagem dos corpos-de-prova cilíndricos $10 \times 20 \mathrm{~cm}$, segundo a ABNT NBR 5738 (2003)

Figura 50 - Fluxograma de resumo dos ensaios no concreto endurecido

Figura 51 - Tanque de cura térmica no laboratório da EPUSP, com aquecimento de água por resistência elétrica e termostato a $(35 \pm 3)^{\circ} \mathrm{C}$, em analogia ao método A da ASTM C 684:1999.

Figura 52 - (a) Câmara de carbonatação acelerada e (b) estufas ventiladas para condição de secagem alternada (AE1 e AE2) e contínua (AE3).

Figura 98 - Modelo do gabarito de madeira utilizado no posicionamento dos sensores do equipamento em 5 pontos de cada corpo-de-prova cilíndrico, mantida uma geratriz de referência para a ordenação dos pontos e topos.

Figura 53 - Progressão dos ciclos de envelhecimento acelerado tipo AE1 e respectiva idade de análise dos corpos-de-prova.

Figura 54 - Prograssão dos ciclos de envelhecimento acelerado tipo AE2 e respectiva idade de análise dos corpos-de-prova.

Figura 55 - Preparo do corpo-de-prova e solução de fenolftaleína para a realização da imersão das metades dos corpos-de-prova e disposição após imersão.

Figura 56 - Métodos de medidas de profundidade de carbonatação, (a) método linear, (b) método por análise de imagem utilizando Image $J$ e (c) método por análise de imagem utilizando Leica Qwin.

Figura 57 - Variação dos resultados de abatimento médio dos concretos de seis caminhões amostrados do lote, na central e na obra, sendo o ensaio conforme ABNT NBR NM 67 (1998).

Figura 58- Variação dos resultados dos ensaios de densidade de massa aparente do concreto fresco em amostras de seis caminhões do lote. ABNT NBR 9833 (2008).

Figura 59 - Variação dos resultados de abatimento médio e teor de ar pelo método pressométrico de cada concreto.

Figura 60 - Variação dos resultados de teor de ar pelos métodos pressométrico e gravimétrico de cada amostra de concreto fresco, dos seis caminhões amostrados do lote. ABNT NBR 9833 (1987).

Figura 61 - Variação dos resultados da compactabilidade média do concreto fresco adensado em 1 minuto e 3 minutos de vibração, das amostras analisadas de seis caminhões do lote. Adaptado da BS EN 12.350-4 (2009)

Figura 62 - Variação dos resultados de espessura compactada do concreto fresco adensado e teor de ar pelo método pressométrico das amostras de seis caminhões do lote analisado.

Figura 63 - Variação dos resultados da compactabilidade média do concreto fresco não-adensado em 1 minuto e 3 minutos de vibração, das amostras analisadas de seis caminhões do lote. Adaptado da BS EN 12.350-4 (2009).......

Figura 64 - Variação dos resultados de espessura compactada do concreto não-adensado e do teor de ar pelo método pressométrico das amostras de concreto fresco, dos seis caminhões do lote analisado.

Figura 65 - Variação dos resultados de umidade das amostras de seis caminhões do lote analisado. Adaptado da ABNT NBR 9605 (1992).

Figura 66 - Variação dos resultados de teor de finos total $<75 \mu \mathrm{m}$ de amostras de concreto fresco dos seis caminhões do lote analisado. Adaptado ABNT NBR 9605 (1992).

Figura 67 - Variação dos resultados de resistência à compressão por cura normal e acelerada de corpos-deprova de concreto de seis dos caminhões do lote analisado. ABNT NBR 5739 (2007).

Figura 68 - Evolução do crescimento de resistência à compressão do concreto do lote analisado, nas condições de cura acelerada e normal resumidas pelas legendas. 
Figura 69 - Variação do grau de saturação entre os ciclos de $24 \mathrm{~h}$ de exposição em câmara de $\mathrm{CO}_{2}$ seguido por 27 dias de secagem em estufa a 40ํ․ (Cálculos Opção A)......

Figura 70 - Variação do grau de saturação entre os ciclos de $24 \mathrm{~h}$ de exposição em câmara de $\mathrm{CO}_{2}$ seguido por 27 dias de secagem em estufa a 40드. (Cálculos Opção B).......

Figura 71 - Variação do grau de saturação entre os ciclos $24 \mathrm{~h}$ de imersão em água seguidos por 27 dias de secagem em estufa a $40^{\circ} \mathrm{C}$. (Cálculos Opção A).

Figura 72 - Variação do grau de saturação entre os ciclos 24 h de imersão em água seguidos por 27 dias de secagem em estufa a $40^{\circ} \mathrm{C}$. (Cálculos Opção B).

Figura 73 - Variação do grau de saturação entre os ciclos de pesagem para exposição à secagem contínua a $\left(40 \pm 5^{\circ} \mathrm{C}\right)$. (Opção A)

Figura 74 - Variação do grau de saturação entre os ciclos de pesagem para exposição à secagem contínua a $\left(40 \pm 5^{\circ} \mathrm{C}\right)$. (Opção B)

Figura 75 - Variação da resistência à tração por compressão diametral média dos corpos-de-prova, submetidos à cura acelerada 24/72h e imersão em água até 7 dias e ciclagem de $24 \mathrm{~h}$ de exposição em câmara de $\mathrm{CO}_{2}$ seguida por 27 dias de secagem contínua (AE1). 191

Figura 76- Variação da resistência à tração por compressão diametral média dos corpos-de-prova, submetidos à cura acelerada $24 / 72 \mathrm{~h}$ e imersão em água até 7 dias e depois à ciclagem de $24 \mathrm{~h}$ de imersão em tanque de água seguido por 27 dias de secagem.

Figura 77 - Variação da resistência à tração por compressão diametral média dos corpos-de-prova, submetidos à cura acelerada 24/72h e imersão em água até 7 dias e depois a ciclos de 28 dias de secagem contínua em estufa a $(40 \pm 5)^{\circ} \mathrm{C}$.

Figura 78 - Variação da resistência à tração por compressão diametral média com a idade, para cada tipo de condição de envelhecimento acelerado.

Figura 79 - Variação da absorção de água média dos corpos-de-prova, submetidos à cura acelerada de 24/72h e imersão em água até 7 dias e depois a ciclos de $24 \mathrm{~h}$ de exposição em câmara de $\mathrm{CO}_{2}$ seguida por 27 dias de secagem em estufa a $40^{\circ} \mathrm{C}(\mathrm{AE} 1)$.

Figura 80 - Variação da absorção de água média dos corpos-de-prova, submetidos à cura acelerada de 24/72h e imersão em água até 7 dias e depois a ciclos de $24 \mathrm{~h}$ de imersão em tanque de água seguida por 27 dias de secagem em estufa a $40^{\circ} \mathrm{C}(\mathrm{AE} 2)$.

Figura 81 - Variação da absorção de água média dos corpos-de-prova, submetidos à cura acelerada 24/72h e imersão em água até 7 dias e depois a ciclos de 28 dias de secagem contínua em estufa ventilada a (40 $\pm 1)^{\circ} \mathrm{C}$, na condição AE3.

Figura 82 - Variação do índice de vazios médio dos corpos-de-prova, submetidos à cura acelerada de 24/72h e imersão em água até 7 dias e à ciclagem de $24 \mathrm{~h}$ de exposição em câmara de $\mathrm{CO}_{2}$ seguida por 27 dias de secagem em estufa ventilada a $40^{\circ} \mathrm{C}$ (AE1)......

Figura 83 - Variação do índice de vazios médio dos corpos-de-prova, submetidos à cura acelerada de 24/72h e imersão em água até 7 dias e ciclagem de $24 \mathrm{~h}$ de imersão em tanque de água seguida por 27 dias de secagem em estufa ventilada a $40^{\circ} \mathrm{C}$ (AE2).

Figura 84 - Variação do índice de vazios médio dos corpos-de-prova, submetidos à cura acelerada de 24/72h e imersão em água até 7 dias e depois a ciclos de 28 dias de secagem contínua em estufa a $(40 \pm 1)^{\circ} \mathrm{C}(\mathrm{AE} 3)$.

Figura 85 - Variação da absorção de água por capilaridade média nos concretos amostrados, submetidos à cura normal, do lote analisado. ABNT NBR 9779 (1995).

Figura 86 - Variação da profundidade de carbonatação média após dois ciclos em câmara de CO2 (5\%; 24h) e 27 dias de secagem a $40^{\circ} \mathrm{C}$ (AE1), por timolftaleína e fenolftaleína, nas metades seccionadas de dois corpos-de-prova de concreto por caminhão a 63 dias - medida linear e pelo programa Image $\mathrm{J}$. 
Figura 87 - Variação da profundidade de carbonatação média após três ciclos em câmara de $\mathrm{CO}_{2}(5 \%$; $24 \mathrm{~h})$ e 27 dias de secagem a $40^{\circ} \mathrm{C}(\mathrm{AE} 1)$, por fenolftaleína, nas metades seccionadas de dois corpos-de-prova de concreto, por caminhão a 91 dias - medida linear e pelo programalmage $\mathrm{J}$.

Figura 88 - Variação da profundidade de carbonatação média por sete ciclos de 24h de exposição em câmara de carbonatação $(5 \%, 24 \mathrm{~h})$ e 27 dias de secagem (AE1), por fenolftaleína, nas metades seccionadas de dois corpos-de-prova de concreto por caminhão a 203 dias - medida linear, programa Image J e programa Leica Qwin.

Figura 89 - Variação da profundidade de carbonatação média em dois ciclos de 24h de imersão em água, seguido por 27 dias de secagem (AE2), por timolftaleína e fenolftaleína, nas metades seccionadas de dois corpos-de-prova de concreto, por caminhão a 63 dias.

Figura 90 - Variação da profundidade de carbonatação média por três ciclos de $24 \mathrm{~h}$ de imersão em água e 27 dias de secagem (AE2), por fenolftaleína, nas metades seccionadas de dois corpos-de-prova de concreto, por caminhão a 91 dias - medida linear e programa Image J.

Figura 91 - Variação da profundidade de carbonatação média por sete ciclos de 24 h de imersão em água e 27 dias de secagem (AE2), por fenolftaleína, nas metades seccionadas de dois corpos-de-prova de concreto por caminhão a 203 dias - medida linear, programa Image J e programa Leica Qwin.

Figura 92 - Variação da profundidade de carbonatação média por sete ciclos de 28 dias de secagem contínua a $40^{\circ} \mathrm{C}$ (AE3), por fenolftaleína, nas metades seccionadas de dois corpos-de-prova de concreto por caminhão a 203 dias - medida linear, programa Image J e programa Leica Qwin.

Figura 93 - Variação da taxa de carbonatação média para os três tipos de condicionamento, por fenolftaleína, nas metades seccionadas de dois corpos-de-prova de concreto por caminhão a 203 dias - medida linear, programa Image $\mathrm{J}$ e programa Leica.

Figura 94 - Valores de $\mathrm{k}_{\mathrm{co} 2}$ calculados para os resultados deste trabalho a 203 dias de idade, sendo (1) medida linear; (2) medida ImageJ e (3) medida Leica Qwin. O valor de $\mathrm{k}_{\mathrm{CO} 2}$ igual a $4,1 \mathrm{~mm} / \mathrm{ano}^{1 / 2}$ é a previsão de Helene (1997) para carbonatação natural de um concreto classe $30 \mathrm{com}$ cimento de alto-forno. 254

Figura 96 - Curva tensão-deformação para os corpos-de-prova ensaiados a 91 dias. 256

Figura 97 - Curva tensão-deformação para os corpos-de-prova ensaiados a 203 dias. 256

Figura 98 - Variação da velocidade média de ultra-som com a idade de ensaio e tipo de condição de envelhecimento acelerado, para velocidade com 5 pontos, que inclui o ponto central do corpo-de-prova. 258

Figura 99 - Comparação da velocidade de propagação da onda ultrassônica no ponto central com os 4 periféricos em função do número de ciclos, para cada ambiente de envelhecimento acelerado, sempre antes do $1^{\circ}$ dia do ciclo.

Figura 100 - Comparação da velocidade de propagação da onda ultrassônica de cada CP em função da massa, para o ambiente de secagem contínua (AE3).

Figura 101 - Legenda das descrições das condições de exposição, nas tabelas de correlação das propriedades.

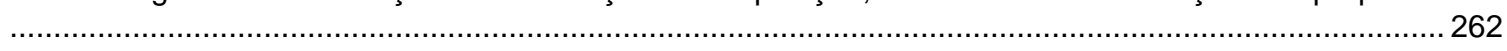

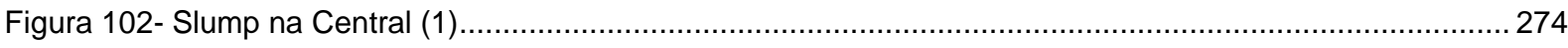

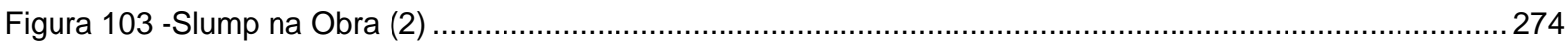

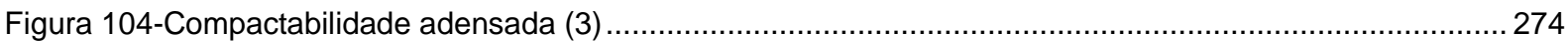

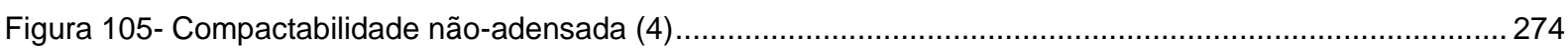

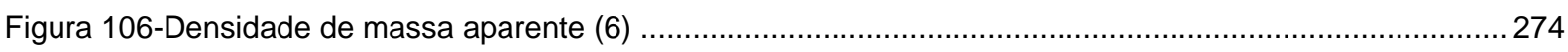

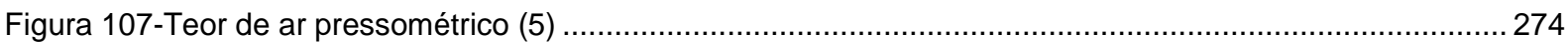

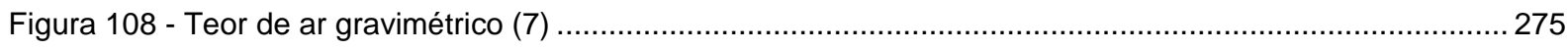

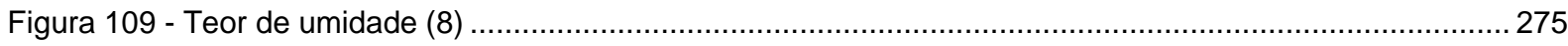




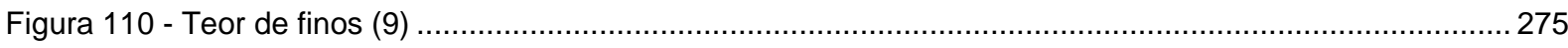

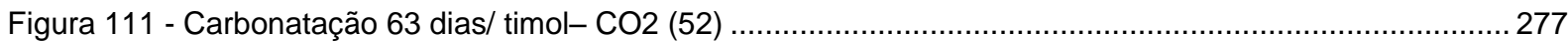

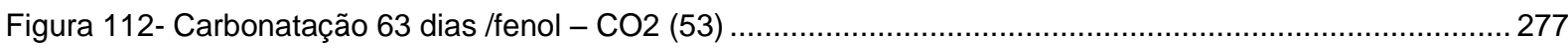

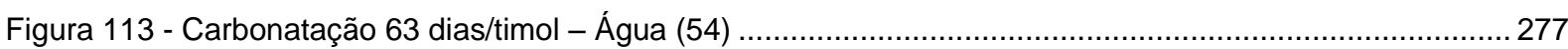

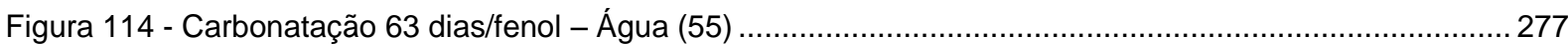

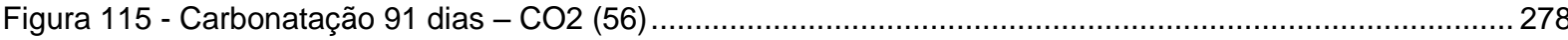

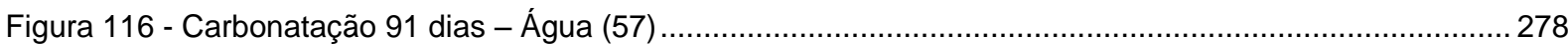

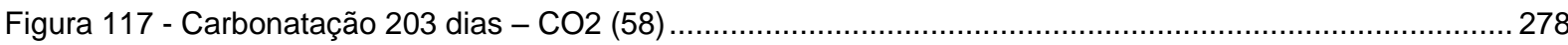

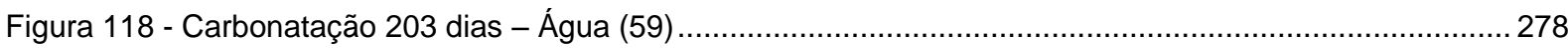

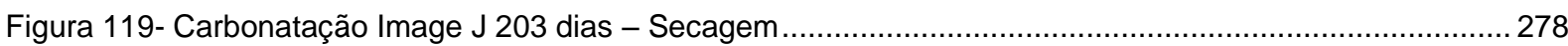

Figura 120 - Carbonatação Image J 63 dias - CO2 (70) ….................................................................2 279

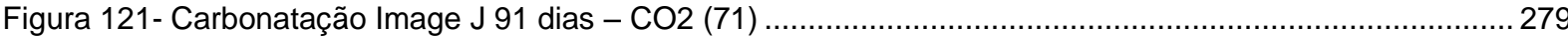

Figura 122 - Carbonatação Image J 91 dias - Água (72) …............................................................2 279

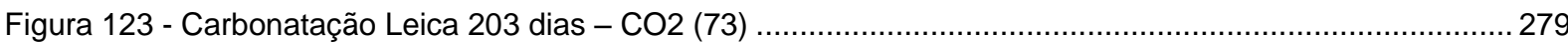

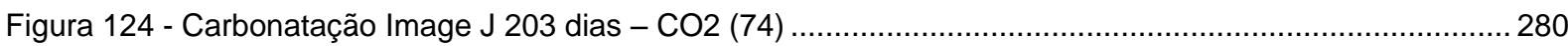

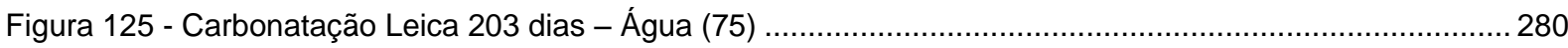

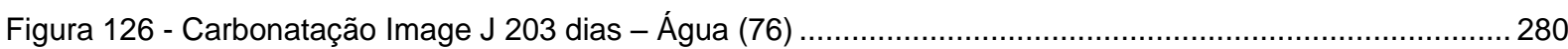

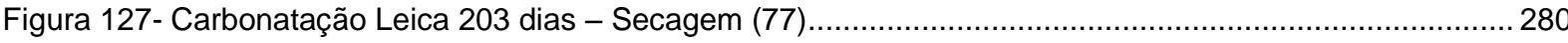

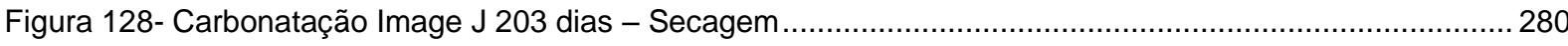

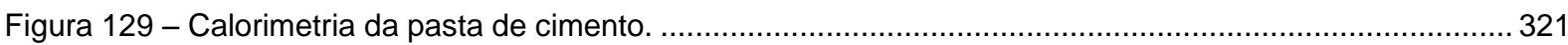

Figura 130 - Calorimetria da pasta de cimento com e sem aditivo....................................................... 321

Figura 131 - Controle de massa dos corpos-de-prova 9, 10, 11 e 12 (AE1) das misturas C1A e C2B.............323

Figura 132 - Controle de massa dos corpos-de-prova 9, 10, 11 e 12 (AE1) e das misturas C3C e C4D..........324

Figura 133 - Controle de massa dos corpos-de-prova 9, 10, 11 e 12 (AE1) e das misturas C5E e C6F...........325

Figura 134 - Controle de massa de corpos-de-prova21, 22, 23 e 24 (AE2) das misturas C1A e C2B.............. 326

Figura 135 - Controle de massa de corpos-de-prova 21, 22, 23 e 24 (AE2) das misturas C3C e C4D............ 327

Figura 136 - Controle de massa de corpos-de-prova 21, 22, 23 e 24 (AE2) das misturas C5E e C6F..............328

Figura 137 - Controle de massa de corpos-de-prova 25 a 32 (AE3) das misturas C1A e C2B. ....................... 329

Figura 138 - Controle de massa de corpos-de-prova 25 a 32 (AE3) das misturas C3C e C4D....................... 330

Figura 139- Controle de massa de corpos-de-prova (AE3) C5E e C6F.................................................. 331

Figura 140 - Gráficos de taxa de carbonatação nas idades de ensaio. ................................................... 338

Figura 142 - Dados climáticos da época da concretagem. ..................................................................... 343 


\section{LISTA DE TABELAS}

TABELA 1 - Principais variáveis que condicionam a velocidade de carbonatação dos concretos de cimento Portland (KAZMIERCZAK, 1995).

Tabela 2 - Autores e respectivos modelos teóricos, resumidos por esta autora a partir de Carmona (2005) e Andrade (2006).

Tabela 3- Coeficientes de cura e exposição. CEB (1996) apud Carmona (2005).

Tabela 4 - Coeficientes de cura e exposição. CEB ${ }^{13}$ (1996) apud Carmona (2005).

Tabela 5 - Comparação da profundidade de carbonatação em 50 anos a partir dos modelos de TUUTTI, PAPADAKIS, CEB, HELENE e thomas, analisados por carmona (2005).

Tabela 6 - Efeito de algumas condições de exposição no processo da carbonatação (BERTOS et al. 2004, citados por SILVA, 2007).

Tabela 7- Classes de agressividade ambiental da ABNT NBR 6118 (2007)

Tabela 8- Classes de agressividade ambiental da EN 206-1:2000 (CEN ${ }^{1}$, 2000) apud Priszkulnik et al. (2005). .66

Tabela 9 - Classes de exposição ambiental da EM 206-1:2000 (CEN $\left.{ }^{1}, 2000\right)$ apud Priszkulnik et al. (2005)......67

Tabela 10- Classes de exposição ambiental da EN 206-1:2000 (CEN¹, 2000)(cont.) apud Priszkulnik et al. (2005).

Tabela 11 - Exigências de durabilidade relacionadas à fissuração e à proteção da armadura, em função das classes de agressividade ambiental e na Tabela 7 do item 2.2.2 (ABNT NBR 6118:2007)

TABELA 12 - Cobrimento nominal para $\Delta c=10 \mathrm{~mm}$ em função da classe de agressividade ambiental e na Tabela 7, item 2.2.2. (ABNT NBR 6118:2007).

Tabela 13 - Critérios prescritivos do concreto pela classe de agressividade ambiental, na Tabela 7, item 2.2.2, segundo a ABNT NBR 6118 (2007) e a ABNT NBR 12655 (2006).

Tabela 14 - Valores limites recomendados para a composição e propriedades do concreto (CEN $\left.{ }^{1}, 2000\right)$ apud Priszkulnik et al. (2005).

Tabela 15 - Classificação dos poros segundo a classificação da IUPAC - International Union of Pure and Applied Chemistry (VIANA, 2004).

Tabela 16 - Classificação dos concretos em função da porosidade e absorção de água (HELENE, 1993)..... 82

Tabela 17 - Resistência à compressão e porosidade das amostras de concreto, de acordo com o tipo de vibração (GONEN; YAZICIOGLU, 2007).

Tabela 18 - Tipos e procedimentos da cura acelerada (ASTM C 684:1999)

Tabela 19- Resumo das condições de ensaios acelerados de carbonatação da literatura. Adaptado e ampliado pela autora a partir de Pauletti (2004).

Tabela 20 - Principais indicadores colorimétricos de faixa de pH, utilizados para medidas da espessura e da frente de carbonatação.

Tabela 21 - Resumo dos ensaios no concreto fresco.

Tabela 22 - Ensaios mecânicos realizados para o lote amostrado.

Tabela 23 - Ensaios físicos realizados para o lote amostrado.

Tabela 24 - Ensaios acelerados de carbonatação para o lote amostrado.

Tabela 25 - Etapas do ensaio 24h exposição em câmara de carbonatação e 27 dias de secagem, para cada data de ensaio dos concretos com maturação acelerada. 
Tabela 26 - Etapas do ensaio acelerado por ciclagem, para cada data de ensaio dos concretos com maturação acelerada.

Tabela 27 - Etapas do ensaio acelerado por ciclagem, para cada data de ensaio dos concretos com maturação acelerada.

Tabela 28 - Dados das notas fiscais referente aos concretos fornecidos à obra.

Tabela 29 - Resultados dos ensaios de abatimento do concreto fresco das seis misturas do lote analisado em 13/08/2009, conforme ABNT NBR NM 67 (1998).

Tabela 30- Resultados do ensaio de densidade de massa aparente do concreto fresco, em amostras de seis caminhões amostrados do lote analisado conforme a ABNT NBR 9833 (2008).

Tabela 31 - Resultados do ensaio de teor de ar por método pressométrico no concreto fresco, em amostras de seis caminhões do lote analisado. ABNT NBR 47 (2002).

Tabela 32 - Resultados do ensaio de teor de ar no concreto fresco pelo método gravimétrico em amostras de seis caminhões do lote analisado. ABNT NBR 9833 (1987).

Tabela 33 - Resultados do ensaio de compactabilidade do concreto fresco adensado (a-vibração 1 min.) (bvibração 3 min.) das amostras de seis caminhões do lote analisado. Adaptado da BS EN 12.350-4 (2009).

Tabela 34 - Resultados do ensaio de compactabilidade no concreto fresco não-adensado (a-vibração 1 min.) (bvibração 3 min.) das amostras de seis caminhões do lote analisado. Adaptado BS EN 12.350-4 (2009). . 161

Tabela 35 - Resultados do ensaio de umidade no concreto fresco das amostras de seis caminhões do lote analisado. Adaptado da ABNT NBR 9605 (1992).

Tabela 36 - Resultados do ensaio de teor de finos total das amostras de concreto fresco de seis caminhões do lote analisado. Adaptado da ABNT NBR 9605 (1992).

Tabela 37 - Resultados do ensaio de resistência à compressão do concreto endurecido a 1 dia de idade, por cura acelerada, de corpos-de-prova moldados de seis dos caminhões do lote analisado. Adaptado da ASTM C 684 (1999) e ABNT NBR 5739 (2007).

Tabela 38 - Resultados do ensaio de resistência à compressão do concreto endurecido a 2 dias de idade, por cura acelerada de 1 a 2 dias, de corpos-de-prova moldados de seis dos caminhões do lote analisado. Adaptado da ASTM C 684 (1999) e ABNT NBR 5739 (2007).

Tabela 39 - Resultados do ensaio de resistência à compressão do concreto endurecido a 3 dias de idade, por cura acelerada de 1 a 3 dias, de corpos-de-prova moldados de seis dos caminhões do lote analisado. Adaptado da ASTm C 684 (1999) e ABNT NBR 5739 (2007).

Tabela 40 - Resultados do ensaio de resistência à compressão do concreto endurecido a 7 dias de idade, por cura acelerada de 1 a 3 dias, de corpos-de-prova moldados de seis doscaminhões do lote analisado. Adaptado da ASTM C 684 (1999) e ABNT NBR 5739 (2007).

Tabela 41 - Resultados do ensaio de resistência à compressão do concreto endurecido a 28 dias de idade por cura normal, de corpos-de-prova de seis dos caminhões do lote analisado. ABNT NBR 5739 (2007)...... 170

Tabela 42 - Resumo dos resultados dos ensaios de resistência à compressão do concreto endurecido nas idades em estudo, em corpos-de-prova moldados de seis dos caminhões do lote analisado ABNT NBR 5739 (2007)

Tabela 43 - Resultados do ensaio de resistência à compressão nos concretos dos seis caminhões do lote analisado. ABNT NBR 5739 (2007).

Tabela 44 - Resistência relativa das várias idades de cura acelerada em relação à de 28 dias de cura normal.

Tabela 45 - Resistência característica por amostragem parcial dos concretos do lote analisado. ABNT NBR 12655 (2006). 
Tabela 46 - Resultados do ensaio de resistência à tração por compressão diametral a 8 dias (AE1) dos concretos do lote analisado. ABNT NBR 7222 (1994).

Tabela 47 - Resultados do ensaio de resistência à tração por compressão diametral a 35 dias (AE1) dos concretos do lote analisado. ABNT NBR 7222 (1994).

Tabela 48 - Resultados do ensaio de resistência à tração por compressão diametral a 63 dias (AE1) dos concretos do lote analisado. ABNT NBR 7222 (1994).

Tabela 49 - Resultados do ensaio de resistência à tração por compressão diametral a 91 dias (AE1) dos concretos do lote analisado. ABNT NBR 7222 (1994).

Tabela 50 - Resultados do ensaio de resistência à tração por compressão diametral a 203 dias (AE1) dos concretos do lote analisado. ABNT NBR 7222 (1994).

Tabela 51 - Resultados do ensaio de resistência à tração por compressão diametral a 8 dias (AE2) dos concretos do lote analisado. ABNT NBR 7222 (1994).

Tabela 52 - Resultados do ensaio de resistência à tração por compressão diametral a 35 dias (AE2) dos concretos do lote analisado. ABNT NBR 7222 (1994).

Tabela 53 - Resultados do ensaio de resistência à tração por compressão diametral a 63 dias (AE2) dos concretos do lote analisado. ABNT NBR 7222 (1994).

Tabela 54 - Resultados do ensaio de resistência à tração por compressão diametral a 91 dias (AE2) dos concretos do lote analisado. ABNT NBR 7222 (1994).

Tabela 55 - Resultados do ensaio de resistência à tração por compressão diametral a 203 dias (AE2) dos concretos do lote analisado. ABNT NBR 7222 (1994).

Tabela 56 - Resultados do ensaio de resistência à tração por compressão diametral a 91 dias (AE3) dos concretos do lote analisado. ABNT NBR 7222 (1994).

Tabela 57 - Resultados do ensaio de resistência à tração por compressão diametral a 203 dias (AE3) dos concretos do lote analisado. ABNT NBR 7222 (1994).

Tabela 58 - Resultados do ensaio de resistência à tração por compressão diametral nos concretos do lote amostrado. ABNT NBR 7222 (1994).

Tabela 59 - Resultados do ensaio de absorção de água a 8 dias (AE1) dos concretos do lote analisado. ABNT NBR 9778 (2005).

Tabela 60 - Resultados do ensaio de absorção de água a 35 dias (AE1) dos concretos do lote analisado. ABNT NBR 9778 (2005).

Tabela 61 - Resultados do ensaio de absorção de água total a 63 dias (AE1) dos concretos do lote analisado. ABNT NBR 9778 (2005).

Tabela 62 - Resultados do ensaio de absorção de água total a 91 dias (AE1) dos concretos do lote analisado. ABNT NBR 9778 (2005).

Tabela 63 - Resultados do ensaio de absorção de água total a 203 dias (AE1) dos concretos do lote analisado. ABNT NBR 9778 (2005)

Tabela 64 - Resultados do ensaio de absorção de água a 8 dias (AE2) dos concretos do lote analisado. ABNT NBR 9778 (2005)

Tabela 65 - Resultados do ensaio de absorção de água a 35 dias (AE2) dos concretos do lote analisado. ABNT NBR 9778 (2005).

Tabela 66 - Resultados do ensaio de absorção de água a 63 dias (AE2) dos concretos do lote analisado. ABNT NBR 9778 (2005).

Tabela 67 - Resultados do ensaio de absorção de água a 91 dias (AE2) dos concretos do lote analisado. ABNT NBR 9778 (2005). 
Tabela 68 - Resultados do ensaio de absorção de água a 203 dias (AE2) dos concretos do lote analisado. ABNT NBR 9778 (2005).

Tabela 69 - Resultados do ensaio de absorção de água a 91 dias (AE3) dos concretos do lote analisado. ABNT NBR 9778 (2005).

Tabela 70 - Resultados do ensaio de absorção de água a 203 dias (AE3) dos concretos do lote analisado. ABNT NBR 9778 (2005).

TABELA 71 - Resultados do ensaio de absorção de água nos concretos amostrados do lote, considerando média dos 12 resultados. ABNT NBR 9778 (2005).

Tabela 72 - Resultados do ensaio de índice de vazios a 8 dias (AE1) dos concretos do lote analisado. ABNT NBR 9778 (2005)

Tabela 73 - Resultados do ensaio de índice de vazios a 35 dias (AE1) dos concretos do lote analisado. ABNT NBR 9778 (2005)

Tabela 74 - Resultados do ensaio de índice de vazios a 63 dias (AE1) dos concretos do lote analisado. ABNT NBR 9778 (2005).

Tabela 75 - Resultados do ensaio de índice de vazios a 91 dias (AE1) dos concretos do lote analisado. ABNT NBR 9778 (2005).

Tabela 76 - Resultados do ensaio de índice de vazios a 203 dias (AE1) dos concretos do lote analisado. ABNT NBR 9778 (2005).

Tabela 77 - Resultados do ensaio de índice de vazios a 8 dias (AE2) dos concretos do lote analisado. ABNT NBR 9778 (2005).

Tabela 78 - Resultados do ensaio de índice de vazios a 35 dias (AE2) dos concretos do lote analisado. ABNT NBR 9778 (2005).

Tabela 79 - Resultados do ensaio de índice de vazios a 63 dias (AE2) dos concretos do lote analisado. ABNT NBR 9778 (2005).

Tabela 80 - Resultados do ensaio de índice de vazios a 91 dias (AE2) dos concretos do lote analisado. ABNT NBR 9778 (2005).

Tabela 81 - Resultados do ensaio de índice de vazios a 203 dias (AE2) dos concretos do lote analisado. ABNT NBR 9778 (2005).

Tabela 82 - Resultados do ensaio de índice de vazios a 91 dias (AE3) dos concretos do lote analisado. ABNT NBR 9778 (2005).

Tabela 83 - Resultados do ensaio de índice de vazios a 203 dias (AE3) dos concretos do lote analisado. ABNT NBR 9778 (2005).

Tabela 84 - Resultados do ensaio de índice de vazios nos concretos do lote amostrado, considerando média de 12 resultados. ABNT NBR 9778 (2005).

Tabela 85 - Resultados dos ensaios de absorção de água por capilaridade, ao final de 72 horas, nos concretos com cura normal de 1 até 91 dias. ABNT NBR 9779 (1995)......

Tabela 86 - Resultados do ensaio de resistência à carbonatação por câmara de CO2 (5\%; 24 horas) a 63 dias (AE1) dos concretos do lote analisado, por timolftaleína - medida linear (Interpretar espessuras de carbonatação em valor inteiro de $\mathrm{mm}^{\star}$ ).

Tabela 87 - Resultados do ensaio de resistência à carbonatação por câmara de $\mathrm{CO} 2$ (5\%; 24 horas) a 63 dias (AE1) dos concretos do lote analisado, por fenolftaleína - medida linear (Interpretar espessuras de carbonatação em valor inteiro de $\mathrm{mm}^{*}$ ).

Tabela 88 - Resultados do ensaio de resistência à carbonatação por câmara de $\mathrm{CO} 2$ (5\%; 24 horas) a 63 dias (AE1) dos concretos do lote analisado, por fenolftaleína - medida através do software Image J (Interpretar espessuras de carbonatação em valor inteiro de $\mathrm{mm}^{\star}$ ). 
Tabela 89 - Resultados do ensaio de resistência à carbonatação por três ciclos de 24h de exposição em câmara de carbonatação $(5 \%, 24 \mathrm{~h})$ e por 27 dias de secagem a $40^{\circ} \mathrm{C}$, a 91 dias (AE1) dos concretos do lote analisado, por fenolftaleína - medida linear (Interpretar espessuras de carbonatação em valor inteiro de $\mathrm{mm})$.

Tabela 90 - Resultados do ensaio de resistência à carbonatação por três ciclos de 24h de exposição em câmara de carbonatação $(5 \%, 24 \mathrm{~h})$ e 27 dias de secagem, a 91 dias (AE1) dos concretos do lote analisado, por fenolftaleína- medida por Image J (Interpretar espessuras de carbonatação em valor inteiro de mm)....... 236

Tabela 91 - Resultados do ensaio de resistência à carbonatação por sete ciclos de $24 \mathrm{~h}$ de exposição em câmara de carbonatação $(5 \%, 24 \mathrm{~h})$ e 27 dias de secagem, a 203 dias (AE1) dos concretos do lote analisado, por fenolftaleína -medida linear (Interpretar espessuras de carbonatação em valor inteiro de mm). 238

Tabela 92 - Resultados do ensaio de resistência à carbonatação por sete ciclos de exposição em câmara de carbonatação $(5 \%, 24 \mathrm{~h})$ e 27 dias de secagem, a 203 dias (AE1) dos concretos do lote analisado, por fenolftaleína- medida por Image J (Interpretar espessuras de carbonatação em valor inteiro de mm)....... 238

Tabela 93 - Resultados do ensaio de resistência à carbonatação por sete ciclos de 24h de exposição em câmara de carbonatação $(5 \%, 24 \mathrm{~h})$ e 27 dias de secagem, a 203 dias (AE1) dos concretos do lote analisado, por fenolftaleína- medida por Leica Qwin (Interpretar espessuras de carbonatação em valor inteiro de mm).. 239

Tabela 94 - Resultados do ensaio de resistência à carbonatação por dois ciclos de 24h de imersão em água, seguido por 27 dias de secagem, a 63 dias (AE2) dos concretos do lote analisado, por timolftaleína medida linear (Interpretar espessuras de carbonatação em valor inteiro de $\mathrm{mm}$ ).....

Tabela 95 - Resultados do ensaio de resistência à carbonatação por dois ciclos de $24 \mathrm{~h}$ imersão em água, seguido por 27 dias de secagem, a 63 dias (AE2) dos concretos do lote analisado, por fenolftaleína medida linear (Interpretar espessuras de carbonatação em valor inteiro de $\mathrm{mm}$ ).......

Tabela 96 - Resultados do ensaio de resistência à carbonatação por três ciclos de 24h de imersão em água e 27 dias de secagem, a 91 dias (AE2) dos concretos do lote analisado, por fenolftaleína - medida linear (Interpretar espessuras de carbonatação em valor inteiro de $\mathrm{mm}$ ).

Tabela 97- Resultados do ensaio de resistência à carbonatação por três ciclos de 24h de imersão em água e 27 dias de secagem, a 91 dias (AE2) dos concretos do lote analisado, por fenolftaleína - medida por Image $\mathrm{J}$ (Interpretar espessuras de carbonatação em valor inteiro de $\mathrm{mm}$ )......

Tabela 98 - Resultados do ensaio de resistência à carbonatação por sete ciclos de 24 h de imersão em água e 27 dias de secagem, a 203 dias (AE2) dos concretos do lote analisado, por fenolftaleína - medida linear (Interpretar espessuras de carbonatação em valor inteiro de $\mathrm{mm}$ ).

Tabela 99 - Resultados do ensaio de resistência à carbonatação por sete ciclos de 24h de imersão em água e 27 dias de secagem, a 203 dias (AE2) dos concretos do lote analisado, por fenolftaleína - medida por Image $\mathrm{J}$ (Interpretar espessuras de carbonatação em valor inteiro de $\mathrm{mm}$ ).

Tabela 100 - Resultados do ensaio de resistência à carbonatação por sete ciclos de $24 \mathrm{~h}$ de imersão em água e 27 dias de secagem, a 203 dias (AE2) dos concretos do lote analisado, por fenolftaleína - medida por Leica Qwin (Interpretar espessuras de carbonatação em valor inteiro de $\mathrm{mm}$ ).

Tabela 101 - Resultados do ensaio de resistência à carbonatação por sete ciclos de 28 dias de secagem contínua, a 203 dias (AE3) dos concretos do lote analisado, por fenolftaleína - medida linear (Interpretar espessuras de carbonatação em valor inteiro de $\mathrm{mm}$ ).

Tabela 102 - Resultados do ensaio de resistência à carbonatação por sete ciclos de 28 dias de secagem contínua, a 203 dias (AE3) dos concretos do lote analisado, por fenolftaleína - medida por Image J (Interpretar espessuras de carbonatação em valor inteiro de $\mathrm{mm}$ ).

Tabela 103 - Resultados do ensaio de resistência à carbonatação por sete ciclos de 28 dias de secagem contínua, a 203 dias (AE3) dos concretos do lote analisado, por fenolftaleína - medida por Leica Qwin (Interpretar espessuras de carbonatação em valor inteiro de $\mathrm{mm}$ ).

Tabela 104 - Resultados do ensaio de profundidade de carbonatação nos concretos do lote amostrado, considerando médias de 12 resultados (Interpretar espessuras de carbonatação em valor inteiro de $\mathrm{mm}$ ). 
Tabela 105 - Resultados de kco2 para a espessura média de carbonatação a 203 dias de idade para diferentes condicionamentos e métodos de medida.......................................................................................... 254

Tabela 106- Condições e resultados dos ensaios de módulo de elasticidade. .............................................255

Tabela 107 - Interpretação das correlações lineares entre as propriedades medidas..................................260

Tabela 108 - Descrição da legenda, conforme Figura 101.

Tabela 109 - Correlações entre as propriedades no estado fresco e resultados de medidas de profundidade de carbonatação.

Tabela 110 - Correlações entre as resistências à compressão e os resultados de medidas de profundidade de carbonatação.

Tabela 111 - Correlações entre as resistências à tração por compressão diametral e medidas de profundidade de carbonatação.

Tabela 112 - Correlações entre os resultados de índice de vazios e os resultados de ensaios de profundidade de carbonatação.

Tabela 113 - Correlações entre os resultados absorção de água e os resultados de ensaios de profundidade de carbonatação

Tabela 114 - Correlações entre os resultados carbonatação linear e os resultados de ensaios de profundidade de carbonatação

Tabela 115 - Significado do tamanho do P-valor conforme Wild; Seber (2000) 273

Tabela 116 - Resultados da análise de normalidade das propriedades do concreto no estado fresco, das amostras de seis caminhões de concreto do lote analisado

Tabela 117 - Resultados da análise de normalidade das propriedades do concreto no estado endurecido, das amostras de seis caminhões de concreto do lote

Tabela 119 - Comparação das médias dos ensaios de carbonatação por Tukey...... 285

Tabela 120 - Resultados das análises dos resultados de carbonatação por ANOVA ( fator triplo) 286

Tabela 121 - Comparação das médias dos ensaios de porcentagem de área carbonatada a 203 dias por método de Tukey

Tabela 122 - Comparação das médias dos ensaios de carbonatação a 91 e 203 dias por ANOVA (fator quádruplo).

Tabela 123 - Comparação das médias dos ensaios de tração por compressão diametral pelo método de Tukey.

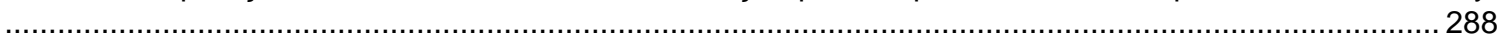

Tabela 124 - Comparação das médias dos ensaios de absorção de água pelo método de Tukey. ....................288

Tabela 125 - Comparação das médias dos ensaios de índice de vazios por Tukey.......................................289

Tabela 126 - Dados completos sobre resistência à tração por compressão diametral. .................................. 332

Tabela 126 - Dados completos sobre ensaios de profundidade de carbonatação....................................... 334

Tabela 127 - Dados completos sobre ensaios de módulo de elasticidade a 91 dias. ....................................339

Tabela 128 - Dados completos sobre ensaios de módulo de elasticidade a 203 dias. .................................... 340

Tabela 129 - Resumo das análises de variância (ANOVA-2Fat) dos ensaios de resistência à tração por compressão diametral com a influência da mistura e dos tipos de ciclagem.

Tabela 130 - Resumo das análises de variância (ANOVA) dos ensaios de absorção de água total com a influência da mistura e dos tipos de ciclagem para 2 fatores. 
Tabela 131 - Resumo das análises de variância (ANOVA) dos ensaios de índice de vazios com a influência da mistura dos tipos de ciclagem para 2 fatores. ........................................................................... 370 


\section{INTRODUÇÃO}

O concreto, como material de construção, tornou-se cada vez mais importante a partir do advento da fabricação do cimento Portland, no século XIX; é o insumo mais utilizado hoje pela indústria da construção civil em todo o mundo e, com certeza, ocupará posição muito similar no mercado futuro. Esta previsão baseia-se nas regras clássicas de demanda, de oferta e de vantagens técnicas e econômicas do concreto sobre outros materiais estruturais, como a madeira e o aço, segundo a opinião de muitos especialistas.

De uma maneira geral, o futuro do concreto convencional não vai ser determinado por tecnologias sofisticadas, aplicáveis a casos específicos, mas pelo esforço de todos em resolver os problemas dos que lidam com o dia-a-dia dos concretos convencionais (MEHTA; MONTEIRO, 1994).

Mas, as diretrizes de projeto e de produção das estruturas e construções em concreto desenvolveram-se essencialmente voltadas ao controle das suas propriedades mecânicas, sem ênfase na predição do seu comportamento específico dentro de cada ambiente e circunstâncias de projeto.

Logo, a durabilidade das construções em concreto, isto é o seu comportamento adequado em serviço, requer mudanças de cultura técnica, na Arquitetura e Engenharia, que precisam ser incentivadas a partir de pesquisas acadêmicas, de normas técnicas e da efetiva aplicação de conceitos de vida útil nas suas obras.

Pesquisas nacionais e internacionais sobre a durabilidade do concreto permitiram um significativo avanço na normalização brasileira, no sentido de subsidiar as decisões dos projetistas e construtores, na busca de conceber e de executar estruturas mais duráveis (GOMES, 2006).

Além disto, a evolução e a aplicação de princípios da Ciência dos Materiais à tecnologia de produção do concreto permitem antever que, no futuro, esse produto será consideravelmente superior ao atualmente utilizado sob o ponto de vista da durabilidade e da sustentabilidade (MEHTA; MONTEIRO, 2008). Ainda segundo esses autores, há uma preocupação crescente com a escolha dos materiais constituintes do concreto, que agora deve ser também orientada pelos preceitos de consiliência, ou seja, de desenvolvimento sócio-econômico com respeito simultâneo a valores éticos, às ciências biológicas e ao meio ambiente. 
Por outro lado, há consenso de renomados especialistas internacionais (HOOTON et al. 2006) sobre a necessidade de desenvolvimento de novos critérios para a dosagem e o controle de concretos estruturais. Ocorre que há certa insatisfação quanto aos ensaios atuais para o controle da qualidade do concreto, já que muitos trabalhos demonstram que a vida útil em serviço de muitas estruturas de concreto não tem se mostrado satisfatória e para cada tipo de projeto é recomendável verificar propriedades críticas ou mais relevantes no âmbito da durabilidade global da obra em serviço.

Entre as exigências mais comuns e freqüentes na especificação do concreto estrutural está o requisito de que atue como barreira física para proteger armaduras de aço carbono contra a corrosão. Isto porque a corrosão de armaduras é considerada por muitos pesquisadores como o mais grave e freqüente problema em estruturas de concreto armado, que além de constituir em um problema técnico-econômico, ainda apresenta um grande desperdício de recursos naturais e um problema de caráter local e mundial (MEHTA; MONTEIRO, 1994).

Os danos por corrosão podem afetar a capacidade dos componentes estruturais, devido fundamentalmente à diminuição da seção transversal das armaduras, à perda de aderência entre o aço e o concreto e a fissuração deste (HELENE, 2003).

Os fatores principais que levam ao fenômeno da corrosão estão associados fundamentalmente às características do aço, do concreto e à espessura com que cobre as armaduras, à geometria e interação dos componentes estruturais com as cargas de serviço e o meio ambiente circundante. Em geral, todos esses fatores podem ser controlados por diretrizes adequadas de projeto, execução e manutenção das estruturas. Em todos os casos, é fundamental a interpretação prévia e detalhada dos riscos de carbonatação e dos outros mecanismos de deterioração das estruturas de concreto, como preconiza a atual norma européia EN 206-1:2000¹, destacada no Capítulo 2, item 2.2.2.

Assim, a abordagem deste trabalho refere-se a uma revisão bibliográfica e a um estudo de prospecção tecnológica, em que se procurou testar a viabilidade de se aplicar métodos e medidas auxiliares, para o controle da resistência à carbonatação de concretos estruturais de cimento Portland, em condições de produção e amostragem do material em campo.

1 CEN - Comitê Europeu de Normalização, EN 206-1, 2000 - British Standard: Concrete - Part 1: Specification, Performance, Production and Conformity (European Concrete Standard). 


\subsection{JUSTIFICATIVAS GERAIS}

\subsubsection{No âmbito da qualidade das estruturas de concreto armado}

A partir das pesquisas acadêmicas sobre a durabilidade das estruturas em concreto armado no Brasil, estimuladas principalmente por Helene (1986; 1993) e Mehta; Monteiro (1994); tornou-se clara a necessidade da abordagem cada vez mais sistêmica e científica do comportamento dessas estruturas e dos seus materiais, bem como a indispensável evolução dos métodos de produção, controle e avaliação dos seus projetos e obras em geral, pela sua importância na construção civil brasileira.

Por outro lado, muitos problemas têm origem em etapas e operações, que precedem ou dizem respeito à fase de concretagem das estruturas, propriamente dita, como bem resume Gomes (2006):

- falhas na especificação, na dosagem, no recebimento, no controle dos materiais ou no controle tecnológico do concreto;

- falta de cuidados no transporte do concreto;

- lançamento inadequado (manuseio excessivo ou não respeitando a altura máxima de lançamento);

- falta de adensamento ou adensamento excessivo.

Através desses problemas, podem surgir anomalias que prejudicam o desempenho do concreto, sendo uma delas o aumento da sua porosidade, principalmente da camada de cobrimento das armaduras, ou ainda na perda total ou parcial da espessura dessa camada.

Assim, a falta de compacidade e a porosidade intrínseca do concreto, associadas a espessuras deficientes de proteção das armaduras, se tornam um fator sinérgico, para o início e a propagação de outras anomalias ainda mais graves e comuns no concreto armado, como o aumento de deformações, de fissuras e de mecanismos físico-químicos de deterioração como é a corrosão das armaduras.

Logo, além da adequada concepção e dimensionamento estrutural, o controle da porosidade do concreto deve estar nas diretrizes de um sistema de qualidade que tenha em vista prevenir processos físico-químicos de deterioração do concreto e das armaduras, pelos riscos de redução da vida útil das obras em serviço e dos impactos econômicos que causam aos usuários. 


\subsubsection{No âmbito da predição de vida útil das armaduras de aço carbono}

A corrosão de armaduras do concreto pode ser definida como uma interação destrutiva do aço carbono com o ambiente, através de reação eletroquímica e que implica no comprometimento do seu uso em serviço.

Nesse caso, o aço carbono é convertido a um estado não-metálico e perde suas qualidades mecânicas essenciais, tais como resistência à tração, elasticidade e ductilidade (CASCUDO, 1997).

Esse fenômeno da corrosão das armaduras causa a deterioração do aço imerso no concreto e é, acompanhado da expansão volumétrica do metal, gerando tensões significativas no concreto. Assim, a manifestação da corrosão das armaduras ocorre sob a forma de fissuras, destacamento do cobrimento, manchas, redução da seção da armadura e perda da aderência aço/concreto.

A concepção atual de projeto das estruturas de concreto armado pondera que a vida útil e a durabilidade das armaduras seja garantida pelo concreto, que deve promover característica alcalina à fase aquosa da pasta circundante das armaduras, mantendo o aço passivado, através dos seguintes compostos:

- o $\mathrm{Ca}(\mathrm{OH})_{2}$ que constitui 20 a $25 \%$ do volume de sólidos na pasta de cimento Portland comum hidratado;

- o $\mathrm{NaOH}$ e o $\mathrm{KOH}$, cuja concentração de hidrolixas $\left(\mathrm{OH}^{-}\right)$proporciona um valor de $\mathrm{pH}$ maior que 13 à citada pasta.

Entretanto, o meio ambiente circundante do concreto, nas estruturas, tende a diminuir o pH da água de poro da pasta, mediante reações de neutralização dos álcalis indicados. Entre as reações de neutralização, que mais podem comprometer a durabilidade das armaduras, se encontra a carbonatação, que é uma reação química mediante a qual os compostos alcalinos que integram a pasta endurecida de cimento hidratado se combinam com o dióxido de carbono dissolvido em seus poros. A principal conseqüência da carbonatação é que a alcalinidade da fase aquosa dos poros do concreto diminui o $\mathrm{pH}$ para um valor abaixo de 9.

A ocorrência da carbonatação não significa obrigatoriamente o desencadeamento do processo corrosivo. Para ocorrência desse fenômeno, interferem diversas outras variáveis (HELENE,1993). A corrosão eletroquímica, ocorrência típica em armaduras embutidas no concreto, é resultado da formação de pilhas ou células de corrosão devida à presença de uma solução nos poros do concreto em interface com a superfície das barras, que atua 
como eletrólito. Portanto, além da diminuição do $\mathrm{pH}$ provocada pela carbonatação do concreto, para que ocorra a corrosão eletroquímica é necessária a presença de umidade.

A corrosão das armaduras em concreto armado, pelo efeito da carbonatação, pode ser classificada como um caso típico de corrosão eletroquímica generalizada, pois há tendência de áreas anódicas e catódicas se tornarem muito próximas, em regiões com maior alternância de umidade na estrutura.

A nocividade do processo corrosivo de armaduras por carbonatação e umidade no concreto se manifesta, em geral, a médio e longo prazo. Torna cara e problemática a manutenção das obras, podendo comprometer a vida útil em serviço, antes mesmo de ser alcançada a vida útil prevista em projeto. Neste caso, o tempo de carbonatação do concreto resulta inferior ao previsto para que as armaduras sejam mantidas passivas, com corrosão desprezível.

Segundo Gonen; Yazicioglu (2007) a carbonatação é um dos processos que mais causam a deterioração das estruturas nos países de clima tropical e equatorial. Eles estudaram a influência da compactação do concreto fresco na carbonatação do concreto, variando o seu adensamento até o nível de ausência de compactação. A pesquisa então investigou a porosidade resultante nos concretos e a sua resistência à carbonatação acelerada e à carbonatação em atmosfera normal. A porosidade, alterada pela compactabilidade variada do concreto, influiu na carbonatação acelerada e na carbonatação à atmosfera normal, para uma mesma umidade e porcentagem de $\mathrm{CO}_{2}$.

Devido à preocupação com a durabilidade das estruturas de concreto armado, surgiram novas linhas de pesquisa, desde a proposta clássica de Tuutti (1982) e outras mais arrojadas como a de Helene (1993), envolvendo o estabelecimento de vida útil de projeto, de vida útil em serviço e de predição de vida útil residual. Muitos estudos deram origem a diversos modelos que tentam estabelecer o comportamento do concreto quando exposto a ambientes agressivos durante um determinado período, sob determinadas condições de pré-condicionamento, como abordado no Capítulo 2.

Segundo levantamento bibliográfico desta autora, grande parte das pesquisas sobre concreto envolvendo durabilidade, são desenvolvidas em laboratório e parte delas está direcionada à compreensão da carbonatação e das variáveis intervenientes como: cura, tipo de cimento, composição e adensamento do concreto, adições, relação água/cimento e porosidade.

Ainda assim, não se tem até hoje um método brasileiro normalizado para medir a carbonatação do concreto, e a tendência é que isto seja feito por métodos com difícil complexidade operacional para laboratórios correntes do mercado, se forem atendidos os 
preceitos clássicos de carbonatação acelerada, muito bem discutidos e revisados em Pauletti; Possan; Dal Molin (2007).

Até que haja uma mudança de cultura técnica, para melhorar o controle de propriedades do concreto relacionadas à sua durabilidade em serviço, como é o caso da predição da velocidade de carbonatação para a vida útil de projeto das armaduras, a comunidade técnica apenas pode dispor de curvas teórico-experimentais com validade questionável para os concretos do futuro.

Uma das primeiras etapas importantes a evoluir, no momento, é o controle tecnológico do controle do concreto fresco, por todas as razões já bem discutidas desde Mehta; Monteiro (1994) e lembrando que nesta idade se formam a maior parte de poros grandes (macroporos), que são o caminho direto para as substâncias agressivas ao concreto. É importante avaliar, por exemplo, se a medida do teor de ar do concreto fresco pode ser utilizada como propriedade auxiliar na previsão ou controle da resistência à carbonatação, como consta nos objetivos desta dissertação no item 1.2, e que se justifica pelos fatos descritos no item 1.3.

Como se sabe, a prestação de serviços tecnológicos, de dosagem ou de controle da qualidade do concreto para o projeto e a construção de edifícios, está longe de caminhar na velocidade com que evoluem e se modificam os métodos de cálculos, os processos construtivos e ainda mais os materiais atuais com que se formulam os novos concretos prémisturados.

O atual esforço da Engenharia Civil em mudar a cultura técnica de normas prescritivas para especificações de desempenho, pela atual velocidade com que evoluem diversos materiais e sistemas construtivos, precisa ser direcionado também às normas de produção do concreto estrutural, pela evolução da NBR 12655 (2006) - Preparo, Controle Recebimento do Concreto.

As especificações prescritivas podem impedir que os produtores de concreto sejam mais coerentes com o consenso internacional para minimizar o consumo de energia nos materiais de construção, pelas dificuldades de enquadrarem em normas convencionais os concretos especiais, de dosagem e composição alternativa que podem incluir: materiais cimentícios, aditivos, cimentos misturados, polímeros, fibras e filer mineral.

Assim, se forem adequadamente elaboradas as especificações de desempenho, por requisitos, critérios e respectivos métodos de verificação, isto pode melhorar a qualidade do concreto, mais explicitamente se essas especificações estiverem introduzidas desde a seleção e o estudo de dosagem, para serem depois verificadas durante as aplicações do concreto em campo. Nesta etapa é importante que possa ser efetuado o controle de 
recebimento das misturas pré-definidas, com o aval de tecnologista de concreto e do calculista responsável pela obra.

De acordo com Hooton et al. (2006), enquanto a resistência à compressão é um bom indicador de resistência de carga, ela não é o melhor indicador da qualidade e durabilidade do concreto. Todavia, normas recentes revisadas no Brasil não puderam ainda fazer diferente, e as especificações de concretos, mesmo em meios mais agressivos, é ainda empírica e deixa margem a muitas dúvidas o próprio texto. Assim, a falta de métodos de ensaios adequados e relacionados ao desempenho e durabilidade, é um dos fatores que inibe a mudança das especificações prescritivas para especificações de desempenho.

Logo, este trabalho deseja também contribuir para serviços tecnológicos relativos ao concreto estrutural, estimulando pesquisas sobre métodos e critérios que possam ser usados de modo mais acessível por laboratórios do mercado, para a dosagem e a préqualificação de concretos para ambientes marítimos e urbanos. Isto também deve ampliar a atuação profissional dos engenheiros civis e de materiais, na cadeia da produção e do controle de qualidade do concreto.

Concluindo, outras justificativas e expectativas para o alcance deste trabalho, é que possa estimular o registro e a memória técnica do ambiente construído pela indústria do concreto, em cada região do país. Observar que a contínua e adequada caracterização do concreto e do aço, em obras no tempo presente, pode mudar paradigmas no controle tecnológico desses materiais, facilitar ajustes e avanços nos modelos de envelhecimento e de deterioração das estruturas e na metodologia de atendimento à vida útil de projeto, e tudo isto contribuir para a durabilidade e manutenção econômica de obras futuras, com impactos mínimos ao meio ambiente. Isto é consiliência.

\subsection{OBJETIVOS}

O objetivo geral desta pesquisa foi contribuir para a evolução do controle tecnológico de concretos estruturais com vistas à proteção de armaduras de aço carbono, sujeitas à perda de passivação por carbonatação do concreto, pelo estudo de métodos e medidas auxiliares para controlar essa propriedade.

O programa experimental objetivou amostrar e caracterizar, em campo um lote de concreto estrutural pré-misturado da classe 30 e de abatimento plástico, com vistas a relacionar as suas propriedades desde o estado fresco com a resistência à carbonatação, e os seguintes objetivos específicos orientaram a metodologia: 
a) Prosseguir estudos de cura acelerada do concreto em temperatura amena, para condições de campo, a partir do método tipo A da ASTM C 684 (1999), aumentando a sua duração em relação à pesquisa inicial conduzida por Cavalcanti Filho (2010);

b) Avaliar se propriedades relacionadas ao teor de ar do concreto fresco poderia auxiliar a controlar a sua resistência à carbonatação por diferentes métodos acelerados;

c) Estudar método inovador de controle de área carbonatada do concreto, por dois programas de análise de imagem, com vistas a um futuro entendimento de como as relações entre área e volume governam esse processo, além das variáveis características intrínsecas ao material.

\subsection{PESQUISAS SOBRE O TEMA}

A carbonatação vem sendo pesquisada há cerca de 40 anos, em alguns países. No Brasil, estudos ocorreram a partir dos anos 90 (Nepomuceno, 1992; Isaia, 1995; Kazmierczak, 1995), com ensaios acelerados em concentrações de $\mathrm{CO}_{2}$ sempre acima de $1 \%$. Muitos pesquisadores nacionais e estrangeiros têm publicado sobre o tema.

Os principais agentes atuantes no mecanismo de carbonatação são o $\mathrm{CO}_{2}$ e a água. Esta permite o dióxido de carbono $\left(\mathrm{CO}_{2}\right)$ se dissolver e reagir com o hidróxido de cálcio $\left(\mathrm{Ca}(\mathrm{OH})_{2}\right)$ presente na pasta de cimento, para resultar em carbonato de cálcio $\left(\mathrm{CaCO}_{3}\right)$ e água, alterando propriedades físico-mecânicas do concreto, como destaca o estado da arte de Jerga (2004).

De acordo com Dal Molin et al. (2007), sob condições de exposição normais, a carbonatação ocorre de forma lenta, sendo necessário, em função do tempo que as estruturas levam para carbonatar naturalmente, o uso de ensaios acelerados. Não há consenso, entretanto, com relação à forma como estes ensaios devem ser realizados.

$\mathrm{Na}$ visão atual de todos os especialistas, a carbonatação avança da superfície para o interior do concreto, ou seja, entendem que o gás carbônico penetra na estrutura de poros do concreto por uma diferença de concentração que gera mecanismos de difusão, através de poros capilares interconectados, microfissuras ou bolhas de ar (CAMARINI et al. 2005).

Os fatores clássicos e de consenso entre pesquisadores, que influenciam a carbonatação, são os ambientais e as características do concreto. Os fatores ambientais são: concentração de $\mathrm{CO}_{2}$, temperatura e umidade relativa, reguladas por clima e incidência 
de chuvas local. As características do concreto são: relação água/cimento, tipo e teor de cimento, aditivos e adições, granulometria dos agregados e tipo de cura, pois definem a sua microestrutura e grau de porosidade.

Assim, alguns desses fatores que podem influenciar na resistência à carbonatação do concreto podem ser detectados no estado fresco, já que macroporos se formam a partir daí. Em análises complementares de resultados de pesquisas com argamassas estruturais de diversas formulações do mercado de São Paulo/SP publicadas em Bertolo; Selmo et al. (2007), constatou-se haver considerável influência do teor de ar no estado fresco de argamassas com os resultados de profundidade de carbonatação por ensaios acelerados, com ciclagem de umidade e temperatura, e isto estimulou a proposição da presente dissertação.

Há uma evolução certa da carbonatação para concretos mais porosos. Partindo da condição que o concreto é um material poroso, a velocidade com que a frente de carbonatação avança depende da estrutura da sua rede de poros, bem como das suas condições de umidade (BAKKER², 1988 apud MEIRA et al. 2006).

Pleau; Pigeon et al. (2001) estudaram muitos ensaios e condições referentes às medidas de ar e suas características no concreto endurecido, inclusive através de exames de análise de imagem, baseados na microscopia do concreto de acordo com a ASTM C 457 $(1999)^{3}$. Através de análises, os pesquisadores definiram também que o ar é um parâmetro muito conveniente, porque pode ser facilmente e rapidamente medido diretamente no concreto fresco, porém não definiram como seriam feitas essas medidas, estudaram somente como medir em concreto endurecido.

Caso haja comprovação dos efeitos do teor de ar na profundidade de carbonatação, é possível então, passar a detectar essas características através de análise e ensaios auxiliares do concreto fresco, e assim, antever e minimizar seus efeitos no concreto endurecido, aumentando a confiabilidade da previsão da sua resistência à carbonatação e, portanto, da qualidade do material.

Hooton et al. (2006), em seu artigo descrevem que as especificações prescritivas para o concreto serviram suficientemente bem no passado, quando a indústria como um todo era

\footnotetext{
2 BAKKER, R. F. M. Initatio period. In: SCHIESSL, P. (Ed.) Corrosion of steel in concrete. New York, RILEM / Chapman and Hall, p. 22-55, 1988.

3 Recommended practice for the microscopical determination of air void content and parameters of the air void system in hardened concrete. ASTM C457-82a, Annual Book of ASTM Standards 04.02. Philadelphia, PA: ASTM; 1999.
} 
muito menos sofisticada do que é agora, porém o estabelecimento de atuais especificações normativas estão longe de garantir que um concreto seja durável.

O pré-requisito para obtenção de um concreto uniforme e de boa qualidade é a exata dosagem dos materiais (SCHOLZ; SEIDLER; JACOSKI; 2008).

Vários pesquisadores, como os citados a seguir e muitos outros, estudaram diferentes dosagens e sua influência na despassivação das armaduras de concreto por carbonatação e o fenômeno da carbonatação propriamente dita, relacionada com outras propriedades físicas e mecânicas e ainda a dos materiais utilizados na dosagem. Mas nenhum discutiu ou analisou a influência do teor de ar no concreto fresco, na resistência à carbonatação do concreto:

- NUNES (1998) - avaliou a influência da dosagem na carbonatação dos concretos;

- REGATTIERI (1998) - avaliou a influência da dosagem do concreto na absorção capilar e penetração de íons cloreto;

- CUNHA (2001) - estudou a despassivação das armaduras de concreto por ação da carbonatação;

- MOREIRA; FIGUEIREDO; HELENE (2001) - avaliaram a influência de alguns agentes agressivos na resistência à compressão de concretos amassados com diferentes tipos de cimentos brasileiros;

- MEDEIROS (2002) - pesquisou a respeito do efeito das propriedades de argamassas de reparo na proteção de armaduras em estruturas de concreto por carbonatação;

- PESSÔA (2002) - estudou a influência do consumo de cimento na corrosão de armaduras em argamassas de cimento sujeitas à carbonatação;

- PAULETTI (2004) - fez uma análise comparativa entre os procedimentos para ensaios acelerados de carbonatação;

- CAMARINI et al. (2005) - avaliaram a carbonatação natural em concretos produzidos com e sem sílica ativa submetidos a diferentes procedimentos de cura;

- BAUER et al. (2006) - estudaram a carbonatação de concretos produzidos no DF;

- MONÇÃO et al. (2006) - analisaram a carbonatação natural com diferentes traços;

- CADORE et al. (2007) - avaliaram ensaios acelerados e naturais na carbonatação de concretos com alto teores de adição mineral;

- GASTALDINI; ISAIA; GOMES (2007) - estudaram a penetração de cloreto e carbonatação em concretos com cinza de casca de arroz e ativadores químicos;

- HOPPE FILHO (2008) - avaliou a eficiência da adição de cal hidratada em reduzir a taxa de carbonatação em concreto com alto teor de cinza volante; 
- PAULeTtI (2009) - estudou estimativas de profundidade de carbonatação natural a partir de ensaios acelerados e modelos de predição.

Assim, através da coletânea de bibliografia levantada para fundamentar esta dissertação e a ser discutida no Capítulo 2, não foram encontrados outros trabalhos com esta mesma abordagem.

Porém, existem muitos trabalhos cujas medidas e resultados forneceram subsídios para antecipar e delinear as expectativas do programa experimental desta dissertação.

Além do trabalho de Bertolo; Selmo et al. (2007) com argamassas estruturais, procurou-se outros feitos diretamente com concretos de resistência normal, em que houvesse ocorrido a determinação experimental do teor de ar do concreto fresco. Como melhor exemplo, pode-se citar as dissertações de Regattieri (1998) e de Cunha (2001), pois os respectivos programas experimentais contêm, de forma detalhada, resultados de algumas das variáveis de interesse nesta pesquisa.

A Figura 01 e Figura 02 mostram um comparativo "relação água/cimento $\mathrm{x}$ teor de ar", dos resultados do trabalho de Regattieri (1998) e Cunha (2001). Pode-se avaliar o comparativo entre relação água/cimento $x$ teor de ar, em ambos os casos, que o teor de ar é sensível ao aumento da relação água/cimento, para traços de concreto com consistência plástica, abatimento $(80 \pm 10) \mathrm{mm}$.

A Figura 03 faz um comparativo entre os dados de Regattieri (1998) e Cunha (2001) quanto à relação água/cimento e teor de ar, em que há um aumento significativo do teor de ar, com o aumento da relação água/cimento, independente da dosagem utilizada.

A Figura 04 faz um comparativo entre consumo de cimento e teor de ar dos resultados do trabalho de Regattieri (1998). Observa-se que quanto maior o consumo de cimento, menor é o teor de ar obtido no concreto fresco, sendo isto lógico do ponto de vista físico.

Na Figura 05, tem-se uma análise comparativa dos dados de Cunha (2001) e referemse às medidas de espessura média de carbonatação para concretos com três tipos de cimento. Quanto maior o teor de ar, maior a espessura carbonatada para os três tipos de cimento. Para os de cimento CP III, foram observadas maiores espessuras médias de carbonatação e maior de teor de ar, tanto para a/c 0,50 quanto para a/c 0,65.

As análises das Figuras 1 à Figura 5 estão destacadas de forma precedente ao estado da arte sobre carbonatação, no Capítulo 2, pois são uma contribuição inédita desta autora e corroboram a importância de pesquisar o teor de ar do concreto fresco, como propriedade auxiliar para controlar a carbonatação do concreto, objetivo específico do programa experimental destacado no item 1.2. Lembrar que há grandes dificuldades em controlar a 
relação água/cimento do concreto fresco, embora haja muitos métodos para este fim, como bem levantado e resumido desde Tango (1983).

Assim, espera-se que os exemplos deste item tenham ilustrado como o teor de ar é propriedade diretamente relacionada à relação a/c do concreto fresco, mas ainda não objetivamente equacionada no controle da resistência à carbonatação de concretos estruturais e sequer é discutida sob esse aspecto, em publicações recentes como a de Isaía (2005) ou de Mehta; Monteiro (2008).

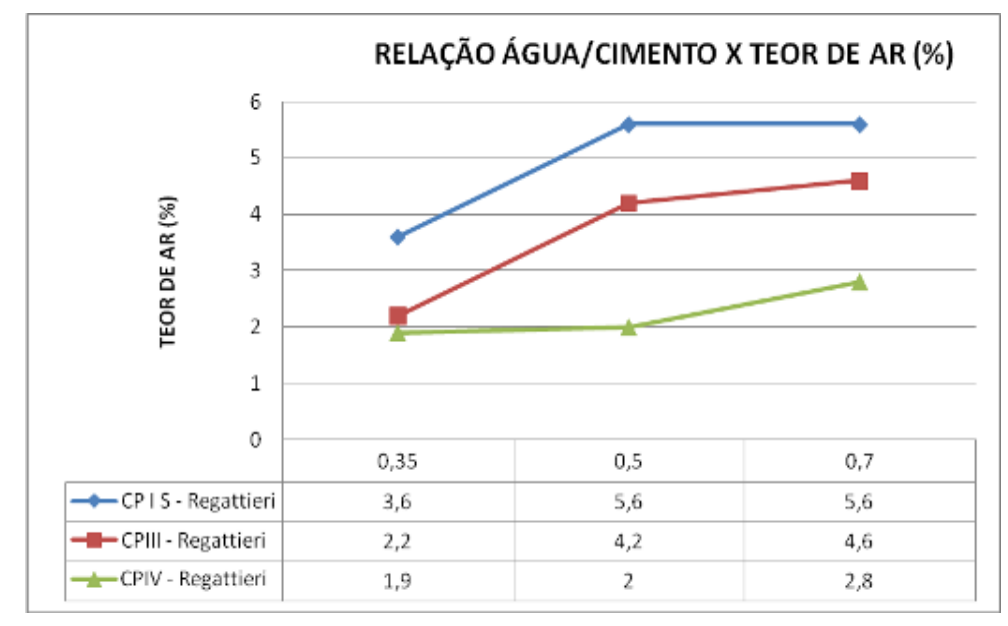

FIGURA 1- Comparativo entre relação água/ cimento e teor de ar do concreto fresco. Dados de Regattieri (1998) interpretados por esta autora.

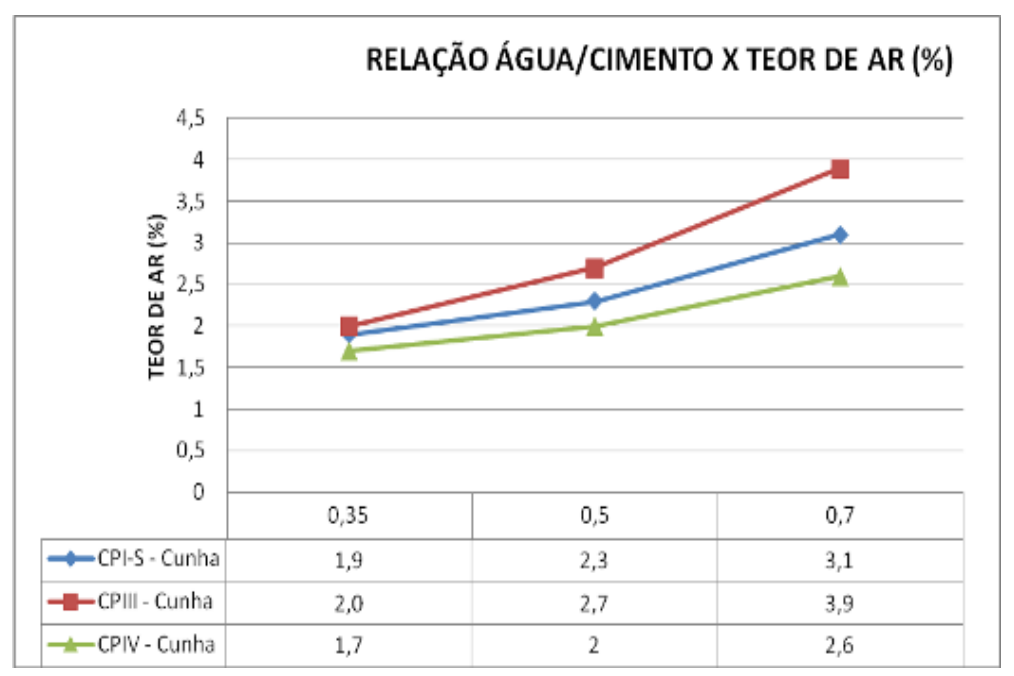

FIGURA 2- Comparativo entre relação água/cimento e teor de ar do concreto fresco. Dados de Cunha (2001), interpretados por esta autora. 


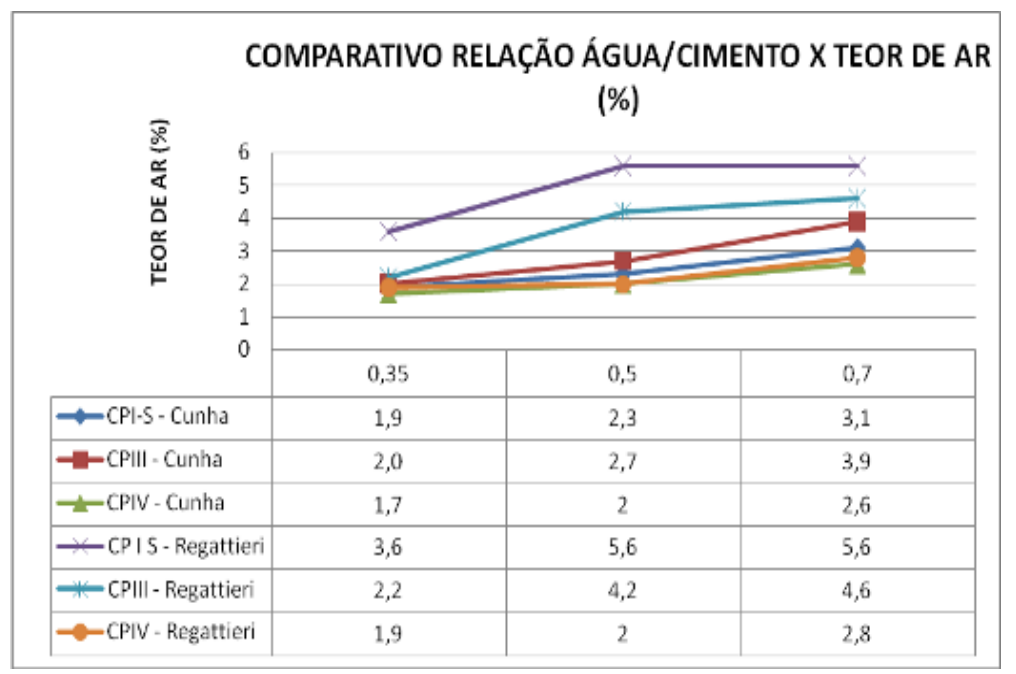

FIGURA 3 - Comparativo entre relação água/cimento e teor de ar. Dados de Regattieri (1998) e Cunha (2001), interpretados por esta autora.

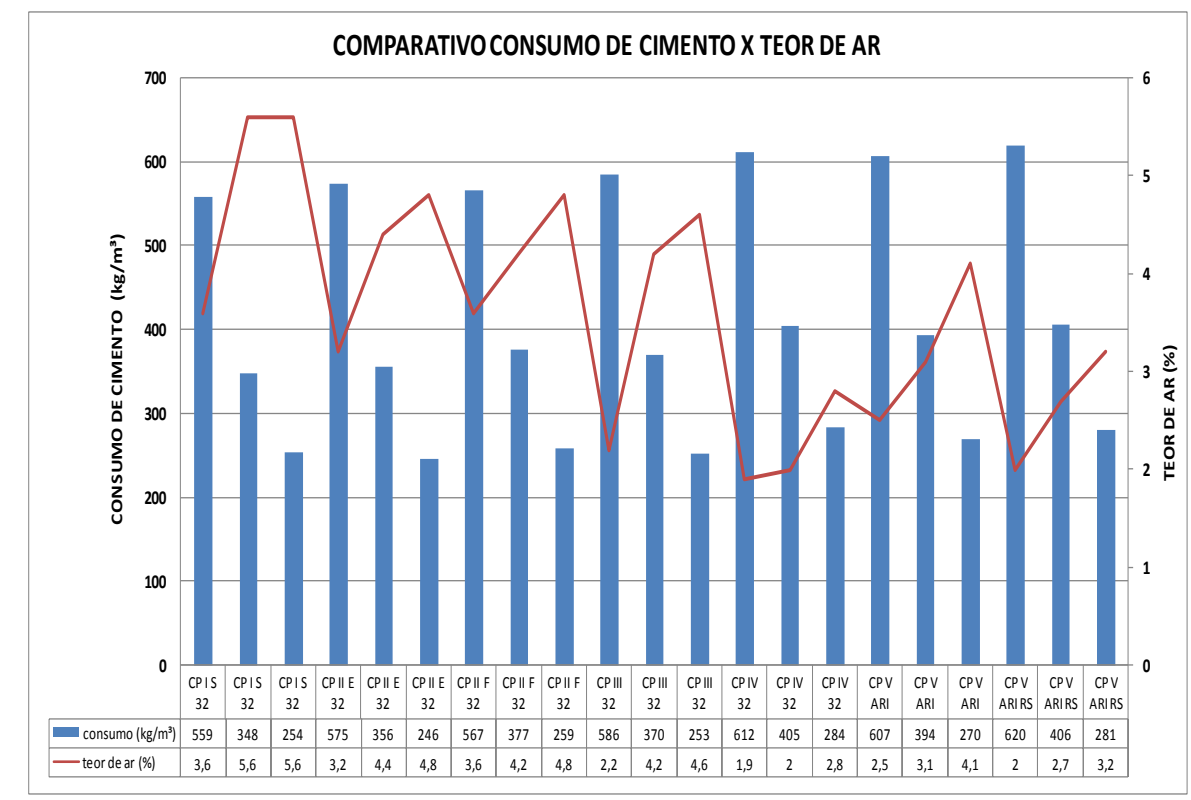

FIGURA 4 - Comparativo entre consumo de cimento e teor de ar do concreto fresco. Dados de Regattieri (1998), interpretados por esta autora. 


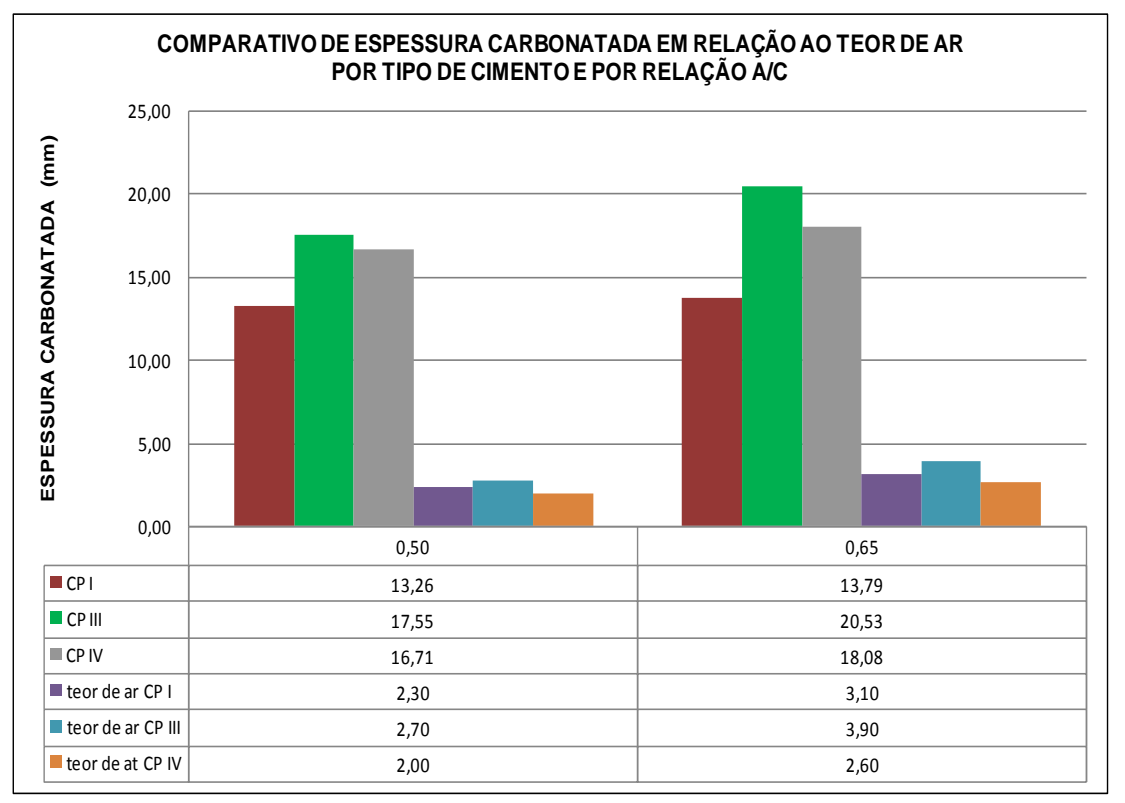

FIGURA 5 - Comparativo de espessura carbonatada por tipo de cimento e por relação a/c. Dados de Cunha (2001), interpretados por esta autora.

\subsection{ESTRUTURA DA DISSERTAÇÃO}

A presente dissertação está dividida em seis capítulos.

Neste primeiro capítulo, é apresentada a introdução que engloba as justificativas, os objetivos, as pesquisas sobre o tema e a estrutura do trabalho, aqui explicada.

No capítulo 2 é abordada a carbonatação do concreto. São destacados da literatura os trabalhos que discutiram os conceitos básicos do fenômeno, os modelos de previsão, as variáveis influentes intrínsecas e extrínsecas ao concreto e, no final do capítulo, é apresentada uma revisão de métodos e medidas para avaliar a carbonatação.

No capítulo 3 é abordado o programa experimental da pesquisa, os procedimentos e métodos utilizados, desde a amostragem do concreto, ensaios no estado fresco e no estado endurecido.

No capítulo 4, são apresentados os resultados dos ensaios, as correlações entre todas as propriedades medidas, análises estatísticas e discussões finais.

No capítulo 5, são apresentadas as considerações finais e conclusões deste estudo, as sugestões para trabalhos futuros e os trabalhos por ora já divulgados ao meio técnico.

As referências bibliográficas são apresentadas no capítulo 6, e há cinco apêndices ao final deste trabalho. 


\section{A CARBONATAÇÃo do CONCRETO E A VIDA ÚtIL de PROJETO DAS ARMADURAS}

Como salientado no Capítulo 1, a corrosão do aço carbono de armaduras é considerada por muitos, como o mais grave e freqüente problema em estruturas de concreto armado, pois além de se constituir em um problema técnico-econômico, é um grande desperdício de recursos naturais e de ocorrência geográfica local e mundial.

Um dos principais mecanismos de envelhecimento natural do concreto ou causado por falhas na sua produção e aplicação em obras, que podem causar a corrosão de armaduras, é a sua carbonatação em presença de umidade.

A carbonatação do concreto é um fenômeno natural até hoje compreendido como resultante da penetração e de dissolução de dióxido de carbono pela sua rede interna de poros e que reage com substâncias alcalinas existentes na água dos poros, crescendo em espessura de reação até atingir as armaduras e proporcionando a sua despassivação.

O período em que se pode contar com a alcalinidade elevada do eletrólito nos poros do concreto, para passivar as armaduras e manter o seu processo de estabilidade eletroquímica controlada, foi designado por Tuutti ${ }^{4}$ (citado por diversos pesquisadores) para ser chamado de "período de iniciação da corrosão" e em Helene (1993) foi proposto para ser interpretado como vida útil de projeto das armaduras.

Assim, para o caso de estruturas localizadas em regiões não-litorâneas, o mecanismo de degradação que causa maiores problemas às armaduras das estruturas de concreto é a perda de passivação pela carbonatação. Isto, em especial, quando a carbonatação é acompanhada de condições propícias ao desenvolvimento da corrosão eletroquímica do aço, quais sejam, diferença de potencial eletroquímico, oxigênio e umidade. A velocidade de ocorrência deste mecanismo pode talvez ser maior nos grandes centros urbanos, como em São Paulo/SP, pelo fato de a poluição ser mais acentuada. Mas há outras cidades não litorâneas e nem densamente ocupadas, como Goiânia/GO ou Brasília/DF, onde se sabe também há preocupações com a vida útil de armaduras pela carbonatação do concreto.

Neste capítulo, está apresentada uma revisão bibliográfica dos conceitos e pesquisas relacionadas à carbonatação, aos fatores intervenientes para que ocorra o fenômeno nas estruturas e às possíveis conseqüências que a mesma pode ocasionar ao concreto armado.

\footnotetext{
4 TUUTTI, K. Corrosion of steel in concrete. Sweden: CBI, 1982. 468p.
} 


\subsection{A PREVISÃo da VIDA ÚtIL de ARMAduRAs POR tAXA DE CARBONATAÇÃO DO CONCRETO}

\subsubsection{A durabilidade e a deterioração de estruturas}

As armaduras inseridas nos componentes estruturais de concreto estão, em princípio, protegidas e passivadas contra corrosão. Essa proteção é proporcionada pelo concreto de cobrimento, que forma uma barreira física ao ingresso de agentes externos e assegura a proteção química conferida pela alta alcalinidade da solução aquosa presente nos poros do concreto (HELENE, 1993).

A perda ou ruptura dessa proteção, ainda que localizada, poderá desencadear a progressiva e crescente deterioração de partes da estrutura de concreto. Entre os fatores que contribuem para a destruição dessa proteção natural, ou para a aceleração da corrosão, podem citar-se, fissuração, solicitações cíclicas, execução inadequada, materiais de natureza diversa, ciclos de molhagem e secagem, variações de temperatura e atmosferas agressivas (HELENE, 1993). A carbonatação no concreto é um dos principais mecanismos iniciadores da corrosão.

Assim, a durabilidade das estruturas de concreto armado pode ser analisada sob abordagens distintas, no que diz respeito à interface e ao desempenho dos dois materiais principais envolvidos. Do ponto de vista do concreto de cimento Porltand, do ponto de vista das armaduras de aço carbono e como sistema construtivo integrado pelos dois materiais, com requisitos, critérios e métodos específicos conforme a exigência focada seja a segurança estrutural, a funcionalidade ou a durabilidade da obra.

Não obstante a abordagem considerada, a ênfase final deve ser a mesma, ou seja, de visão holística e integrada desses materiais e por isto conhecer e aprofundar mecanismos de carbonatação e de corrosão de forma isolada inicialmente e depois integrada, é muito importante para o avanço em tecnologias de projeto, produção e manutenção das estruturas.

A influência e a necessidade de uma visão sistêmica para a durabilidade das estruturas de concreto podem ser visualizadas por meio do resumo esquemático na Figura 6, que demonstra as variáveis que influenciam na durabilidade desde itens de projeto, quanto aos materiais componentes, execução da obra e condições de cura do concreto. Todas essas variáveis influenciam na natureza e distribuição dos poros do concreto, desencadeando mecanismos de transporte para sua deterioração. 


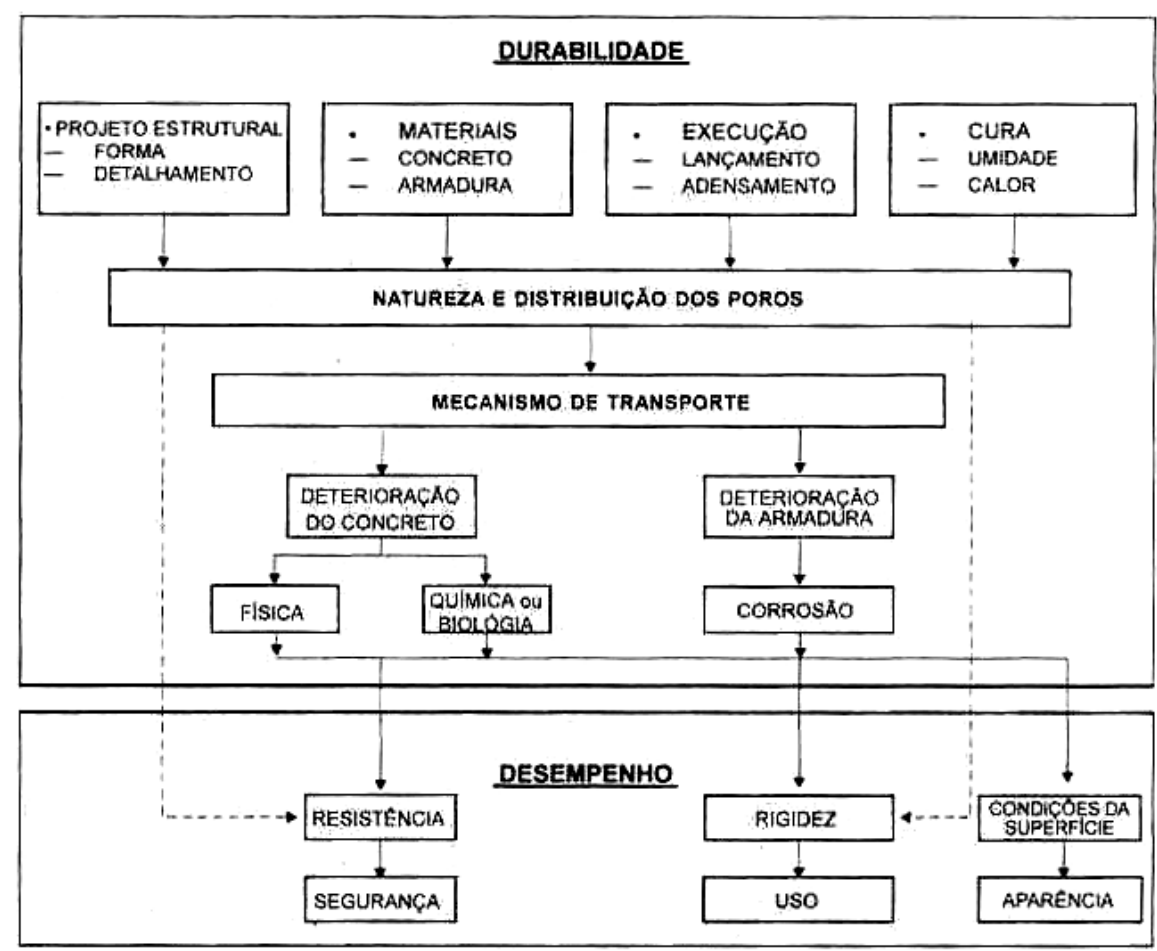

FIGURA 6 - Durabilidade e desempenho do concreto (CEB 51989 adaptado por SILVA, 1995).

A deterioração do concreto contendo armaduras de reforço (armado e protendido) é atribuída, geralmente, ao efeito combinado de mais do que uma única causa; entretanto, a corrosão do aço embutido, invariavelmente, é uma das principais.

Segundo Mehta; Monteiro (2008), um levantamento 6 em edifícios que entraram em processo de ruína na Inglaterra, de 1974 a 1978, mostrou que a causa imediata do colapso em pelo menos oito das estruturas de concreto foi a corrosão do aço da estrutura armada ou protendida. As estruturas tinham de 12 a 40 anos de idade na época do desmoronamento, com exceção de uma que tinha apenas dois anos.

Quando a armadura está protegida do ar por uma adequada espessura de cobrimento, com concreto de baixa permeabilidade, a expectativa é de que a corrosão do aço e outros problemas associados a ela não ocorram. Isso não é completamente verdadeiro na prática e fica evidente pela alta freqüência com que estruturas de concreto armado e protendido começam a apresentar deterioração prematura devida à corrosão do aço, mesmo quando adequadamente executadas (MEHTA; MONTEIRO, 2008). Na Figura 7, esses autores

5 COMITÉ EURO-INTERNATIONAL DU BETÓN - Durable Concrete Structure Design Guide, Bulletin d'Information, 2 ed. Lausane, n. 182, 1989.

${ }^{6}$ Building Research Establishment News, Her Majesty's Statinery Office, London, Winter 1979. 
propõem um modelo holístico da deterioração do concreto pelos efeitos ambientais mais comuns.

De acordo com esse modelo, um concreto com compacidade inadequada, mesmo sendo inicialmente impermeável, pode gradativamente apresentar a conexão de microfissuras e poros em seu interior, por efeito de fadiga ambiental, e isto resultar em uma rede interconectada de caminhos que cheguem à sua superfície.

O modelo da Figura 7 destaca ainda que a exposição do concreto a ciclos de molhagem-secagem facilitam a propagação de microfissuras normalmente pré-existentes na zona de transição, isto é na interface entre a pasta de cimento e as partículas dos agregados graúdos. Logo, a consideração deste processo de deterioração deveria estar mais presente nas pesquisas acadêmicas de qualificação de concretos e não somente para estudos de corrosão de armaduras, como tem sido classicamente empregado.

Como já visto os danos causados ao concreto resultantes da corrosão da armadura se manifestam na forma de expansão, fissuração e eventual lascamento do concreto de cobrimento. Além da perda de cobrimento, um elemento de concreto armado pode sofrer dano estrutural devido à perda não só de aderência entre o aço e o concreto, como também de área de seção transversal da barra - às vezes a ponto de tornar o colapso estrutural inevitável (MEHTA; MONTEIRO, 2008).

O cobrimento das armaduras está intimamente ligado à durabilidade da estrutura de concreto armado e concreto protendido, portanto ele deve ter uma espessura adequada, alta compacidade, adequado teor de argamassa e homogeneidade. Esse cobrimento tem como finalidade constituir uma barreira física à entrada de agentes agressivos e uma barreira química, a alcalinidade do concreto, que garante a passivação da armadura (SILVA, 2007).

Segundo Cascudo (2005), todos os aspectos da tecnologia do concreto que contribuem para obter um produto de maior compacidade e de menor índice de vazios, contendo uma porosidade que minimize o transporte de íons, gases e líquidos através de sua estrutura interna, são relevantes sob o ponto de vista da prevenção à corrosão de armaduras.

As normas para projeto e execução de estruturas de concreto prescrevem diversos requisitos e critérios a serem atendidas em ambas as etapas do processo construtivo e isto está resumido mais adiante neste capítulo. 


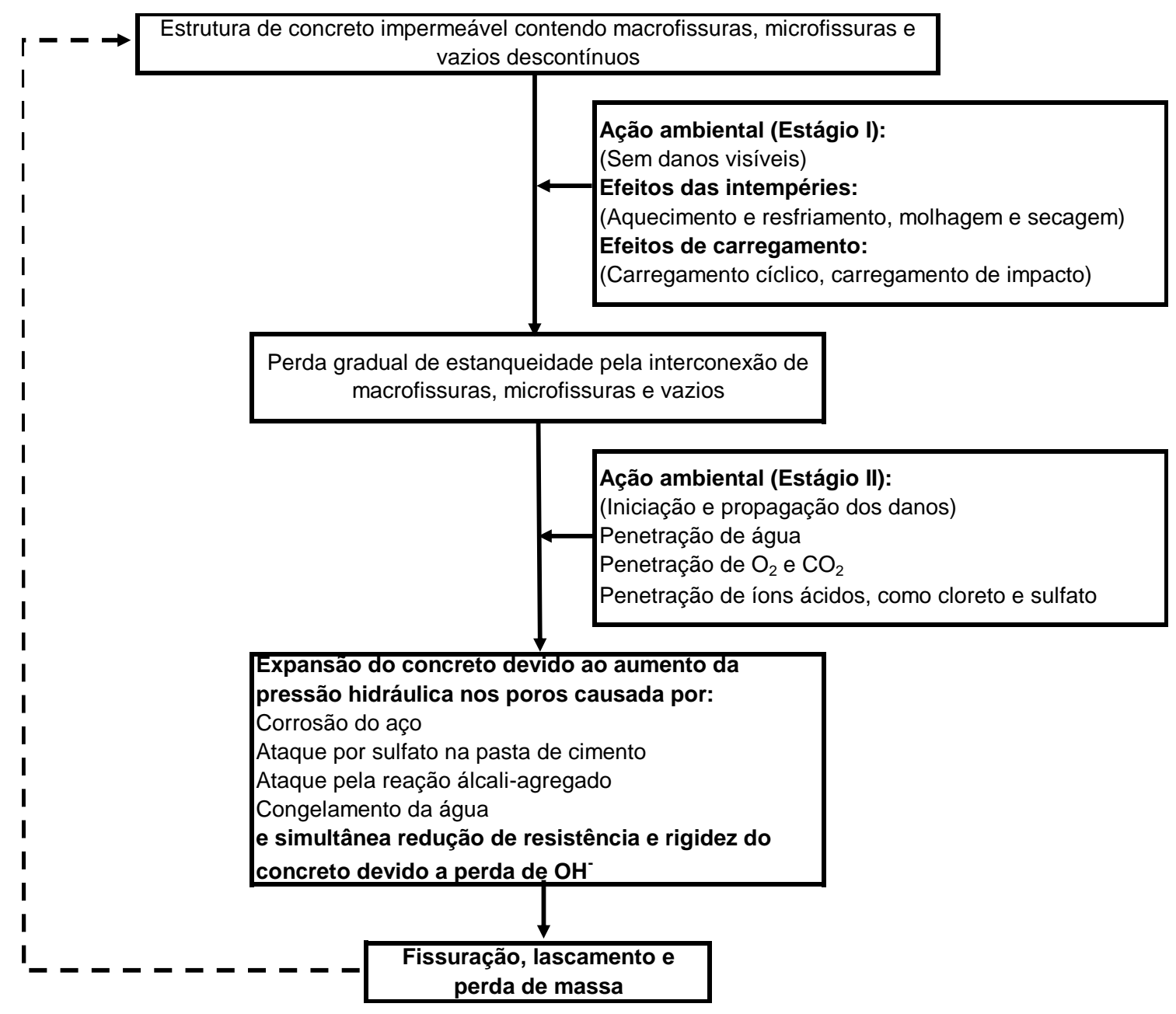

FIGURA 7 - Um modelo holístico da deterioração do concreto a partir dos efeitos ambientais mais freqüentes (MEHTA; MONTEIRO, 2008).

No escopo deste item, o importante é destacar que a carbonatação do concreto de cobrimento das armaduras é fator decisivo no processo de deterioração e envelhecimento das estruturas para atmosferas não-marítimas. Nesses casos, a comunidade técnica e normas atuais admitem cada vez mais esse processo como determinante da vida útil de projeto das armaduras e extensivo à própria estrutura, conforme a norma, as circunstâncias e o momento de desenvolvimento e finalização do projeto estrutural.

Este modelo foi gradativamente difundido e ampliado no Brasil, a partir da proposição inicial de Tuutti $^{4}$ (Figura 8), em Andrade (1992) e depois por Helene (1993), Cascudo (1997), Silva (1995) e Fortes (1995), entre outros. Tuutti ${ }^{4}$ divide o processo corrosivo das armaduras em duas fases: iniciação e propagação. A fase de iniciação vai da execução da estrutura até o agente agressivo alcançar a armadura e despassivá-la; a propagação consiste no desenvolvimento da corrosão até um limite inaceitável. Helene (1993), aliás, ampliou e detalhou o conceito de Tuutti $^{4}$ para a fase de propagação da corrosão, mas foge ao escopo 
deste trabalho abordar.

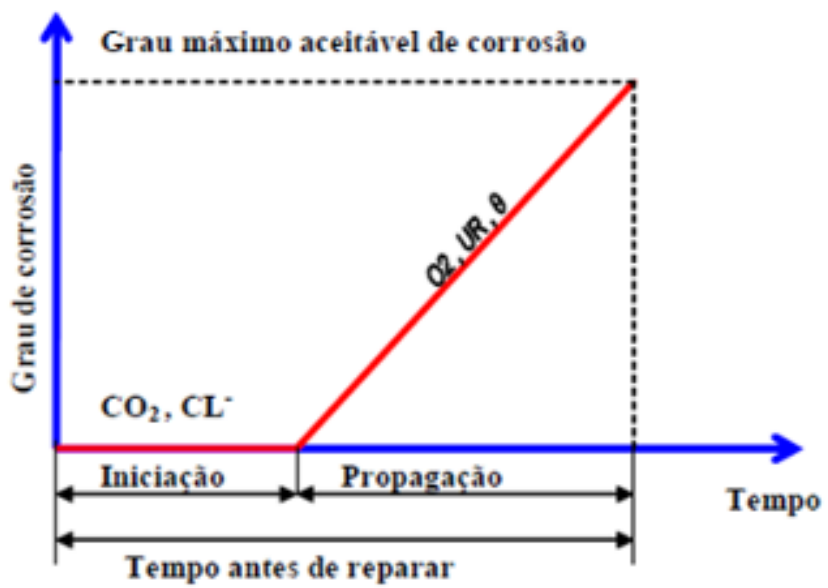

FIGURA 8 - Modelo de vida útil de Tuutti $^{4}$ (citado por ANDRADE, 1992).

\subsubsection{A corrosão de armaduras}

$\mathrm{O}$ aço envolto pela pasta de cimento Portland hidratada forma rapidamente uma camada de passivação delgada de óxido que lhe proporciona uma proteção completa contra a reação com oxigênio e com a água, isto é, contra a corrosão ou formação de ferrugem. Esse estado do aço é denominado passivação. A preservação da passivação é condicionada por um $\mathrm{pH}$ adequadamente alto da água dos poros em contato com a camada passivadora (NEVILLE, 1997).

Assim, o filme passivante é a grande defesa do aço no interior do concreto e a garantia de que não será corroído. Entretanto, o filme pode ser destruído, segundo Cascudo (1997), por duas condições básicas:

a) presença de íons de cloreto em quantidade suficiente; podendo ser tanto de fonte externa e atingir a armadura por difusão, quanto estar contido no concreto devido à água ou agregados contaminados, ou mesmo por aditivos aceleradores de pega a base de cloreto de cálcio $\left(\mathrm{CaCl}_{2}\right)$; e

b) diminuição da alcalinidade do concreto; pode ser devido às reações de carbonatação ou por penetração de substâncias ácidas no concreto. Em casos especiais pode ser oriunda da lixiviação do concreto, em que a solução alcalina intersticial é lavada pelo ataque das águas, sendo neste caso necessária certa pressão hidráulica. 
A ocorrência da carbonatação não significa obrigatoriamente o desencadeamento do processo corrosivo. Para a ocorrência da corrosão do aço, interferem diversas outras variáveis (HELENE, 1993). A corrosão eletroquímica, de ocorrência típica em armaduras embutidas no concreto, é resultado da formação de pilhas ou células de corrosão devida à presença de uma diferença de potencial nas barras e em presença de um eletrólito aquoso aerado, nos poros do concreto que as envolve. Portanto, além da diminuição do pH provocado pela carbonatação do concreto, para que ocorra a corrosão eletroquímica é necessária a presença de umidade. De acordo com Cunha; Helene (2001), a diferença de potencial pode ser causada pela diferença de umidade, aeração, concentração salina, tensão do concreto e/ou no aço, impurezas no metal, heterogeneidades inerentes ao concreto, pela carbonatação ou pela presença de íons.

Assim, a corrosão propriamente dita é uma reação eletroquímica e ocorre, como na maioria dos processos corrosivos, com presença de água ou em ambiente úmido (HELENE, 1986).

Conforme observado na Figura 9, as reações químicas envolvidas no processo corrosivo são: reação de oxidação ou anódica e reação de redução ou catódica e apenas estão ilustradas neste tópico para introduzir mais alguns aspectos importantes sobre este mecanismo. Segundo citação de Cunha (2001), o processo de corrosão desenvolve-se, simplificadamente, da seguinte maneira:

- Nas regiões corroídas (zonas anódicas), ocorrem as reações principais de dissolução do metal (oxidação). Esse processo ocorre na superfície do metal;

- Nas regiões não corroídas (zonas catódicas) para o caso das armaduras do concreto, ocorrem reações de redução de oxigênio, esse processo ocorre na interface entre o metal e o eletrólito e depende da disponibilidade de oxigênio dissolvido e do $\mathrm{pH}$ da interface metal-eletrólito.

A corrosão das armaduras em concreto armado, pelo efeito da carbonatação, pode ser classificada como um caso típico de corrosão eletroquímica generalizada. 


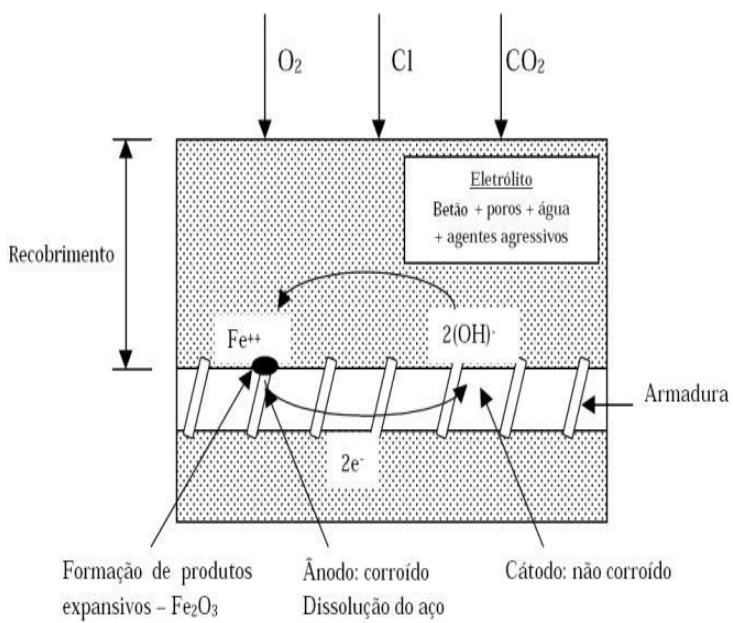

FIGURA 9 - Célula simplificada de corrosão (ANDRADE, 2001).

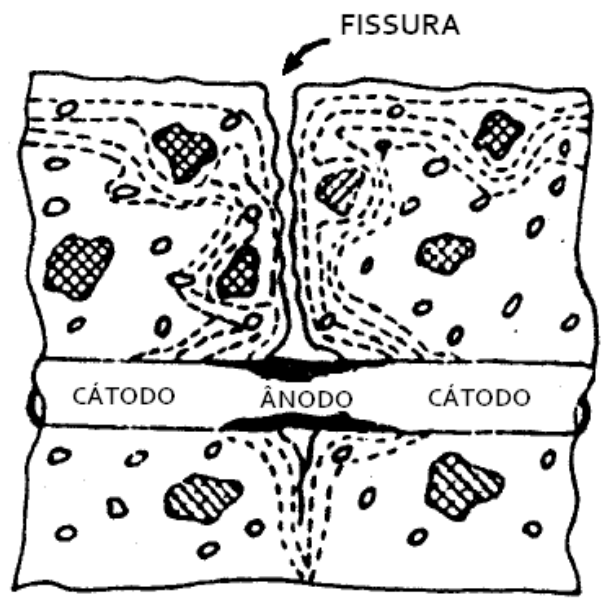

FIGURA 10 - Corrosão numa fissura (FIGUEIREDO et al. 1994).

Assim, quando a carbonatação aumenta e o pH menor atinge as proximidades da superfície do aço da armadura, a película protetora é alterada ou mesmo perdida e pode ocorrer a corrosão do aço, desde que estejam presentes o oxigênio, a umidade e uma diferença de potencial necessários para as reações de corrosão. Por esse motivo, é importante conhecer a profundidade de carbonatação e, especificamente, a velocidade com que a frente de carbonatação avança no concreto, o que está sendo discutido por alguns modelos, e está apresentado neste capítulo.

Cabe ser ainda observado que, se houver fissuras no concreto com origem em processos físicos, mecânicos ou químicos de deterioração, o ingresso de umidade e $\mathrm{CO}_{2}$ pode avançar localmente a partir dessas fissuras, Figura 10, sendo esta situação há muito discutida e até hoje estudada, como na tese de Silva (2007). Em muitos casos, com carbonatação parcial, pode haver corrosão mesmo com a frente de carbonatação completa a alguns milímetros da superfície do aço (NEVILLE, 1997).

Danos causados pela corrosão de armaduras por carbonatação manifestam-se sob a forma de expansão (em decorrência dos produtos finais de corrosão que possuem um volume maior que a armadura original), fissuração, destacamentos do cobrimento, perda de aderência e redução significativa de seção da armadura e muitas vezes afeta a vida útil de serviço da estrutura, elevando os custos de manutenção e reparo (HELENE, 1986). 


\subsubsection{Conceitos básicos sobre a carbonatação do concreto de cimento Portland}

$\mathrm{Na}$ hidratação do cimento Portland ocorrem reações químicas nas quais materiais carbonatáveis são produzidos. Os processos físico-químicos da carbonatação envolvem reações de dissolução gasosa e precipitação de sólidos. As reações envolvidas nas diversas etapas deste processo são apresentadas por Papadakis et al. (19897, 1991a ${ }^{8}, 1991 b^{9}$, $\left.1992^{10}\right)$ citados por Pauletti (2009) e, segundo aqueles autores, consistem em:

- difusão do $\mathrm{CO}_{2}$ da atmosfera na fase gasosa dos poros do material e posterior dissolução na água dos poros;

- dissolução do $\mathrm{Ca}(\mathrm{OH})_{2}$ sólido na água dos poros e difusão do $\mathrm{Ca}(\mathrm{OH})_{2}$ dissolvido das regiões de maior alcalinidade para as de menor alcalinidade;

- reação do $\mathrm{CO}_{2}$ dissolvido com o $\mathrm{Ca}(\mathrm{OH})_{2}$ dissolvido na água dos poros;

- reação do $\mathrm{CO}_{2}$ dissolvido com o C-S-H e os compostos não hidratados $\left(\mathrm{C}_{2} \mathrm{~S}\right.$ e $\left.\mathrm{C}_{3} \mathrm{~S}\right)$ da pasta de cimento endurecida;

- redução do volume dos poros devido à precipitação dos produtos de carbonatação;

- condensação do vapor de água (gerado na reação de carbonatação) nas paredes dos poros do material, em equilíbrio com a temperatura e as condições de umidade relativa do ambiente de exposição.

Em suma, a carbonatação é conhecida como a ação natural do $\mathrm{CO}_{2}$ nos concretos de cimento Portland em que o gás carbônico reage com o hidróxido de cálcio $\mathrm{Ca}(\mathrm{OH})_{2}$, resultando $\mathrm{CaCO}_{3}$.

Entende-se que o gás carbônico penetra nos poros do concreto de cobrimento, principalmente por difusão. A difusão é um processo lento se os poros da pasta de cimento hidratado estiverem preenchidos com água, pois a difusão do $\mathrm{CO}_{2}$ através da água é quatro

\footnotetext{
7 PAPADAKIS,V.G.; VAYENAS,C.G.; FARDIS, M.N. A reaction engineering approach to the problemof concrete carbonation. ACI Materials Journal, v.35, n.10, p.1639-1650, 1989.

8 PAPADAKIS,V.G.; VAYENAS,C.G.; FARDIS, M.N. Fundamental modeling and experimental investigation of concrete carbonation. ACI Materials Journal, n.88, p.363-373, 1991.

9 PAPADAKIS,V.G.; VAYENAS,C.G.; FARDIS, M.N. Fundamental concrete carbonation model and application to durability of reinforced concrete. In: DURABILITY OF BUILDING MATERIALS AND COMPONENTS. Proceedings....p.27-38. London, 1991.

10 PAPADAKIS,V.G.; VAYENAS,C.G.; FARDIS, M.N. Hydration and Carbonation of Pozzolanic Cements. ACI Materials Journal, v. 89, n.2, p.119-130, 1992.
} 
ordens de grandeza mais lenta do que através do ar. Por outro lado, se a água dos poros for insuficiente, $\mathrm{o} \mathrm{CO}_{2}$ permanece na forma de gás e não reage com o cimento hidratado. $\mathrm{A}$ velocidade de carbonatação depende do teor de umidade do concreto, que varia com a distância à superfície exposta.

A difusão é o fenômeno de transporte de massa através de um fluido por efeito de gradientes de concentração. Se a difusão ocorre em estado estacionário, pode ser modelada pela primeira lei de Fick, se for em condição transiente pode ser descrita pela segunda lei de Fick. O CEB ${ }^{11}$ (1993) e Helene (1993), entre outros, descrevem as leis de Fick. No caso do concreto apresentar fissuras este fluxo dá-se tanto pelos capilares como pela própria fissura (Figura 11).

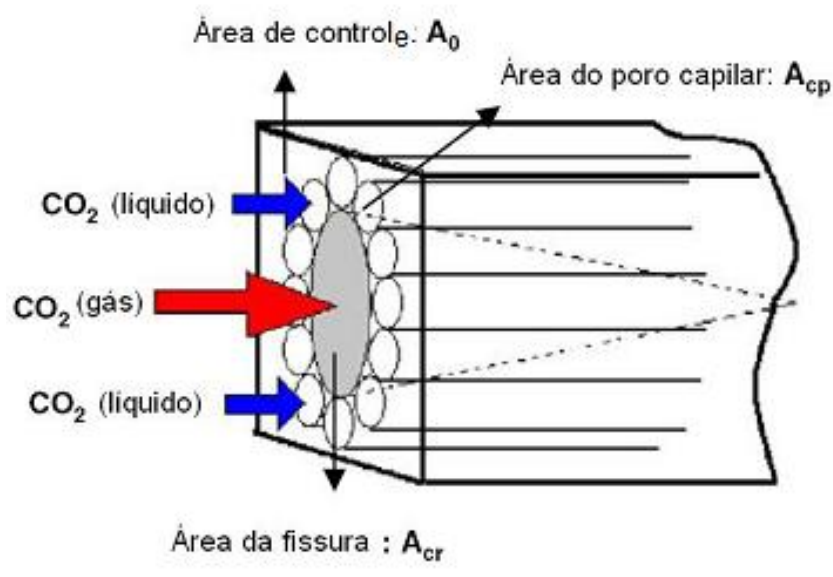

FIGURA 11 - Difusão de $\mathrm{CO}_{2}$ através do elemento de controle. SONG (2006) ${ }^{12}$ et al. adaptado por SIMAS (2007).

A taxa de difusão do $\mathrm{CO}_{2}$ depende de diversos fatores como porosidade total, tamanho e distribuição dos poros, quantidade de água, cimento, agregados, cura, idade, temperatura, concentração de $\mathrm{CO}_{2}$ e umidade relativa, entre outros (PAPADAKIS ${ }^{10}$ et al., 1992; SAETTA; VITALIANI, 2004).

O desempenho do concreto, enquanto barreira para diminuição do transporte de agentes potencialmente causadores de corrosão das armaduras, está relacionado com a sua porosidade. Assim, modificar a porosidade do concreto pode ser uma solução econômica, eficiente e simples para aumentar a durabilidade do concreto armado. Dentro deste contexto, Sato (1998) analisou a influência do volume total de vazios e das dimensões

11 COMITÉ EURO-INTERNATIONAL DU BETÓN. CEB-FIP Code Model 1990. Bulletin d'Information n.213/214, Lausane: CEB, 1993.

12 SONG, H.; KWON, S.; BYUN, K.; PARK, C. Predicting carbonation in early-aged cracked concrete, Cement and Concrete Research v. 36, p. 979-989, 2006. 
dos poros nas propriedades de transporte de água, de íons cloreto e de $\mathrm{CO}_{2}$ em concretos, sendo abordado em maior profundidade, o transporte de água.

A carbonatação em si, não causa deterioração do concreto, mas tem efeitos importantes. A carbonatação é um processo físico-químico, ou seja, químico porque ocorre alteração na composição química do concreto que interfere nas propriedades físicas do mesmo. A precipitação de carbonato de cálcio, como produto final da carbonatação, pode até melhorar algumas propriedades do concreto, como aumentar a resistência à compressão e diminuir a permeabilidade. Este mecanismo é conhecido como colmatação, ou seja, ocorre uma redução do volume de poros do concreto devido à precipitação de cristais de carbonato de cálcio (NEVILLE, 1982). Um dos efeitos desse processo físicoquímico é a retração por carbonatação.

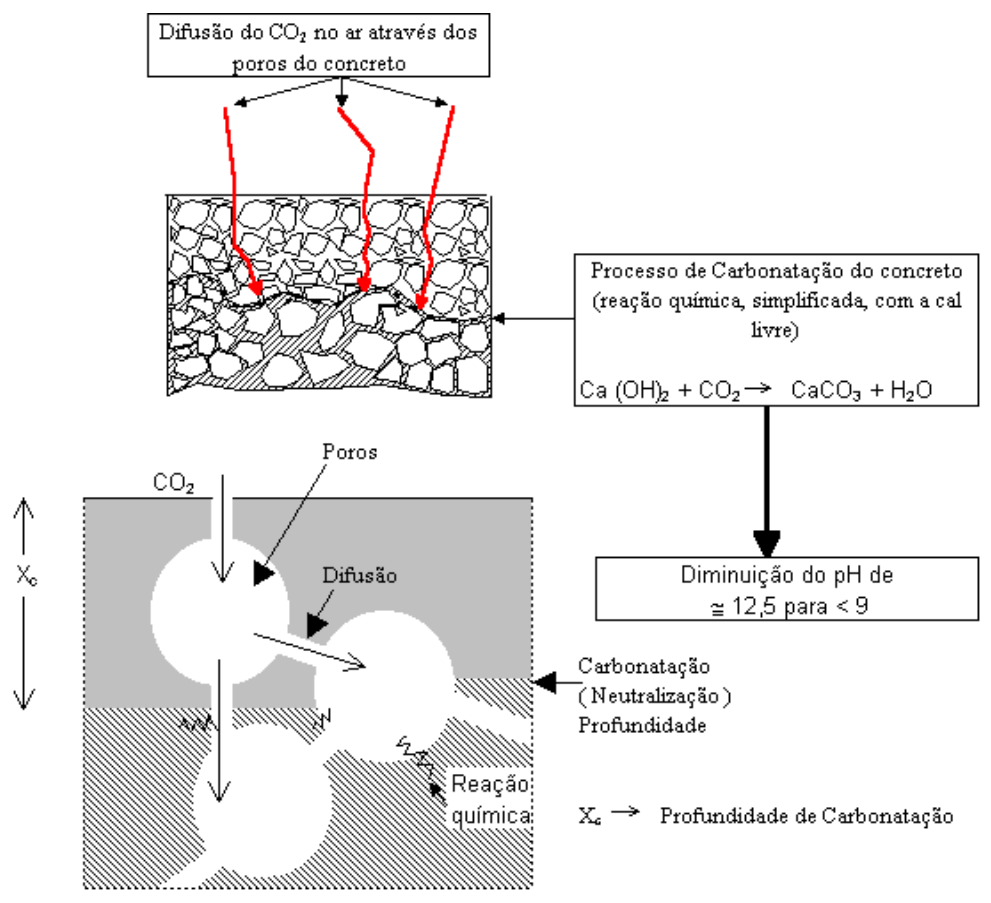

FIGURA 12 - Processo de carbonatação (CEB apud ISAIA, 2005).

Com relação à durabilidade das armaduras, a importância da carbonatação reside no fato de que ela reduz o pH da água dos poros da pasta de cimento de valores entre 12,6 e 13,5 para cerca de 9. Quando todo $\circ \mathrm{Ca}(\mathrm{OH})_{2}$ se carbonata, o $\mathrm{pH}$ é reduzido a 8,3 (NEVILLE, 1997).

A carbonatação ocorre quando o $\mathrm{CO}_{2}$, do ar ou em água agressivas, se combina com o $\mathrm{Ca}(\mathrm{OH})_{2}$, formando o carbonato de cálcio, $\mathrm{CaCO}_{3}$, bem menos solúvel. Este processo faz cair o pH da solução de equilíbrio de 12,5 para 9,4, que é o pH que precipita este composto. Para Gentil (2003) este novo pH fica entre 8,5 e 9,0. Andrade (1992) cita pH próximos de 7 
como típicos do concreto carbonatado. De acordo com Helene (1986) o pH de precipitação do $\mathrm{CaCO}_{3}$ é cerca de 9,4, à temperatura ambiente.

Apesar da diferença entre os diversos autores consultados, todos concordam que a redução de $\mathrm{pH}$ é capaz de despassivar a armadura e deixar o aço vulnerável para a corrosão das armaduras. Segundo Nogueira ${ }^{13}$ apud Fortes (1995), vários autores defendem um pH entre 11,5 a 11,8 como susceptível de despassivação do aço carbono, embora existam registros de $\mathrm{pH}$ inferiores sem que tenha havido despassivação.

Segundo revisão bibliográfica de Silva (1995), a ação do $\mathrm{CO}_{2}$ sobre os constituintes do cimento hidratado é muito complexa, não se limitando apenas ao hidróxido de cálcio, atacando e decompondo todos os produtos da hidratação do cimento.

Mas, em concretos contendo somente cimento Portland, é apenas a carbonatação do $\mathrm{Ca}(\mathrm{OH})_{2}$ que interessa. No entanto, quando se esgota o $\mathrm{Ca}(\mathrm{OH})_{2}$, por exemplo, através de uma reação secundária com a sílica das pozolanas, também é possível a carbonatação do

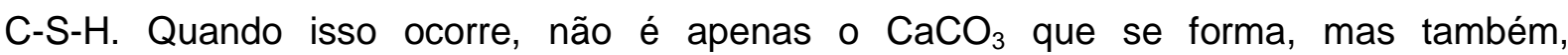
simultaneamente, o gel de sílica, com poros grandes e maiores do que $100 \mathrm{~nm}$, que facilita a carbonatação subseqüente (NEVILLE, 1997).

Segundo Neville (1982), o processo ocorre em várias etapas envolvendo diversas reações secundárias, embora o carbonato de cálcio seja sempre um dos produtos finais.

A reação de carbonatação costuma ser representada de maneira simplificada de acordo com o mostrado na Equação 1:

$$
\mathrm{Ca}(\mathrm{OH})_{2}+\mathrm{CO}_{2} \stackrel{\mathrm{H}_{2} \mathrm{O}}{\longrightarrow} \mathrm{CaCO}_{3}+\mathrm{H}_{2} \mathrm{O}
$$

(EQUAÇÃO 1)

Admitindo-se então que $\circ \mathrm{pH}$ de precipitação do $\mathrm{CaCO}_{3}$ (carbonato de cálcio) seja cerca de 9,4 (HELENE, 1986; SILVA; LIBÓRIO, 2002). O concreto é separado em duas regiões com $\mathrm{pH}$ diferentes, na frente de carbonatação, uma com $\mathrm{pH}$ menor do que 9 (região carbonatada) e outra com pH maior que 12 (região não carbonatada) (CASCUDO, 1997; CASTRO et al., 2003).

Como já comentado, não somente o hidróxido de cálcio carbonata, mas também o silicato de cálcio hidratado $(\mathrm{C}-\mathrm{S}-\mathrm{H})$, silicatos tricálcio $\left(\mathrm{C}_{3} \mathrm{~S}\right)$ e dicálcio $\left(\mathrm{C}_{2} \mathrm{~S}\right)$ anidros, segundo as Equações 2 a 4, transcritas de Papadakis ${ }^{4}$ et al. apud Camarini et al. (2005):

\footnotetext{
13 NOGUEIRA, R. P. A Corrosão do Aço em Concreto : Influência do PH e do Potencial de Eletrodo. 1989.
} Dissertação (Mestrado). Universidade Federal do Rio de Janeiro COPPE/UFRJ. Rio de Janeiro. 1989. 
C-S-H: $\left(3 \mathrm{CaO} .2 \mathrm{SiO}_{2} .3 \mathrm{H}_{2} \mathrm{O}\right)+3 \mathrm{CO}_{2} \longrightarrow\left(3 \mathrm{CaCO}_{3} .2 \mathrm{SiO}_{2} .3 \mathrm{H}_{2} \mathrm{O}\right) \quad($ EQUAÇÃO 2$)$

$\mathrm{C}_{3} \mathrm{~S}: \quad\left(3 \mathrm{CaO}_{2} \mathrm{SiO}_{2}\right)+3 \mathrm{CO}_{2}+\mathrm{J} \mathrm{H}_{2} \mathrm{O} \longrightarrow \mathrm{SiO}_{2} . \mathrm{J} \mathrm{H}_{2} \mathrm{O}+3 \mathrm{CaCO}_{3}$ (EQUAÇÃO 3 )

$\mathrm{C}_{2} \mathrm{~S}: \quad\left(2 \mathrm{CaO} . \mathrm{SiO}_{2}\right)+2 \mathrm{CO}_{2}+\mathrm{JH}_{2} \mathrm{O} \longrightarrow \mathrm{SiO}_{2} . \mathrm{J} \mathrm{H}_{2} \mathrm{O}+2 \mathrm{CaCO}_{3}($ EQUAÇÃO 4$)$

Segundo Parrot (1986), apesar de todos os compostos hidratados do cimento poderem reagir com $\mathrm{O} \mathrm{CO}_{2}$ a concentrações atmosféricas normais (de 0,03\% em volume), os compostos não hidratados só reagirão com o $\mathrm{CO}_{2}$ quando este estiver presente em altas concentrações, mas não nas condições normais.

A água que é produzida nas reações de carbonatação difunde da frente de reação para a superfície, onde a umidade é normalmente menor (HOUST ${ }^{14}, 1993$ apud PAULETTI, 2009). Andrade (1992) descreve que após a carbonatação, devido à redução dos poros, o concreto está constantemente úmido. Isso acontece porque o mesmo é capaz de absorver água facilmente, no entanto, a perda dessa água é muito lenta.

Ishida e Maekawa (2000) abordam o processo da carbonatação considerando, para a modelagem, a Lei da Conservação de Massa. Os fenômenos associados ao transporte e equilíbrio do dióxido de carbono nos poros do concreto, bem como a reação de carbonatação, estão representados de forma esquemática na Figura 13.

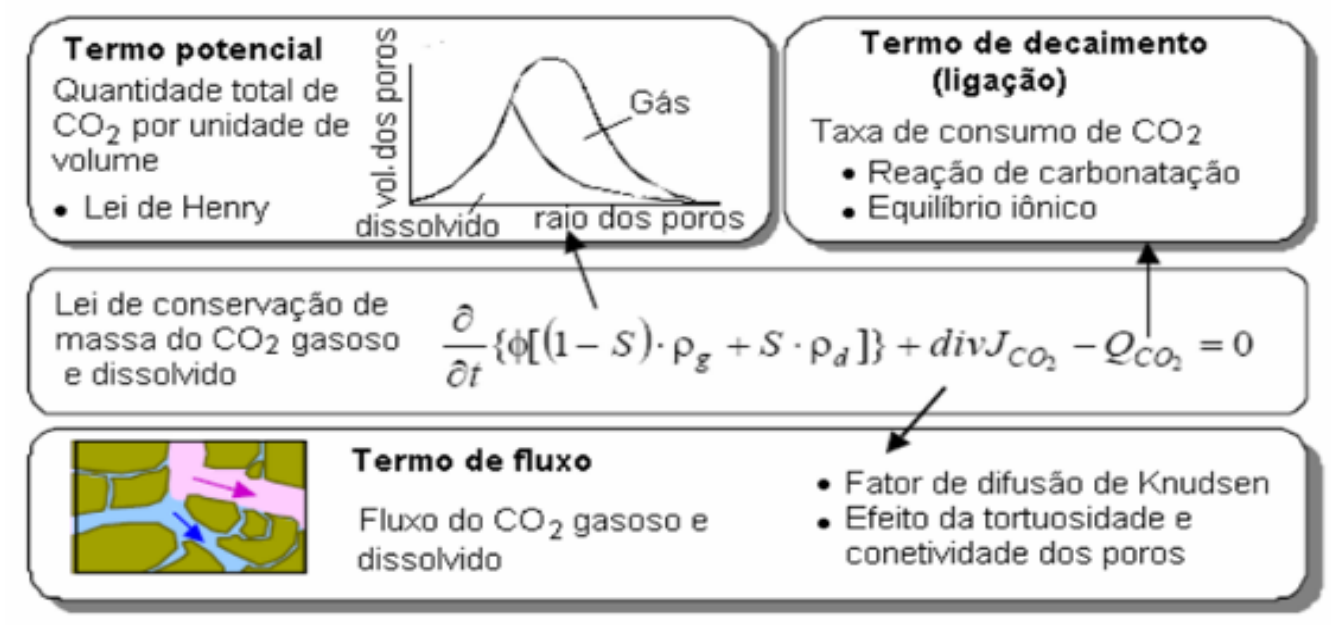

FIGURA 13 - Lei da conservação de massa e modelos constituintes da carbonatação (ISHIDA; MAEKAWA, 2000).

14 HOUST, Y.F. Diffusion de gaz, carbonatation et retrait de la pâte de ciment durcie. Thèse (Doctorat), Ecole Polytéchnique Federale de Lausanne, Lausanne, 1993. 


\subsubsection{Modelos de previsão da carbonatação}

\section{A) O modelo clássico e outros em pesquisa}

Como visto no item 2.1.3, a carbonatação é interpretada como um mecanismo que se desenvolve da superfície para o interior do concreto, até atingir as armaduras gerando a sua despassivação e podendo iniciar a corrosão. As variáveis que podem ser determinantes para que ocorra a carbonatação estão listadas na TABELA 1 e podem ser assim agrupadas:

- variáveis ambientais externas ao concreto, tratadas no item 2.2;

- variáveis intrínsecas ao concreto, tratadas no item 2.3.

TABELA 1 - Principais variáveis que condicionam a velocidade de carbonatação dos concretos de cimento Portland (KAZMIERCZAK, 1995).

\begin{tabular}{|c|c|c|}
\hline & Fatores Condicionantes & Caracteristicas Influenciadas \\
\hline $\begin{array}{l}\text { Condiçб̄es de } \\
\text { Exposição }\end{array}$ & $\begin{array}{l}\text { Concentração de } \mathrm{CO}_{2} \\
\text { Umidade relativa do ar } \\
\text { Temperatura }\end{array}$ & $\begin{array}{l}\text { - Mecanismo fisico-quimico } \\
\text { - Velocidade de carbonatação } \\
\text { - Grau de saturaçăo dos poros } \\
\text { - Velocidade de carbonataçăo }\end{array}$ \\
\hline $\begin{array}{c}\text { Caracteristicas } \\
\text { do concreto }\end{array}$ & $\begin{array}{c}\text { Composição quimica do cimento } \\
\text { - Caracteristicas do clinquer } \\
\text { - Teor de adiçōes } \\
\text { Traço } \\
\text { Qualidade de Execução } \\
\text { - Defeitos } \\
\text { - Cuidados com a cura }\end{array}$ & $\begin{array}{l}\text { - Porosidade da pasta carbonatada } \\
\text { - Reserva alcalina }\end{array}$ \\
\hline
\end{tabular}

Nem todos os concretos carbonatam a uma mesma velocidade, pois esta depende da difusividade do $\mathrm{CO}_{2}$ que está relacionada a numerosas variáveis, tais como: consumo e tipo de cimento, porosidade, umidade relativa, relação a/c, grau de hidratação, entre outras (ANDRADE, 1992; NEVILLE, 1997). Uma análise sintética destes fatores está apresentada no item 2.3.

Segundo Helene (1986), o progresso da carbonatação pode cessar após determinado período em função do aumento da compacidade pela deposição dos produtos de hidratação e carbonatação, dificultando a entrada do $\mathrm{CO}_{2}$. Mas caberia considerar em que condições ambientais isto pode ocorrer.

Métodos matemático-numéricos da velocidade do processo de carbonatação continuam em pauta até a presente década e têm sido propostos por vários pesquisadores, 
na expectativa de prever o tempo de início da corrosão de armaduras para estruturas de concreto armado em função das características específicas do concreto. Os modelos mais recentes têm sido abordados pelos seguintes pesquisadores, através dos artigos indicados e extraídos do levantamento de Pauletti (2009):

- STEFFENS et al. (2002) - Modeling carbonation for corrosion risk prediction of concrete structures;

- SAETTA; VITALIANI (2004, 2005) - Experimental investigation and numerical modeling of carbonation process in reinforced concrete structures Part I: Theoretical formulation e Part II. Practical applications;

- THIÉRY (2005) - Modélisation de la carbonatation atmosphérique des bétons - Prise en compte des effets cinétiques et de l'état hydrique;

- CASTELLOTE; ANDRADE (2008) - Modelling the carbonation of cementitious matrixes by means of the unreacted-core model;

- MUNTEAN; BÖHM (2009) - A moving-boundary problem of concrete carbonation: Global existence and uniqueness of weak solutions.

A equação Equação 5, ilustrada na Figura 14 foi endossada no modelo de Tuutti $^{4}$ em 1982 e é a mais antiga e aceita para se calcular a espessura do processo de carbonatação em função do tempo:

$$
\mathbf{e}=\mathbf{k}_{\mathrm{CO} 2} \sqrt{\mathbf{t}} \quad(\text { EQUAÇÃO 5) }
$$

onde:

$\mathrm{e}=$ espessura carbonatada em $\mathrm{mm}$;

$\mathrm{t}=$ tempo de exposição em ano;

$\mathrm{k}_{\mathrm{CO} 2}=$ coeficiente de carbonatação, em mm/ano0,5 (Neville, 1997). Depende das características do concreto e das condições ambientais, ou seja, da difusividade efetiva do $\mathrm{CO}_{2}$ através do concreto. É freqüentemente maior que 3 ou $4 \mathrm{~mm} / \mathrm{ano}^{0,5}$. 


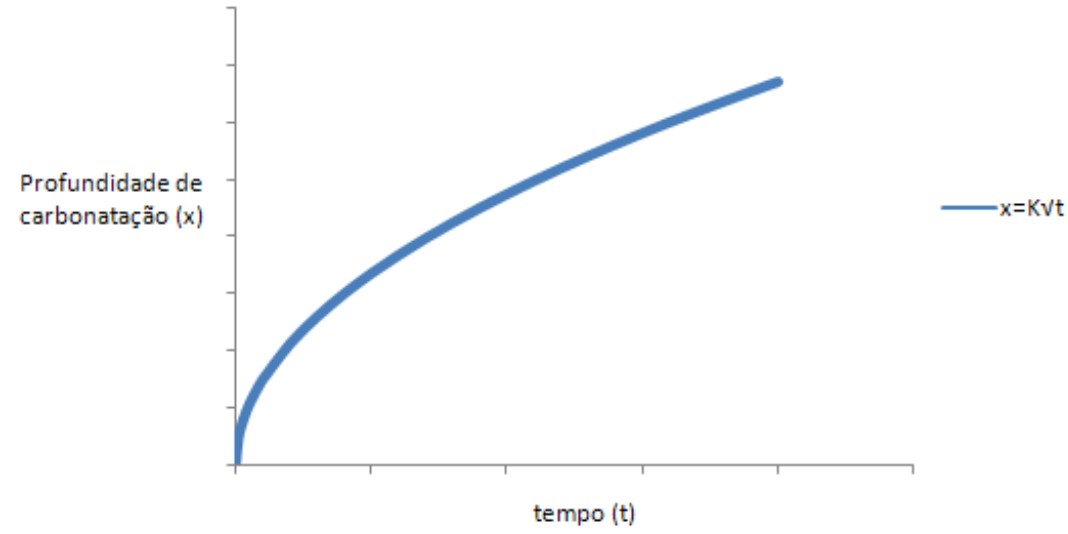

FIGURA 14 - Profundidade de carbonatação em função do tempo, por previsão simplificada e endossada no modelo de vida útil das armaduras de Tuutti $^{4}$ (SIMAS, 2007).

Papadakis ${ }^{7}$ et al. (1989) ressaltam que em estudos realizados em ambientes internos, isto é, protegidos das intempéries, onde as condições climáticas foram controladas, houve concordâncias com a equação. Porém, quando realizados externamente, sem proteção das intempéries, houve desvios da equação, uma vez que variações na umidade provocaram variações na profundidade de carbonatação. Segundo Neville (1997), a Equação 5 é aceita de um modo geral, entretanto, não é válida para condições higrométricas instáveis e nem pode ser interpretada com o mesmo valor, para situações em que há diferença de exposição à umidade. Aquele autor afirma que a profundidade de carbonatação é diferente na face interna e externa de um mesmo elemento estrutural. Para Andrade (1992), K é uma constante cujo valor pode ser determinado quando se conhecem a espessura da capa carbonatada e a idade da estrutura. Uma vez conhecido $\mathrm{K}$, pode-se conferir ou aferir a velocidade de avanço da frente de carbonatação.

$\mathrm{Na}$ dissertação de Carmona (2005) é apresentada uma coletânea dos principais modelos de previsão da velocidade de despassivação das armaduras em estruturas de concreto sujeitas à carbonatação, conforme esta autora resume na Tabela 2, já acrescentando literatura mais recente.

Em geral, são modelos complexos e com muitas variáveis tais como: tipo de concreto, concentração de $\mathrm{CO}_{2}$ no ar e no concreto, coeficiente de difusão de $\mathrm{CO}_{2}$, permeabilidade, umidade relativa, grau de hidratação, resistência à compressão, entre outros. 
TABELA 2 - Autores e respectivos modelos teóricos, resumidos por esta autora a partir de Carmona (2005) e Andrade (2006).

\begin{tabular}{|c|c|c|c|}
\hline ANO & AUTOR & REFERÊNCIA & PRINCÍPIOS \\
\hline 1982 & TUUTTI & $\begin{array}{l}\text { TUUTTI,K. Corrosion of steel in Concrete, Stokholm, } \\
\text { 1982.469p. Swedish Cement na Concrete Research, } \\
\text { Fo no } 504 \text {. }\end{array}$ & $\begin{array}{l}\text { Para aplicar o modelo do autor, supõe-se que o coeficiente de difusão } \\
\text { efetivo do } \mathrm{CO} 2 \text { é igual ao do } \mathrm{O} 2 \text {. }\end{array}$ \\
\hline 1987 & PARROT & $\begin{array}{l}\text { PARROT. Review of carbonation in reinforced } \\
\text { concrete. Cement and Concrete Association Report } \\
\text { C/1, 1987. 126p. }\end{array}$ & $\begin{array}{l}\text { Se deve a esse autor a idéia de uma redução dos valores do expoente } \\
\text { do tempo em função da umidade. }\end{array}$ \\
\hline 1988 & BAKKER & $\begin{array}{l}\text { BAKKER, R.F.M.Chapter Three. In:SCHIESSL, P.ed. } \\
\text { Corrosion of Steel in Concrete. Report of the } \\
\text { Technical Committee } 60 \text { - CSC. RILEM. London, } \\
\text { Chapman \& Hall, 1988. p.36-42 }\end{array}$ & $\begin{array}{l}\text { Em seu modelo, despreza a carbonatação quando o concreto está } \\
\text { úmido, então o concreto primeiramente terá que secar para } \\
\text { posteriormente carbonatar. }\end{array}$ \\
\hline 1988 & SCHIESSL & $\begin{array}{l}\text { SCHEISSL, P. Corrosion of steel in Concrete. RILEM. } \\
\text { Chapman \& Hall, 1988. 102p. }\end{array}$ & $\begin{array}{l}\text { Introduziu um fator "f" que descreve a diminuição do valor de } \mathrm{D}_{\mathrm{CO} 2} \mathrm{com} \\
\text { a profundidade e um fator de retardamento da carbonatação "b", } \\
\text { determinado pela quantidade de compostos alcalinos que se difundem } \\
\text { do interior do concreto até a frente de carbonatação. }\end{array}$ \\
\hline $\begin{array}{l}1989,1991 a, \\
1991 \text { b, } 1992\end{array}$ & PAPADAKIS et al. & $\begin{array}{l}\text { PAPADAKIS et. al.,A Reaction engineering approach } \\
\text { to the problem of concrete carbonation. Journal of the } \\
\text { American Institute of Chemical Engineers, v.35, n.10, } \\
\text { 1989. p.1639-1650 }\end{array}$ & $\begin{array}{l}\text { Partindo de considerações físico-químicas modela a reação do } \mathrm{CO}_{2} \\
\text { com } \mathrm{CH}, \mathrm{CSH}, \mathrm{C}_{3} \mathrm{Se} \mathrm{C}_{2} \mathrm{~S} \text {. }\end{array}$ \\
\hline 1992 & $\begin{array}{l}\text { THOMAS \& } \\
\text { MATHEWS }\end{array}$ & $\begin{array}{l}\text { THOMAS, M.A.; MATTHEWS,J.D. Carbonation of Fly } \\
\text { Ash Concrete. Magazine of Concrete Research, v.44, } \\
\text { n.160, p.217-228, Sep. } 1992 .\end{array}$ & $\begin{array}{l}\text { Esses pesquisadores propõem a adoção de nomogramas ao invés de } \\
\text { equações, para representar as variáveis envolvidas no processo de } \\
\text { carbonatação e que atuam simultaneamente. }\end{array}$ \\
\hline 1996 & CEB & $\begin{array}{l}\text { COMITE EURO-INTERNACIONAL du BETON. CEB- } \\
\text { FIP Model Code 1990. Design Code. Lausanne, CEB, } \\
\text { May 1996.437p. (Bulletin D'Onformation, 213-214) }\end{array}$ & Conforme equações 6,7 e 8. \\
\hline 1997 & HELENE & $\begin{array}{l}\text { HELENE, P.R.L.Vida útil das estruturas de concreto. } \\
\text { In: IV Congresso IberoAmericano de Patologia das } \\
\text { Construções. Anais...Porto Alegre, RS, } 1997 .\end{array}$ & $\begin{array}{l}\text { Propõe ábacos para a determinação de cobrimentos de armaduras de } \\
\text { estruturas expostas à carbonatação em função da vida útil de projeto } \\
\text { desejada (período de iniciação) }\end{array}$ \\
\hline 2003 & IZQUIERDO & $\begin{array}{l}\text { IZQUIERDO, L.D.Bases de diseñopara um } \\
\text { tratamiento probabilista de los procesos de corrosión } \\
\text { de la armadura em el hormigón, 2003. Tese } \\
\text { (Doutorado) Universidade Politécnica de Madrid, } \\
\text { Canales y Puertos. }\end{array}$ & $\begin{array}{l}\text { Baseado no modelo do CEB e em função de um estudo amplo de } \\
\text { resultados de laboratório e campo de diversos investigadores } \\
\text { apresenta um modelo estatítico, nas equações } 9 \text { e } 10 .\end{array}$ \\
\hline 2004 & ANDRADE & $\begin{array}{l}\text { ANDRADE,C. Calculation of initiation and propagation } \\
\text { periods of service life of reinforcements by using the } \\
\text { electrical resistivity. Proceedings of the International } \\
\text { Symposium on advances in concrete througth science } \\
\text { and engineering, March 22-24, 2004, RILEM. Evason, } \\
\text { Northwestern University, USA. }\end{array}$ & $\begin{array}{l}\text { Segundo a autora o processo de penetração de agentes agressivos } \\
\text { não segue uma única lei e é decorrente de diversos fenômenos } \\
\text { simultaneamente e que não se podem modelar pelas leis de difusão. } \\
\text { Com os conhecimentos atuais é mais conveniente estabelecer } \\
\text { modelos de vida útil baseados em parâmetros de medição mais fácil e } \\
\text { propõe um modelo baseado na resistividade do concreto, aplicável } \\
\text { tanto à penetração de cloretos como à carbonatação.(Equação 6) }\end{array}$ \\
\hline 2006 & ANDRADE et. al. & $\begin{array}{l}\text { ANDRADE, et. al. Carbonation effect on reinforced } \\
\text { concrete durability in Iberoamerican countries: } \\
\text { DURACON PROJECT/CYTED. LATINCORR, } 2006 . \\
\text { Fortaleza, maio, 2006. }\end{array}$ & $\begin{array}{l}\text { Através do modelo de previsão de TUUTTI (1982), os autores aplicaram } \\
\text { investigações recentes de HOUST (1994) que a difusão através da } \\
\text { pasta de cimento pode ser melhor entendida utilizando um modelo de } \\
\text { difusão que considera dois níveis de porosidade do concreto. O } \\
\text { modelo de Parrot, pode ser melhor para determinar a estimativa de } \\
\text { vida em serviço. (Equações } 11 \text { a 16) }\end{array}$ \\
\hline
\end{tabular}

Dentre os modelos de previsão na Tabela 2, cabe destacar os quatro modelos a seguir, para antever profundidades e taxas de carbonatação: 
B) Modelo do CEB (1996)

$$
\begin{array}{ll}
e=k_{\mathrm{CO}_{2}}\left(\frac{t_{0}}{t}\right)^{n} \cdot \sqrt{t} & \text { (EQUAÇÃO 6) } \\
k_{\mathrm{CO}_{2}}=\sqrt{\frac{2 \cdot D_{\mathrm{CO}_{2}} \cdot C_{s} \cdot K_{1} \cdot K_{2}}{a}} & \text { (EQUAÇÃO 7) } \\
D_{\mathrm{CO}_{2}}=10^{-\left(7+0,025 \frac{f c k}{10}\right)} & \text { (EQUAÇÃO 8) }
\end{array}
$$

sendo:

$\mathrm{e}=$ profundidade de carbonatação $(\mathrm{m})$;

$\mathrm{D}_{\mathrm{CO} 2}=$ coeficiente de difusão do $\mathrm{CO}_{2}$ no concreto carbonatado $\left(\mathrm{m}^{2} / \mathrm{s}\right)$;

$\mathrm{C}_{\mathrm{s}}=$ concentração de $\mathrm{CO}_{2}$ no $\mathrm{ar}\left(\mathrm{kg} / \mathrm{m}^{3}\right)$;

$\mathrm{a}=$ teor de $\mathrm{CO}_{2}$ em $1 \mathrm{~m}^{3}$ de concreto $\left(\mathrm{kg} / \mathrm{m}^{3}\right)$;

$\mathrm{t}=$ tempo (s);

$\mathrm{t}_{0}=$ tempo de cura;

$\mathrm{n}=$ fator de idade;

$\mathrm{K}_{1} \cdot \mathrm{K}_{2}$ = coeficientes de cura e exposição;

$\mathrm{K}_{\mathrm{CO} 2}=$ coeficiente de carbonatação $\left(\mathrm{m} / \mathrm{s}^{0,5}\right)$;

$\mathrm{f}_{\mathrm{ck}}=$ resistência característica do concreto $(\mathrm{MPa})$.

TABELA 3- Coeficientes de cura e exposição. CEB ${ }^{15}$ (1996) apud Carmona (2005).

\begin{tabular}{c|c|c}
\hline Tipo de exposição & Cura & $\mathbf{K}_{\mathbf{1}} \times \mathbf{K}_{\mathbf{2}}$ \\
\hline Interior & Boa & 1,0 \\
\hline Interior & Má & 2,0 \\
\hline Exterior & Boa & 0,5 \\
\hline
\end{tabular}

TABELA 4 - Coeficientes de cura e exposição. CEB ${ }^{13}$ (1996) apud Carmona (2005).

\begin{tabular}{c|c}
\hline Tipo de exposição & $\mathbf{N}$ \\
\hline Interior & 0,0 \\
\hline Exterior protegida & 0,1 \\
\hline Exterior não protegida & 0,4 \\
\hline
\end{tabular}

C) Modelo de Izquierdo (2003)

$$
e=\sqrt{\frac{2 \cdot D_{\mathrm{CO}_{2}} \cdot C_{s} \cdot K_{t} \cdot K_{e} \cdot K_{P}}{a}} \cdot\left(\frac{t_{0}}{t}\right) \cdot \sqrt{t} \quad \text { (EQUAÇÃO 9) }
$$


$D_{\mathrm{CO}_{2}}=10^{\varepsilon+A+B \cdot \log (a / c)}$

(EQUAÇÃO 10)

onde:

$A=$ coeficiente de regressão;

$\mathrm{B}=$ coeficiente de regressão;

$\varepsilon=$ termo de erro;

$\mathrm{K}_{\mathrm{t}}=$ coeficiente da raiz do tempo;

$\mathrm{K}_{\mathrm{e}}=$ fator de umidade relativa;

$\mathrm{K}_{\mathrm{P}}=$ fator geral de modelo;

$\mathrm{n}=$ fator de idade do concreto;

$\mathrm{C}_{\mathrm{s}}=$ concentração superficial de $\mathrm{CO}_{2}\left(\mathrm{~kg} / \mathrm{m}^{3}\right)$;

$\mathrm{a} / \mathrm{c}=$ relação água / cimento;

$\mathrm{a}=$ reserva alcalina do concreto $\left(\mathrm{kg} / \mathrm{m}^{3}\right)$;

$\mathrm{t}_{0}=$ tempo de cura (s);

$\mathrm{t}=$ tempo $(\mathrm{s})$;

D) Modelo de Andrade et al. (2006)

$$
\mathrm{t}=\mathrm{ti}+\mathrm{tp} \quad(\text { EQUAÇÃO 11) }
$$

onde:

$\mathrm{ti}$ = período de iniciação;

tp $=$ período de propagação .

Para o período de iniciação, tem-se:

$d=a k^{0,4} t_{i}^{n} / c^{0,5}$

(EQUACÃO 12)

onde:

$\mathrm{d}=$ profundidade de carbonatação $(\mathrm{mm})$;

$\mathrm{a}=$ constante de difusão (mais de um autor concorda em considerar o valor de 0,64 );

$\mathrm{k}=$ permeabilidade ao ar do concreto $\left(10^{-16} \mathrm{~m}^{2}\right)$;

$\mathrm{C}=$ óxido de cálcio contido na matriz de cimento hidratada $\left(\mathrm{kg} / \mathrm{m}^{3}\right)$ que pode reagir e retardar a penetração do $\mathrm{CO}_{2}$. Esta variável pode depender da composição do cimento e condições de exposição.

A variável da permeabilidade ao ar do concreto $(k)$ depende da porcentagem de umidade relativa (r) e é representada por:

$\mathrm{k}=\mathrm{mk}_{60}$

(EQUAÇÃO 13)

onde:

$m=1,6-0,00115 r-0,0001475 r^{2}$

$$
m=1,0 \text { se } r<60 \% \quad \text { (EQUAÇÃO 14) }
$$

$\mathrm{k}_{60}=$ permeabilidade de uma amostra ensaiada com $60 \%$ de umidade relativa ( $r$ );

$\mathrm{n}=$ expoente caracterizado por: 
$n=0,02536+0,01785 r-0,0001623 r^{2}(E Q U A C ̧ A ̃ O ~ 15)$

No entanto, o período de propagação, $\left(t_{p}\right)$ depende de:

$t_{p}=C D / C R$

(EQUAÇÃO 16)

$C D=$ profundidade admissível de fratura por corrosão $(\mu \mathrm{m})$;

$\mathrm{CR}=$ proporção de corrosão $(\mu \mathrm{m} / \mathrm{ano})$

O inconveniente dos três modelos analisados em B) até D) é que requerem um conhecimento experimental das variáveis intervenientes na carbonatação para interpretações efetivas, o que não condiz com as circunstâncias de projeto da maioria das estruturas. Portanto, são de maior interesse ao estudo do mecanismo da carbonatação ou ao desenvolvimento e formulação de concretos especiais até que possam ser aperfeiçoados em programas informatizados, como propôs Carmona (2005) ao adotar um modelo mais simples de Helene (1997) que se analisa no item E).

\section{E) Modelo de Helene (1997)}

Helene (1997) propõe a adoção de ábacos empírico-experimentais de sua autoria (Figura 15) para a determinação de cobrimentos de armaduras de estruturas expostas à carbonatação, em função da vida útil de projeto desejada, significando ser o cobrimento equivalente ao período de passivação das armaduras ou de iniciação da corrosão.

Assim, embora o resultado desse ábaco seja a espessura de cobrimento, os valores de $\mathrm{k}_{\mathrm{CO} 2}$ podem sem deduzidos para cada tipo de concreto, em função da vida útil de projeto e do cobrimento indicado, utilizando-se a Equação 5, como fez Carmona (2005). 


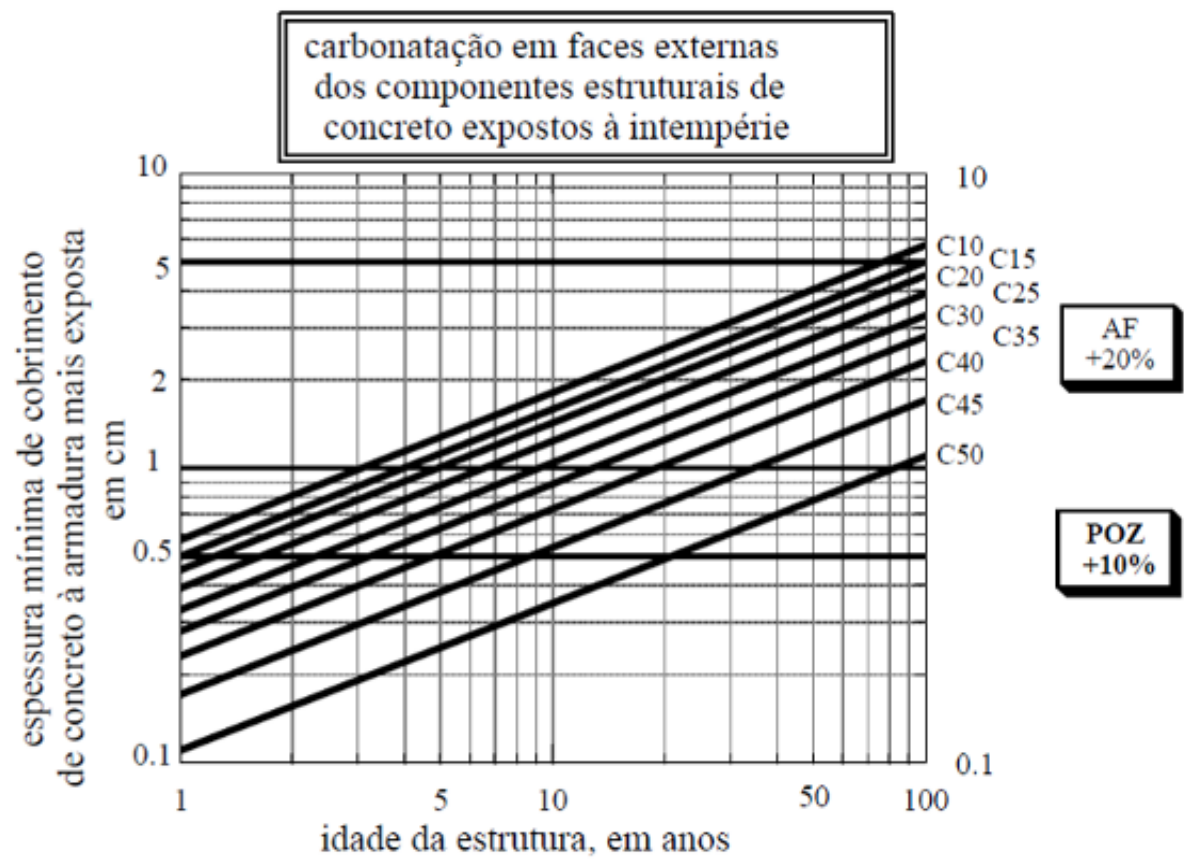

FIGURA 15 - Ábaco para obtenção da espessura de cobrimento com relação à carbonatação em função do tipo de concreto (C10 A C50) e da vida útil de projeto desejada (1 A 100 ANOS) (HELENE, 1997).

O ajuste dos valores de $\mathrm{k}_{\mathrm{CO} 2}$ em função do tipo de concreto revela uma relação linear e a previsão como se vê na Figura 16.

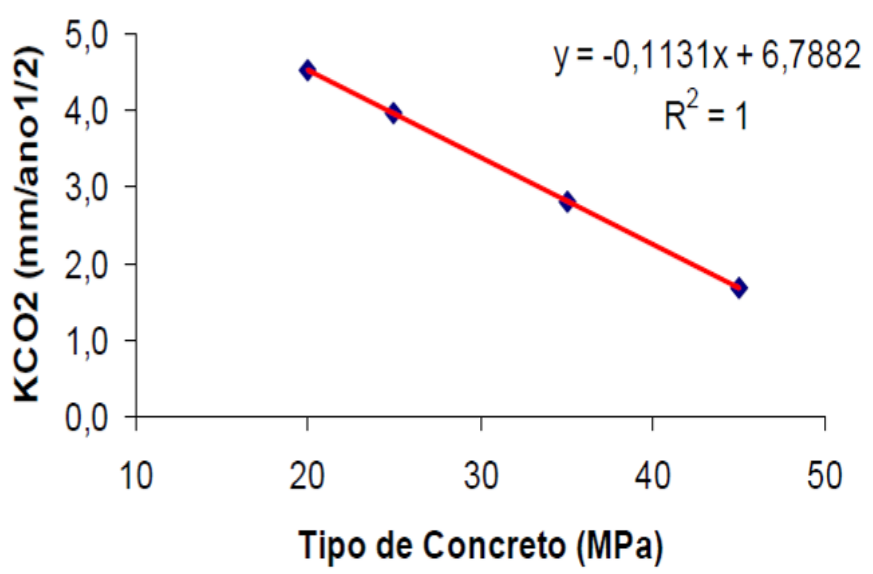

FIGURA 16 - Relação entre o tipo de concreto e $\mathbf{k}_{\mathrm{CO} 2}$ em função do tipo de concreto, segundo interpretação de Carmona (2005), nos ábacos de HELENE (1997).

Assim, pelo modelo de Helene (1997), Carmona (2005) verificou que a previsão de $\mathrm{k}_{\mathrm{cO} 2}$ pode ser feita pela equação:

$$
k_{\mathrm{CO} 2}=6,7882-0,1131 . f_{c k}
$$

Onde:

$\mathrm{k}_{\mathrm{cO} 2}=$ Coeficiente de carbonatação $\left(\mathrm{mm} / \mathrm{ano}^{1 / 2}\right)$; 
$\mathrm{f}_{\mathrm{ck}}=$ resistência característica à compressão do concreto $(\mathrm{MPa})$

Observar que a Equação 17 está descrita em função da resistência característica à compressão do concreto e que deve ser ultrapassada por $95 \%$ do concreto posto em obra. O coeficiente de carbonatação calculado desta forma resulta então a favor da segurança, pois é previsível que a resistência média do concreto sendo mais alta, promova então valores menores de coeficiente. Todavia, este tipo de previsão é apenas orientativo à fase de projeto das estruturas, para a verificação de cobrimento de armaduras e não serve para a seleção de materiais, estudos de dosagem ou para a produção de concreto.

Ainda segundo este modelo, a utilização de cimentos de alto-forno e pozolânicos levam a profundidades carbonatadas 20 e $10 \%$ maiores respectivamente em relação ao cimento Portland e assim as equações para a estimativa de $\mathrm{k}_{\mathrm{CO} 2}$ podem ser escritas da seguinte maneira:

$\mathrm{k}_{\mathrm{CO} 2 \mathrm{AF}}=1,2 \cdot\left(6,7882-0,1131 \cdot \mathrm{f}_{\mathrm{ck}}\right)$

(EQUAÇÃO 18)

$k_{\mathrm{CO} 2 \mathrm{POz}}=1,1 \cdot\left(6,7882-0,1131 . \mathrm{f}_{\mathrm{ck}}\right)$

(EQUAÇÃO 19)

Onde:

$\mathrm{k}_{\mathrm{CO} 2 \mathrm{AF}}=$ Coeficiente de carbonatação para cimentos de alto forno $\left(\mathrm{mm} / \mathrm{ano}^{1 / 2}\right)$;

$\mathrm{k}_{\mathrm{CO} 2 \mathrm{POZ}}=$ Coeficiente de carbonatação para cimentos pozolânicos $\left(\mathrm{mm} / \mathrm{ano}^{1 / 2}\right)$;

$\mathrm{f}_{\mathrm{ck}}=$ resistência à compressão característica do concreto $(\mathrm{MPa})$.

O ábaco da Figura 15 foi desenvolvido para uma concentração de $\mathrm{CO}_{2}$ ambiente e Carmona (2005) sugere ainda uma equação complementar para considerar o efeito da concentração de $\mathrm{CO}_{2}$ no ábaco, mas como não cita se a reproduziu diretamente de Helene (1997) ou se é uma sugestão sua, optou-se aqui não reproduzí-la.

Carmona (2005) fez ainda uma comparação da profundidade de carbonatação em 50 anos a partir dos modelos de Tuutti, Papadakis, CEB, Helene e Thomas, conforme a Figura 17.

TABELA 5 - Comparação da profundidade de carbonatação em 50 anos a partir dos modelos de TUUTTI, PAPADAKIS, CEB, HELENE E THOMAS, analisados por CARMONA (2005).

\begin{tabular}{|l|l|l|l|l|l|l|l|l|}
\hline & \multicolumn{7}{|c|}{ Profundidade de Carbonatação em 50 anos (mm) } \\
\hline \hline $\begin{array}{l}\mathbf{f}_{\text {ck }} \\
(\mathbf{M P a})\end{array}$ & $\mathbf{a / c}$ & ag/c & $\begin{array}{l}\mathbf{C} \\
\left(\mathbf{k g} / \mathbf{m}^{3}\right)\end{array}$ & TUUTTI & CEB & PAPADAKIS & HELENE & THOMAS \\
\hline $\mathbf{2 0}$ & 0,75 & 7,4 & 250 & 34 & 13 & 16 & 23 & 63 \\
\hline \hline $\mathbf{2 5}$ & 0,65 & 6,5 & 280 & 30 & 13 & 13 & 20 & 47 \\
\hline \hline $\mathbf{3 5}$ & 0,50 & 4,9 & 350 & 24 & 12 & 9 & 14 & 30 \\
\hline \hline $\mathbf{4 5}$ & 0,40 & 3,5 & 470 & 10 & 10 & 6 & 8 & 16 \\
\hline
\end{tabular}




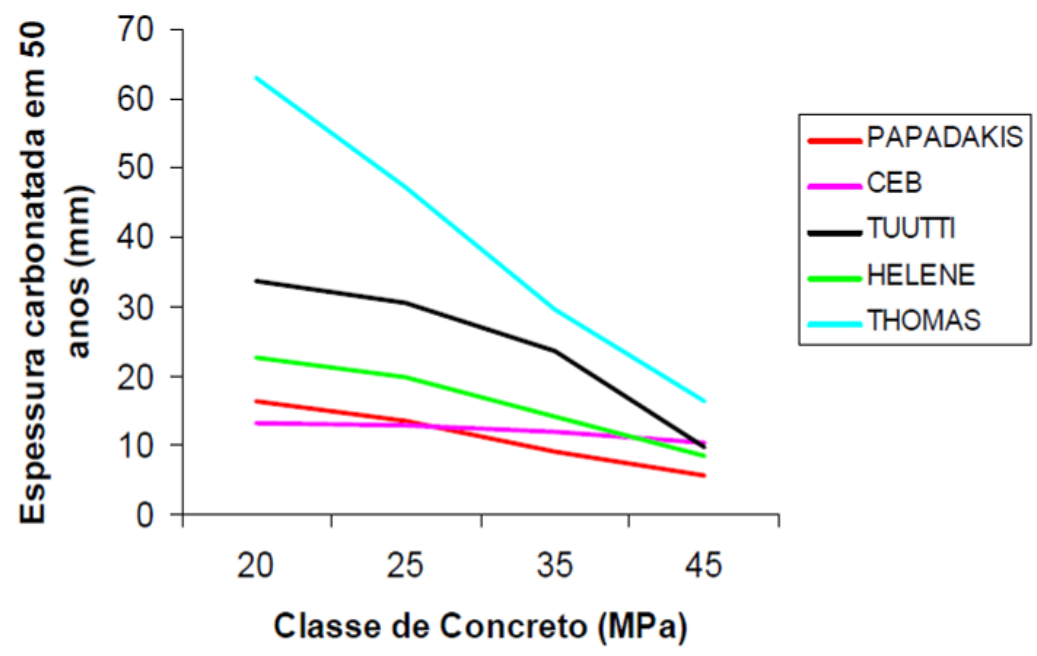

FIGURA 17 - Profundidade de carbonatação em 50 anos, em função do tipo de concreto segundo os modelos de TUUTTI, PAPADAKIS, CEB, HELENE e THOMAS.

Nota-se que para os dados de entrada utilizados os valores mais próximos são os obtidos pelos modelos do CEB e PAPADAKIS. Os modelos confirmam que concretos de maior resistência apresentam profundidades carbonatadas muito inferiores a concretos de menor resistência (CARMONA, 2005).

\section{Outros exemplos em ábacos}

Desde Helene (1993) discute-se o uso de ábacos para predição da carbonatação, conforme a Figura 18, também endossado por Silva (1995), e são idealizados como opções mais acessíveis, para estimativas da profundidade de carbonatação em fase de projeto de estruturas, ainda que necessitem de revisões e aferições periódicas, o que não ocorre na prática.

O ábaco da Figura 18, por exemplo, é aplicável para concretos curados via úmida por 3 dias e com previsão de comportamento até 50 anos. Foi estabelecido há muitos anos atrás, e possivelmente por ensaios de materiais da época. No ábaco consta o exemplo de um concreto com 20 anos, $\mathrm{a} / \mathrm{c}=0,6$, cimento Portland comum, em ambiente externo seco, chegando ao resultado de $12 \mathrm{~mm}$ de profundidade de carbonatação. Esta previsão é muito similar à que pode ser feita pelo ábaco de Helene (1997) na Figura 15. 


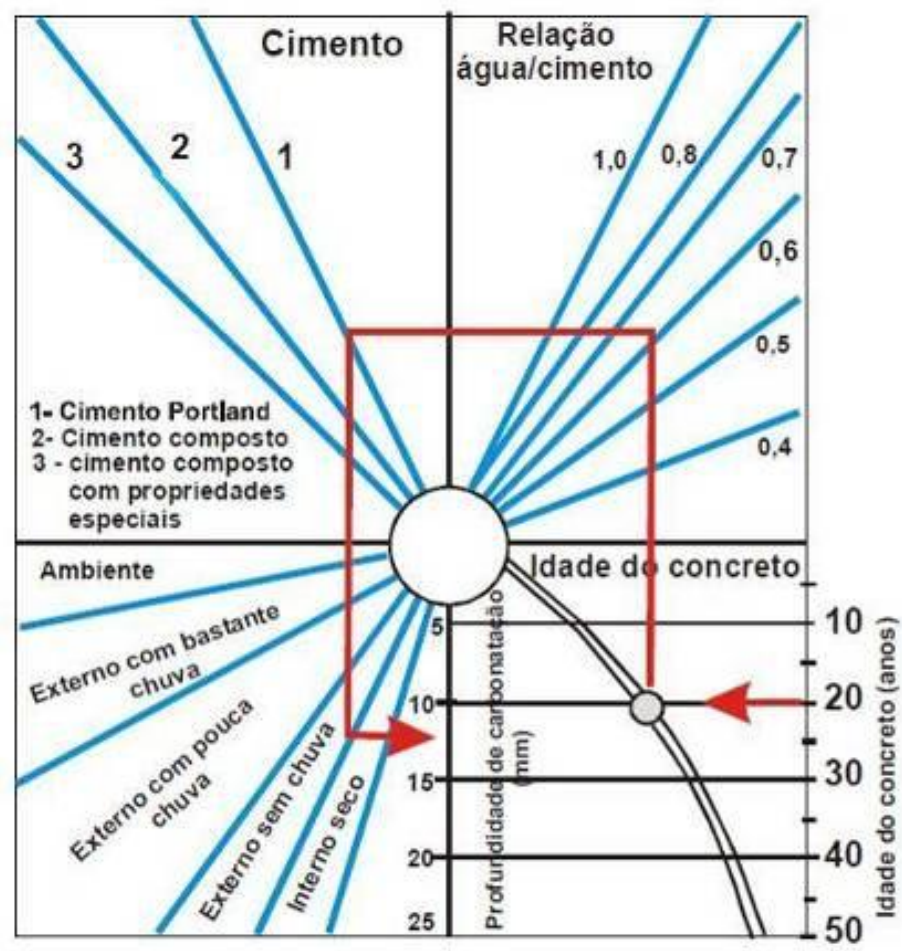

FIGURA 18 - Ábaco para estimar a profundidade de carbonatação (MEYER ${ }^{16}, 1987$ apud SILVA, 1995).

Outros autores que também propõem ábacos, mas em função de outras variáveis como a resistência à compressão do concreto são: Thomas e Mattews ${ }^{17}$, segundo Carmona (2005).

Vários modelos têm sido desenvolvidos, porém, quase todos são de base empírica ou semi-empírica. O desenvolvimento de um modelo que permita determinar com algum grau de confiabilidade o período de iniciação da corrosão devido à carbonatação seria de grande utilidade. Quanto menos fenomenológico o modelo for, maior será a sua aplicabilidade (SIMAS, 2007).

Os modelos e estudos sobre carbonatação na maioria das vezes referem-se a ensaios de corpos-de-prova ou peças pré-moldadas executadas sob condições controladas de laboratório em que houve controle tecnológico do concreto e condições artificiais de exposição de $\mathrm{CO}_{2}$, como feito recentemente por Silva (2007).

16 MEYER A. The importance of the surface layer for the durability of concrete structures. In: Katherine, Bryant Mather, editors. International conference on concrete durability, p. 48-61, Atlanta, USA; 1987.

17 THOMAS, M.A.; MATTHEWS, J.D. Carbonation of fly ash concrete. Magazine of Concrete Reaearch, v.44, n.160, p.217-228, 1992. 
Nas estruturas reais, as condições são significativamente diferentes, como: as dimensões das peças, as condições climáticas, a exposição aleatória aos agentes atmosféricos, as diferentes intensidades dos esforços em cada elemento, a falta de uniformidade e homogeneidade do concreto, a existência de microfissuras e até algumas fissuras, entre outras variáveis.

Tudo isso dificulta a determinação de valores representativos da profundidade de carbonatação em diferentes estruturas. Na realidade, as medidas de carbonatação in situ indicam áreas com $\mathrm{pH}$ mais reduzido e, através de medições, procura-se estipular de maneira aproximada uma profundidade "média", embora os valores máximos sejam os críticos para a corrosão (NAKAO et al., 2006).

\subsection{VARIÁVEIS AMBIENTAIS INFLUENTES NA CARBONATAÇÃO}

\subsubsection{Diferenciação entre clima regional, local e microclima}

As condições de exposição das estruturas de concreto, segundo o CEB 238 (Comité Euro-Internacional du Béton, 1997) podem ser caracterizadas em clima regional, local e microclima.

O clima regional ou macroclima refere-se ao clima da região onde a estrutura está inserida. Corresponde ao clima médio ocorrente num território relativamente vasto, exigindo, para sua caracterização, dados de um conjunto de postos meteorológicos; sendo que em zonas com relevo acentuado os dados macroclimáticos possuem um valor apenas relativo. Inversamente, um mesmo macroclima poderá englobar áreas de planície muito extensas ${ }^{18}$. É representado por dados de temperatura do ar e da água, da quantidade de íons cloreto e umidade relativa do ar e precipitação. A consideração do macroclima para efeito das especificações de projeto das estruturas de concreto está abordada no item 2.2.3.

O clima local é relativo ao entorno da estrutura e leva em consideração o local específico da construção. É representado pelo teor de $\mathrm{CO}_{2}$ da atmosfera local e pela intensidade e direção do vento.

18 (http://sistemasdeproducao.cnptia.embrapa.br/FontesHTML/Uva/UvaAmericanaHibridaClimaTemperado/clima $\mathrm{htm}$, site consultado em 10/09/2008). 
O microclima é referente às condições de acesso dos agentes climáticos ou outros agentes agressivos na superfície do concreto, como exposição à chuva (protegido ou desprotegido), radiação solar, contato com solo, umidade, entre outros.

A Tabela 6 a seguir, resume as principais variáveis ambientais consideradas de maior importância no processo da carbonatação.

\begin{tabular}{|c|c|}
\hline Condição & Efeitos \\
\hline Pressão parcial de $\mathrm{CO}_{2}$ & $\begin{array}{l}\text { Quanto maior a quantidade de } \mathrm{CO}_{2} \text { na fase gasosa, maior é a } \\
\text { taxa de carbonatação. No entanto, o aumento da pressão de } \\
\mathrm{CO}_{2} \text { não proporciona maior carbonatação. }\end{array}$ \\
\hline Umidade relativa & $\begin{array}{l}\text { A carbonatação é mais rápida para umidade relativa entre } 50 \\
\text { e } 70 \% \text { e decresce para altos e baixos níveis de umidade } \\
\text { relativa. }\end{array}$ \\
\hline Temperatura & $\begin{array}{l}\text { Temperaturas elevadas diminuem a solubilidade do } \mathrm{CO}_{2} \text { em } \\
\text { água, diminuindo a carbonatação. A reação da carbonatação é } \\
\text { exotérmica, o que promove a formação de } \mathrm{CaCO}_{3} \text { meta- } \\
\text { estável. Para obter a calcita, forma mais estável do carbonato } \\
\text { de cálcio, a temperatura deve ser mantida de } 0 \text { a } 10^{\circ} \mathrm{C} \text {. }\end{array}$ \\
\hline
\end{tabular}

Observar que não houve preocupação pelos autores da Tabela 6 de destacar ou fazer menção a qualquer parâmetro pluviométrico. Uma das razões para isto pode ser a falta de dados comparativos relativos à carbonatação natural de concretos em diferentes regiões climáticas.

Andrade et al. (2006) divulgaram a realização de uma pesquisa para avaliação da influência climática e de parâmetros ambientais nos efeitos da carbonatação e durabilidade do concreto armado, em diferentes locais de exposição, com a classificação da agressividade atmosférica baseada na metodologia da norma ISO Standard 9233. Os autores envolveram no estudo os dez seguintes países: Argentina, Bolívia, Brasil, Colômbia, Costa Rica, México, Espanha, Portugal, Uruguai e Venezuela. Foram incluídos em cada país tanto os ambientes urbanos quanto rurais. É provável que ao final do trabalho, as informações possam subsidiar a revisão dos modelos atuais de taxa de carbonatação vistos no item 2.1.4.

19 BERTOS, M. F.; SIMONS, S. J. R.; HILLS, C. D.; CAREY, P. J. A review of accelerated carbonation technology in the treatment of cement-based materials and sequestration of $\mathrm{CO}_{2}$. Journal of Hazardous Materials v.112, 3, 2004, p. 193-205. 
Embora a atmosfera poluída e industrializada dos grandes centros urbanos seja agressiva ao concreto, não se pode descartar a possibilidade de haver ambientes agressivos ao concreto em outras regiões, distantes dos grandes centros.

Por exemplo, Nakao et al. (2006) realizaram um estudo em Campo Grande, MS, para avaliar a Classe de Agressividade Ambiental a partir da análise do grau de carbonatação de algumas estruturas de concreto armado. Embora o Centro Oeste não possua grandes centros urbanos ou industriais, por sua vocação agropecuária, é uma região onde ocorrem grandes focos de queimadas e há casos de contaminação de cidades, por sua topografia plana, por nuvens de agrotóxicos de lavouras próximas às cidades. As queimadas são fontes de $\mathrm{CO}_{2}$, que além do ataque direto sobre a estrutura de concreto, podem formar chuvas ácidas.

Já as condições de microclima da estrutura são função de condicionantes do partido arquitetônico e do arcabouço estrutural integrados em um determinado ambiente, que sempre variam da condição de enterrado em solo ou água, no caso das fundações, até a completa exposição ou não à chuva, conforme o tipo de cobertura, acabamento e disposição dos elementos de concreto.

Desde Meyer (1969) está representada graficamente (Figura 19) a influência do ambiente de exposição do concreto na carbonatação.

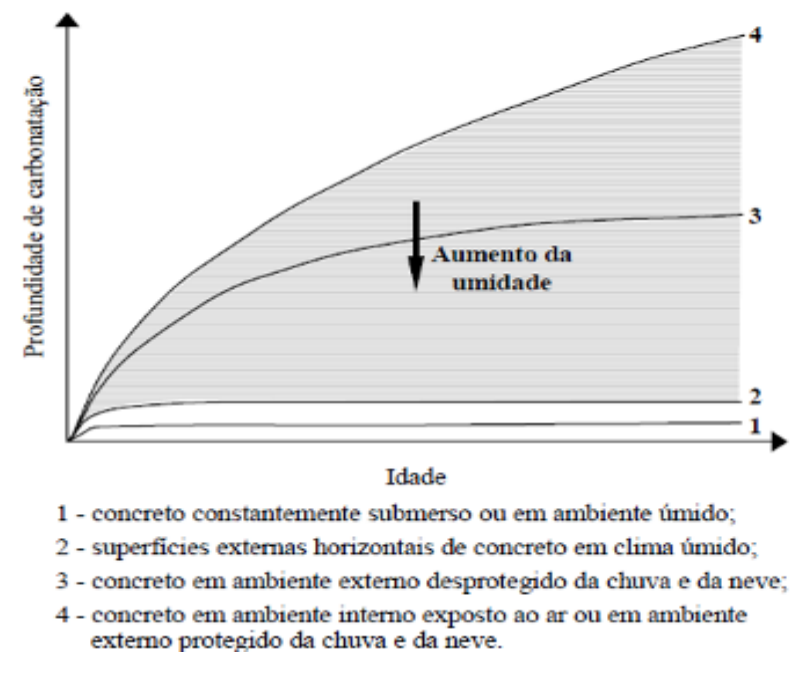

FIGURA 19 - Efeito das condições de exposição na carbonatação (Modelo de MEYER, 1969).

As seguintes pesquisas evidenciam o que está postulado graficamente pela Figura 19:

- Para as amostras dispostas ao ambiente natural de degradação, Ho e Lewis (1987) obtiveram diferentes resultados de profundidade de carbonatação, sendo que os corpos-de- 
prova dispostos na vertical carbonataram mais que os inclinados a $45^{\circ}$. Segundo os autores, as amostras inclinadas receberam $540 \mathrm{~mm}$ de chuva, enquanto que as amostras dispostas verticalmente somente $40 \mathrm{~mm}$. No entanto, a correlação entre os resultados de ensaios acelerados e ensaios ao natural é fortemente dependente das condições de exposição;

- Barker e Matthews (1994) verificaram que concretos armazenados em ambiente de laboratório, com UR de $65 \%$ e temperatura de $20^{\circ} \mathrm{C}$, carbonataram com maior velocidade do que os armazenados ao ar livre (protegidos da chuva), sendo que estes apresentaram redução de $40 \%$ na profundidade de carbonatação quando comparados aos concretos dispostos em recinto fechado;

- Houst e Wittmann (2002) relatam que, geralmente os concretos expostos ao ar livre, protegidos da chuva, carbonatam mais rapidamente do que os concretos desprotegidos. Isso se deve devido ao fechamento dos poros pela água da chuva;

- Figueiredo (2004) comparou espessuras de carbonatação de estruturas expostas e não expostas às intempéries e constatou que a profundidade carbonatada em ambiente externo não protegido da chuva corresponde a $30 \%$ daquela encontrada em ambiente protegido da chuva.

\subsubsection{As variáveis ambientais nas normas de projeto brasileira e européia}

A ABNT NBR 6118 (2007) estabelece que "as estruturas de concreto devem ser projetadas e construídas de modo que, sob as condições ambientais previstas na época do projeto, e quando utilizadas conforme preconizado em projeto conservem sua segurança, estabilidade e aptidão em serviço durante um período correspondente à sua vida útil". O clima regional e o microclima é considerado pelas quatro classes e condições resumidas na Tabela 7. 
TABELA 7- Classes de agressividade ambiental da ABNT NBR 6118 (2007).

\begin{tabular}{|c|c|c|c|}
\hline $\begin{array}{c}\text { Classe de } \\
\text { agressividade }\end{array}$ & Agressividade & $\begin{array}{c}\text { Classificaçäo geral } \\
\text { do tipo de ambiente } \\
\text { para } \\
\text { efeito de projeto }\end{array}$ & $\begin{array}{c}\text { Risco de deterioração da } \\
\text { estrutura }\end{array}$ \\
\hline 1 & Fraca & $\begin{array}{l}\text { Rural } \\
\text { Submersa }\end{array}$ & insignificante \\
\hline II & Moderada & Urbana $1 / .2)$ & Pequeno \\
\hline III & Forte & $\begin{array}{c}\text { Marinha" } \\
\text { Industrial| }\end{array}$ & Grande \\
\hline IV & Muito forte & $\begin{array}{c}\text { Industrial }^{1,3\rangle} \\
\text { Respingos de } \\
\text { maré }\end{array}$ & Elevado \\
\hline \multicolumn{4}{|c|}{$\begin{array}{l}\text { 1) Pode-se admitir um microclima com uma classe de agressividade mais branda (um } \\
\text { nivel acima) para ambientes internos secos (salas, dormitórios, banheiros, cozinhas, } \\
\text { áreas de serviço de apartamentos residenciais e conjuntos comerciais ou ambientes com } \\
\text { concreto revestido com argamassa e pintura). } \\
\text { 2) Pode-se admitir uma classe de agressividade mais branda (um nivel acima) em obras } \\
\text { em regiöes de clima seco, com umidade relativa do ar menor ou igual a } 65 \% \text {, partes da } \\
\text { estrutura protegidas de chuva em ambientes predominantemente secos ou regiőes onde } \\
\text { chove raramente. } \\
\text { 3) Ambientes quimicamente agressivos; tanques industriais, galvanoplastia, } \\
\text { branqueamento em indústrias de celulose e papel, armazéns de fertilizantes, indústrias } \\
\text { quimicas. }\end{array}$} \\
\hline
\end{tabular}

Por outro lado, através do levantamento de Priszkulnik et al. (2005), transcrito na Tabela 8 até a Tabela 10, é possível observar que a Norma Européia EN 206 (CEN, 2000) tem um outro tipo de abordagem para a classificação do ambiente de exposição ao concreto, pois associa as classes ao tipo mais provável de ataque ou de deterioração que podem ser previstos a cada projeto.

Por esse agrupamento, ficam então bem mais evidenciado quais são os microclimas mais determinantes da corrosão de armaduras. Cabe observar que o clima mais agressivo para a carbonatação é o de alternância à umidade e à secagem (classe XC4), o que não foi considerado pela ABNT NBR 6118 e nem na maioria das pesquisas acadêmicas, que investigam a suscetibilidade à carbonatação de concretos. Este é outro ponto importante que corrobora e justifica ainda mais a realização da presente pesquisa.

TABELA 8- Classes de agressividade ambiental da EN 206-1:2000 (CEN 1,2000 ) apud PRISZKULNIK et al. (2005).

\begin{tabular}{|c|l|}
\hline $\begin{array}{c}\text { Classe de } \\
\text { agressividade } \\
\text { ambiental }\end{array}$ & \multicolumn{1}{c|}{ Tipo de ataque ao concreto } \\
\hline X0 & Sem risco de corrosäo ou ataque \\
\hline$X C 1$ a XC4 & Corrosäo provocada por carbonataça \\
\hline$X S 1$ a XS3 & Corrosäo provocada por cloretos da água do mar \\
\hline XD1 a XD3 & $\begin{array}{l}\text { Corrosăo provocada por cloretos não provenientes da água } \\
\text { do mar }\end{array}$ \\
\hline$X F 1$ a XF4 & Ciclos de congelamento e degelo \\
\hline$X A 1$ a XA3 & Ataque químico \\
\hline
\end{tabular}


Tabela 9 - Classes de exposição ambiental da EM 206-1:2000 (CEN ${ }^{1}, 2000$ ) apud PRISZKULNIK et al. (2005).

\begin{tabular}{|c|c|c|}
\hline $\begin{array}{c}\text { Designação da } \\
\text { classe }\end{array}$ & $\begin{array}{l}\text { Descrição do } \\
\text { ambiente }\end{array}$ & $\begin{array}{l}\text { Exemplos informativos onde as } \\
\text { classes de exposição podem ocorrer }\end{array}$ \\
\hline \multicolumn{3}{|c|}{ 1. Sem risco de corrosão ou ataque } \\
\hline $\mathrm{xO}$ & $\begin{array}{l}\text { Para concreto sem } \\
\text { armadura ou metal } \\
\text { embutido: todos os } \\
\text { ambientes exceto na } \\
\text { ocorrência de } \\
\text { congelamento e } \\
\text { degelo, abrasão ou } \\
\text { ataque químico. } \\
\text { Para concreto armado } \\
\text { ou com metal } \\
\text { embutido: muito seco. }\end{array}$ & $\begin{array}{l}\text { Concreto no interior de edifícios com } \\
\text { umidade relativa do ar muito baixa. }\end{array}$ \\
\hline \multicolumn{3}{|c|}{ 2. Corrosão provocada por carbonatação } \\
\hline $\mathrm{XC} 1$ & $\begin{array}{l}\text { Seco ou } \\
\text { permanentemente } \\
\text { úmido }\end{array}$ & $\begin{array}{l}\text { Concreto no interior de edifícios com } \\
\text { baixa umidade do ar. } \\
\text { Concreto permanentemente imerso em } \\
\text { água. }\end{array}$ \\
\hline $\mathrm{XC} 2$ & $\begin{array}{l}\text { Úmido, } \\
\text { raramente seco }\end{array}$ & $\begin{array}{l}\text { Superfícies de concreto expostas a } \\
\text { contato prolongado com água. } \\
\text { Muitas fundaçốes. }\end{array}$ \\
\hline $\mathrm{xC} 3$ & Umidade moderada & $\begin{array}{l}\text { Concreto no interior de edifícios com } \\
\text { umidade do ar moderada ou elevada. } \\
\text { Concreto exterior protegido da chuva. }\end{array}$ \\
\hline $\mathrm{XC4}$ & $\begin{array}{c}\text { Alternadamente úmido } \\
\text { e seco }\end{array}$ & $\begin{array}{l}\text { Superfícies de concreto em contato com } \\
\text { água, não incluídas na classe de } \\
\text { exposição XC2. }\end{array}$ \\
\hline \multicolumn{3}{|c|}{$\begin{array}{l}\text { Observação: A condição de umidade refere-se à do cobrimento da armadura ou do } \\
\text { metal embutido, sendo, para tanto, adequada a classificação do ambiente envolvente. } \\
\text { Não é, entretanto, o caso em que há uma barreira entre o concreto e o ambiente. }\end{array}$} \\
\hline \multicolumn{3}{|c|}{ 3. Corrosão provocada por cloretos que não os da água do mar } \\
\hline $\mathrm{XD1}$ & Umidade moderada & $\begin{array}{l}\text { Superfícies de concreto expostas a } \\
\text { cloretos transportados pelo ar }\end{array}$ \\
\hline $\mathrm{XD} 2$ & $\begin{array}{l}\text { Úmido, raramente } \\
\text { seco }\end{array}$ & $\begin{array}{l}\text { Piscinas } \\
\text { Concreto exposto a águas industriais } \\
\text { contendo cloretos }\end{array}$ \\
\hline XD3 & $\begin{array}{l}\text { Ciclicamente úmido e } \\
\text { seco }\end{array}$ & $\begin{array}{l}\text { Partes de pontes expostas a névoa } \\
\text { contendo cloretos } \\
\text { Pavimentos } \\
\text { Lajes de estacionamento de veículos }\end{array}$ \\
\hline
\end{tabular}


TABELA 10- Classes de exposição ambiental da EN 206-1:2000 (CEN ${ }^{1}, 2000$ )(cont.) apud PRISZKULNIK et al. (2005).

\begin{tabular}{|c|c|c|c|}
\hline $\begin{array}{l}\text { Designação da } \\
\text { classe }\end{array}$ & $\begin{array}{l}\text { Descrição do } \\
\text { ambiente }\end{array}$ & \multicolumn{2}{|c|}{$\begin{array}{l}\text { Exemplos informativos onde as } \\
\text { classes de exposição podem ocorrer }\end{array}$} \\
\hline \multicolumn{4}{|c|}{$\begin{array}{l}\text { 4. Corrosão provocada por cloretos da água do mar } \\
\text { (concreto armado ou contendo metal embutido em contato com } \\
\text { cloretos da água do mar ou com o ar da maresia) }\end{array}$} \\
\hline Xs1 & $\begin{array}{l}\text { Exposiçäo ao ar } \\
\text { marítimo mas não em } \\
\text { contato direto com a } \\
\text { água do mar }\end{array}$ & \multicolumn{2}{|c|}{ Estruturas na costa ou junto à costa } \\
\hline $\mathrm{xS} 2$ & $\begin{array}{l}\text { Permanentemente } \\
\text { imerso }\end{array}$ & \multicolumn{2}{|c|}{ Partes de estruturas marítimas. } \\
\hline XS3 & $\begin{array}{l}\text { Zonas de marés, } \\
\text { rebentaçäo e salpicos }\end{array}$ & \multicolumn{2}{|c|}{ Partes de estruturas marítimas. } \\
\hline \multicolumn{4}{|c|}{$\begin{array}{l}\text { 5. Ataque pelo congelamento e degelo sem ou com agentes descongelantes } \\
\text { (concreto exposto a ataque significativo por congelamento e degelo estando úmido) }\end{array}$} \\
\hline $\mathrm{XF} 1$ & $\begin{array}{l}\text { Moderamente saturado } \\
\text { de água, sem agente } \\
\text { descongelante }\end{array}$ & \multicolumn{2}{|c|}{$\begin{array}{l}\text { Superficies verticais de concreto } \\
\text { expostas a chuva e congelamento }\end{array}$} \\
\hline $\mathrm{XF} 2$ & $\begin{array}{l}\text { Moderamente saturado } \\
\text { de água, com agente } \\
\text { descongelante }\end{array}$ & \multicolumn{2}{|c|}{$\begin{array}{l}\text { Superficies verticais de concreto de } \\
\text { estruturas rodoviárias expostas a } \\
\text { congelamento e agentes descongelantes } \\
\text { transportados pelo ar }\end{array}$} \\
\hline $\mathrm{XF} 3$ & $\begin{array}{l}\text { Altamente saturado de } \\
\text { água, sem agente } \\
\text { descongelante }\end{array}$ & \multicolumn{2}{|c|}{$\begin{array}{l}\text { Superficies horizontais de concreto } \\
\text { expostas a chuva e congelamento }\end{array}$} \\
\hline $\mathrm{XF} 4$ & $\begin{array}{l}\text { Altamente saturado de } \\
\text { água, com agente } \\
\text { descongelante ou } \\
\text { água do mar }\end{array}$ & \multicolumn{2}{|c|}{$\begin{array}{l}\text { Pavimentos de rodovias e pontes } \\
\text { expostos a agentes descongelantes } \\
\text { Superficies de concreto expostas a } \\
\text { névoa direta contendo agentes } \\
\text { descongelantes e congelamento } \\
\text { Zonas de flutuaçäo em estruturas } \\
\text { marítimas expostas a congelamento }\end{array}$} \\
\hline \multicolumn{4}{|c|}{$\begin{array}{l}\text { 6. Ataque químico } \\
\text { (concreto exposto ao ataque químico por solos naturais ou lençol de água, como } \\
\text { apresentado na tabela n } n^{\circ} \text {. A classificação da água do mar depende da localização } \\
\text { geográfica, devendo-se aplicar a classificação válida no local de emprego do concreto) } \\
\text { NOTA: Pode ser necessário realizar um estudo especial para caracterizar a } \\
\text { agressividade do meio quando se verificar: } \\
\text { a) valores fora dos limites da tabela } n^{\circ} 4 \text {; } \\
\text { b) a presença de outras substâncias químicas agressivas; } \\
\text { c) solo ou água quimicamente poluídos; } \\
\text { d) elevada velocidade da água em conjunto com as substâncias químicas da tabela } n^{\circ} \\
\text { 4. }\end{array}$} \\
\hline XA1 & \multicolumn{2}{|c|}{$\begin{array}{l}\text { Agressividade química fraca de } \\
\text { acordo com a tabela } n^{\circ} 4\end{array}$} & \\
\hline XA2 & \multicolumn{2}{|c|}{$\begin{array}{l}\text { Agressividade química moderada } \\
\text { de acordo com a tabela } n^{\circ} 4\end{array}$} & \\
\hline XA3 & \multicolumn{2}{|c|}{$\begin{array}{l}\text { Agressividade química elevada de } \\
\text { acordo com a tabela } n^{\circ} 4\end{array}$} & \\
\hline
\end{tabular}




\subsubsection{Critérios simplificados de projeto das estruturas a partir das classes de agressividade ambiental}

Com vistas à durabilidade das estruturas, a ABNT NBR 6118 (2007) estabelece limites para fissuração e proteção das armaduras, como resumido a seguir, a partir da classificação ambiental segundo a Tabela 7 no item 2.2.2:

- Para garantir um cobrimento mínimo da armadura $C_{\text {mín. }}$ o projeto e a execução devem considerar o cobrimento nominal $\left(\mathrm{C}_{\text {nom }}\right)$, que é o cobrimento mínimo acrescido da tolerância de execução $(\Delta c)$. As dimensões das armaduras e os espaçadores devem obedecer aos cobrimentos nominais especificados pela norma, conforme a Tabela 12;

- Quanto à dimensão máxima característica do agregado (Dmáx.), não pode superar em $20 \%$ a espessura nominal do cobrimento $\left(C_{\text {nom }}\right)$, ou seja, Dmáx. $\leq 1,2 C_{\text {nom; }}$;

- A tolerância de execução do cobrimento $(\Delta c)$ é igual a $5 \mathrm{~mm}$ quando houver um adequado controle de qualidade e rígidos limites de tolerância da variabilidade das medidas durante a execução, devendo a exigência de controle rigoroso ser aplicada nos desenhos de projeto. Neste caso, a redução dos cobrimentos nominais da Tabela 12 é permitida em 5 $\mathrm{mm}$;

- A presença de fissuras com aberturas limitadas, em estruturas bem projetadas, construídas e submetidas às cargas previstas na normalização, não denotam perda de durabilidade ou perda de segurança quanto aos estados limites últimos²0;

- As fissuras podem ocorrer por outros motivos, como por retração plástica, retração térmica, retração higrométrica, ou devido a reações químicas do concreto nas primeiras idades, devendo ser evitadas ou limitadas por cuidados tecnológicos, especialmente na definição do traço e na cura do concreto;

- A abertura máxima característica $w_{k}$ das fissuras, desde que não exceda valores da ordem de $0,2 \mathrm{~mm}$ a $0,4 \mathrm{~mm}$, sob ação das combinações freqüentes, não tem importância significativa na corrosão das armaduras passivas;

- O CEB21 152 (1983) citado por Silva (2007) afirma que a influência da fissura, com aberturas entre 0,15 e $0,35 \mathrm{~mm}$ na taxa de corrosão da armadura é relativamente baixa, e que a espessura do cobrimento do concreto é mais relevante. Segundo essa

\footnotetext{
20 Pesquisas realizadas, como SILVA (2007), não concordam com esta informação. 
TABELA 12 - Cobrimento nominal para $\Delta c=10 \mathrm{~mm}$ em função da classe de agressividade ambiental e na Tabela 7, item 2.2.2. (ABNT NBR 6118:2007).

\begin{tabular}{|c|c|c|c|c|c|}
\hline \multirow{3}{*}{$\begin{array}{l}\text { Tipo de } \\
\text { estrutura }\end{array}$} & \multirow{3}{*}{$\begin{array}{l}\text { Componente } \\
\text { ou elemento }\end{array}$} & \multicolumn{4}{|c|}{ Classe de agressividade ambiental } \\
\hline & & I & II & III & $I^{3)}$ \\
\hline & & \multicolumn{4}{|c|}{ Cobrimento nominal (mm) } \\
\hline \multirow{2}{*}{$\begin{array}{l}\text { Concreto } \\
\text { armado }\end{array}$} & Laje $^{2)}$ & 20 & 25 & 35 & 45 \\
\hline & Viga / Pilar & 25 & 30 & 40 & 50 \\
\hline $\begin{array}{l}\text { Concreto } \\
\text { protendido }\end{array}$ & Todos & 30 & 35 & 45 & 55 \\
\hline
\end{tabular}

1) cobrimento nominal da armadura passiva que envolve a bainha ou os fios, cabos $\mathrm{e}$ cordoalhas, sempre superior ao especificado para o elemento de concreto armado, devido aos riscos de corrosão fragilizante sob tensão.

2) para a face superior de lajes e vigas que serão revestidas com argamassas de contrapiso, com revestimentos finais secos tipo carpete e madeira, com argamassas de revestimento e acabamento tais como pisos de elevado desempenho, pisos cerâmicos, pisos asfálticos e outros tantos, as exigências da tabela podem ser substituídas pelas seguintes: $C_{\text {nom }} \geq \Phi$ barra; $\quad C_{\text {nom }} \geq \Phi$ feixe $=\Phi_{n}=\Phi \sqrt{n} ; C_{\text {nom } 2} \geq 0,5 \Phi$ bainha, respeitado um cobrimento nominal $\geq 15 \mathrm{~mm}$.

3) nas faces inferiores de lajes e vigas de resevatórios, estações de tratamento de água e esgoto, condutos de esgoto, canaletas de efluentes e outras obras em ambientes química e intensamente agressivos, a armadura deve ter cobrimento nominal $\geq 45 \mathrm{~mm}$.

Com o controle da qualidade das estruturas de concreto, de uma maneira geral, é sistêmico, ainda exige uma série de outros requisitos e critérios desde a elaboração do projeto, a seleção dos materiais, a composição do concreto, a metodologia construtiva, a proteção, a cura e finalmente, a observação da manutenção preventiva, como bem destacada pela Figura 6, apresentada no item 2.1.1 deste capítulo.

Quanto às características do concreto, a ABNT NBR 6118 (2007) e a ABNT NBR 12655 (2006) impõem condições em função da classe de agressividade, conforme constam na Tabela 13, considerando a correspondência entre a relação água/cimento e a resistência à compressão do concreto com a sua maior aptidão à durabilidade nas estruturas. No item 7.4.3 da citada norma, consta que os requisitos indicados são válidos para concretos executados com cimento Portland que atenda, conforme seu tipo e classe, à especificação respectiva, conforme item 2.3.2 - A). 
TABELA 13 - Critérios prescritivos do concreto pela classe de agressividade ambiental, na TABELA 7, item 2.2.2, segundo a ABNT NBR 6118 (2007) e a ABNT NBR 12655 (2006).

\begin{tabular}{|c|c|c|c|c|c|}
\hline \multirow[b]{2}{*}{ Concreto } & \multirow[b]{2}{*}{ Tipo } & \multicolumn{4}{|c|}{ Classe de agressividade do ambiente } \\
\hline & & I & II & III & IV \\
\hline \multirow{2}{*}{$\begin{array}{l}\text { Relação } \\
\text { água/cimento } \\
\text { em massa }\end{array}$} & CA & $\leq 0,65$ & $\leq 0,60$ & $\leq 0,55$ & $\leq 0,45$ \\
\hline & $\mathrm{CP}$ & $\leq 0,60$ & $\leq 0,55$ & $\leq 0,50$ & $\leq 0,45$ \\
\hline Classe do & CA & $\geq \mathrm{C} 20$ & $2 \mathrm{C} 25$ & $2 \mathrm{C} 30$ & $\geq C 40$ \\
\hline Concreto (ABNT) & $\mathrm{CP}$ & $\geq \mathrm{C} 25$ & $2 \mathrm{C} 30$ & $\geq C 35$ & $2 \mathrm{C} 40$ \\
\hline $\begin{array}{l}\text { Consumo de cimento } \\
\text { por metro cúbico de } \\
\text { concreto } \mathrm{kg} / \mathrm{m}^{3}\end{array}$ & $\mid \begin{array}{ll}\mathrm{CA} & \mathrm{e} \\
\mathrm{CP} & \end{array}$ & $\geq 260$ & $\geq 280$ & $\geq 320$ & $\geq 360$ \\
\hline
\end{tabular}

Embora a edição mais atual da NBR 6118 (ABNT, 2007) estabeleça exigências associadas para a relação água/cimento e a classe de resistência à compressão do concreto, é preciso reconhecer que o emprego de aditivos super ou hiperplastificantes, e de pós reativos, de grande utilidade na produção dos concretos, permite o atendimento das condições especificadas para consumos de material cimentício que podem não atender às exigências de durabilidade (PRISZKULNIK et al., 2005).

De modo ilustrativo, na Tabela 14, constam as exigências análogas da EN 206-1:2000, para a produção do concreto, segundo compilado por Priszkulnik et al. (2005).

Aqui é importante observar que a classe XC4 de concreto é menos tolerante que a norma brasileira em relação ao valor da relação água/cimento máxima.

À exceção de concretos para serem submetidos a gelo e degelo, não há também preocupação na limitação de teor de ar nos concretos frescos.

A relação água/cimento é assim uma das variáveis mais utilizadas em prescrições empíricas para a especificação e produção de concreto estrutural, mas carece até o presente de procedimentos efetivos para o seu controle, na prática operacional de muitas usinas, o que se justifica pela complexidade de controle da umidade, nas partidas de agregados.

Nisto o programa experimental desta dissertação também procurou contribuir e optou por testar um procedimento gravimétrico indireto e o mais simples possível, mas focado na determinação da umidade total do concreto fresco, já que pode ser relacionada à relação água/cimento uma vez conhecida proporção ou traço de mistura. 
De fato, o mercado apresenta opções de equipamentos para controle da relação água/cimento do concreto fresco e pesquisas acadêmicas futuras podem cooperar na análise e seleção daqueles mais eficazes.

TABELA 14 - Valores limites recomendados para a composição e propriedades do concreto (CEN $\left.{ }^{1}, 2000\right)$ apud PRISZKULNIK et al. (2005).

\begin{tabular}{|c|c|c|c|c|}
\hline \multicolumn{5}{|c|}{ Valores limites em função das classes de exposição } \\
\hline \multicolumn{5}{|l|}{ Sem risco de corrosão ou ataque } \\
\hline Classe de exposição & \multicolumn{4}{|c|}{$\mathrm{XO}$} \\
\hline Relaçäo a/c máxima & \multicolumn{4}{|c|}{-} \\
\hline Classe de resistência (cilindro / cubo) & \multicolumn{4}{|c|}{$12 / 15$} \\
\hline Conteúdo de cimento mínimo $\left(\mathrm{kg} / \mathrm{m}^{3}\right)$ & \multicolumn{4}{|c|}{-} \\
\hline Teor de ar mínimo (\%) & \multicolumn{4}{|c|}{-} \\
\hline \multicolumn{5}{|l|}{ Corrosão induzida por carbonatação } \\
\hline Classe de exposiçäo & $\mathrm{XC1}$ & $\mathrm{XC2}$ & $\mathrm{XC3}$ & $\mathrm{XC4}$ \\
\hline Relação a/c máxima & 0,65 & 0,60 & 0,55 & 0,50 \\
\hline Classe de resistência (cilindro / cubo) & $20 / 25$ & $25 / 30$ & $30 / 37$ & $30 / 37$ \\
\hline Conteúdo de cimento mínimo $\left(\mathrm{kg} / \mathrm{m}^{3}\right)$ & 260 & 280 & 280 & 300 \\
\hline Teor de ar mínimo (\%) & - & & - & - \\
\hline \multicolumn{4}{|c|}{ Corrosão induzida por cloretos provenientes da água do mar } & \\
\hline Classe de exposiçäo & \multicolumn{2}{|l|}{ XS1 } & XS2 & XS3 \\
\hline Relação a/c máxima & \multicolumn{2}{|l|}{0,50} & 0,45 & 0,45 \\
\hline Classe de resistência (cilindro / cubo) & \multicolumn{2}{|l|}{$30 / 37$} & $35 / 45$ & $35 / 45$ \\
\hline Conteúdo de cimento mínimo $\left(\mathrm{kg} / \mathrm{m}^{3}\right)$ & \multicolumn{2}{|l|}{300} & 320 & 340 \\
\hline Teor de ar mínimo (\%) & \multirow{2}{*}{\multicolumn{2}{|c|}{\begin{tabular}{c|c}
- & \\
nientes da áqua do \\
\end{tabular}}} & - & - \\
\hline \multicolumn{3}{|c|}{ Corrosão induzida por cloretos näo provenientes da água do mar } & & \\
\hline Classe de exposiçäo & \multicolumn{2}{|l|}{ XD1 } & $\mathrm{XD2}$ & $\mathrm{XD3}$ \\
\hline Relação a/c máxima & 0,55 & & 0,55 & 0,45 \\
\hline Classe de resistência (cilindro / cubo) & $30 / 37$ & & $30 / 37$ & $35 / 45$ \\
\hline Conteúdo de cimento mínimo $\left(\mathrm{kg} / \mathrm{m}^{3}\right)$ & 300 & & 300 & 320 \\
\hline Teor de ar mínimo (\%) & - & & - & - \\
\hline Ataque por congelamento e degelo & & & & \\
\hline Classe de exposição & $\mathrm{XF1}$ & XF2 & $\mathrm{XF3}$ & XF4 \\
\hline Relaçāo a/c máxima & 0,55 & 0,55 & 0,50 & 0,45 \\
\hline Classe de resistência (cilindro / cubo) & $30 / 37$ & $25 / 30$ & $30 / 37$ & $30 / 37$ \\
\hline Conteúdo de cimento mínimo $\left(\mathrm{kg} / \mathrm{m}^{3}\right)$ & 300 & 300 & 320 & 340 \\
\hline Teor de ar mínimo (\%) & - & $4,0(2)$ & $4,0(2)$ & $4,0(2)$ \\
\hline Outras exigências & (1) & (1) & (1) & (1) \\
\hline Meios quimicamente agressivos & & & & \\
\hline Classe de exposiçäo & XA1 & & XA2 & XA3 \\
\hline Relaç̃o a/c máxima & 0,55 & & 0,50 & 0,45 \\
\hline Classe de resistência & $30 / 37$ & & $30 / 37$ & $35 / 45$ \\
\hline Conteúdo de cimento mínimo $(\mathrm{kg} / \mathrm{m} 3)$ & 300 & & 320 & 360 \\
\hline Teor de ar mínimo (\%) & - & & - & - \\
\hline Outras exigências & - & & (3) & (3) \\
\hline
\end{tabular}

Obs: (1) Agregado de acordo com a prEN 12620/2000, com resistência suficiente ao congelamento e degelo.

(2) Para concreto sem ar incorporado, o desempenho deve ser comprovado através de ensaio comparativo a outro cuja resistência ao congelamento e degelo tenha sido comprovada para a respectiva classe de exposição.

(3) Caso o teor de $\mathrm{SO}_{4}^{-2}$ conduza às classes XA2 $\mathrm{e}$ XA3, é essencial o uso de cimento resistente a sulfatos. Para a classe XA2 deve-se empregar cimento de moderada ou de alta resistência aos sulfatos (e, também, quando aplicável à classe XA1); para a classe XA3 deve-se empregar cimento de alta resistência aos sulfatns 


\subsection{VARIÁVEIS INTRÍNSECAS AO CONCRETO INFLUENTES NA CARBONATAÇÃO}

Como já apresentado, as características do concreto apresentam grande influência na carbonatação, dentre as quais, a porosidade do material, tipo de cimento, adições minerais, aditivos, agregados, água de amassamento.

As variáveis definidas pelo tipo e dosagem dos materiais e qualidade da execução apresentam significativa importância, dentre elas estão: relação água/cimento, proporção agregado/cimento, procedimentos de vibração, procedimentos de cura do concreto e permeabilidade e absorção resultantes no material.

Mas, em geral, são as propriedades mecânicas que se estabelecem como prioritárias na especificação do concreto estrutural, por razões óbvias. Por razões práticas, a carbonatação é então controlada indiretamente pelas propriedades mecânicas, principalmente, a resistência característica à compressão e o controle de abertura de fissuras do concreto, como resumido no item 2.2.3.

Porém, esta premissa é válida principalmente quando a produção do concreto ocorre sob controle estatístico de processo e, portanto, é possível também comparar a resistência média à compressão e os desvios de produção, para a melhor correlação com as propriedades físicas relacionadas à porosidade e à carbonatação do concreto.

Além disso, como visto no item 2.2, evoluir no conhecimento da carbonatação e nas formas de medida desse mecanismo significa evoluir em desenvolvimento da modelagem da vida útil de projeto e de vida útil residual de estruturas, variáveis consideradas cada vez mais importantes do ponto de vista do ciclo de vida das obras e do desenvolvimento sustentável da indústria da construção civil e ainda importante para projetos em condições de serviço mais agressivo.

\subsubsection{Porosidade}

\section{A) Importância}

A porosidade de um material é a propriedade física ampla que descreve as suas características quanto à forma, conexão e volume dos seus poros ou vazios. De forma sintética, o termo porosidade tem sido empregado na tecnologia do concreto para representar a fração do volume total de um concreto no estado sólido ou endurecido, que é 
ocupada por poros ou por espaços vazios. É uma das características que mais interfere nas propriedades físicas e mecânicas do concreto e deve ser controlada, sempre que possível, para melhorar a resistência do concreto a meios agressivos e a durabilidade das obras em geral.

A durabilidade de um concreto está diretamente ligada ao comportamento da rede de poros de seu interior e às suas condições particulares de exposição, como visto no item 2.1.1. A intercomunicabilidade da rede de poros pode indicar e definir a durabilidade do concreto. A limitação da continuidade da rede de poros é conseguida com a adição de complementos ativos ou inertes neste concreto (AITCIN, 2000). Mas, na opinião desta autora, há que se ponderar limite por efeitos de retração, já que há um refinamento dos poros.

Os fatores envolvidos que evidenciam a estrutura dos poros e a configuração das fissuras, juntamente com o teor de água contido nestes vazios, são os fatores determinantes do transporte de fluidos ou substâncias dissolvidas, através da microestrutura do concreto endurecido.

Segundo Helene (1993), a penetração de gás carbônico no concreto dá-se preponderantemente por um mecanismo de difusão. Os mecanismos de absorção capilar22 e migração de íons raramente se aplicam ao caso. Na maioria das vezes, só a concentração de $\mathrm{CO}_{2}$ no ambiente externo junto à estrutura, comparativamente à concentração de $\mathrm{CO}_{2}$ nos poros capilares do concreto influirá no mecanismo de propagação do $\mathrm{CO}_{2}$ no interior do concreto. Em poros excessivamente secos ou em poros saturados não haverá condições para propagação do $\mathrm{CO}_{2}$.

A Figura 20 apresenta uma representação gráfica dos mecanismos de transporte em função da dimensão dos poros, e no item B) são apresentados conceitos complementares sobre a sua classificação e importância.

\footnotetext{
22 Observar que nesta afirmativa, Helene (1993) não considera o processo de molhagem e absorção de água capilar pelo concreto como um mecanismo que pode também propiciar a dissolução de $\mathrm{CO}_{2}$ e a sua penetração em profundidades até maiores no concreto do que por difusão, a depender da alternância e tempo transcorrido para uma fase de secagem subseqüente. Por outro lado. Helene (1995) sempre alertou para a maior agressividade dos ciclos de molhagem e secagem do concreto, mas os considerando uma situação menos favorável à carbonatação do que a condição de UR constante entre $70 \pm 10 \%$ (HELENE, 1993, p.184). Já a atual classificação européia nas Tabelas 9 e 14, evidenciam a importância de se considerar o efeito sinérgico da carbonatação com a ação cíclica da água para a corrosão de armaduras.
} 


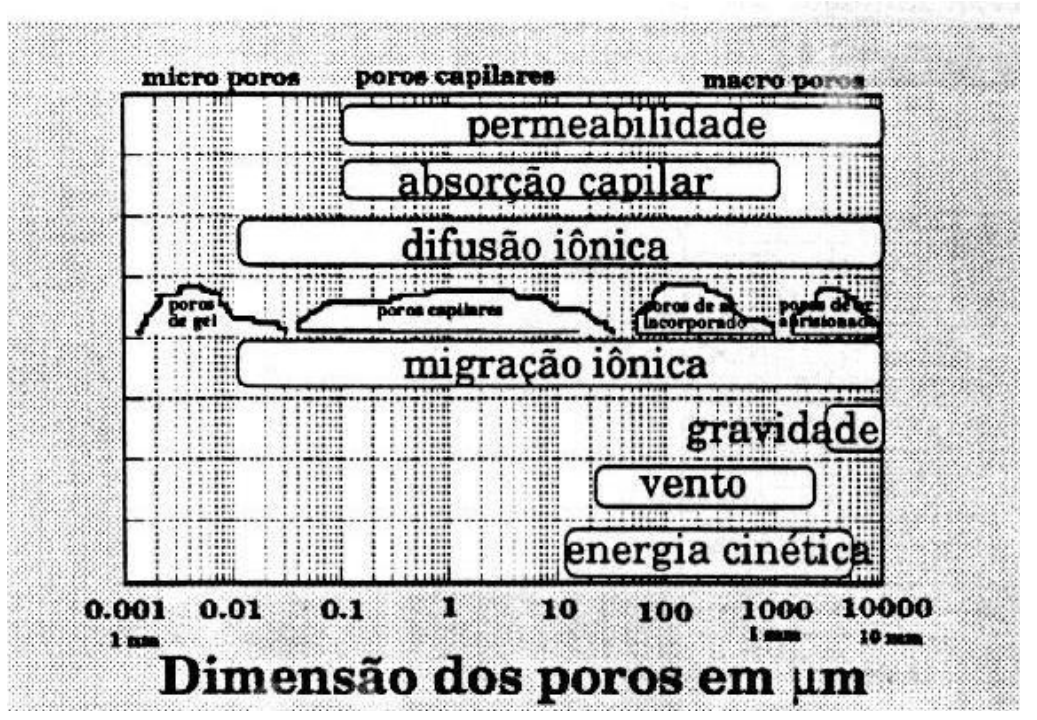

FIGURA 20 - Representação gráfica dos mecanismos de penetração em função da porosidade (HELENE, 1993).

O desempenho do concreto, enquanto barreira para diminuição do transporte de agentes potencialmente causadores de corrosão das armaduras, está relacionado com a sua porosidade. Assim, modificar a porosidade do concreto pode ser uma solução econômica, eficiente e simples para aumentar a durabilidade do concreto armado. Dentro deste contexto, Sato (1998) analisou a influência do volume total de vazios e das dimensões dos poros nas propriedades de transporte de água, de íons cloreto e de $\mathrm{CO}_{2}$ em concretos, sendo abordado em maior profundidade, o transporte de água.

A mudança na estrutura do espaço poroso pode ser feita tanto por meio da diminuição do volume total de vazios como também com modificações na distribuição de tamanho de poros. O desenvolvimento do espaço poroso do concreto não depende somente da sua composição, mas também, das condições de cura e de exposição.

Diversos pesquisadores (Houst ${ }^{14}$, Papadakis ${ }^{7,8,9,10}$ et al. citados por Pauletti, 2004; 2009) concluíram que devido à carbonatação, há uma redução na porosidade e concomitante diminuição da dimensão dos poros. A porosidade decresce com o tempo por causa do volume de sólidos dos produtos das reações químicas de hidratação e carbonatação.

Ishida e Maekawa (2000) constataram que os poros se tornam mais finos após a carbonatação, no entanto, ressaltam que não há consenso sobre como a porosidade e sua distribuição mudam. Os autores indicam que o volume do cristal de $\mathrm{CaCO}_{3}$ é aproximadamente $11,7 \%$ maior que o do $\mathrm{Ca}(\mathrm{OH})_{2}$. Papadakis ${ }^{10}$ et al. (1992) definem porosidade final como o volume de poros do volume total do concreto, após a completa hidratação, atividade pozolânica e carbonatação. 
A porosidade pode ser melhorada com a dosagem, com a adequação tecnológica de aplicação e com a intervenção na sua microestrutura, através de complementos cimentícios ativos ou inertes. Mas não existe um conceito holístico ou integrado sobre como otimizá-la do ponto de vista mecânico e de durabilidade das armaduras.

Outro fato a ser considerado é a interação que existe entre o teor de umidade ambiente e a porosidade, o primeiro influindo na hidratação do cimento e na ocorrência de reações químicas e em conseqüência na porosidade e esta afetando a quantidade de umidade retida no material. Estas inter-relações estão representadas na Figura 21. Os poros dependem essencialmente da relação água/cimento, do tempo de cura e do refinamento causado por adições.

Segundo Sato (1998), os concretos expostos ao ar apresentam porosidade diferente nas regiões próximas à superfície quando comparada com as regiões mais internas, devido às diferenças no processo de hidratação e às reações químicas que podem ocorrer entre as substâncias presentes no meio ambiente e no concreto, como é o caso da reação de carbonatação.

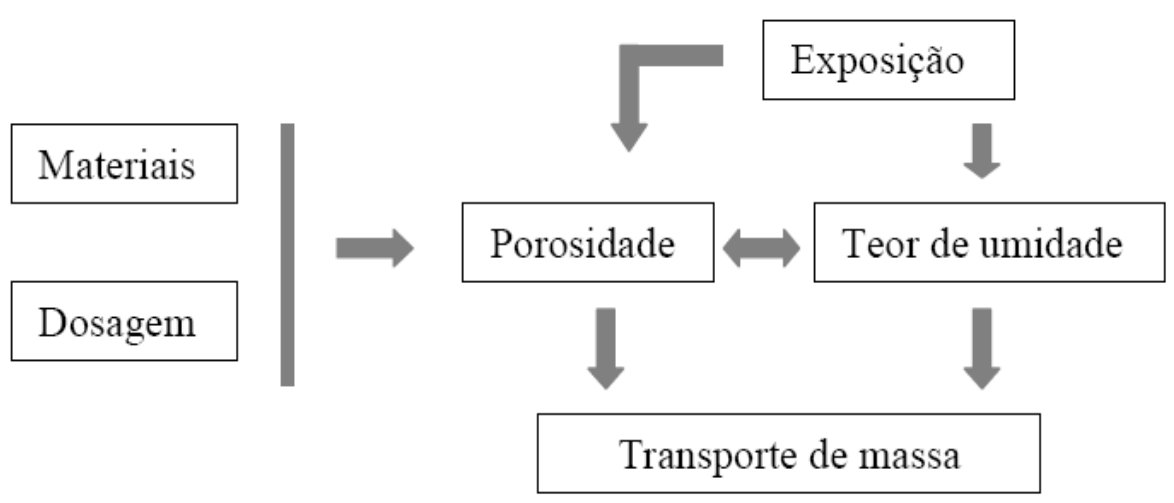

FIGURA 21 - Fatores que interferem na porosidade e no transporte de massa (SATO, 1998).

Estas considerações mostram a importância de pesquisas visando o estudo da influência da estrutura porosa na taxa de transporte de água e agentes agressivos para o interior do concreto.

No caso do concreto, em algumas regiões, a massa de pasta de cimento hidratada apresenta ser tão densa quanto o agregado, enquanto que em outras ela é altamente porosa, especialmente na zona de transição entre pasta e agregado graúdo. Não é a porosidade total, mas a distribuição do tamanho dos poros, em especial na interface pasta/agregados, o que controla efetivamente a resistência, a permeabilidade, e as variações de volume em uma pasta de cimento endurecida (Figura 22). A distribuição do tamanho dos poros é afetada pela relação água/cimento, pela idade (grau) de hidratação do 
cimento e demais caracteríticas de produção do concreto. Os poros grandes influenciam principalmente na resistência à compressão e na permeabilidade; os poros pequenos influenciam mais a retração por secagem e fluência (MEHTA; MONTEIRO, 1994; 2008).
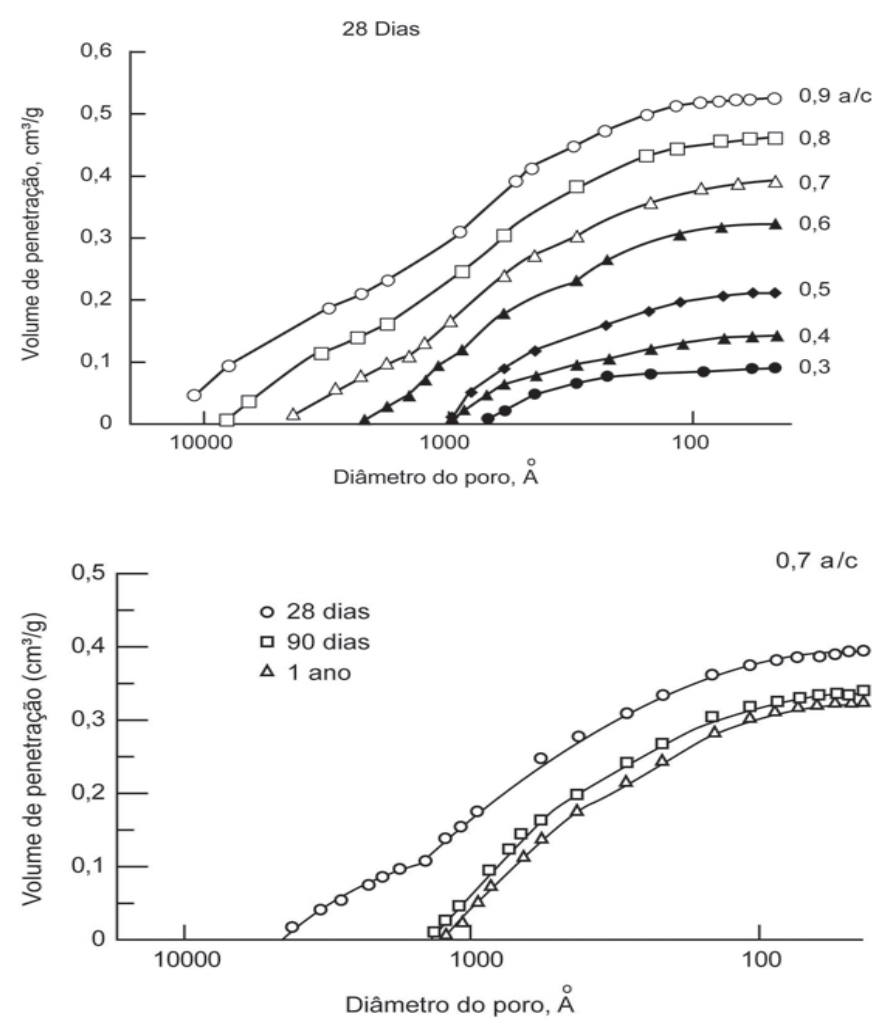

FIGURA 22- Distribuição do tamanho dos poros em pastas de cimento hidratado. (MEHTA; MONTEIRO, 1994).

O tamanho e a continuidade dos poros na microestrutura do sólido determinam sua permeabilidade. A permeabilidade é definida como a facilidade com que um fluido sob pressão pode fluir através de um sólido. Resistência e permeabilidade da pasta de cimento hidratada são dois lados da mesma moeda, numa analogia prática e uma vez que ambos são estreitamente relacionados à porosidade capilar ou à relação sólido/espaço. Isso fica evidente na curva de permeabilidade mostrada na Figura 23, que se baseia em valores determinados experimentalmente por Powers (MEHTA; MONTEIRO, 1994; 2008). 

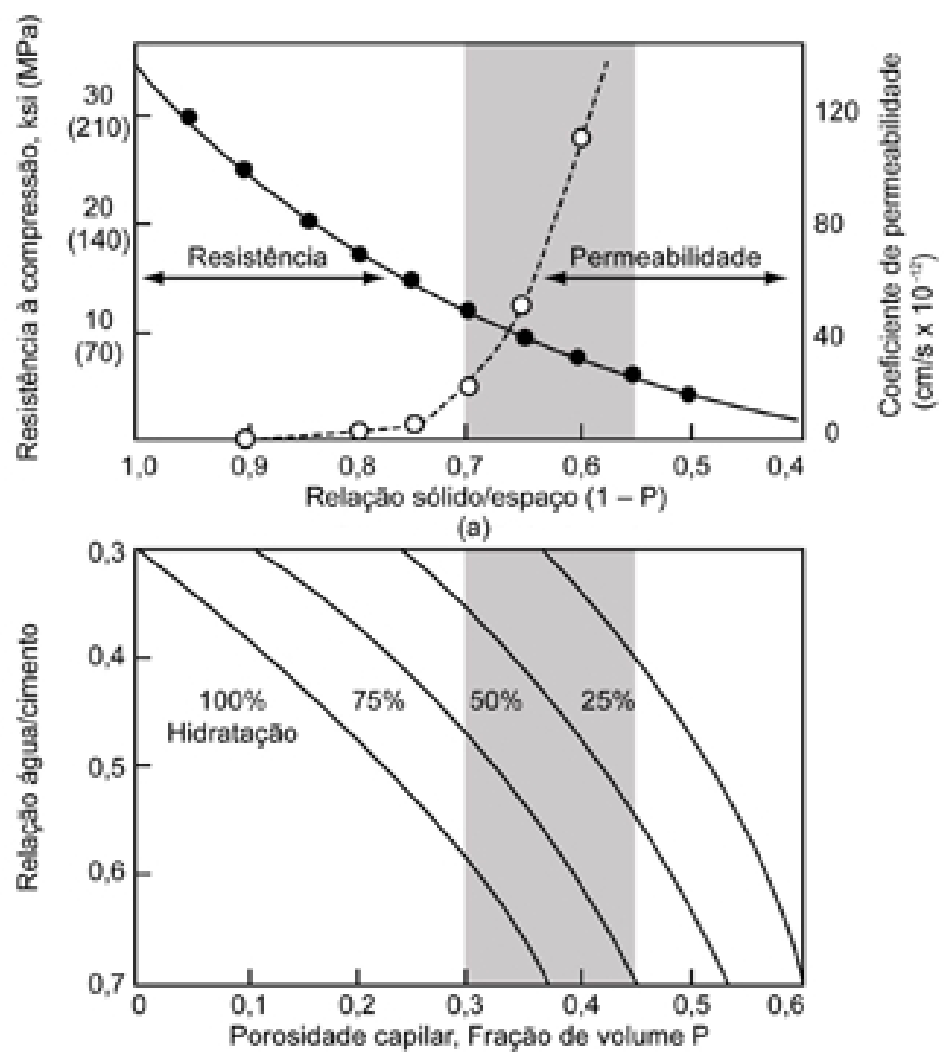

(b)

FIGURA 23 - Influência da relação água/cimento e do grau de hidratação sobre a resistência e a permeabilidade (MEHTA; MONTEIRO, 1994).

A relação exponencial entre permeabilidade e porosidade, mostrada na Figura 23 pode ser compreendida a partir da influência que os vários tipos de poros exercem na permeabilidade. À medida que a hidratação se processa, o espaço vazio entre partículas originalmente individualizadas de cimento começa a ser gradualmente preenchido com os produtos da hidratação (MEHTA; MONTEIRO, 1994).

\section{B) Classificação dos poros}

No estudo de materiais porosos é importante classificar os poros quanto ao tamanho e tipo. Num mesmo sólido podem existir poros com grande variedade de formas e tamanhos. $\mathrm{Na}$ Tabela 15 estão relacionados os tipos de poros existentes e suas respectivas dimensões, de acordo com a classificação mais atual da IUPAC - International Union of Pure and Applied Chemistry que resultou dos avanços em equipamentos e pesquisas em nanotecnologia de cerâmicas avançadas, provavelmente. 
TABELA 15 - Classificação dos poros segundo a classificação da IUPAC INTERNATIONAL UNION OF PURE AND APPLIED CHEMISTRY (VIANA, 2004).

\begin{tabular}{c|c}
\hline \multicolumn{1}{c|}{ Tipo de poro } & Dimensão \\
\hline a) Macroporo & Maior que $500 \AA(50 \mathrm{~nm})$ \\
\hline b) Mesoporo & Entre 20 e $500 \AA(2$ até $50 \mathrm{~nm})$ \\
\hline c) Microporo & Entre 6 e $20 \AA(2 \mathrm{~nm})$ \\
\hline d) Ultramicroporo & Menor que $6 \AA(0,6 \mathrm{~nm})$ \\
\hline
\end{tabular}

Essa classificação foi divulgada para a tecnologia de concreto por proposição de Mehta, entre outros especialistas, e tem sido adotada desde então, inclusive no Brasil23, porém ainda um tanto desconhecida, pois é sempre difícil a análise de poros, por causa da representatividade da amostragem em materiais compósitos de distribuição granulométrica muito variada como é o caso do concreto.

A Figura 24 ilustra outra forma de se visualizar o tamanho e distribuição dos poros na pasta de cimento.

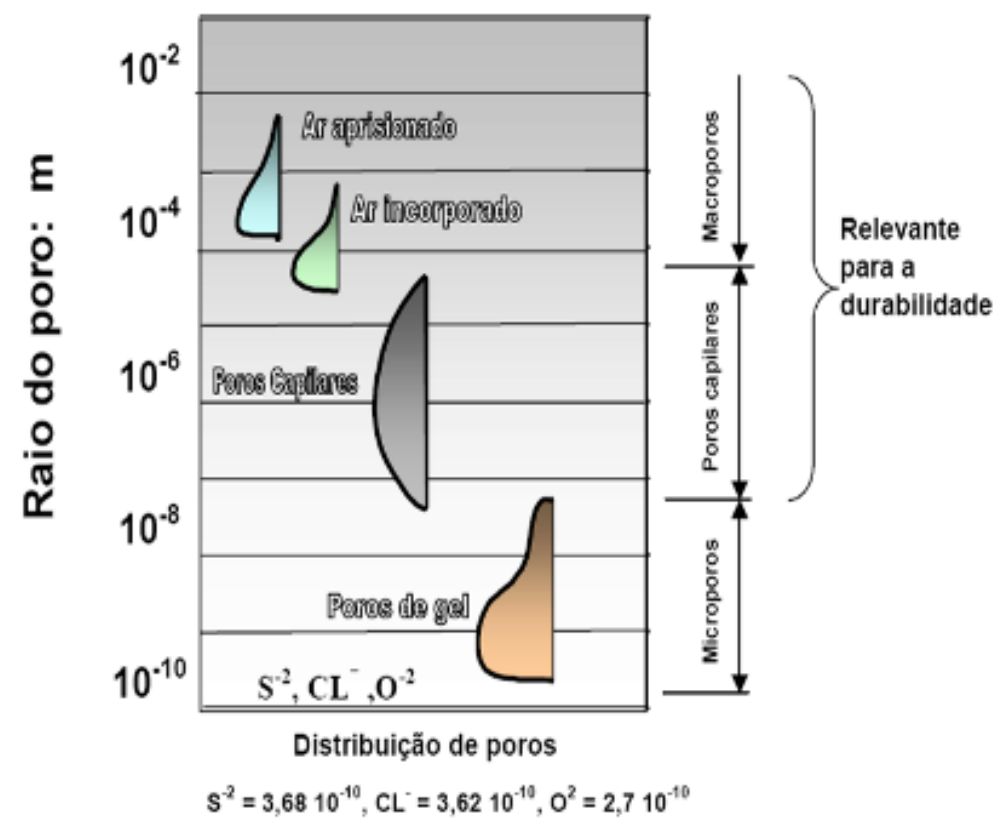

FIGURA 24 - Distribuição do tamanho de poros na pasta de cimento endurecida (CASCUDO, 1997 adaptado por POLITO, 2006).

\footnotetext{
23 Por exemplo, em Selmo (1997) quando relacionou os critérios da IUPAC ao comportamento físico e mecânico de pastas de gesso. Para cimentos com adições, a tese de Melo Neto (2007) empregou esta classificação na discussão da microestrutura e comportamento de pastas e argamassas.
} 
Como resume Cascudo (1997), com base no CEB24 (1992), os poros capilares e os poros de ar são os mais importantes para a durabilidade. A permeabilidade é mais afetada pelo número e dimensões dos macroporos, que pelos microporos. Da mesma forma, podese esperar que valores de índice de vazios e de absorção de água sejam determinados pelo volume de macroporos, principalmente, como discutido por Bertolo (2006) para argamassas estruturais de reparo.

Andrade (2005) chama o concreto de falso sólido. O autor atribui a existência dos vazios a três causas: ao excesso de água na mistura; ao ar emulsionado retido durante a concretagem, ocupando volumes de 1 a $5 \%$; e ao fato do volume absoluto dos componentes hidratados da matriz ser inferior à soma dos componentes não hidratados, portanto, o espaço ocupado pela matriz hidratada é inferior ao da matriz antes do endurecimento, qualquer que seja a relação água/cimento.

\section{C) Qualificação da porosidade por critérios de índices de vazios ou de absorção de água}

A porosidade aparente ou volume de poros permeáveis é a medida da proporção relativa ao volume total do concreto ocupada pelos poros permeáveis à água, geralmente expressa em porcentagem. Enquanto o volume de poros é fator determinante da capacidade do concreto em resistir à carga, a taxa de transporte de massa é afetada principalmente pela porosidade efetiva, que é definida pelo grau de continuidade do sistema de poros. Assim sendo, caso o volume de poros seja grande e os poros estejam interligados, os poros contribuem para o deslocamento de fluidos através do concreto, de modo que a permeabilidade e a difusividade também passam a ser altas. Por outro lado, se os poros forem descontínuos, a permeabilidade do concreto será baixa, mesmo com um elevado volume de poros (NEVILLE, 1997).

Andrade (1992) coloca que é possível usar a porosidade como indicador da permeabilidade do concreto: porosidade menor que 10\%, indica boa qualidade e bem compacto; entre 10 e 15\%, representa boa qualidade, porém permeável e não adequado para ambientes agressivos; acima de 15\%, muito permeável e inadequado para proteger a armadura por muito tempo.

24 COMITÉ EURO-INTERNATIONAL DU BÉTON. Durable Concrete Structures CEB Design Guide: Thomas Telford. Lausane, 1992. $112 \mathrm{p}$. 
Helene (1993) defendeu a mesma classificação de concretos quanto à esta propriedade, mas este conhecimento não foi até hoje incorporado ou bem interpretado com vistas às práticas ou normas para especificação ou controle do concreto. A Tabela 16 apresenta a proposição desse autor quanto à classificação de concretos pelo índice de vazios ou porosidade e ela é uma opção alternativa à classificação de outras propriedades relacionadas à porosidade como é o caso da absorção de água. Todavia, estes critérios não prevaleceram para as especificações de projeto do concreto estrutural, mas há várias normas de componentes pré-fabricados que adotam essa propriedade entre os requisitos para fabricação e compra e por isto considerou-se importante incluir esta propriedade para estudo no programa experimental do capítulo 3.

Mas, no concreto fresco, é bem mais complexo avaliar como o aumento da porosidade pode aumentar a velocidade de carbonatação, e ao final desta, reduzir as dimensões dos poros pela deposição dos produtos da reação de carbonatação. Por estar diretamente relacionada com a relação a/c, a porosidade pode ser reduzida com a diminuição dessa relação. Além disso, a cura e as pozolanas também exercem influência sobre a porosidade.

TABELA 16 - Classificação dos concretos em função da porosidade e absorção de água (HELENE, 1993).

\begin{tabular}{cccc}
$\begin{array}{c}\text { Concreto } \\
\text { armado }\end{array}$ & Porosidade & $\begin{array}{c}\text { Absorção de } \\
\text { água por } \\
\text { imersão }\end{array}$ & $\begin{array}{c}\text { Resistência } \\
\text { característica }\end{array}$ \\
\hline Durável & $\leq 10 \%$ & $<4,2 \%$ & $\mathrm{f}_{\alpha<}>35 \mathrm{MPa}$ \\
Normal & entre 10 e $15 \%$ & entre 4,2 e $6,3 \%$ & $20 \leq \mathrm{f}_{\alpha \kappa} \leq 35 \mathrm{MPa}$ \\
Deficiente & $\geq 15 \%$ & $>6,3 \%$ & $\mathrm{f}_{\alpha<}<20 \mathrm{MPa}$ \\
\hline
\end{tabular}

\subsubsection{Efeitos da natureza e dosagem dos materiais constituintes}

As pesquisas sobre efeitos dos materiais e da sua dosagem, na resistência à carbonatação de concretos de cimento Portland devem ter caráter regional25, tanto pela variação de jazidas produtoras de agregados, quanto pelas disponibilidades locais de cimentos e aditivos, mas não cabe no escopo desta dissertação estender a abordagem pelo

25 A pesquisa de Andrade et. al (2006) poderá evidenciar diferenças e semelhanças importantes nas características de concretos latino-americanos quanto à proteção de armaduras, pois muitas propriedades foram medidas e caracterizadas para os concretos no estado fresco e endurecido. Mas cabe observar que o citado artigo não menciona a caracterização do teor de ar do concreto fresco e nem o refinamento de medidas de profundidade de carbonatação, como visado no programa experimental desta dissertação. 
foco do programa experimental. Logo, os subitens seguintes fazem brevem recapitulação de algums pontos importantes acerca deste tema, selecionando alguns aspectos que já são consenso na comunidade técnica ou outros ainda pouco pesquisados.

\section{A) Cimento Portland}

O cimento Portland é fabricado no país segundo as especificações referentes aos tipos comuns - CP I (ABNT NBR 5732), composto CP II (ABNT NBR 11578), de alto forno - CP III (ABNT NBR 5735), pozolânico - CP IV (ABNT NBR 5736), de alta resistência inicial - CP $V$ (NBR 5733), e ainda outros especiais como é o caso do resistente aos sulfatos (ABNT NBR 5737), branco (ABNT NBR 12989) ou de baixo calor de hidratação (ABNT NBR 13116).

O tipo de cimento pode interferir na velocidade de penetração do $\mathrm{CO}_{2}$, mas também pela sua finura e quantidade relativa no concreto referida a outros constituintes importantes como é o caso da água e aditivos, dado que é a composição química do cimento e a porosidade final resultante o que disponibiliza os produtos para a reação de carbonatação, entre eles o hidróxido de cálcio, sódio e potássio e o silicato de cálcio hidratado, como visto no item 2.1.3.

As adições ativas dos cimentos portland, como escórias do CP III e as pozolanas do CP IV, que melhoram a maioria de suas propriedades, aumentam a velocidade da carbonatação (HELENE, 1993), segundo visto em item 2.1.4 E). Isso pode ser explicado pelo conceito da reserva alcalina, ou seja, à medida que aumenta a quantidade de adições ativas ao clínquer Portland na produção dos cimentos, a solução intersticial do concreto preparado com esses cimentos apresentará uma menor quantidade de $\mathrm{Ca}(\mathrm{OH})_{2}$. Assim, o $\mathrm{CO}_{2}$ penetrará com maior velocidade, pois ficará mais fácil a etapa inicial desse processo que é primeiro baixar $\mathrm{o} \mathrm{pH}$, reagindo com todo $\mathrm{o} \mathrm{Ca}(\mathrm{OH})_{2}$, penetrando e propiciando o $\mathrm{CaCO}_{3}$ precipitar, mais rapidamente na solução.

Segundo Helene (1997) e Pauletti (2004), o cimento CPI tende a carbonatar menos que os cimentos com adições por possuir maiores quantidades de $\mathrm{Ca}(\mathrm{OH})_{2}$. Nas reações pozolânicas existentes em outros cimentos como o CPIV, o $\mathrm{Ca}(\mathrm{OH})_{2}$ é consumido, enquanto que no CPI ele é produzido. 
B) Água

$\mathrm{Na}$ cadeia de produção do concreto, a água de amassamento nem sempre é valorizada como material importante ao desenvolvimento das suas propriedades, o que tem provável origem na forma e disponibilidade desse recurso natural, especialmente no Brasil.

Exemplo disto, é que nas composições de custos dos serviços de engenharia não se inclui o item água, mesmo sabendo-se que para a confecção de um metro cúbico de concreto gastam-se em média de 160 a 200 litros e para a compactação de um metro cúbico de aterro pode ser consumido até 300 litros de água. ${ }^{26}$

A água utilizada para o amassamento dos aglomerantes deve ter certas qualidades químicas, não pode conter impurezas e ainda deve estar dentro dos parâmetros recomendados pelas normas técnicas, a fim de que se garanta a homogeneidade da mistura. As impurezas e os sais dissolvidos na água, quando em excesso, podem ser nocivos para os aglomerantes utilizados na preparação de concretos e argamassas.

Não foram localizadas na literatura, pesquisas específicas sobre efeitos combinados da água de amassamento à dosagem dos demais materiais e eventual relação com a resistência à carbonatação de concretos.

\section{C) Aditivos}

Aditivos $^{27}$ são materiais usados em baixo teor em concretos ou argamassas, adicionados em misturadores mecânicos, imediatamente antes ou durante a sua produção, com finalidade de modificar as suas propriedades no estado fresco ou endurecido, inclusive o custo.

Mais de 20 propriedades podem ser consideradas para serem modificadas pelo uso de aditivos ao concreto, como aumentar a plasticidade do concreto sem aumentar o teor de água; reduzir a exsudação e a segregação; retardar ou acelerar o tempo de pega; acelerar a velocidade de desenvolvimento da resistência nas primeiras idades; retardar a taxa de

\footnotetext{
26 NETO, A.F. "Dicionário do Engenheiro". 2ª ed. 2006. Água como material de construção. In www.guiadaobra.rg3.net, consultado em 11.10.2008.

Lembra este autor que a água é usada em quase todos os serviços de engenharia, às vezes como componente e noutras como ferramenta. Entra como componentes nos concretos e argamassas e na compactação dos aterros e como ferramenta nos trabalhos de limpeza, resfriamento e cura do concreto. É um dos componentes mais importantes na confecção de concretos e argamassas e imprescindível na umidificação do solo em compactação de aterros. Um material de construção nobre, que influencia diretamente na qualidade e segurança das obras.

27 Produtos comerciais adicionados em pequena dosagem da massa do cimento, com limite geralmente reportado a $5 \%$.
} 
evolução de calor; aumentar a resistência à deterioração em condições agressivas de exposição, como a ação do gelo, à fissuração térmica, à expansão álcali-agregado, entre outras.

O crescente entendimento de que as propriedades do concreto, tanto no estado fresco como no endurecido, podem ser modificadas pelo uso de certos aditivos é responsável pelo enorme crescimento da indústria produtora durante as últimas décadas. Centenas de produtos estão sendo comercializados hoje, e em alguns países é comum que 70 a $80 \%$ de todo o concreto produzido contenha um ou mais aditivos (MEHTA; MONTEIRO, 1994; 2008).

Os aditivos podem certamente melhorar as propriedades de um concreto, mas não se deve esperar que compensem a baixa qualidade dos constituintes do concreto ou de uma dosagem inadequada.

Os problemas associados ao mau uso dos aditivos continuam a crescer. A origem da maior parte dos problemas parece estar na incompatibilidade entre um dado aditivo e uma composição do cimento ou entre dois ou mais aditivos que podem estar presentes na mistura. Por isso, é altamente recomendável a realização de ensaios de laboratório envolvendo materiais e condições de obra antes do emprego efetivo de aditivos em concreto, particularmente quando grandes projetos são empreitados ou quando os materiais de preparo do concreto estão sujeitos a variações significativas de qualidade (MEHTA; MONTEIRO, 1994; 2008).

Os aditivos incorporadores de ar têm sua utilização bastante difundida em países com climas frios, sujeitos ao fenômeno de gelo e degelo. A saturação de água dos poros capilares e o seu posterior congelamento submetem o concreto a tensões de fadiga, levando à sua ruptura. A inclusão de bolhas de ar no concreto pela adição de um aditivo incorporador de ar faz com que, no momento do congelamento, a água encontre um espaço livre para se expandir, reduzindo as tensões sobre o concreto e aumentando sua durabilidade, conforme a Figura 25, localizada a partir de Martin (2005).

De acordo com Mindess; Young (1981) o ar incorporado melhora a trabalhabilidade e coesão do concreto tanto para baixos como para altos abatimentos. Uma técnica usada comumente, dado que o ar incorporado faz mais coesivo o concreto, é reduzir o conteúdo de areia e água para uma trabalhabilidade determinada; nesses casos, não se produz segregação. 


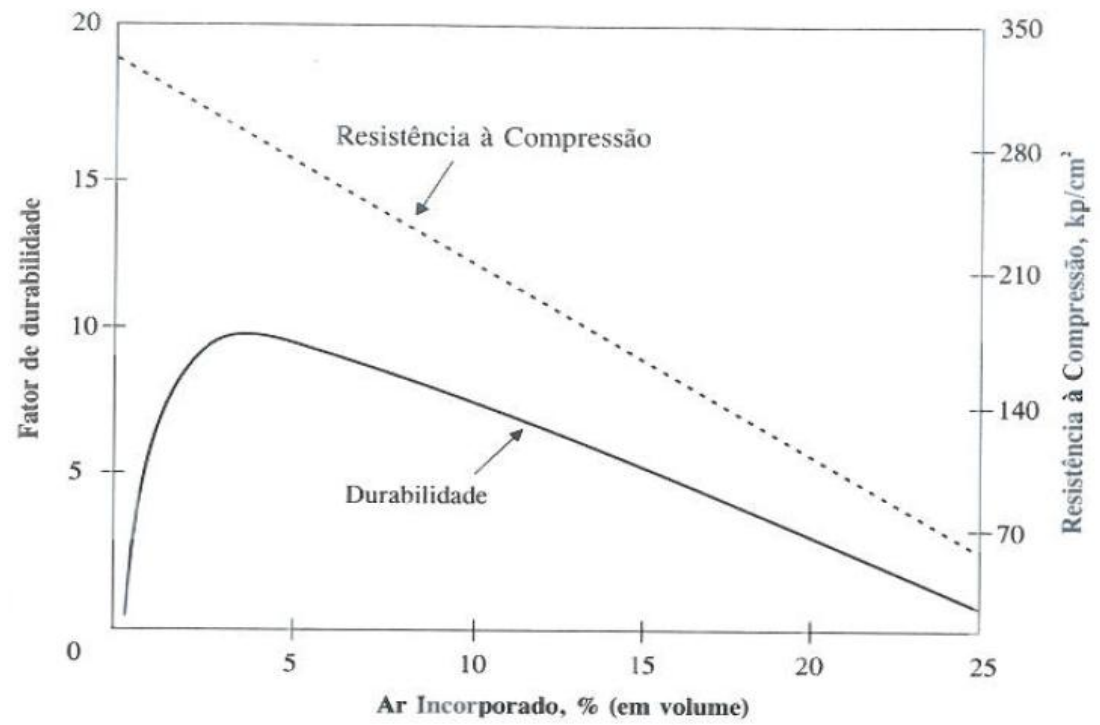

FIGURA 25 - Efeito do ar incorporado na durabilidade de concretos, por ação de gelo e degelo. (MINDESS; YOUNG, 1981 adaptado por MARTIN, 2005).

O controle do teor de ar no concreto fresco é fundamental ao controle de qualidade da produção do concreto estrutural, quer seja para verificar limites máximos e mínimos desejáveis de ar incorporado, ou para identificar a ocorrência de efeitos colaterais de outros aditivos ou ainda os efeitos de variações da curva granulométrica do cimento, adições ou dos agregados.

Mas, como salientado no Capítulo 1, não se localizou na literatura informações mais explícitas acerca da importância das variações do teor de ar do concreto fresco na sua resistência à carbonatação, e observar que podem auxiliar à evolução futura de critérios por curvas análogas às da Figura 25. Assim, o programa experimental desta dissertação fez uma pesquisa exploratória a este respeito.

\section{D) Agregados}

Os agregados são os constituintes que entram em maior quantidade nos concretos de resistência normal e, portanto, influem de modo considerável em todas as suas propriedades.

Especialistas em Ciência dos Materiais tem elucidado desde a década de 80 (Séc. XX) a importância das características dos agregados em todas as propriedades físicas que levam ao transporte de água e gases e à deterioração das estruturas de concreto por mecanismos químicos ou ambientais, conforme ilustrado pela Figura 7. 
O tamanho e a granulometria dos agregados afetam as características de exsudação da mistura do concreto, a qual, por sua vez, influi na resistência da zona de transição, elevando a relação a/c na referida zona. A zona de transição (Figura 26) é uma película delgada com 10 a $50 \mathrm{~nm}\left(=1\right.$ a $\left.5 \times 10^{5} \AA\right)$ de espessura, ao redor o agregado graúdo e, geralmente, apresentando propriedades inferiores às dos agregados e pasta. A zona de transição é, aproximadamente, 50\% mais porosa que a pasta de cimento, em concretos de média a baixa resistência. Durante o período inicial da hidratação, a zona de transição é fraca e vulnerável à fissuração, devido às deformações diferenciais entre a pasta de cimento e o agregado, induzidas geralmente por retração por secagem, retração térmica e cargas externas aplicadas prematuramente. As fissuras na zona de transição são pequenas demais para serem vistas a olho nu, mas são maiores, em abertura, que a maioria dos poros capilares presentes na matriz da pasta e, assim, colaboram para estabelecer as interconexões, que aumentam a permeabilidade do sistema (MEHTA; MONTEIRO, 2008).

Quanto maior o tamanho do agregado no concreto e mais elevada a proporção de partículas chatas e alongadas, maior será a tendência do filme de água se acumular próximo à superfície do agregado (exsudação), enfraquecendo assim a zona de transição pasta-agregado, conforme mostra a Figura 26 (MEHTA; MONTEIRO, 2008).

As características dos agregados que são importantes para a tecnologia do concreto incluem porosidade, composição granulométrica, absorção de água, forma e textura superficial das partículas, resistência à compressão, módulo de elasticidade e os tipos de substâncias deletérias presentes.

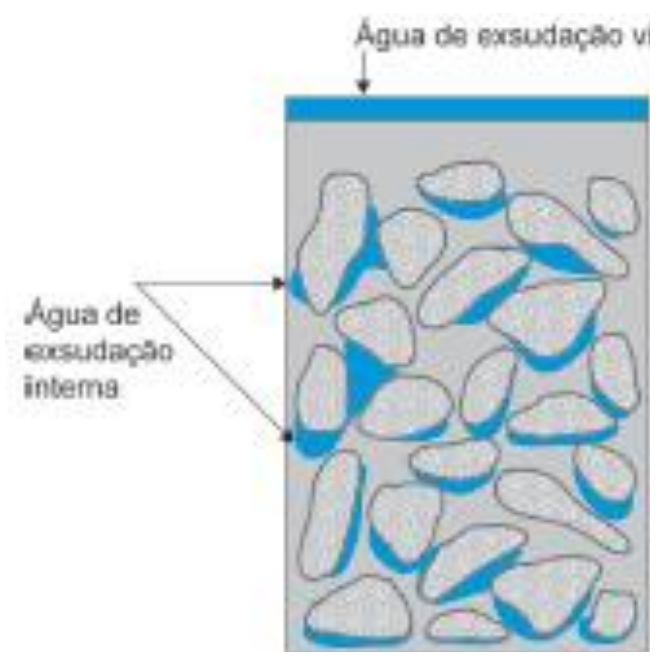

FIGURA 26 - Representação esquemática de exsudação no concreto fresco. (MEHTA; MONTEIRO, 1994, 2008). 
O conhecimento das características dos agregados é uma exigência para a dosagem dos concretos, e os fatores determinantes das suas propriedades tem origem nas características da jazida e processo de beneficiamento do agregado.

\section{E) Adições}

A idéia de se utilizar adições de fina granulometria e de origem industrial aos concretos de cimentos Portland está focada em metas de se confeccionar materiais hidráulicos, com qualidade superior e menores teores de clínquer Portland, uma vez que a fabricação deste consome energia, recursos naturais e é responsável por $5 \%$ da emissão de dióxido de carbono na atmosfera. Mas, por razões óbvias, o aumento da escala de adições aos concretos de cimento Portland apenas deve ocorrer pelo crescimento e evolução industrial do restante da cadeia produtora, ou seja, a indústria de aditivos, de agregados e dos produtores de concreto.

Gastaldini et al. (1999), constataram que o modo como é feito a incorporação e o teor da adição ao cimento Portland utilizado, condiciona o desempenho quanto à carbonatação, se por adição ou substituição ao cimento.

Segundo Helene (1993), as adições em substituição ao clínquer de cimento Portland reduzem a porosidade, permeabilidade e aumentam a resistência à compressão do concreto, entretanto, aumentam a profundidade de carbonatação. A explicação relaciona-se com a reserva alcalina: com um maior teor de clínquer Portland há aumento do $\mathrm{Ca}(\mathrm{OH})_{2}$ na solução intersticial, e o $\mathrm{CO}_{2}$ não penetra com a mesma velocidade pois precisa primeiro solubilizar na água de poro, baixar o $\mathrm{pH}$ e depois reagir com o $\mathrm{Ca}(\mathrm{OH})_{2}$ para então seguir penetrando e precipitando $\mathrm{CaCO}_{3}$. Para esse autor, o que importa é a quantidade de $\mathrm{Ca}(\mathrm{OH})_{2}$ na solução intersticial dos poros e não a quantidade total de $\mathrm{Ca}(\mathrm{OH})_{2}$.

A Figura 27 mostra que o uso de cinza volante por substituição ao cimento Portland pode aumentar a carbonatação, pois vai reduzir o teor de clínquer e já que é dele a liberação de álcalis que regulam a frente de carbonatação no concreto. Abreu (2004) constatou que cimentos, mesmo com baixos teores de cinza volante (15\%), carbonatam mais que cimentos comuns, concordando com Helene (1997). 


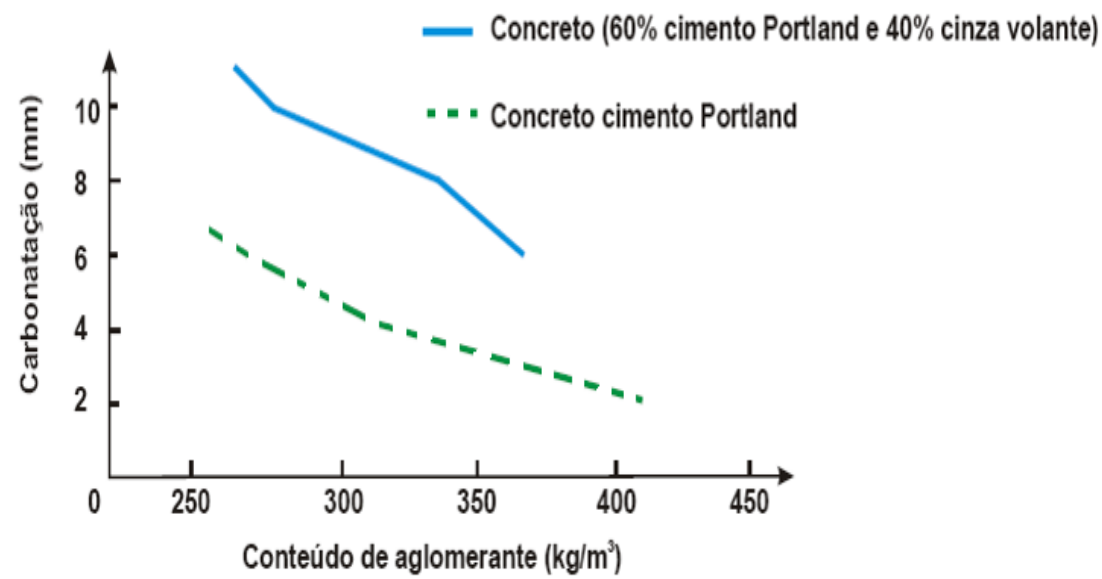

FIGURA 27 - Influência do tipo de cimento e sua quantidade por $\mathrm{m}^{3}$ de concreto sobre a profundidade de carbonatação. HO; LEWIS, 1987 (adaptado por POLITO, 2006).

$\mathrm{Na}$ corrosão de armaduras desencadeada por carbonatação, foi observado que o efeito da sílica ativa no concreto é influenciado pelo teor de adição utilizado. Para adições de até $10 \%$ de sílica ativa ocorre efeito favorável na resistência à corrosão das armaduras, e ocorre melhoria significativa nas demais propriedades, embora aumente a profundidade de carbonatação. Para teores maiores do que $10 \%$ de sílica ativa, além de aumentar a profundidade de carbonatação, o concreto torna-se desfavorável em relação à corrosão (SILVA; LIBÓRIO, 2007).

Estudos de carbonatação em vigas por Silva (2007) mostraram que a sílica de casca de arroz em substituição ao cimento no teor de $10 \%$ proporcionou uma redução significativa da profundidade de carbonatação, comparada a concretos com e sem adição de sílica de ferro-silício ou silício metálico. Explica que o melhor desempenho foi ocasionado pela maior área específica da sílica da casca de arroz (96 m²/g), o que propiciou uma melhor aderência pasta-agregado e fortalecimento da zona de interface. Cabe lembrar que o uso de pozolanas de alta eficiência, como as estudadas pela citada autora, e de todas as adições de fina granulometria ao concreto requerem estudos criteriosos e simultâneos da eficiência de aditivos e de dosagem global dos constituintes, para que o compósito resulte com propriedades físicas, químicas e mecânicas adequadas.

No caso do uso da escória de alto-forno por adição, de acordo com ensaio de carbonatação acelerada a $10 \%$ de $\mathrm{CO}_{2}$ realizado por Costa Junior et al. (2005), segundo a Figura 28, verificaram-se profundidades crescentes de carbonatação para os concretos com maior teor de escória (crescente na ordem do CP II E-32, CP III-32-RS e CP III-32-RS + Escória), em três das quatro classes de resistência à compressão estudadas (C30, C35 e C40). 


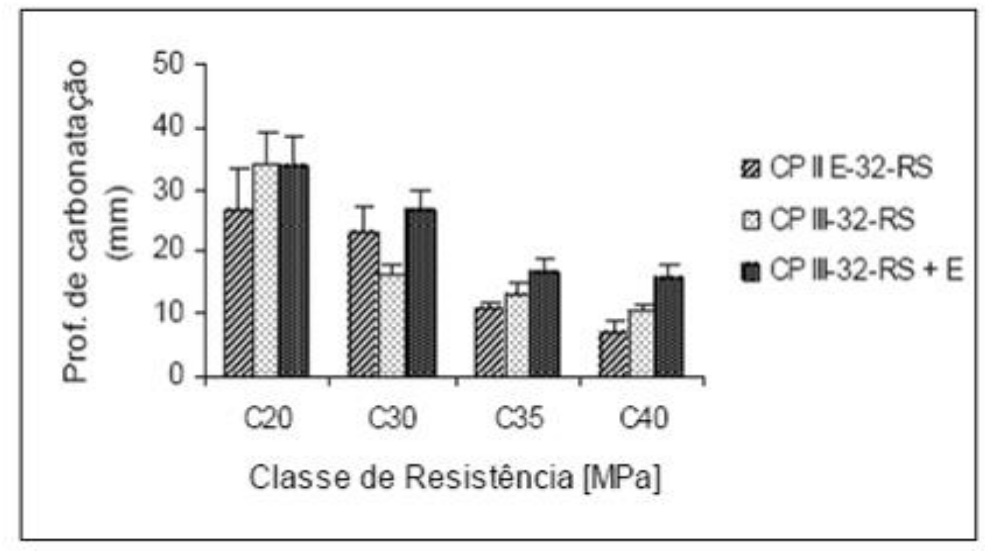

FIGURA 28 - Profundidade de carbonatação acelerada a $10 \%$ aos 91 dias $(t=4$ semanas de exposição), para os concretos das classes 20, 30, 35 e 40 para os três diferentes tipos de materiais cimentícios (COSTA JUNIOR et al. 2005).

Observar que pelos resultados da Figura 28, o aumento do consumo de cimento entre as classes C35 e C40 resultou em incremento pouco significativo de resistência à carbonatação, exemplificando que a relação entre essa propriedade e classes de $f_{c k}$ do concreto devem sempre ser verificadas para as circunstâncias locais e regionais da sua produção.

Na prática, é difícil prever o período efetivo de cura úmida das estruturas, por isto há que se tomar cuidados adicionais de cura naquelas concretadas com cimentos com adições ou com concretos especialmente formulados tais produtos.

\section{F) Método de dosagem e proporção de uso dos materiais}

A relação água/cimento é um dos principais fatores que interferem diretamente na porosidade e permeabilidade do concreto. Com a redução dessa relação, há uma diminuição do tamanho dos poros capilares e, possivelmente, uma maior descontinuidade desses vazios, ocasionando profundidades de carbonatação menores.

Inicialmente, para o atendimento da resistência à compressão, a relação a/c é definida:

a) pela natureza e proporcionamento relativo entre os materiais, incluídos os aditivos e pelo(s) método(s) de dosagem envolvidos na sua definição;

b) pelas propriedades fixadas para o concreto fresco, em termos de abatimento ou outra medida de aferição de trabalhabilidade, pois em geral essa propriedade não se aplica para avaliação de concretos de consistência muito baixa (ditos de consistência fluida ou auto-adensáveis) ou de consistência muito elevada (ditos de consistência seca). 
Atualmente, qualquer método de dosagem que seja usado deve ainda verificar o atendimento às variáveis definidas pela ABNT NBR 6118 (2007) e ABNT NBR 12655 (2006), como a relação água/cimento e o consumo de cimento, conforme a classe de exposição ambiental do concreto (Tabela 7, no item 2.2.2 e Tabela 13, no item 2.2.3).

Segundo Helene (1993), concretos com elevado consumo de cimento (elevada quantidade de $\mathrm{Ca}(\mathrm{OH})_{2}$ total) devem ter profundidades de carbonatação iguais a concretos com baixo consumo de cimento, mantidos a relação a/c, o tipo de cimento, a cura e as condições de exposição. O fator de controle é a concentração de $\mathrm{Ca}(\mathrm{OH})_{2}$ nos poros, que depende do tipo de cimento, da relação a/c e do grau de hidratação do cimento, não importando o consumo de cimento.

$\mathrm{Na}$ prática, o controle de relação a/c para um concreto de abatimento fixo, como estabelece hoje a ABNT NBR 6118 (2007), só pode ser obtido pelo uso de aditivos tensoativos ou surfactantes, como são os redutores de água (também chamados de plastificantes ou fluidificantes) e os incorporadores de ar, pois as características granulométricas do cimento Portland e dos agregados são muito variadas e com tendência à redução de dimensão das suas partículas, o que torna os aditivos ainda mais importantes no futuro da tecnologia do concreto.

Quanto ao consumo de cimento por metro cúbico do concreto, sendo uma variável diretamente afetada pela relação a/c e pela natureza dos aditivos redutores de água e pela proporção relativa entre agregados e cimento, ou seja do traço, ela se torna uma variável dependente do método de dosagem, quando a natureza dos materiais e a trabalhabilidade do concreto está fixada.

No item 1.3 do Capítulo 1, destacam-se alguns estudos de dosagem pelas Figuras de 1 a 4, em que está bem evidenciado os efeitos de variações do traço e do consumo de cimento no teor de ar das misturas do estado fresco.

Do ponto de vista do controle tecnológico, apenas a relação água/cimento e o consumo de cimento do concreto fresco e endurecido são hoje as variáveis de dosagem exigidas, mas demandam conhecimento e controle contínuo dos materiais empregados por métodos e equipamentos de maior custo e a ser realizado por técnico com grau diferenciado de instrução.

Assim, é necessário investir em pesquisas e práticas de mudança desta situação, pois essas duas variáveis são hoje requisitos generalizados pela ABNT NBR 6118 (2007) e ABNT NBR 12655 (2006) para serem atendidos nos mais diversos tipos de estruturas em concreto armado, como visto no item 2.2.2 e 2.2.3. Aliás, em Tango (1983) até havia descrença quanto à real exeqüibilidade de serem implementadas no controle da produção 
de rotina do concreto, mas a evolução das últimas décadas em instrumentação eletrônica tem introduzido equipamentos mais eficientes e de menor preço no mercado, e há agora melhores perspectivas.

De modo alternativo, no programa experimental desta pesquisa, além de métodos para controle do teor de ar no estado fresco, foram testados dois tipos de procedimentos auxiliares para o controle indireto daquelas variáveis no concreto fresco, com base no conceito clássico de relação água/materiais secos do concreto $(H)$ e da premissa de que a fração predominante de partículas abaixo de $75 \mu \mathrm{m}$ no concreto fresco é de materiais cimentícios. Ambas são variáveis também de interesse quanto ao controle potencial de outras propriedades do concreto como a retração por secagem e fluência.

\subsection{VARIÁVEIS DA CONCRETAGEM INFLUENTES NA CARBONATAÇÃO}

Este item não tem a pretensão de ser exaustivo, mas sim de fazer uma breve revisão sobre a importância dos procedimentos de vibração e cura do concreto na produção de estruturas, para aumentar a resistência à carbonatação do concreto.

A qualidade do adensamento e a cura são certamente as duas principais variáveis que controlam a porosidade e a resistência mecânica nas primeiras idades, para que o concreto possa suportar os esforços mecânicos e ambientais a que fica sujeito a partir da concretagem e até a resistência mecânica adequada para a desforma ser alcançada.

\section{A) Adensamento}

O concreto depois de misturado deve ser lançado o mais próximo possível de sua posição final e com a brevidade possível, já que as reações entre o cimento Portland em pó e a água de amassamento resultam usualmente controladas apenas em prazos de uma a duas horas após a pasta ser produzida.

A consolidação ou adensamento é o processo de moldagem do concreto nas fôrmas e em torno das peças embutidas com o objetivo de expulsar bolhas de ar e bolsões de ar retidos no interior do concreto fresco.

A vibração externa ou interna é o método mais usado para adensar o concreto. $O$ atrito entre as partículas de agregado graúdo é muito reduzido na vibração; conseqüentemente, a mistura começa a fluir facilitando o adensamento. 
Misturas fluidas devem ser auto-adensáveis e se adensadas isto deve ser feito com cuidado porque o concreto fica propenso a segregar quando vibrado.

Gonen; Yazicioglu (2007) estudaram a influência dos poros compactados do concreto na sua carbonatação. Segundo os autores, o transporte de agentes agressivos dentro do concreto depende da estrutura dos poros, das condições de exposição e características de difusividade das substâncias. As técnicas utilizadas envolviam vibração intensa para compactação, tornando o concreto com poucos poros (PCP1 e PCP2, respectivamente), média compactação dos poros (MCP) e não compactado com alta porosidade (HCP). Assim, diferentes níveis de porosidade foram obtidos pelo emprego de técnicas variáveis de compactação, como se pode observar nos resultados obtidos na Tabela 17, em que a vibração do concreto influencia nos resultados de porosidade e de resistência à compressão.

TABELA 17 - Resistência à compressão e porosidade das amostras de concreto, de acordo com o tipo de vibração (GONEN; YAZICIOGLU, 2007).

\begin{tabular}{lrrrr}
\multicolumn{1}{c}{ Código da mistura } & PCP1 $^{*}$ & PCP2 $^{*}$ & MCP $^{*}$ & HCP $^{*}$ \\
\hline Porosidade (\%) & 9 & 12 & 17 & 20 \\
Resistência à compressão $\left(\mathrm{N} / \mathrm{mm}^{2}\right)$ & 47,3 & 47,5 & 45,5 & 31,8 \\
\hline
\end{tabular}

*PCP1 e PCP2 - alta compactação, MCP - média compactação e HCP - não houve compactação.

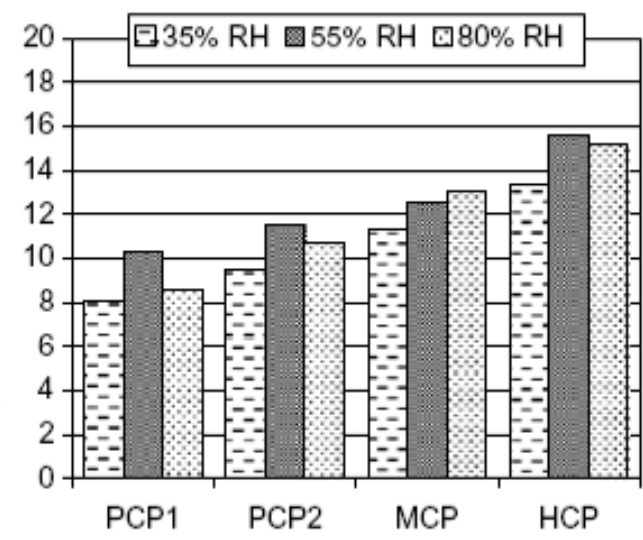

a

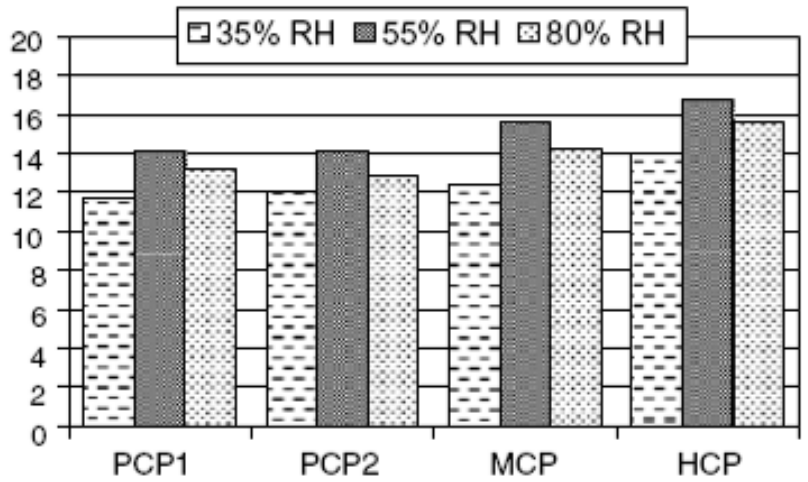

b

a) Ensaios acelerados por 6 horas versus Profundidade de carbonatação (mm);

b) Ensaios acelerados por 24 horas versus Profundidade de carbonatação (mm);

FIGURA 29 - Profundidade de carbonatação de concreto com diferentes porosidades (GONEN; YAZICIOGLU, 2007). 
Conforme se observa na Figura 29, quanto mais compactados os poros do concreto, menor foi a profundidade de carbonatação, pois estes resultaram mais fechados para a entrada de $\mathrm{CO}_{2}$.

\section{B) Cura nas primeiras idades}

A ABNT NBR 14931 (2004) diz em seu texto que: "Elementos estruturais de superfície devem ser curados até que atinjam resistência característica à compressão $\left(f_{c k}\right)$, de acordo com a ABNT NBR12655 (2006), igual ou maior que 15 MPa". Ou seja, peças com grande superfície em relação ao seu volume, tais como placas, cascas e lajes precisam receber ainda maior atenção quanto ao prazo de cura, por possuírem maior área para interagir com o ambiente, sendo mais suscetíveis à perda precoce de água do concreto pela ação do sol e vento.

Os processos de cura úmida visam garantir as reações de hidratação e retardar a retração dos concretos, de forma que o concreto possa desenvolver resistência razoável antes que se manifestem as tensões de tração nas superfícies das peças (THOMAZ, 1999).

O impedimento da perda precoce de umidade diminui a formação de poros e microfissuras no concreto, o que melhora a sua resistência, bem como a sua durabilidade.

A importância da cura é cada vez maior na medida em que se utilizam cimentos mais finos e com diversificadas adições minerais. A cura deve ser iniciada logo após o início da hidratação do cimento, duas a três horas após o lançamento. Não há um tempo predeterminado para a realização da cura, sabe-se que quanto maior for a duração da cura melhores serão as condições de formação dos cristais, mais refinada será a estrutura interna, com maior resistência e maior durabilidade (THOMAZ, 1999).

Para garantir certos aspectos da durabilidade das estruturas seria conveniente definir em projeto o tipo de cura.

Os métodos de cura em temperatura ambiente mais usual são: o borrifamento de água, revestimentos saturados, areia molhada e películas químicas. Também há métodos acelerados que fazem uso de técnicas para manter ou introduzir mais energia térmica à pasta em hidratação. 


\section{B.1) Cura úmida normal}

Os dois objetivos da cura úmida normal são impedir a perda precoce de umidade e controlar a temperatura do concreto durante um período suficiente para que este alcance um nível de resistência desejado. O ACl28 (1991), pelo Comitê 201, recomenda cura mínima de 7 dias.

Segundo Neville (1997), a hidratação em velocidade máxima somente ocorre em condições de saturação, sendo desejável uma umidade de pelo menos $80 \%$ no interior do concreto. Segundo o autor, para que a hidratação de um elemento selado após a desmoldagem seja completa, a quantidade de água deve ser ao menos de duas vezes a água combinada.

Como visto no item 2.3.1, se um sólido resulta mais permeável, significa que fluidos agressivos podem entrar com mais facilidade no mesmo, isto explica a eficiência da cura na durabilidade do concreto, uma vez que a mesma diminui a permeabilidade da pasta de cimento.

De acordo com Helene (1993), a profundidade de carbonatação depende da cura, pois esta afeta as condições de hidratação nos primeiros milímetros superficiais. Cimentos com adições podem ter a profundidade de carbonatação minimizada com boa e prolongada cura.

Quanto maior o tempo de cura e mais eficiente for o método de cura empregado maior será o grau de hidratação do cimento, menor será a porosidade e a permeabilidade e, consequentemente, menor será a carbonatação.

No estudo de Battagin et al. (2002), foi verificada a influência de ciclos de cura no concreto com relação às suas propriedades, da seguinte forma:

- 1 dia ao ar da câmara úmida e 28 dias em câmara seca;

- 2 dias ao ar da câmara úmida e 26 dias em câmara seca;

- 3 dias ao ar da câmara úmida e 25 dias em câmara seca;

- 7 dias ao ar da câmara úmida e 21 dias em câmara seca;

- 10 dias ao ar da câmara úmida e 18 dias em câmara seca;

- 14 dias ao ar da câmara úmida e 14 dias em câmara seca;

- 21 dias ao ar da câmara úmida e 7 dias em câmara seca;

- 28 dias ao ar da câmara úmida.

28 AMERICAN CONCRETE INSTITUTE. Guide to Durable Concrete: reported by ACl Committee 201. ACI Materials Journal, v.88, n.5, p. 544-582, 1991. 
As condições da câmara úmida foram: umidade relativa do ar superior a $95 \%$ e temperatura de $2^{\circ} \mathrm{C} \pm 2^{\circ} \mathrm{C}$. As condições da câmara seca foram: umidade relativa ao ar de $50 \pm 4 \%$ e temperatura de $23^{\circ} \mathrm{C} \pm 2^{\circ} \mathrm{C}$. Os corpos-de-prova foram curados de acordo com os ciclos citados anteriormente até a idade de 28 dias. Após a cura, os corpos-de-prova foram colocados na câmara de carbonatação (umidade relativa de $65 \%$, teor de $\mathrm{CO}_{2}$ de $5 \%$ e temperatura de $23^{\circ} \mathrm{C} \pm 2^{\circ} \mathrm{C}$ ), durante 4 semanas. Os resultados indicam (Figura 30), como era de esperar, que a profundidade de carbonatação aumenta com o aumento da relação a/c. Dentro de um mesmo ciclo de cura, a profundidade de carbonatação é tanto menor quanto mais tempo o concreto foi submetido à cura úmida. Para concreto com relação a/c igual a 0,30 , os ciclos de cura parecem não ter influenciado a profundidade de carbonatação, sendo o fenômeno ausente nos níveis de aceleração da carbonatação adotados.

Os concretos com a/c 0,45 com 1 e 2 dias apenas de cura úmida apresentaram espessuras de carbonatação similares àqueles com relação $a / c=0,65$ curados entre 21 e 28 dias em câmara úmida. Mas, essa conclusão dos autores pode ser questionada, se os seus resultados forem apreciados na escala de cobrimentos mínimos de projeto das armaduras, conforme a TABELA 12.

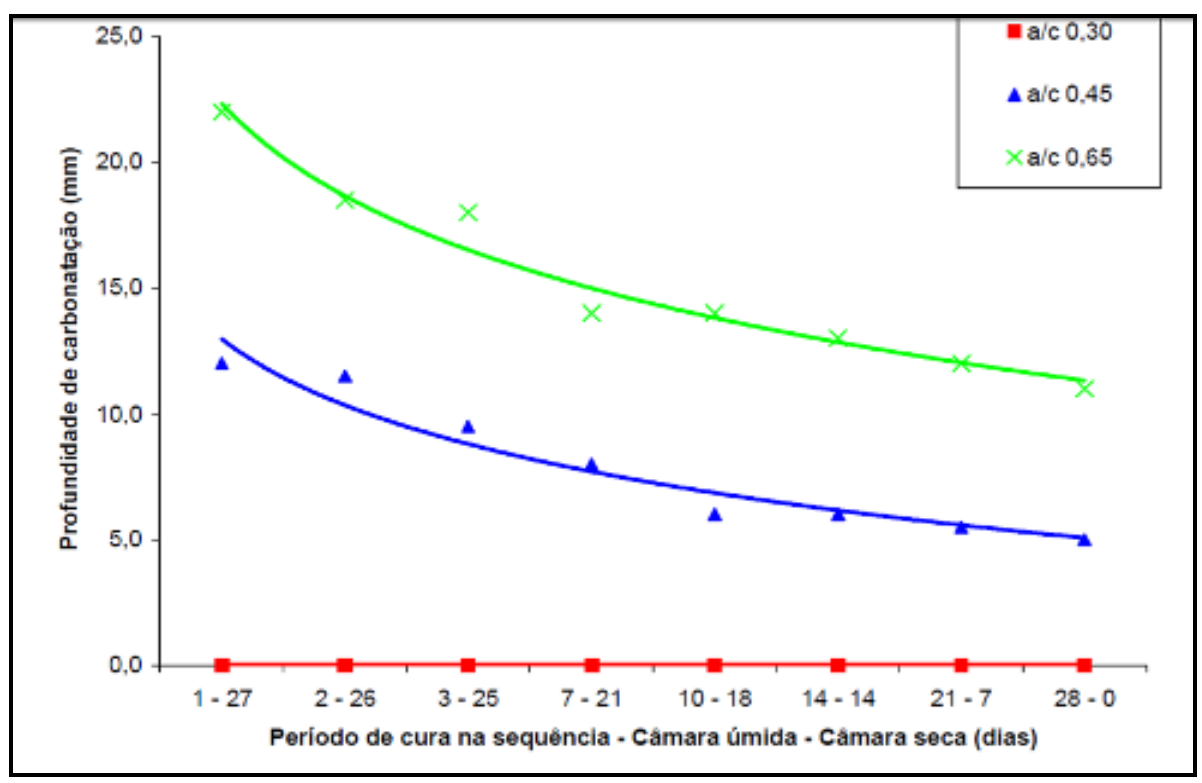

FIGURA 30 - Influência da cura úmida inicial e sequência de exposição do concreto em ambiente seco, na profundidade de carbonatação em câmara de carbonatação acelerada (umidade relativa de $65 \%$, teor de $\mathrm{CO}_{2}$ de $5 \%$ e temperatura de $23^{\circ} \mathrm{C} \pm 2^{\circ} \mathrm{C}$ ), durante quatro semanas (Battagin et al., 2002). 


\section{B.2) Cura acelerada}

As reações de hidratação dos compostos do cimento Portland são exotérmicas e decorrem do processo de fabricação do cimento, que no estado anidro é quimicamente instável e acumula energia latente. O aquecimento da pasta em hidratação é fator importante no processo de formação da sua microestrutura.

De acordo com Mindess; Young (1981), a temperatura de cura afeta a taxa de desenvolvimento da resistência e acredita-se que nem a estrutura química nem a física dos produtos de hidratação são radicalmente afetados pela temperatura de hidratação de aproximadamente $45^{\circ} \mathrm{C}$.

A cura térmica, limitando-se a temperatura do concreto no máximo a $70^{\circ} \mathrm{C}$, implicará que o cimento se hidrate com cristais mais graúdos, com menor interpenetração, o que resultará em resistência potencialmente menor do concreto nas idades avançadas (comparativamente com a resistência esperada, se a cura fosse realizada com temperaturas entre $20^{\circ} \mathrm{C}$ e $\left.30^{\circ} \mathrm{C}\right)$ (THOMAZ, 1999).

Há processos especiais de cura térmica com temperatura acima da ambiente, seja para pré-fabricados, seja para previsão de resistência do concreto, em controle tecnológico. O tempo para conhecimento da resistência à compressão do concreto aos 28 dias, não é compatível com a velocidade nas execuções das estruturas de concreto armado, por isso, justifica-se o emprego de cura com temperaturas acima da ambiente.

A ASTM C 684 (1999) - Standard practice test method for making accelerated curing, and testing concrete compression test specimens é uma das normas que classifica, didaticamente, os quatro métodos de cura, conforme a Tabela 18, sendo que três utilizam temperatura alta ou procedimentos complexos de execução e um é de fácil execução e temperatura amena.

TABELA 18 - Tipos e procedimentos da cura acelerada (ASTM C 684:1999)

\begin{tabular}{|c|c|c|c|c|c|c|c|}
\hline \multicolumn{2}{|c|}{ Procedimento } & \multirow{2}{*}{$\begin{array}{c}\text { Moldes } \\
\text { Reutilizáveis } \\
\text { ou } \\
\text { descartável }\end{array}$} & \multirow{2}{*}{$\begin{array}{c}\begin{array}{c}\text { Origem da } \\
\text { aceleração da } \\
\text { resistência }\end{array} \\
\begin{array}{c}\text { Calor de } \\
\text { hidratação }\end{array}\end{array}$} & \multirow{2}{*}{$\begin{array}{c}\begin{array}{c}\text { Temperatura de cura } \\
\text { acelerada }{ }^{\circ} \mathrm{C}\left({ }^{\circ} \mathrm{F}\right)\end{array} \\
35(95)\end{array}$} & \multirow{2}{*}{ 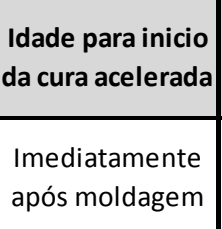 } & \multirow{2}{*}{$\begin{array}{c}\text { Duração da } \\
\text { cura acelerada }\end{array}$} & \multirow{2}{*}{$\begin{array}{c}\begin{array}{c}\text { Idade de } \\
\text { ensaio }\end{array} \\
24 \mathrm{~h} \pm 15 \mathrm{~min}\end{array}$} \\
\hline$A$ & Água quente & & & & & & \\
\hline B & Água fervente & $\begin{array}{c}\text { Reutilizáveis } \\
\text { ou } \\
\text { descartável }\end{array}$ & Água fervente & Ebulição & $\begin{array}{c}23 \mathrm{~h} \pm 30 \mathrm{~min} \\
\text { após moldagem }\end{array}$ & $3,5 \mathrm{~h} \pm 5 \mathrm{~min}$ & $28,5 \mathrm{~h} \pm 15 \mathrm{~min}$ \\
\hline $\mathrm{C}$ & Autógena & Uso único & $\begin{array}{c}\text { Calor de } \\
\text { hidratação }\end{array}$ & $\begin{array}{l}\text { A temperatura inicial do } \\
\text { concreto é aumentada } \\
\text { pelo calor de hidratação }\end{array}$ & $\begin{array}{l}\text { Imediatamente } \\
\text { após moldagem }\end{array}$ & $48 \mathrm{~h} \pm 15 \mathrm{~min}$ & $49 \mathrm{~h} \pm 15 \mathrm{~min}$ \\
\hline $\mathrm{D}$ & $\begin{array}{c}\text { Alta } \\
\text { temperatura e } \\
\text { pressão }\end{array}$ & Reutilizáveis & $\begin{array}{c}\text { Calor e pressão } \\
\text { externos }\end{array}$ & $150(300)$ & $\begin{array}{l}\text { Imediatamente } \\
\text { após moldagem }\end{array}$ & $5 \mathrm{~h} \pm 5 \mathrm{~min}$ & $5,25 \mathrm{~h} \pm 5 \mathrm{~min}$ \\
\hline
\end{tabular}


Na cura acelerada pelo método A da ASTM, conforme a Tabela 18, os corpos-deprova são imersos em água aquecida à temperatura nominal de $35^{\circ} \mathrm{C} \pm 3^{\circ} \mathrm{C}$ durante $23,5 \mathrm{~h} \pm$ 0,5h, período este iniciado logo após a moldagem dos corpos-de-prova. Os corpos-de-prova após moldados devem ser acomodados com espaçamento de $100 \mathrm{~mm}$ entre os mesmos e $100 \mathrm{~mm}$ de cobertura de água.

A função principal do aquecimento moderado da água usada no procedimento $A$ é conservar o calor gerado na hidratação. O método A da ASTM C 684:99 devido à baixa temperatura do aquecimento da água não agride a estrutura interna do concreto, além de ser operacionalmente mais viável para utilização em campo, como é o caso deste trabalho. Porém, para que a cura tenha início logo após a moldagem de corpos-de-prova do concreto, isto requer a adoção de procedimentos especiais em campo, para que um tanque com aquecimento térmico possa ser instalado, o que pode dificultar a adoção desta cura de forma mais rotineira.

O programa experimental dessa dissertação avaliou a cura térmica do Tipo A e procedimentos alternativos derivados, em prosseguimento à pesquisa de Cavalcanti Filho (2010).

O método Tipo A da ASTM C 684:99 foi aprovado por estudos americanos já há algumas décadas e atestado por Mehta; Monteiro (2008), que afirmam que os ensaios de resistência acelerada com este método podem ser uma alternativa confiável para o controle rotineiro da qualidade de concretos estruturais, com redução de prazos para as informações advindas de variações do controle da produção.

Este método de cura tem sido utilizado ainda para estudos como os de Tokyay (1999), Ozkul (2001) e Lo et al. (2009), para obterem correlações entre as resistências com cura acelerada e cura normal a 28 dias. Tokyay (1999) discutiu sobre a obtenção de uma equação de previsão de resistência a uma determinada idade, a partir de resultados experimentais, utilizando regressão linear, em concretos com adição de fly ash. Ozkul (2001) constatou em seus resultados que o tipo de cimento influencia na previsão de resistência e que a cura acelerada foi mais eficiente para o cimento puro do que para o cimento composto em geral. Lo et al. (2009) estudaram a influência da cura acelerada na resistência à compressão e também na resistência à carbonatação em concretos com adições de sílica e fly ash. Os autores encontraram que concretos com fly ash e sílica quando incorporados nas misturas de concreto em até 35\%, têm resistência maior do que o concreto com cimento puro em cura acelerada. Por outro lado, em cura normal, a resistência de concretos com fly ash e sílica foi menor que com cimento puro. 


\subsection{MÉTODOS DE CONDICIONAMENTO E MEDIDAS DE CARBONATAÇÃO}

Os ensaios de carbonatação acelerada e de determinação da profundidade de carbonatação são muito utilizados na avaliação da durabilidade dos concretos. Isto para a orientação ou confirmação de previsões da vida útil de projeto das armaduras, segundo proposto por Tuutti $^{4}$ e vários outros que o seguiram, e ainda porque o processo de carbonatação natural é lento.

Novos materiais estão sendo constantemente pesquisados e tais ensaios permitem a obtenção de informações sobre seu comportamento frente a ambientes agressivos, bem como a diferenciação de concretos com diferentes origens de fornecimento.

Este item reúne e discute de forma sintética os procedimentos que tem sido empregado em medidas de resistência à carbonatação do concreto e que não tem cooperado para a evolução mais rápida de um método de ensaio normalizado. Nisto reside um ponto importante em que o programa experimental desta dissertação procurou colaborar, pois optou por estudar procedimentos que possam facilitar um futuro programa interlaboratorial entre laboratórios comerciais do mercado, considerando as dificuldades e constatações discutidas por Pauletti (2004) e Gianotti; Helene (2007).

\section{A) Estado da arte quanto aos métodos empregados}

A Figura 31 de Pauletti et al. (2007) reúne de forma muito didática todas as variáveis influentes em processos de carbonatação acelerada ou naturais de concretos e argamassas de cimento Portland, considerando que aquelas assinaladas com " $X$ " ainda carecem de pesquisa, seja para a compreensão de como atuam no mecanismo, seja para a normalização de um método de ensaio que está hoje em curso no Brasil.

A comissão CB 18:300.6 - Comissão de Estudos de Durabilidade de Concreto, da ABNT foi formada em meados de 2009 e visa, entre outros assuntos, a elaboração de uma norma de procedimento para os ensaios de carbonatação, a qual deve ser dividida em "ensaio acelerado" e "medida da carbonatação". 


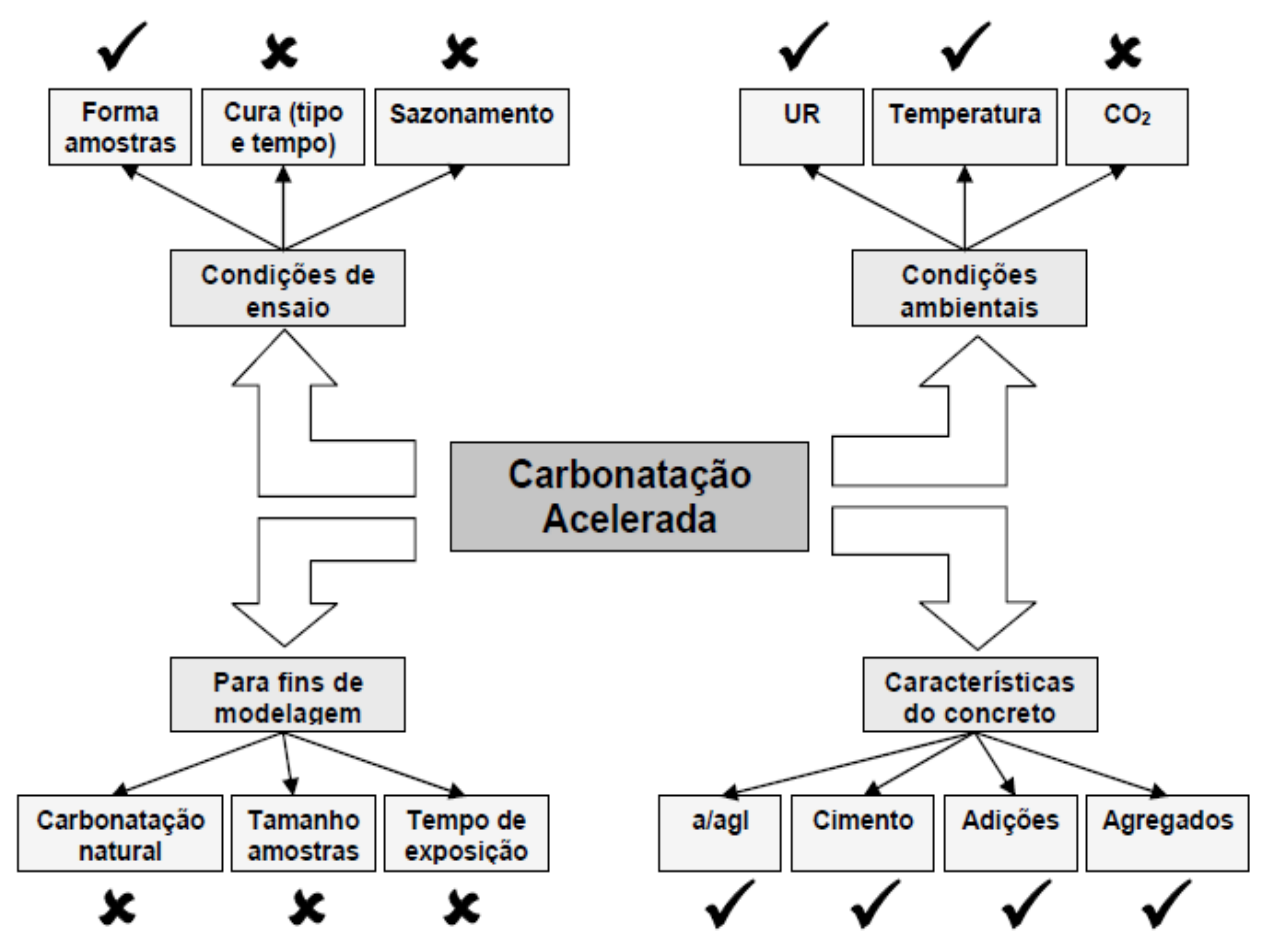

FIGURA 31- Esquema do estado da arte das pesquisas de carbonatação acelerada no Brasil (PAULETTI et al. 2007).

Atualmente, já há método de ensaio normalizado para medidas de carbonatação, como é o da BS EN 14630:2006, "Products and Systems for the Protection and Repair of Concrete Structures Test Methods, Determination of Carbonation Depth in Hardened Concrete by the Phenolphthalein Method".

A Figura 32 mostra um exemplo de câmara de carbonatação para a realização dos ensaios acelerados.

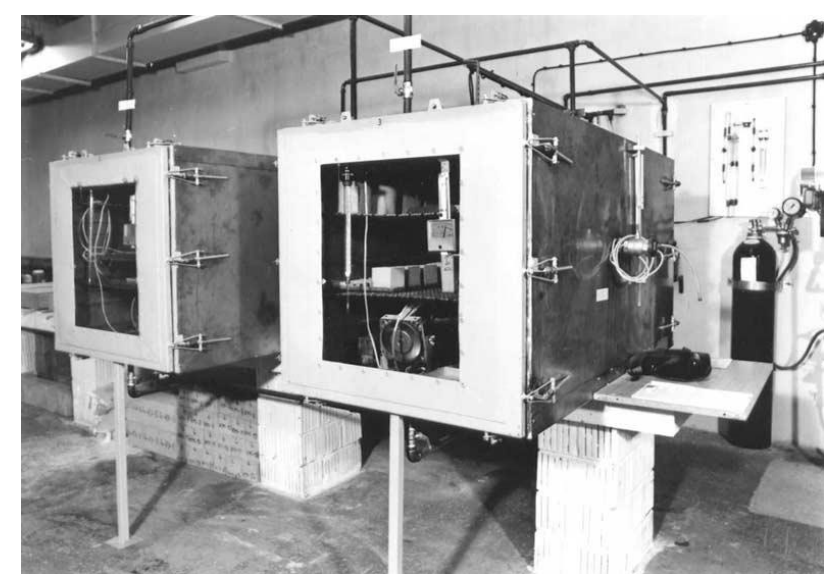

FIGURA 32 - Câmara de carbonatação para ensaio acelerado com aumento da concentração de $\mathrm{CO}_{2}$ (JERGA, 2004). 
Segundo Giannotti; Helene (2007) é possível observar que há uma grande variabilidade dos métodos, dos parâmetros adotados, das condições nas quais o material é submetido à ação do $\mathrm{CO}_{2} \mathrm{e}$, conseqüentemente, dos resultados obtidos. Assim, torna-se impossível fazer uma comparação e uma correlação direta entre os materiais estudados em diferentes pesquisas, havendo a necessidade de padronização de tais metodologias.

Como mostra a Tabela 19, cada pesquisador adota um critério para a realização de ensaios de carbonatação. Os ensaios podem ser realizados com as concentrações de $\mathrm{CO}_{2}$ usualmente encontradas no ambiente (entre 0,015\% até aproximadamente $1 \%$ ) ou em condições aceleradas (concentrações de 1\% até 100\% e realizados em câmaras como a da Figura 32). As pesquisas que utilizam condições naturais, com concentrações atmosféricas, muitas vezes não descrevem os percentuais de $\mathrm{CO}_{2}$ do meio em que foram realizados os ensaios.

Mas até a presente década, as pesquisas que envolvem ensaios de carbonatação têm a preocupação de manter os procedimentos de ensaio durante todo o estudo, porém, em geral, não existe a padronização entre pesquisas, como mostra a Tabela 19. Desta forma, os resultados obtidos dessas pesquisas dificilmente são comparáveis entre si. Cada pesquisador procura uma forma de estabelecer uma relação entre as variáveis que está estudando, sem poder facilmente compará-las com as variáveis de outras pesquisas (PAULETTI, 2004). 


\begin{tabular}{|c|c|c|c|c|c|}
\hline \multicolumn{6}{|c|}{ TABELA 19 - Resumo das condições de ensaios acelerados de carbonatação da literatura } \\
\hline Referencia & $\% \mathrm{CO}_{2}$ & UR (\%) & Tempo de exposição & Cura / condicionamento & Observações/ Sazonamento \\
\hline Tuutti (1982) & 1 & 80 & 90 dias & Cura submersa 7 dias & 6 meses em laboratório \\
\hline $\begin{array}{l}\text { Papadakis et } \\
\text { al. (1991 b) }\end{array}$ & 3 & 61 & $1,3,5,10,15$ e 20 dias & úmida 90 dias & estufa \\
\hline $\begin{array}{l}\text { Papadakis; } \\
\text { Fardis; } \\
\text { Vayenas } \\
\text { (1992) } \\
\end{array}$ & 50 & 65 & 25 dias & - & temperatura de $30^{\circ} \mathrm{C}$ \\
\hline $\begin{array}{c}\text { Nepomuceno } \\
(1992)\end{array}$ & 100 & 50 a 70 & variável & úmida/ao ar 1, 7 e 28 dias & 70 dias laboratório \\
\hline Isaia (1995) & 10 & - & $28,56,84$ e 112 dias & úmida 7 dias & 28 dias em laboratório \\
\hline Bauer (1995) & 50 & 65 a 70 & - & \begin{tabular}{|c|} 
Cura em camara umida até 63 \\
dias / secagem em estufa \\
ventilad $50^{\circ} \mathrm{C}$ por 14 dias após \\
camara seca
\end{tabular} & $\begin{array}{c}\text { Terminada a carbonatação acelerada } \\
\text { o ensaio continuou na etapa de } \\
\text { imersão parcial }\end{array}$ \\
\hline $\begin{array}{l}\text { Nunes, } \\
(1998)\end{array}$ & 15 & 65 & 12 semanas & $\begin{array}{c}\text { Cura úmida por } 7 \text { dias + pré } \\
\text { condicionamento de } 21 \text { dias a } \\
70 \% \text { e UR }\end{array}$ & temperatura de $24^{\circ} \pm 2^{\circ} \mathrm{C}$ \\
\hline $\begin{array}{c}\text { Martins; } \\
\text { Montiolli; } \\
\text { Camarini } \\
(2001)\end{array}$ & 100 & 60 a 75 & 42 dias & $\begin{array}{c}\text { Cura por } 7 \text { dias submersa e } \\
\text { cura térmica + pré } \\
\text { condicionamento até } 28 \text { dias }\end{array}$ & - \\
\hline Tula $(2000)$ & 5 & 59 & 7 dias & - & $\begin{array}{c}7 \text { dias na camara de carbonatação e } \\
14 \text { dias fora }\end{array}$ \\
\hline $\begin{array}{c}\text { Papadakis } \\
(2000)\end{array}$ & 3 & 61 & 100 dias & submersa 365 dias & 28 dias laboratório \\
\hline $\begin{array}{c}\text { Cunha e } \\
\text { Helene(2001) }\end{array}$ & 100 & 65 & $\begin{array}{c}2 \mathrm{~h} / 2 \mathrm{~h}(\mathrm{a} / \mathrm{c}=0,35) 4 \mathrm{~h} / 4 \mathrm{~h} \\
(\mathrm{a} / \mathrm{c}=0,65)\end{array}$ & $\begin{array}{c}\text { Cura por } 28 \text { dias em camara } \\
\text { umida }\end{array}$ & 15 dias em ambiente de laboratorio \\
\hline $\begin{array}{c}\text { Monteiro } \\
(2002)\end{array}$ & 100 & 70 & - & - & - \\
\hline $\begin{array}{l}\text { Venquiaruto } \\
\text { (2002) }\end{array}$ & 5 & 75 & 28,56 e 84 & úmida 7 dias & 35 dias laboratório/ estufa RILEM \\
\hline $\begin{array}{c}\begin{array}{c}\text { Kulakowski } \\
(2002)\end{array} \\
\end{array}$ & 5 & 70 & $35,56,91$ e 126 dias & $\begin{array}{c}\text { úmida amostras embaladas } 14 \\
\text { dias }\end{array}$ & $\begin{array}{l}14 \text { dias em câmara de sazonamento } \\
\text { (isenta de } \mathrm{CO}_{2} \text { ) }\end{array}$ \\
\hline Abreu (2004) & $5 e<50$ & 70 & 63 e 195 dias & úmida 28 dias & $\begin{array}{l}32 \text { dias, câmara de sazonamento } \\
\text { isenta de } \mathrm{CO}_{2}\end{array}$ \\
\hline $\begin{array}{c}\text { Pauletti } \\
(2004)\end{array}$ & 6 e 100 & $70 \pm 5$ & \begin{tabular}{|c|}
$2,7,14,21,28,42,63,91,11$ \\
$9,168,252$ e 365
\end{tabular} & cura submersa 7 e 28 dias & \\
\hline $\begin{array}{l}\text { Costa Jr; } \\
\text { Silva; } \\
\text { Zandonade; } \\
\text { Morimoto } \\
(2005)\end{array}$ & 10 & 60 & 77 e 91 dias & cura úmida ate 15 dias & $\begin{array}{c}\text { Após a cura, os cp's foram colocados } \\
\text { em camara seca c/ temperatura entre } \\
22 \text { e } 24^{\circ} \mathrm{C} \text { e umidade relativa em torno } \\
\text { de } 50 \% \text { até a idade de } 63 \text { dias, } \\
\text { quando foi feita a primeira medida de } \\
\text { profundiade de carbonatação. } \mathrm{N} \\
\text { camara de carbonatação a temeratura } \\
\text { era de } 26 \pm 2^{\circ} \mathrm{C} \text {. }\end{array}$ \\
\hline $\begin{array}{l}\text { Pauletti; Dal } \\
\text { Molin; } \\
\text { Kazmierczak } \\
(2005) \\
\end{array}$ & 6 e 100 & $70 \pm 5$ & $7,14,28$ e 63 dias & $\begin{array}{c}\text { Cura umida com superficie } \\
\text { protegida (UR } 100 \% \text { ) por } 24 \mathrm{hs}, \\
\text { após cura submersa por } 28 \\
\text { dias. }\end{array}$ & $\begin{array}{l}\text { Temperatura de ensaio de } 20 \pm 1^{\circ} \mathrm{C} \text {. Foi } \\
\text { utilizado duas camaras de } \\
\text { carbonatação com } 6 \% \text { e } 100 \% \text { de } \mathrm{CO}_{2}\end{array}$ \\
\hline $\begin{array}{c}\text { Cavalcanti; } \\
\text { Monteiro; } \\
\text { Helene } \\
(2005) \\
\end{array}$ & natural & 70 & 28 dias & cura por 28 dias ao ar livre & temperatura em torno de $22^{\circ} \mathrm{C}$ \\
\hline $\begin{array}{l}\text { Bourguignon; } \\
\text { Silva, Costa } \\
\text { Jr.; } \\
\text { Zandonade; } \\
\text { Morimoto, } \\
(2006)\end{array}$ & $\begin{array}{c}\text { natural } \\
\mathrm{e} \\
\text { acelera } \\
\text { da com } \\
10\end{array}$ & $\begin{array}{l}\text { natural: } \\
50 \text { e } \\
\text { acelerad } \\
\text { a: } 65 \pm 5\end{array}$ & $\begin{array}{l}\text { natural: } 365 \text { dias; } \\
\text { acelrada: } 91 \text { dias }\end{array}$ & $\begin{array}{c}\text { Cura úmida ate } 15 \text { e } 28 \text { dias, } \\
\text { após camara seca }\end{array}$ & $\begin{array}{c}\text { Carbonatação natural - após a cura } \\
\text { úmida os cp's são submetidos a cura } \\
\text { ao ar, em camara seca até } 365 \text { dias } \\
\text { (UR } 50 \% \text { e temperatura } \\
26^{\circ} \mathrm{C} \text { ).Carbonatação acelerada - após } \\
\text { a cura úmida, camara seca ate } 63 \\
\text { dias, após camara de carbonatação } \\
\text { ate } 91 \text { dias. }\end{array}$ \\
\hline $\begin{array}{l}\text { Gomes } \\
(2006)\end{array}$ & natural & 65 & - & Natural & ensaios em estrutura interrompida \\
\hline $\begin{array}{c}\text { Nakao; } \\
\text { Bertocini; } \\
\text { Almeida Neto } \\
(2006) \\
\end{array}$ & natural & - & - & - & ensaios in loco \\
\hline
\end{tabular}




\section{B) Determinação da espessura de carbonatação}

Independente do procedimento de carbonatação empregado, o resultado do ensaio é em geral expresso por medidas da espessura ou profundidade de reação entre o $\mathrm{CO}_{2}$ e os álcalis livres, alcançada da superfície para o interior do corpo-de-prova empregado.

Quanto à detecção e definição da espessura de carbonatação, existem duas classes ou tipos de métodos que podem ser aplicados para a sua obtenção:

a) Métodos analíticos de precisão, por medidas e cálculos para pequenas porções de amostra extraídas em profundidades controladas de corpos-deprova de pastas e argamassas, mas de dificuldade e representatividade questionáveis para a amostragem em concretos, pelas dimensões dos agregados graúdos. Os métodos analíticos utilizados para medir a profundidade de carbonatação, segundo Silva (2007), podem ser: difração de raios- $X$, termogravimetria, microscopia eletrônica de varredura, análise térmica diferencial e espectroscopia por infravermelho. Cada método é utilizado de acordo com a sua necessidade e disponibilidade, muitas vezes, até para complementar as pesquisas. Alguns podem ser bastante incomuns, de difícil execução e custo elevado;

b) Métodos semi-quantitativos por indicadores colorimétricos de $\mathrm{pH}$. A determinação da profundidade de carbonatação por meio de um indicador químico colorimétrico de mudança de $\mathrm{pH}$ é um método semi-quantitativo e o mais difundido para a determinação da espessura e da frente de carbonatação, devido à sua praticidade e baixo custo. Para a determinação da profundidade de carbonatação por meio desses indicadores químicos podem ser utilizada uma das soluções da Tabela 20, ou seja, de fenolftaleína, de timolftaleína ou de amarelo de alizarina, que possuem intervalos diferentes de mudança de cor. De um modo geral, a fenolftaleína é o indicador de pH mais empregado no meio científico devido à facilidade de uso, rapidez na realização do ensaio, custo baixo e precisão relativamente boa, como bem destaca Silva (2007). 
TABELA 20 - Principais indicadores colorimétricos de faixa de $\mathrm{pH}$, utilizados para medidas da espessura e da frente de carbonatação.

\begin{tabular}{|c|c|}
\hline Indicador de $\mathrm{pH}$ & Intervalo de mudança de cor \\
\hline Fenolftaleína & Incolor-vermelho carmim $\mathrm{pH}, 8,0-9,8$ \\
\hline Timolftaleína & Incolor-azul $\mathrm{pH}, 9,3-10,5$ \\
\hline Amarelo de alizarina GG & Amarelo claro - amarelo escuro $\mathrm{pH}, 10,0-12,0$ \\
\hline Amarelo de alizarina $\mathrm{R}$ & Amarelo-vermelho alaranjado $\mathrm{pH}, 10,1-12,0$ \\
\hline
\end{tabular}

${ }^{*}$ Fonte: (Silva, 2007)

$\mathrm{Na}$ Tabela 20, comparando os intervalos de mudança de cor (faixa de $\mathrm{pH}$ ) da fenolftaleína, da timolftaleína e do amarelo de alizarina observa-se que a fenolftaleina é o indicador capaz de determinar valores de $\mathrm{pH}$ mais baixos.

Diversos pesquisadores relatam a metodologia a ser utilizada na determinação da profundidade de carbonatação com indicadores químicos, porém, não há consenso entre eles sobre a faixa de $\mathrm{pH}$ na qual há a troca de coloração do indicador.

Andrade (1992) diz que uma solução de fenolftaleína a 1\% dissolvida em álcool etílico é incolor em $\mathrm{pH}$ inferior a 8,3, para valores de $\mathrm{pH}$ superiores a 9,5 torna-se vermelhocarmim e entre 8,0 e 9,5 fica com coloração variável de rosa a vermelho-carmim.

Para pH acima de 9,5 a fenolftaleína apresenta coloração rosa. A cor rosa indica a elevada concentração de $\mathrm{Ca}(\mathrm{OH})_{2}$, mas não a ausência total de carbonatação. A metodologia não faz distinção entre pH baixo por carbonatação ou outros gases ácidos (NEVILLE, 1997).

Segundo Chang; Chen (2006) quando o pH da solução aquosa presente nos poros for menor que 7,5 o grau de carbonatação do corpo-de-prova é de $100 \%$, para pH entre 7,5 e 9,0 o grau de carbonatação está entre 50 e 100\%, quando pH está entre 9,0 e 11,5 o grau de carbonatação varia de 0 a $50 \%$ e para pH superior a 11,5 o corpo-de-prova não está carbonatado.

De acordo com Chang; Chen (2006), a camada passivante protetora da armadura é uma estrutura densa e estável para pH acima de 11,5. Com a redução no valor do pH da água dos poros do concreto tem-se a despassivação da armadura, portanto soluções de fenolftaleína ou de timolftaleína são consideradas adequadas, para verificar se a armadura está despassivada e a velocidade de corrosão pode aumentar em taxas significativas. Por outro lado, a solução de amarelo de alizarina $\mathrm{R}$ pode ser o indicador mais seguro para precisar o início da despassivação e talvez devesse ser mais empregada em estudos de 
durabilidade, mas isto talvez não seja feito por causa do contraste de cor ser mais difícil de visualizar para a definição da frente de carbonatação.

A RILEM (1988) ${ }^{29}$ apud Pauletti (2004) recomenda a utilização de uma solução com $1 \%$ de fenolftaleína, em $70 \%$ de álcool etílico e $29 \%$ de água destilada. Essa solução deve ser borrifada, na forma de névoa, na superfície dos corpos-de-prova ou estruturas inspecionadas. Na região não carbonatada observa-se uma coloração vermelho carmim, enquanto a região carbonatada permanece incolor. Recomenda-se a realização de várias medidas em diferentes localizações para obtenção de um valor médio, uma vez que a frente de carbonatação não é uniforme.

A RILEM (1988)29 apud Pauletti (2004) sob a designação CPC-18, descreve ainda outros detalhes sobre os procedimentos para o ensaio. $O$ indicador deve ser aspergido em uma região recém-fraturada, antes que a face exposta pela fratura venha a se carbonatar ao reagir com $\circ \mathrm{CO}_{2}$ do ar. Após a secagem do indicador pode-se passar uma resina incolor, sem brilho, para fixação da cor. A RILEM ${ }^{30}$ (1999) recomenda que a medição da profundidade de carbonatação seja feita 24 horas após a aspersão do indicador, quando o limite entre as faces carbonatadas e não carbonatadas é mais evidente. A precisão deve ser de $0,5 \mathrm{~mm}$, não sendo levados em conta valores de carbonatação inferiores. Os cantos de amostras prismáticas devem ser ignorados, uma vez que o $\mathrm{CO}_{2}$ entra por dois lados. Em amostras com agregados muito grandes, a carbonatação deve apenas ser medida na pasta de cimento.

A Figura 33 refere-se à medida de carbonatação realizada por Chang; Chen (2006), utilizando fenolftaleína a 1\%, em corpos-de-prova cilíndricos, por método parecido ao empregado no programa experimental desta pesquisa. A profundidade de carbonatação média "Xp" abrangem as regiões menos coloridas pela fenolftaleína e foram medidas em três pontos, perpendiculares às duas bordas da face partida, em que as faces foram borrifadas logo após a fratura e as leituras realizadas após 24 horas.

29 REUNION INTERNATIONALE DE LABORATOIRES D'ESSAIS ET MATERIAUX. CPC-18: Measurement of hardened concrete carbonation depth. (RILEM Recommendations CPC-18). Materials and Structures, [s. n.], p.453-455, 1988.

30 REUNION INTERNATIONALE DE LABORATOIRES D'ESSAIS ET MATERIAUX. TC 116-PCD: Permeability of concrete as a criterion of its durability: tests for gas permeability of concrete. (RILEM Recommendation TC 116-PCD). Materials and Structures, v.32, p.174-179, 1999. 


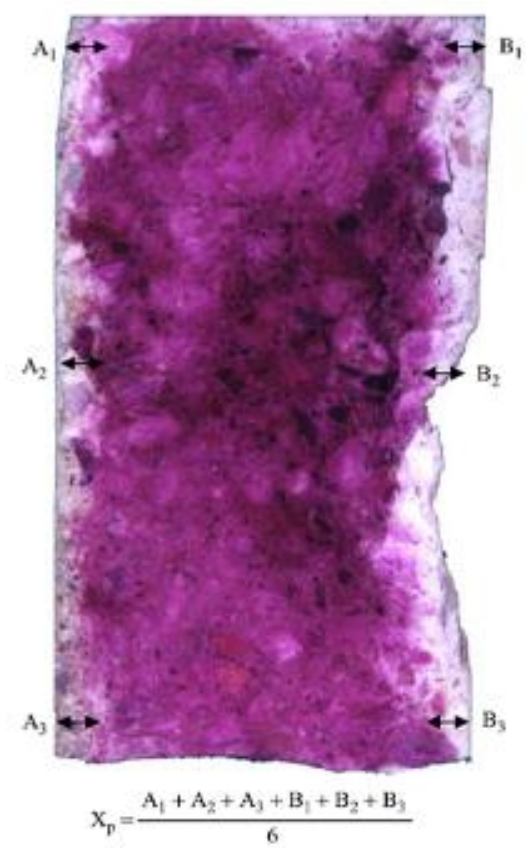

FIGURA 33 - Medidas de profundidade de carbonatação (CHANG; CHEN, 2006).

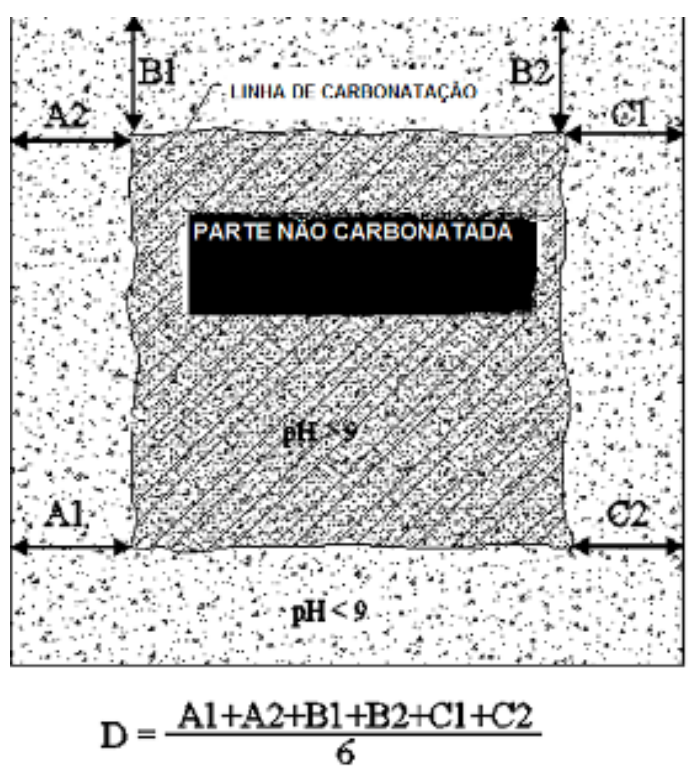

FIGURA 34 - Medida da profundidade de carbonatação (GONEN; YAZICIOGLU, 2007).

A Figura 34 mostra a medida de carbonatação realizada por Gonen; Yazicioglu (2007), de acordo com a metodologia recomendada pela RILEM CPC-18.

Pauletti (2004) realizou medidas de espessura de carbonatação por método inovador, empregando um programa ${ }^{31}$ de análise de imagem, que possibilita um grande número de medidas precisas dessa grandeza, como ilustra a Figura 35.

Kulakowski32 (2002) também fez uso do mesmo recurso de análise de imagem que Pauletti (2004) e ambas bem destacam as suas vantagens, como segue:

a) com o corpo-de-prova fotografado se pode realizar e conferir as medidas quantas vezes forem necessárias;

b) os critérios para a análise, assim como as medidas propriamente ditas, ficam armazenados, permitindo sua conferência;

c) a precisão das medidas é maior;

31 O programa utilizado foi o Carl Zeiss Vision (realise 3.0).

32 KULAKOWSKI, M. P. Contribuição ao estudo da carbonatação em concretos e argamassas compostos com adição de sílica ativa. 2002. 199f. Tese (Doutorado em Engenharia), Universidade Federal do Rio Grande do Sul, Porto Alegre, 2002. 
d) as médias dos resultados podem ser melhoradas pela possibilidade de se realizar diversas medidas por face, ou pela determinação da média obtida pela integral da área carbonatada;

e) os erros introduzidos pelo desgaste do operador, no uso do paquímetro, podem ser minimizados.

$\mathrm{Na}$ pesquisa de Pauletti (2004), as amostras fraturadas e aspergidas com a fenolftaleína foram fotografadas com uma câmera fotográfica digital. As fotos foram obtidas após cerca de 1 hora da solução de fenolftaleína ter sido aspergida, de modo antecipado ao prazo de 24 h do procedimento da RILEM ${ }^{29}$ (1988) CPC-18. É possível que a autora tenha adotado um prazo mais precoce, pois a coloração rosa-carmim de áreas não carbonatadas das amostras pode perder intensidade e dificultar a visualização para a medição, conforme o concreto.

No método de Pauletti (2004), as imagens estavam acompanhadas de uma escala, para realizar a calibração das medidas. Além disso, procurou a maior planicidade da face de ruptura para minimizar as sombras e melhor enquadrar a imagem e a escala. Nem todas as amostras rompidas possuíam a planicidade desejada, no entanto, o efeito desse tipo de desvio não se mostrou importante no resultado final da medida, pois, comparando a mesma amostra, com e sem o desvio, as diferenças nos resultados foram menores que os erros de medição especificados pela RILEM ${ }^{29}$ (1988), cerca de $0,5 \mathrm{~mm}$. Na medição, foram consideradas as duas laterais dos corpos-de-prova, ignorando as faces superior e inferior de moldagem. As etapas para realização das medidas de cada imagem, pelo método citado, foram as seguintes, conforme ilustrações: a) abertura da imagem no programa de análise de imagens; b) calibração dimensional das imagens, através da escala que acompanha cada imagem; c) delimitação da área não carbonatada, seguindo os critérios de eliminar os cantos da amostra, por onde o $\mathrm{CO}_{2}$ penetra em duas direções e de modo que o retângulo formado no centro da amostra compreenda apenas uma área não carbonatada, a qual seja a maior possível; d) medição da área carbonatada em cada uma das laterais do corpo-de-prova, delimitada pelas linhas traçadas na Figura 35c; e) medição da distância entre as duas delimitações do retângulo, conforme a Figura 35d) para cálculo da profundidade de carbonatação média, através da divisão da área por essa distância; medição da maior e menor profundidade de carbonatação em cada lateral (Figura 35e). Na análise dos resultados foram utilizadas as profundidades médias de carbonatação, que foram obtidas dividindo a área da lateral, pela distância delimitada pelo retângulo (em linhas traço, ponto, ponto). Como o número de amostras por proporcionamento de argamassa era de três, e em cada uma delas se obteve dois resultados (duas laterais), foram totalizados seis resultados para cada mistura, em cada idade de medição. 
O método de Pauletti (2004) permite que vários pontos sejam medidos, como por exemplo, para encontrar o ponto de maior e menor profundidade de carbonatação, com menor possibilidade de erros aleatórios pelo operador. Mas, não foi testado para corpos-deprova de concreto e que tem em geral maiores dimensões, além de poderem experimentar carbonatação diferenciada segundo o topo e fundo de moldagem.
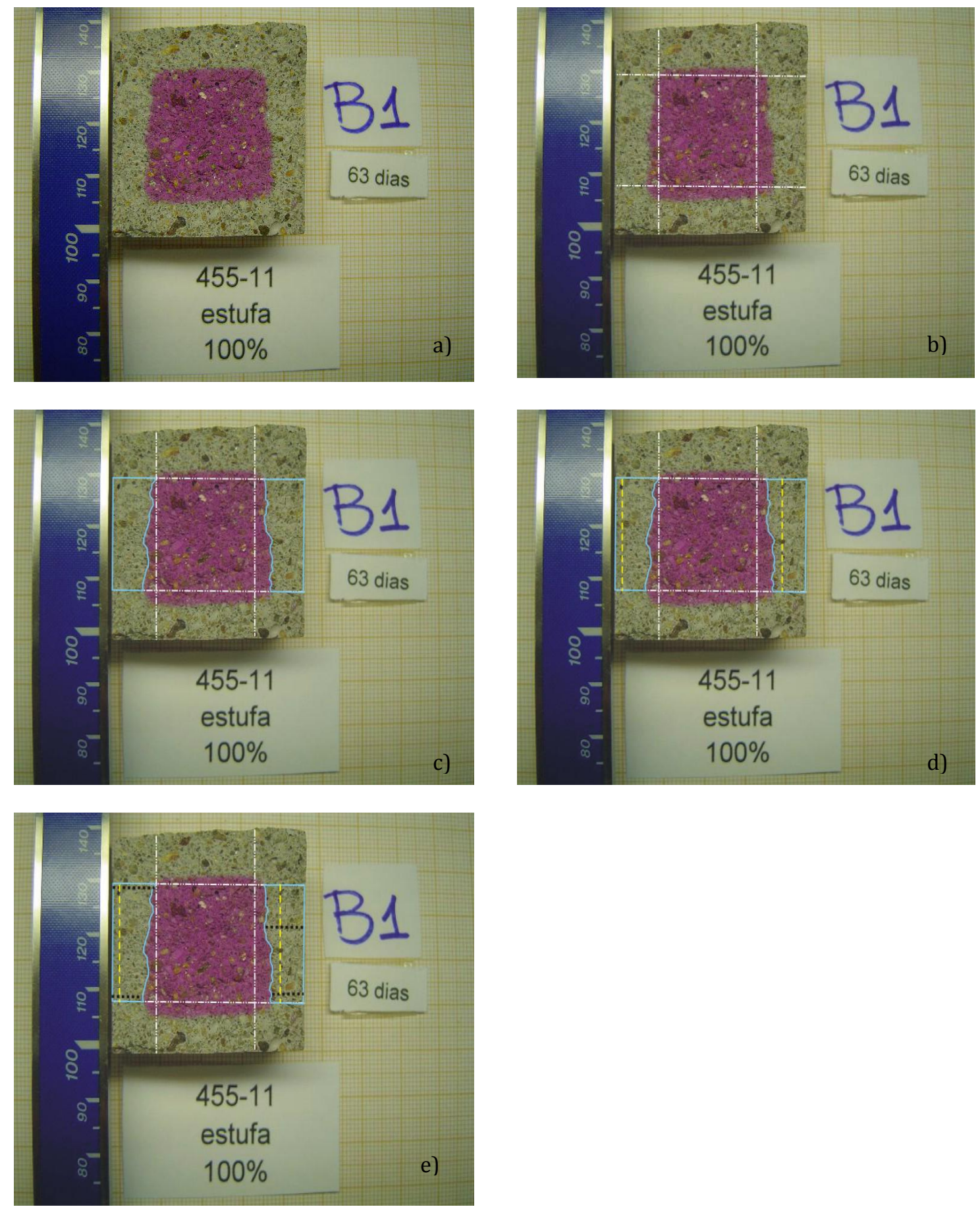

FIGURA 35 - As imagens de a) a b) ilustram o método de análise de imagem adotado por Pauletti (2004). As medidas da maior e menor profundidade de carbonatação para cada uma das laterais estão representadas por linhas pretas pontilhadas. 
Isaia et al. (2001), após analisarem o trabalho de diversos pesquisadores que compararam métodos de medição da profundidade de carbonatação, concluíram que o emprego de indicadores para esse fim é um meio bastante prático, fácil e de baixo custo, embora apresente deficiências como a de subestimar a frente real de carbonatação e a dispersão razoável das leituras. Consideram que é um ensaio cujos resultados são válidos para efeito comparativo entre diversos traços de concreto de laboratório, embora para casos de obras acabadas com o intuito de avaliação da verdadeira frente de carbonatação deixa de ser fidedigno, devendo ser realizados ensaios complementares por outros métodos.

Segundo Pauletti (2004) os métodos analíticos de medida de profundidade de carbonatação, como a análise termogravimétrica, a análise química, a difração de Raios-X, a microscopia ótica e a análise da solução do $\mathrm{pH}$ dos poros, entre outros, dão resultados superiores e mais precisos aos indicados pela fenolftaleína. Resultados obtidos por Lo e Lee $^{33}$ (2002) indicaram que a carbonatação de concretos analisados com espectroscopia por infravermelho é cerca de $24 \%$ maior que a apresentada pela fenolftaleína.

Apesar das diferenças apresentadas pelos vários métodos de medição da carbonatação, o uso de indicadores químicos, como a fenolftaleína, tem-se mostrado adequado para a avaliação da carbonatação, pela rapidez e baixo custo. Todavia, deve-se ter em mente que as medidas de carbonatação por fenolftaleína em um dado conjunto de corpos-de-prova de concreto tendem a ser de um valor médio mínimo. Então, é importante conhecer a resistência média e a variabilidade real de produção do concreto, para melhor caracterizar a sua resistência à carbonatação.

\section{C) Concentração de $\mathrm{CO}_{2}$}

Segundo Neville (1997), a ação do $\mathrm{CO}_{2}$ ocorre mesmo com concentrações pequenas como as que se observam em ambiente rural, onde o teor de $\mathrm{CO}_{2}$ é de cerca de $0,03 \%$ em volume. Em um laboratório não ventilado, o teor pode chegar a mais de 0,1\%; em grandes cidades, pode chegar a $0,3 \%$ e, excepcionalmente até $1 \%$. Um exemplo de concreto exposto a concentrações muito altas de $\mathrm{CO}_{2}$ é o de revestimento de túneis para veículos.

De acordo com a literatura, a velocidade de carbonatação aumenta consideravelmente com o aumento da concentração de $\mathrm{CO}_{2}$ presente no meio ambiente em contato com a superfície do concreto. Assim, quanto maior o gradiente de concentração entre o meio

33 LO, Y.; LEE, H. M. Curing effects on carbonation of concrete using a phenolphthalein indicator and Fouriertransform infrared spectroscopy. Building and Environment, v. 37, n.5, p. 507-514, 2002. 
externo e o interior do concreto, maior será a velocidade de penetração do $\mathrm{CO}_{2}$ e, conseqüentemente, maior a frente de carbonatação.

Porém, se a reação é rápida, a massa de carbonato de cálcio produzida em um dado intervalo de tempo coincide com a liberação de uma quantidade de água maior que aquela que a porosidade da matriz é capaz de expelir, no mesmo intervalo de tempo, diminuindo, assim, a velocidade de penetração do $\mathrm{CO}_{2}$, conforme Saetta; Vitaliani (2004).

Estudos desenvolvidos por Pauletti (2004) mostram que argamassas submetidas à câmara de carbonatação com teor de $6 \%$ de $\mathrm{CO}_{2}$, carbonatam em média 2 vezes mais que aquelas submetidas à câmara saturada de $\mathrm{CO}_{2}$.

Pauletti (2009) em seu estudo de doutorado verificou que muitas pesquisas são conduzidas com percentuais de $\mathrm{CO}_{2}$ bastante elevados (maiores que $50 \%$ ) muito superiores aos que as estruturas estão submetidas em situações normais de exposição. Ainda mais, para todos esses estudos sobre o tema há falta de informações sobre as diferenças entre o comportamento do fenômeno entre os percentuais de $\mathrm{CO}_{2}$ mais baixos (5-10\%) e mais altos (maiores que $50 \%$ ).

Figueiredo (2005) cita que Ying-Yu; Qui-Dong34 (1987) utilizaram concentrações na ordem de $20 \%$ e não constataram alteração no mecanismo físico-químico da carbonatação e concluíram que é possível relacionar os resultados de carbonatação natural e acelerada.

Alguns trabalhos podem ser citados quanto ao estudo de incremento de $\mathrm{CO}_{2}$ nos ensaios de carbonatação, como: Castellote et al. (2009), Glasser; Matschei (2007), Peter et al. (2008).

Conforme o projeto de norma PrEN 13295 (2000) do Comitê Europeu para Normalização (citado por Giannotti; Helene, 2007), para a determinação da resistência à carbonatação de argamassas de reparo de concreto, teores ainda menores de $\mathrm{CO}_{2}$ são sugeridos. A comissão sugere que a carbonatação seja feita em atmosfera contendo $1 \%$ de $\mathrm{CO}_{2}$ a $21 \pm 2^{\circ} \mathrm{C}$, cuja justificativa é o desenvolvimento de produtos de reação similares aos produtos hidratados do cimento em uma atmosfera de $0,03 \%$.

A frente de carbonatação de concretos expostos a concentrações menores de $\mathrm{CO}_{2}$ também é mais homogênea, segundo Sanjuán; Olmo35 apud Gianotti; Helene (2007), comparando-se teores de exposição de 5, 20 e 100\% de $\mathrm{CO}_{2}$. O carbonato de cálcio formado

\footnotetext{
34 YING-YU, L.; QUI-DONG, W. The mechanism of carbonation of mortars and the dependence of carbonation on pore structure. In.: INTERNATIONAL CONFERENCE ON CONCRETE DURABILITY, 1987, Atlanta, USA. Proceedings... Detroit: American Concrete Institute, 1987, 2v. p.1915-1943. (SP-100).

35 SANJUÁN, M. A.; OLMO, C. del. Carbonation resistance of one industrial mortar used as a concrete coating. Building and Environment, v.36, n. 8, p. 949-953, Oct. 2001.
} 
tem uma estrutura cristalina bastante diferenciada do produzido quando o processo é lento, alterando as condições de difusão do $\mathrm{CO}_{2}$ para o interior do concreto.

Uemoto e Takada (1993), verificando a influência do teor de $\mathrm{CO}_{2}$ no avanço da frente de carbonatação, submeteram espécimes de concreto a concentrações de $\mathrm{CO}_{2}$ de $0,07 \%$ (ambiente natural interno), $1 \%$ e $10 \%$ (teste acelerado), sob temperatura e umidade controladas $\left(T=20^{\circ} \mathrm{C}\right.$ e UR $\left.=55 \%\right)$. Conforme apresenta o gráfico da Figura 36 , o aumento do teor de $\mathrm{CO}_{2}$ elevou a velocidade de carbonatação dos concretos.

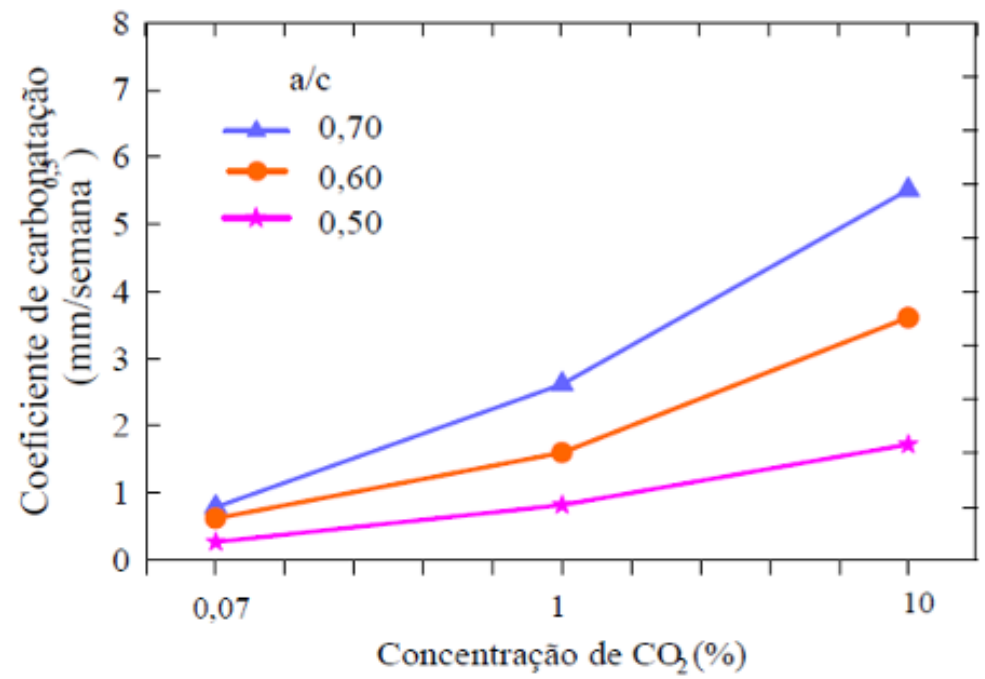

FIGURA 36 - Influência do teor de $\mathrm{CO}_{2}$ no coeficiente de carbonatação (UEMOTO; TAKADA, 1993).

A lógica sempre é imaginar o ingresso progressivo do $\mathrm{CO}_{2}$ do meio externo para o concreto, sem ponderar o fato da disponibilidade de $\mathrm{CO}_{2}$ já interior ao concreto, de forma análoga como se pensa para cloretos. Por isto, focalizar a interpretação de volume de ar no concreto fresco, como feito nesta dissertação, ou controlar o volume de vazios do concreto endurecido, como discute Helene (1993), são alternativas importantes para se melhorar o domínio sobre este mecanismo.

\section{D) Umidade relativa no ensaio}

A umidade relativa do ambiente é outra variável importante relacionada à carbonatação, uma vez que influencia a umidade interna do concreto ou grau de saturação dos poros. Para ocorrer o processo de carbonatação é necessário que os poros existentes no concreto não estejam nem saturados, nem secos. Necessita-se de certa quantidade de ar para que $\circ \mathrm{CO}_{2}$ possa difundir-se pelos poros, mas também necessita-se de quantidade suficiente de água 
para que haja a solubilização do $\mathrm{CO}_{2}$ e do $\mathrm{Ca}(\mathrm{OH})_{2}$, imprescindíveis para ocorrência da carbonatação. Como a difusão do $\mathrm{CO}_{2}$ em meio líquido é mais lenta do que em meio gasoso, na ordem de $10^{4}$ vezes menor (Kazmierczak, 1995), em meios saturados o $\mathrm{CO}_{2}$ praticamente não penetra.

O concreto absorve com facilidade a umidade do ambiente, mas em compensação seca lentamente. Quando a umidade externa é constante, chega-se a estabelecer um equilíbrio entre o conteúdo de umidade do interior do concreto e a umidade relativa ambiente. Porém, quando a umidade exterior oscila, o interior do concreto não pode acompanhar as trocas com a mesma velocidade. Conseqüentemente só a camada externa da estrutura é que mantém o equilíbrio com a umidade relativa exterior (FIGUEIREDO, 2004).

Isaia et al. (2001) descrevem que o teor de umidade de equilíbrio em que as medidas de profundidade de carbonatação aceleradas são realizadas, afeta essa comparação, visto que os ensaios naturais podem podem ser afetados por condições ambientais diversas tais como: exposição interna, externa abrigada ou externa desabrigada, diminuindo a profundidade de carbonatação da primeira em direção à última, pois, na condição interna, a umidade relativa se mantém quase todo tempo dentro da faixa de carbonatação máxima (50-80\%), enquanto que, nas externas, as variações higrotérmicas dos poros são influenciadas pelas secagens e molhagens sucessivas.

Ceukelaire e Nieuwenburg ${ }^{36}$ citados por Possan (2004) avaliaram a influência da umidade relativa na profundidade de carbonatação de concretos. Para tal, após desmoldagem, os corpos-de-prova foram curados por 6 dias em ambiente com umidade relativa de $90 \%$ e temperatura de $20^{\circ} \mathrm{C}$. Durante a cura os corpos-de-prova ficaram expostos à concentração de $\mathrm{CO}_{2}$ do ambiente natural. Nos ensaios, os parâmetros considerados foram temperatura constante de $20^{\circ} \mathrm{C}, 6$ faixas de umidade relativa variando de 40 a $90 \%$, com incrementos de $10 \%$ e concentrações de $\mathrm{CO}_{2}$ de $10 \%$ e $0,03 \%$, simulando uma atmosfera enriquecida e uma natural, respectivamente. Os autores verificaram que, para os dois teores de $\mathrm{CO}_{2}$, a carbonatação atingiu profundidade máxima na umidade relativa de aproximadamente 50\% (Figura 37).

É interessante observar que, por essa pesquisa, a carbonatação a taxas ambientes naturais não foi suficiente para evidenciar efeitos da UR e que apenas foi ligeiramente superior a $50 \%$.

36 CEUKELAIRE, L.; NIEUWENBURG, V. Accelerated carbonation of a blast-furnace cement concrete. Cement and Concrete Research . v.23. p.442-452, 1993. 


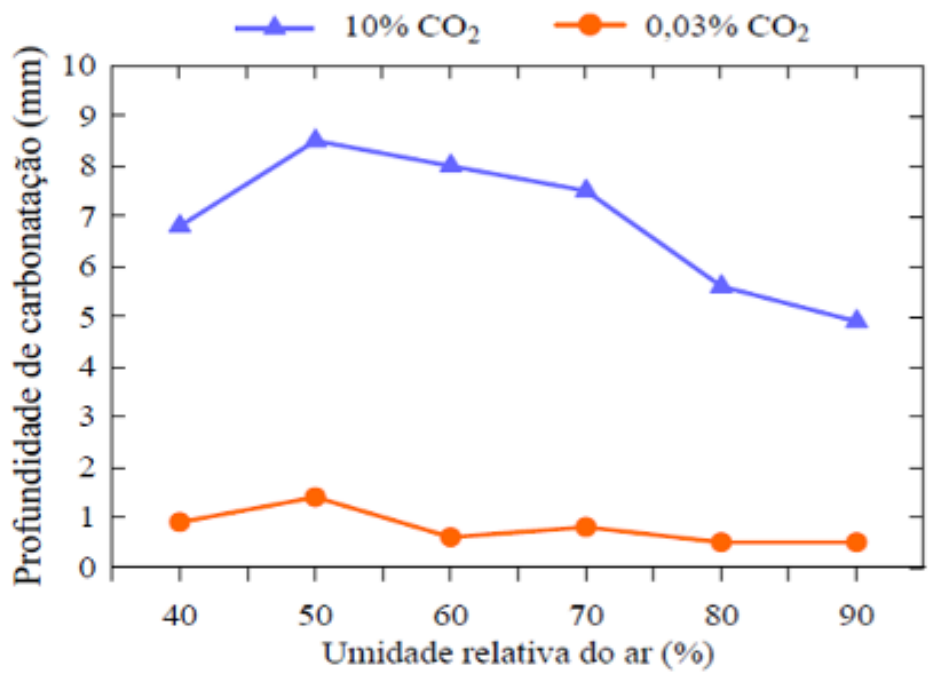

FIGURA 37 - Profundidade de carbonatação em relação à umidade relativa e o teor de $\mathrm{CO}_{2}$ (CEUKELAIRE E NIEUWENBURG ${ }^{36}, 1993$ citados por POSSAN, 2004).

Roy et al. (1999) investigaram a carbonatação acelerada de concretos de diferentes classes de resistências, com relações água/aglomerante entre 0,55 e 0,80, concentração de $\mathrm{CO}_{2}$ de $6 \%$ e umidades relativas de $52 \%, 64 \%, 75 \%, 84 \%$ e $92 \%$. Os resultados indicaram que, para todas as classes de resistências analisadas, houve aumento na profundidade de carbonatação com o incremento de $52 \%$ para $75 \%$. Porém, para umidades relativas entre $84 \%$ e $95 \%$ a profundidade carbonatada foi menor que a observada no intervalo de $52 \%$ a $75 \%$ (Figura 38).

Embora pareça ser consenso que as maiores taxas de carbonatação sempre ocorram em umidade relativa entre 50 e $75 \%$, Roy et al. (1999), além de verificarem profundidades carbonatadas coerentes com a umidade relativa, observaram também que em umidade relativa em torno de 95\%, a profundidade de carbonatação em idades mais avançadas (no caso, nas leituras feitas após 4 semanas) foi superior às registradas para os corpos-deprova carbonatados em umidades consideradas críticas, conforme ilustra a Figura 38. Portanto, ao que parece, o prazo de 56 dias é o mínimo a ser adotado para ensaios de carbonatação em umidades relativas elevadas. 


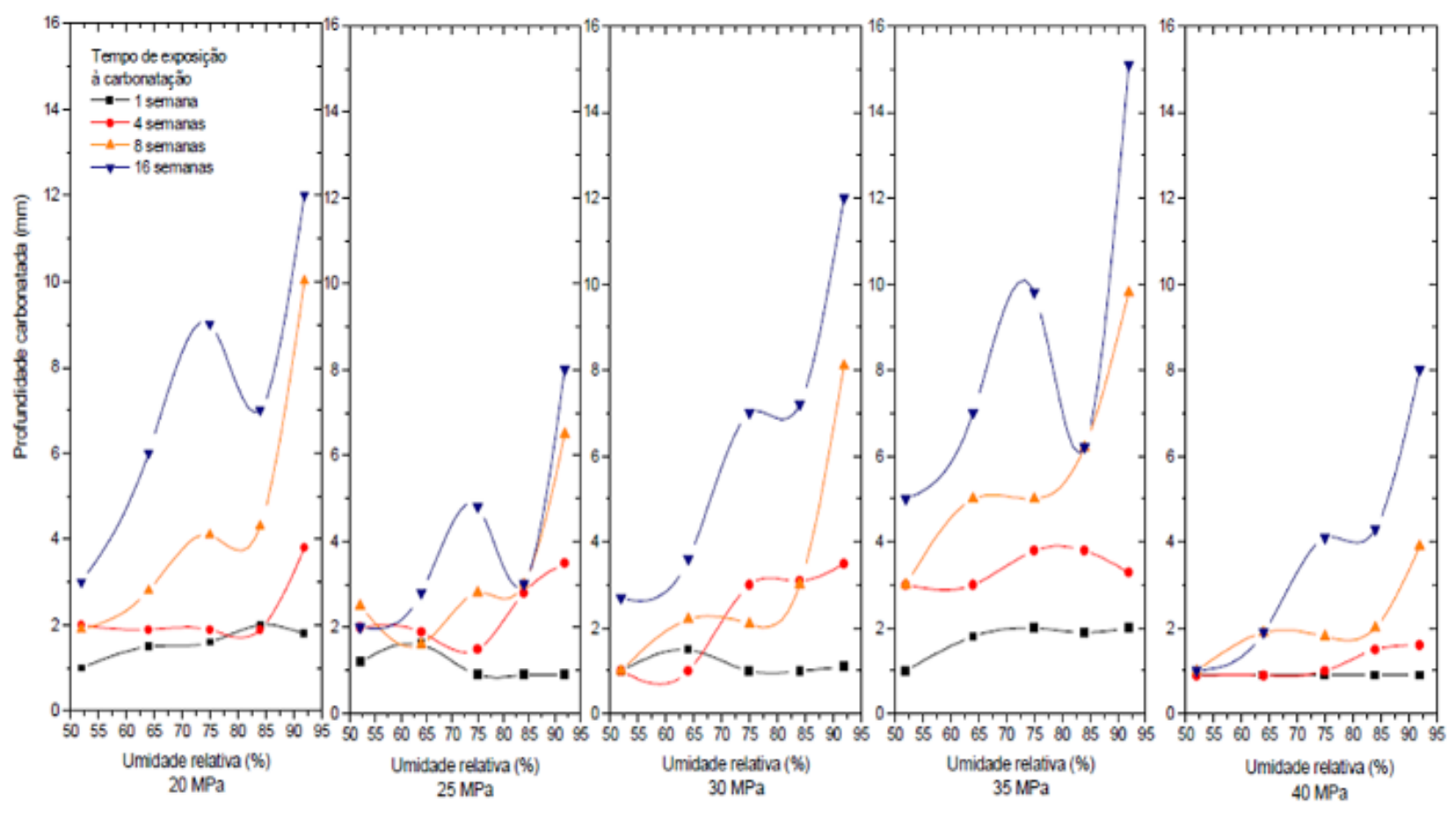

FIGURA 38 - Profundidade carbonatada em relação à umidade relativa, para diferentes classes de concreto (ROY et al., 1999).

Com base nos resultados apresentados na Figura 38, Roy et al. (1999) observaram também a redução na profundidade carbonatada de concreto quando a umidade vai de 75 para $84 \%$, e após, um novo aumento para umidades de até $92 \%$. Maiores profundidades de carbonatação foram detectadas por Roy et al. (1999) para a umidade de 92\%. Os autores consideram possível que as diferenças se devam aos mecanismos de carbonatação em testes acelerados e sugerem mais pesquisas para justificar o que foi observado.

Os dados de Gonen; Yazicioglu (2007) ilustrados na Figura 39 mostram que a melhor velocidade de carbonatação foi obtida com a umidade relativa de $55 \%$, mas distam muito pouco os resultados dos valores encontrados para UR de $80 \%$, o que concorda com a previsão da Figura 38. 


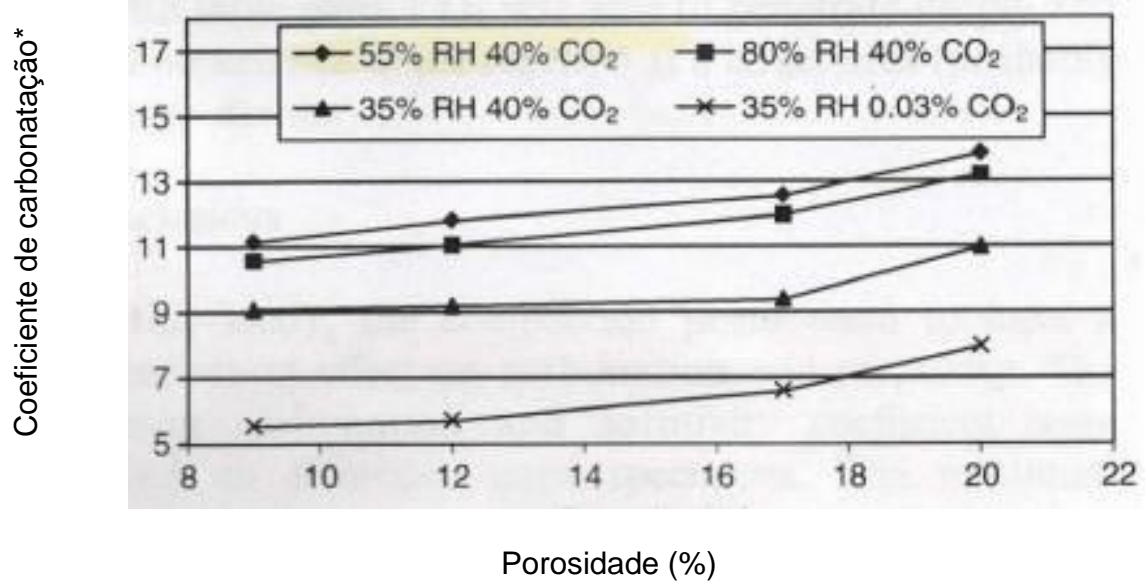

${ }^{*}$ Coeficiente de carbonatação é em mm/dia ${ }^{0,5}$ e mm/ano ${ }^{0,5}$ para ambiente com $40 \% \mathrm{CO}_{2}$ e $0,03 \%$ $\mathrm{CO}_{2}$, respectivamente.

FIGURA 39 - Porosidade versus coeficiente de carbonatação para atmosfera normal e acelerada, em função da umidade relativa de ensaio (GONEN; YAZICIOGLU, 2007).

\section{E) Precondicionamento dos corpos-de-prova}

O transporte de substâncias gasosas através do concreto será sensivelmente afetado pela umidade dos poros. Uma alta umidade irá bloquear o fluxo de gás, mas incrementará o fluxo de substâncias dissolvidas. Da mesma forma, a água capilar livre que evapora em decorrência da secagem tem uma grande influência no fluxo de gás no concreto, pois a permeabilidade irá aumentar à medida que o concreto secar (SUGIYAMA ${ }^{37}$ apud REGATTIERI, 1998).

A interação entre os fluidos ambientais e o interior do concreto depende do estado de umidade dos poros: se estiverem totalmente secos ou saturados a difusão de gases não ocorre pela falta ou excesso de água (a difusão de gases na água é da ordem de $10^{-4}$ vezes menor do que no ar), sendo máxima quando os poros estiverem parcialmente preenchidos, ou seja, quando as superfícies internas dos poros estiverem cobertas por uma película de água adsorvida. Assim, não só para os gases, como para os líquidos ou substâncias dissolvidas na água, o fluxo dependerá do estado de umidade tanto do ambiente quanto dos poros, que governará os processos de difusão do exterior para o interior ${ }^{38}$.

37 SUGIYAMA, T. et al. Effect of stress on gas permeability in concrete. ACI Materials Journal, Michigan, v.93, n.5, p.443-450, Sept./Oct. 1996.

38 COMITÉ EURO-INTERNATIONAL DU BÉTON. Durable Concrete Structures. London: Thomas Telford, 1992. 
Assim, a umidade relativa interna do concreto interfere na quantidade de água disponível nos poros do concreto, o concreto absorve facilmente a umidade do ambiente, mas seca lentamente.

O levantamento de Pauletti et al. (2007) e a Tabela 19 mostram que no procedimento de precondicionamento dos corpos-de-prova após a cura, também há muita divergência nos trabalhos. Este é um ponto fundamental a ser esclarecido para futura normalização, já que tal processo pode resultar em ensaios de corpos-de-prova com variado teor de umidade, pois a secagem do concreto é função da sua porosidade.

Há um método normalizado pela RILEM ${ }^{30}$ TC 116-PCD (1999) apud Pauletti et al. (2007) que descreve o procedimento para precondicionamento de corpos-de-prova para medição da permeabilidade a gases e absorção de água. Após a cura, os corpos-de-prova são colocados em estufa à temperatura de $50 \pm 1^{\circ} \mathrm{C}$ até alcançar a perda de massa preestabelecida e inferior a 0,1g. Em seguida, devem ser embalados para serem isolados quanto à troca de umidade e permanecerem a $50 \pm 1^{\circ} \mathrm{C}$ por mais 14 dias, para redistribuição da umidade restante no interior do corpo-de-prova. Após este período, cada corpo-de-prova é resfriado a temperatura ambiente por mais $24 \mathrm{~h}$, antes de se iniciar o ensaio de carbonatação, propriamente.

O projeto de norma PrEN 13295, 2000 (citado por Giannotti; Helene, 2007) também cita a etapa de pré-condicionamento como parte dos procedimentos de ensaio, sugerindo um período de secagem que antecede à carbonatação do corpo-de-prova. Recomendam que a secagem deve ser feita por um período mínimo de 14 dias, considerando, para a finalização desta etapa que a variação de massa deve ser menor que 0,2\% em 24 horas.

\section{F) Temperatura}

A temperatura é uma das variáveis relacionadas ao meio ambiente que pode influenciar o processo da carbonatação. Dependendo do valor da temperatura ao qual o concreto é exposto, há uma tendência à aceleração das reações de hidratação do cimento, melhorando as condições microestruturais ou, no caso de ser excessivamente alta, causar a microfissuração do material e acelerar o ingresso dos agentes agressivos no concreto (GIANNOTTI; HELENE, 2007). 
Mas, segundo Parrot ${ }^{39}$ (1990), a velocidade de carbonatação não sofre aceleração direta pelo acréscimo de temperatura, entre valores de $20^{\circ} \mathrm{C}$ e $45^{\circ} \mathrm{C}$.

Deve-se ainda considerar que a temperatura exerce influência na taxa de corrosão de armadura, não podendo ser desprezada na estimativa de durabilidade de uma estrutura de concreto armado (KAZMIERCZAK, 1995).

\subsection{CONCLUSÕES SOBRE O ESTADO DA ARTE}

Através da revisão bibliográfica para este estudo, observou-se que existem muitas pesquisas nacionais e internacionais sobre a durabilidade das estruturas de concreto armado e também sobre os seus mecanismos de deterioração, como é o caso da corrosão de armaduras pela carbonatação e umidade no concreto, ênfase deste trabalho.

De modo a prevenir a deterioração precoce das estruturas, é sempre recomendável que no desenvolvimento do projeto sejam bem caracterizados o clima regional, local e os microclimas a que os elementos portantes principais estarão expostos, na expectativa de antever os possíveis mecanismos de deterioração e as medidas preventivas, caso a caso.

Por exemplo, em norma da Comunidade Européia, foi constatada uma classificação mais detalhada dos riscos da agressividade ambiental à durabilidade das estruturas de concreto, destacada no item 2.2.2. Nessa classificação, o risco de deterioração por corrosão de armaduras em microclimas com alternância de molhagem e secagem do concreto é considerado elevado, corroborando a importância do programa experimental desta dissertação. Já a principal norma brasileira que trata deste tema, como é a ABNT NBR 6118 (2007), dá ênfase à classificação de macroclima e recomenda genericamente uma séria de medidas preventivas à ação da umidade nos edifícios.

Por outro lado, mesmo tendo ocorrido um significativo avanço na normalização brasileira no campo do projeto e execução das estruturas de concreto armado, pela ABNT NBR 6118 (2003), ABNT NBR 14931 (2004) e ABNT NBR 12655 (2006), visando estruturas mais duráveis; o estado da arte e os resultados desta dissertação confirmam que ainda há a necessidade de evolução nas rotinas de controle tecnológico, especialmente na ABNT NBR 12655 (2006).

Pelas normas brasileiras citadas, por exemplo, os concretos passaram a ser especificados por critérios de relação água/cimento máxima e de consumo de cimento

39 PARROT, L. J. Damage caused by carbonation of reinforced concrete RILEM Recommendation, p.230-234, 1990. 
mínimo, atendidos por estudos de dosagem experimental, mas o controle de produção e recebimento continuam sendo feitos, na prática, apenas por critérios de abatimento no estado fresco e de atendimento à resistência característica à compressão de projeto. Não há ainda difusão de práticas sobre como medir e controlar essas variáveis ou outras auxiliares de controle da porosidade do concreto, nas rotinas de produção ou de recebimento do concreto estrutural.

Além disto, constatou-se o consenso de renomados especialistas internacionais (HOOTON et al. 2006) sobre a necessidade de desenvolvimento de novos critérios para a dosagem e o controle de concretos estruturais, e aqueles manifestam uma certa insatisfação quanto aos ensaios atuais para o controle da qualidade do concreto, principalmente, em condições de exposição mais agressivas das estruturas ou para obras especiais.

Devido a esta preocupação com a durabilidade das estruturas de concreto armado, muitos pesquisadores continuam propondo novos métodos e modelos para prever o comportamento do concreto quanto à carbonatação. Sempre a expectativa é de predição do período de passivação das armaduras, ou seja, da vida útil de projeto, por ensaios acelerados diversos. Mas, a maior parte dos ensaios acelerados apenas permite medidas comparativas entre diferentes concretos, pois os fatores de degradação desses ensaios são muito diferentes das condições reais de serviço das estruturas.

Destaca-se ainda que a maioria dos modelos de carbonatação existentes, muito bem discutidos por Carmona (2005), resumidos e atualizados nesta dissertação, no item 2.1.4, seria de difícil aplicação às situações correntes em rotinas de controle tecnológico. Também alguns modelos são de aplicação limitada ou dúbia, pelas mudanças importantes na classificação dos cimentos, como ocorreu na década de 80, pela introdução dos tipos CP II E, CP II Z e CP II F. Além disso, mudanças previsíveis ou freqüentes nas características de agregados, adições e aditivos nos concretos estruturais correntes suscitam a verificação contínua do comportamento do concreto, e assim é recomendável manter requisitos, métodos e critérios de dosagem também em avaliação permanente.

Mas, ainda existe carência de norma brasileira para medir a resistência à carbonatação do concreto, o que seria desejável para avanços tecnológicos em predição de vida útil de projeto de armaduras. Por exemplo, as seguintes variáveis foram apontadas por Pauletti et al. (2007), como ainda necessárias de serem investigadas para efeito da futura norma: a) procedimentos e prazos de cura e de precondicionamento do concreto, antes de iniciar o ensaio; b) pressão de $\mathrm{CO}_{2}$ e tempo de exposição; c) tamanho de amostras.

Até que um método padrão de ensaio de carbonatação seja colocado em prática, as possibilidades de correlação desses ensaios com envelhecimento natural ou a sua aplicação 
em estudos de modelagem estarão, principalmente, limitadas a obras especiais. Já o grande volume de produção do concreto para obras correntes, não será atendido e ficará ainda sujeito à disponibilidade comercial de câmaras de carbonatação, pelas empresas de controle tecnológico do mercado.

Portanto, é importante discutir alternativas para métodos de medida da resistência à carbonatação de concretos, especialmente, alguns mais relacionados às situações usuais de ocorrência deste mecanismo nas estruturas, e que possam ser aplicados por um maior número de empresas e laboratórios do mercado.

Embora seja consenso que as características do concreto no estado fresco são fundamentais para o seu desempenho estrutural em serviço, a literatura pouco tem discutido sobre as relações do teor de ar no estado fresco com a resistência à carbonatação para a durabilidade de armaduras, como feito no programa experimental desta dissertação. A este respeito, apenas foram encontradas proposições qualitativas por Mindess; Young (1981), endossadas por Martin (2005), mas relacionadas à resistência a gelo e degelo, que não são próprias do Brasil. 


\section{PROGRAMA EXPERIMENTAL}

Este capítulo apresenta o programa experimental realizado em campo e laboratório com o objetivo de contribuir para o desenvolvimento de propriedades auxiliares para o controle tecnológico do concreto estrutural, com vistas à predição da sua resistência à carbonatação e capacidade de proteção de armaduras de aço carbono, em estruturas de edifícios, e onde em geral é concomitante a ação da umidade para desencadear a corrosão de armaduras.

Esta pesquisa é um prosseguimento de outra com escopo similar e conduzida por Cavalcanti Filho (2010), também sob orientação da Prof ${ }^{a}$ Silvia Selmo.

\subsection{OBJETIVOS}

O programa experimental focalizou a amostragem e caracterização, em campo e laboratório, de um lote de concreto com $\mathrm{f}_{\mathrm{ck}} 30 \mathrm{MPa}$ produzido por uma central dosadora, na cidade de São Paulo/SP, com os seguintes objetivos específicos:

a) Verificar medidas de controle do concreto no estado fresco com vistas à previsão da sua resistência à carbonatação. Especificamente, foram selecionados e testados quatro métodos de caracterização do teor de ar do concreto no estado fresco, um gravimétrico, um pressométrico e outros dois por medidas físicas de compactabilidade e analisadas as suas relações com os resultados de resistência à carbonatação;

b) Prosseguir a pesquisa de um método de maturação acelerada do concreto em temperatura amena e, na sequência, comparar três diferentes tipos de exposição para realizar a carbonatação acelerada do concreto entre 8 e 203 dias de idade;

c) Testar dois métodos de análise de imagem para obter medidas de resistência à carbonatação do concreto, por área relativa, em comparação ao método unidirecional, manual e clássico de avaliar esta propriedade;

d) Analisar as demais possíveis correlações entre propriedades do concreto fresco e endurecido e a sua resistência à carbonatação acelerada.

Em resumo, o programa experimental caracterizou uma certa composição de concreto 
estrutural, de $\mathrm{f}_{\mathrm{ck}} 30 \mathrm{MPa}$ para ambiente classe II da ABNT NBR 6118 (2007), quanto à sua resistência à carbonatação, através de certas propriedades do estado fresco e com maturação acelerada para ensaios de envelhecimento acelerado a partir de 7 dias e até 203 dias.

\subsection{METODOLOGIA PARA A DEFINIÇÃO DO LOTE DE CONCRETO}

Este programa optou por um estudo de campo para que o desenvolvimento da metodologia fosse baseado em condições reais de variabilidade das propriedades do concreto estrutural.

Assim adotou-se a caracterização de concreto pré-misturado, em uma central dosadora de grande porte na cidade de São Paulo, nas condições a serem entregues em obra, para se poder melhor aferir a variabilidade real das propriedades visadas pelo estudo, com vistas a conclusões mais efetivas quanto à sua adequação ou não para rotinas de controle tecnológico ou estudos de dosagem.

\subsubsection{Definições da classe de resistência, cidade e central dosadora do lote}

Foi fixado um lote de concreto estrutural de $\mathrm{f}_{\mathrm{ck}} 30 \mathrm{MPa}$, produzido em uma central dosadora, na cidade de São Paulo/SP, como objeto de estudo e caracterização pelo programa experimental.

A escolha dessa resistência característica se deu pelas seguintes razões:

$\checkmark \mathrm{Of}_{\mathrm{ck}} 30 \mathrm{MPa}$ atende a três das quatro classes de agressividade da ABNT NBR 6118 (2007), conforme condições apresentadas na Tabela 13 no Capítulo 2.

A cidade de São Paulo/SP foi escolhida para sediar o estudo pelos seguintes motivos:

$\checkmark$ Por ser uma cidade tipicamente urbana e representativa de classe de agressividade ambiental II;

$\checkmark$ Por terem sido obtidos subsídios de infra-estrutura mínima e necessária à pesquisa, pelo apoio da Universidade de São Paulo e da empresa Votorantim Cimentos (Engemix), no fornecimento de laboratórios, da mão-de-obra, do concreto e dos equipamentos;

$\checkmark$ Por a cidade apresentar contínua expansão de centrais dosadoras e de obras 
em edifícios com estrutura de concreto armado.

Assim foi escolhida uma obra de edifício próxima à Universidade e à central dosadora de concreto, para fins logísticos e pela otimização da utilização de equipamentos, mão-deobra e realização dos ensaios de concreto fresco. A especificação do concreto dessa obra era de abatimento $(10 \mathrm{~cm} \pm 2 \mathrm{~cm}$ ), bombeável e de resistência característica a 28 dias igual a $30 \mathrm{MPa}$.

Os valores de $f_{c k}$ e abatimento foram valores pré-fixados, mas os materiais, dosagem $e$ valores da relação a/c máxima e do consumo de cimento embora pudessem ser também preestabelecidos, através da ABNT NBR 6118 (2007), não foram controlados por esta pesquisa, e sim deixados a critério do contrato existente entre a obra e a central, pois poderiam interferir na sua produção de rotina.

Portanto, a fixação do concreto e da obra para a realização do programa experimental foi definida aleatoriamente, após a qualificação de algumas premissas técnicas e operacionais de infraestrutura.

\subsubsection{Seleção e visita preliminar à obra}

Nesta etapa foram feitos contatos de interesse, para o reconhecimento de empresa construtora com obra em andamento e atendida pela central dosadora escolhida.

O objetivo do reconhecimento preliminar foi confirmar a disponibilidade da empresa construtora indicada pela central dosadora, em participar do projeto, principalmente fornecendo previsões e dados sobre as concretagens. Foram solicitadas as características especificadas para o concreto (abatimento, aditivos, relação a/c e outras que possam ter sido especificadas pelo projeto) e ainda informações sobre a produção da estrutura (cobrimento das armaduras, resultados de controle do concreto em lotes anteriores, volume de lotes, plano de concretagem).

Para o desenvolvimento desta etapa, foram realizadas algumas visitas técnicas para acompanhar uma concretagem e tratar da infraestrutura.

Mesmo com todas as providências tomadas, relacionamento e acordo com o pessoal da obra, foi excluída a hipótese de se realizar os ensaios na obra, devido às limitações constatadas durante as visitas, como segue:

$\checkmark$ Espaço físico da obra bastante comprometido para acesso com equipamentos e pessoas;

$\checkmark$ Falta de instalações elétricas e hidráulicas, próximo ao local fornecido pela obra, para a realização dos ensaios; 
$\checkmark$ Limitação de horário para retirada de corpos-de-prova e equipamentos da obra;

Dificuldade em fazer planejamento de datas de concretagens para fazer a reserva de equipamentos e contratação de terceiros, devido à falta de antecipação nas programações de concretagens entre a obra e a central. $O$ ritmo da obra era bastante acelerado e estavam executando várias torres ao mesmo tempo, porém não foi liberado o acesso a todas essas torres, para a realização dos ensaios, somente àquelas próximas aos portões de acesso;

$\checkmark$ A obra realizava os ensaios de abatimento e retirada de amostras na chegada dos caminhões e próximo aos portões de acesso e não do terço médio do caminhão, conforme especificado pela norma ABNT NBR NM 33 (1994) Concreto - Amostragem do concreto fresco;

Devido às dificuldades apresentadas, os concretos do lote em estudo, foram amostrados e caracterizados inicialmente, no pátio da central dosadora de concreto, onde se obteve maior apoio quanto à espaço físico, fornecimento de equipamentos e pessoas para auxiliar na realização deste trabalho.

\subsubsection{Plano básico de amostragem do lote em estudo}

A norma brasileira ABNT NBR 12655 (2006) faculta a amostragem de lotes de concreto pelos dois procedimentos seguintes:

$\checkmark$ Amostragem parcial, com coleta e caracterização de pelo menos seis caminhões-betoneira constituintes de um dado lote homogêneo de produção de concreto;

$\checkmark$ Amostragem total, com coleta e caracterização de todos os caminhõesbetoneira constituintes de um dado lote.

O lote de concretagem da obra foi de $160,0 \mathrm{~m}^{3}$ (20 caminhões-betoneira) e para esta pesquisa, definiu-se que esse lote seria amostrado pelos concretos de seis caminhõesbetoneira, produzidos para a dada concretagem, no decorrer de única data, com escolha aleatória dos caminhões e admitindo ser um lote homogêneo.

Para as seis amostras deste lote, foi realizado um conjunto de ensaios no concreto fresco, sendo que cada ensaio foi realizado com uma repetição. Para as principais propriedades de interesse relacionadas à resistência à carbonatação foram amostrados os 
concretos, conforme resumido no fluxograma da Figura 40. Para alguns ensaios complementares de caracterização, foi amostrado apenas um caminhão do lote.

Para cada caminhão amostrado, foram registrados inicialmente números de notas fiscais de fornecimento e números dos caminhões, pela central produtora, para posterior rastreabilidade quanto à composição de materiais constituintes da carga.

O concreto de cada caminhão amostrado foi caracterizado em prazo compreendido entre 20 a 30 min do início da mistura, na respectiva central.

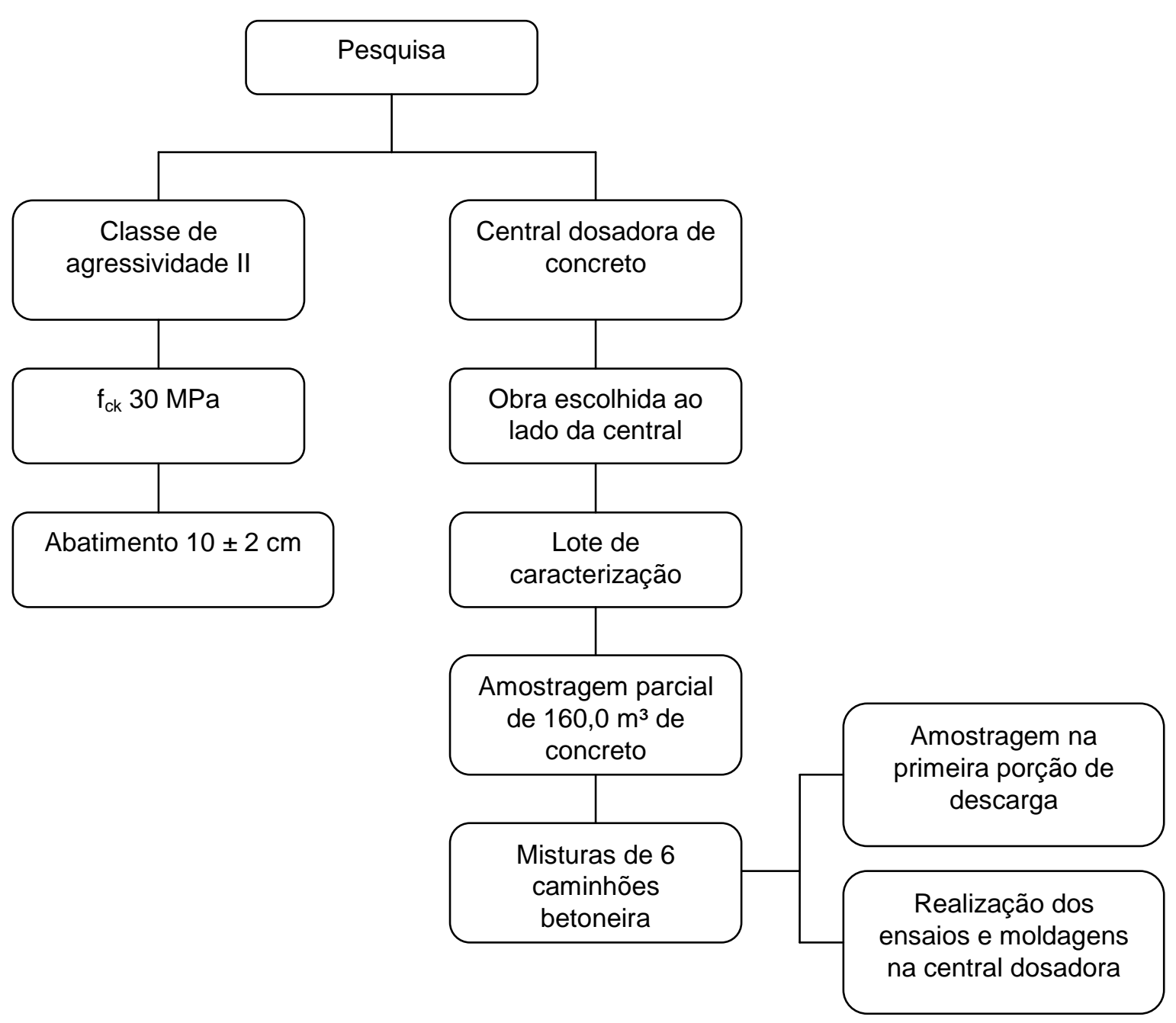

FIGURA 40 - Fluxograma de amostragem do lote de concreto analisado. 


\subsubsection{Caracterização dos materiais constituintes e dosagem do concreto}

Os materiais constituintes e respectiva dosagem do lote de concreto deste estudo foram integralmente definidos pela central produtora, sem qualquer envolvimento prévio desta autora e demais da equipe de pesquisa, limitando-se este programa experimental a analisar a variação e a relação entre as propriedades das seis amostras de concreto fresco e endurecido.

As características dos materiais constituintes do lote amostrado foram fornecidas pela central produtora, com base na ABNT NBR 12654 (1992), através de certificados próprios ou de terceiros, e foram confirmadas apenas para propriedades de interesse da pesquisa. $O$ resumo dos materiais e sua massa específica constam na Figura 41. Os demais resultados de caracterização dos materiais, obtidos através de ensaios informados pela central, estão apresentados no Apêndice A.

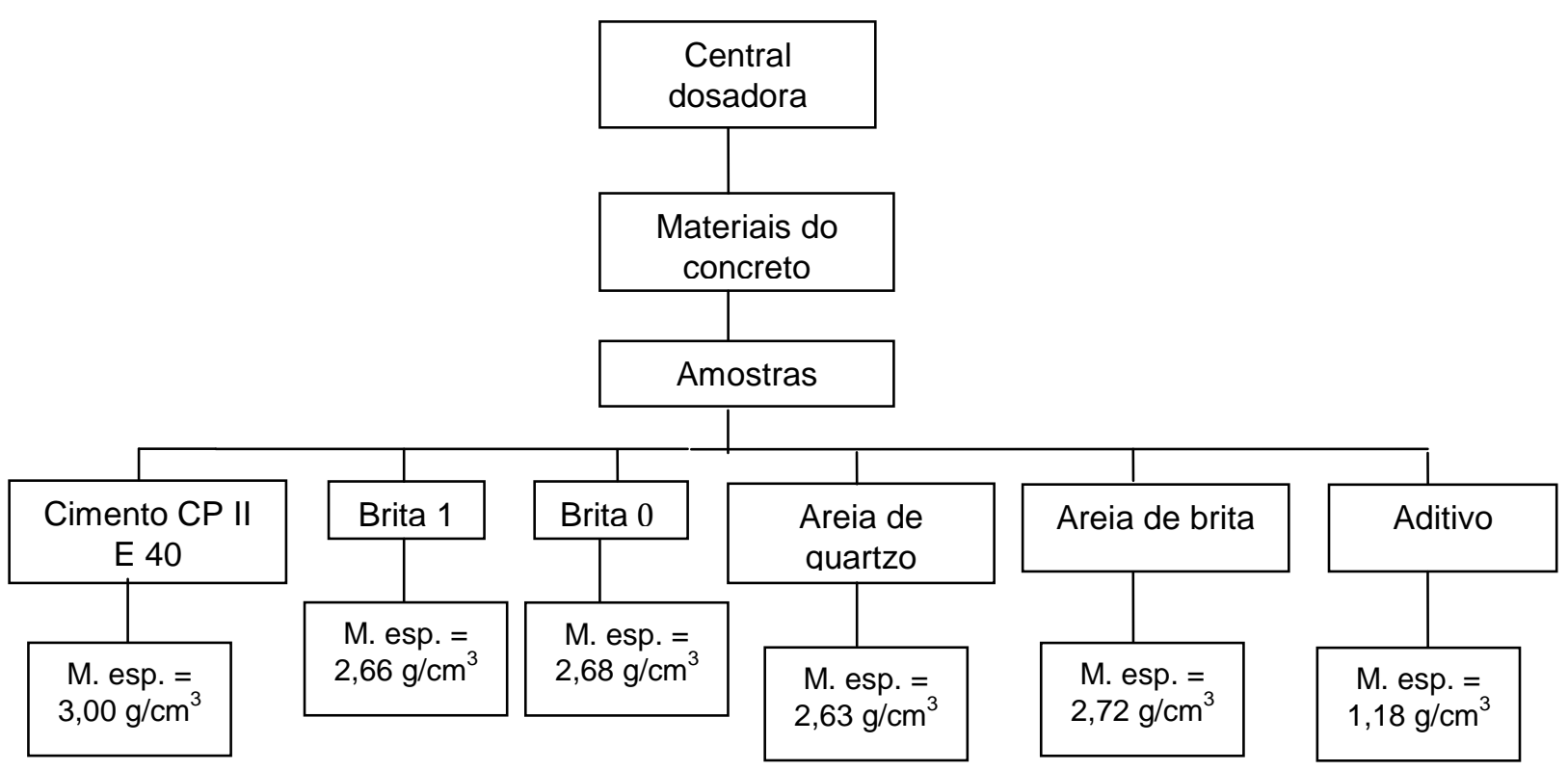

FIGURA 41- Resumo das características dos materiais utilizados nos concretos amostrados para o lote analisado.

De forma ideal, a amostragem e caracterização deveria ter sido repetida também na data de produção do lote em estudo, mas isto foi realizado apenas em parte, como informado a seguir.

As amostras coletadas na central de concreto na data da concretagem foram as seguintes: 
$\checkmark$ Amostras do cimento, com cerca de $5 \mathrm{~kg}$, para ensaios de calorimetria;

$\checkmark$ Amostras dos agregados graúdos e miúdos com cerca de $10 \mathrm{~kg}$ cada uma, para ensaios físicos de caracterização da granulométrica, massa específica e absorção de água. Por motivo de limitação operacional da equipe, não pode ser determinada a umidade dos agregados na concretagem. Os dados de umidade adotados para os agregados foram os da própria central, que tem como procedimento realizar ensaios de umidade das areias três vezes ao dia. A central possui baias de descanso para os materiais recémchegados e ainda é provida de baias cobertas.

\subsection{AMOSTRAGEM E CARACTERIZAÇÃO DO CONCRETO}

Os itens 3.3.1 a 3.3.3 detalham os procedimentos do programa de pesquisa, com vista aos objetivos no item 3.1 .

\subsubsection{Ensaios no concreto fresco}

As cargas de materiais em cada caminhão-betoneira eram dosadas pela balança da central, de forma automatizada. Depois, cada caminhão seguia para o dosador de água, para ajuste de abatimento, de acordo com a quantidade limite de água especificada. Após mistura de 15 a 20 minutos, o concreto era descarregado com um volume em torno de 400 litros por caminhão, em cima de uma lona plástica cercada por ripas de madeira, instaladas sobre uma laje de piso regularizada de concreto. O concreto ainda era misturado na caixa novamente com o auxilio de uma enxada, antes da realização dos ensaios de repetição.

Assim, a amostragem e a caracterização dos concretos de cada caminhão-betoneira seguiram o fluxograma, conforme a Figura 42. 


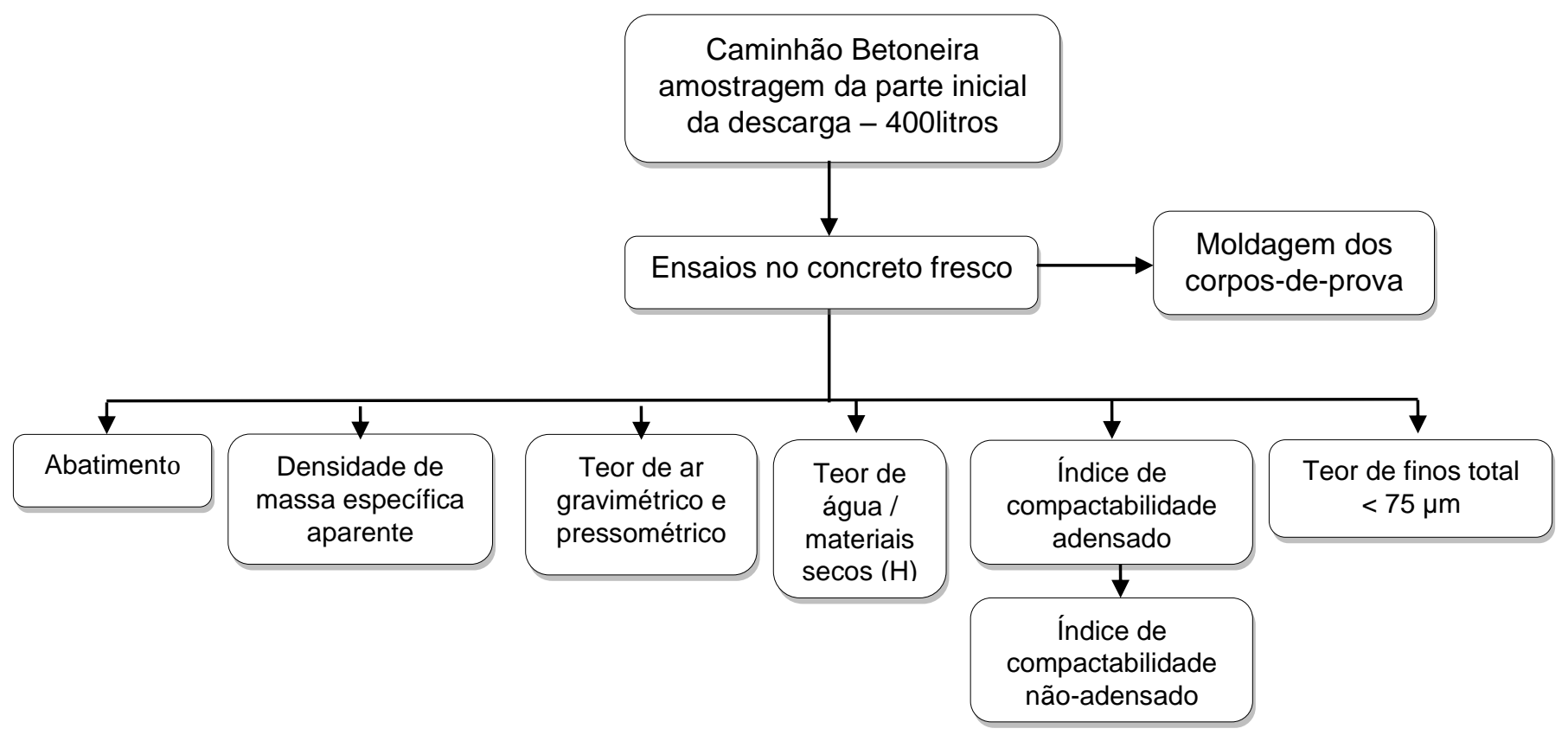

FIGURA 42- Fluxograma de amostragem e dos ensaios no concreto fresco de cada caminhão-betoneira integrante da amostra constituída para representar o lote analisado.

A Figura 43 ilustra o momento da descarga para amostragem do concreto fresco na central dosadora.
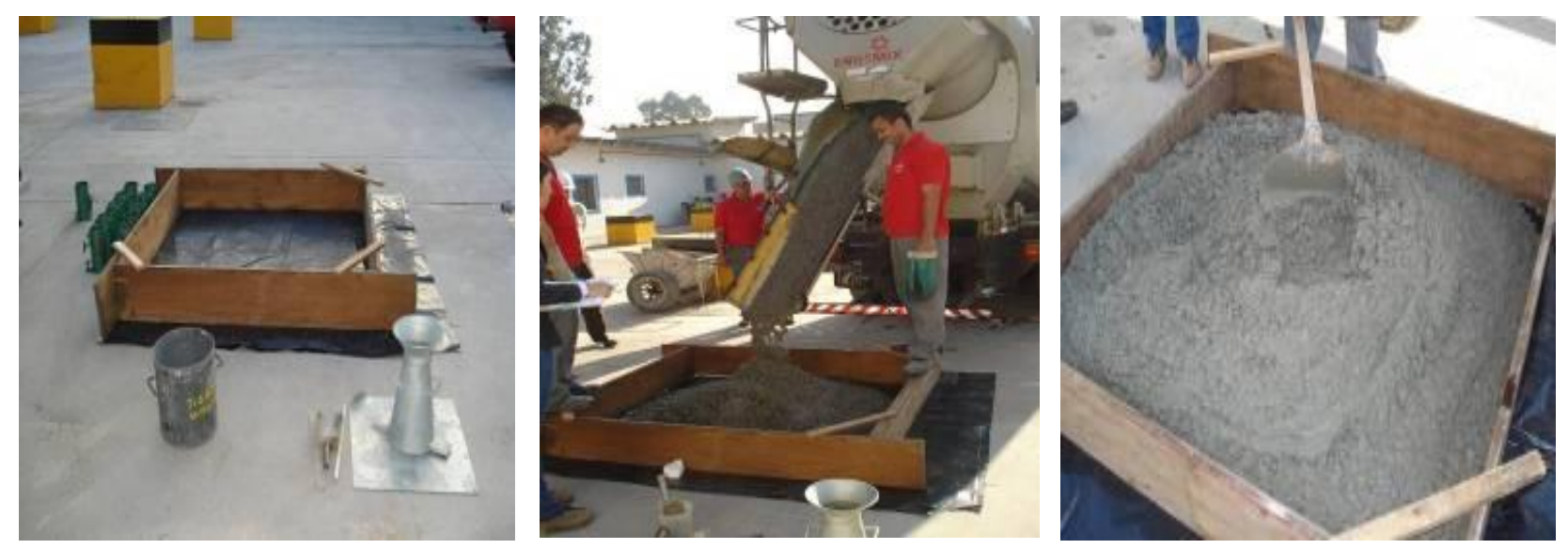

FIGURA 43- Preparo para recebimento do concreto, descarga do caminhão-betoneira e homogeneização para realização dos ensaios e suas repetições.

As equipes de técnicos envolvidas na caracterização integral dos caminhões do lote receberam um treinamento antecipado dos ensaios e demais atividades antes da concretagem, contando com visitas à obra.

A equipe de pesquisa na data da concretagem foi composta de dois estudantes de graduação da universidade, que auxiliaram em determinados ensaios do concreto fresco, 
por dois técnicos de concreto disponibilizados pela central dosadora, por três auxiliares, por esta pesquisadora e pela orientadora desta pesquisa, em sintonia com o pessoal de balança e motoristas de caminhões-betoneira da central. O Eng. Antônio Nereu Cavalcanti Filho participou das medidas de abatimento do concreto e ainda contribuiu com a sua experiência pelo trabalho prévio em Cavalcanti Filho (2010).

As propriedades de caracterização básica do concreto fresco foram as seguintes: abatimento, densidade de massa específica aparente, teor de ar pressométrico e gravimétrico, compactabilidade adensado e não-adensado, relação água/materiais seco (umidade) e teor de finos total abaixo de $75 \mu \mathrm{m}$ do concreto fresco como forma de estimar o consumo de aglomerantes, conforme apresentados na Tabela 21.

TABELA 21 - Resumo dos ensaios no concreto fresco.

\begin{tabular}{|c|c|c|c|c|c|c|c|}
\hline $\begin{array}{l}\text { Idade de } \\
\text { análise }\end{array}$ & Condições & Propriedades & Métodos de ensaio & Abreviatura & $\begin{array}{c}\mathrm{N}^{\circ} \mathrm{de} \\
\text { ensaios por } \\
\text { caminhão }\end{array}$ & $\begin{array}{c}\mathrm{N}^{\circ} \mathrm{de} \\
\text { caminhóes }\end{array}$ & $\begin{array}{c}\mathrm{N}^{\circ} \text { de } \\
\text { ensaios }\end{array}$ \\
\hline \multirow{7}{*}{$\begin{array}{l}\text { Concreto } \\
\text { Fresco }\end{array}$} & \multirow{7}{*}{$\begin{array}{l}\text { Concreto fresco } \\
\text { amostrado } \\
\text { conforme } \\
\text { fluxograma da } \\
\text { Figura } 40 .\end{array}$} & $\begin{array}{l}\text { Abatimento pelo tronco } \\
\text { de cone "slump" }\end{array}$ & $\begin{array}{c}\text { ABNT NBR NM } 067 \\
(1998)\end{array}$ & slumpCT & 2 & 6 & 12 \\
\hline & & $\begin{array}{l}\text { Densidade de massa } \\
\text { especifica aparente }\end{array}$ & $\begin{array}{c}\text { ABNT NBR } 9833 \\
(2008)\end{array}$ & Densidade & 2 & 6 & 12 \\
\hline & & $\begin{array}{l}\text { Teor de ar } \\
\text { pressométrico }\end{array}$ & $\begin{array}{l}\text { ABNT NBR NM } 47 \\
(2002)\end{array}$ & Pressométrico & 2 & 6 & 12 \\
\hline & & $\begin{array}{l}\text { Compactabilidade do } \\
\text { concreto pré-adensado }\end{array}$ & $\begin{array}{l}\text { Adaptado BS-EN } \\
12350-4: 2009\end{array}$ & Compactad & 2 & 6 & 12 \\
\hline & & $\begin{array}{l}\text { Compactabilidade do } \\
\text { concreto não adensado }\end{array}$ & $\begin{array}{c}\text { Adaptado BS-EN } \\
12350-4: 2009\end{array}$ & Compactnad & 2 & 6 & 12 \\
\hline & & $\begin{array}{c}\text { Relação água/materiais } \\
\text { secos ou Umidade }(\mathrm{H})\end{array}$ & $\begin{array}{c}\text { ABNT NBR } 9605 \\
(1992)\end{array}$ & Umidade & 2 & 6 & 12 \\
\hline & & $\begin{array}{c}\text { Teor total de finos }<75 \\
\mu \mathrm{m}\end{array}$ & $\begin{array}{c}\text { ABNT NBR } 9605 \\
(1992)\end{array}$ & Finos & 2 & 6 & 12 \\
\hline
\end{tabular}

À exceção do abatimento, os demais ensaios da Tabela 21, visaram verificar se seria possível relacionar a resistência potencial à carbonatação nos concretos às medidas de teor de ar no estado fresco, por analogia e constatações experimentais de Selmo; Buonopane et al. (2007), que no caso ocorreram para argamassa de reparo industrializadas com diferentes procedências e formulações e pelo estudo realizado por Cavalcanti Filho (2010), precedente à parte experimental desta pesquisa.

A amostragem na central não foi prejudicial à pesquisa, embora pudesse ter sido melhor realizada, se o concreto tivesse sido colocado dentro de uma betoneira, ao invés de ter sido despejado em área confinada e protegida de piso plano, no pátio da central. 
A Figura 48 ilustra a maioria dos ensaios realizados para o concreto no estado fresco, conforme abordado neste item.

O controle do teor de ar é fundamental ao controle da qualidade do concreto, quer seja para verificar limites máximos e mínimos desejáveis de ar incorporado, ou para identificar ar aprisionado no concreto. No Brasil, a ABNT NBR NM 47 (2002) - Concreto Fresco Determinação do Teor de Ar pelo Método Pressométrico, é o ensaio utilizado para a obtenção do valor do ar incorporado e/ou aprisionado no concreto, como apresentado neste programa experimental.

Na Figura 44 apresenta-se o equipamento utilizado para realização do ensaio de medição do ar pelo método pressométrico, o qual consiste de um recipiente hermeticamente fechado, que é preenchido com concreto fresco. Através de orifícios na tampa é injetada água e ar sob pressão, no recipiente fechado, de forma a expulsar o ar do concreto fresco. O manômetro detecta a perda de pressão e indica o percentual de ar equivalente na mistura. A Figura 44 mostra todos os materiais e equipamentos utilizados no ensaio, e as Figuras 44 a 47 ilustram a seqüência de procedimentos adotados para a realização do ensaio, de acordo com a ABNT NBR NM 47 (2003).

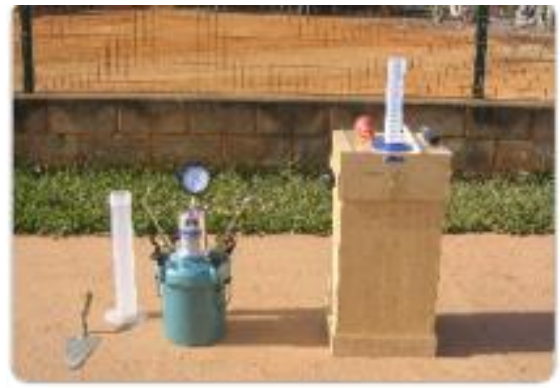

FIGURA 44- Aparelho medidor de ar no concreto, por método pressométrico

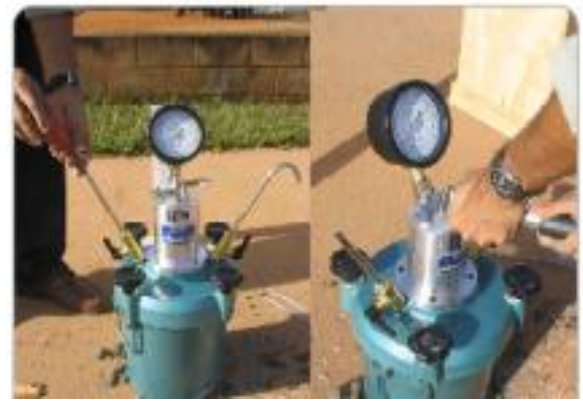

FIGURA 46- Injeção de água e ar.

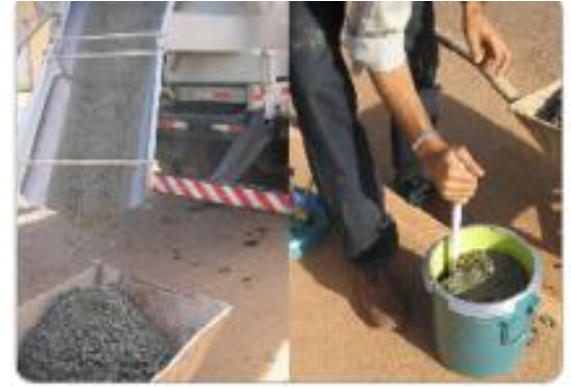

FIGURA 45- Adensamento do concreto

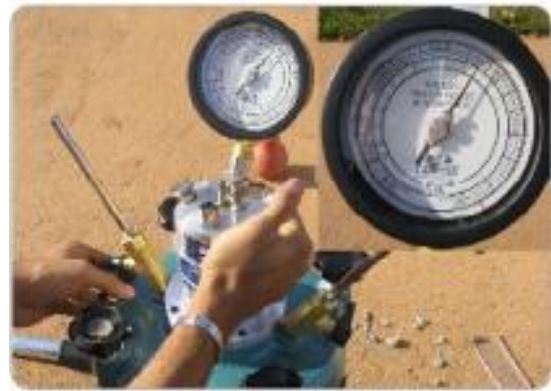

FIGURA 47- Leitura do teor de ar.

Dois ensaios de compactabilidade do concreto fresco foram adaptados e testados a partir da BS EN 12350-4:2009. Neste trabalho, adotou-se um recipiente cilíndrico de 
aproximadamente 15 litros e altura de $280 \mathrm{~mm}$, pois é o mesmo normalizado para a massa específica pela ABNT NBR 9833 (2008). A compactabilidade do concreto foi medida de duas formas:

$\checkmark$ Adensado: em 3 camadas iguais, aplicando-se em cada camada 30 golpes uniformes, tal que a haste de aço carbono da ABNT NBR 9833 (2008) não penetrasse na camada anteriormente adensada, em profundidade maior do que $25 \mathrm{~mm}$. Após este adensamento foi feito o rasamento do concreto na borda superior do recipiente, com régua metálica em movimentos de vai-e-vem, realizou-se a limpeza da sua parede externa e se adensou o concreto em mesa vibratória. Após 1 minuto desligou-se a mesa vibratória e mediu-se a profundidade que o concreto compactou, em quatro pontos do recipiente, ou seja, mediu-se o quanto a superfície desceu, em relação à borda original do recipiente e calculou-se o valor médio com precisão de milímetro. O mesmo procedimento se repetiu para o tempo de 3 minutos de vibração em mesa vibratória (Figura 48 c e d);

$\checkmark$ Não-adensado: a medida de compactabilidade do concreto não-adensado teve uma modificação principal em relação ao ensaio anterior e mais próxima às instruções da BS EN 12350-4:2009 e, que foi o não-adensamento do concreto ao ser lançado no recipiente, tendo o enchimento ocorrido de forma contínua. $O$ procedimento seguiu a mesma seqüência do método adensado, a 1 e 3 minutos de vibração em mesa vibratória. Os resultados foram calculados da mesma forma.

O método de ensaio para determinação da umidade do concreto fresco foi adaptado da ABNT NBR 9605 (1992) Concreto - Reconstituição do traço de concreto fresco. O ensaio consistiu na coleta e pesagem do concreto fresco no momento da amostragem em recipientes de alumínio previamente adicionados com $100 \mathrm{ml}$ de água e $10 \mathrm{~g}$ de açúcar, com o objetivo de retardar a pega até a realização do ensaio no laboratório. Após coleta e transporte, o concreto foi pesado e colocado em estufa a $100^{\circ} \mathrm{C}$ por 24 horas. Após esse período o concreto seco foi pesado e conhecido sua massa seca, conforme ilustra a Figura $48 \mathrm{c}$.

Os ensaios de teor de finos total foram feitos pelo método de lavagem e peneiramento do concreto em três diferentes malhas de peneiras. Após o peneiramento por lavagem, as frações foram colocadas em estufa a $100^{\circ} \mathrm{C}$ e posteriormente pesadas, conforme a Figura $48 f$. 

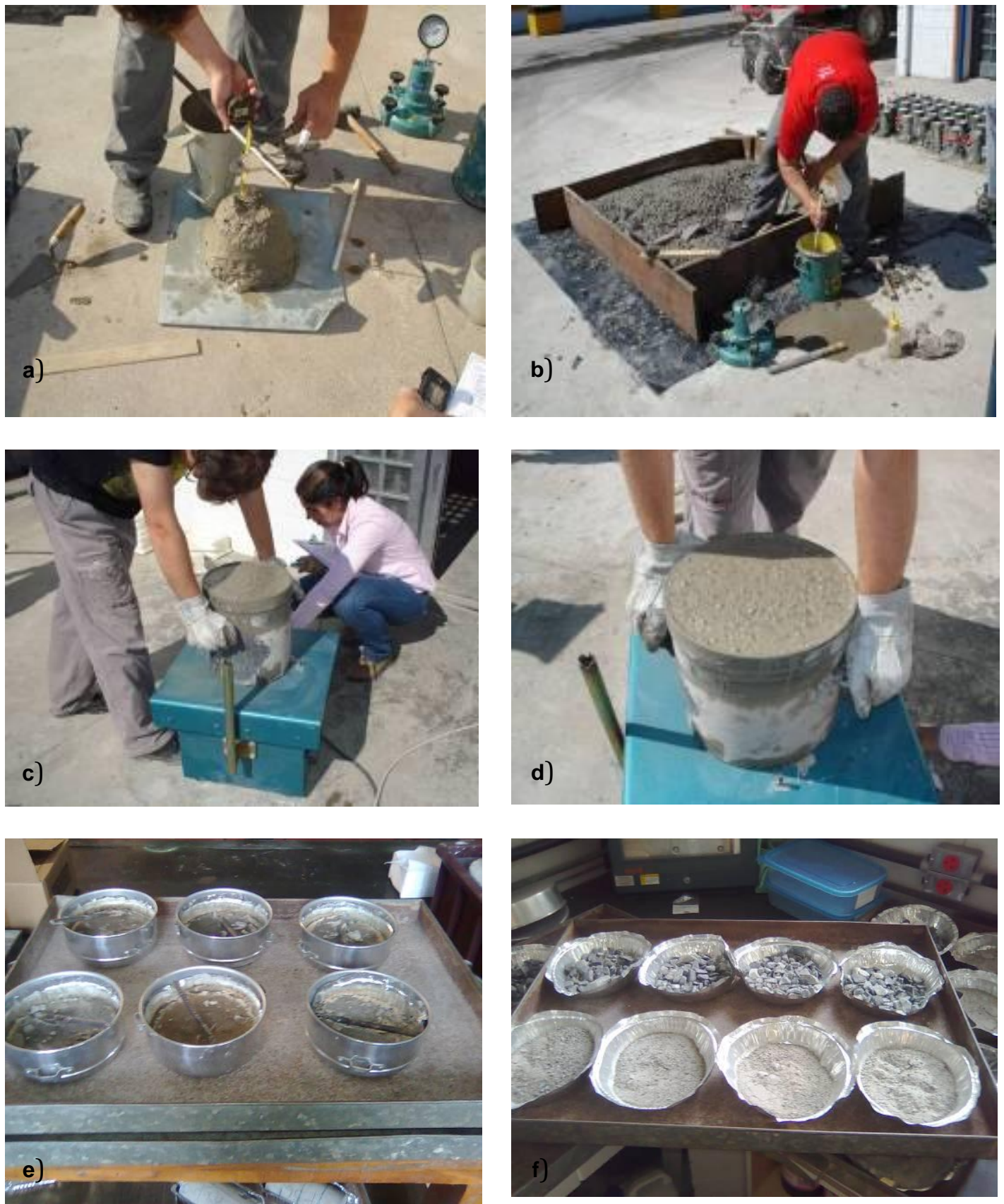

FIGURA 48 - Ensaios do concreto no estado fresco - a) abatimento, b) densidade de massa específica e teor de ar pressométrico, c e d) compactabilidade, e) e f) ensaio de umidade e de finos total $<75 \mu \mathrm{m}$ do concreto realizado no laboratório.

\subsubsection{Moldagem de corpos-de-prova e ensaios no concreto endurecido}

No ato da amostragem de cada caminhão, também foram moldados corpos-de-prova para ensaios no concreto endurecido, sendo realizado cada ensaio sempre com uma repetição.

Para avaliação do concreto endurecido, foram moldados corpos-de-prova, conforme a 
ABNT NBR 5738 (2003) e conforme ilustra a Figura 49, após as moldagens foram realizados os seguintes ensaios:

$\checkmark$ Ensaios com cura acelerada;

$\checkmark$ Ensaios com cura normal.
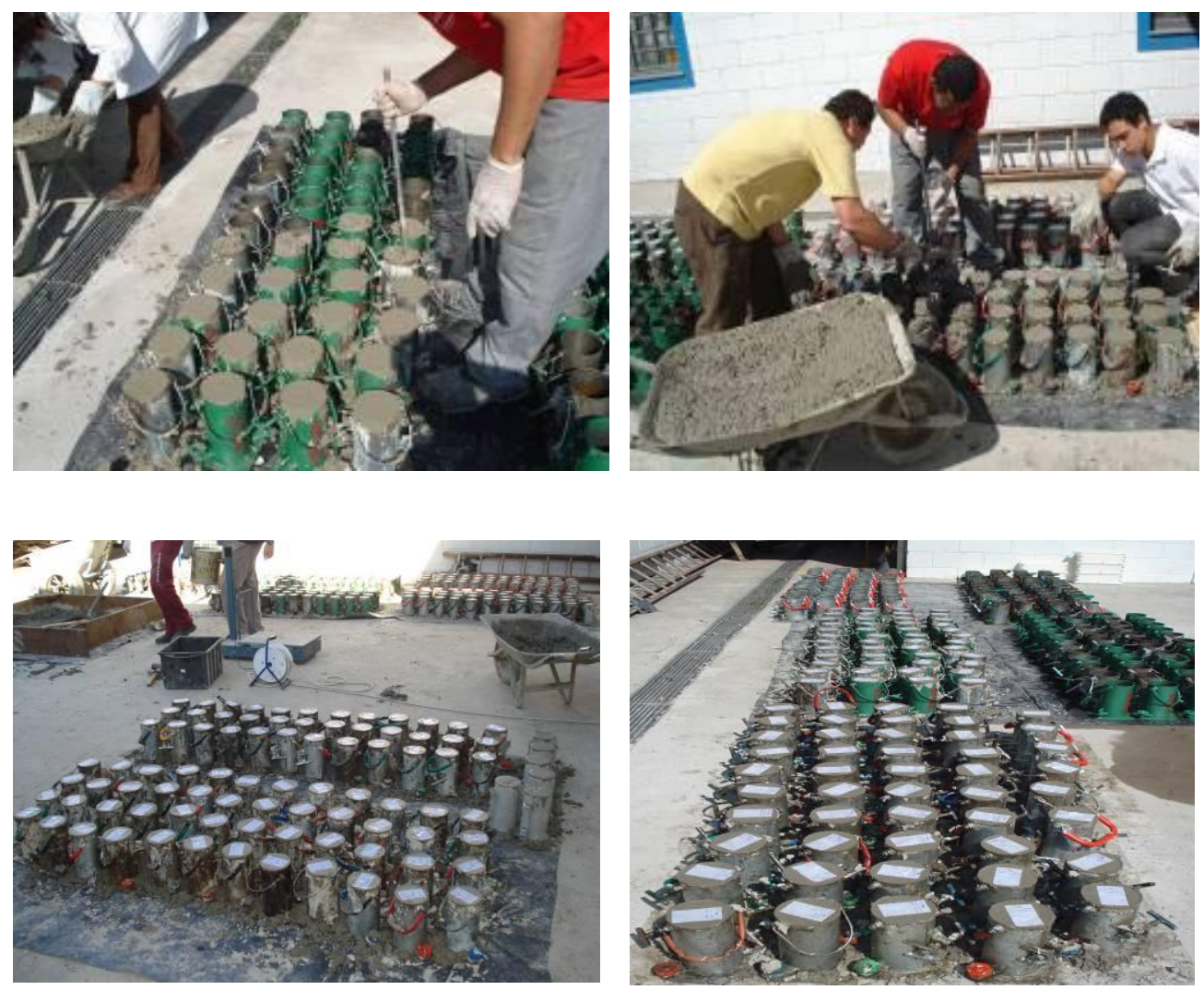

FIGURA 49 - Moldagem dos corpos-de-prova cilíndricos $10 \times 20 \mathrm{~cm}$, segundo a ABNT NBR 5738 (2003).

O fluxograma da Figura 50 apresenta um resumo desses ensaios. As propriedades de caracterização dos concretos podem ser agrupadas pelas idades de análise e respectivas condições de cura. 


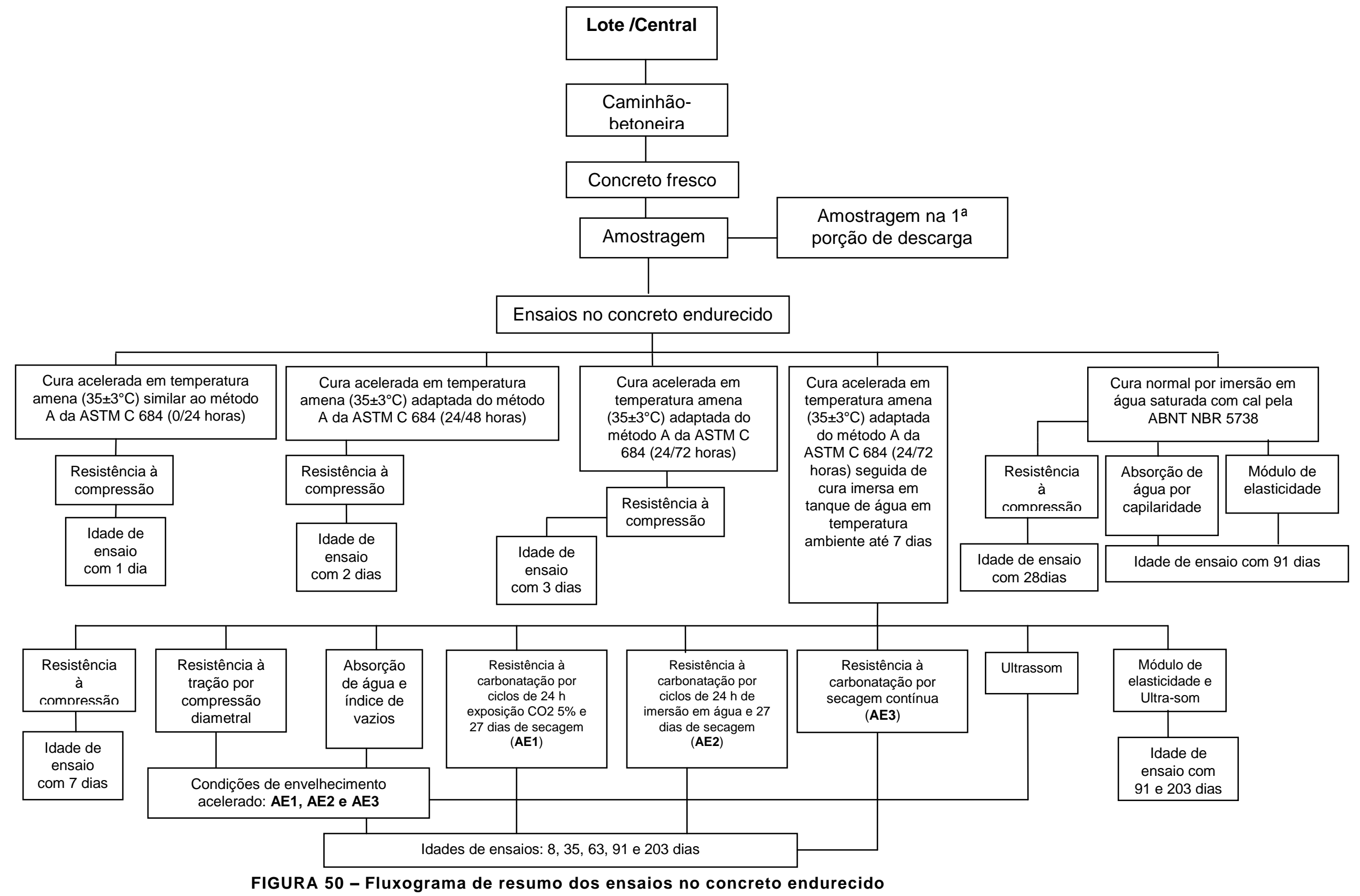


Cada propriedade e idade do concreto no estado endurecido foram caracterizadas por dois corpos-de-prova irmãos de cada caminhão-betoneira constituinte do lote. Os resultados serviram para avaliar as propriedades do concreto endurecido e para correlacionar os resultados dos ensaios físicos e mecânicos com as propriedades do concreto no estado fresco.

\subsubsection{Procedimentos de cura dos corpos-de-prova}

Conforme resumido pelo fluxograma da Figura 50, foram testados quatro tipos de cura por maturação acelerada, em temperatura amena, a partir do Método A da ASTM C 684 (1999) Standard Test Method Curing and Testing Concrete Compression Test Specimens. $O$ quinto procedimento foi o de cura convencional da ABNT NBR 5738 (2003).

A cura convencional dos corpos-de-prova, pela ABNT NBR 5738 (2003) foi por imersão total em tanque de água saturada de cal, de 1 dia de idade até 28 e 91 dias, quando foram então ensaiados.

A escolha pelo Método A da ASTM C 684 (1999) foi devida à temperatura amena de aquecimento da água, que não agride a estrutura interna do concreto, além de ser operacional e economicamente mais viável para utilização por empresas de controle tecnológico.

Nas curas aceleradas, a água do tanque (piscina) foi aquecida por meio de duas resistências elétricas e o controle de temperatura foi feito através de um termostato, conforme ilustra a Figura 51. 

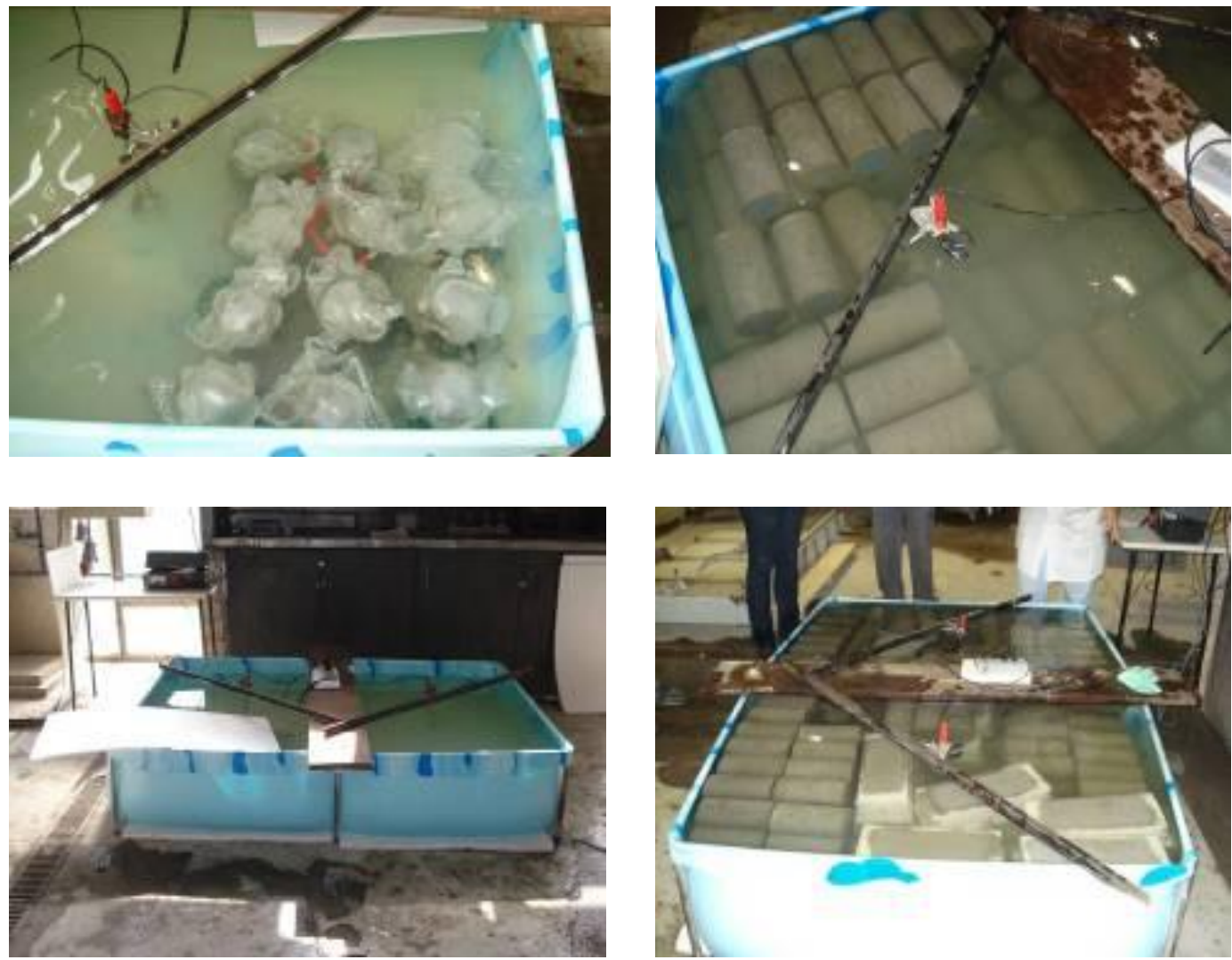

FIGURA 51 - Tanque de cura térmica no laboratório da EPUSP, com aquecimento de água por resistência elétrica e termostato a $(35 \pm 3)^{\circ} \mathrm{C}$, em analogia ao método $A$ da ASTM C 684:1999.

O primeiro procedimento de cura acelerada foi executado de forma o mais similar possível ao método A da ASTM C 684 (1999), e apenas aplicado para o ensaio de resistência à compressão simples a um dia ( $\left.f_{c 1 a c e l}\right)$. Desta forma, os corpos-de-prova foram colocados em cura acelerada logo que possível após moldagem e retirados dessa cura no dia seguinte, ou seja, em prazo nominal de 0/24 horas. Para este grupo, optou-se pelo transporte dos corpos-de-prova devidamente acomodados em caixas, no final da concretagem para o laboratório da EPUSP, sendo isto feito cerca de 2 a 3 horas após a moldagem. A opção de transportá-los ao laboratório da EPUSP foi feita devido à falta de condições para instalação do tanque de cura térmica na central de concreto.

O segundo, terceiro e quarto procedimentos de cura térmica aqui testados foram propositadamente defasados em relação ao período de cura do Método A da ASTM C 684 (1999). Mas os corpos-de-prova foram todos imersos em água aquecida a temperatura nominal de $(35 \pm 3)^{\circ} \mathrm{C}$, variando-se o tempo de exposição a essa temperatura. Assim, a cura acelerada foi iniciada no dia seguinte da moldagem, sendo que até um dia em média, os corpos-de-prova foram mantidos nas fôrmas no pátio aberto da central, apenas com a proteção por uma lona plástica, e o transporte para o laboratório da EPUSP foi realizado em 
prazo de $20 \pm 4$ h das moldagens.

No segundo procedimento acelerado, os corpos-de-prova, após o período de cura térmica entre 24 e 48 horas, foram ensaiados à compressão simples a 2 dias ( $\left.f_{\text {c2acel. }}\right)$. No terceiro procedimento acelerado, os corpos-de-prova, após o período de cura térmica entre 24 e 72 horas, foram ensaiados à compressão simples a 3 dias $\left(f_{\text {c3acel. }}\right)$. No quarto procedimento acelerado, os corpos-de-prova, após o período de cura térmica entre 24 e 72 horas, permaneceram ainda em água a temperatura ambiente até 7 dias de idade e prosseguiram para os devidos ensaios, conforme a Figura 50. A razão de se estender o prazo de cura até 7 dias se deu como uma forma de compensar o retardo de 24 horas no início da cura térmica.

Ressalta-se que as identificações mais adiante de 0/24; 24/48 e 24/72 horas são prazos nominais e que foram períodos médios equivalentes a 0/1 dia, 1/2 dias e 1/3 dias.

Cabe observar ainda, que se considerou este estudo exploratório quanto à aceleração da maturidade do concreto e pesquisas a respeito devem prosseguir em outros trabalhos, pois seria recomendável uma tolerância inferior a 30 minutos, no atendimento dos prazos nominais citados, e isto aqui não foi possível.

\subsubsection{Condições de envelhecimento acelerado dos corpos-de-prova}

Após a realização da cura por maturação acelerada de $1 / 3$ dias e em temperatura ambiente até 7 dias, os corpos-de-prova foram separados e encaminhados para três diferentes condições de envelhecimento acelerado, como ilustrada na Figura 50 e a seguir explicado:

$\checkmark$ AE1 - ambiente de exposicão 1 ou CO2 - os corpos-de-prova foram submetidos a ciclos de 24 horas de exposição em câmara de carbonatação, com pressão de $(5 \pm 0,5) \%$ de $\mathrm{CO}_{2}$, (Figura 52-a), temperatura de $(23 \pm 3)^{\circ} \mathrm{C} \mathrm{e}$ umidade relativa de $(75 \pm 5) \%$ UR e 27 dias de secagem em estufa ventilada a $(40 \pm 1)^{\circ} \mathrm{C}$, sendo esta ciclagem iniciada a partir dos 7 dias de idade dos corpos-de-prova com cura acelerada;

$\checkmark$ AE2 - ambiente de exposição 2 ou H2O - os corpos-de-prova foram submetidos a ciclos de 24 horas de imersão em água a $(20 \pm 5)^{\circ} \mathrm{C}$ e 27 dias de secagem em estufa ventilada a $(40 \pm 1)^{\circ} \mathrm{C}$, sendo esta ciclagem iniciada a partir dos 7 dias de idade dos corpos-de-prova com cura acelerada;

$\checkmark$ AE3 - ambiente de exposicão 3 ou SEC - os corpos-de-prova foram 
submetidos a secagem contínua em estufa ventilada a $(40 \pm 1)^{\circ} \mathrm{C}$, (Figura 52 b) iniciada a partir dos 7 dias de idade dos corpos-de-prova com cura acelerada.
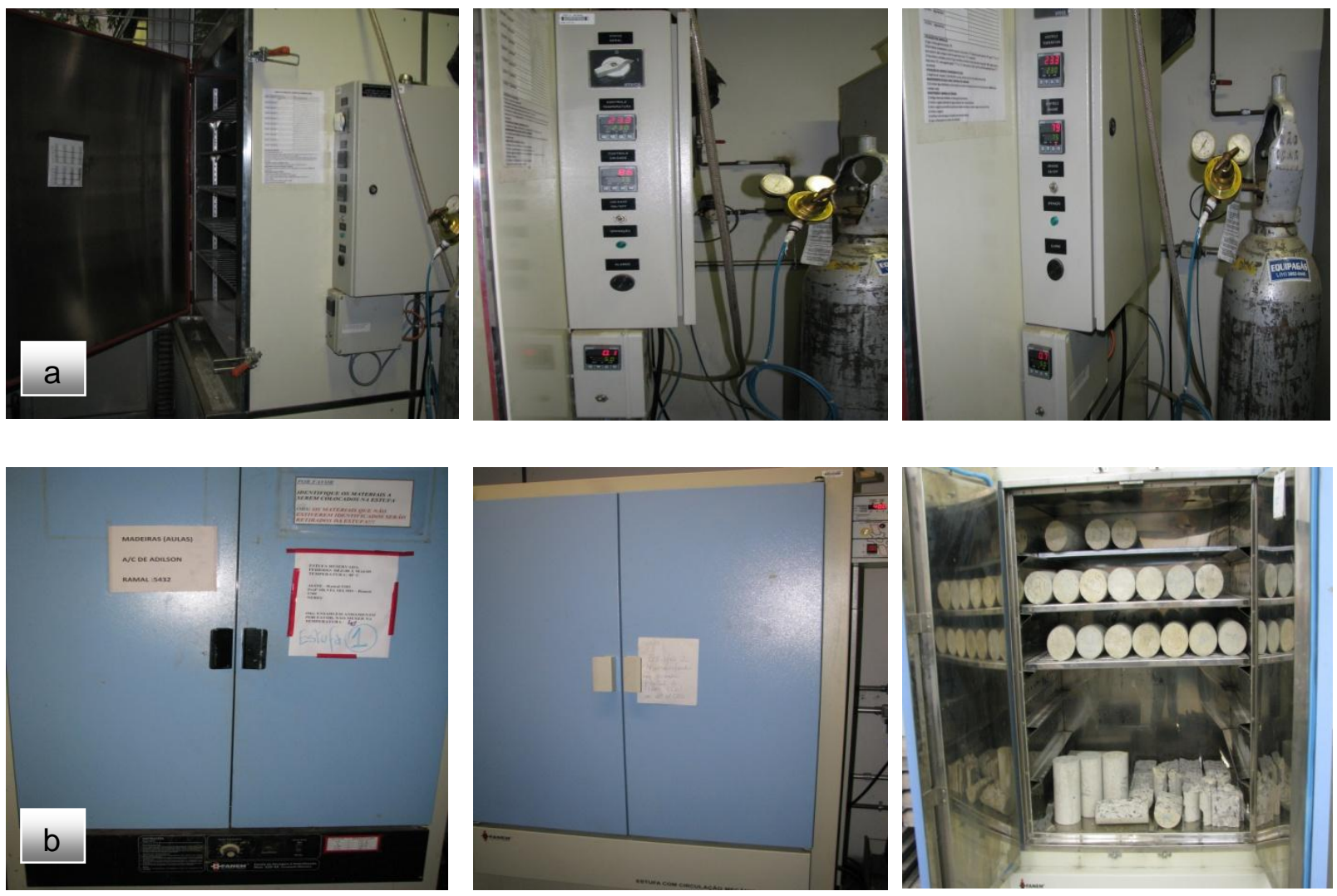

FIGURA 52 - (a) Câmara de carbonatação acelerada e (b) estufas ventiladas para condição de secagem alternada (AE1 e AE2) e contínua (AE3).

Os itens 3.3.5 C1 a 3.3.5 C3 detalham os ciclos doa ambientes AE1, AE2 e AE3, em função do número de repetições e da idade dos corpos-de-prova.

\subsubsection{Ensaios no concreto endurecido}

De forma resumida, as propriedades de caracterização dos concretos podem ser agrupadas pelas idades de análise, respectivas condições de cura ou exposição e tipo de ensaios, a saber:

$\checkmark$ Ensaios de predição da resistência à carbonatação acelerada, por exposição aos ambientes $A E 1, A E 2$ ou $A E 3$, conforme item 3.3.4; 
$\checkmark$ Ensaios físicos e mecânicos complementares nos mesmos ou em outros corpos-de-prova;

$\checkmark$ Ensaios físicos e mecânicos complementares em corpos-de-prova de referência.

\section{A) Ensaios de compressão simples, tração por compressão diametral, módulo de elasticidade e ultrassom}

As propriedades mecânicas estudadas foram a resistência à compressão axial, tração por compressão diametral nas idades e condições de cura conforme a Figura 50 e a Tabela 22 a seguir. Para alguns corpos-de-prova foram ainda medidos o módulo de elasticidade e ultrassom.

TABELA 22 - Ensaios mecânicos realizados para o lote amostrado.

\begin{tabular}{|c|c|c|c|c|c|c|c|c|}
\hline Tipos de Cura & $\begin{array}{l}\text { Condição de } \\
\text { envelhecimento } \\
\text { acelerado }\end{array}$ & $\begin{array}{l}\text { Idade de } \\
\text { ensaio }\end{array}$ & $\begin{array}{l}\text { Propriedades } \\
\text { analisadas }\end{array}$ & 空 & $\begin{array}{l}\text { Método de } \\
\text { ensaio }\end{array}$ & 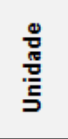 & $\begin{array}{l}\mathrm{N}^{\circ} \text { de corpos- } \\
\text { de-prova por } \\
\text { idade e cura }\end{array}$ & $\begin{array}{l}\mathrm{N}^{\circ} \text { total de } \\
\text { corpos-de- } \\
\text { prova por } \\
\text { caminhão }\end{array}$ \\
\hline $\begin{array}{c}\text { Cura acelerada de } 0 / 24 \mathrm{~h} \\
\text { a } 35 \pm 3^{\circ} \mathrm{C} \text { (mais similar } \\
\text { ao método A da ASTM C } \\
684: 1999 \text { ) }\end{array}$ & - & 1 dia & $\begin{array}{l}\text { Resistência à } \\
\text { compressão }\end{array}$ & $f_{\text {clacel. }}$ & $\begin{array}{l}\text { ABNT NBR } \\
5739(2007)\end{array}$ & $\mathrm{MPa}$ & 2 & 2 \\
\hline $\begin{array}{c}\text { Cura acelerada de } 24 / 48 \\
\text { h a } 35 \pm 3^{\circ} \mathrm{C} \text { (adaptada } \\
\text { do método A da ASTM C } \\
684: 1999 \text { ) }\end{array}$ & - & 2 dias & $\begin{array}{l}\text { Resistência à } \\
\text { compressão. }\end{array}$ & $f_{c 2 a c e l}$ & $\begin{array}{l}\text { ABNT NBR } \\
5739(2007)\end{array}$ & $\mathrm{MPa}$ & 2 & 2 \\
\hline $\begin{array}{c}\text { Cura acelerada de } 24 / 72 \\
\text { h a } 35 \pm 3^{\circ} \mathrm{C} \text { (adaptada } \\
\text { do método A da ASTM C } \\
684: 1999 \text { ) }\end{array}$ & - & 3 dias & $\begin{array}{l}\text { Resistência à } \\
\text { compressão. }\end{array}$ & 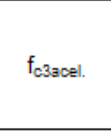 & $\begin{array}{l}\text { ABNT NBR } \\
5739(2007)\end{array}$ & $\mathrm{MPa}$ & 2 & 2 \\
\hline \multirow{4}{*}{$\begin{array}{c}\text { Cura acelerada de } 24 / 72 \\
\text { h a } 35 \pm 3^{\circ} \mathrm{C} \text { (adaptada } \\
\text { do método A da ASTM C } \\
684: 1999 \text { ) seguida de } \\
\text { cura submersa em água } \\
\text { até } 7 \text { dias. }\end{array}$} & - & 7 dias & $\begin{array}{l}\text { Resistência à } \\
\text { compressão }\end{array}$ & $f_{c 7 a c e l}$. & $\begin{array}{l}\text { ABNT NBR } \\
5739(2007)\end{array}$ & $\mathrm{MPa}$ & 2 & 2 \\
\hline & $\begin{array}{c}\mathrm{AE} 1-\mathrm{CO} 2 ; \mathrm{AE} 2-\mathrm{H} 2 \mathrm{O} ; \\
\mathrm{AE} 3-\mathrm{SEC}\end{array}$ & $\begin{array}{c}8,35,63,91 \\
\text { e } 203 \text { dias }\end{array}$ & $\begin{array}{c}\text { Resistência à tração } \\
\text { por compressão } \\
\text { diametral }\end{array}$ & $\begin{array}{l}f_{\text {ct, sp idade }} \\
\text { exposiçăa }\end{array}$ & $\begin{array}{l}\text { ABNT NBR } \\
7222(1994)\end{array}$ & $\mathrm{MPa}$ & 2 & $12^{*}$ \\
\hline & $\begin{array}{c}\mathrm{AE} 1 \text { - } \mathrm{CO} 2 ; \mathrm{AE} 2-\mathrm{H} 2 \mathrm{O} ; \\
\mathrm{AE} 3-\mathrm{SEC}\end{array}$ & $\begin{array}{c}8,35,63,91 \\
203 \text { dias }\end{array}$ & Ultrassom & US & $\begin{array}{l}\text { ABNT NBR } \\
8802(1994)\end{array}$ & $\mathrm{m} / \mathrm{s}$ & 2 & $12^{*}$ \\
\hline & $\begin{array}{c}\mathrm{AE} 1-\mathrm{CO} 2 ; \mathrm{AE} 2-\mathrm{H} 2 \mathrm{O} \\
\mathrm{AE} 3-\mathrm{SEC}\end{array}$ & 91 e 203 dias & $\begin{array}{l}\text { Resistência à } \\
\text { compressão, módulo } \\
\text { de elasticidade. }\end{array}$ & $f_{c} / E$ & $\begin{array}{l}\text { ABNT NBR } \\
5739(2007) \\
\text { ABNT NBR } \\
8522(2008)\end{array}$ & $\begin{array}{r}\mathrm{Mpa} / \\
\mathrm{GPa}\end{array}$ & 2 & $6^{*}$ \\
\hline \multirow{2}{*}{$\begin{array}{l}\text { Cura normal imersa em } \\
\text { água saturada de cal }\end{array}$} & - & 28,91 dias & $\begin{array}{c}\text { Resistência à } \\
\text { compressão }\end{array}$ & $\mathrm{f}_{\mathrm{c} 28 \mathrm{n}} / \mathrm{f}_{\mathrm{c} 91 \mathrm{n}}$ & $\begin{array}{l}\text { NBR } 5739 \\
(2007) \\
\end{array}$ & $\mathrm{MPa}$ & 2 & 4 \\
\hline & - & 91 dias & $\begin{array}{l}\text { Módulo de } \\
\text { elasticidade }\end{array}$ & $E$ & $\begin{array}{l}\text { ABNT NBR } \\
8522(2008)\end{array}$ & $\mathrm{GPa}$ & 2 & 2 \\
\hline
\end{tabular}

*Dois corpos-de-prova de cada caminhão prosseguiram em ciclagem após 203 dias, para análise futura, em conjunto com outros grupos submetidos a envelhecimento natural após 91 dias, mas não analisados nesta dissertação. 


\section{A.1) Ensaios de ultrassom}

O ultrassom, por ser um método de ensaio não destrutivo, tornou-se uma importante técnica de avaliação de materiais pela Engenharia, seja em pesquisas de laboratório ou para inspeção de estruturas e peças em serviço. Pode monitorar e estimar propriedades físicas e mecânicas dos mais diversos materiais, utilizando modelos experimentais que as relacionam com a velocidade de propagação das ondas, já que essas são sensíveis à densidade de massa e à umidade presente no meio em análise, entre outras variáveis.

Conhecendo-se a distância (L) entre transdutores emissor e receptor de onda ultrassônica e medindo-se o tempo (t) transcorrido para esse percurso, calcula-se a velocidade de propagação do ultrassom no concreto como $\mathrm{Vc}_{\mathrm{c}}=\mathrm{L} / \mathrm{t}$.

Nesta pesquisa, o objetivo de uso da técnica foi avaliar a sua capacidade em detectar as mudanças da estrutura física superficial do concreto em estudo, em decorrência dos três tipos de envelhecimento acelerado para a carbonatação e a que foram submetidos os corpos-de-prova cilíndricos moldados e curados segundo o item 3.3.2. Em cada corpo-deprova, as medidas de transmissão direta do ultrassom foram feitas através de um dispositivo que permitiu padronizar e diferenciar as quatro leituras periféricas (1 a 4) em relação à central (5), como ilustra a Figura 53.

As leituras foram feitas com equipamento modelo PUNDIT - Portable Ultrasonic Nondestructive Digital Indicanting Tester, fabricado pela CNS (atualmente CNS Farnell Ltda. PROCEQ), com resolução de 0,1 segundos, trandutores de diâmetro nominal de $20 \mathrm{~mm}$ e freqüência de operação na faixa de $200 \mathrm{kHz}$. O contato entre o corpo-de-prova e os trandutores do equipamento foi feito com álcool em gel. Com os dados destas leituras, estimou-se o módulo de elasticidade dinâmico dos concretos, através da fómula simplificada a seguir, descrita em Kolmos et al. ${ }^{40}$ (1996):

$$
\boldsymbol{E}=\boldsymbol{d} \cdot \boldsymbol{v}^{\mathbf{2}} \cdot \mathbf{0 , 9} \quad \text { EQUAÇÃO } 20
$$

Onde:

$\mathrm{E}=$ Módulo de elasticidade dinâmico, em $\mathrm{MN} / \mathrm{m}^{2}$;

$\mathrm{d}=$ densidade do concreto, em $\mathrm{kg} / \mathrm{m}^{3}$;

$\mathrm{v}=$ velocidade do ultrassom, em $\mathrm{km} / \mathrm{s}$.

40 KOMLOS, K.; POPOVICS, S.; NÜRNBERGEROVÁ, T.; BABÁL, B.; POPOVICS, J.S. Ultrasonic pulse velocity testo $f$ concrete properties as specified in various Standards. Cement and Concrete Composites. n.18, p. 357364, 1996. 
Os ensaios de ultrassom foram feitos para os seguintes ciclos de envelhecimento acelerado: 0, 1, 2, 3, 4, 5, 6 e 8, em um grupo de corpos-de-prova com cura similar a todos os demais, ou seja, permaneceram em cura acelerada de $24 / 72 \mathrm{~h}$ em tanque de água a temperatura de $35 \pm 3^{\circ} \mathrm{C}$ seguida de cura submersa em água temperatura ambiente até 7 dias e na sequência ocorreu a exposição às três condições de envelhecimento acelerado.

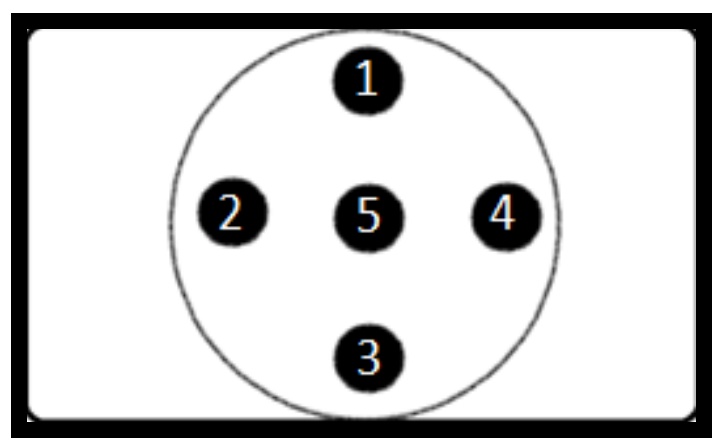

FIGURA 53 - Modelo do gabarito de madeira utilizado no posicionamento dos sensores do equipamento em 5 pontos de cada corpo-de-prova cilíndrico, mantida uma geratriz de referência para a ordenação dos pontos e topos.

\section{B) Ensaios indicadores de porosidade}

As propriedades físicas estudadas foram a absorção de água por capilaridade, absorção de água por imersão e índice de vazios, com cura acelerada e imersão em água até 7 dias e cura normal por imersão em água saturada de cal, conforme a Tabela 23.

TABELA 23 - Ensaios físicos realizados para o lote amostrado.

\begin{tabular}{|c|c|c|c|c|c|c|c|c|}
\hline Tipos de Cura & $\begin{array}{l}\text { Condições de } \\
\text { envelhecimento } \\
\text { acelerado }\end{array}$ & $\begin{array}{l}\text { Idade de } \\
\text { ensaio }\end{array}$ & $\begin{array}{l}\text { Propriedades } \\
\text { analisadas }\end{array}$ & 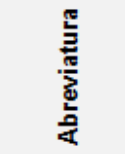 & $\begin{array}{l}\text { Método de } \\
\text { ensaio }\end{array}$ & $\begin{array}{l}\frac{\mathscr{7}}{\pi} \\
\frac{\pi}{50} \\
5\end{array}$ & $\begin{array}{c}\mathrm{N}^{\circ} \text { de corpos- } \\
\text { de-prova por } \\
\text { idade, cura e } \\
\text { ciclagem }\end{array}$ & $\begin{array}{l}\mathrm{N}^{\circ} \text { total de } \\
\text { corpos-de- } \\
\text { prova por } \\
\text { caminhão }\end{array}$ \\
\hline \multirow{5}{*}{$\begin{array}{c}\text { Cura acelerada de } \\
24 / 72 \mathrm{~h} \text { a } 35 \pm 3^{\circ} \mathrm{C} \\
\text { (adaptada do método } \\
\text { A da ASTM C } \\
\text { 684:1999) seguida de } \\
\text { cura submersa em } \\
\text { água até } 7 \text { dias }\end{array}$} & \multirow{5}{*}{$\begin{array}{l}\mathrm{AE} 1 \text { - } \mathrm{CO} 2 \\
\mathrm{AE} 2-\mathrm{H} 2 \mathrm{O} \\
\mathrm{AE} 3-\mathrm{SEC}^{\star}\end{array}$} & 8 dias & \multirow{5}{*}{$\begin{array}{l}\text { Absorção de água } \\
\text { e indice de vazios }\end{array}$} & $\begin{array}{l}\mathrm{ABS} / \mathrm{IV} \\
\mathrm{AE}^{\star \star} 8\end{array}$ & \multirow{5}{*}{$\begin{array}{l}\text { ABNT NBR } \\
9778(2005)\end{array}$} & \multirow{5}{*}{$\%$} & 2 & 4 \\
\hline & & 35 dias & & $\begin{array}{l}\mathrm{ABS} / \mathrm{IV} \\
\mathrm{AE}^{* \star} 35\end{array}$ & & & 2 & 4 \\
\hline & & 63 dias & & $\begin{array}{l}\mathrm{ABS} / \mathrm{IV} \\
\mathrm{AE}^{\star \star} 63\end{array}$ & & & 2 & 4 \\
\hline & & 91 dias & & $\begin{array}{l}\mathrm{ABS} / \mathrm{IV} \\
\mathrm{AE}^{\star \star} 91\end{array}$ & & & 2 & 6 \\
\hline & & 203 dias & & $\begin{array}{l}\mathrm{ABS} / \mathrm{IV} \\
\mathrm{AE}^{\star \star} 203\end{array}$ & & & 2 & 6 \\
\hline $\begin{array}{l}\text { Cura úmida normal } \\
\text { por imersão em água } \\
\text { saturada de cal }\end{array}$ & - & 91 dias & $\begin{array}{l}\text { Absorção de água } \\
\text { por capilaridade }\end{array}$ & $\begin{array}{c}\text { abs } \\
\text { cap91 }\end{array}$ & $\begin{array}{l}\text { ABNT NBR } \\
9779 \text { (1995) }\end{array}$ & $\mathrm{g} / \mathrm{cm}^{2}$ & 2 & 2 \\
\hline
\end{tabular}


* Para ambiente AE3, as idades destes ensaios foram apenas a 91 e 203 dias.

** Sigla do ambiente de exposição (CO2, H2O ou SEC).

\section{C) Ensaios acelerados quanto à profundidade de carbonatação}

A avaliação da resistência à carbonatação foi realizada nas idades de 8, 35, 63, 91 e 203 dias de idade, dos concretos maturados pelo procedimento de cura acelerada adaptado através do método A da ASTM C 684 (1999) e três tipos de condições de envelhecimento natural conforme descrito no item 3.3.4 e Tabela 24.

TABELA 24 - Ensaios acelerados de carbonatação para o lote amostrado.

\begin{tabular}{|c|c|c|c|c|c|c|c|}
\hline Tipos de Cura & $\begin{array}{l}\text { Condições de } \\
\text { envelhecimento } \\
\text { acelerado }\end{array}$ & $\begin{array}{l}\text { Idade de } \\
\text { ensaio }\end{array}$ & $\begin{array}{l}\text { Propriedade } \\
\text { analisada }\end{array}$ & 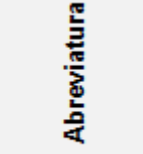 & Unidade & $\begin{array}{l}\mathrm{N}^{\circ} \text { de corpos- } \\
\text { de-prova por } \\
\text { idade e cura }\end{array}$ & $\begin{array}{l}\mathrm{N}^{\circ} \text { total de } \\
\text { corpos-de- } \\
\text { prova por } \\
\text { caminhão* }\end{array}$ \\
\hline \multirow{5}{*}{$\begin{array}{c}\text { Cura acelerada de } \\
24 / 72 \mathrm{~h} \text { a } 35 \pm 3^{\circ} \mathrm{C} \\
\text { (adaptada do } \\
\text { método A da ASTM } \\
\mathrm{C} 684: 1999 \text { ) } \\
\text { seguida de cura } \\
\text { imersa em água até } \\
7 \text { dias. }\end{array}$} & \multirow{5}{*}{$\begin{array}{l}\mathrm{AE} 1 \text { - } \mathrm{CO} 2 \\
\mathrm{AE} 2 \text { - } \mathrm{H} 2 \mathrm{O} \\
\mathrm{AE} 3 \text { - SEC }\end{array}$} & 8 dias & \multirow{5}{*}{$\begin{array}{l}\text { Profundidade de } \\
\text { carbonataçãa }\end{array}$} & $\begin{array}{l}\text { Carb, } 8 \\
\text { amb exp }{ }^{\star \star}\end{array}$ & \multirow{5}{*}{$\mathrm{mm}$} & 2 & 6 \\
\hline & & 35 dias & & $\begin{array}{l}\text { Carb, } 35 \\
\text { amb exp }{ }^{\star *}\end{array}$ & & 2 & 6 \\
\hline & & 63 dias & & $\begin{array}{l}\text { Carb, } 63 \\
\text { amb exp }{ }^{* *}\end{array}$ & & 2 & 6 \\
\hline & & 91 dias & & $\begin{array}{l}\text { Carb, } 91 \\
\text { amb exp }{ }^{* \star}\end{array}$ & & 2 & 6 \\
\hline & & 203 dias & & $\begin{array}{l}\text { Carb, } 203 \\
\text { amb exp }{ }^{\star \star}\end{array}$ & & 2 & 6 \\
\hline
\end{tabular}

* Alguns cp's de cada caminhão e ambiente de exposição seguiram em ciclagem para análise futura.

** Sigla do ambiente de exposição (CO2, H2O ou SEC).

\section{C.1) Ensaios acelerados de resistência à carbonatação por exposição em câmara de $\mathrm{CO}_{2}$ alternada com secagem (AE1)}

Os ensaios de resistência à carbonatação por exposição a $\mathrm{CO}_{2}$ sob pressão foram realizados com duração de 24 horas em câmara automática da BASS (Figura 52a), conforme fluxograma da Figura 54 e Tabela 25 para as seguintes condições de operação:

$\checkmark$ Pressão nominal de $(5 \pm 0,5) \%$ de $\mathrm{CO}_{2}$;

$\checkmark$ Umidade relativa de $(75 \pm 5,0) \%$, com limites registrados durante os ensaios;

$\checkmark$ Temperatura de $(23 \pm 3)^{\circ} \mathrm{C}$, com limites registrados durante os ensaios.

A cada 24 horas de exposição ao $\mathrm{CO}_{2}$ sob pressão seguiam-se mais 27 dias de secagem forçada em estufa ventilada da FANEM a $(40 \pm 1)^{\circ} \mathrm{C}$ conforme Figura $52 \mathrm{~b}$. 


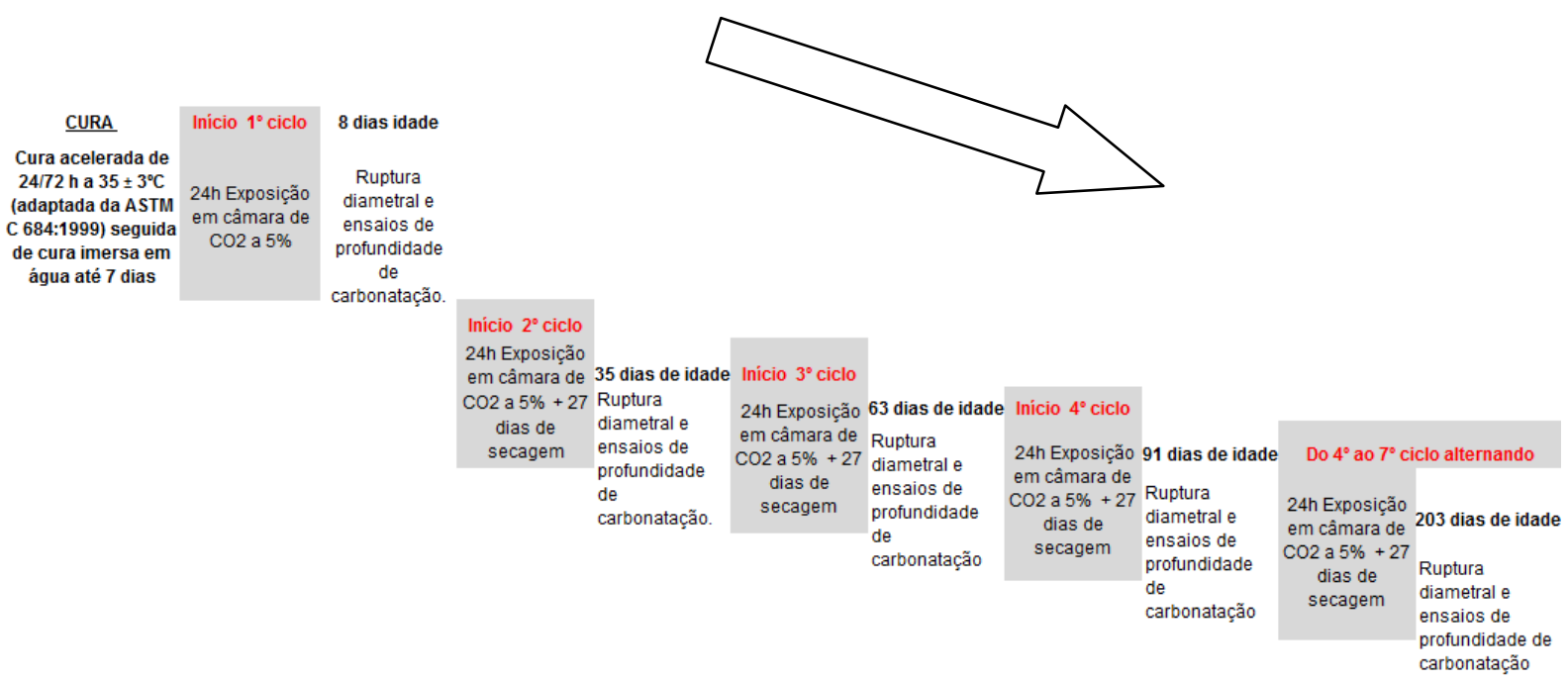

FIGURA 54 - Progressão dos ciclos de envelhecimento acelerado tipo AE1 e respectiva idade de análise dos corpos-de-prova.

TABELA 25 - Etapas do ensaio 24h exposição em câmara de carbonatação e 27 dias de secagem, para cada data de ensaio dos concretos com maturação acelerada.

\begin{tabular}{|c|c|c|c|}
\hline Cura & Etapa & Duração & Condicionamento \\
\hline $\begin{array}{l}\text { Exposição de } 0 / 24 \mathrm{~h} \text { - } \\
\text { em campo; cura } \\
\text { acelerada de } 24 / 72 \text { hs a }\end{array}$ & $\begin{array}{l}\mathrm{CO} 2 \text { sob } \\
\text { pressão }\end{array}$ & 24 horas & $\begin{array}{l}\text { Câmara de carbonatação, com (5 } \\
\pm 0,5) \% \text { de } \mathrm{CO}_{2} \text {, temperatura de } \\
(23 \pm 3)^{\circ} \mathrm{C} \text { e umidade relativa de } \\
(75 \pm 5) \% \text { UR. }\end{array}$ \\
\hline a temperatura ambiente. & Secagem & 27 dias & $\begin{array}{l}\text { Secagem em estufa ventilada a } \\
\qquad(40 \pm 1)^{\circ} \mathrm{C}\end{array}$ \\
\hline
\end{tabular}

C.2) Ensaios acelerados de resistência à carbonatação por ciclagem de $24 \mathrm{~h}$ de imersão em tanque de água alternada com secagem (AE2).

Os ensaios de carbonatação por ciclagem de secagem alternada com 24 horas em tanque de água foram realizados nas seguintes condições de operação, conforme fluxograma da Figura 55 e Tabela 26:

$\checkmark$ Água a $(20 \pm 5)^{\circ} \mathrm{C}$;

$\checkmark$ Estufa ventilada da marca Fanem a $(40 \pm 1)^{\circ} \mathrm{C}$.

A condição de ciclagem por 24 horas de imersão em água seguida por 27 dias de secagem dos corpos-de-prova consistiu em dispor os corpos-de-prova totalmente imersos em água por 24 horas e posteriormente por 27 dias em estufa ventilada da Figura 52b, 
mantendo a sua temperatura em $40 \pm 1^{\circ} \mathrm{C}$, controlando a sua massa semanalmente.

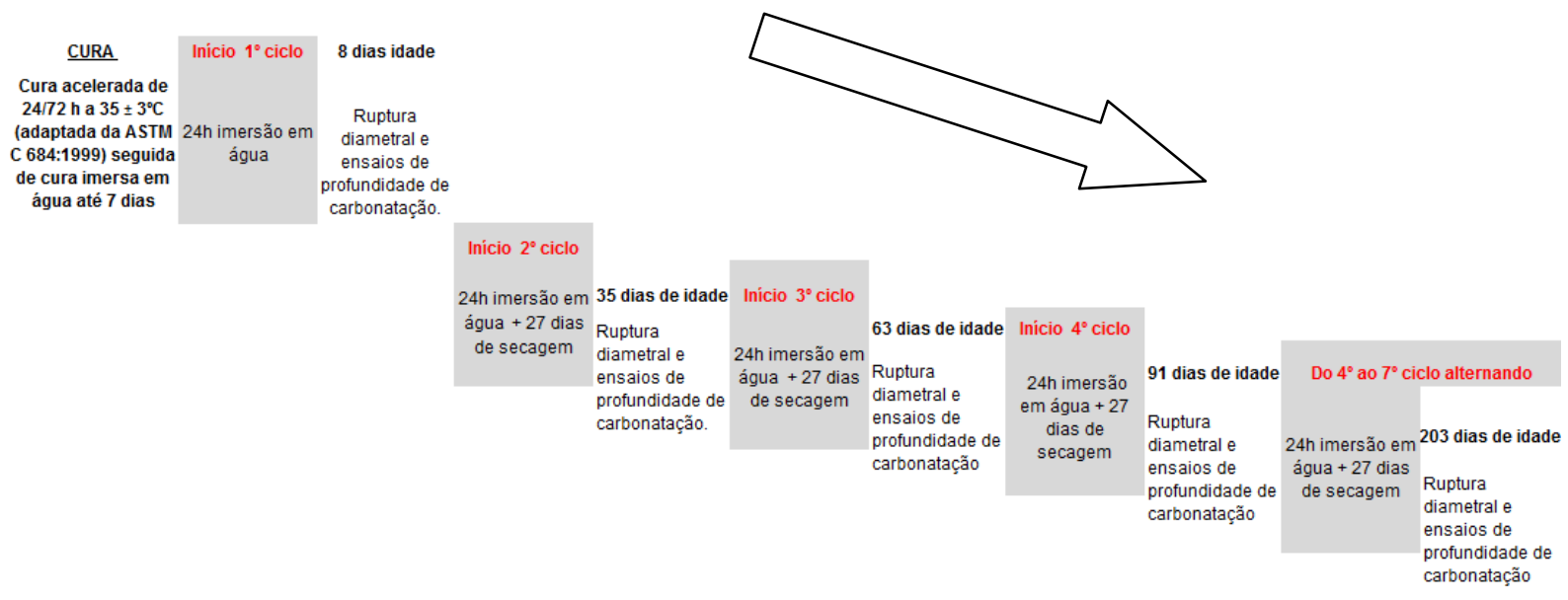

FIGURA 55 - Prograssão dos ciclos de envelhecimento acelerado tipo AE2 e respectiva idade de análise dos corpos-de-prova.

TABELA 26 - Etapas do ensaio acelerado por ciclagem, para cada data de ensaio dos concretos com maturação acelerada.

\begin{tabular}{lccc}
\hline Cura & Etapa & Duração & Condicionamento \\
\hline & & & \\
Exposição de $0 / 24 \mathrm{~h}-$ & Imersão em & 24 horas & Imersão em tanque de água a $(20 \pm 5)^{\circ} \mathrm{C}$. \\
em campo; cura & $\begin{array}{c}\text { Inque de água } \\
\text { acelerada de } 24 / 72 \mathrm{hs} \text { a } \\
35 \pm 3^{\circ} \mathrm{C} \text { e de } 72 \mathrm{~h} / 7 \\
\text { dias em cura imersa no } \\
\text { mesmo tanque a }\end{array}$ \\
$\begin{array}{c}\text { temperatura ambiente. } \\
\end{array}$ & Secagem & 27 dias & Secagem em estufa ventilada a $(40 \pm 1)^{\circ} \mathrm{C}$. \\
\end{tabular}

\section{C.3) Ensaios acelerados de resistência à carbonatação por secagem contínua} (AE3).

Os ensaios de carbonatação por secagem contínua foram realizados nas seguintes condições de operação e conforme a Tabela 27.

$\checkmark$ Estufa ventilada da marca Fanem a $(40 \pm 1)^{\circ} \mathrm{C}$, da Figura $52 \mathrm{~b}$, com exposição contínua, até as respectivas datas de pesagem ou ensaio.

Assim, a condição de secagem contínua dos corpos-de-prova consistiu em dispor os mesmos em estufa ventilada e manter a sua temperatura em $40 \pm 1^{\circ} \mathrm{C}$ por ciclos de 28 dias, controlando a sua massa a cada sete ou 28 dias, conforme evoluiu a idade dos concretos. 
TABELA 27 - Etapas do ensaio acelerado por ciclagem, para cada data de ensaio dos concretos com maturação acelerada.

\begin{tabular}{cccc}
\hline Cura & Etapa & Duração & Condicionamento \\
\hline $\begin{array}{c}\text { Exposição de } 0 / 24 \mathrm{~h} \text { - } \\
\text { em campo; cura }\end{array}$ & $\begin{array}{c}\text { Secagem } \\
\text { Contínua }\end{array}$ & 28 dias & $\begin{array}{c}\text { Secagem em estufa ventilada a } \\
(40 \pm 1)^{\circ} \mathrm{C} .\end{array}$ \\
$35 \pm 3^{\circ} \mathrm{C}$ e de $24 / 72 \mathrm{~h} / 7$ & & \\
dias em cura imersa no & & & \\
mesmo tanque a & & & \\
temperatura ambiente. & & & \\
\hline
\end{tabular}

\section{D) Métodos de medidas de profundidade de carbonatação}

Após completar o ciclo, nas datas de ensaio, conforme subitens C.1 a C.3 precedentes, os corpos-de-prova com dimensões de $10 \mathrm{~cm} \times 20 \mathrm{~cm}$ foram rompidos diametralmente e uma metade foi destinada à medida de carbonatação e a outra à medida de absorção de água por imersão e índice de vazios.

A solução de timolftaleína foi utilizada nas primeiras idades, sendo excluída a sua utilização nas demais, devido às dificuldades de fixação da cor e de realização das medidas, passando-se a utilizar somente a fenolftaleína. As soluções foram preparadas com a seguinte formulação, segundo prescrições da literatura resumidas em Figueiredo (2005):

a) Solução de fenolftaleína: $1 \%$ de fenolftaleína dissolvida em uma solução de $70 \%$ de álcool etílico e $30 \%$ de água destilada;

b) Solução de timolftaleína: $0,4 \mathrm{~g}$ de timolftaleína dissolvida em uma solução de 600 $\mathrm{cm}^{3}$ de álcool etílico diluída em água destilada até $1000 \mathrm{~cm}^{3}$. 

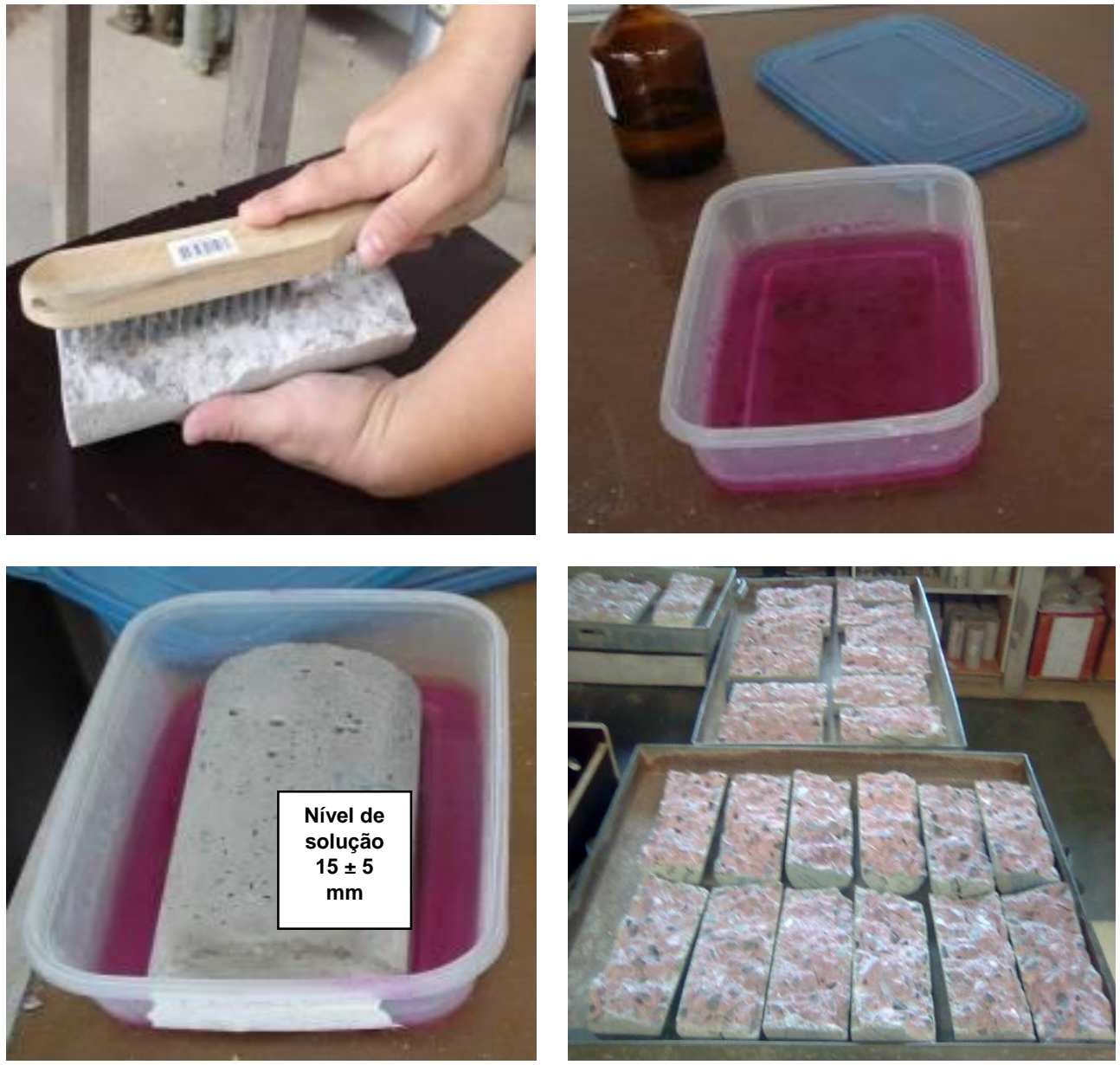

FIGURA 56 - Preparo do corpo-de-prova e solução de fenolftaleína para a realização da imersão das metades dos corpos-de-prova e disposição após imersão.

Os corpos-de-prova após pesagem, medidas e ruptura à tração por compressão diametral, eram separados e escovados com escova de cerdas de aço, para retirar as partes quebradiças e soltas. Após essa escovagem, uma metade era imersa em um recipiente plástico com nível de solução de fenolftaleína $(15 \pm 5 \mathrm{~mm})$, durante 1 minuto, sendo escorrido o excesso de solução. Então, essas metades ficavam dispostas em travessas metálicas em ambiente de laboratório, para que as medidas de profundidade fossem feitas 24 horas depois, para que a franja estivesse mais bem definida, conforme recomendado pela RILEM ${ }^{41}$ (Figura 56).

As medidas de profundidade de carbonatação foram feitas utilizando método tradicional através de medidas lineares - manuais utilizando paquímetro digital em 8 pontos da face partida do corpos-de-prova de concreto, 3 medidas em cada uma das laterais e 1

\footnotetext{
41 A metodologia recomendada pela RILEM especifica a borrifação da solução de fenolftaleína na face do corpo-de-prova, porém neste estudo esta metodologia foi alterada por imersão capilar das faces abertas na solução, pois se observou nesta pesquisa e na de Cavalcanti Filho (2010) que os concretos poderiam ficar com manchas ou umidade diferenciada pelo escorrimento do borrifamento na grande superfície de exposição $(10 \times 20 \mathrm{~cm})$.
} 
medida de topo e outra medida de fundo. As medidas lineares foram feitas em 8 pontos por esta pesquisadora (Manual1) e em 10 pontos (incluindo mais duas medidas, sendo uma a mais no topo e outra a mais no fundo) pelo estudante de graduação que contribuiu para esta pesquisa (Manual2). Porém esta última medida não foi considerada na apresentação dos resultados, devido ao maior desvio padrão apresentado. Verificou-se estatisticamente que não houve diferença em se colocar medidas de topo e fundo ou somente as medidas lateriais, no caso deste concreto.

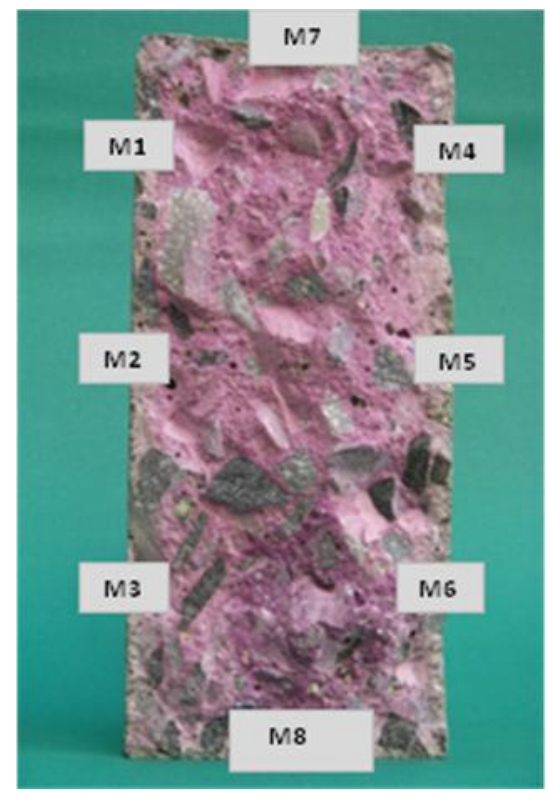

(a)
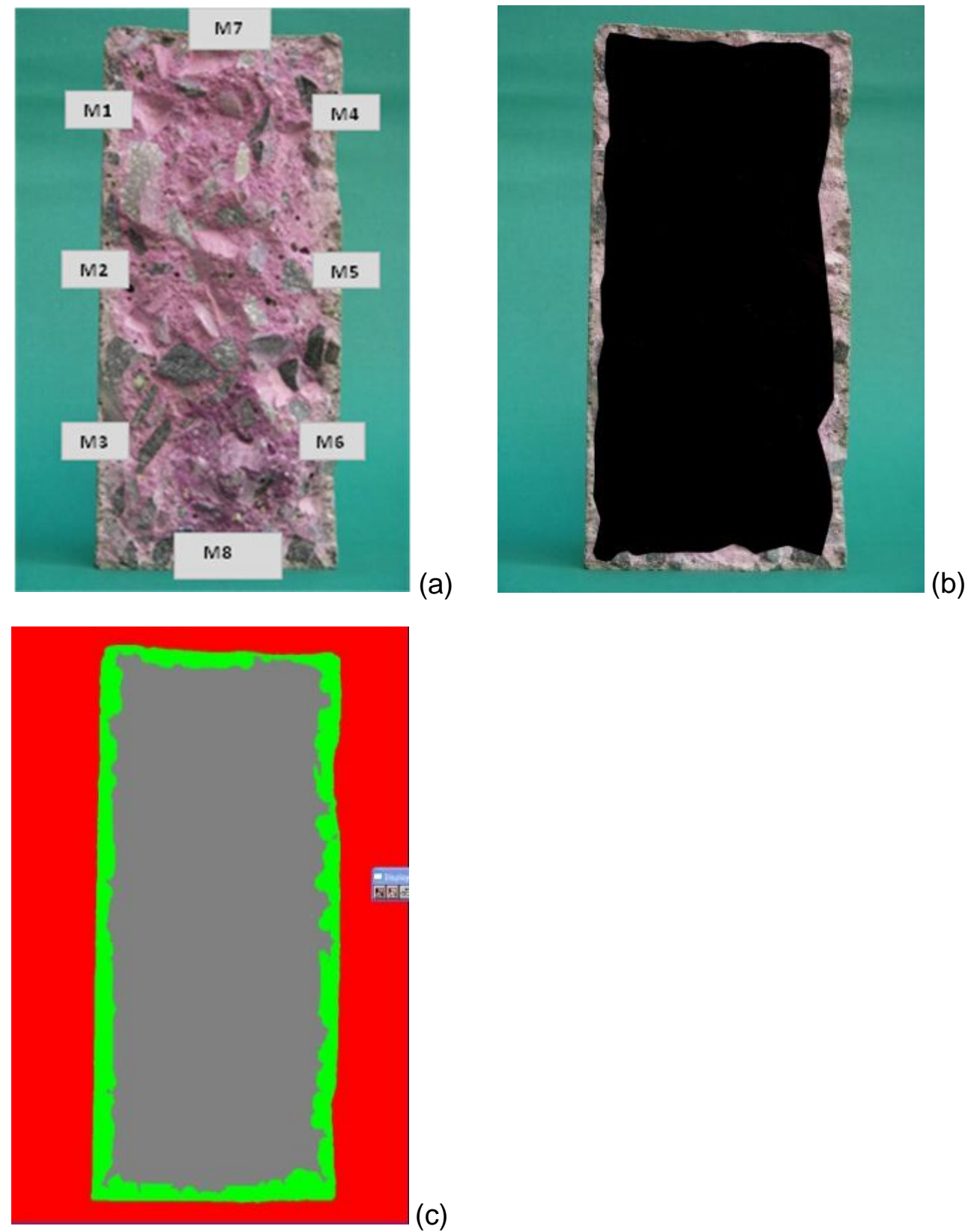

FIGURA 57 - Métodos de medidas de profundidade de carbonatação, (a) método linear, (b) método por análise de imagem utilizando Image $J$ e (c) método por análise de imagem utilizando Leica Qwin.

Outros dois métodos verificados para as medidas de profundidade de carbonatação através de fotos desses mesmos corpos-de-prova foram utilizando análise de imagem por 
dois diferentes programas: o Image $J$ (acesso gratuito pela internet) e o Leica Qwin, disponibilizado pelo Laboratório de Caracterização Tecnológica de Materiais do Departamento de Engenharia de Minas e Petróleo da Universidade de São Paulo. Ambos os programas podem ser utilizados de maneira relativamente simples, através da delimitação e cálculo da porcentagem de área carbonatada em relação à área aparente externa de cada seção em análise por contraste de cor com a área não-carbonatada, como se pode observar na Figura 57.

Porém estes métodos não são completamente automáticos, sendo que o ajuste final da franja de carbonatação pela interferência do agregado graúdo é um pouco subjetivo e delimitado pelo operador. Após a delimitação da área, obtém-se uma porcentagem de área carbonatada no corpo-de-prova e para obter a medida linear teórica, multiplica-se a porcentagem de área medida pela área total real da face do corpo-de-prova e divide-se este resultado pelo perímetro do corpo-de-prova, calculado pelo seu diâmetro médio.

Neste trabalho, para melhor aplicação das análises estatísticas, tranformou-se as medidas lineares do método manual em porcentagem de área, ou seja, multiplicou-se a profundidade média de carbonatação pelo perímetro real do corpo-de-prova e dividiu-se pela área total real, para a obtenção da porcentagem teórica de área carbonatada. Isto foi feito para diminuir a variabilidade dos resultados pelos erros de leitura no diâmetro dos corposde-prova, pois desta forma esses erros afetaram igualmente todas as comparações entre os métodos de análise de imagem e de medida linear.

As imagens realizadas para a leitura das medidas de profundidade de carbonatação constam no Apêndice C. 


\section{APRESENTACÃO E DISCUSSÃO DOS RESULTADOS}

Neste capítulo estão apresentados os resultados dos ensaios e as discussões relacionadas à comparação entre os concretos dos caminhões amostrados do lote classe 30-II, empregado no programa experimental, e as correlações entre as suas propriedades médias.

Os resultados completos dos seis concretos amostrados do lote constam no Apêndice B e estão resumidos nos itens seguintes deste capítulo, através da apresentação de média, desvio padrão, coeficiente de variação, valor máximo e mínimo e amplitude de cada uma das propriedades objeto do estudo, conforme apresentado na Figura 42. Como conclusões deste capítulo são apresentadas as comparações entre as propriedades desses concretos, suas correlações e análises de variância, ao final, com foco nas medidas de carbonatação.

\subsection{RESULTADOS E ANÁLISE COMPARATIVA ENTRE OS CONCRETOS AMOSTRADOS}

\subsubsection{Propriedades no estado fresco}

\section{A) Informações e composição nominal do concreto fornecido}

$\mathrm{Na}$ Tabela 28 são apresentados os dados das notas fiscais de fornecimento do concreto à obra especificada, bem como os dados referentes às cargas nominais de dosagem dos materiais e horários de produção de cada um, na data de 13/08/2009. 
TABELA 28 - Dados das notas fiscais referente aos concretos fornecidos à obra.

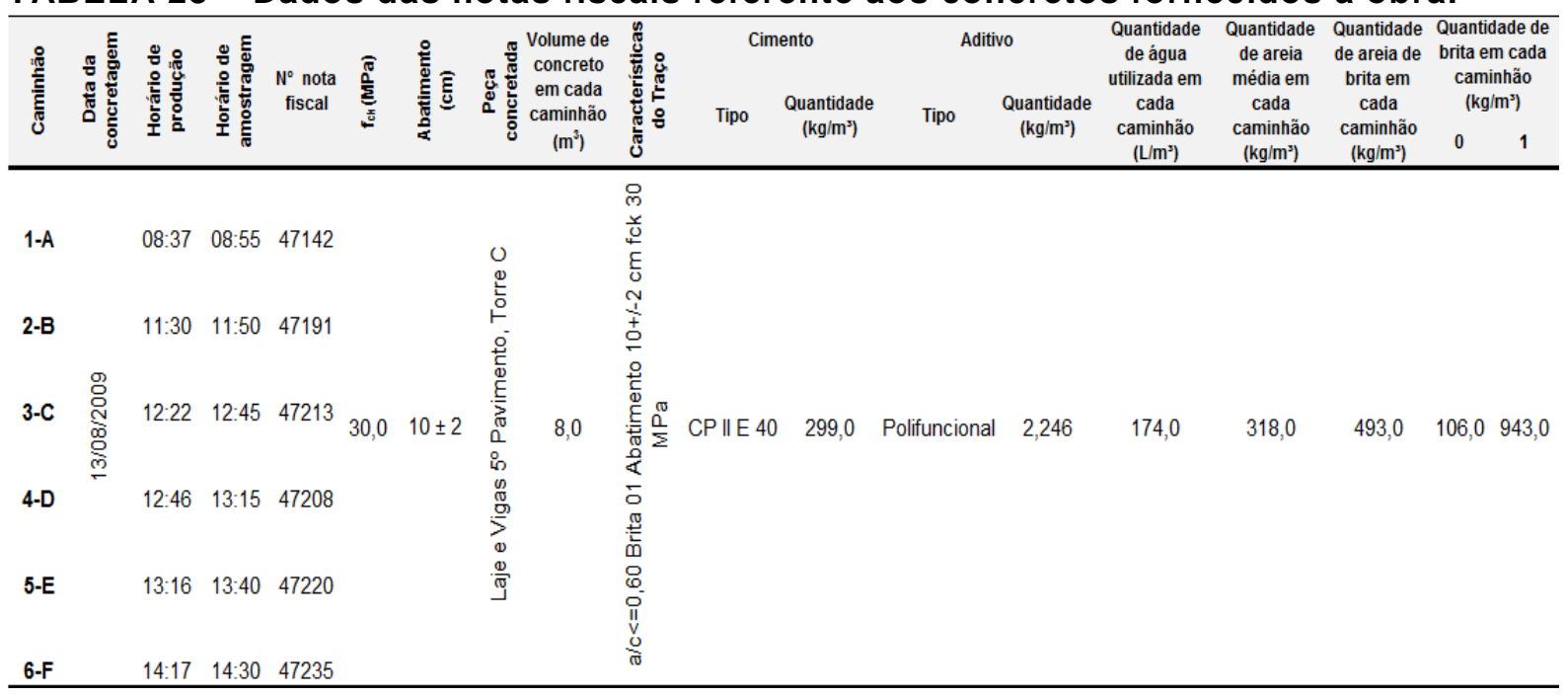

- Traço teórico nominal, considerando 3\% de ar nos cálculos.

O valor teórico da relação água/cimento encontrado pela composição do concreto fornecido à obra foi de 0,58, estando de acordo com a especificação da ABNT NBR 6118 (2003) e da ABNT NBR 12655 (2006). A composição teórica do concreto atende às normas em epígrafe para a classe de agressividade II, em que se enquadra a obra em questão nos requisitos de relação água/cimento para concreto armado $(C A \leq 0,60)$, classe do concreto $(\geq$ C25) e quanto ao consumo de cimento $\left(\geq 280 \mathrm{~kg} / \mathrm{m}^{3}\right)$. O traço em massa tem a seguinte composição: 1: 2,712: 3,508: 0,58, teor de umidade $\mathrm{H}_{\text {teórico }}=8,0 \%$, teor de argamassa $\alpha_{\text {teórico }}$ $=51,4 \%$ e teor de finos total de $15 \%$, incluindo-se nesta parcela todas as frações abaixo de $75 \mu \mathrm{m}$, tanto do cimento quanto dos agregados.

\section{B) Abatimento do tronco de cone (slump)}

A Tabela 29 apresenta os resultados das medidas, as médias, os desvios padrão, os valores máximos e mínimos, as amplitudes e os coeficientes de variação para as misturas de seis caminhões do lote analisado. Os dados de média geral do lote são calculados a partir das seis médias originadas de duas medidas do concreto amostrado de cada caminhão. Percebe-se que as médias de cinco dos seis caminhões do lote resultaram em abatimentos superiores ao previsto de $(10 \pm 2 \mathrm{~cm})$, exceto o caminhão 5 -E, cujo concreto resultou com abatimento dentro do previsto para a descarga na obra. A explicação para esses resultados diz respeito ao dimensionamento do traço de concreto pela central dosadora, que considera uma perda de abatimento de percurso entre a central e a obra, considerando também o tempo médio que o caminhão aguarda para descarregar na obra. 
Como o ensaio foi realizado na central, os abatimentos estavam superiores ao estabelecido, como previsto. Para confirmar se os resultados dos ensaios estavam dentro dos requisitos estabelecidos pela obra, foram solicitados à mesma, os resultados dos ensaios realizados pelo laboratório de controle tecnológico contratado pela construtora. Os resultados estão apresentados também na Tabela 29. O relatório completo dos ensaios realizados pelo laboratório de controle consta no Apêndice B.

TABELA 29 - Resultados dos ensaios de abatimento do concreto fresco das seis misturas do lote analisado em 13/08/2009, conforme ABNT NBR NM 67 (1998).

\begin{tabular}{|c|c|c|c|c|c|c|c|c|c|c|c|c|c|c|c|c|c|}
\hline \multicolumn{4}{|c|}{ Mistura } & \multicolumn{6}{|c|}{ Medidas por amostra $( \pm 400$ litros) } & \multicolumn{7}{|c|}{ Cálculos para o lote } & \multirow{2}{*}{$\begin{array}{l}\text { Ab. Obra } \\
\text { Medida . } \\
\text { obra }(\mathrm{cm})\end{array}$} \\
\hline $\begin{array}{l}5 \\
\varepsilon \\
0 \\
0 \\
i \pi \\
\frac{5}{E} \\
\frac{1}{\varepsilon} \\
0 \\
0\end{array}$ & 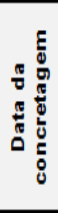 & 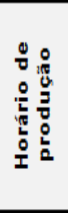 & 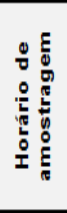 & $\begin{array}{l}\text { Medida } 1 \\
\text { (cm) }\end{array}$ & $\begin{array}{l}\text { Medida } 2 \\
(\mathrm{~cm})\end{array}$ & $\begin{array}{l}\text { Média } \\
(\mathrm{cm})\end{array}$ & $\begin{array}{l}\text { Valor } \\
\text { Máximo } \\
(\mathrm{cm})\end{array}$ & $\begin{array}{l}\text { Valor } \\
\text { Mínimo } \\
\text { (cm) }\end{array}$ & $\begin{array}{c}\text { Amplitude } \\
(\mathrm{cm})\end{array}$ & $\begin{array}{l}\text { Média } \\
(\mathrm{cm})\end{array}$ & $\begin{array}{c}\text { Desvio } \\
\text { Padrão } \\
\text { (cm) }\end{array}$ & $\begin{array}{c}\text { Coef. } \\
\text { Variação } \\
(\%)\end{array}$ & $\begin{array}{l}\text { Valor } \\
\text { Máximo } \\
\text { (cm) }\end{array}$ & $\begin{array}{l}\text { Valor } \\
\text { Mínimo } \\
\text { (cm) }\end{array}$ & $\begin{array}{l}\text { Amplitude } \\
\text { das } \\
\text { médias } \\
\text { (cm) }\end{array}$ & $\begin{array}{c}\text { Intervalo } \\
\text { de } \\
\text { confiança } \\
\text { da média } \\
95 \% \\
( \pm \mathrm{cm})\end{array}$ & \\
\hline $1-A$ & & $08: 37$ & $08: 55$ & 15,0 & 14,0 & 14,5 & 15,0 & 14,0 & 1,0 & & & & & & & & 11,0 \\
\hline $2 \cdot B$ & $\sigma$ & $11: 30$ & $11: 50$ & 16,0 & 17,0 & 16,5 & 17,0 & 16,0 & 1,0 & & & & & & & & 10,0 \\
\hline $3-C$ & $\stackrel{\mathrm{O}}{\mathrm{N}}$ & $12: 22$ & $12: 45$ & 17,0 & 15,0 & 16,0 & 17,0 & 15,0 & 2,0 & & & & & & 75 & & 11,0 \\
\hline 4-D & $\stackrel{\text { g }}{\mathrm{g}}$ & $12: 46$ & $13: 15$ & 15,0 & 15,0 & 15,0 & 15,0 & 15,0 & 0,0 & & & & & & 1,0 & 2,0 & 10,0 \\
\hline 5-E & & $13: 16$ & $13: 40$ & 9,0 & 9,0 & 9,0 & 9,0 & 9,0 & 0,0 & & & & & & & & 10,0 \\
\hline $6 \cdot F$ & & $14: 17$ & $14: 30$ & 17,0 & 16,0 & 16,5 & 17,0 & 16,0 & 1,0 & & & & & & & & 11,0 \\
\hline
\end{tabular}

A Figura 58 ilustra os resultados de abatimento do tronco de cone, do concreto de cada caminhão que representa o lote analisado. Assim, a redução de abatimento ilustrada pela Figura 58, pode ser explicada pela diferença nos prazos de amostragem e diferença de horário de descarga efetiva na obra, que não foi informada pelo laudo do laboratório terceirizado. 


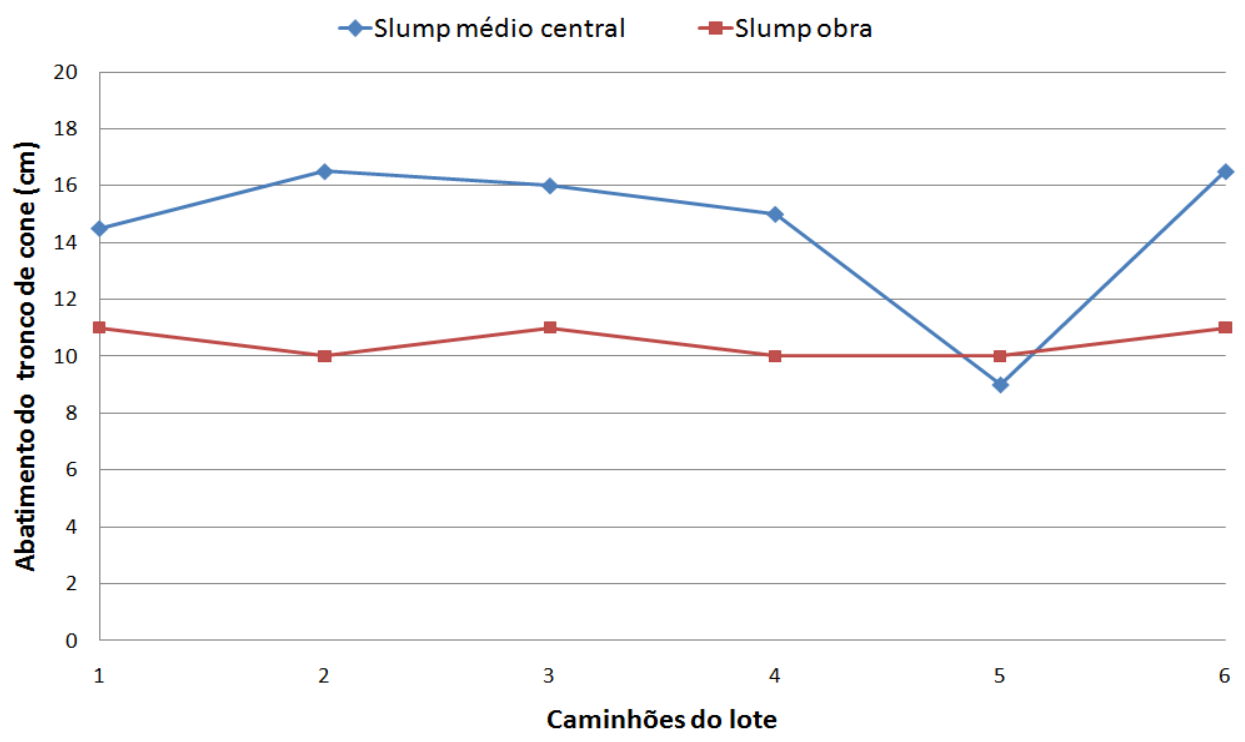

FIGURA 58 - Variação dos resultados de abatimento médio dos concretos de seis caminhões amostrados do lote, na central e na obra, sendo o ensaio conforme ABNT NBR NM 67 (1998).

\section{C) Densidade de massa aparente do concreto fresco}

A Tabela 30 apresenta os resultados das medidas, as médias, o desvio padrão, os valores máximos e mínimos, as amplitudes e os coeficientes de variação dos ensaios de densidade de massa aparente do concreto fresco, dos seis caminhões do lote analisado. Os dados de média geral do lote são calculados a partir das seis médias, originadas de duas medidas do concreto de cada caminhão. A variação de cerca de $70 \mathrm{~kg} / \mathrm{m}^{3}$ entre as medidas dos concretos dos seis caminhões do lote, pode ser vista também na Figura 59. 
TABELA 30- Resultados do ensaio de densidade de massa aparente do concreto fresco, em amostras de seis caminhões amostrados do lote analisado conforme a ABNT NBR 9833 (2008).

\begin{tabular}{|c|c|c|c|c|c|c|c|c|c|c|c|c|c|}
\hline \multirow[b]{2}{*}{ 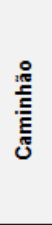 } & \multicolumn{6}{|c|}{ Medidas por amostra } & \multicolumn{7}{|c|}{ Cálculos para o lote } \\
\hline & $\begin{array}{c}\text { Medida } 1 \\
\left(\mathrm{~kg} / \mathrm{m}^{3}\right)\end{array}$ & $\begin{array}{c}\text { Medida } 2 \\
\left(\mathrm{~kg} / \mathrm{m}^{3}\right)\end{array}$ & $\begin{array}{l}\text { Média } \\
\left(\mathrm{kg} / \mathrm{m}^{3}\right)\end{array}$ & $\begin{array}{l}\text { Valor } \\
\text { Máximo } \\
\left(\mathrm{kg} / \mathrm{m}^{2}\right)\end{array}$ & $\begin{array}{l}\text { Valor } \\
\text { Mínimo } \\
\left(\mathrm{kg} / \mathrm{m}^{3}\right)\end{array}$ & $\begin{array}{c}\text { Amplitude } \\
\left(\mathrm{kg} / \mathrm{m}^{2}\right)\end{array}$ & $\begin{array}{l}\text { Média } \\
\left(\mathrm{kg} / \mathrm{m}^{2}\right)\end{array}$ & $\begin{array}{l}\text { Desvio } \\
\text { padrão } \\
\left(\mathrm{kg} / \mathrm{m}^{2}\right)\end{array}$ & $\begin{array}{c}\text { Coeficiente } \\
\text { de variação } \\
(\%)\end{array}$ & $\begin{array}{l}\text { Valor } \\
\text { Máximo } \\
\left(\mathrm{kg} / \mathrm{m}^{3}\right)\end{array}$ & $\begin{array}{l}\text { Valor } \\
\text { Mínimo } \\
\left(\mathrm{kg} / \mathrm{m}^{3}\right)\end{array}$ & $\begin{array}{l}\text { Amplitude } \\
\text { das } \\
\text { médias } \\
\left(\mathbf{k g} / \mathrm{m}^{2}\right)\end{array}$ & $\begin{array}{c}\text { Intervalo } \\
\text { de } \\
\text { confiança } \\
\text { da média } \\
95 \% \\
\left(\mathrm{~kg} / \mathrm{m}^{3}\right)\end{array}$ \\
\hline $1 \mathrm{~A}$ & 2446 & 2459 & 2452 & 2459 & 2446 & 12,8 & & & & & & & \\
\hline 2B & 2380 & 2384 & 2382 & 2384 & 2380 & 3,4 & & & & & & & \\
\hline $3 \mathrm{C}$ & 2397 & 2394 & 2396 & 2397 & 2394 & 3,4 & & & & & & & \\
\hline 4D & 2387 & 2387 & 2387 & 2387 & 2387 & 0,2 & 2412 & 28,4 & $1 \%$ & 2452 & 2382 & 70,4 & \pm 23 \\
\hline $5 \mathrm{E}$ & 2418 & 2425 & 2421 & 2425 & 2418 & 7,1 & & & & & & & \\
\hline $6 \mathrm{~F}$ & 2438 & 2432 & 2435 & 2438 & 2432 & 6,4 & & & & & & & \\
\hline
\end{tabular}

$\mathrm{Na}$ Figura 59 estão mostrados os valores individuais das medidas de densidade de massa aparente do concreto fresco amostrado de cada um dos seis caminhões do lote. Verifica-se que o concreto 2B apresentou valor médio inferior em relação aos demais, porém seus resultados aproximaram-se dos resultados dos concretos $3 \mathrm{C}$ e 4D. Os resultados dos concretos $1 \mathrm{~A}$ e $6 \mathrm{~F}$ ficaram acima dos demais, sendo que o resultado de repetição do concreto $1 \mathrm{~A}$ foi um tanto discrepante em relação ao seu par, apresentando maior desvio padrão e coeficiente de variação, o que pode ser justificado por alguma alteração de dosagem, na amostragem dos concretos no início da descarga do caminhão ou pelos próprios procedimentos de ensaio. Nos relatórios de pesagem automática da central não foi possível observar grandes diferenças de massas que pudessem explicar essas variações. 


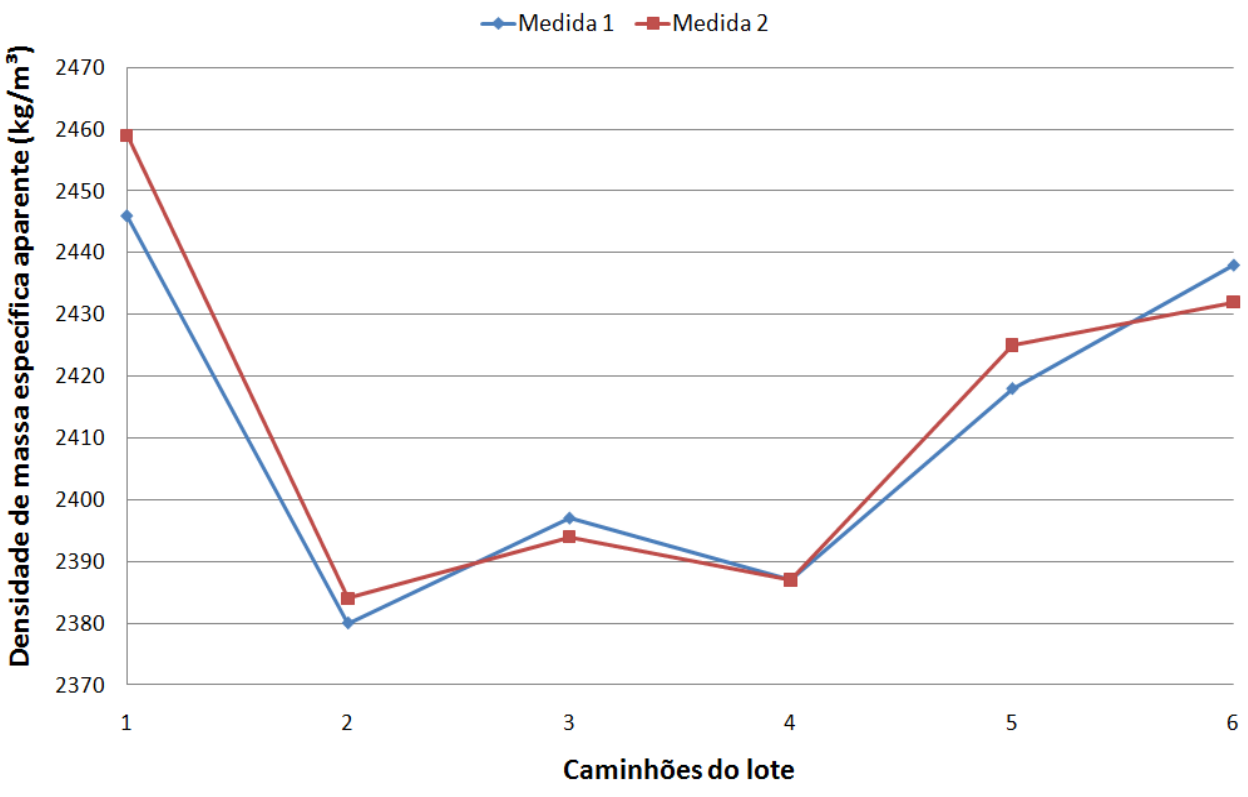

FIGURA 59- Variação dos resultados dos ensaios de densidade de massa aparente do concreto fresco em amostras de seis caminhões do lote. ABNT NBR 9833 (2008).

D) Teor de ar

\section{D.1) Teor de ar pelo método pressométrico}

A Tabela 31 apresenta os resultados das medidas individuais, as médias, o desvio padrão, os valores máximos e mínimos, as amplitudes e o coeficiente de variação dos ensaios de teor de ar pressométrico dos seis caminhões que representam o lote analisado. Pode-se observar que os concretos tiveram resultados sem grandes variações, porém os concretos $2 \mathrm{~B}$ e 5E apresentaram resultados ligeiramente superiores aos demais concretos do lote. Quanto ao concreto 2B pode-se confirmar a relação entre o teor de ar e o abatimento, porém não mostra relação com os ensaios de compactabilidade, mais a diante analisados. Já os resultados do concreto $5 \mathrm{E}$, pode-se verificar uma relação entre os resultados de teor de ar e resultados de compactabilidade (Figura 63), porém não se observou correlação com os resultados de abatimento. Para o concreto 4D, tanto os resultados de teor de ar quanto de compactabilidade adensada e não-adensada, foram os menores em relação aos demais concretos do lote. 
TABELA 31 - Resultados do ensaio de teor de ar por método pressométrico no concreto fresco, em amostras de seis caminhões do lote analisado. ABNT NBR 47 (2002).

\begin{tabular}{|c|c|c|c|c|c|c|c|c|c|c|c|c|c|}
\hline \multirow[b]{2}{*}{ 疍 } & \multicolumn{6}{|c|}{ Medidas por amostra } & \multicolumn{7}{|c|}{ Cálculos para o lote } \\
\hline & $\begin{array}{c}\text { Medida } 1 \\
(\%)\end{array}$ & $\begin{array}{c}\text { Medida } 2 \\
(\%)\end{array}$ & $\begin{array}{c}\text { Média } \\
(\%)\end{array}$ & $\begin{array}{c}\text { Valor } \\
\text { Máximo } \\
(\%)\end{array}$ & $\begin{array}{c}\text { Valor } \\
\text { Mínimo } \\
(\%)\end{array}$ & $\begin{array}{c}\text { Amplitude } \\
(\%)\end{array}$ & Média (\%) & $\begin{array}{c}\text { Desvio } \\
\text { padrão } \\
(\%)\end{array}$ & $\begin{array}{l}\text { Coeficiente } \\
\text { de variação } \\
(\%)\end{array}$ & $\begin{array}{c}\text { Valor } \\
\text { Máximo } \\
(\%)\end{array}$ & $\begin{array}{c}\text { Valor } \\
\text { Mínimo } \\
(\%)\end{array}$ & $\begin{array}{c}\text { Amplitude } \\
\text { das } \\
\text { médias } \\
(\%)\end{array}$ & $\begin{array}{l}\text { Intervalo de } \\
\text { confiança da } \\
\text { média } 95 \%(\%)\end{array}$ \\
\hline $1-A$ & 1,70 & 1,70 & 1,70 & 1,70 & 1,70 & 0,00 & & & & & & & \\
\hline 2-B & 2,10 & 1,90 & 2,00 & 2,10 & 1,90 & 0,20 & & & & & & & \\
\hline $3-\mathrm{C}$ & 1,70 & 1,60 & 1,65 & 1,70 & 1,60 & 0,10 & 1,69 & 0,25 & $15 \%$ & 2,00 & 1,30 & 0,70 & $\pm 0,20$ \\
\hline 4-D & 1,30 & 1,40 & 1,35 & 1,40 & 1,30 & 0,10 & & & & & & & \\
\hline 5-E & 2,00 & 1,90 & 1,95 & 2,00 & 1,90 & 0,10 & & & & & & & \\
\hline $6-\mathrm{F}$ & 1,50 & 1,50 & 1,50 & 1,50 & 1,50 & 0,00 & & & & & & & \\
\hline
\end{tabular}

A Figura 60 ilustra de forma comparativa os resultados do ensaio de slump médio e teor de ar pressométrico dos seis caminhões que representam o lote.

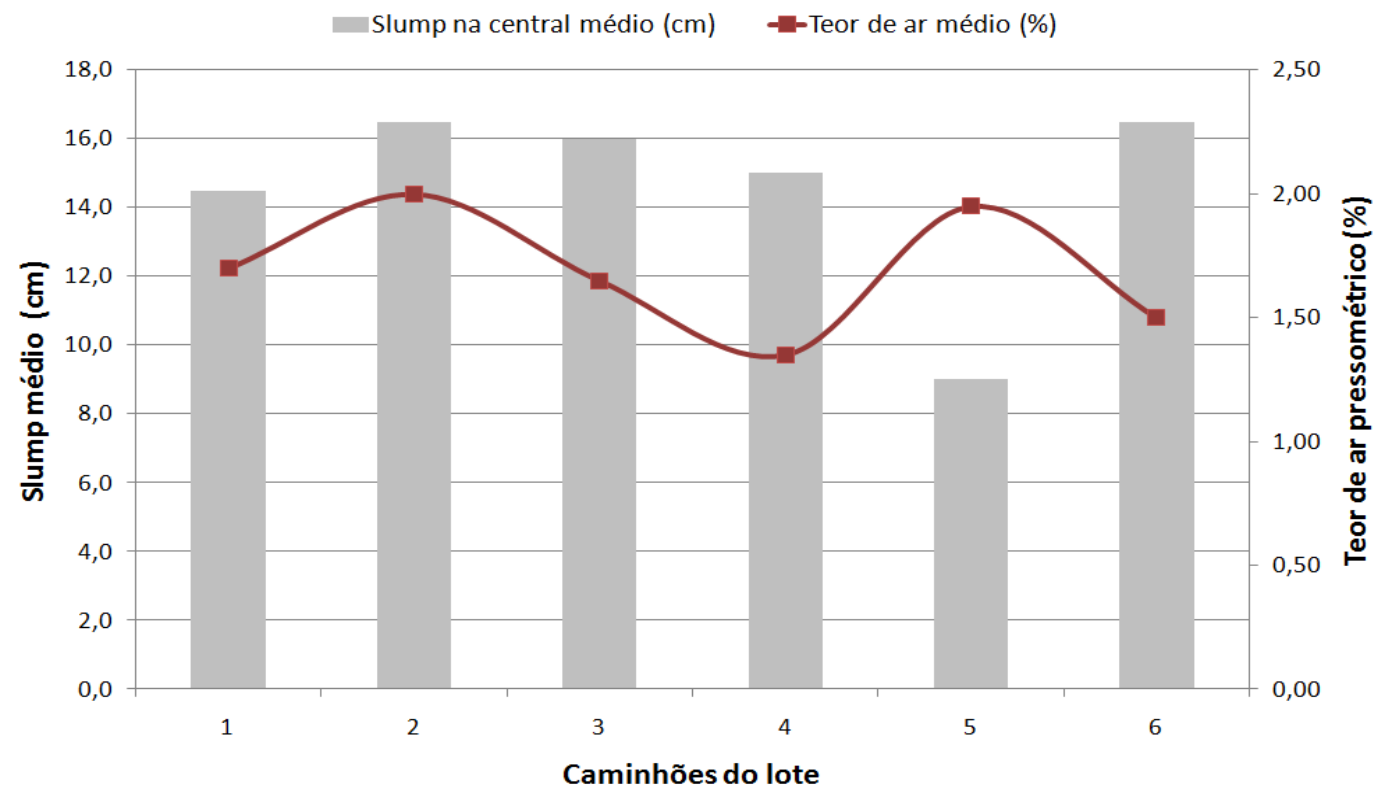

FIGURA 60 - Variação dos resultados de abatimento médio e teor de ar pelo método pressométrico de cada concreto.

\section{D.2) Teor de ar pelo método gravimétrico}

A Tabela 32 apresenta os resultados das medidas individuais, as médias, os desvios padrão, os valores máximos e mínimos, as amplitudes e o coeficiente de variação dos ensaios de teor de ar pelo método gravimétrico do concreto fresco. 
TABELA 32 - Resultados do ensaio de teor de ar no concreto fresco pelo método gravimétrico em amostras de seis caminhões do lote analisado. ABNT NBR 9833 (1987).

\begin{tabular}{|c|c|c|c|c|c|c|c|c|c|c|c|c|c|}
\hline \multirow[b]{2}{*}{ 选 } & \multicolumn{6}{|c|}{ Medidas por amostra } & \multicolumn{7}{|c|}{ Cálculos para o lote } \\
\hline & $\begin{array}{c}\text { Medida } 1 \\
(\%)\end{array}$ & $\begin{array}{c}\text { Medida } 2 \\
(\%)\end{array}$ & $\begin{array}{l}\text { Média } \\
(\%)\end{array}$ & $\begin{array}{c}\text { Valor } \\
\text { máximo } \\
(\%)\end{array}$ & $\begin{array}{c}\text { Valor } \\
\text { mínimo } \\
(\%)\end{array}$ & $\begin{array}{c}\text { Amplitude } \\
(\%)\end{array}$ & $\begin{array}{c}\text { Média } \\
(\%)\end{array}$ & $\begin{array}{c}\text { Desvio } \\
\text { padrão } \\
(\%)\end{array}$ & $\begin{array}{l}\text { Coeficiente } \\
\text { de variação } \\
(\%)\end{array}$ & $\begin{array}{c}\text { Valor } \\
\text { máximo } \\
(\%)\end{array}$ & $\begin{array}{c}\text { Valor } \\
\text { mínimo } \\
(\%)\end{array}$ & $\begin{array}{c}\text { Amplitude } \\
\text { das } \\
\text { médias } \\
(\%)\end{array}$ & $\begin{array}{c}\text { Intervalo de } \\
\text { confiança } \\
\text { da média } \\
95 \%(\%)\end{array}$ \\
\hline $1 \mathrm{~A}$ & $-0,34$ & $-0,87$ & $-0,61$ & $-0,34$ & $-0,87$ & 0,53 & & & & & & & \\
\hline $2 \mathrm{~B}$ & 1,13 & 0,99 & 1,06 & 1,13 & 0,99 & 0,14 & & & & & & & \\
\hline $3 \mathrm{C}$ & 0,55 & 0,70 & 0,63 & 0,70 & 0,55 & 0,14 & 0,07 & 0,91 & 13,0 & 1,06 & $-1,20$ & 2,26 & $\pm 0,73$ \\
\hline 4D & 0,87 & 0,87 & 0,87 & 0,87 & 0,87 & 0,00 & & & & & & & \\
\hline $5 \mathrm{E}$ & $-0,19$ & $-0,47$ & $-0,33$ & $-0,19$ & $-0,47$ & 0,28 & & & & & & & \\
\hline $6 \mathrm{~F}$ & $-1,34$ & -1.06 & $-1,20$ & $-1,06$ & $-1,34$ & 0,28 & & & & & & & \\
\hline
\end{tabular}

A Figura 61 ilustra os resultados do ensaio de teor de ar pressométrico e gravimétrico dos seis concretos que representam o lote analisado. Pode-se observar que os concretos tiveram resultados com grandes variações pelo método gravimétrico, e os concretos $2 \mathrm{~B}, 3 \mathrm{C}$ e 4D apresentaram resultados superiores aos demais concretos do lote, sendo que o concreto 2B também mostrou maior resultado de teor de ar em relação aos demais pelo método pressométrico, com maior coerência.

Não foi possível correlacionar a maioria dos resultados dos ensaios de teor de ar gravimétrico com os dos ensaios de teor de ar pressométrico. Portanto, pode-se concluir que:

a) as massas específicas dos agregados e as pesagens dos materiais por caminhão podem introduzir variações aleatórias e erros no cálculo do teor de ar pelo método gravimétrico;

b) foram mais constantes os resultados do teor de ar pelo método pressométrico da ABNT NBR 47 (2002) do que pela ABNT NBR 9833 (1987). 


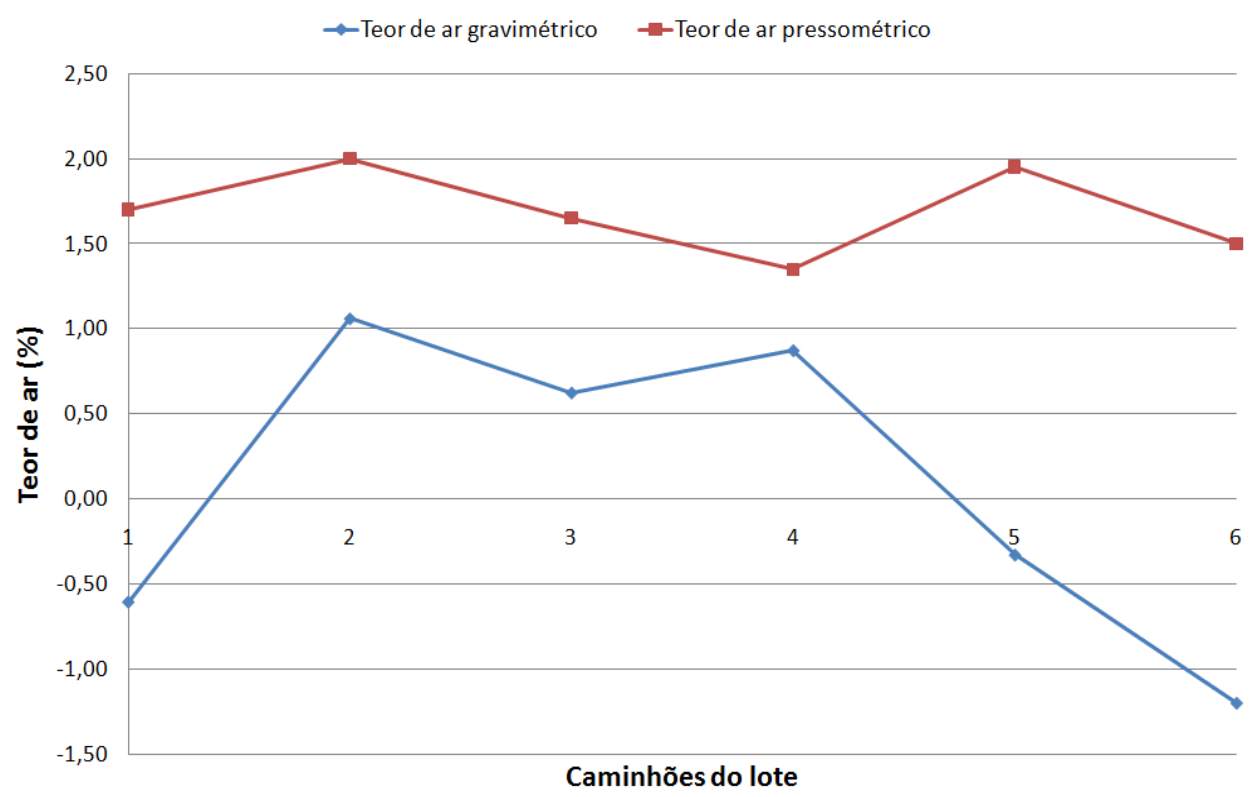

FIGURA 61 - Variação dos resultados de teor de ar pelos métodos pressométrico e gravimétrico de cada amostra de concreto fresco, dos seis caminhões amostrados do lote. ABNT NBR 9833 (1987).

\section{E) Compactabilidade de concreto fresco}

\section{E.1) Compactabilidade do concreto adensado}

A Tabela 33 a) e b) apresenta os resultados das medidas individuais, as médias, o desvio padrão, os valores máximos e mínimos, as amplitudes e o coeficiente de variação dos ensaios de compactabilidade do concreto fresco, quando submetidos a adensamento prévio, por vibração de 1 e 3 minutos, respectivamente. Percebe-se que os resultados seguem uma mesma tendência para cada concreto, tanto nas medidas de compactação vibrando-se 1 minuto, quanto nas medidas compactadas por vibração de 3 minutos, exceto para os resultados do concreto $1 \mathrm{~A}$, que seguem direções opostas, pois não houve nenhuma compactação com 1 minuto de vibração, porém houve uma maior compactação com 3 minutos de vibração, o que pode ser visto também na Figura 62. 
TABELA 33 - Resultados do ensaio de compactabilidade do concreto fresco adensado (a-vibração $1 \mathrm{~min}$.) (b-vibração $3 \mathrm{~min}$.) das amostras de seis caminhões do lote analisado. Adaptado da BS EN 12.350-4 (2009).

\begin{tabular}{|c|c|c|c|c|c|c|c|c|c|c|c|c|c|c|}
\hline \multicolumn{15}{|c|}{ a) Espessura compactada - mesa vibratória 1 minuto - Adensado } \\
\hline \multirow[b]{2}{*}{ 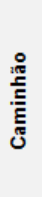 } & \multicolumn{6}{|c|}{ Medidas por amostra } & \multicolumn{8}{|c|}{ Cálculos para o lote } \\
\hline & $\begin{array}{c}\text { Medida } 1 \\
(\mathrm{~mm})\end{array}$ & $\begin{array}{l}\text { Medida } 2 \\
(\mathrm{~mm})\end{array}$ & $\begin{array}{l}\text { Média } \\
(\mathrm{mm})\end{array}$ & $\begin{array}{c}\text { Valor } \\
\text { máximo } \\
(\mathrm{mm})\end{array}$ & $\begin{array}{c}\text { Valor } \\
\text { mínimo } \\
(\mathrm{mm})\end{array}$ & $\begin{array}{l}\text { Amplitude } \\
\text { (mm) }\end{array}$ & $\begin{array}{l}\text { Média } \\
(\mathrm{mm})\end{array}$ & $\begin{array}{c}\text { Desvio } \\
\text { padrão } \\
(\mathrm{mm})\end{array}$ & $\begin{array}{c}\text { Coeficiente } \\
\text { de } \\
\text { variação } \\
(\%)\end{array}$ & $\begin{array}{l}\text { Valor } \\
\text { máximo } \\
\text { (mm) }\end{array}$ & $\begin{array}{c}\text { Valor } \\
\text { mínimo } \\
(\mathrm{mm})\end{array}$ & $\begin{array}{l}\text { Amplitude } \\
\text { das } \\
\text { médias } \\
(\mathrm{mm})\end{array}$ & $\begin{array}{l}\text { Intervalo } \\
\text { de } \\
\text { confiança } \\
\text { da média } \\
95 \%(\mathrm{~mm})\end{array}$ & $\begin{array}{c}\text { Teor de ar } \\
\text { equivalente } \\
(\%)\end{array}$ \\
\hline $1-A$ & 0,0 & 0,0 & 0,0 & 0,0 & 0,0 & 0,0 & & & & & & & & 0,0 \\
\hline 2-B & 3,0 & 2,2 & 2,6 & 3,0 & 2,2 & 0,8 & & & & & & & & 0,9 \\
\hline $3-\mathrm{C}$ & 3,1 & 3,9 & 3,5 & 3,9 & 3,1 & 0,9 & 2,1 & 1,5 & $72 \%$ & 3,8 & 0,0 & 3,8 & $\pm 1,2$ & 1,2 \\
\hline 4-D & 1,5 & 0,9 & 1,2 & 1,5 & 0,9 & 0,6 & & & & & & & & 0,4 \\
\hline $5-\mathrm{E}$ & 3,4 & 4,1 & 3,8 & 4,1 & 3,4 & 0,7 & & & & & & & & 1,3 \\
\hline 6-F & 1,5 & 1,0 & 1,2 & 1,5 & 1,0 & 0,5 & & & & & & & & 0,4 \\
\hline \multicolumn{15}{|c|}{ b) Espessura compactada - mesa vibratória 3 minutos - Adensado } \\
\hline \multirow[b]{2}{*}{ 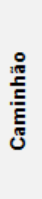 } & \multicolumn{6}{|c|}{ Medidas por amostra } & \multicolumn{8}{|c|}{ Cálculos para o lote } \\
\hline & $\begin{array}{c}\text { Medida } 1 \\
(\mathrm{~mm})\end{array}$ & $\begin{array}{l}\text { Medida } 2 \\
(\mathrm{~mm})\end{array}$ & $\begin{array}{l}\text { Média } \\
(\mathrm{mm})\end{array}$ & $\begin{array}{c}\text { Valor } \\
\text { máximo } \\
(\mathrm{mm})\end{array}$ & $\begin{array}{l}\text { Valor } \\
\text { mínimo } \\
(\mathrm{mm})\end{array}$ & $\begin{array}{l}\text { Amplitude } \\
\text { (mm) }\end{array}$ & $\begin{array}{l}\text { Média } \\
(\mathrm{mm})\end{array}$ & $\begin{array}{c}\text { Desvio } \\
\text { padrão } \\
(\mathrm{mm})\end{array}$ & $\begin{array}{c}\text { Coeficiente } \\
\text { de } \\
\text { variação } \\
(\%)\end{array}$ & $\begin{array}{l}\text { Valor } \\
\text { máximo } \\
(\mathrm{mm})\end{array}$ & $\begin{array}{c}\text { Valor } \\
\text { mínimo } \\
(\mathrm{mm})\end{array}$ & $\begin{array}{l}\text { Amplitude } \\
\text { das } \\
\text { médias } \\
\text { (mm) }\end{array}$ & 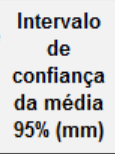 & $\begin{array}{c}\text { Teor de ar } \\
\text { equivalente } \\
\text { (\%) }\end{array}$ \\
\hline $1 . \mathrm{A}$ & 4,0 & 3,5 & 3,7 & 4,0 & 3,5 & 0,6 & & & & & & & & 1,3 \\
\hline 2-B & 3,0 & 2,7 & 2,8 & 3,0 & 2,7 & 0,4 & & & & & & & & 1,0 \\
\hline $3-\mathrm{C}$ & 4,6 & 3,4 & 4,0 & 4,6 & 3,4 & 1,1 & 2,6 & 1,5 & $56 \%$ & 4,0 & 0,3 & 3,7 & $\pm 1,2$ & 1,4 \\
\hline 4-D & 0,4 & 0,3 & 0,3 & 0,4 & 0,3 & 0,2 & & & & & & & & 0,1 \\
\hline 5-E & 2,7 & 4,4 & 3,5 & 4,4 & 2,7 & 1,6 & & & & & & & & 1,2 \\
\hline 6-F & 2,2 & 0,5 & 1,4 & 2,2 & 0,5 & 1,7 & & & & & & & & 0,5 \\
\hline
\end{tabular}

O teor de ar equivalente para os ensaios de compactabilidade foram calculados conforme a Equação 20:

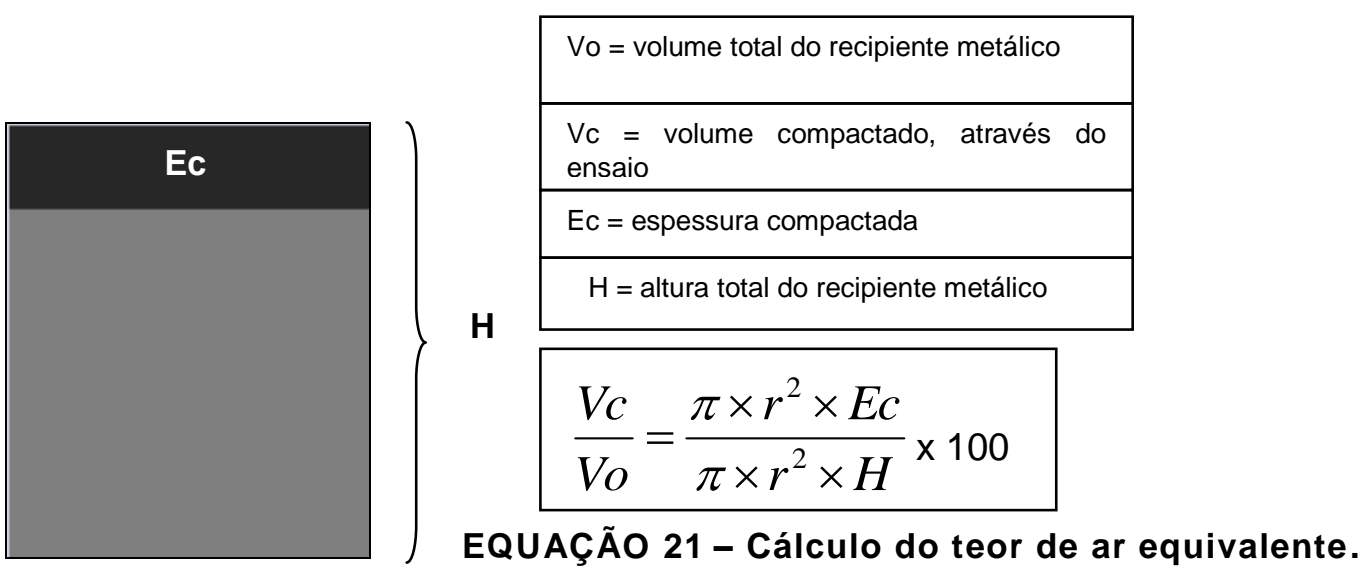

Para os ensaios de compactabilidade com vibração de 3 minutos obteve-se maiores médias de espessuras compactadas, exceto para os concretos $4 \mathrm{D}$ e $5 \mathrm{E}$ que tiveram uma compactação menor nesse tempo. 
Percebe-se uma variação significativa nos resultados, observando o coeficiente de variação, em ambos os tempos de vibração do concreto, o que provavelmente é indicativo da necessidade de melhor padronização da forma de adensamento ou de redução do volume de concreto a ser compactado. A norma européia também não especifica qual é o tempo ideal de compactação pela mesa vibratória.

Para os ensaios de compactabilidade com vibração de 3 minutos obteve-se maiores amplitudes nas medidas, que pode ser explicado pelo respingamento do concreto fresco do recipiente, enquanto o mesmo era submetido a esse tempo em mesa vibratória, o que não ocorreu quando submetido a 1 minuto de vibração. Devido a esta observação, excluiu-se a realização dos ensaios de compactação com 5 minutos em mesa vibratória.

A Figura 62 ilustra os resultados de espessura compactada com adensamento dos concretos dos seis caminhões do lote.

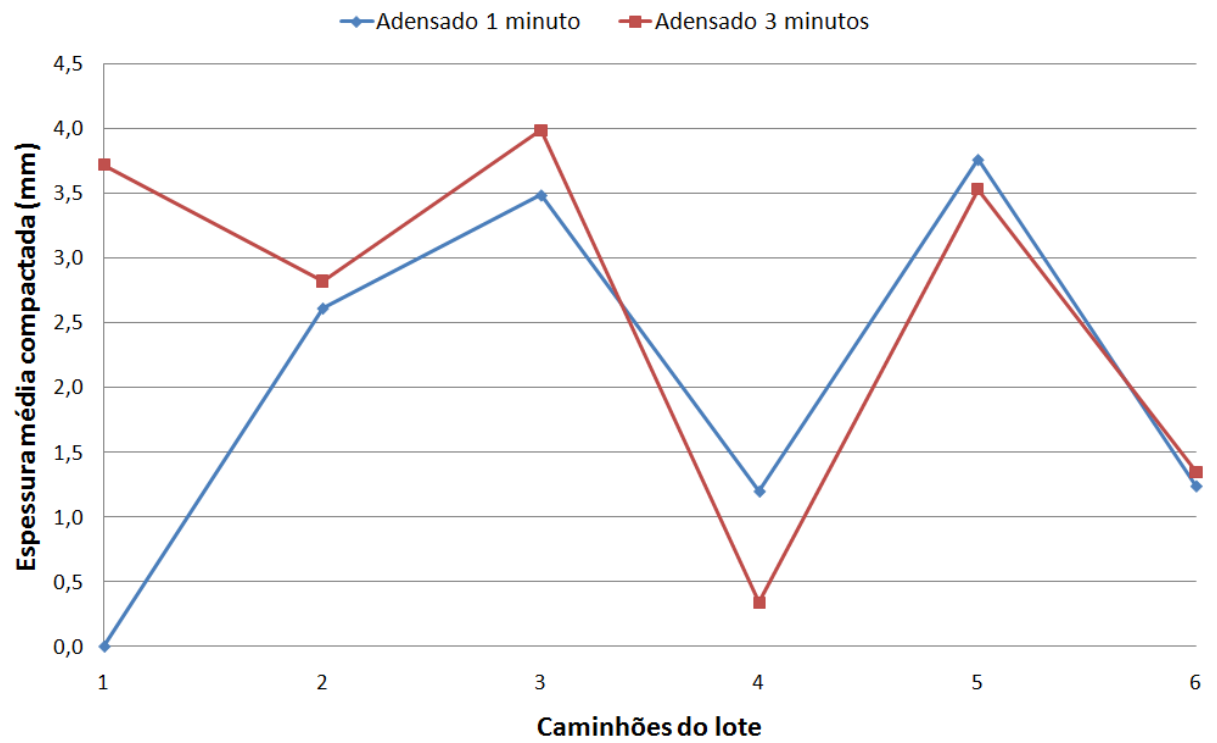

FIGURA 62 - Variação dos resultados da compactabilidade média do concreto fresco adensado em 1 minuto e 3 minutos de vibração, das amostras analisadas de seis caminhões do lote. Adaptado da BS EN 12.350-4 (2009).

Por comparação entre espessura compactada e teor de ar pressométrico pela Figura 63 , observa-se a dificuldade em comparar essas propriedades no estado fresco. Por exemplo, para o concreto $2 \mathrm{~B}$, o maior resultado de teor de ar pressométrico, sem correspondência para as espessuras médias compactadas a 1 e 3 minutos. Por outro lado, para os concretos 4D e 6F, em que foram obtidos os menores valores de espessuras compactadas médias, também foram obtidos os menores teores de ar pressométrico respectivamente. 


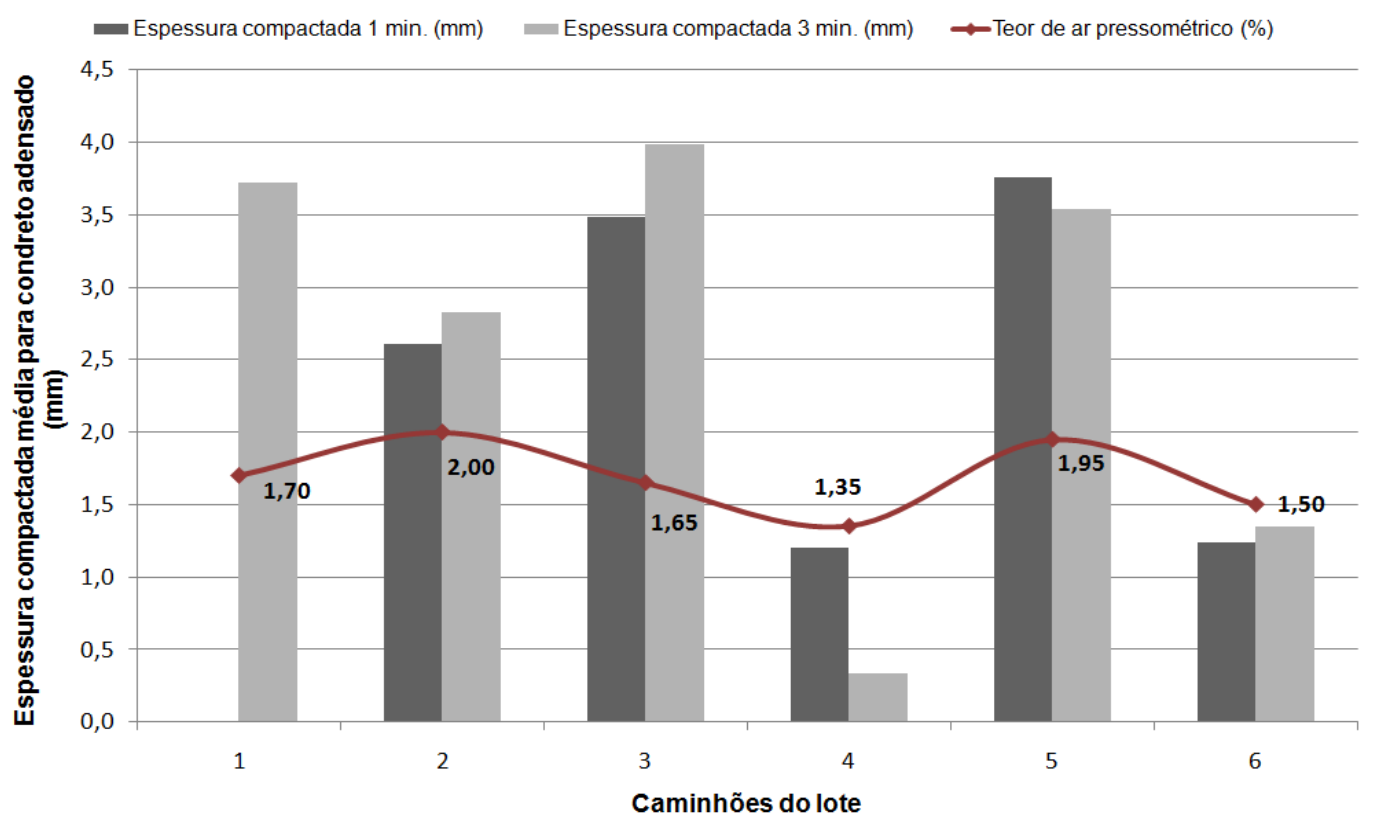

FIGURA 63 - Variação dos resultados de espessura compactada do concreto fresco adensado e teor de ar pelo método pressométrico das amostras de seis caminhões do lote analisado.

A norma européia BS EN 12350-4 (2009) expressa à interpretação dos resultados obtidos pelas médias de quatro medidas individuais de compactação, por um "grau de compactabilidade" em relação à altura do recipiente metálico em que é realizado o ensaio.

Assim, estes resultados podem ilustrar o quanto pode ser impreciso e inconclusivo determinar a qualidade do concreto fresco tão somente pelo ensaio de abatimento.

\section{E.2) Compactabilidade do concreto não-adensado}

A Tabela 34 a) e b) apresenta os resultados das medidas individuais, as médias por caminhão e média por lote, o desvio padrão, os valores máximos e mínimos, as amplitudes e o coeficiente de variação dos ensaios de compactabilidade do concreto fresco, quando não submetido a adensamento prévio, para o teste de compactação por vibração de 1 e 3 minutos, respectivamente. 
TABELA 34 - Resultados do ensaio de compactabilidade no concreto fresco nãoadensado (a-vibração $1 \mathrm{~min}$.) (b-vibração $3 \mathrm{~min}$.) das amostras de seis caminhões do lote analisado. Adaptado BS EN 12.350-4 (2009).

\begin{tabular}{|c|c|c|c|c|c|c|c|c|c|c|c|c|c|c|}
\hline \multicolumn{15}{|c|}{ a) Espessura compactada - mesa vibratória 1 minuto - Não-Adensado } \\
\hline \multirow[b]{2}{*}{ 昰 } & \multicolumn{6}{|c|}{ Medidas por amostra } & \multicolumn{8}{|c|}{ Cálculos para o lote } \\
\hline & $\begin{array}{c}\text { Medida } 1 \\
(\mathrm{~mm})\end{array}$ & $\begin{array}{c}\text { Medida } 2 \\
(\mathrm{~mm})\end{array}$ & $\begin{array}{l}\text { Média } \\
(\mathrm{mm})\end{array}$ & $\begin{array}{c}\text { Valor } \\
\text { máximo } \\
(\mathrm{mm})\end{array}$ & $\begin{array}{c}\text { Valor } \\
\text { mínimo } \\
(\mathrm{mm})\end{array}$ & $\begin{array}{l}\text { Amplitude } \\
\text { (mm) }\end{array}$ & $\begin{array}{l}\text { Média } \\
(\mathrm{mm})\end{array}$ & $\begin{array}{c}\text { Desvio } \\
\text { padrão } \\
(\mathrm{mm})\end{array}$ & $\begin{array}{c}\text { Coeficiente } \\
\text { de } \\
\text { variação } \\
(\%)\end{array}$ & $\begin{array}{l}\text { Valor } \\
\text { máximo } \\
(\mathrm{mm})\end{array}$ & $\begin{array}{c}\text { Valor } \\
\text { mínimo } \\
(\mathrm{mm})\end{array}$ & $\begin{array}{l}\text { Amplitude } \\
\text { das } \\
\text { médias } \\
\text { (mm) }\end{array}$ & $\begin{array}{l}\text { Intervalo } \\
\text { de } \\
\text { confiança } \\
\text { da média } \\
95 \%(\mathrm{~mm})\end{array}$ & $\begin{array}{c}\text { Teor de ar } \\
\text { equivalente } \\
(\%)\end{array}$ \\
\hline $1-\mathrm{A}$ & - & - & - & - & - & - & & & & & & & & - \\
\hline 2-B & 5,3 & 2,9 & 4,1 & 5,3 & 2,9 & 2,5 & & & & & & & & 1,4 \\
\hline $3-C$ & 2,8 & 4,3 & 3,6 & 4,3 & 2,8 & 1,5 & 4,1 & 2,4 & $58 \%$ & 6,4 & 0,4 & 5,9 & $\pm 2,1$ & 1,2 \\
\hline 4-D & 0,4 & 0,5 & 0,5 & 0,5 & 0,4 & 0,1 & & & & & & & & 0,2 \\
\hline $5-\mathrm{E}$ & 6,7 & 5,6 & 6,1 & 6,7 & 5,6 & 1,1 & & & & & & & & 2,1 \\
\hline 6-F & 5,4 & 7,4 & 6,4 & 7,4 & 5,4 & 2,0 & & & & & & & & 2,2 \\
\hline \multicolumn{15}{|c|}{ b) Espessura compactada - mesa vibratória 3 minutos - Não Adensado } \\
\hline \multirow[b]{2}{*}{ 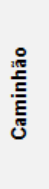 } & \multicolumn{6}{|c|}{ Medidas por amostra } & \multicolumn{8}{|c|}{ Cálculos para o lote } \\
\hline & $\begin{array}{c}\text { Medida } 1 \\
(\mathrm{~mm})\end{array}$ & $\begin{array}{c}\text { Medida } 2 \\
(\mathrm{~mm})\end{array}$ & $\begin{array}{c}\text { Média } \\
(\mathrm{mm})\end{array}$ & $\begin{array}{l}\text { Valor } \\
\text { máximo } \\
(\mathrm{mm})\end{array}$ & $\begin{array}{c}\text { Valor } \\
\text { mínimo } \\
(\mathrm{mm})\end{array}$ & $\begin{array}{l}\text { Amplitude } \\
\text { (mm) }\end{array}$ & $\begin{array}{c}\text { Média } \\
(\mathrm{mm})\end{array}$ & $\begin{array}{l}\text { Desvio } \\
\text { padrão } \\
\text { (mm) }\end{array}$ & $\begin{array}{c}\text { Coeficiente } \\
\text { de } \\
\text { variação } \\
(\%)\end{array}$ & $\begin{array}{l}\text { Valor } \\
\text { máximo } \\
(\mathrm{mm})\end{array}$ & $\begin{array}{c}\text { Valor } \\
\text { mínimo } \\
(\mathrm{mm})\end{array}$ & $\begin{array}{l}\text { Amplitude } \\
\text { das } \\
\text { médias } \\
(\mathrm{mm})\end{array}$ & $\begin{array}{l}\text { Intervalo } \\
\text { de } \\
\text { confiança } \\
\text { da média } \\
95 \%(\mathrm{~mm})\end{array}$ & $\begin{array}{c}\text { Teor de ar } \\
\text { médio } \\
\text { equivalente } \\
(\%)\end{array}$ \\
\hline $1-\mathrm{A}$ & - & - & - & - & - & - & & & & & & & & - \\
\hline 2-B & 4,0 & 2,9 & 3,5 & 4,0 & 2,9 & 1,1 & & & & & & & & 1,2 \\
\hline $3-C$ & 3,9 & 4,0 & 3,9 & 4,0 & 3,9 & 0,1 & 4,7 & 3,2 & $67 \%$ & 8,4 & 0,5 & 7,9 & $\pm 2,8$ & 1,4 \\
\hline 4-D & 0,4 & 0,6 & 0,5 & 0,6 & 0,4 & 0,1 & & & & & & & & 0,2 \\
\hline $5-E$ & 9,2 & 7,5 & 8,4 & 9,2 & 7,5 & 1,7 & & & & & & & & 2,9 \\
\hline 6-F & 6,7 & 8,0 & 7,3 & 8,0 & 6,7 & 1,3 & & & & & & & & 2,5 \\
\hline
\end{tabular}

A Figura 64 ilustra os resultados de espessura compactada média sem adensamento dos concretos dos seis caminhões do lote. Observa-se que os concretos dos caminhões $5 \mathrm{E}$ e 6F apresentaram valores mais elevados em comparação aos concretos dos demais caminhões.

Percebe-se, na Figura 64, que os resultados seguem uma mesma tendência para os concretos de cada caminhão, tanto nas medidas de compactação vibrando-se 1 minuto, quanto nas medidas de compactação por vibração de 3 minutos.

Para os ensaios de compactabilidade com vibração de 3 minutos obteve-se maiores médias de espessuras compactadas, exceto para o concreto $2 \mathrm{~B}$ que resultou com uma compactação menor nesse tempo e para o concreto $4 \mathrm{D}$, de mesmo resultado. Para o concreto $1 \mathrm{~A}$ essa propriedade não foi medida.

Percebe-se uma variação significativa nos resultados, observando as amplitudes e o coeficiente de variação, em ambos os tempos de vibração do concreto, o que provavelmente é indicativo da necessidade de melhor padronização do procedimento, por exemplo, usando a compactação de um volume menor de concreto fresco. 


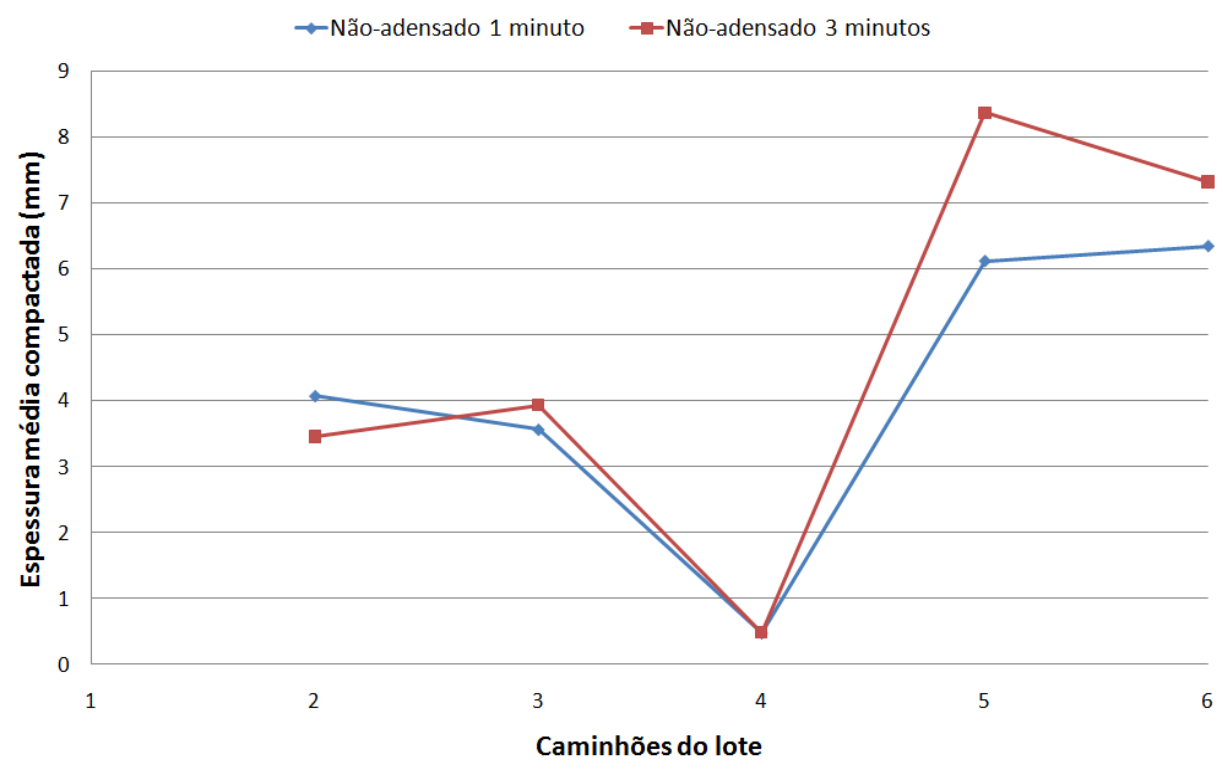

FIGURA 64 - Variação dos resultados da compactabilidade média do concreto fresco não-adensado em 1 minuto e 3 minutos de vibração, das amostras analisadas de seis caminhões do lote. Adaptado da BS EN 12.350-4 (2009).

Por comparação entre as espessuras compactadas e o teor de ar pelo método pressométrico pela Figura 65, observa-se algumas discrepâncias em comparar as propriedades no estado fresco, quanto a esta característica. Por exemplo, para o concreto 2B em que se verifica o maior resultado de teor de ar pelo método pressométrico, os resultados de espessura média compactada a 1 e 3 minutos não foram os maiores valores do lote. Por outro lado, para o concreto $4 \mathrm{D}$, foram obtidos os menores valores de espessura compactada média e também o menor teor de ar pressométrico. 


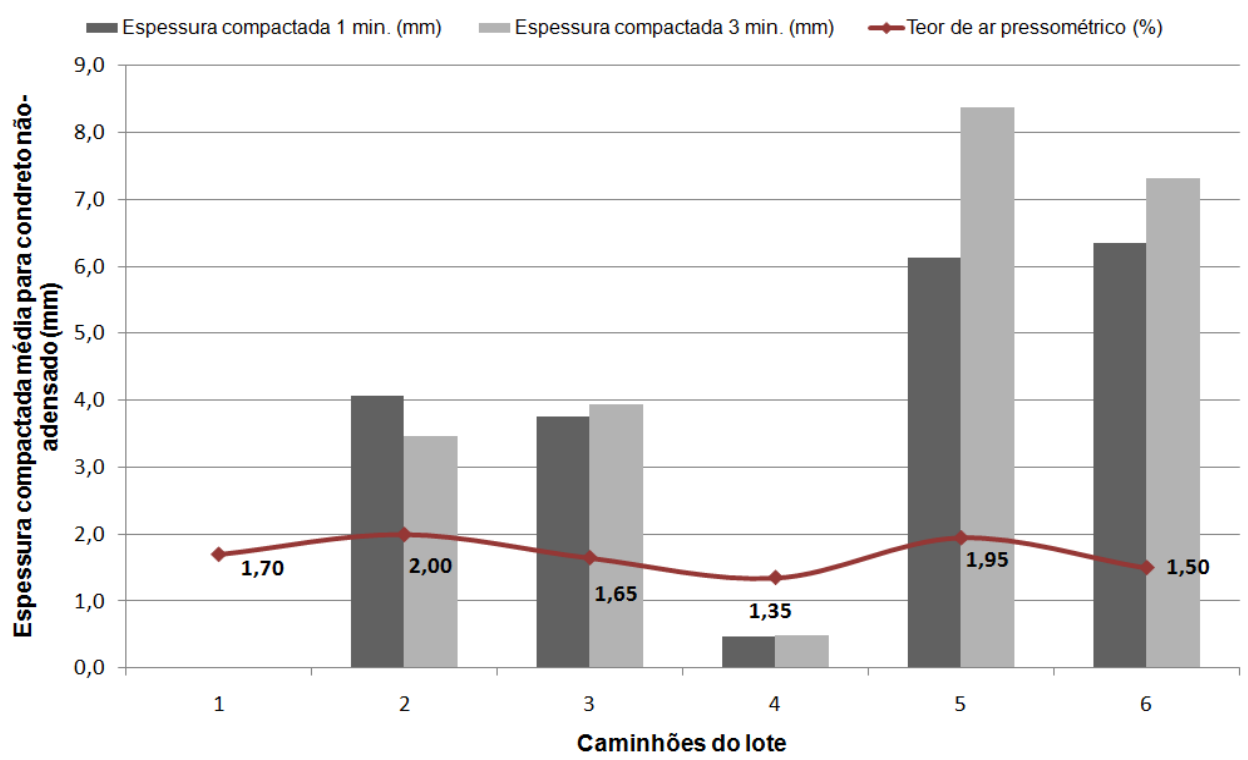

FIGURA 65 - Variação dos resultados de espessura compactada do concreto nãoadensado e do teor de ar pelo método pressométrico das amostras de concreto fresco, dos seis caminhões do lote analisado.

\section{F) Umidade do concreto fresco}

A Tabela 35 apresenta os resultados das medidas individuais, as médias, o desvio padrão, os valores máximos e mínimos, as amplitudes e o coeficiente de variação dos ensaios de umidade do concreto fresco dos seis caminhões do lote estudado.

Os valores de umidade determinados foram homogêneos, como pode ser verificado pela Figura 66, exceto para o concreto $2 \mathrm{~B}$, em que o resultado médio de umidade obtido foi o maior dentre os concretos do lote analisado. Além do que, pode-se observar também que o concreto 2B apresentou valores médios de teor de ar gravimétrico, teor de ar pressométrico e slump acima dos demais, porém esse concreto apresentou menor valor de massa específica. Então é possível que o concreto $2 \mathrm{~B}$ tenha sido fornecido com alguma alteração de dosagem que esteja relacionada a um maior teor de argamassa, pelo menos nas amostras que se caracterizou a umidade. Apesar de não ter sido encontrado nada diferente, nos relatórios de pesagem da automação da central dosadora, isto pode ser uma explicação. 
TABELA 35 - Resultados do ensaio de umidade no concreto fresco das amostras de seis caminhões do lote analisado. Adaptado da ABNT NBR 9605 (1992).

\begin{tabular}{|c|c|c|c|c|c|c|c|c|c|c|c|c|c|}
\hline \multirow[b]{2}{*}{ 昰 } & \multicolumn{6}{|c|}{ Medidas por amostra } & \multicolumn{7}{|c|}{ Cálculos para o lote } \\
\hline & $\begin{array}{c}\text { Medida } 1 \\
(\%)\end{array}$ & $\begin{array}{c}\text { Medida } 2 \\
(\%)\end{array}$ & $\begin{array}{c}\text { Média } \\
(\%)\end{array}$ & $\begin{array}{c}\text { Valor } \\
\text { Máximo } \\
(\%)\end{array}$ & $\begin{array}{c}\text { Valor } \\
\text { Mínimo } \\
(\%)\end{array}$ & $\begin{array}{l}\text { Amplitude } \\
(\%)\end{array}$ & $\begin{array}{c}\text { Média } \\
(\%)\end{array}$ & $\begin{array}{l}\text { Desvio } \\
\text { padrão }\end{array}$ & $\begin{array}{l}\text { Coef. de } \\
\text { variação }\end{array}$ & $\begin{array}{c}\text { Valor } \\
\text { Máximo } \\
(\%)\end{array}$ & $\begin{array}{c}\text { Valor } \\
\text { Mínimo } \\
(\%)\end{array}$ & $\begin{array}{l}\text { Amplitude } \\
\text { das } \\
\text { médias (\%) }\end{array}$ & $\begin{array}{c}\text { Intervalo } \\
\text { de } \\
\text { confiança } \\
\text { da média } \\
95 \%(\%)\end{array}$ \\
\hline $1 \mathrm{~A}$ & 7,6 & 6,6 & 7,1 & 9,1 & 6,6 & 2,5 & \multirow{6}{*}{7,5} & \multirow{6}{*}{0,8} & \multirow{6}{*}{$10 \%$} & \multirow{6}{*}{9,1} & \multirow{6}{*}{7,1} & \multirow{6}{*}{2,0} & \multirow{6}{*}{ $\pm 0,6$} \\
\hline $2 \mathrm{~B}$ & 9,1 & 9,0 & 9,1 & 9,1 & 9,0 & 0,1 & & & & & & & \\
\hline $3 \mathrm{C}$ & 7,9 & 7,0 & 7,4 & 7,9 & 7,0 & 0,9 & & & & & & & \\
\hline $4 \mathrm{D}$ & 7,2 & 7,1 & 7,2 & 7,5 & 7,1 & 0,4 & & & & & & & \\
\hline $5 \mathrm{E}$ & 6,9 & 7,5 & 7,2 & 7,5 & 6,9 & 0,7 & & & & & & & \\
\hline $6 \mathrm{~F}$ & 6,9 & 7,5 & 7,2 & 7,5 & 6,9 & 0,5 & & & & & & & \\
\hline
\end{tabular}

O método de ensaio testado se mostrou eficiente, de fácil execução em laboratório e possível de ser realizado para controle tecnológico, mas exige condições especiais para ser executado em campo.

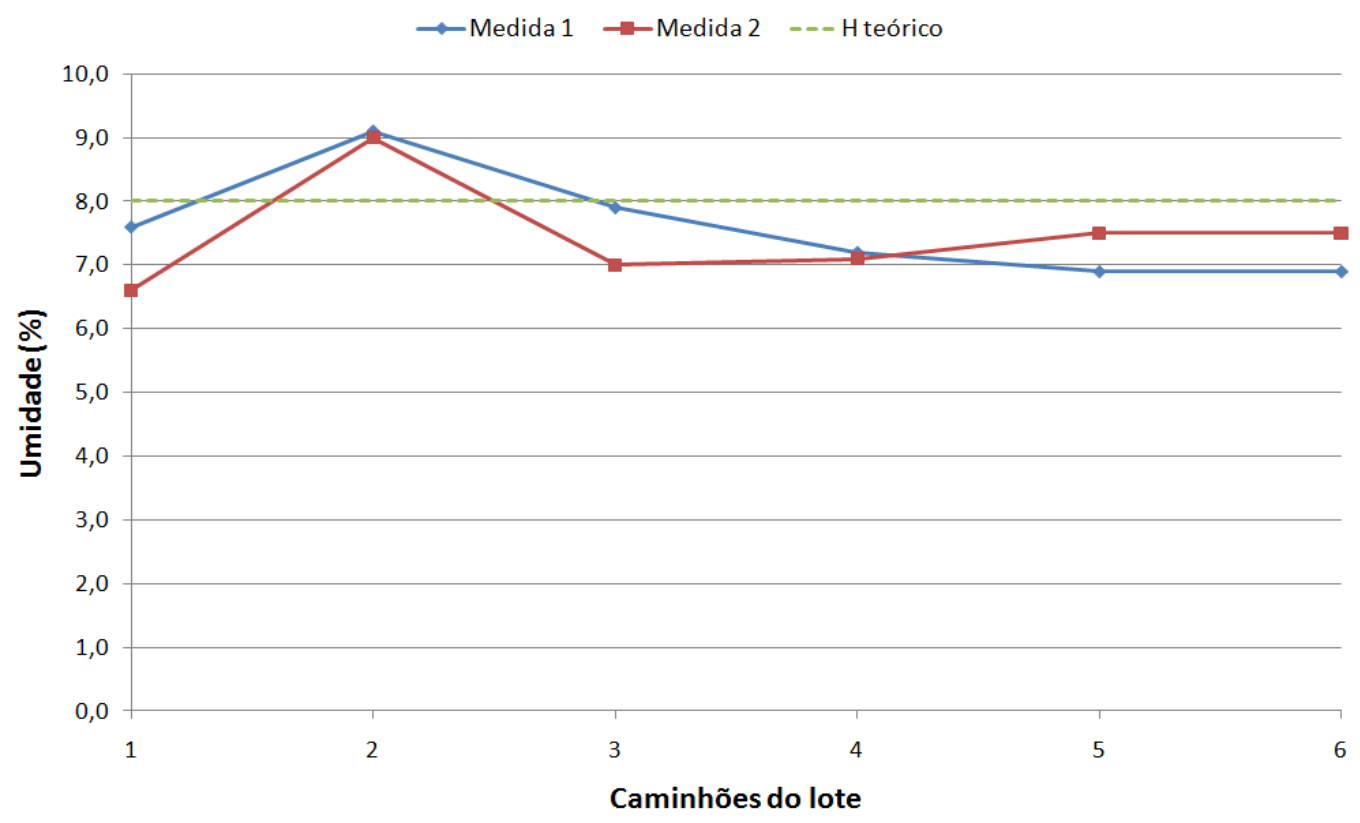

FIGURA 66 - Variação dos resultados de umidade das amostras de seis caminhões do lote analisado. Adaptado da ABNT NBR 9605 (1992). 
G) Teor de finos total $<75 \mu \mathrm{m}$ no concreto fresco

A Tabela 36 apresenta os resultados das medidas individuais, as médias, o desvio padrão, os valores máximos e mínimos, as amplitudes e o coeficiente de variação dos ensaios de lavagem do concreto fresco - determinação do teor de finos total $<75 \mu \mathrm{m}$, referidos à massa seca esperimental dos concretos dos seis caminhões do lote estudado.

TABELA 36 - Resultados do ensaio de teor de finos total das amostras de concreto fresco de seis caminhões do lote analisado. Adaptado da ABNT NBR 9605 (1992).

\begin{tabular}{|c|c|c|c|c|c|c|c|c|c|c|c|c|c|}
\hline \multirow[b]{2}{*}{ 这 } & \multicolumn{6}{|c|}{ Medidas por amostra } & \multicolumn{7}{|c|}{ Cálculos para o lote } \\
\hline & $\begin{array}{c}\text { Medida } 1 \\
(\%)\end{array}$ & $\begin{array}{c}\text { Medida } 2 \\
(\%)\end{array}$ & $\begin{array}{c}\text { Média } \\
(\%)\end{array}$ & $\begin{array}{c}\text { Valor } \\
\text { máximo } \\
(\%)\end{array}$ & $\begin{array}{c}\text { Valor } \\
\text { mínimo } \\
(\%)\end{array}$ & $\begin{array}{c}\text { Amplitude } \\
(\%)\end{array}$ & Média (\%) & $\begin{array}{c}\text { Desvio } \\
\text { Padrão } \\
(\%)\end{array}$ & $\begin{array}{c}\text { Coeficiente } \\
\text { de } \\
\text { variação } \\
(\%) \\
\end{array}$ & $\begin{array}{c}\text { Valor } \\
\text { máximo } \\
(\%)\end{array}$ & $\begin{array}{c}\text { Valor } \\
\text { mínimo } \\
(\%)\end{array}$ & $\begin{array}{l}\text { Amplitude } \\
\text { das } \\
\text { médias (\%) }\end{array}$ & $\begin{array}{c}\text { Intervalo de } \\
\text { confiança } \\
\text { da média } \\
95 \%(\%)\end{array}$ \\
\hline $1 \mathrm{~A}$ & 17,7 & 16,4 & 17,0 & 17,7 & 16,4 & 1,28 & & & & & & & \\
\hline $2 B$ & 17,6 & 17,6 & 17,6 & 17,6 & 17,6 & 0,00 & & & & & & & \\
\hline $3 \mathrm{C}$ & 15,0 & 14,6 & 14,8 & 15,0 & 14,6 & 0,36 & & & & & & & \\
\hline & & & & & & & 16,1 & 1,0 & $7 \%$ & 17,6 & 14,8 & 2,8 & $\pm 0,84$ \\
\hline 4D & 15,7 & 15,1 & 15,4 & 15,7 & 15,1 & 0,57 & & & & & & & \\
\hline $5 \mathrm{E}$ & 15,6 & 16,1 & 15,8 & 16,1 & 15,6 & 0,50 & & & & & & & \\
\hline $6 \mathrm{~F}$ & 16,0 & 15,6 & 15,8 & 16,0 & 15,6 & 0,37 & & & & & & & \\
\hline
\end{tabular}

Pela Figura 67 percebe-se que o concreto 2B apresentou um resultado de teor de finos total $<75 \mu \mathrm{m}$ maior quando comparado com os demais concretos, estando este resultado mais próximo ao resultado médio do concreto $1 \mathrm{~A}$. $\mathrm{O}$ resultado do concreto $2 \mathrm{~B}$ pode ser explicado por alguma falha na execução do ensaio desse caminhão, porém os resultados das duas amostras foram iguais. Este resultado referente ao concreto 2B pode também ser correlacionado com o resultado de umidade deste mesmo concreto, que foi o maior resultado dentre os demais concretos. Para o concreto $3 \mathrm{C}$ obteve-se o menor resultado de teor de finos total, porém as medidas estão próximas aos demais concretos 4D, 5E e 6F. O ensaio se mostrou homogêneo para os todos os concretos do lote, como se podem observar através dos resultados de desvios padrão e coeficientes de variação, que estão dentro de limites aceitáveis. O teor de finos total teórico calculado para as quantidades de material do traço, com seus respectivos materiais aglomerantes e fração de pulverulentos dos agregados foi de $15 \%$. 


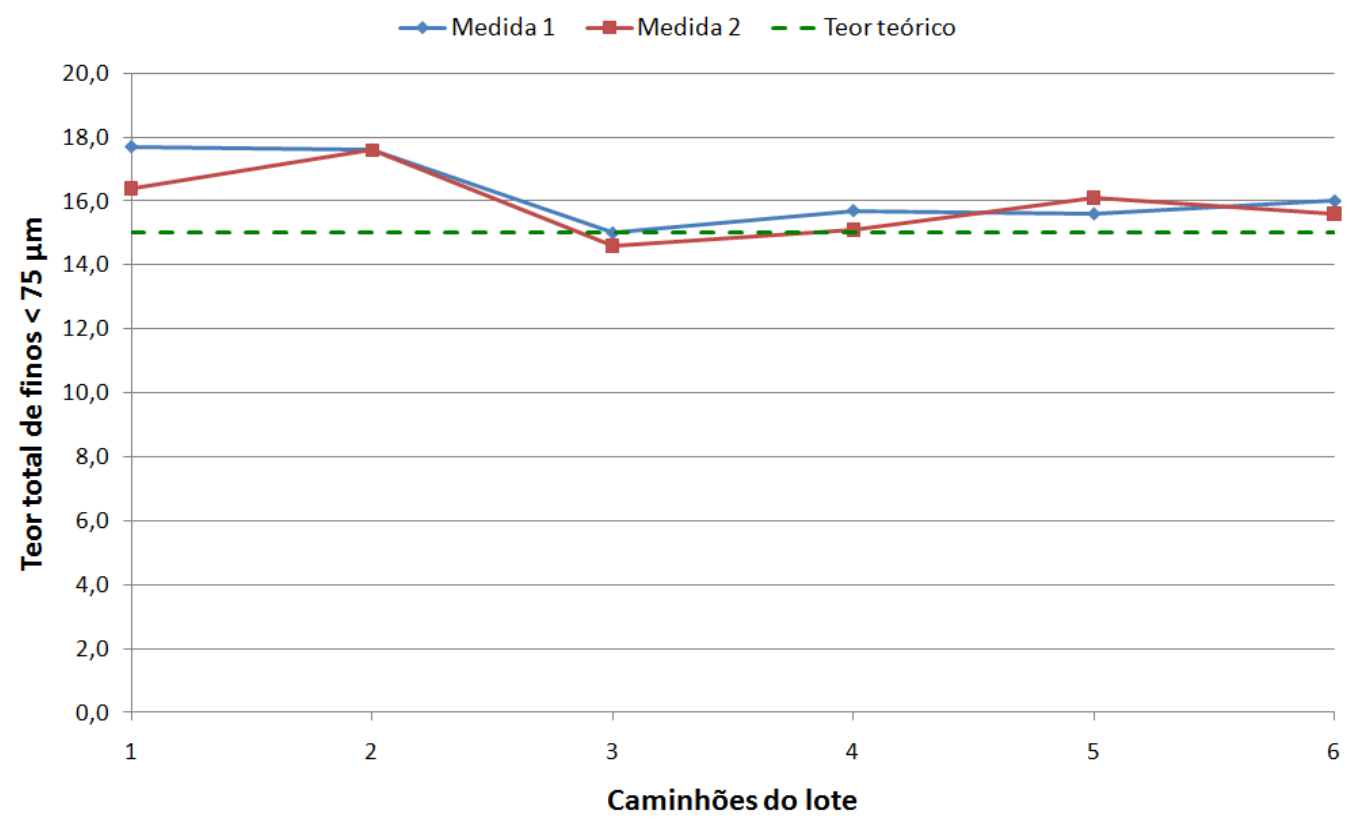

FIGURA 67 - Variação dos resultados de teor de finos total $<75 \mu \mathrm{m}$ de amostras de concreto fresco dos seis caminhões do lote analisado. Adaptado ABNT NBR 9605 (1992).

\subsubsection{Propriedades do concreto endurecido}

\section{A) Resistência à compressão}

As propriedades a seguir discutidas foram medidas em corpos-de-prova moldados e curados segundo os procedimentos descritos no Capítulo 3. Cabe observar que no ato da desforma de todos os corpos-de-prova, em dia seguinte à moldagem, observou-se um assentamento e retração plástica do concreto, o qual, entretanto não pode ser medido, mas foi depois interpretado por ensaio de calorimetria em amostras similares do cimento e aditivos usados na concretagem (Item 1.6 Apêndice A).

\section{A.1) Resistência à compressão a 1 dia por cura acelerada de 1 dia $\left(f c_{1}\right.$-acel 0/1)}

A Tabela 37 apresenta os resultados das medidas individuais, as médias, o desvio padrão, os valores máximos e mínimos, as amplitudes e o coeficiente de variação dos ensaios de resistência à compressão a 1 dia de idade $\left(f_{c 1-a c e l .0 / 1}\right)$ do concreto de seis dos caminhões do lote estudado. Os corpos-de-prova foram submetidos à cura acelerada por 
aproximadamente 24 horas a uma temperatura amena da água, em torno de $35 \pm 3^{\circ} \mathrm{C}$. Conforme a NBR 12655 (2006), a resistência do exemplar é o maior valor entre os dois valores obtidos e é isto o que está considerado nas análises.

Pelos resultados apresentados, os concretos $1 \mathrm{~A}$ e $2 \mathrm{~B}$ apresentaram maiores resistências em comparação aos demais. Estes concretos apresentaram em comum, maiores resultados de teor de finos total, podendo ser as justificativas para obterem maiores resistências iniciais. Em observação aos relatórios de pesagem da automação da central dosadores, verificou-se que para o concreto $1 \mathrm{~A}$ a relação água/cimento real foi menor em relação aos demais concretos. Este concreto apresentou um desvio na pesagem do cimento a maior, cerca de $60 \mathrm{~kg}$. Porém não pode ser contatado para o concreto $2 \mathrm{~B}$ esse desvio significativo na pesagem do cimento.

TABELA 37 - Resultados do ensaio de resistência à compressão do concreto endurecido a 1 dia de idade, por cura acelerada, de corpos-de-prova moldados de seis dos caminhões do lote analisado. Adaptado da ASTM C 684 (1999) e ABNT NBR 5739 (2007).

\begin{tabular}{|c|c|c|c|c|c|c|c|c|c|c|c|c|}
\hline \multirow[b]{2}{*}{ 昰 } & \multicolumn{5}{|c|}{ Medidas por amostra } & \multicolumn{7}{|c|}{ Cálculos para o lote } \\
\hline & $\begin{array}{c}\mathrm{f}_{\mathrm{c} 1-\text { acel. } 0 / 1} \\
(\mathrm{MPa})\end{array}$ & $\begin{array}{l}\text { Média } \\
(\mathrm{MPa})\end{array}$ & $\begin{array}{c}\text { Valor } \\
\text { Máximo* }^{*} \\
\text { (MPa) }\end{array}$ & $\begin{array}{l}\text { Valor } \\
\text { Mínimo } \\
\text { (MPa) }\end{array}$ & $\begin{array}{l}\text { Amplitude } \\
\text { (MPa) }\end{array}$ & $\begin{array}{l}\text { Média } \\
(\mathrm{MPa})\end{array}$ & $\begin{array}{c}\text { Desvio } \\
\text { padrão (MPa) }\end{array}$ & $\begin{array}{l}\text { Coeficient } \\
\text { e de } \\
\text { variação } \\
(\%)\end{array}$ & $\begin{array}{l}\text { Valor } \\
\text { Máximo } \\
\text { (MPa) }\end{array}$ & $\begin{array}{l}\text { Valor } \\
\text { Mínimo } \\
\text { (MPa) }\end{array}$ & $\begin{array}{c}\text { Amplitude } \\
\text { das } \\
\text { médias } \\
\text { (MPa) }\end{array}$ & $\begin{array}{c}\text { Intervalo de } \\
\text { confiança da } \\
\text { média 95\% } \\
\text { (MPa) }\end{array}$ \\
\hline $1 \mathrm{~A}$ & $\begin{array}{l}25,4 \\
27,7\end{array}$ & 26,6 & 27,7 & 25,4 & 2,3 & \multirow{6}{*}{23,4} & \multirow{6}{*}{3,1} & \multirow{6}{*}{$13 \%$} & \multirow{6}{*}{27,7} & \multirow{6}{*}{20,3} & \multirow{6}{*}{7,4} & \multirow{6}{*}{ $\pm 2,5$} \\
\hline $2 \mathrm{~B}$ & $\begin{array}{l}28,5 \\
26,9\end{array}$ & 27,7 & 28,5 & 26,9 & 1,6 & & & & & & & \\
\hline $3 \mathrm{C}$ & $\begin{array}{l}24,0 \\
23,6\end{array}$ & 23,8 & 24,0 & 23,6 & 0,4 & & & & & & & \\
\hline $4 \mathrm{D}$ & $\begin{array}{l}22,2 \\
20,7\end{array}$ & 21,4 & 22,2 & 20,7 & 1,5 & & & & & & & \\
\hline $5 \mathrm{E}$ & $\begin{array}{l}21,4 \\
20,4\end{array}$ & 20,9 & 21,4 & 20,4 & 1,0 & & & & & & & \\
\hline $6 \mathrm{~F}$ & $\begin{array}{l}20,3 \\
20,2\end{array}$ & 20,3 & 20,3 & 20,2 & 0,1 & & & & & & & \\
\hline
\end{tabular}

$\left(^{\star}\right)$ Valor do exemplar para cálculo de $f_{c k, e s t}$.

Os valores de resistência dos exemplares de $5 \mathrm{E}$ e $6 \mathrm{~F}$ podem estar afetados pela idade de maturação, no horário do ensaio.

\section{A.2) Resistência à compressão a 2 dias por cura acelerada de 1 a 2 dias} $\left(f_{\mathrm{c} 2-\text { acel.1/2) }}\right)$

A Tabela 38 apresenta os resultados das medidas individuais, as médias, o desvio padrão, os valores máximos e mínimos, as amplitudes e o coeficiente de variação dos ensaios de resistência à compressão a 2 dias de idade $\left(\mathfrak{f}_{c 2-\text { acel.1/2) }}\right)$ do concreto de seis dos caminhões do lote estudado. Os corpos-de-prova foram submetidos à cura acelerada de aproximadamente 24 até 48 horas a uma temperatura amena da água, em torno de $35 \pm$ 
$3^{\circ} \mathrm{C}$. Pelos resultados apresentados, os concretos $1 \mathrm{~A}$ e $2 \mathrm{~B}$ apresentaram novamente maiores resistências dos concretos em comparação aos demais concretos.

Os resultados dos concretos $1 \mathrm{~A}$ e $2 \mathrm{~B}$ apresentaram resistências muito próximas à resistência característica ( $f_{c k} 30 \mathrm{MPa}$ ) chamando à atenção de que é possível obter eficiência da cura acelerada testada neste trabalho, para efeito de controle de qualidade.

TABELA 38 - Resultados do ensaio de resistência à compressão do concreto endurecido a 2 dias de idade, por cura acelerada de 1 a 2 dias, de corpos-de-prova moldados de seis dos caminhões do lote analisado. Adaptado da ASTM C 684 (1999) e ABNT NBR 5739 (2007).

\begin{tabular}{|c|c|c|c|c|c|c|c|c|c|c|c|c|}
\hline \multirow[b]{2}{*}{ } & \multicolumn{5}{|c|}{ Medidas por amostra } & \multicolumn{7}{|c|}{ Cálculos para o lote } \\
\hline & $\begin{array}{c}\mathrm{f}_{\mathrm{c} 2 \text { - acel.1/2 }} \\
(\mathrm{MPa})\end{array}$ & $\begin{array}{l}\text { Média } \\
(\mathrm{MPa})\end{array}$ & $\begin{array}{l}\text { Valor } \\
\text { Máximo } \\
\text { (MPa) }\end{array}$ & $\begin{array}{c}\text { Valor } \\
\text { Mínimo } \\
\text { (MPa) }\end{array}$ & $\begin{array}{c}\text { Amplitude } \\
\text { (MPa) }\end{array}$ & $\begin{array}{l}\text { Média } \\
(\mathrm{MPa})\end{array}$ & $\begin{array}{c}\text { Desvio } \\
\text { padrão (MPa) }\end{array}$ & $\begin{array}{c}\text { Coeficiente } \\
\text { de } \\
\text { variação } \\
(\%)\end{array}$ & $\begin{array}{l}\text { Valor } \\
\text { Máximo } \\
\text { (MPa) }\end{array}$ & $\begin{array}{c}\text { Valor } \\
\text { Mínimo } \\
\text { (MPa) }\end{array}$ & $\begin{array}{l}\text { Amplitude } \\
\text { (MPa) }\end{array}$ & $\begin{array}{c}\text { Intervalo de } \\
\text { confiança da } \\
\text { média 95\% } \\
\text { (MPa) }\end{array}$ \\
\hline $1 \mathrm{~A}$ & $\begin{array}{l}28,9 \\
29,0\end{array}$ & 28,9 & 29,0 & 28,9 & 0,1 & \multirow{6}{*}{26,1} & \multirow{6}{*}{3,0} & \multirow{6}{*}{$11 \%$} & \multirow{6}{*}{29,5} & \multirow{6}{*}{20,7} & \multirow{6}{*}{8,8} & \multirow{6}{*}{ $\pm 2,4$} \\
\hline $2 \mathrm{~B}$ & $\begin{array}{l}29,8 \\
29,1\end{array}$ & 29,5 & 29,8 & 29,1 & 0,7 & & & & & & & \\
\hline $3 \mathrm{C}$ & $\begin{array}{l}25,7 \\
27,0\end{array}$ & 26,3 & 27,0 & 25,7 & 1,3 & & & & & & & \\
\hline $4 \mathrm{D}$ & $\begin{array}{l}22,0 \\
20,7\end{array}$ & 21,4 & 22,0 & 20,7 & 1,3 & & & & & & & \\
\hline $5 \mathrm{E}$ & $\begin{array}{l}26,5 \\
25,5\end{array}$ & 26,0 & 26,5 & 25,5 & 1,0 & & & & & & & \\
\hline $6 \mathrm{~F}$ & $\begin{array}{l}24,5 \\
24,9 \\
\end{array}$ & 24,7 & 24,9 & 24,5 & 0,4 & & & & & & & \\
\hline
\end{tabular}

O concreto 4D apresentou resultado inferior entre todos, mantendo o comportamento inferior aos outros concretos nas demais idades e apresentou também menores resultados de compactabilidade adensada e não-adensada.

\section{A.3) Resistência à compressão a 3 dias por cura acelerada de 1 a 3 dias}

$\left(f_{c 3-\text { acel.1/3) }}\right.$

A Tabela 39 apresenta os resultados das medidas individuais, as médias, o desvio padrão, os valores máximos e mínimos, as amplitudes e o coeficiente de variação dos ensaios de resistência à compressão a 3 dias de idade $\left(f_{c 3}\right.$ - acel.1/3) de corpos-de-prova de seis dos caminhões do lote estudado. Os corpos-de-prova foram submetidos à cura acelerada de aproximadamente 24/72 horas a uma temperatura amena da água em torno de $35 \pm 3^{\circ} \mathrm{C}$. Pelos resultados apresentados, constata-se uma maior proximidade nos valores das resistências nessa idade, exceto para o concreto $5 \mathrm{E}$ que obteve maior valor de resistência e concreto 4D que obteve menor resistência. 
TABELA 39 - Resultados do ensaio de resistência à compressão do concreto endurecido a 3 dias de idade, por cura acelerada de 1 a 3 dias, de corpos-de-prova moldados de seis dos caminhões do lote analisado. Adaptado da ASTm C 684 (1999) e ABNT NBR 5739 (2007).

\begin{tabular}{|c|c|c|c|c|c|c|c|c|c|c|c|c|c|}
\hline \multirow[b]{2}{*}{ 竞 } & \multicolumn{5}{|c|}{ Medidas por amostra } & \multicolumn{8}{|c|}{ Cálculos para o lote } \\
\hline & $\begin{array}{c}\mathrm{f}_{\mathrm{c} 3 \text { - acel.1/3 }} \\
(\mathrm{MPa})\end{array}$ & $\begin{array}{l}\text { Média } \\
\text { (MPa) }\end{array}$ & $\begin{array}{l}\text { Valor } \\
\text { Máximo } \\
\text { (MPa) }\end{array}$ & $\begin{array}{c}\text { Valor } \\
\text { Mínimo } \\
\text { (MPa) }\end{array}$ & $\begin{array}{c}\text { Amplitude } \\
\text { (MPa) }\end{array}$ & Média & (MPa) & $\begin{array}{c}\text { Desvio } \\
\text { padrão }(\mathrm{MPa})\end{array}$ & $\begin{array}{c}\text { Coeficiente } \\
\text { de } \\
\text { variação } \\
(\%)\end{array}$ & $\begin{array}{l}\text { Valor } \\
\text { Máximo } \\
\text { (MPa) }\end{array}$ & $\begin{array}{l}\text { Valor } \\
\text { Mínimo } \\
\text { (MPa) }\end{array}$ & $\begin{array}{c}\text { Amplitude } \\
\text { das } \\
\text { médias } \\
\text { (MPa) }\end{array}$ & $\begin{array}{c}\text { Intervalo de } \\
\text { confiança da } \\
\text { média } 95 \% \\
\text { (MPa) }\end{array}$ \\
\hline $1 \mathrm{~A}$ & $\begin{array}{l}31,4 \\
32,7\end{array}$ & 32,0 & 32,7 & 31,4 & 1,3 & \multirow{6}{*}{31,8} & & \multirow{6}{*}{2,4} & \multirow{6}{*}{$7 \%$} & \multirow{6}{*}{34,7} & \multirow{6}{*}{28,4} & \multirow{6}{*}{6,3} & \multirow{6}{*}{ $\pm 1,9$} \\
\hline $2 \mathrm{~B}$ & $\begin{array}{l}33,6 \\
33,6\end{array}$ & 33,6 & 33,6 & 33,6 & 0,0 & & & & & & & & \\
\hline $3 \mathrm{C}$ & $\begin{array}{l}32,9 \\
31,5\end{array}$ & 32,2 & 32,9 & 31,5 & 1,4 & & & & & & & & \\
\hline 4D & $\begin{array}{l}28,2 \\
28,6\end{array}$ & 28,4 & 28,6 & 28,2 & 0,4 & & & & & & & & \\
\hline $5 \mathrm{E}$ & $\begin{array}{l}34,8 \\
34,6\end{array}$ & 34,7 & 34,8 & 34,6 & 0,1 & & & & & & & & \\
\hline $6 \mathrm{~F}$ & $\begin{array}{l}29,3 \\
30,0\end{array}$ & 29,6 & 30,0 & 29,3 & 0,8 & & & & & & & & \\
\hline
\end{tabular}

Com exceção do concreto 4D, que apresentou alguma anomalia, os demais concretos do lote amostrado já apresentaram resultados iguais ou superiores à resistência característica ( $f_{c k} 30 \mathrm{MPa}$ ) e com baixo coeficiente de variação, podendo-se afirmar eficiência no método de cura acelerada testada neste trabalho. Mesmo assim, há necessidade de maiores estudos para prolongar o tempo no tanque de cura, pois em comparação com os resultados aos 28 dias de idade em cura normal, observa-se que as resistências continuaram crescendo, ou seja, pode-se obter a resistência característica, mas a resistência cura normal foi ainda maior. Como o aditivo polifuncional usado mostrou efeito sobre o calor de hidratação, é necessário ponderar isto também.

\section{A.4) Resistência à compressão a 7 dias por cura acelerada de 1 a 3 dias $\left(f_{c 7 a c e l .}\right)$}

A Tabela 40 apresenta os resultados das medidas individuais, as médias, o desvio padrão, os valores máximos e mínimos, as amplitudes e o coeficiente de variação dos ensaios de resistência à compressão a 7 dias de idade $\left(f_{\text {c7- acel.1/7 }}\right)$ dos corpos-de-prova de seis dos caminhões do lote estudado. Os corpos-de-prova foram submetidos à cura acelerada de aproximadamente 24/72 horas a uma temperatura amena da água em torno de $35 \pm 3^{\circ} \mathrm{C}$ seguida de cura submersa em água temperatura ambiente até 7 dias de idade. Pelos resultados apresentados, constata-se um crescimento de $20 \%$ da resistência em relação à condição do item A.3. As resistências dos caminhões se mostraram em média $30 \%$ maiores que a resistência característica ( $\left.f_{c k} 30 \mathrm{MPa}\right)$. 
TABELA 40 - Resultados do ensaio de resistência à compressão do concreto endurecido a 7 dias de idade, por cura acelerada de 1 a 3 dias, de corpos-de-prova moldados de seis doscaminhões do lote analisado. Adaptado da ASTM C 684 (1999) e ABNT NBR 5739 (2007).

\begin{tabular}{|c|c|c|c|c|c|c|c|c|c|c|c|c|}
\hline \multirow[b]{2}{*}{ 选 } & \multicolumn{5}{|c|}{ Medidas por amostra } & \multicolumn{7}{|c|}{ Cálculos para o lote } \\
\hline & $\begin{array}{c}\mathrm{f}_{\mathrm{c7} \text { - acel.11/7 }} \\
\mathrm{MPa} \text { ) }\end{array}$ & $\begin{array}{l}\text { Média } \\
(\mathrm{MPa})\end{array}$ & $\begin{array}{l}\text { Valor } \\
\text { Máximo } \\
\text { (MPa) }\end{array}$ & $\begin{array}{c}\text { Valor } \\
\text { Mínimo } \\
\text { (MPa) }\end{array}$ & $\begin{array}{c}\text { Amplitude } \\
\text { (MPa) }\end{array}$ & $\begin{array}{l}\text { Média } \\
(\mathrm{MPa})\end{array}$ & $\begin{array}{c}\text { Desvio } \\
\text { padrão (MPa) }\end{array}$ & $\begin{array}{c}\text { Coeficiente } \\
\text { de } \\
\text { variação } \\
(\%)\end{array}$ & $\begin{array}{l}\text { Valor } \\
\text { Máximo } \\
\text { (MPa) }\end{array}$ & $\begin{array}{c}\text { Valor } \\
\text { Mínimo } \\
\text { (MPa) }\end{array}$ & $\begin{array}{c}\text { Amplitude } \\
\text { das } \\
\text { médias } \\
\text { (MPa) }\end{array}$ & $\begin{array}{l}\text { Intervalo de } \\
\text { confiança da } \\
\text { média } 95 \% \\
\text { (MPa) }\end{array}$ \\
\hline $1 \mathrm{~A}$ & $\begin{array}{l}42,8 \\
38,3\end{array}$ & 40,5 & 42,8 & 38,3 & 4,4 & \multirow{6}{*}{37,5} & \multirow{6}{*}{3,9} & \multirow{6}{*}{$10 \%$} & \multirow{6}{*}{40,5} & \multirow{6}{*}{30,3} & \multirow{6}{*}{10,3} & \multirow{6}{*}{ $\pm 3,1$} \\
\hline $2 \mathrm{~B}$ & $\begin{array}{l}40,1 \\
40,2\end{array}$ & 40,1 & 40,2 & 40,1 & 0,0 & & & & & & & \\
\hline $3 \mathrm{C}$ & $\begin{array}{l}38,8 \\
38,0\end{array}$ & 38,4 & 38,8 & 38,0 & 0,8 & & & & & & & \\
\hline 4D & $\begin{array}{l}31,4 \\
29,1\end{array}$ & 30,3 & 31,4 & 29,1 & 2,3 & & & & & & & \\
\hline $5 \mathrm{E}$ & $\begin{array}{l}40,4 \\
38,9\end{array}$ & 39,7 & 40,4 & 38,9 & 1,6 & & & & & & & \\
\hline $6 \mathrm{~F}$ & $\begin{array}{l}35,8 \\
36,3\end{array}$ & 36,0 & 36,3 & 35,8 & 0,4 & & & & & & & \\
\hline
\end{tabular}

O concreto 4D apresentou resultado inferior entre todos, mantendo o comportamento inferior aos outros concretos nas demais idades.

\section{A.5) Resistência à compressão por cura normal de 1 a 28 dias $\left(f_{c 28 n}\right)$}

A Tabela 41 apresenta os resultados das medidas individuais, as médias, o desvio padrão, os valores máximos e mínimos, as amplitudes e o coeficiente de variação dos ensaios de resistência à compressão a 28 dias de idade $\left(f_{c 28 n}\right)$ dos seis caminhões do lote estudado. Os corpos-de-prova foram submetidos à cura úmida normal de 24 horas até 28 dias. Pelos resultados apresentados, constata-se que o concreto $5 \mathrm{E}$ obteve maiores resistências.

TABELA 41 - Resultados do ensaio de resistência à compressão do concreto endurecido a 28 dias de idade por cura normal, de corpos-de-prova de seis dos caminhões do lote analisado. ABNT NBR 5739 (2007).

\begin{tabular}{|c|c|c|c|c|c|c|c|c|c|c|c|c|}
\hline \multirow[b]{2}{*}{ 远 } & \multicolumn{5}{|c|}{ Medidas por amostra } & \multicolumn{7}{|c|}{ Cálculos para o lote } \\
\hline & $\begin{array}{c}\mathrm{f}_{\mathrm{c} 28 \mathrm{n}} \\
(\mathrm{MPa})\end{array}$ & $\begin{array}{l}\text { Média } \\
(\mathrm{MPa})\end{array}$ & $\begin{array}{l}\text { Valor } \\
\text { Máximo } \\
\text { (MPa) }\end{array}$ & $\begin{array}{l}\text { Valor } \\
\text { Mínimo } \\
\text { (MPa) }\end{array}$ & $\begin{array}{c}\text { Amplitude } \\
\text { (MPa) }\end{array}$ & $\begin{array}{l}\text { Média } \\
(\mathrm{MPa})\end{array}$ & $\begin{array}{c}\text { Desvio } \\
\text { padrão (MPa) }\end{array}$ & $\begin{array}{c}\text { Coeficiente } \\
\text { de } \\
\text { variação } \\
(\%)\end{array}$ & $\begin{array}{l}\text { Valor } \\
\text { Máximo } \\
\text { (MPa) }\end{array}$ & $\begin{array}{l}\text { Valor } \\
\text { Mínimo } \\
\text { (MPa) }\end{array}$ & $\begin{array}{c}\text { Amplitude } \\
\text { (MPa) }\end{array}$ & $\begin{array}{c}\text { Intervalo de } \\
\text { confiança da } \\
\text { média 95\% } \\
\text { (MPa) }\end{array}$ \\
\hline $1 \mathrm{~A}$ & $\begin{array}{l}48,2 \\
45,1\end{array}$ & 46,7 & 48,2 & 45,1 & 3,1 & \multirow{6}{*}{44,6} & \multirow{6}{*}{4,1} & \multirow{6}{*}{$9 \%$} & \multirow{6}{*}{49,9} & \multirow{6}{*}{39,4} & \multirow{6}{*}{10,5} & \multirow{6}{*}{ $\pm 3,3$} \\
\hline $2 B$ & $\begin{array}{l}46,9 \\
46,3\end{array}$ & 46,6 & 46,9 & 46,3 & 0,6 & & & & & & & \\
\hline $3 \mathrm{C}$ & $\begin{array}{l}45,2 \\
44,0\end{array}$ & 44,6 & 45,2 & 44,0 & 1,1 & & & & & & & \\
\hline $4 \mathrm{D}$ & $\begin{array}{l}39,0 \\
39,8\end{array}$ & 39,4 & 39,8 & 39,0 & 0,8 & & & & & & & \\
\hline $5 \mathrm{E}$ & $\begin{array}{l}50,9 \\
49,0\end{array}$ & 49,9 & 50,9 & 49,0 & 1,9 & & & & & & & \\
\hline $6 \mathrm{~F}$ & $\begin{array}{l}42,2 \\
38,2 \\
\end{array}$ & 40,2 & 42,2 & 38,2 & 4,1 & & & & & & & \\
\hline
\end{tabular}


As resistências do concreto 4D se confirmaram menores, como aconteceram com os resultados da cura acelerada. As resistências dos concretos se mostraram em média 50\% maiores que a resistência característica ( $\left.f_{\mathrm{ck}} 30 \mathrm{MPa}\right)$.

\section{A.6) Análise conjunta das resistências à compressão, nas idades com cura acelerada e normal}

A Tabela 42 apresenta os resultados das resistências à compressão nas idades analisadas, com os dois tipos de cura estudados - cura acelerada e cura úmida normal, dos corpos-de-prova moldados de seis doscaminhões do lote analisado.

Conforme a NBR 12655 (2006), a resistência do exemplar é o maior valor entre os dois valores e na Tabela 42 esses valores são apresentados de forma comparativa.

TABELA 42 - Resumo dos resultados dos ensaios de resistência à compressão do concreto endurecido nas idades em estudo, em corpos-de-prova moldados de seis dos caminhões do lote analisado ABNT NBR 5739 (2007).

\begin{tabular}{|c|c|c|c|c|c|c|c|}
\hline \multirow{2}{*}{ 昰 } & \multicolumn{7}{|c|}{ Resistência do exemplar* } \\
\hline & $\begin{array}{c}\mathrm{f}_{\mathrm{c} 1-\text { acel } 0 / 1} \\
(\mathrm{MPa})\end{array}$ & $\begin{array}{c}\mathrm{f}_{\mathrm{c} 2-\text { acel } 1 / 2} \\
(\mathrm{MPa})\end{array}$ & $\begin{array}{c}\mathrm{f}_{\mathrm{c} 3 \text {-acel } 1 / 3} \\
(\mathrm{MPa})\end{array}$ & $\begin{array}{c}\mathrm{f}_{\mathrm{c} 7-\text { acel } 1 / 7} \\
(\mathrm{MPa})\end{array}$ & $\begin{array}{l}\mathrm{f}_{\mathrm{c} 7 \text {-obra }} \\
\text { (MPa) }\end{array}$ & $\mathrm{f}_{\mathrm{c} 28-\mathrm{n}}(\mathrm{MPa})$ & $\mathrm{f}_{\mathrm{c} 28 \text {-obra }}(\mathrm{MPa})$ \\
\hline $1 \mathrm{~A}$ & 27,7 & 29,0 & 32,7 & 42,8 & 26,0 & 48,2 & 39,8 \\
\hline $2 \mathrm{~B}$ & 28,5 & 29,8 & 33,6 & 40,2 & 26,5 & 46,9 & 39,8 \\
\hline $3 \mathrm{C}$ & 24,0 & 27,0 & 32,9 & 38,8 & 24,5 & 45,2 & 39,8 \\
\hline $4 \mathrm{D}$ & 22,2 & 22,0 & 28,6 & 31,4 & 23,5 & 39,8 & 37,2 \\
\hline $5 \mathrm{E}$ & 21,4 & 26,5 & 34,8 & 40,4 & 31,0 & 50,9 & 46,9 \\
\hline $6 \mathrm{~F}$ & 20,3 & 24,9 & 30,0 & 36,3 & 26,0 & 42,2 & 38,8 \\
\hline
\end{tabular}

*Valor máximo dos dois corpos-de-prova.

A Figura 68 apresenta os resultados das resistências à compressão dos corpos-deprova moldados de seis dos caminhões amostrados do lote, em todas as idades e tipos de cura analisadas. Vê-se que o resultado dos procedimentos de cura acelerada é eficiente, em comparação à cura normal, considerando a forma simples do procedimento operacional para a sua aplicação, porém o método pode ser ainda aperfeiçoado, para que os resultados das resistências a curto período, sejam o mais próximo possível das resistências a 28 dias, tornando-se assim um método confiável de predição de resistência à compressão. Como neste estudo, houve provável efeito do aditivo polifuncional na hidratação do cimento, isto precisa ser melhor investigado quanto às suas conseqüências sobre a duração da cura 
acelerada em temperatura amena, além da interferência da temperatura no campo, antes dos corpos-de-prova seguirem para laboratório.

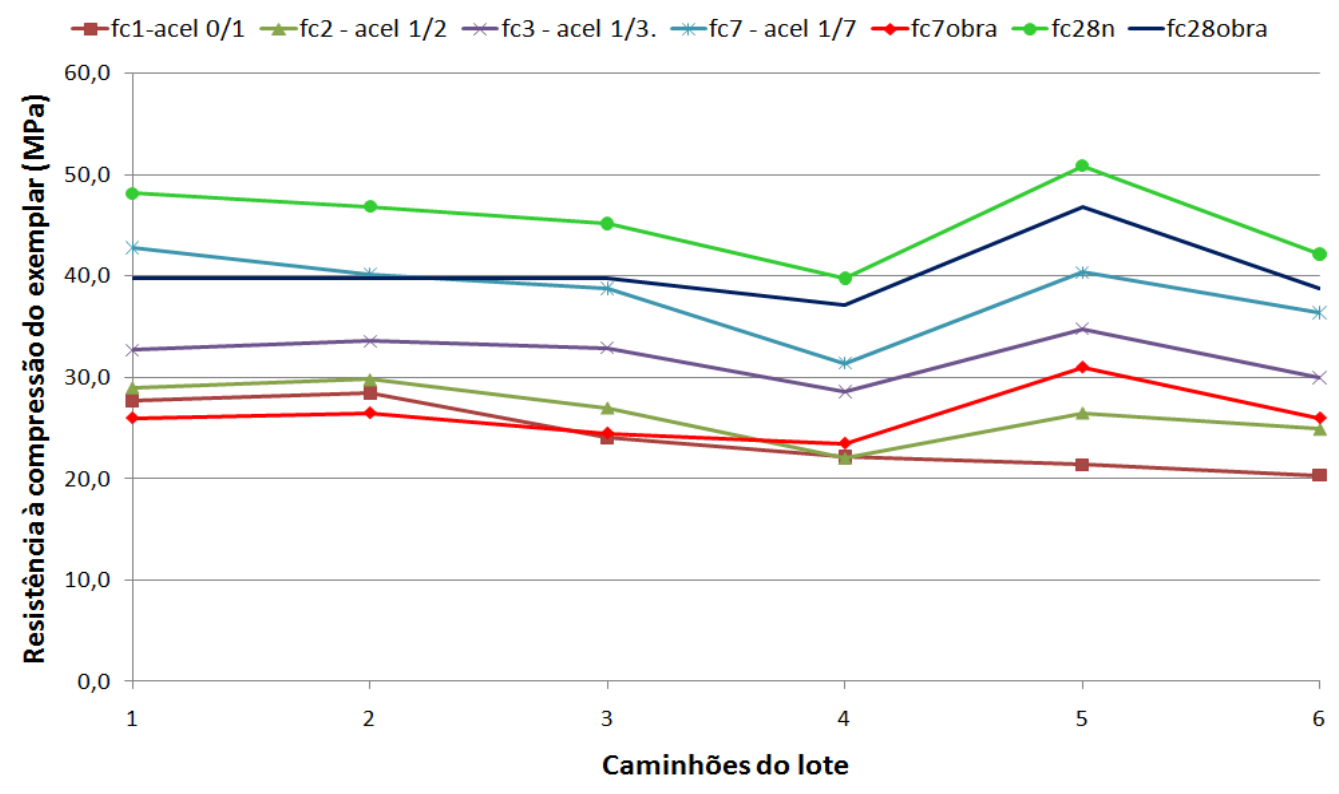

FIGURA 68 - Variação dos resultados de resistência à compressão por cura normal e acelerada de corpos-de-prova de concreto de seis dos caminhões do lote analisado. ABNT NBR 5739 (2007).

A Tabela 43 apresenta os resultados das resistências à compressão nas idades analisadas e com os procedimentos de cura testados, as respectivas médias, valores máximos e mínimos, o desvio padrão e o coeficiente de variação nos corpos-de-prova moldados desse lote.

Conforme a ABNT NBR 12655 (2006), a resistência do exemplar é o maior valor entre os dois obtidos nos ensaios, e na Tabela 43 esses valores são apresentados de forma sublinhada. As médias, os valores de máximo e mínimo, o desvio padrão e o coeficiente de variação foram calculados em função dos maiores valores entre os corpos-de-prova irmãos, ou seja, em função dos exemplares. 
TABELA 43 - Resultados do ensaio de resistência à compressão nos concretos dos seis caminhões do lote analisado. ABNT NBR 5739 (2007).

\begin{tabular}{|c|c|c|c|c|c|c|c|c|c|}
\hline Caminhão & $\begin{array}{l}\mathrm{f}_{\mathrm{c1} \text { - acel }} \\
0 / 24 \mathrm{~h} \\
\text { (MPa) }\end{array}$ & $\begin{array}{l}\mathrm{f}_{\mathrm{c} 2-\mathrm{acel}} \\
24 / 48 \mathrm{~h} \\
(\mathrm{MPa})\end{array}$ & $\begin{array}{l}\mathrm{f}_{\mathrm{c} 3 \text { - acel }} \\
247 / 2 \mathrm{~h} \\
(\mathrm{MPa})\end{array}$ & $\begin{array}{c}\mathbf{f}_{\mathrm{c} 7 \text { - acel }} \\
\text { 24/72h+imersão } \\
\text { (MPa) }\end{array}$ & $\begin{array}{c}f_{\mathrm{c} 28 \mathrm{n}} \\
(\mathrm{MPPa})\end{array}$ & $\begin{array}{c}\mathrm{f}_{\mathrm{c} 91 \mathrm{accl}} 24 / 72 \mathrm{~h} \\
\text { timersão } \\
(\mathrm{MPa})\end{array}$ & (MPa) & $\begin{array}{l}\mathrm{f}_{\mathrm{c7} \text { obra }} \\
(\mathrm{MPa})\end{array}$ & $\begin{array}{l}\mathrm{f}_{\mathrm{c} 228 \text { obra }} \\
\text { (MPa) }\end{array}$ \\
\hline \multirow{2}{*}{$1 A$} & 25,4 & 28,9 & 31,4 & $\underline{42.8}$ & $\underline{48.2}$ & - & -- & 25,1 & $\underline{39.8}$ \\
\hline & $\underline{27.7}$ & $\underline{29.0}$ & $\underline{32.7}$ & 38,3 & 45,1 & - & - & $\underline{26.0}$ & 38,6 \\
\hline \multirow{2}{*}{$2 \mathrm{~B}$} & $\underline{28.5}$ & $\underline{29.8}$ & $\underline{33,6}$ & 40,1 & $\underline{46.9}$ & - & - & 26,0 & 38,1 \\
\hline & 26,9 & 29,1 & 33,6 & 40.2 & 46,3 & -- & -- & $\underline{26.5}$ & $\underline{39.8}$ \\
\hline \multirow{2}{*}{$3 \mathrm{C}$} & $\underline{24,0}$ & 25,7 & $\underline{32.9}$ & $\underline{38.8}$ & $\underline{45,2}$ & - & - & 23,5 & $\underline{39.8}$ \\
\hline & 23,6 & $\underline{27.0}$ & 31,5 & 38,0 & 44,0 & - & - & $\underline{24.5}$ & 37,5 \\
\hline \multirow{2}{*}{ 4D } & $\underline{22.2}$ & $\underline{22.0}$ & 28,2 & $\underline{31.4}$ & 39,0 & - & - & $\underline{23.5}$ & $\underline{37.2}$ \\
\hline & 20,7 & 20,7 & $\underline{28.6}$ & 29,1 & $\underline{39.8}$ & - & - & 22,6 & 35,1 \\
\hline \multirow{2}{*}{$5 \mathrm{E}$} & $\underline{21.4}$ & $\underline{26.5}$ & $\underline{34.8}$ & $\underline{40.4}$ & $\underline{50.9}$ & - & - & 30,2 & $\underline{46.9}$ \\
\hline & 20,4 & 25,5 & 34,6 & 38,9 & 49,0 & -- & -- & $\underline{31.0}$ & 46,9 \\
\hline \multirow{2}{*}{$6 \mathrm{~F}$} & $\underline{20.3}$ & 24,5 & 29,3 & 35,8 & $\underline{42.2}$ & $\underline{45,3}$ & 45,3 & $\underline{26.0}$ & 36,2 \\
\hline & 20,2 & $\underline{24.9}$ & $\underline{30.0}$ & $\underline{36.3}$ & 38,2 & 42,7 & $\underline{47.1}$ & 25,0 & $\underline{38.8}$ \\
\hline $\begin{array}{l}\text { Média dos } \\
\text { exemplares } \\
\text { (MPa) }\end{array}$ & 24,0 & 26,5 & 32,1 & 38,3 & 45,5 & 45,3 & 47,1 & 26,3 & 40,4 \\
\hline $\begin{array}{c}\text { Valor } \\
\text { máximo dos } \\
\text { exemplares } \\
\text { (MPa) }\end{array}$ & 28,5 & 29,8 & 34,8 & 42,8 & 50,9 & 45,3 & 47,1 & 31,0 & 46,9 \\
\hline $\begin{array}{c}\text { Valor } \\
\text { mínimo dos } \\
\text { exemplares } \\
\text { (MPa) }\end{array}$ & 20,3 & 22,0 & 28,6 & 31,4 & 39,8 & 42,7 & 45,3 & 23,5 & 37,2 \\
\hline $\begin{array}{c}\text { Desvio } \\
\text { padrão dos } \\
\text { exemplares } \\
\text { (MPa) }\end{array}$ & 3,4 & 2,8 & 2,3 & 4,0 & 4,0 & -- & -- & 2,6 & 3,4 \\
\hline $\begin{array}{c}\text { Coeficiente } \\
\text { de variação } \\
\text { dos } \\
\text { exemplares } \\
(\%)\end{array}$ & $14 \%$ & $11 \%$ & $7 \%$ & $10 \%$ & $9 \%$ & -- & -- & $10 \%$ & $8 \%$ \\
\hline $\begin{array}{c}\text { Amplitude } \\
\text { dos } \\
\text { exemplares } \\
\text { (MPa) }\end{array}$ & 8 & 8 & 6 & 11 & 11 & 3 & 2 & 8 & 10 \\
\hline $\begin{array}{c}\text { Intervalo de } \\
\text { confiança da } \\
\text { media 95\% } \\
\text { (MPa) }\end{array}$ & \pm 3 & \pm 2 & \pm 2 & \pm 3 & \pm 3 & - & - & \pm 2 & \pm 3 \\
\hline
\end{tabular}

A Figura 69 ilustra a curva de crescimento dos corpos-de-prova de concreto do lote amostrado, considerando a média dos maiores valores de todas as idades e procedimentos de cura analisados. O resultado de resistência a 91 dias foi controlado para apenas um dos caminhões. 


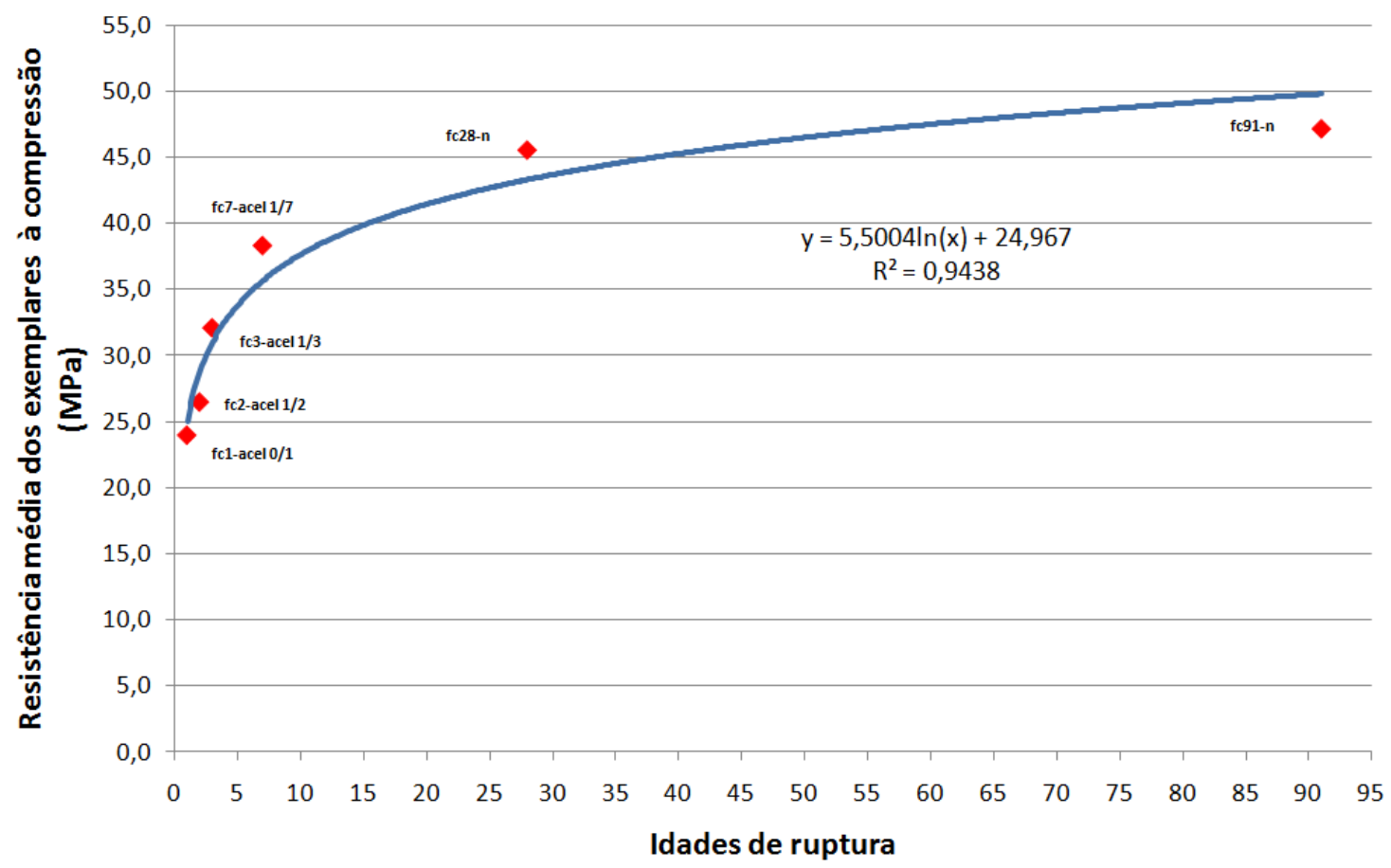

FIGURA 69 - Evolução do crescimento de resistência à compressão do concreto do lote analisado, nas condições de cura acelerada e normal resumidas pelas legendas.

B) Análise da evolução da resistência relativa à cura normal de 28 dias

A Tabela 44 apresenta a evolução da resistência em função da resistência a 28 dias de idade por cura normal dos corpos-de-prova amostrados de seis dos caminhões do lote analisado. A evolução da resistência foi calculada para os maiores valores entre os corposde-prova irmãos. 
TABELA 44 - Resistência relativa das várias idades de cura acelerada em relação à de 28 dias de cura normal.

\begin{tabular}{|c|c|c|c|c|c|c|c|c|c|}
\hline Caminhão & $\begin{array}{c}\mathrm{f}_{\text {c1acelerado }} \\
\text { (MPa) }\end{array}$ & $\begin{array}{l}\mathrm{f}_{\mathrm{c} 1 \mathrm{ace} . \mathrm{l}} / \\
\mathrm{f}_{\mathrm{c} 28 \mathrm{n}(\%)}\end{array}$ & $\begin{array}{l}\mathrm{f}_{\mathrm{c} \text { 2acelerado }} \\
(\mathrm{MPa})\end{array}$ & $\begin{array}{l}\mathrm{f}_{\text {c2acel. }} / \\
\mathrm{f}_{\mathrm{c} 28 \mathrm{n}(\%)}\end{array}$ & $\begin{array}{c}\mathrm{f}_{\mathrm{c} 3 \text { acelerado }} \\
(\mathrm{MPa})\end{array}$ & $\begin{array}{l}\mathrm{f}_{\mathrm{c} 33 \mathrm{ccel}} . / \\
\mathrm{f}_{\mathrm{c} 28 \mathrm{n}(\%)}\end{array}$ & $\begin{array}{c}\mathrm{f}_{\mathrm{c} 7 \mathrm{acele} \text { rado }} \\
(\mathrm{MPa})\end{array}$ & $\begin{array}{l}\mathrm{f}_{\mathrm{c} 7 \mathrm{acel} .} / \\
\mathrm{f}_{\mathrm{c} 28 \mathrm{n}(\%)}\end{array}$ & $\begin{array}{c}f_{\mathrm{c} 28 n o r m a l} \\
(\mathrm{MPa})\end{array}$ \\
\hline $1 \mathrm{~A}$ & 27,7 & 57,5 & 29,0 & 60,1 & 32,7 & 67,8 & 42,8 & 88,7 & 48,2 \\
\hline $2 \mathrm{~B}$ & 28,5 & 60,7 & 29,8 & 63,6 & 33,6 & 71,7 & 40,2 & 85,6 & 46,9 \\
\hline $3 \mathrm{C}$ & 24,0 & 53,2 & 27,0 & 59,7 & 32,9 & 72,7 & 38,8 & 85,9 & 45,2 \\
\hline $4 \mathrm{D}$ & 22,2 & 55,8 & 22,0 & 55,3 & 28,6 & 71,9 & 31,4 & 78,9 & 39,8 \\
\hline $5 \mathrm{E}$ & 21,4 & 42,1 & 26,5 & 52,1 & 34,8 & 68,3 & 40,4 & 79,5 & 50,9 \\
\hline $6 \mathrm{~F}$ & 20,3 & 48,2 & 24,9 & 59,0 & 30,0 & 71,1 & 36,3 & 85,9 & 42,2 \\
\hline $\begin{array}{c}\text { Resistência } \\
\text { relativa } \\
\text { média (\%) }\end{array}$ & - & 52,9 & - & 58,3 & - & 70,6 & - & 84,1 & - \\
\hline
\end{tabular}

\section{C) Cálculo da resistência característica estimada à compressão}

Como já mencionando no item 3.3.2 do Capítulo 3, o volume de concreto do lote analisado foi de $160 \mathrm{~m}^{3}$, sendo caracterizado para este estudo uma amostragem parcial de 6 caminhões de um total de 20, conforme a ABNT NBR 12655 (2006).

Os valores calculados da resistência característica à compressão para o lote podem ser observados na Tabela 45. Para amostragem parcial, a resistência característica à compressão a 28 dias foi superior à resistência especificada pela obra, logo de acordo com a ABNT NBR 12655 (2006), o lote seria aceito. Já a resistência característica à compressão a 7 dias por cura acelerada apresentou valor inferior ao de projeto, e de acordo com a ABNT NBR 12655 (2006) o lote poderia ser rejeitado nessa idade. Segundo a norma o lote deve ser aceito se: $\mathbf{f}_{\text {ckest }} \geq \mathbf{f}_{\text {ck. }}$. Conforme já comentado é necessário prosseguir em estudos de duração da cura acelerada em temperatura amena especialmente em circusntâncias de se ter concreto aditivado ou variações climáticas muito extremas no campo. 
TABELA 45 - Resistência característica por amostragem parcial dos concretos do lote analisado. ABNT NBR 12655 (2006).

\begin{tabular}{|c|c|c|c|c|c|}
\hline \multirow[t]{2}{*}{$\begin{array}{c}\text { Simulação } \\
\text { de } \\
\text { amostragem }\end{array}$} & \multicolumn{2}{|c|}{$\begin{array}{c}\text { Resistência } \\
\text { característica à } \\
\text { compressão - } \mathrm{f}_{\text {ckest }} \\
\text { (MPa) }\end{array}$} & \multirow[t]{2}{*}{$\begin{array}{c}\text { Simulação } \\
\text { de } \\
\text { amostragem }\end{array}$} & \multicolumn{2}{|c|}{$\begin{array}{c}\text { Resistência } \\
\text { característica à } \\
\text { compressão - } \mathrm{f}_{\text {ckest }} \\
\text { (MPa) }\end{array}$} \\
\hline & $f_{\text {clacel. }}$ o/1 & 19,5 & & 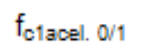 & 20,3 \\
\hline \multirow{4}{*}{ Parcial } & 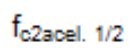 & 20,4 & & 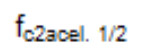 & 22,0 \\
\hline & $f_{c 3 a c e l .1 / 3}$ & 26,3 & $\underline{\text { Total }}$ & $f_{c 3 a c e l .1} 1 / 3$ & 28,6 \\
\hline & $f_{c 7 a c e l}, 1 / 7$ & 28,9 & & $\mathrm{f}_{\mathrm{c} 7 \mathrm{acel}} .1 / 7$ & 31,4 \\
\hline & $f_{c 28 n}$ & 36,8 & & $f_{c 28 n}$ & 39,8 \\
\hline
\end{tabular}

A Tabela 45 apresenta uma simulação da resistência característica à compressão, caso a amostragem fosse total para o lote de concreto analisado, pelos critérios da ABNT NBR 12655 (2006).

Pela simulação realizada, percebe-se que as resistências características à compressão pelos dois critérios de amostragem apresentaram resultados próximos, mas a resistência característica estimada por amostragem total resultou ligeiramente superior em todas as idades, já que envolve maior confiabilidade dos dados, ao se considerar a disponibilidade de amostra de todos os caminhões de um dado lote, o que, aliás, sempre é recomendável em concretagem de pilares.

Pelos critérios de amostragem total da ABNT NBR 12655 (2006), os concretos com cura acelerada de 24/72 horas seguida de cura submersa até 7 dias, e os submetidos a cura

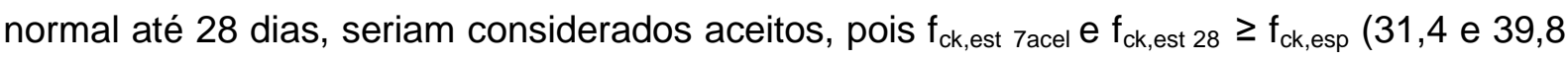
$\mathrm{MPa} \geq 30 \mathrm{MPa}$ ).

\section{D) Controle de massa dos corpos-de-prova em condições de exposição por envelhecimento acelerado}

As variações de massa nas etapas de cada ciclagem estão apresentadas de forma completa no Apêndice B.

O controle de massa está apresentado em função do grau de saturação dos corposde-prova de concreto moldados de seis dos caminhões do lote analisado.

O grau de saturação dos corpos-de-prova foi calculado de duas formas: a seguir explicadas como opção $A$ e opção $B$, em função da massa saturada a 7 dias, da absorção 
de água total de meio corpo-de-prova a 8 e 204 dias e das massas pesadas durante a ciclagem, tudo referente aos mesmos corpos-de-prova ciclados.

\section{1) Opção A}

Massa seca teórica $\mathrm{A}=\frac{m s a t_{7 d}}{\left(1+\frac{A b s_{8 d}}{100}\right)}$

Grau de saturação $A=\left(\frac{m_{\text {data }}-m_{\text {sec } a t A}}{m_{\text {sat7d }}-m_{\text {sec } a t A}}\right)$

\section{2) Opção B}

Massa seca teórica $\mathrm{B}=\frac{\mathrm{msat}_{7 d}}{\left(1+\frac{A b s_{204 d}}{100}\right)}$

Grau de saturação $\mathrm{B}=\left(\frac{m_{\text {data }}-m_{\sec t B}}{m_{\text {sat7d }}-m_{\sec t B}}\right)$

Sendo:

$\mathrm{m}_{\text {sat7d }}=$ massa saturada dos corpos-de-prova a 7 dias de idades;

$\mathrm{Abs}_{8 \mathrm{~d}, 204 d}=$ absorção de água total a 8 e 204 dias de idade;

$\mathrm{m}_{\text {data }}=$ massa na data da pesagem dos corpos-de-prova;

$m_{\text {sectA,B }}=$ massa seca teórica opção $A$ ou opção B.

D.1) Grau de saturação - cura acelerada 24/72 horas seguida por imersão em água até 7 dias e ciclos de exposição por 24 horas em câmara de carbonatação e 27 dias de secagem em estufa a $\left(40 \pm 1^{\circ} \mathrm{C}\right)$. (AE1)

A Figura 70 apresenta as variações do grau de saturação nas etapas de ciclagem de 24 horas em câmara de $\mathrm{CO}_{2}$ à $(5 \pm 0,5) \%$ de $\mathrm{CO}_{2}$ alternada por 27 dias de secagem a $(40 \pm$ $1)^{\circ} \mathrm{C}$ de dois corpos-de-prova amostrados nos seis caminhões do lote, para idades até 203 dias. Neste caso, utilizou-se os resultados de absorção total de água a 8 dias (Opção A).

Percebe-se com o decorrer da ciclagem, que os corpos-de-prova apresentaram secagem em perfil quase contínuo ao longo do tempo, com pequenos picos de oscilação 
pela exposição à carbonatação acelerada por 24h, chegando em 203 dias a uma faixa de umidade entre 0 e $20 \%$ do grau de saturação a 7 dias.

A Figura 71 apresenta a variação do grau de saturação nas etapas de ciclagem de 24 horas em câmara de $\mathrm{CO}_{2}$ alternada com 27 dias de secagem de dois corpos-de-prova amostrados nos seis caminhões do lote, para idades até 203 dias. Neste caso, a massa seca teórica considerada para os cálculos utilizou os resultados de absorção total de água a 204 dias (Opção B).

Percebe-se com o decorrer da ciclagem, os corpos-de-prova apresentaram um perfil de secagem quase contínua ao longo do tempo, chegando em 203 dias a uma faixa de umidade entre 20 e $40 \%$ do grau de saturação na mesma idade (203 dias), possivelmente explicado por uma maior fixação do $\mathrm{CO}_{2}$ nas últimas etapas de exposição ou por uma maior secagem e capacidade de absorção de água pelos poros ao final desse período, conforme está mostrado no item F) pertinente. 


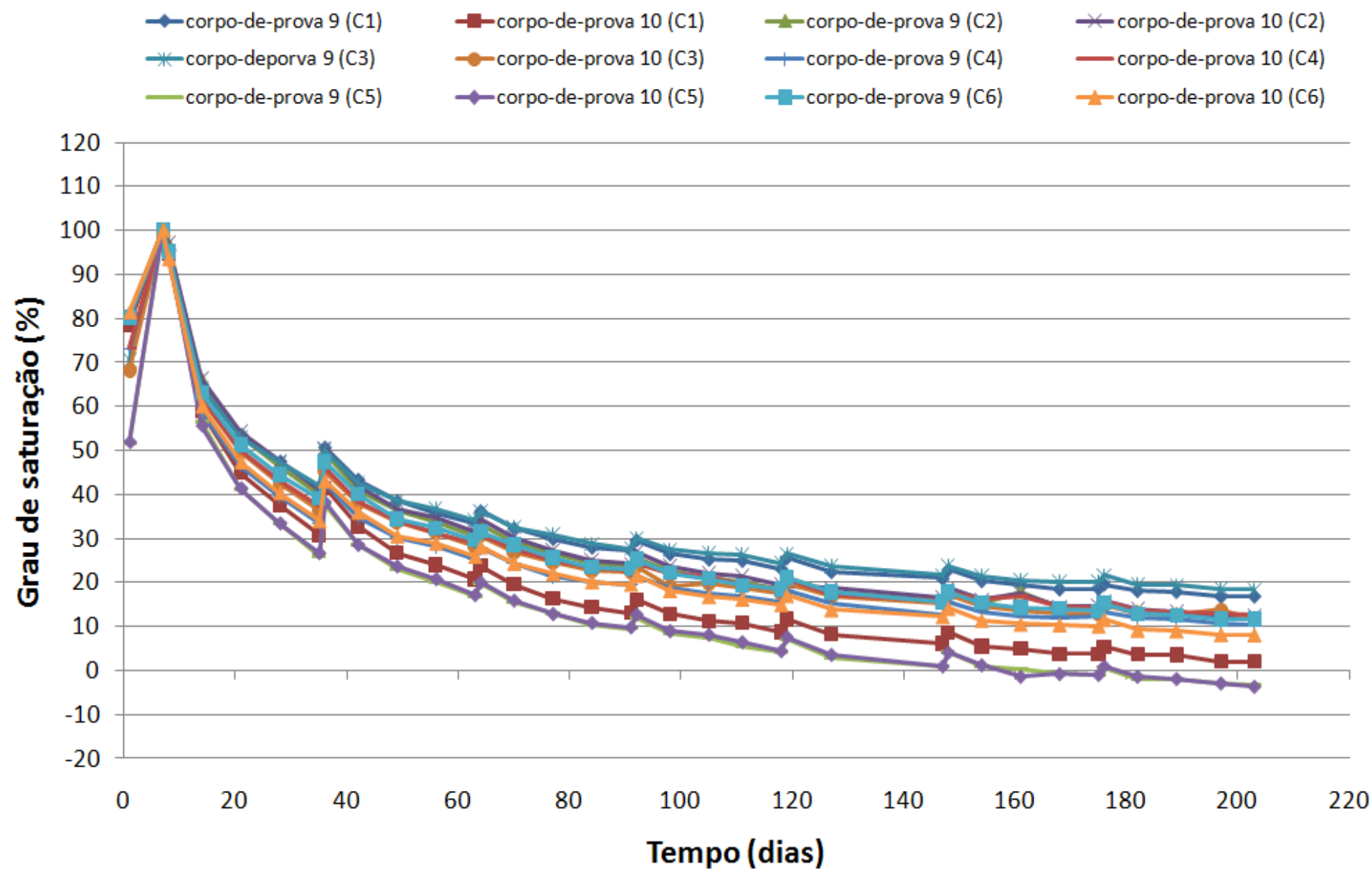

FIGURA 70 - Variação do grau de saturação entre os ciclos de $24 \mathrm{~h}$ de exposição em câmara de $\mathrm{CO}_{2}$ seguido por 27 dias de secagem em estufa a $40^{\circ} \mathrm{C}$. (Cálculos Opção A). 


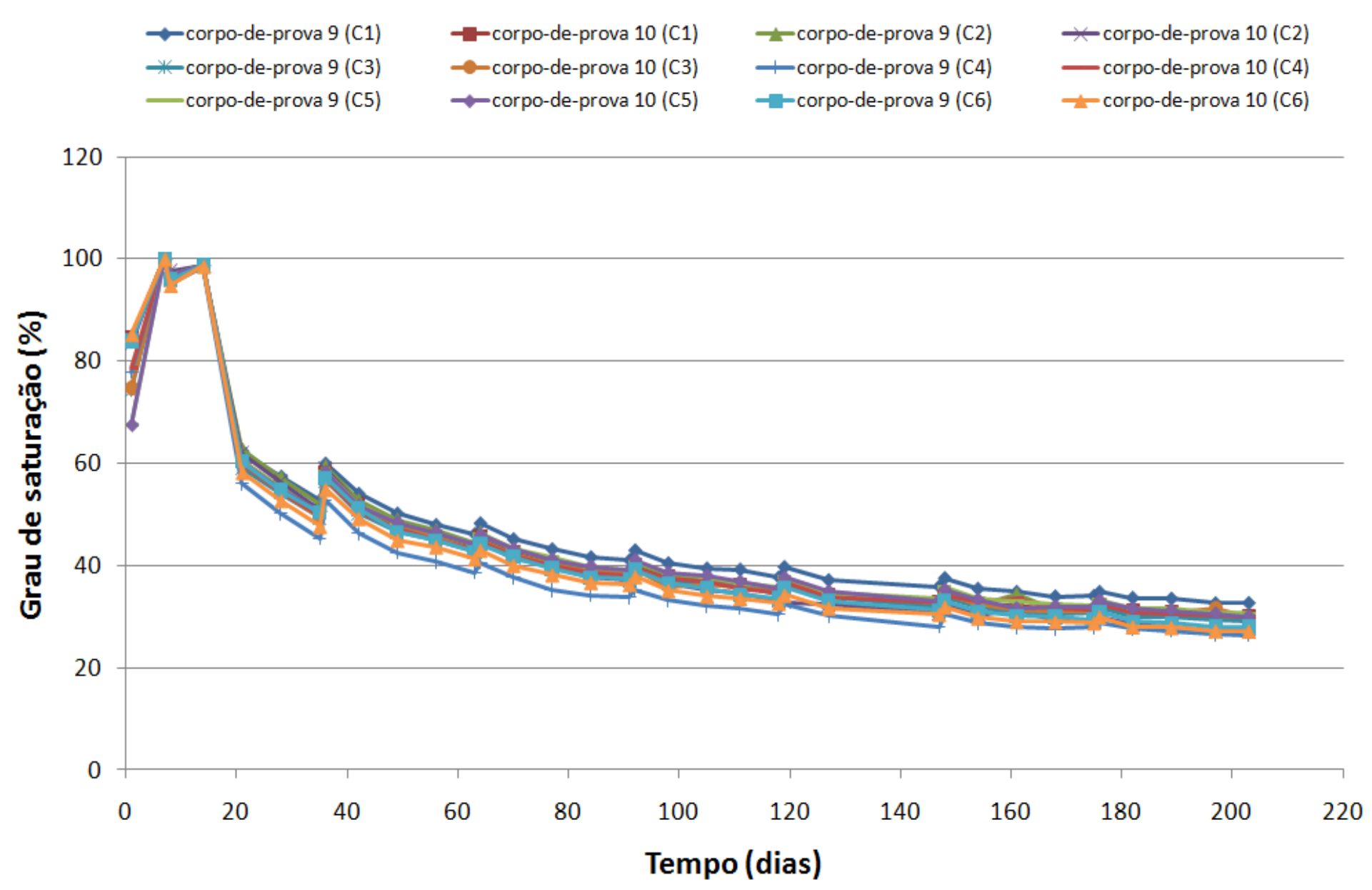

FIGURA 71 - Variação do grau de saturação entre os ciclos de $24 \mathrm{~h}$ de exposição em câmara de $\mathrm{CO}_{2}$ seguido por 27 dias de secagem em estufa a $40^{\circ} \mathrm{C}$. (Cálculos Opção B). 


\section{D.2) Grau de saturação - cura acelerada $24 / 72$ horas seguida por imersão em água até 7 dias e ciclos de 24 horas de imersão em água e 27 dias de secagem em estufa a $(40 \pm 1 \div C)(A E 2)$.}

A Figura 72 apresenta as variações do grau de saturação nas etapas de ciclagem de 24 horas em tanque de água seguida de 27 dias de secagem em estufa, de dois corpos-deprova amostrados nos seis caminhões do lote, para idadeS de até 203 dias. A massa seca teórica considerada para os cálculos utilizou os resultados de absorção total de água a 8 dias (Opção A).

Percebe-se com o decorrer da ciclagem, que os corpos-de-prova apresentaram uma secagem com um valor médio mínimo de grau de saturação de 30\%. O corpo-de-prova 21 apresentou um grau de saturação anômalo na segunda ciclagem e isto possivelmente devido a uma secagem superficial deficiente ao final da etapa de imersão. No último ciclo, alguns resultados também apresentaram anomalias, devido a algum erro de pesagem ou secagem superficial deficiente dos corpos-de-prova, pois houve variações acima do normal.

A Figura 73 apresenta a variação do grau de saturação nas etapas de ciclagem de 24 horas de imersão em tanque de água seguida de 27 dias de secagem de dois corpos-deprova amostrados nos seis caminhões do lote, para idades até 203 dias. A massa seca teórica considerada para os cálculos utilizou os resultados de absorção total de água a 204 dias (Opção B).

Percebe-se com o decorrer da ciclagem, que os corpos-de-prova apresentaram uma tendência a maior saturação e menor secagem, com um valor médio mínimo de grau de saturação de 40 a 50\%, possivelmente, explicado por uma maior absorção de água, considerando nos cálculos o valor da absorção de 204 dias. 


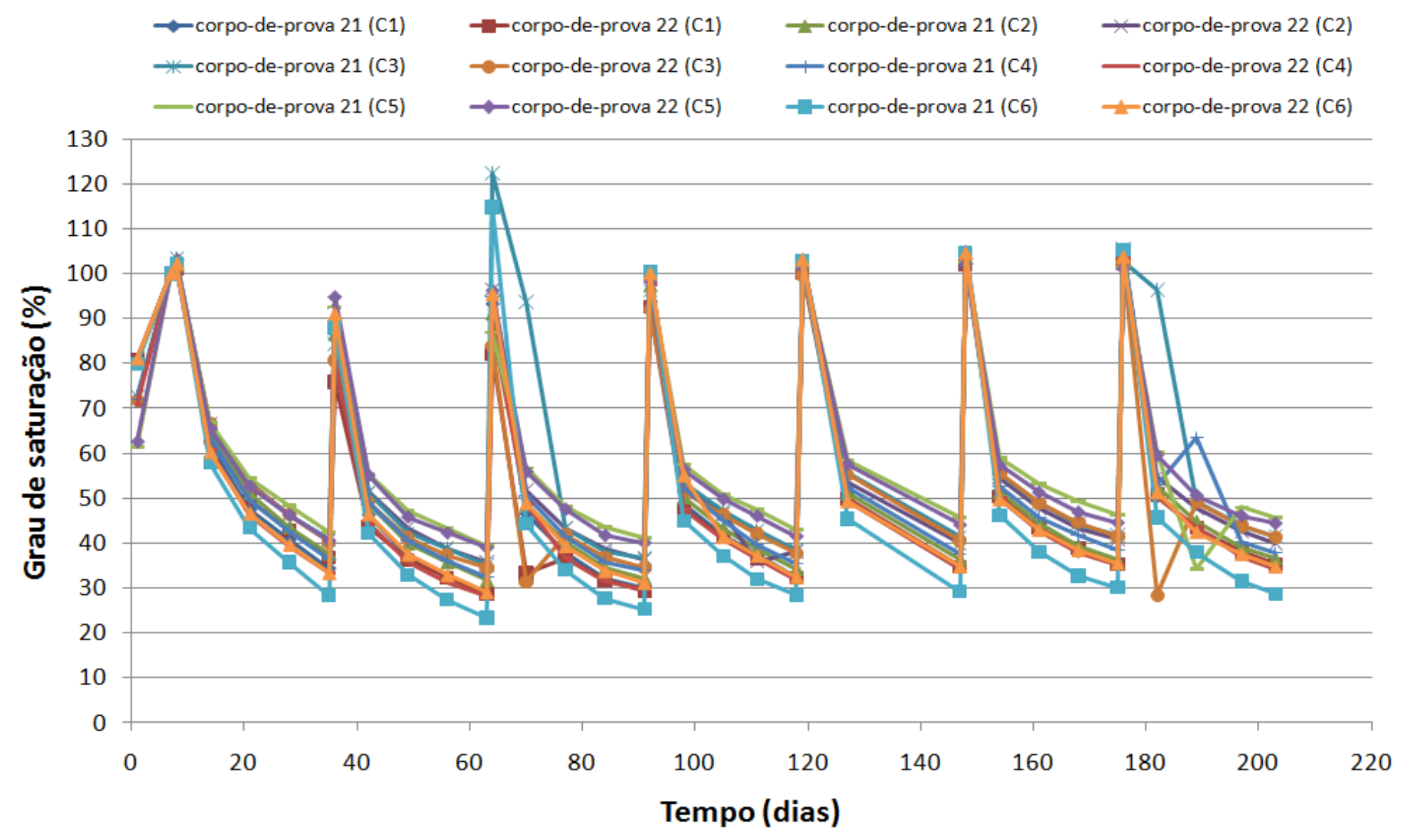

FIGURA 72 - Variação do grau de saturação entre os ciclos $24 \mathrm{~h}$ de imersão em água seguidos por 27 dias de secagem em estufa a $40^{\circ} \mathrm{C}$. (Cálculos Opção A). 


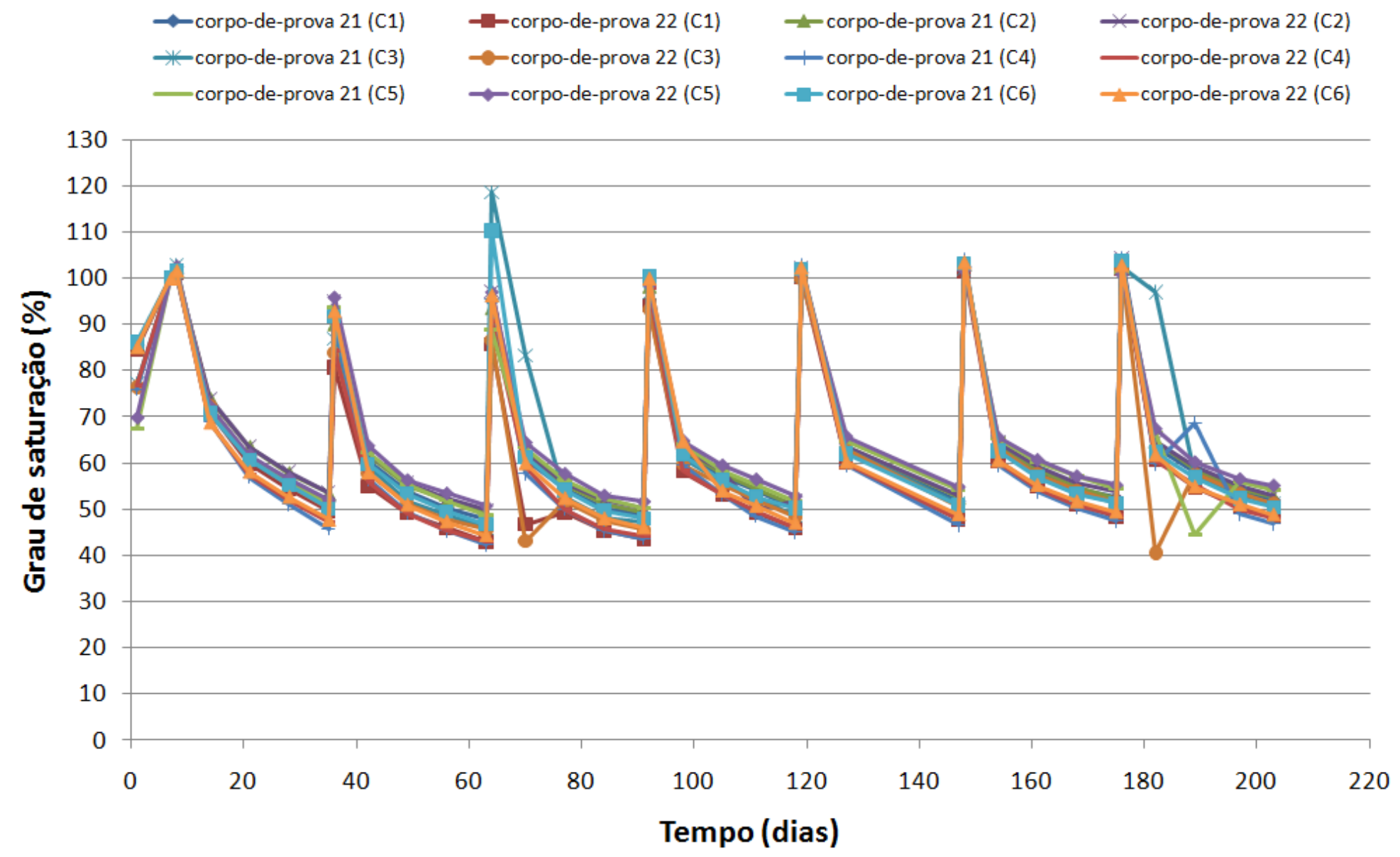

FIGURA 73 - Variação do grau de saturação entre os ciclos $24 \mathrm{~h}$ de imersão em água seguidos por 27 dias de secagem em estufa a $40^{\circ} \mathrm{C}$. (Cálculos Opção B). 


\section{D.3) Grau de saturação - cura acelerada de 24/72 horas seguida por imersão em água até 7 dias e ciclos de secagem contínua em estufa ventilada a (40士 $\left.5^{\circ} \mathrm{C}\right)(\mathrm{AE} 3)$.}

Nesta ciclagem, a oscilação de temperatura para secagem pode ter sido maior do que em AE1 e AE2, por ser a estufa com controle mecânico.

A Figura 74 apresenta as variações do grau de saturação ao longo de ciclos de pesagem para 28 dias de secagem contínua de dois corpos-de-prova amostrados nos seis caminhões do lote, para idades até 203 dias. A massa seca teórica considerada para os cálculos utilizou os resultados de absorção total de água a 8 dias (Opção A).

Percebe-se com o decorrer da secagem, que os corpos-de-prova apresentaram tendência contínua de secagem ao longo do tempo, chegando a uma faixa de umidade entre $0 \%$ e $10 \%$ do grau de saturação a 203 dias.

A Figura 75 apresenta a variação do grau de saturação nas etapas de ciclos de 28 dias de secagem contínua de dois corpos-de-prova amostrados nos seis caminhões do lote, para a idade de até 203 dias. A massa seca teórica considerada para os cálculos utilizou os resultados de absorção total de água a 204 dias (Opção B).

Percebe-se com o decorrer da secagem, que os corpos-de-prova apresentaram uma tendência de secagem menor ao longo do tempo, chegando a uma faixa de umidade entre $20 \%$ e $30 \%$ do grau de saturação a 203 dias.

Através da observação dos métodos de cálculos de grau de saturação e gráficos, pode-se observar que a Opção $B$ apresenta dados mais consistentes no que se refere à secagem dos corpos-de-prova, pois seu núcleo dificilmente estará seco por completo, conforme apresenta a Opção $A$, para as condições de envelhecimento acelerado AE1 $\left(\mathrm{CO}_{2}\right)$ e AE3 (Secagem). 


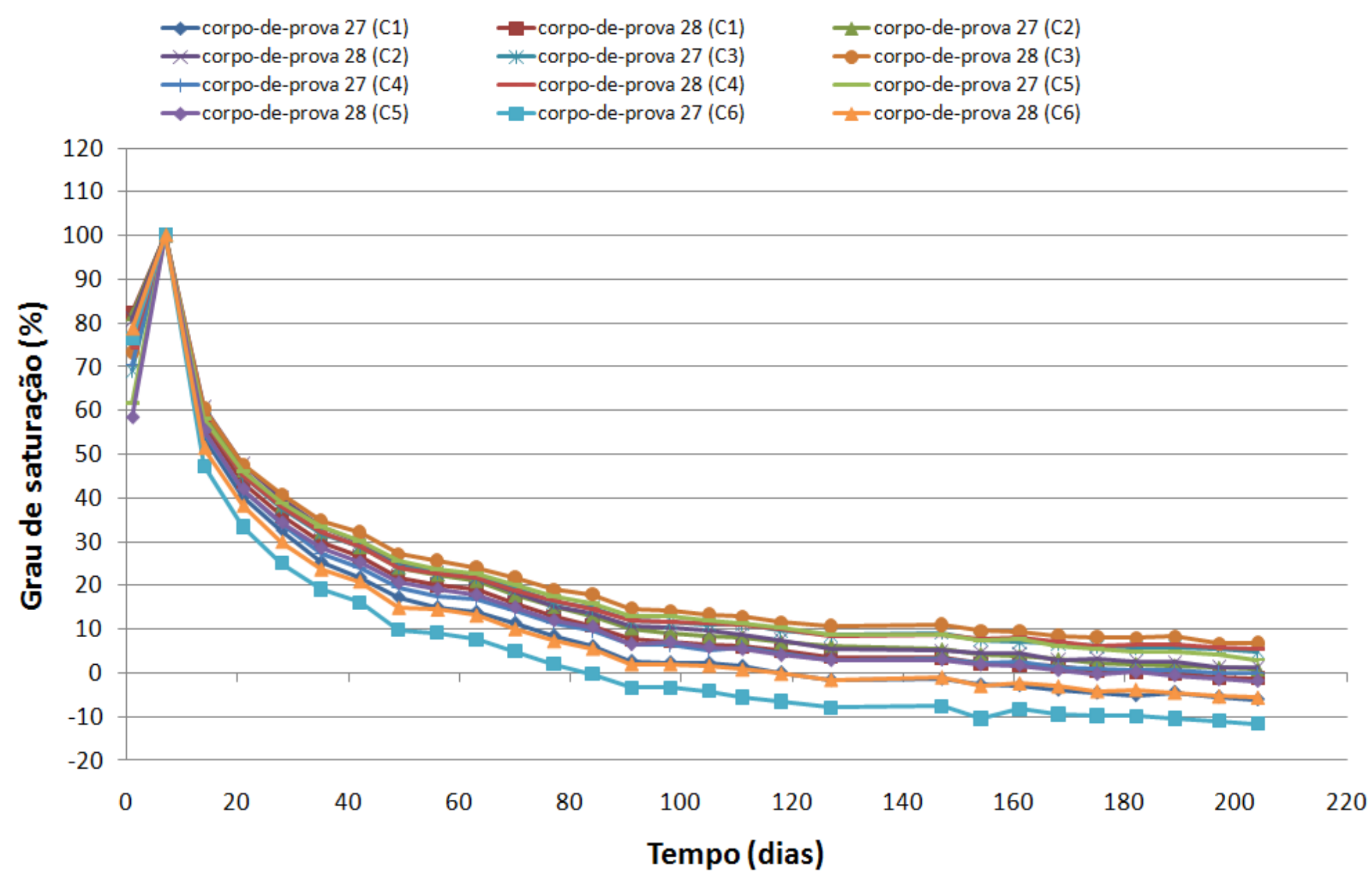

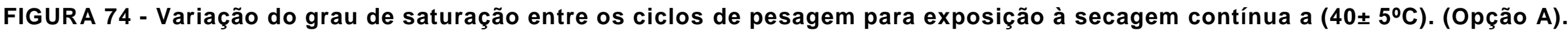




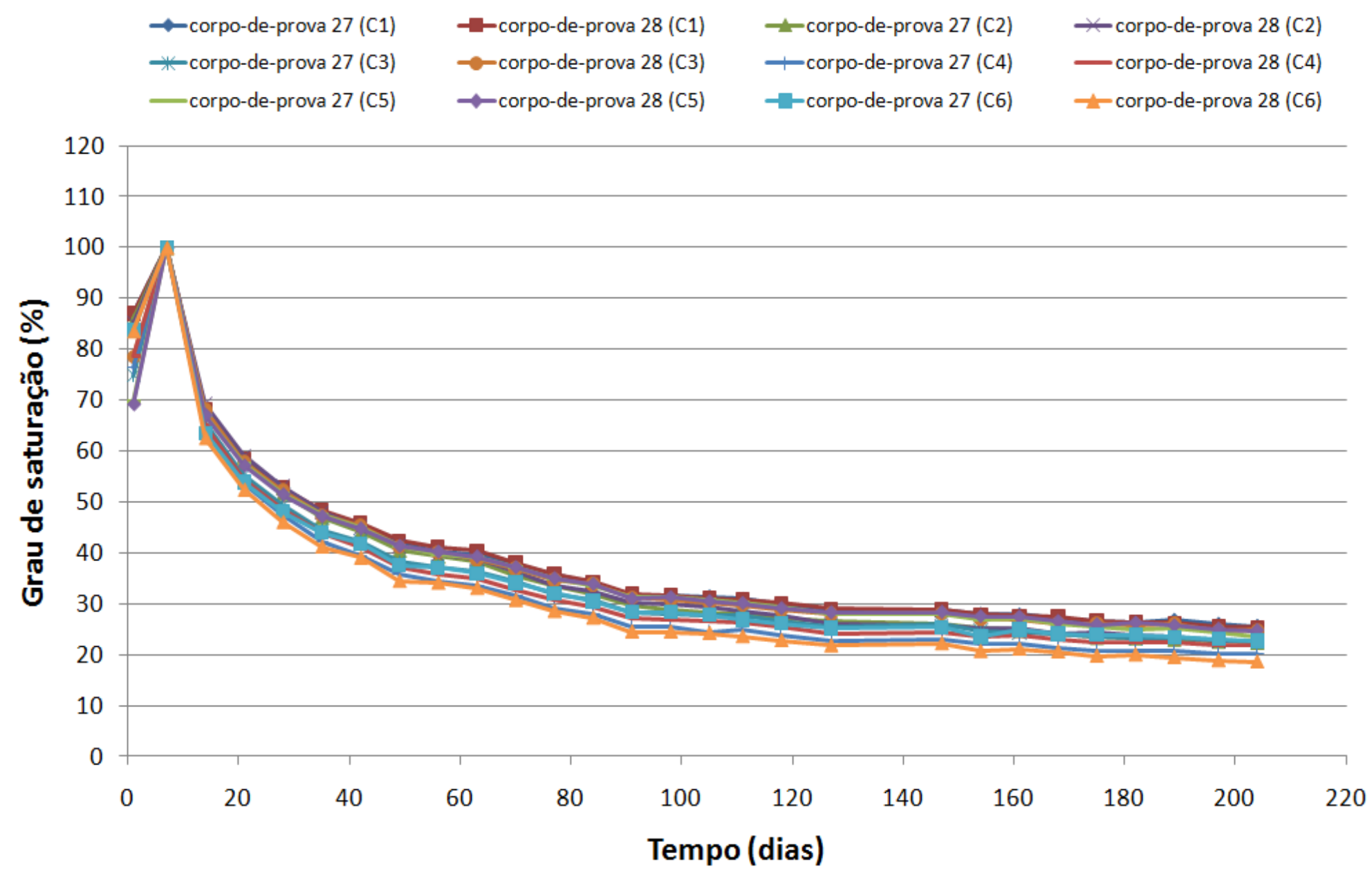

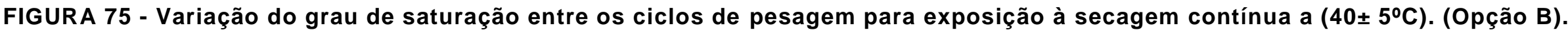


E) Resistência à tração por envelhecimento acelerado

\section{E.1) Cura acelerada 24/72 horas seguida por imersão em água até 7 dias e ciclos de 24 horas em câmara de carbonatação e 27 dias de secagem (AE1).}

Os itens a seguir apresentam os resultados dos ensaios de resistência à tração a 8, 35, 63, 91 e 203 dias dos concretos do lote analisado, para este tipo de condicionamento.

\section{E.1a) Resistência à tração a 8 dias por cura acelerada de 1 a 3 dias $\left(f_{c t, s p}\right.$ 8acel.AE1)}

A Tabela 46 apresenta as medidas individuais dos corpos-de-prova, as médias, o desvio padrão, os valores máximos e mínimos, as amplitudes e o coeficiente de variação dos resultados do ensaio de resistência à tração por compressão diametral a 8 dias por cura acelerada 24/72 horas seguida de cura imersa em água até 7 dias, sendo os corpos-deprova expostos à câmara de carbonatação a $5 \%$ de $\mathrm{CO}_{2}$ por 24 horas, no primeiro dia da condição $A E 1$, antes da realização do ensaio.

O concreto $5 \mathrm{E}$ apresentou maior média de resultados de resistência à tração. Os demais concretos mantiveram uma média de resultados muito próxima, e os concretos $2 \mathrm{~B}$, $3 \mathrm{C}$ e $6 \mathrm{~F}$ obtiveram resultados médios iguais.

TABELA 46 - Resultados do ensaio de resistência à tração por compressão diametral a 8 dias (AE1) dos concretos do lote analisado. ABNT NBR 7222 (1994).

\begin{tabular}{|c|c|c|c|c|c|c|c|c|c|c|c|c|}
\hline \multirow[b]{2}{*}{ } & \multicolumn{5}{|c|}{ Medidas por amostra } & \multicolumn{7}{|c|}{ Cálculo para o lote } \\
\hline & 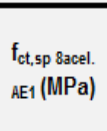 & $\begin{array}{l}\text { Média } \\
\text { (MPa) }\end{array}$ & $\begin{array}{c}\text { Valor } \\
\text { Máximo } \\
\text { (MPa) }\end{array}$ & $\begin{array}{c}\text { Valor } \\
\text { Mínimo } \\
\text { (MPa) }\end{array}$ & $\begin{array}{l}\text { Amplitude } \\
\text { (MPa) }\end{array}$ & $\begin{array}{l}\text { Média } \\
\text { (MPa) }\end{array}$ & $\begin{array}{r}\text { Desvio } \\
\text { padrão } \\
\text { (MPa) }\end{array}$ & $\begin{array}{c}\text { Coeficiente } \\
\text { de } \\
\text { variação } \\
(\%)\end{array}$ & $\begin{array}{l}\text { Valor } \\
\text { Máximo } \\
\text { (MPa) }\end{array}$ & $\begin{array}{c}\text { Valor } \\
\text { Mínimo } \\
\text { (MPa) }\end{array}$ & $\begin{array}{c}\text { Amplitude } \\
\text { (MPa) }\end{array}$ & $\begin{array}{c}\text { Intervalo de } \\
\text { confiança da } \\
\text { média } 95 \% \\
\text { (MPa) }\end{array}$ \\
\hline $1 \mathrm{~A}$ & $\begin{array}{l}4,1 \\
3,7\end{array}$ & 3,9 & 4,1 & 3,7 & 0,4 & \multirow{6}{*}{3,9} & \multirow{6}{*}{0,2} & \multirow{6}{*}{$5 \%$} & \multirow{6}{*}{4,5} & \multirow{6}{*}{3,4} & \multirow{6}{*}{1,2} & \multirow{6}{*}{ $\pm 0,1$} \\
\hline $2 B$ & $\begin{array}{l}3,7 \\
4,0\end{array}$ & 3,8 & 4,0 & 3,7 & 0,2 & & & & & & & \\
\hline $3 C$ & $\begin{array}{l}4,1 \\
3,6\end{array}$ & 3,8 & 4,1 & 3,6 & 0,5 & & & & & & & \\
\hline 4D & $\begin{array}{l}3,4 \\
3,8\end{array}$ & 3,6 & 3,8 & 3,4 & 0,4 & & & & & & & \\
\hline $5 \mathrm{E}$ & $\begin{array}{l}3,8 \\
4,5\end{array}$ & 4,2 & 4,5 & 3,8 & 0,8 & & & & & & & \\
\hline $6 \mathrm{~F}$ & $\begin{array}{l}4,1 \\
3,5\end{array}$ & 3,8 & 4,1 & 3,5 & 0,6 & & & & & & & \\
\hline
\end{tabular}




\section{E.1b) Resistência à tração a 35 dias por cura acelerada de 1 a 3 dias $\left(f_{c t, s p}\right.$} 35acel.AE1)

A Tabela 47 apresenta as medidas individuais, as médias, o desvio padrão, os valores máximos e mínimos, as amplitudes e o coeficiente de variação dos resultados do ensaio de resistência à tração por compressão diametral a 35 dias, por cura acelerada 24/72 horas seguida de cura imersa em água até 7 dias, sendo os corpos-de-prova mantidos por 24 horas em câmara de carbonatação a $5 \%$ de $\mathrm{CO}_{2}$ seguida de 27 dias de secagem em estufa, na condição $A E 1$, antes da realização do ensaio.

O concreto do caminhão $1 \mathrm{~A}$ apresentou maior média de resultados de resistência à tração. Os demais concretos mantiveram uma média de resultados próximos. $\mathrm{O}$ concreto $6 \mathrm{~F}$ apresentou menor resultado médio de resistência à tração por compressão diametral a 35 dias.

TABELA 47 - Resultados do ensaio de resistência à tração por compressão diametral a 35 dias (AE1) dos concretos do lote analisado. ABNT NBR 7222 (1994).

\begin{tabular}{|c|c|c|c|c|c|c|c|c|c|c|c|c|}
\hline \multirow[b]{2}{*}{ 穷 } & \multicolumn{5}{|c|}{ Medidas por amostra } & \multicolumn{7}{|c|}{ Cálculos para o lote } \\
\hline & $\begin{array}{c}\mathbf{f}_{\mathrm{ct}, \mathrm{sp}} \\
\text { 35acel.AE1 } \\
\text { (MPa) }\end{array}$ & $\begin{array}{l}\text { Média } \\
(\mathrm{MPa})\end{array}$ & $\begin{array}{c}\text { Valor } \\
\text { Máximo } \\
\text { (MPa) }\end{array}$ & $\begin{array}{c}\text { Valor } \\
\text { Mínimo } \\
\text { (MPa) }\end{array}$ & $\begin{array}{c}\text { Amplitude } \\
\text { (MPa) }\end{array}$ & $\begin{array}{r}\text { Média } \\
\text { (MPa) }\end{array}$ & $\begin{array}{c}\text { Desvio } \\
\text { padrão } \\
\text { (MPa) }\end{array}$ & $\begin{array}{c}\text { Coeficiente } \\
\text { de } \\
\text { variação } \\
(\%)\end{array}$ & $\begin{array}{c}\text { Valor } \\
\text { Máximo } \\
\text { (MPa) }\end{array}$ & $\begin{array}{c}\text { Valor } \\
\text { Mínimo } \\
(\mathrm{MPa})\end{array}$ & $\begin{array}{c}\text { Amplitude } \\
\text { (MPa) }\end{array}$ & $\begin{array}{l}\text { Intervalo de } \\
\text { confiança da } \\
\text { média } 95 \% \\
(\mathrm{MPa})\end{array}$ \\
\hline $1 \mathrm{~A}$ & $\begin{array}{l}4,1 \\
4,8\end{array}$ & 4,5 & 4,8 & 4,1 & 0,6 & & & & & & & \\
\hline $2 B$ & $\begin{array}{l}4,0 \\
3,9\end{array}$ & 4,0 & 4,0 & 3,9 & 0,1 & & & & & & & \\
\hline $3 C$ & $\begin{array}{l}4,4 \\
4,4\end{array}$ & 4,4 & 4,4 & 4,4 & 0,0 & 42 & 03 & $7 \%$ & 45 & 37 & 08 & $+0 ?$ \\
\hline 4D & $\begin{array}{l}4,3 \\
4,0\end{array}$ & 4,2 & 4,3 & 4,0 & 0,3 & & & & & & & \\
\hline $5 \mathrm{E}$ & $\begin{array}{l}4,1 \\
4,5\end{array}$ & 4,3 & 4,5 & 4,1 & 0,4 & & & & & & & \\
\hline $6 \mathrm{~F}$ & $\begin{array}{l}3,8 \\
3,6 \\
\end{array}$ & 3,7 & 3,8 & 3,6 & 0,2 & & & & & & & \\
\hline
\end{tabular}

\section{E.1c) Resistência à tração a 63 dias por cura acelerada de 1 a 3 dias $\left(f_{c t, s p}\right.$} 63acel.AE1)

A Tabela 48 apresenta as medidas individuais dos corpos-de-prova, as médias, o desvio padrão, os valores máximos e mínimos, as amplitudes e o coeficiente de variação dos resultados do ensaio de resistência à tração por compressão diametral a 63 dias, por cura acelerada 24/72 horas seguida de cura imersa em água até 7 dias, sendo os corposde-prova mantidos em ciclos de 24 horas de exposição em câmara de carbonatação a 5\% de $\mathrm{CO}_{2}$ seguida por 27 dias de secagem em estufa, na condição $\mathrm{AE} 1$, antes da realização do ensaio. 
Os concretos dos caminhões $5 \mathrm{E}$ e $6 \mathrm{~F}$ apresentaram maiores médias de resultados de resistência à tração. Os demais concretos mantiveram uma média de resultados próximos.

TABELA 48 - Resultados do ensaio de resistência à tração por compressão diametral a 63 dias (AE1) dos concretos do lote analisado. ABNT NBR 7222 (1994).

\begin{tabular}{|c|c|c|c|c|c|c|c|c|c|c|c|c|}
\hline \multirow{2}{*}{ 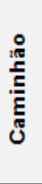 } & \multicolumn{5}{|c|}{ Medidas por amostra } & \multicolumn{7}{|c|}{ Cálculos para o lote } \\
\hline & $\begin{array}{c}\mathrm{f}_{\mathrm{ct}, \mathrm{sp}} \\
\text { 63acel.AE1 } \\
(\mathrm{MPa})\end{array}$ & $\begin{array}{l}\text { Média } \\
\text { (MPa) }\end{array}$ & $\begin{array}{l}\text { Valor } \\
\text { Máximo } \\
\text { (MPa) }\end{array}$ & $\begin{array}{l}\text { Valor } \\
\text { Mínimo } \\
\text { (MPa) }\end{array}$ & $\begin{array}{c}\text { Amplitude } \\
\text { (MPa) }\end{array}$ & $\begin{array}{l}\text { Média } \\
\text { (MPa) }\end{array}$ & $\begin{array}{c}\text { Desvio } \\
\text { padrão } \\
\text { (MPa) }\end{array}$ & $\begin{array}{c}\text { Coeficiente } \\
\text { de } \\
\text { variação } \\
(\mathrm{MPa})\end{array}$ & $\begin{array}{l}\text { Valor } \\
\text { Máximo } \\
\text { (MPa) }\end{array}$ & $\begin{array}{c}\text { Valor } \\
\text { Mínimo } \\
\text { (MPa) }\end{array}$ & $\begin{array}{l}\text { Amplitude } \\
\text { (MPa) }\end{array}$ & $\begin{array}{l}\text { Intervalo de } \\
\text { confiança da } \\
\text { média } 95 \% \\
(\mathrm{MPa})\end{array}$ \\
\hline $1 \mathrm{~A}$ & $\begin{array}{l}3,7 \\
3,9\end{array}$ & 3,8 & 3,9 & 3,7 & 0,2 & \multirow{6}{*}{3,8} & \multirow{6}{*}{0,3} & \multirow{6}{*}{$9 \%$} & \multirow{6}{*}{4,2} & \multirow{6}{*}{3,4} & \multirow{6}{*}{0,9} & \multirow{6}{*}{ $\pm 0,3$} \\
\hline $2 B$ & $\begin{array}{l}2,9 \\
4,4\end{array}$ & 3,7 & 4,4 & 2,9 & 1,5 & & & & & & & \\
\hline $3 C$ & $\begin{array}{l}3,5 \\
3,4\end{array}$ & 3,4 & 3,5 & 3,4 & 0,1 & & & & & & & \\
\hline $4 \mathrm{D}$ & $\begin{array}{l}3,3 \\
3,5\end{array}$ & 3,4 & 3,5 & 3,3 & 0,2 & & & & & & & \\
\hline $5 \mathrm{E}$ & $\begin{array}{l}3,7 \\
4,6\end{array}$ & 4,1 & 4,6 & 3,7 & 0,9 & & & & & & & \\
\hline $6 \mathrm{~F}$ & $\begin{array}{l}4,4 \\
4,1\end{array}$ & 4,2 & 4,4 & 4,1 & 0,4 & & & & & & & \\
\hline
\end{tabular}

E.1d) Resistência à tração a 91 dias por cura acelerada de 1 a 3 dias $\left(f_{c t, s p}\right.$ 91acel.AE1)

A Tabela 49 apresenta as medidas individuais dos corpos-de-prova, as médias, o desvio padrão, os valores máximos e mínimos, as amplitudes e o coeficiente de variação dos resultados do ensaio de resistência à tração por compressão diametral a 91 dias, por cura acelerada 24/72 horas seguida de cura imersa em água até 7 dias, sendo os corposde-prova mantidos em ciclos de 24 horas em câmara de carbonatação a 5\% de $\mathrm{CO}_{2}$ seguida por 27 dias de secagem em estufa, na condição $A E 1$, antes da realização do ensaio.

$\mathrm{O}$ concreto do caminhão $2 \mathrm{~B}$ apresentou maior média de resultado de resistência à tração. Os demais caminhões mantiveram uma média de resultados próximos. O concreto do caminhão 4D apresentou menor valor de resistência à tração por compressão diametral entre os concretos dos demais caminhões. 
TABELA 49 - Resultados do ensaio de resistência à tração por compressão diametral a 91 dias (AE1) dos concretos do lote analisado. ABNT NBR 7222 (1994).

\begin{tabular}{|c|c|c|c|c|c|c|c|c|c|c|c|c|}
\hline \multirow[b]{2}{*}{ 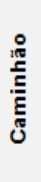 } & \multicolumn{5}{|c|}{ Medidas por amostra } & \multicolumn{7}{|c|}{ Cálculos para o lote } \\
\hline & $\begin{array}{c}f_{c t, s p} \\
\text { 91acel.AE1 } \\
\text { (MPa) }\end{array}$ & $\begin{array}{l}\text { Média } \\
\text { (MPa) }\end{array}$ & $\begin{array}{c}\text { Valor } \\
\text { Máximo } \\
\text { (MPa) }\end{array}$ & $\begin{array}{c}\text { Valor } \\
\text { Mínimo } \\
\text { (MPa) }\end{array}$ & $\begin{array}{l}\text { Amplitude } \\
\text { (MPa) }\end{array}$ & $\begin{array}{l}\text { Média } \\
\text { (MPa) }\end{array}$ & $\begin{array}{c}\text { Desvio } \\
\text { padrão } \\
\text { (MPa) }\end{array}$ & $\begin{array}{c}\text { Coeficiente } \\
\text { de } \\
\text { variação } \\
(\%)\end{array}$ & $\begin{array}{l}\text { Valor } \\
\text { Máximo } \\
\text { (MPa) }\end{array}$ & $\begin{array}{c}\text { Valor } \\
\text { Mínimo } \\
\text { (MPa) }\end{array}$ & $\begin{array}{c}\text { Amplitude } \\
\text { (MPa) }\end{array}$ & $\begin{array}{c}\text { Intervalo de } \\
\text { confiança da } \\
\text { média } 95 \% \\
(\mathrm{MPa})\end{array}$ \\
\hline $1 \mathrm{~A}$ & $\begin{array}{l}3,8 \\
3,5\end{array}$ & 3,6 & 3,8 & 3,5 & 0,3 & \multirow{6}{*}{3,8} & \multirow{6}{*}{0,3} & \multirow{6}{*}{$8 \%$} & \multirow{6}{*}{4,2} & \multirow{6}{*}{3,4} & \multirow{6}{*}{0,8} & \multirow{6}{*}{ $\pm 0,2$} \\
\hline $2 \mathrm{~B}$ & $\begin{array}{l}4,1 \\
4,3\end{array}$ & 4,2 & 4,3 & 4,1 & 0,2 & & & & & & & \\
\hline $3 C$ & $\begin{array}{l}3,9 \\
3,7\end{array}$ & 3,8 & 3,9 & 3,7 & 0,3 & & & & & & & \\
\hline 4D & $\begin{array}{l}3,4 \\
3,4\end{array}$ & 3,4 & 3,4 & 3,4 & 0,0 & & & & & & & \\
\hline $5 \mathrm{E}$ & $\begin{array}{l}4,0 \\
4,2\end{array}$ & 4,1 & 4,2 & 4,0 & 0,2 & & & & & & & \\
\hline $6 \mathrm{~F}$ & $\begin{array}{l}3,9 \\
4,1 \\
\end{array}$ & 4,0 & 4,1 & 3,9 & 0,3 & & & & & & & \\
\hline
\end{tabular}

\section{E.1e) Resistência à tração a 203 dias por cura acelerada de 1 a 3 dias $\left(f_{c t, s p}\right.$} 203acel.AE1)

A Tabela 50 apresenta as medidas individuais dos corpos-de-prova, as médias, o desvio padrão, os valores máximos e mínimos, as amplitudes e o coeficiente de variação dos resultados do ensaio de resistência à tração por compressão diametral a 203 dias, por cura acelerada 24/72 horas seguida de cura imersa em água até 7 dias, sendo os corposde-prova mantidos em ciclos de 24 horas em câmara de carbonatação a $5 \%$ de $\mathrm{CO}_{2}$ seguida por 27 dias de secagem em estufa, na condição AE1, antes da realização do ensaio.

Os concretos dos caminhões $1 \mathrm{~A}$ e $5 \mathrm{E}$ apresentaram maior média de resultado de resistência à tração. Os demais concretos mantiveram uma média de resultados próximos. O concreto do caminhão 6F apresentou menor valor de resistência à tração por compressão diametral.

TABELA 50 - Resultados do ensaio de resistência à tração por compressão diametral a 203 dias (AE1) dos concretos do lote analisado. ABNT NBR 7222 (1994).

\begin{tabular}{|c|c|c|c|c|c|c|c|c|c|c|c|c|}
\hline \multirow[b]{2}{*}{ 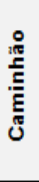 } & \multicolumn{5}{|c|}{ Medidas por amostra } & \multicolumn{7}{|c|}{ Cálculos para o lote } \\
\hline & $\begin{array}{c}f_{c t, 5 p} \\
\text { 203acel.AE1 } \\
\text { (MPa) }\end{array}$ & $\begin{array}{l}\text { Média } \\
(\mathrm{MPa})\end{array}$ & $\begin{array}{c}\text { Valor } \\
\text { Máximo } \\
\text { (MPa) }\end{array}$ & $\begin{array}{l}\text { Valor } \\
\text { Mínimo } \\
\text { (MPa) }\end{array}$ & $\begin{array}{c}\text { Amplitude } \\
\text { (MPa) }\end{array}$ & Média (MPa) & $\begin{array}{c}\text { Desvio } \\
\text { padrão } \\
(\mathrm{MPa})\end{array}$ & $\begin{array}{c}\text { Coeficiente } \\
\text { de } \\
\text { variação } \\
(\%)\end{array}$ & $\begin{array}{l}\text { Valor } \\
\text { Máximo } \\
(\mathrm{MPa})\end{array}$ & $\begin{array}{c}\text { Valor } \\
\text { Mínimo } \\
(\mathrm{MPa})\end{array}$ & $\begin{array}{l}\text { Amplitude } \\
\text { (MPa) }\end{array}$ & $\begin{array}{l}\text { Intervalo de } \\
\text { confiança da } \\
\text { média 95\% } \\
\text { (MPa) }\end{array}$ \\
\hline $1 \mathrm{~A}$ & $\begin{array}{l}4,6 \\
4,3\end{array}$ & 4,5 & 4,6 & 4,3 & 0,2 & & & & & & & \\
\hline $2 B$ & $\begin{array}{l}4,2 \\
4,6\end{array}$ & 4,4 & 4,6 & 4,2 & 0,4 & & & & & & & \\
\hline $3 C$ & $\begin{array}{l}4,0 \\
4,6\end{array}$ & 4,3 & 4,6 & 4,0 & 0,6 & 43 & 02 & $5 \%$ & 4.5 & 39 & 06 & +02 \\
\hline 4D & $\begin{array}{l}3,8 \\
4,6\end{array}$ & 4,2 & 4,6 & 3,8 & 0,7 & 4,3 & 0,2 & $3 \%$ & 4,5 & 3,9 & 0,6 & $\pm 0,2$ \\
\hline $5 \mathrm{E}$ & $\begin{array}{l}4,2 \\
4,8\end{array}$ & 4,5 & 4,8 & 4,2 & 0,6 & & & & & & & \\
\hline $6 \mathrm{~F}$ & $\begin{array}{l}4,0 \\
3,8\end{array}$ & 3,9 & 4,0 & 3,8 & 0,3 & & & & & & & \\
\hline
\end{tabular}


A Figura 76 ilustra as resistências médias à tração para as idades de ruptura entre $8 \mathrm{e}$ 203 dias, para as condições de envelhecimento acelerado por exposição a 24h em câmara de carbonatação seguida de 27 dias de secagem em estufa ventilada a $40 \pm 1^{\circ} \mathrm{C}$ (AE1).

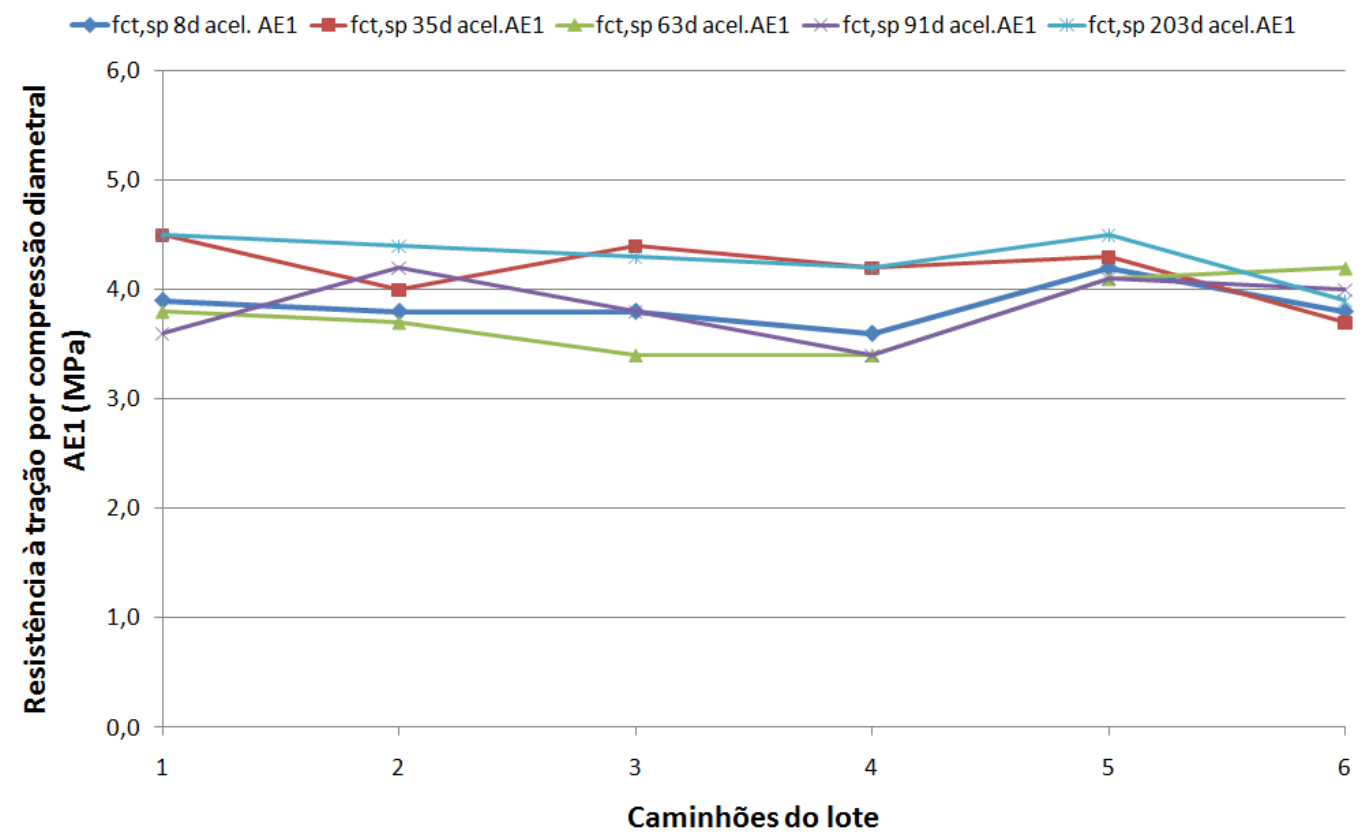

FIGURA 76 - Variação da resistência à tração por compressão diametral média dos corpos-de-prova, submetidos à cura acelerada 24/72h e imersão em água até 7 dias e ciclagem de $24 \mathrm{~h}$ de exposição em câmara de $\mathrm{CO}_{2}$ seguida por 27 dias de secagem contínua (AE1).

No geral, como esperado, não se observa grandes diferençasentre os concretos amostrados.

\section{E.2) Cura acelerada 24/72 horas seguida por imersão em água até 7 dias e ciclos de 24 horas de imersão em tanque com água seguidos por 27 dias de secagem (AE2).}

\section{E.2a) Resistência à tração a 8 dias por cura acelerada de 1 a 3 dias $\left(f_{c t, s p}\right.$ 8acel.AE2)}

A Tabela 51 apresenta as medidas individuais dos corpos-de-prova, as médias, o desvio padrão, os valores máximos e mínimos, as amplitudes e o coeficiente de variação dos resultados do ensaio de resistência à tração por compressão diametral a 8 dias por cura acelerada 24/72 horas seguida de cura imersa em água até 7 dias, sendo os corpos-deprova mantidos por 24 horas em tanque de água limpa no primeiro dia da condição AE2, antes da realização do ensaio. 
O concreto do caminhão $5 \mathrm{E}$ apresentou novamente maior média de resultados de resistência à tração, com igual valor do concreto do caminhão $2 \mathrm{~B}$. Os demais concretos mantiveram uma média de resultados mais próximos.

TABELA 51 - Resultados do ensaio de resistência à tração por compressão diametral a 8 dias (AE2) dos concretos do lote analisado. ABNT NBR 7222 (1994).

\begin{tabular}{|c|c|c|c|c|c|c|c|c|c|c|c|c|}
\hline \multirow{2}{*}{ 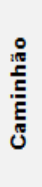 } & \multicolumn{5}{|c|}{ Medidas por amostra } & \multicolumn{7}{|c|}{ Cálculo para o lote } \\
\hline & $\begin{array}{l}\mathrm{f}_{\text {ct,sp }} \\
\text { 8acel.AE2 } \\
(\mathrm{MPa})\end{array}$ & $\begin{array}{l}\text { Média } \\
\text { (MPa) }\end{array}$ & $\begin{array}{c}\text { Valor } \\
\text { Máximo } \\
\text { (MPa) }\end{array}$ & $\begin{array}{c}\text { Valor } \\
\text { Mínimo } \\
(\mathrm{MPa})\end{array}$ & $\begin{array}{l}\text { Amplitude } \\
\text { (MPa) }\end{array}$ & $\begin{array}{l}\text { Média } \\
\text { (MPa) }\end{array}$ & $\begin{array}{c}\text { Desvio } \\
\text { padrão } \\
\text { (MPa) }\end{array}$ & $\begin{array}{c}\text { Coeficiente } \\
\text { de } \\
\text { variação } \\
(\%)\end{array}$ & $\begin{array}{l}\text { Valor } \\
\text { Máximo } \\
(\mathrm{MPa})\end{array}$ & $\begin{array}{l}\text { Valor } \\
\text { Mínimo } \\
\text { (MPa) }\end{array}$ & $\begin{array}{c}\text { Amplitude } \\
\text { (MPa) }\end{array}$ & $\begin{array}{l}\text { Intervalo de } \\
\text { confiança da } \\
\text { média } 95 \% \\
\text { (MPa) }\end{array}$ \\
\hline $1 \mathrm{~A}$ & $\begin{array}{l}4,1 \\
3,0\end{array}$ & 3,5 & 4,1 & 3,0 & 1,1 & & & & & & & \\
\hline $2 B$ & $\begin{array}{l}4,0 \\
4,0\end{array}$ & 4,0 & 4,0 & 4,0 & 0,0 & & & & & & & \\
\hline $3 C$ & $\begin{array}{l}3,8 \\
4,0\end{array}$ & 3,9 & 4,0 & 3,8 & 0,2 & 3.8 & 0,3 & $7 \%$ & 4.0 & 34 & 0.7 & \pm 0.2 \\
\hline 4D & $\begin{array}{l}3,5 \\
3,3\end{array}$ & 3,4 & 3,5 & 3,3 & 0,2 & & & & & & & \\
\hline $5 \mathrm{E}$ & $\begin{array}{l}4,1 \\
4,0\end{array}$ & 4,0 & 4,1 & 4,0 & 0,1 & & & & & & & \\
\hline $6 \mathrm{~F}$ & $\begin{array}{l}4,0 \\
3,5\end{array}$ & 3,7 & 4,0 & 3,5 & 0,4 & & & & & & & \\
\hline
\end{tabular}

Observa-se que o concreto do caminhão 4D mostrou menor resultado de resistência à tração a 8 dias, nesta condição de exposição e na condição do item A.1, que são aliás muito similares no início, dado apenas diferirem da condição de exposição do $7^{\circ}$ para o $8^{\circ}$ dia.

\section{E.2b) Resistência à tração a 35 dias por cura acelerada de 1 a 3 dias $\left(f_{c t, s p}\right.$} 35acel.AE2)

A Tabela 52 apresenta as medidas individuais dos corpos-de-prova, as médias, o desvio padrão, os valores máximos e mínimos, as amplitudes e o coeficiente de variação dos resultados do ensaio de resistência à tração por compressão diametral a 35 dias, por cura acelerada 24/72 horas seguida de cura imersa em água até 7 dias, sendo os corposde-prova mantidos por ciclo de 24 horas em tanque de água limpa seguido de 27 dias de secagem em estufa, na condição AE2, antes da realização do ensaio.

$\mathrm{O}$ concreto do caminhão $2 \mathrm{~B}$ apresentou maior média de resultados de resistência à tração. Os demais concretos mantiveram uma média de resultados mais próximos. $O$ concreto do caminhão 4D apresentou menor resultado médio de resistência à tração também nesta idade. 
TABELA 52 - Resultados do ensaio de resistência à tração por compressão diametral a 35 dias (AE2) dos concretos do lote analisado. ABNT NBR 7222 (1994).

\begin{tabular}{|c|c|c|c|c|c|c|c|c|c|c|c|c|}
\hline \multirow[b]{2}{*}{ 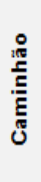 } & \multicolumn{5}{|c|}{ Medidas por amostra } & \multicolumn{7}{|c|}{ Cálculos para o lote } \\
\hline & $\begin{array}{c}\mathbf{f}_{\mathrm{ct}, \text { sp }} \\
\text { 35acel.AE2 } \\
\text { (MPa) }\end{array}$ & $\begin{array}{l}\text { Média } \\
(\mathrm{MPa})\end{array}$ & $\begin{array}{c}\text { Valor } \\
\text { Máximo } \\
\text { (MPa) }\end{array}$ & $\begin{array}{c}\text { Valor } \\
\text { Mínimo } \\
(\mathrm{MPa})\end{array}$ & $\begin{array}{c}\text { Amplitude } \\
\text { (MPa) }\end{array}$ & $\begin{array}{l}\text { Média } \\
\text { (MPa) }\end{array}$ & $\begin{array}{c}\text { Desvio } \\
\text { padrão } \\
\text { (MPa) }\end{array}$ & $\begin{array}{c}\text { Coeficiente } \\
\text { de } \\
\text { variação } \\
(\%)\end{array}$ & $\begin{array}{c}\text { Valor } \\
\text { Máximo } \\
\text { (MPa) }\end{array}$ & $\begin{array}{c}\text { Valor } \\
\text { Mínimo } \\
(\mathrm{MPa})\end{array}$ & $\begin{array}{c}\text { Amplitude } \\
\text { (MPa) }\end{array}$ & $\begin{array}{c}\text { Intervalo de } \\
\text { confiança da } \\
\text { média } 95 \% \\
(\mathrm{MPa})\end{array}$ \\
\hline $1 \mathrm{~A}$ & $\begin{array}{l}4,3 \\
4,3\end{array}$ & 4,3 & 4,3 & 4,3 & 0,1 & \multirow{6}{*}{4,2} & \multirow{6}{*}{0,2} & \multirow{6}{*}{$4 \%$} & \multirow{6}{*}{4,5} & \multirow{6}{*}{3,9} & \multirow{6}{*}{0,5} & \multirow{6}{*}{ $\pm 0,1$} \\
\hline $2 \mathrm{~B}$ & $\begin{array}{l}4,4 \\
4,6\end{array}$ & 4,5 & 4,6 & 4,4 & 0,2 & & & & & & & \\
\hline $3 C$ & $\begin{array}{l}4,1 \\
4,2\end{array}$ & 4,2 & 4,2 & 4,1 & 0,1 & & & & & & & \\
\hline $4 \mathrm{D}$ & $\begin{array}{l}4,0 \\
3,9\end{array}$ & 3,9 & 4,0 & 3,9 & 0,1 & & & & & & & \\
\hline $5 \mathrm{E}$ & $\begin{array}{l}3,9 \\
4,2\end{array}$ & 4,1 & 4,2 & 3,9 & 0,3 & & & & & & & \\
\hline $6 \mathrm{~F}$ & $\begin{array}{l}4,5 \\
4,0\end{array}$ & 4,2 & 4,5 & 4,0 & 0,5 & & & & & & & \\
\hline
\end{tabular}

E.2c) Resistência à tração a 63 dias por cura acelerada de 1 a 3 dias $\left(f_{c t, s p}\right.$ 63acel.AE2)

A Tabela 53 apresenta as medidas individuais dos corpos-de-prova, as médias, o desvio padrão, os valores máximos e mínimos, as amplitudes e o coeficiente de variação dos resultados do ensaio de resistência à tração por compressão diametral a 63 dias por cura acelerada 24/72 horas seguida de cura imersa em água até 7 dias, sendo os corposde-prova mantidos por ciclos de 24 horas de imersão em tanque de água limpa seguido de 27 dias de secagem em estufa, na condição AE2, antes da realização do ensaio.

Os concretos dos caminhões 2B e 3C apresentaram maiores médias de resultados de resistência à tração. Os demais concretos mantiveram uma média de resultados próximos. Os concretos dos caminhões 4D e 6F apresentaram menores resultados médios de resistência à tração.

TABELA 53 - Resultados do ensaio de resistência à tração por compressão diametral a 63 dias (AE2) dos concretos do lote analisado. ABNT NBR 7222 (1994).

\begin{tabular}{|c|c|c|c|c|c|c|c|c|c|c|c|c|}
\hline \multirow[b]{2}{*}{ 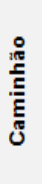 } & \multicolumn{5}{|c|}{ Medidas por amostra } & \multicolumn{7}{|c|}{ Cálculos para o lote } \\
\hline & $\begin{array}{c}\mathrm{f}_{\mathrm{ctt}, 5 \mathrm{p}} \\
\text { 63acel.AE2 } \\
\text { (MPa) }\end{array}$ & $\begin{array}{l}\text { Média } \\
\text { (MPa) }\end{array}$ & $\begin{array}{c}\text { Valor } \\
\text { Máximo } \\
\text { (MPa) }\end{array}$ & $\begin{array}{c}\text { Valor } \\
\text { Mínimo } \\
\text { (MPa) }\end{array}$ & $\begin{array}{c}\text { Amplitude } \\
\text { (MPa) }\end{array}$ & $\begin{array}{l}\text { Média } \\
\text { (MPa) }\end{array}$ & $\begin{array}{c}\text { Desvio } \\
\text { padrão } \\
\text { (MPa) }\end{array}$ & $\begin{array}{c}\text { Coeficiente } \\
\text { de } \\
\text { variação } \\
(\%)\end{array}$ & $\begin{array}{c}\text { Valor } \\
\text { Máximo } \\
\text { (MPa) }\end{array}$ & $\begin{array}{c}\text { Valor } \\
\text { Mínimo } \\
\text { (MPa) }\end{array}$ & $\begin{array}{l}\text { Amplitude } \\
\text { (MPa) }\end{array}$ & $\begin{array}{l}\text { Intervalo de } \\
\text { confiança da } \\
\text { média 95\% } \\
(\mathrm{MPa})\end{array}$ \\
\hline $1 \mathrm{~A}$ & $\begin{array}{l}3,6 \\
4,2\end{array}$ & 3,9 & 4,2 & 3,6 & 0,6 & \multirow{6}{*}{4,1} & \multirow{6}{*}{0,3} & \multirow{6}{*}{$8 \%$} & \multirow{6}{*}{4,5} & \multirow{6}{*}{3,8} & \multirow{6}{*}{0,8} & \multirow{6}{*}{ $\pm 0,3$} \\
\hline $2 B$ & $\begin{array}{l}4,7 \\
4,4\end{array}$ & 4,5 & 4,7 & 4,4 & 0,4 & & & & & & & \\
\hline $3 \mathrm{C}$ & $\begin{array}{l}4,7 \\
4,3\end{array}$ & 4,5 & 4,7 & 4,3 & 0,5 & & & & & & & \\
\hline $4 \mathrm{D}$ & $\begin{array}{l}3,9 \\
3,7\end{array}$ & 3,8 & 3,9 & 3,7 & 0,2 & & & & & & & \\
\hline $5 \mathrm{E}$ & $\begin{array}{l}4,2 \\
3,9\end{array}$ & 4,1 & 4,2 & 3,9 & 0,3 & & & & & & & \\
\hline $6 \mathrm{~F}$ & $\begin{array}{l}3,9 \\
3,7\end{array}$ & 3,8 & 3,9 & 3,7 & 0,2 & & & & & & & \\
\hline
\end{tabular}




\section{E.2d) Resistência à tração a 91 dias por cura acelerada de 1 a 3 dias $\left(f_{c t, s p}\right.$} 91 acel.AE2)

A Tabela 54 apresenta as medidas, as médias individuais dos corpos-de-prova, o desvio padrão, os valores máximos e mínimos, as amplitudes e o coeficiente de variação dos resultados do ensaio de resistência à tração por compressão diametral a 91 dias, por cura acelerada 24/72 horas seguida de cura imersa em água até 7 dias, sendo os corposde-prova mantidos em ciclos de 24 horas imersos em tanque de água seguido de 27 dias de secagem em estufa, na condição AE2, antes da realização do ensaio.

$\mathrm{O}$ concreto do caminhão $2 \mathrm{~B}$ apresentou maior média de resultado de resistência à tração. Os demais concretos mantiveram uma média de resultados próximos, com exceção do concreto do caminhão 4D que apresentou novamente menor valor de resistência à tração por compressão diametral, entre os demais concretos.

TABELA 54 - Resultados do ensaio de resistência à tração por compressão diametral a 91 dias (AE2) dos concretos do lote analisado. ABNT NBR 7222 (1994).

\begin{tabular}{|c|c|c|c|c|c|c|c|c|c|c|c|c|c|}
\hline \multirow[b]{2}{*}{ ֻْ } & \multicolumn{5}{|c|}{ Medidas por amostra } & \multicolumn{8}{|c|}{ Cálculos para o lote } \\
\hline & $\begin{array}{c}\mathrm{f}_{\mathrm{ct}, 5 \mathrm{pp}} \\
91 \mathrm{acel} . \mathrm{AE} 2 \\
(\mathrm{MPa})\end{array}$ & $\begin{array}{l}\text { Média } \\
\text { (MPa) }\end{array}$ & $\begin{array}{l}\text { Valor } \\
\text { Máximo } \\
\text { (MPa) }\end{array}$ & $\begin{array}{c}\text { Valor } \\
\text { Minimo } \\
\text { (MPa) }\end{array}$ & $\begin{array}{c}\text { Amplitude } \\
\text { (MPa) }\end{array}$ & Média & (MPa) & $\begin{array}{l}\text { Desvio } \\
\text { padrão } \\
\text { (MPa) }\end{array}$ & $\begin{array}{c}\text { Coeficiente } \\
\text { de } \\
\text { variação } \\
(\%) \\
\end{array}$ & $\begin{array}{l}\text { Valor } \\
\text { Máximo } \\
\text { (MPa) }\end{array}$ & $\begin{array}{c}\text { Valor } \\
\text { Mínimo } \\
\text { (MPa) }\end{array}$ & $\begin{array}{c}\text { Amplitude } \\
\text { (MPa) }\end{array}$ & $\begin{array}{c}\text { Intervalo de } \\
\text { confiança da } \\
\text { média 95\% } \\
\text { (MPa) }\end{array}$ \\
\hline $1 \mathrm{~A}$ & $\begin{array}{l}4,6 \\
4,8\end{array}$ & 4,7 & 4,8 & 4,6 & 0,2 & & & & & & & & \\
\hline $2 \mathrm{~B}$ & $\begin{array}{l}4,9 \\
4,7\end{array}$ & 4,8 & 4,9 & 4,7 & 0,2 & & & & & & & & \\
\hline $3 \mathrm{C}$ & $\begin{array}{l}4,9 \\
4,5\end{array}$ & 4,7 & 4,9 & 4,5 & 0,4 & & 5 & 0,3 & $8 \%$ & 4,8 & 3,9 & 1,0 & $\pm 0,3$ \\
\hline $4 \mathrm{D}$ & $\begin{array}{l}4,0 \\
3,7\end{array}$ & 3,9 & 4,0 & 3,7 & 0,3 & & & & & & & & \\
\hline $5 \mathrm{E}$ & $\begin{array}{l}4,6 \\
4,6\end{array}$ & 4,6 & 4,6 & 4,6 & 0,0 & & & & & & & & \\
\hline $6 \mathrm{~F}$ & $\begin{array}{l}4,6 \\
4,5\end{array}$ & 4,6 & 4,6 & 4,5 & 0,0 & & & & & & & & \\
\hline
\end{tabular}

\section{E.2e) Resistência à tração a 203 dias por cura acelerada de 1 a 3 dias}

$\left(f_{c t, s p ~ 203 a c e l . A E 2}\right)$

A Tabela 55 apresenta as medidas individuais dos corpos-de-prova, as médias, o desvio padrão, os valores máximos e mínimos, as amplitudes e o coeficiente de variação dos resultados do ensaio de resistência à tração por compressão diametral a 203 dias, por cura acelerada 24/72 horas seguida de cura imersa em água até 7 dias, sendo os corposde-prova mantidos em ciclos de 24 horas de imersão em tanque de água seguido de 27 dias de secagem em estufa, na condição AE2, antes da realização do ensaio. 
O concreto do caminhão 2B apresentou maior resistência média à tração. Os demais concretos mantiveram uma média de resultados próximos, com exceção do concreto 4D que apresentou consecutivamente o menor valor de resistência à tração por compressão diametral, entre os demais caminhões. Observa-se que os concretos $2 \mathrm{~B}$ e $5 \mathrm{E}$ apresentaram maiores resultados de resistência à tração a 203 dias nesta condição de exposição.

TABELA 55 - Resultados do ensaio de resistência à tração por compressão diametral a 203 dias (AE2) dos concretos do lote analisado. ABNT NBR 7222 (1994).

\begin{tabular}{|c|c|c|c|c|c|c|c|c|c|c|c|c|}
\hline \multirow{2}{*}{ 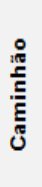 } & \multicolumn{5}{|c|}{ Medidas por amostra } & \multicolumn{7}{|c|}{ Cálculos para o lote } \\
\hline & $\begin{array}{c}\mathrm{f}_{\mathrm{ct}, \mathrm{sp}} \\
\text { 203acel.AE2 } \\
(\mathrm{MPa})\end{array}$ & $\begin{array}{l}\text { Média } \\
\text { (MPa) }\end{array}$ & $\begin{array}{l}\text { Valor } \\
\text { Máximo } \\
\text { (MPa) }\end{array}$ & $\begin{array}{c}\text { Valor } \\
\text { Mínimo } \\
\text { (MPa) }\end{array}$ & $\begin{array}{l}\text { Amplitude } \\
\text { (MPa) }\end{array}$ & Média (MPa) & $\begin{array}{c}\text { Desvio } \\
\text { padrão } \\
\text { (MPa) }\end{array}$ & $\begin{array}{c}\text { Coeficiente } \\
\text { de } \\
\text { variação } \\
(\%)\end{array}$ & $\begin{array}{c}\text { Valor } \\
\text { Máximo } \\
\text { (MPa) }\end{array}$ & $\begin{array}{c}\text { Valor } \\
\text { Mínimo } \\
\text { (MPa) }\end{array}$ & $\begin{array}{c}\text { Amplitude } \\
\text { (MPa) }\end{array}$ & $\begin{array}{l}\text { Intervalo de } \\
\text { confiança da } \\
\text { média 95\% } \\
\text { (MPa) }\end{array}$ \\
\hline $1 \mathrm{~A}$ & $\begin{array}{l}4,9 \\
4,5\end{array}$ & 4,7 & 4,9 & 4,5 & 0,4 & & & & & & & \\
\hline $2 \mathrm{~B}$ & $\begin{array}{l}5,0 \\
5,1\end{array}$ & 5,1 & 5,1 & 5,0 & 0,1 & & & & & & & \\
\hline $3 \mathrm{C}$ & $\begin{array}{l}4,6 \\
4,9\end{array}$ & 4,7 & 4,9 & 4,6 & 0,4 & 4,7 & 0,3 & $6 \%$ & 5,1 & 4,3 & 0,7 & $\pm 0,2$ \\
\hline 4D & $\begin{array}{l}4,0 \\
4,7\end{array}$ & 4,3 & 4,7 & 4,0 & 0,6 & & & & & & & \\
\hline $5 \mathrm{E}$ & $\begin{array}{l}4,9 \\
5,2\end{array}$ & 5,0 & 5,2 & 4,9 & 0,3 & & & & & & & \\
\hline $6 \mathrm{~F}$ & $\begin{array}{l}4,7 \\
4,5\end{array}$ & 4,6 & 4,7 & 4,5 & 0,3 & & & & & & & \\
\hline
\end{tabular}

A Figura 77 a seguir ilustra as resistências médias à tração para as idades de ruptura para a condição de envelhecimento acelerado AE2 por exposição a $24 \mathrm{~h}$ de imersão em tanque de água limpa seguido de 27 dias de secagem em estufa.

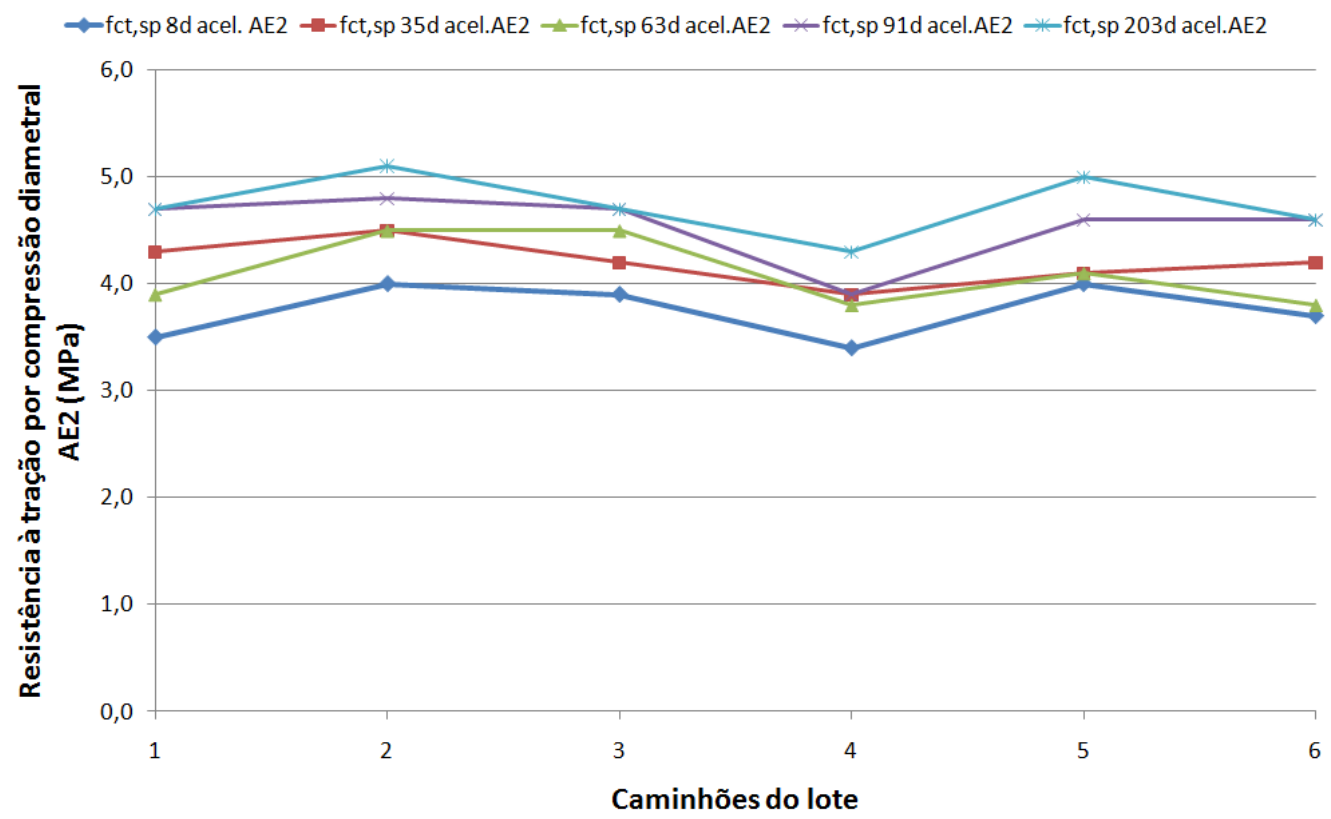

FIGURA 77- Variação da resistência à tração por compressão diametral média dos corpos-de-prova, submetidos à cura acelerada $24 / 72 \mathrm{~h}$ e imersão em água até 7 dias e depois à ciclagem de $24 \mathrm{~h}$ de imersão em tanque de água seguido por 27 dias de secagem. 
De modo diferente da condição $\mathrm{AE} 1$, a ciclagem na condição $\mathrm{AE} 2$ destacou a menor resistência à tração para o concreto do caminhão 4D em todas as idades. Este resultado coincide com o que foi observado como tendência nas medidas de resistência à compressão simples conforme a Figura 68. Também o caminhão 4D destacou-se nas medidas do concreto fresco, por conter o menor teor de ar.

\section{E.3) Cura acelerada $24 / 72$ horas seguida por imersão em água até 7 dias e ciclos de 28 dias de secagem contínua (AE3).}

\section{E.3a) Resistência à tração a 91 dias por cura acelerada de 1 a 3 dias $\left(f_{c t, s p}\right.$ 91acel.AE3)}

A Tabela 56 apresenta as medidas individuais dos corpos-de-prova, as médias, o desvio padrão, os valores máximos e mínimos, as amplitudes e o coeficiente de variação dos resultados do ensaio de resistência à tração por compressão diametral a 91 dias, por cura acelerada 24/72 horas seguida de cura imersa em água até 7 dias, sendo os corposde-prova mantidos em ciclos de 28 dias de secagem contínua em estufa a $(40 \pm 5)^{\circ} \mathrm{C}$, na condição AE3, antes da realização do ensaio.

Os concretos dos caminhões 3C e 5D apresentaram maiores médias de resultado de resistência à tração. Os demais concretos mostraram resultados médios próximos.

Observa-se que os concretos dos caminhões 1A e $6 \mathrm{~F}$ apresentaram menores resultados de resistência à tração a 91 dias nesta condição de exposição.

TABELA 56 - Resultados do ensaio de resistência à tração por compressão diametral a 91 dias (AE3) dos concretos do lote analisado. ABNT NBR 7222 (1994).

\begin{tabular}{|c|c|c|c|c|c|c|c|c|c|c|c|c|}
\hline \multirow[b]{2}{*}{ 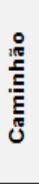 } & \multicolumn{5}{|c|}{ Medidas por amostra } & \multicolumn{7}{|c|}{ Cálculos para o lote } \\
\hline & $\begin{array}{c}\mathrm{f}_{\text {ct, sp }} \\
91 \text { acel.AE3 } \\
\text { (MPa) }\end{array}$ & $\begin{array}{l}\text { Média } \\
\text { (MPa) }\end{array}$ & $\begin{array}{l}\text { Valor } \\
\text { Máximo } \\
\text { (MPa) }\end{array}$ & $\begin{array}{c}\text { Valor } \\
\text { Mínimo } \\
\text { (MPa) }\end{array}$ & $\begin{array}{l}\text { Amplitude } \\
\text { (MPa) }\end{array}$ & $\begin{array}{l}\text { Média } \\
(\mathrm{MPa})\end{array}$ & $\begin{array}{c}\text { Desvio } \\
\text { padrão } \\
\text { (MPa) }\end{array}$ & $\begin{array}{c}\text { Coeficiente } \\
\text { de } \\
\text { variação } \\
(\%)\end{array}$ & $\begin{array}{l}\text { Valor } \\
\text { Máximo } \\
\text { (MPa) }\end{array}$ & $\begin{array}{l}\text { Valor } \\
\text { Mínimo } \\
(\mathrm{MPa})\end{array}$ & $\begin{array}{l}\text { Amplitude } \\
\text { (MPa) }\end{array}$ & $\begin{array}{c}\text { Intervalo de } \\
\text { confiança da } \\
\text { média 95\% } \\
\text { (MPa) }\end{array}$ \\
\hline $1 \mathrm{~A}$ & $\begin{array}{l}3,6 \\
3,9\end{array}$ & 3,7 & 3,9 & 3,6 & 0,3 & \multirow{6}{*}{4,0} & \multirow{6}{*}{0,3} & \multirow{6}{*}{$7 \%$} & \multirow{6}{*}{4,3} & \multirow{6}{*}{3,7} & \multirow{6}{*}{0,6} & \multirow{6}{*}{ $\pm 0,2$} \\
\hline $2 B$ & $\begin{array}{l}3,9 \\
4,1\end{array}$ & 4,0 & 4,1 & 3,9 & 0,2 & & & & & & & \\
\hline $3 \mathrm{C}$ & $\begin{array}{l}4,5 \\
4,1\end{array}$ & 4,3 & 4,5 & 4,1 & 0,4 & & & & & & & \\
\hline $4 \mathrm{D}$ & $\begin{array}{l}3,5 \\
3,9\end{array}$ & 3,7 & 3,9 & 3,5 & 0,3 & & & & & & & \\
\hline $5 \mathrm{E}$ & $\begin{array}{l}4,2 \\
4,5\end{array}$ & 4,3 & 4,5 & 4,2 & 0,3 & & & & & & & \\
\hline $6 \mathrm{~F}$ & $\begin{array}{l}3,9 \\
3,6\end{array}$ & 3,8 & 3,9 & 3,6 & 0,3 & & & & & & & \\
\hline
\end{tabular}




\section{E.3b) Resistência à tração a 203 dias por cura acelerada de 1 a 3 dias}

$\left(f_{\text {ct,sp 203acel.AE3 })}\right.$

A Tabela 57 apresenta as medidas individuais dos corpos-de-prova, as médias, o desvio padrão, os valores máximos e mínimos, as amplitudes e o coeficiente de variação dos resultados do ensaio de resistência à tração por compressão diametral a 203 dias, por cura acelerada 24/72 horas seguida de cura imersa em água até 7 dias, sendo os corposde-prova mantidos em ciclos de 28 dias de secagem contínua em estufa a $(40 \pm 5)^{\circ} \mathrm{C}$, na condição $A E 3$, antes da realização do ensaio.

Os concretos dos caminhões 2B e 3C apresentaram maiores médias de resultados de resistência à tração. Os demais concretos mantiveram resultados médios muito próximos.

TABELA 57 - Resultados do ensaio de resistência à tração por compressão diametral a 203 dias (AE3) dos concretos do lote analisado. ABNT NBR 7222 (1994).

\begin{tabular}{|c|c|c|c|c|c|c|c|c|c|c|c|c|}
\hline \multirow[b]{2}{*}{ 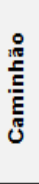 } & \multicolumn{5}{|c|}{ Medidas por amostra } & \multicolumn{7}{|c|}{ Cálculos para o lote } \\
\hline & $\begin{array}{c}f_{c t, s p} \\
\text { 203acel.AE3 } \\
\text { (MPa) }\end{array}$ & $\begin{array}{l}\text { Média } \\
(\mathrm{MPa})\end{array}$ & $\begin{array}{c}\text { Valor } \\
\text { Máximo } \\
\text { (MPa) }\end{array}$ & $\begin{array}{c}\text { Valor } \\
\text { Mínimo } \\
\text { (MPa) }\end{array}$ & $\begin{array}{c}\text { Amplitude } \\
\text { (MPa) }\end{array}$ & $\begin{array}{l}\text { Média } \\
(\mathrm{MPa})\end{array}$ & $\begin{array}{c}\text { Desvio } \\
\text { padrão } \\
\text { (MPa) }\end{array}$ & $\begin{array}{c}\text { Coeficiente } \\
\text { de } \\
\text { variação } \\
(\%)\end{array}$ & $\begin{array}{l}\text { Valor } \\
\text { Máximo } \\
\text { (MPa) }\end{array}$ & $\begin{array}{c}\text { Valor } \\
\text { Mínimo } \\
(\mathrm{MPa})\end{array}$ & $\begin{array}{c}\text { Amplitude } \\
\text { (MPa) }\end{array}$ & $\begin{array}{l}\text { Intervalo de } \\
\text { confiança da } \\
\text { média 95\% } \\
\text { (MPa) }\end{array}$ \\
\hline $1 \mathrm{~A}$ & $\begin{array}{l}3,8 \\
3,8\end{array}$ & 3,8 & 3,8 & 3,8 & 0,0 & \multirow{6}{*}{3,9} & \multirow{6}{*}{0,1} & \multirow{6}{*}{$3 \%$} & \multirow{6}{*}{4,1} & \multirow{6}{*}{3,8} & \multirow{6}{*}{0,4} & \multirow{6}{*}{ $\pm 0,1$} \\
\hline $2 B$ & $\begin{array}{l}3,6 \\
4,6\end{array}$ & 4,1 & 4,6 & 3,6 & 1,0 & & & & & & & \\
\hline $3 \mathrm{C}$ & $\begin{array}{l}4,1 \\
4,0\end{array}$ & 4,1 & 4,1 & 4,0 & 0,1 & & & & & & & \\
\hline $4 \mathrm{D}$ & $\begin{array}{l}3,5 \\
4,2\end{array}$ & 3,9 & 4,2 & 3,5 & 0,8 & & & & & & & \\
\hline $5 \mathrm{E}$ & $\begin{array}{l}4,1 \\
3,7\end{array}$ & 3,9 & 4,1 & 3,7 & 0,4 & & & & & & & \\
\hline $6 \mathrm{~F}$ & $\begin{array}{l}4,1 \\
3,7\end{array}$ & 3,9 & 4,1 & 3,7 & 0,4 & & & & & & & \\
\hline
\end{tabular}

A Figura 78 a seguir ilustra as resistências médias à tração para as idades de ruptura e para as condições de envelhecimento acelerado por secagem contínua em estufa ventilada a $(40 \pm 5)^{\circ} \mathrm{C}$, na condição $A E 3$. 


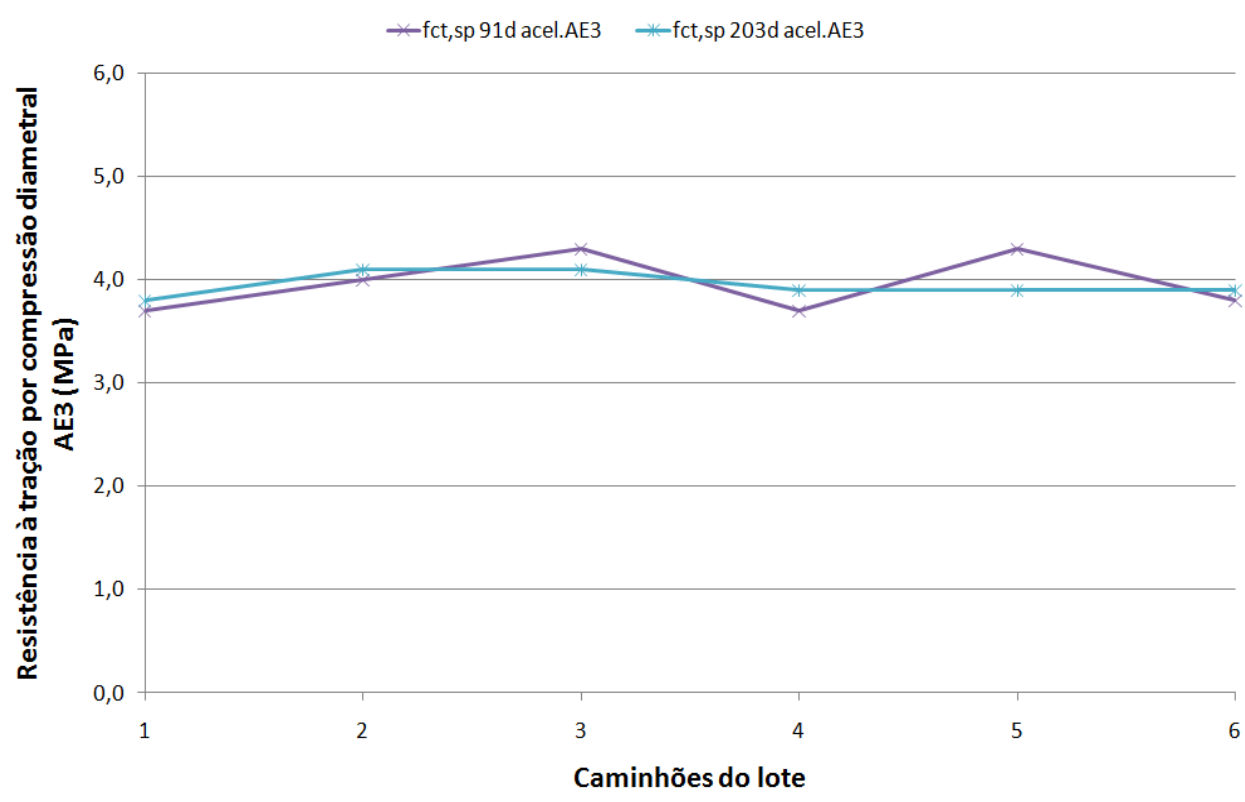

FIGURA 78 - Variação da resistência à tração por compressão diametral média dos corpos-de-prova, submetidos à cura acelerada $24 / 72 \mathrm{~h}$ e imersão em água até 7 dias e depois a ciclos de 28 dias de secagem contínua em estufa a $(40 \pm 5)^{\circ} \mathrm{C}$.

\section{E.4) Análise conjunta da resistência à tração para todas as idades e condições} de envelhecimento acelerado

A Tabela 58 apresenta as medidas individuais dos corpos-de-prova, as médias, o desvio padrão, os valores máximos e mínimos e o coeficiente de variação dos resultados para o lote analisado, quanto ao ensaio de resistência à tração por compressão diametral, por cura acelerada 24/72 horas seguida de cura imersa em água até 7 dias, sendo os corpos-de-prova mantidos respectivamente nas três seguintes condições de envelhecimento acelerado:

$\checkmark$ AE1 (ciclos de $24 \mathrm{~h}$ de exposição em câmara de $\mathrm{CO}_{2}$ e 27 dias de secagem em estufa a $\left.40 \pm 1^{\circ} \mathrm{C}\right)$;

$\checkmark$ AE2 (ciclos de $24 \mathrm{~h}$ de imersão em tanque de água e 27 dias de secagem em estufa a $40 \pm 1^{\circ} \mathrm{C}$ ) $\mathrm{e}$;

$\checkmark$ AE3 (ciclos de 28 dias de secagem contínua em estufa a $40 \pm 5 \circ C$ ).

As médias, os valores máximos e mínimos, os desvios padrão e os coeficientes de variação foram calculados em função dos maiores valores entre os corpos-de-prova irmãos. Conforme a ABNT NBR 12655 (2006), a resistência do exemplar é o maior valor entre dois valores obtidos, e na Tabela 58 esses valores estão apresentados de forma sublinhada. 
Para os concretos de todos os caminhões, para todas as idades e tipo de condição de envelhecimento acelerado, os coeficientes de variação entre os resultados foram excelentes, sendo que a maioria deles foi menor que $10 \%$, com exceção do resultado de $f_{c t, s p 63 a c e l . A E 1}$. 
TABELA 58 - Resultados do ensaio de resistência à tração por compressão diametral nos concretos do lote amostrado. ABNT NBR 7222 (1994).

\begin{tabular}{|c|c|c|c|c|c|c|c|c|c|c|c|c|}
\hline \multirow{2}{*}{ 远 } & \multicolumn{2}{|c|}{8 dias } & \multicolumn{2}{|c|}{35 dias } & \multicolumn{2}{|c|}{63 dias } & \multicolumn{3}{|c|}{91 dias } & \multicolumn{3}{|c|}{203 dias } \\
\hline & $\begin{array}{c}\mathbf{f}_{\mathrm{ctt}, \mathrm{sp}} \\
\text { 8acel.AE1 } \\
\text { (MPa) }\end{array}$ & $\begin{array}{c}f_{\text {ct.sp }} \\
\text { 8acel.AE2 } \\
\text { (MPa) }\end{array}$ & $\begin{array}{c}\mathbf{f}_{\mathrm{ct}, \mathrm{sp}, 35 \text { acel.AE1 }} \\
\text { (MPa) }\end{array}$ & $\begin{array}{c}\mathbf{f}_{\mathrm{ctt.sp}} \\
\text { 35acel.AE2 } \\
\text { (MPa) }\end{array}$ & $\begin{array}{c}f_{\text {ct.sp }} \\
\text { 63acel.AE1 } \\
\text { (MPa) }\end{array}$ & $\begin{array}{c}\mathbf{f}_{\mathrm{ct}, \mathrm{sp}} \text { 63acel.AE2 } \\
(\mathrm{MPa})\end{array}$ & $\begin{array}{c}f_{\text {ct.,sp }} \\
\text { 91acel.AE1 } \\
\text { (MPa) }\end{array}$ & $\begin{array}{c}\mathbf{f}_{\mathrm{ctt} \text {.sp }} \\
\text { 91acel.AE2 } \\
\text { (MPa) }\end{array}$ & $\begin{array}{c}f_{\text {ct.,sp }} \\
\text { 91acel.AE3 } \\
\text { (MPa) }\end{array}$ & $\begin{array}{c}\mathbf{f}_{\text {ct.sp }} \\
\text { 203acel.AE1 } \\
\text { (MPa) }\end{array}$ & $\begin{array}{c}\mathbf{f}_{\mathrm{ct}, \mathrm{sp}} \\
\text { 203acel.AE2 } \\
\text { (MPa) }\end{array}$ & $\begin{array}{c}\mathbf{f}_{\text {ct, sp 203acel.AE } 3} \\
\text { (MPa) }\end{array}$ \\
\hline \multirow{2}{*}{$1 \mathrm{~A}$} & $\underline{4.1}$ & $\underline{4.1}$ & 4,1 & $\underline{4.3}$ & 3,7 & 3,6 & $\underline{3.8}$ & 4,6 & 3,6 & $\underline{4.6}$ & $\underline{4.9}$ & $\underline{3.8}$ \\
\hline & 3,7 & 3,0 & $\underline{4.8}$ & 4,3 & $\underline{3.9}$ & $\underline{4.2}$ & 3,5 & $\underline{4.8}$ & $\underline{3.9}$ & 4,3 & 4,5 & 3,8 \\
\hline \multirow{2}{*}{$2 B$} & 3,7 & $\underline{4.0}$ & $\underline{4.0}$ & 4,4 & 2,9 & $\underline{4.7}$ & 4,1 & $\underline{4.9}$ & 3,9 & 4,2 & 5,0 & 3,6 \\
\hline & $\underline{4.0}$ & 4,0 & 3,9 & $\underline{4.6}$ & 4.4 & 4,4 & $\underline{4.3}$ & 4,7 & $\underline{4.1}$ & $\underline{4.6}$ & $\underline{5.1}$ & $\underline{4.6}$ \\
\hline \multirow{2}{*}{$3 C$} & $\underline{4.1}$ & 3,8 & $\underline{4.4}$ & 4,1 & $\underline{3.5}$ & $\underline{4.7}$ & $\underline{3.9}$ & $\underline{4.9}$ & $\underline{4.5}$ & 4,0 & 4,6 & 4.1 \\
\hline & 3,6 & $\underline{4.0}$ & 4,4 & $\underline{4.2}$ & 3,4 & 4,3 & 3,7 & 4,5 & 4,1 & $\underline{4.6}$ & $\underline{4.9}$ & 4,0 \\
\hline \multirow{2}{*}{$4 \mathrm{D}$} & 3,4 & $\underline{3.5}$ & $\underline{4.3}$ & $\underline{4.0}$ & 3,3 & $\underline{3.9}$ & $\underline{3.4}$ & $\underline{4.0}$ & 3,5 & 3,8 & 4,0 & 3,5 \\
\hline & $\underline{3.8}$ & 3,3 & 4,0 & 3,9 & $\underline{3.5}$ & 3,7 & 3,4 & 3,7 & $\underline{3.9}$ & $\underline{4.6}$ & 4.7 & 4.2 \\
\hline \multirow{2}{*}{$5 \mathrm{E}$} & 3,8 & $\underline{4.1}$ & 4,1 & 3,9 & 3,7 & $\underline{4.2}$ & 4,0 & $\underline{4.6}$ & 4,2 & 4,2 & 4,9 & $\underline{4.1}$ \\
\hline & $\underline{4.5}$ & 4,0 & $\underline{4.5}$ & 4.2 & $\underline{4.6}$ & 3,9 & $\underline{4.2}$ & 4,6 & $\underline{4.5}$ & $\underline{4.8}$ & $\underline{5.2}$ & 3,7 \\
\hline \multirow{2}{*}{$6 F$} & $\underline{4.1}$ & $\underline{4.0}$ & $\underline{3.8}$ & $\underline{4.5}$ & $\underline{4.4}$ & $\underline{3.9}$ & 3,9 & $\underline{4.6}$ & $\underline{3.9}$ & $\underline{4.0}$ & $\underline{4.7}$ & $\underline{4.1}$ \\
\hline & 3,5 & 3,5 & 3,6 & 4,0 & 4,1 & 3,7 & $\underline{4.1}$ & 4,5 & 3,6 & 3,8 & 4,5 & 3,7 \\
\hline $\begin{array}{c}\text { Média do lote } \\
\text { entre os } \\
\text { exemplares } \\
\text { (MPa) }\end{array}$ & 4,1 & 3,9 & 4,3 & 4,3 & 4,0 & 4,3 & 4,0 & 4,6 & 4,1 & 4,5 & 4,9 & 4,1 \\
\hline $\begin{array}{l}\text { Valor máximo } \\
\text { (MPa) }\end{array}$ & 4,5 & 4,1 & 4,8 & 4,6 & 4,6 & 4,7 & 4,3 & 4,9 & 4,5 & 4,8 & 5,2 & 4,6 \\
\hline $\begin{array}{l}\text { Valor mínimo } \\
\quad \text { (MPa) }\end{array}$ & 3,8 & 3,5 & 3,8 & 4,0 & 3,5 & 3,9 & 3,4 & 4,0 & 3,9 & 4,0 & 4,7 & 3,8 \\
\hline $\begin{array}{l}\text { Desvio padrão } \\
\text { para os } \\
\text { exemplares } \\
\text { (MPa) }\end{array}$ & 0,3 & 0,2 & 0,3 & 0,2 & 0,5 & 0,4 & 0,3 & 0,3 & 0,3 & 0,3 & 0,2 & 0,3 \\
\hline $\begin{array}{c}\text { Coeficientes de } \\
\text { variação para os } \\
\text { exemplares (\%) }\end{array}$ & 6,2 & 5,8 & 7,9 & 4,9 & 12,1 & 9,1 & 8,3 & 7,3 & 7,3 & 5,8 & 4,3 & 6,5 \\
\hline
\end{tabular}


Pela Tabela 58 e Figura 79 observa-se que a resistência à tração por compressão diametral apresentou uma tendência de acréscimo com a evolução da ciclagem, mais nitidamente nas condições AE1 e AE2.

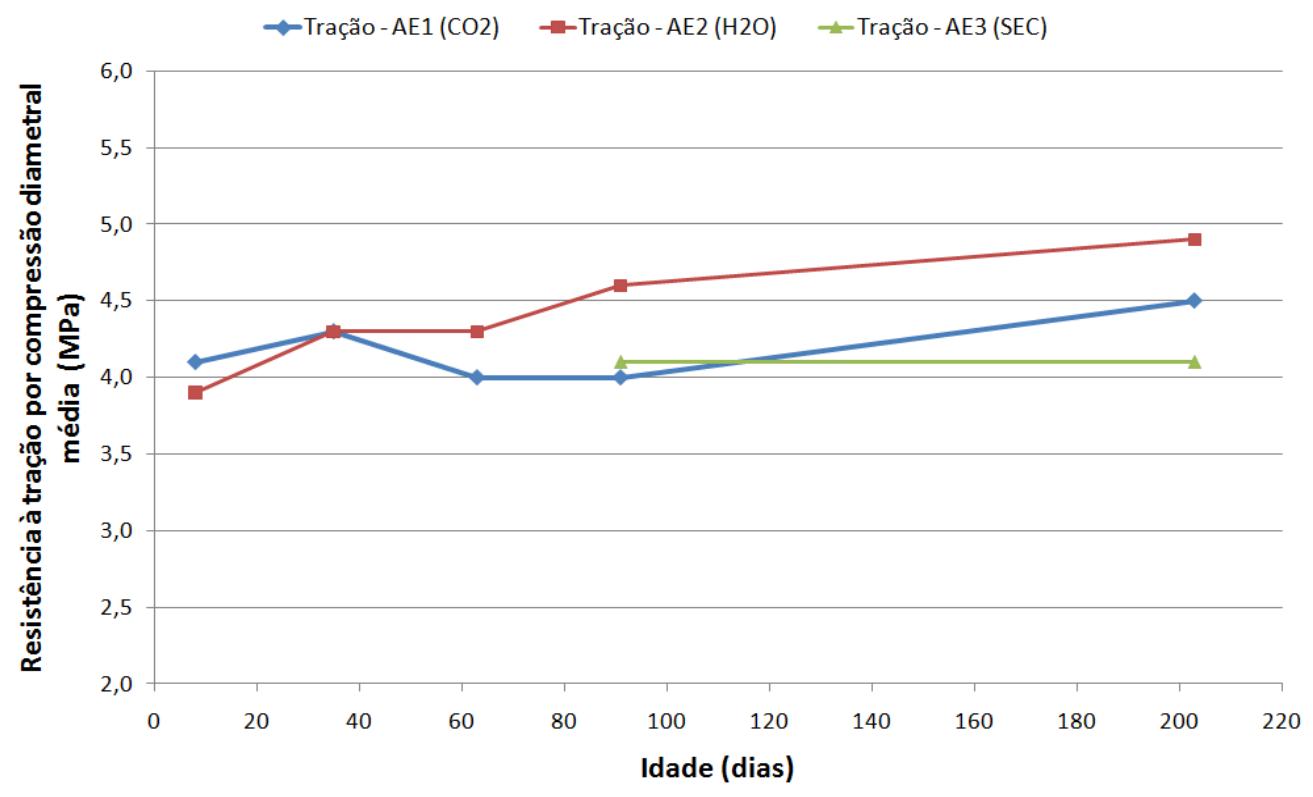

FIGURA 79 - Variação da resistência à tração por compressão diametral média com a idade, para cada tipo de condição de envelhecimento acelerado. 
F) Absorção de água

\section{F.1) Cura acelerada 24/72 horas seguida por imersão em água até 7 dias e ciclos de 24 horas em câmara de carbonatação e 27 dias de secagem em estufa (AE1).}

Os itens a seguir apresentam os resultados dos ensaios de absorção de água total a 8, $35,63,91$ e 203 dias dos concretos do lote analisado, para este tipo de condicionamento.

\section{F.1a) Absorção de água a 8 dias}

A Tabela 59 apresenta os resultados das medidas individuais em metade de corposde-prova partidos por compressão diametral, as médias, o desvio padrão, os valores máximo e mínimo, as amplitudes e o coeficiente de variação do ensaio de absorção de água dos concretos com cura acelerada de 24/72 horas seguida de cura imersa em água até 7 dias, sendo os corpos-de-prova ainda submetidos a 24 horas em câmara de carbonatação a $5 \%$ de $\mathrm{CO}_{2}$, antes da realização deste ensaio. A idade de 8 dias é de referência do ensaio mecânico inicial.

Observa-se que o concreto do caminhão 2B mostrou maior resultado médio de absorção de água total a 8 dias para este tipo de condicionamento. Pode-se verificar que o concreto do caminhão 5E mostrou menor resultado de absorção de água total, em relação aos demais concretos do lote, concordando com a resistência à compressão, que para este caminhão foi maior. 
TABELA 59 - Resultados do ensaio de absorção de água a 8 dias (AE1) dos concretos do lote analisado. ABNT NBR 9778 (2005).

\begin{tabular}{|c|c|c|c|c|c|c|c|c|c|c|c|c|}
\hline \multirow[b]{2}{*}{ 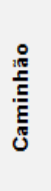 } & \multicolumn{5}{|c|}{ Medidas por amostra } & \multicolumn{7}{|c|}{ Cálculos para o lote } \\
\hline & $\begin{array}{c}\text { Absorção } \\
\text { total } \\
(\%)\end{array}$ & Média (\%) & $\begin{array}{c}\text { Valor } \\
\text { Máximo (\%) }\end{array}$ & $\begin{array}{c}\text { Valor } \\
\text { Minimo (\%) }\end{array}$ & $\begin{array}{c}\text { Amplitude } \\
(\%)\end{array}$ & Média (\%) & $\begin{array}{c}\text { Desvio } \\
\text { padrão (\%) }\end{array}$ & $\begin{array}{c}\text { Coeficient } \\
\text { e de } \\
\text { variação } \\
(\%)\end{array}$ & $\begin{array}{c}\text { Valor } \\
\text { Máximo (\%) }\end{array}$ & $\begin{array}{c}\text { Valor } \\
\text { Minimo (\%) }\end{array}$ & $\begin{array}{l}\text { Amplitude } \\
(\%)\end{array}$ & $\begin{array}{c}\text { Intervalo de } \\
\text { confiança } \\
\text { da média } \\
95 \%(\%)\end{array}$ \\
\hline $1 \mathrm{~A}$ & $\begin{array}{l}4,1 \\
3,6\end{array}$ & 3,9 & 4,1 & 3,6 & 0,4 & \multirow{6}{*}{4,0} & \multirow{6}{*}{0,4} & \multirow{6}{*}{$10 \%$} & \multirow{6}{*}{4,3} & \multirow{6}{*}{3,3} & \multirow{6}{*}{1,0} & \multirow{6}{*}{ $\pm 0,31$} \\
\hline $2 B$ & $\begin{array}{l}4,4 \\
4,3\end{array}$ & 4,3 & 4,4 & 4,3 & 0,1 & & & & & & & \\
\hline $3 \mathrm{C}$ & $\begin{array}{l}4,3 \\
3,8\end{array}$ & 4,0 & 4,3 & 3,8 & 0,5 & & & & & & & \\
\hline 4D & $\begin{array}{l}4,2 \\
4,2\end{array}$ & 4,2 & 4,2 & 4,2 & 0,1 & & & & & & & \\
\hline $5 \mathrm{E}$ & $\begin{array}{l}3,3 \\
3,3\end{array}$ & 3,3 & 3,3 & 3,3 & 0,1 & & & & & & & \\
\hline $6 \mathrm{~F}$ & $\begin{array}{l}4,2 \\
4,3\end{array}$ & 4,3 & 4,3 & 4,2 & 0,1 & & & & & & & \\
\hline
\end{tabular}

\section{F.1b) Absorção de água a 35 dias}

A Tabela 60 apresenta os resultados das medidas individuais em metade de corposde-prova partidos por compressão diametral, as médias, o desvio padrão, os valores máximo e mínimo, as amplitudes e o coeficiente de variação do ensaio de absorção de água dos concretos com cura acelerada de 24/72 horas seguida de cura imersa em água até 7 dias. Os corpos-de-prova íntegros foram submetidos a um ciclo de 24 horas em câmara de carbonatação a $5 \%$ de $\mathrm{CO}_{2}$, e 27 dias em estufa a $(40 \pm 1)^{\circ} \mathrm{C}$, antes da realização deste ensaio. A idade de 35 dias é de referência do ensaio mecânico precedente ao de absorção de água.

Pode-se observar que o concreto do caminhão $5 \mathrm{E}$ mostrou menor resultado de absorção de água total, em relação aos demais concretos do lote, concordando com a resistência à compressão, que para este caminhão foi maior também.

TABELA 60 - Resultados do ensaio de absorção de água a 35 dias (AE1) dos concretos do lote analisado. ABNT NBR 9778 (2005).

\begin{tabular}{|c|c|c|c|c|c|c|c|c|c|c|c|c|}
\hline \multirow[b]{2}{*}{ 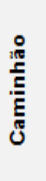 } & \multicolumn{5}{|c|}{ Medidas por amostra } & \multicolumn{7}{|c|}{ Cálculos para o lote } \\
\hline & $\begin{array}{c}\text { Absorção } \\
\text { total } \\
(\%)\end{array}$ & Média (\%) & $\begin{array}{c}\text { Valor } \\
\text { Máximo (\%) }\end{array}$ & $\begin{array}{c}\text { Valor } \\
\text { Minimo (\%) }\end{array}$ & $\begin{array}{l}\text { Amplitude } \\
(\%)\end{array}$ & Média (\%) & $\begin{array}{c}\text { Desvio } \\
\text { padrão (\%) }\end{array}$ & $\begin{array}{c}\text { Coeficiente } \\
\text { de } \\
\text { variação } \\
(\%)\end{array}$ & $\begin{array}{l}\text { Valor } \\
\text { Máximo } \\
(\%)\end{array}$ & $\begin{array}{c}\text { Valor } \\
\text { Minimo (\%) }\end{array}$ & $\begin{array}{c}\text { Amplitude } \\
(\%)\end{array}$ & $\begin{array}{c}\text { Intervalo de } \\
\text { confiança da } \\
\text { média 95\% } \\
\text { (\%) }\end{array}$ \\
\hline $1 \mathrm{~A}$ & $\begin{array}{l}4,5 \\
4,2\end{array}$ & 4,3 & 4,5 & 4,2 & 0,3 & \multirow{6}{*}{4,1} & \multirow{6}{*}{0,4} & \multirow{6}{*}{$10 \%$} & \multirow{6}{*}{4,7} & \multirow{6}{*}{3,6} & \multirow{6}{*}{1,1} & \multirow{6}{*}{ $\pm 0,32$} \\
\hline $2 B$ & $\begin{array}{l}4,6 \\
4,8\end{array}$ & 4,7 & 4,8 & 4,6 & 0,2 & & & & & & & \\
\hline $3 C$ & $\begin{array}{l}4,2 \\
3,8\end{array}$ & 4,0 & 4,2 & 3,8 & 0,4 & & & & & & & \\
\hline $4 \mathrm{D}$ & $\begin{array}{l}4,4 \\
3,4\end{array}$ & 3,9 & 4,4 & 3,4 & 0,9 & & & & & & & \\
\hline $5 \mathrm{E}$ & $\begin{array}{l}3,6 \\
3,5\end{array}$ & 3,6 & 3,6 & 3,5 & 0,1 & & & & & & & \\
\hline $6 \mathrm{~F}$ & $\begin{array}{r}4,5 \\
4,3\end{array}$ & 4,4 & 4,5 & 4,3 & 0,3 & & & & & & & \\
\hline
\end{tabular}




\section{F.1c) Absorção de água a 63 dias}

A Tabela 61 apresenta os resultados das medidas individuais em metade de corposde-prova partidos por compressão diametral, as médias, o desvio padrão, os valores máximo e mínimo, as amplitudes e o coeficiente de variação do ensaio de absorção de água dos concretos com cura acelerada de 24/72 horas seguida de cura imersa em água até 7 dias. Os corpos-de-prova íntegros foram ainda submetidos a dois ciclos de 24 horas em câmara de carbonatação a $5 \%$ de $\mathrm{CO}_{2}$, seguidos de 27 dias em estufa a $(40 \pm 1)^{\circ} \mathrm{C}$, antes da realização deste ensaio. A idade de 63 dias é de referência do ensaio mecânico precedente ao de absorção de água.

Pode-se observar que o concreto do caminhão 4D mostrou menor resultado de absorção de água total, em relação aos demais concretos do lote. O concreto do caminhão 2B mostrou maior resultado médio de absorção de água total, para este tipo de condicionamento.

TABELA 61 - Resultados do ensaio de absorção de água total a 63 dias (AE1) dos concretos do lote analisado. ABNT NBR 9778 (2005).

\begin{tabular}{|c|c|c|c|c|c|c|c|c|c|c|c|c|}
\hline \multirow[b]{2}{*}{ 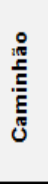 } & \multicolumn{5}{|c|}{ Medidas por amostra } & \multicolumn{7}{|c|}{ Cálculos para o lote } \\
\hline & $\begin{array}{c}\text { Absorç̧ão } \\
\text { total } \\
(\%)\end{array}$ & Média (\%) & $\begin{array}{c}\text { Valor } \\
\text { Máximo (\%) }\end{array}$ & $\begin{array}{c}\text { Valor } \\
\text { Mínimo (\%) }\end{array}$ & $\begin{array}{l}\text { Amplitude } \\
(\%)\end{array}$ & Média (\%) & $\begin{array}{c}\text { Desvio } \\
\text { padrão (\%) }\end{array}$ & $\begin{array}{c}\text { Coeficiente } \\
\text { de } \\
\text { variação } \\
(\%)\end{array}$ & $\begin{array}{l}\text { Valor } \\
\text { Máximo } \\
(\%)\end{array}$ & $\begin{array}{c}\text { Valor } \\
\text { Minimo (\%) }\end{array}$ & $\begin{array}{c}\text { Amplitude } \\
(\%)\end{array}$ & $\begin{array}{c}\text { Intervalo de } \\
\text { confiança da } \\
\text { média } 95 \% \\
(\%)\end{array}$ \\
\hline $1 A$ & $\begin{array}{l}4,1 \\
4,1\end{array}$ & 4,1 & 4,1 & 4,1 & 0,0 & \multirow{6}{*}{4,0} & \multirow{6}{*}{0,3} & \multirow{6}{*}{$8 \%$} & \multirow{6}{*}{4,6} & \multirow{6}{*}{3,7} & \multirow{6}{*}{0,9} & \multirow{6}{*}{ $\pm 0,27$} \\
\hline $2 \mathrm{~B}$ & $\begin{array}{l}4,8 \\
4,4\end{array}$ & 4,6 & 4,8 & 4,4 & 0,5 & & & & & & & \\
\hline $3 C$ & $\begin{array}{l}3,6 \\
3,9\end{array}$ & 3,8 & 3,9 & 3,6 & 0,3 & & & & & & & \\
\hline $4 \mathrm{D}$ & $\begin{array}{l}4,0 \\
3,4\end{array}$ & 3,7 & 4,0 & 3,4 & 0,6 & & & & & & & \\
\hline $5 \mathrm{E}$ & $\begin{array}{l}3,9 \\
3,8\end{array}$ & 3,9 & 3,9 & 3,8 & 0,1 & & & & & & & \\
\hline $6 \mathrm{~F}$ & $\begin{array}{l}3,9 \\
4,0\end{array}$ & 3,9 & 4,0 & 3,9 & 0,0 & & & & & & & \\
\hline
\end{tabular}

\section{F.1d) Absorção de água a 91 dias}

A Tabela 62 apresenta os resultados das medidas individuais em metade de corposde-prova partidos por compressão diametral, as médias, o desvio padrão, os valores máximo e mínimo, as amplitudes e o coeficiente de variação do ensaio de absorção de água dos concretos com cura acelerada de 24/72 horas seguida de cura imersa em água até 7 dias. Os corpos-de-prova íntegros foram ainda submetidos a três ciclos de 24 horas em câmara de carbonatação a $5 \%$ de $\mathrm{CO}_{2}$, e 27 dias de secagem em estufa a $(40 \pm 1)^{\circ} \mathrm{C}$, antes da realização deste ensaio. A idade de 91 dias é de referência do ensaio mecânico precedente à absorção de água. 
Pode-se observar que o concreto do caminhão 3C mostrou menor resultado de absorção de água total, em relação aos demais concretos do lote. O concreto do caminhão 2B mostrou maior resultado médio de absorção de água total, para este tipo de condicionamento.

TABELA 62 - Resultados do ensaio de absorção de água total a 91 dias (AE1) dos concretos do lote analisado. ABNT NBR 9778 (2005).

\begin{tabular}{|c|c|c|c|c|c|c|c|c|c|c|c|c|}
\hline \multirow[b]{2}{*}{ 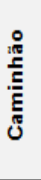 } & \multicolumn{5}{|c|}{ Medidas por amostra } & \multicolumn{7}{|c|}{ Cálculos para o lote } \\
\hline & $\begin{array}{c}\text { Absorção } \\
\text { total } \\
(\%)\end{array}$ & $\begin{array}{c}\text { Média } \\
(\%)\end{array}$ & $\begin{array}{c}\text { Valor } \\
\text { Máximo (\%) }\end{array}$ & $\begin{array}{c}\text { Valor } \\
\text { Mínimo (\%) }\end{array}$ & $\begin{array}{c}\text { Amplitude } \\
(\%)\end{array}$ & Média(\%) & $\begin{array}{c}\text { Desvio } \\
\text { padrão (\%) }\end{array}$ & $\begin{array}{c}\text { Coeficiente } \\
\text { de } \\
\text { variação } \\
(\%)\end{array}$ & $\begin{array}{c}\text { Valor } \\
\text { Máximo } \\
(\%)\end{array}$ & $\begin{array}{c}\text { Valor } \\
\text { Mínimo (\%) }\end{array}$ & $\begin{array}{c}\text { Amplitude } \\
(\%)\end{array}$ & $\begin{array}{c}\text { Intervalo de } \\
\text { confiança da } \\
\text { média } 95 \% \\
(\%)\end{array}$ \\
\hline $1 \mathrm{~A}$ & $\begin{array}{l}4,5 \\
4,6\end{array}$ & 4,5 & 4,6 & 4,5 & 0,1 & \multirow{6}{*}{4,7} & \multirow{6}{*}{0,3} & \multirow{6}{*}{$6 \%$} & \multirow{6}{*}{5,1} & \multirow{6}{*}{4,3} & \multirow{6}{*}{0,8} & \multirow{6}{*}{ $\pm 0,24$} \\
\hline $2 \mathrm{~B}$ & $\begin{array}{l}4,9 \\
5,3\end{array}$ & 5,1 & 5,3 & 4,9 & 0,3 & & & & & & & \\
\hline $3 \mathrm{C}$ & $\begin{array}{l}4,4 \\
4,3\end{array}$ & 4,3 & 4,4 & 4,3 & 0,1 & & & & & & & \\
\hline $4 \mathrm{D}$ & $\begin{array}{l}4,8 \\
4,8\end{array}$ & 4,8 & 4,8 & 4,8 & 0,1 & & & & & & & \\
\hline $5 \mathrm{E}$ & $\begin{array}{l}4,6 \\
4,4\end{array}$ & 4,5 & 4,6 & 4,4 & 0,2 & & & & & & & \\
\hline $6 \mathrm{~F}$ & $\begin{array}{l}4,9 \\
5,1\end{array}$ & 5,0 & 5,1 & 4,9 & 0,2 & & & & & & & \\
\hline
\end{tabular}

\section{F.1e) Absorção de água a 203 dias}

A Tabela 63 apresenta os resultados das medidas individuais em metade de corposde-prova partidos por compressão diametral, as médias, o desvio padrão, os valores máximo e mínimo, as amplitudes e o coeficiente de variação do ensaio de absorção de água dos concretos com cura acelerada de 24/72 horas seguida de cura imersa em água até 7 dias. Os corpos-de-prova íntegros foram ainda submetidos a sete ciclos de 24 horas em câmara de carbonatação a $5 \%$ de $\mathrm{CO}_{2}$, e 27 dias de secagem em estufa a $(40 \pm 1)^{\circ} \mathrm{C}$, antes da realização deste ensaio. A idade de 203 dias é de referência do ensaio mecânico precedente à absorção de água.

Pode-se observar que os concretos dos caminhões $3 \mathrm{C}$ e $5 \mathrm{E}$ mostraram menores resultados de absorção de água total, em relação aos demais caminhões do lote. O concreto do caminhão 2B mostrou novamente maior resultado médio de absorção de água total, para este tipo de condicionamento. 
TABELA 63 - Resultados do ensaio de absorção de água total a 203 dias (AE1) dos concretos do lote analisado. ABNT NBR 9778 (2005).

\begin{tabular}{|c|c|c|c|c|c|c|c|c|c|c|c|c|}
\hline \multirow[b]{2}{*}{ 昰 } & \multicolumn{5}{|c|}{ Medidas por amostra } & \multicolumn{7}{|c|}{ Cálculos para o lote } \\
\hline & $\begin{array}{c}\text { Absorção } \\
\text { total } \\
(\%)\end{array}$ & Média (\%) & $\begin{array}{c}\text { Valor } \\
\text { Máximo (\%) }\end{array}$ & $\begin{array}{c}\text { Valor } \\
\text { Mínimo (\%) }\end{array}$ & $\begin{array}{c}\text { Amplitude } \\
(\%)\end{array}$ & Média $(\%)$ & $\begin{array}{c}\text { Desvio } \\
\text { padrão } \\
(\%)\end{array}$ & $\begin{array}{c}\text { Coeficiente } \\
\text { de } \\
\text { variação } \\
(\%)\end{array}$ & $\begin{array}{c}\text { Valor } \\
\text { Máximo } \\
(\%)\end{array}$ & $\begin{array}{c}\text { Valor } \\
\text { Mínimo (\%) }\end{array}$ & $\begin{array}{c}\text { Amplitude } \\
(\%)\end{array}$ & $\begin{array}{c}\text { Intervalo de } \\
\text { confiança da } \\
\text { média } 95 \% \\
(\%)\end{array}$ \\
\hline $1 \mathrm{~A}$ & $\begin{array}{l}5,1 \\
5,2\end{array}$ & 5,1 & 5,2 & 5,1 & 0,1 & \multirow{6}{*}{5,2} & \multirow{6}{*}{0,2} & \multirow{6}{*}{$4 \%$} & \multirow{6}{*}{5,4} & \multirow{6}{*}{4,9} & \multirow{6}{*}{0,5} & \multirow{6}{*}{ $\pm 0,16$} \\
\hline 2B & $\begin{array}{l}5,5 \\
5,2\end{array}$ & 5,4 & 5,5 & 5,2 & 0,3 & & & & & & & \\
\hline $3 \mathrm{C}$ & $\begin{array}{l}5,0 \\
4,8\end{array}$ & 4,9 & 5,0 & 4,8 & 0,1 & & & & & & & \\
\hline $4 \mathrm{D}$ & $\begin{array}{l}5,2 \\
5,3\end{array}$ & 5,2 & 5,3 & 5,2 & 0,1 & & & & & & & \\
\hline $5 \mathrm{E}$ & $\begin{array}{l}5,0 \\
4,9\end{array}$ & 5,0 & 5,0 & 4,9 & 0,2 & & & & & & & \\
\hline $6 \mathrm{~F}$ & $\begin{array}{l}5,2 \\
5,5\end{array}$ & 5,3 & 5,5 & 5,2 & 0,3 & & & & & & & \\
\hline
\end{tabular}

A Figura 80 a seguir ilustra a absorção de água média para as idades de ensaio e para as condições de envelhecimento acelerado por ciclos de exposição de $24 \mathrm{~h}$ em câmara de carbonatação a $5 \% \mathrm{CO}_{2}$ seguidos de 27 dias de secagem em estufa a $(40 \pm 1)^{\circ} \mathrm{C}$, dita condição AE1.

As idades de 91 e 203 dias mostram resultados de absorção de água dos concretos em valores médios mais altos para todos os caminhões, e isto pode ter relação com a condição de secagem gradual mostrada no item D.1). 


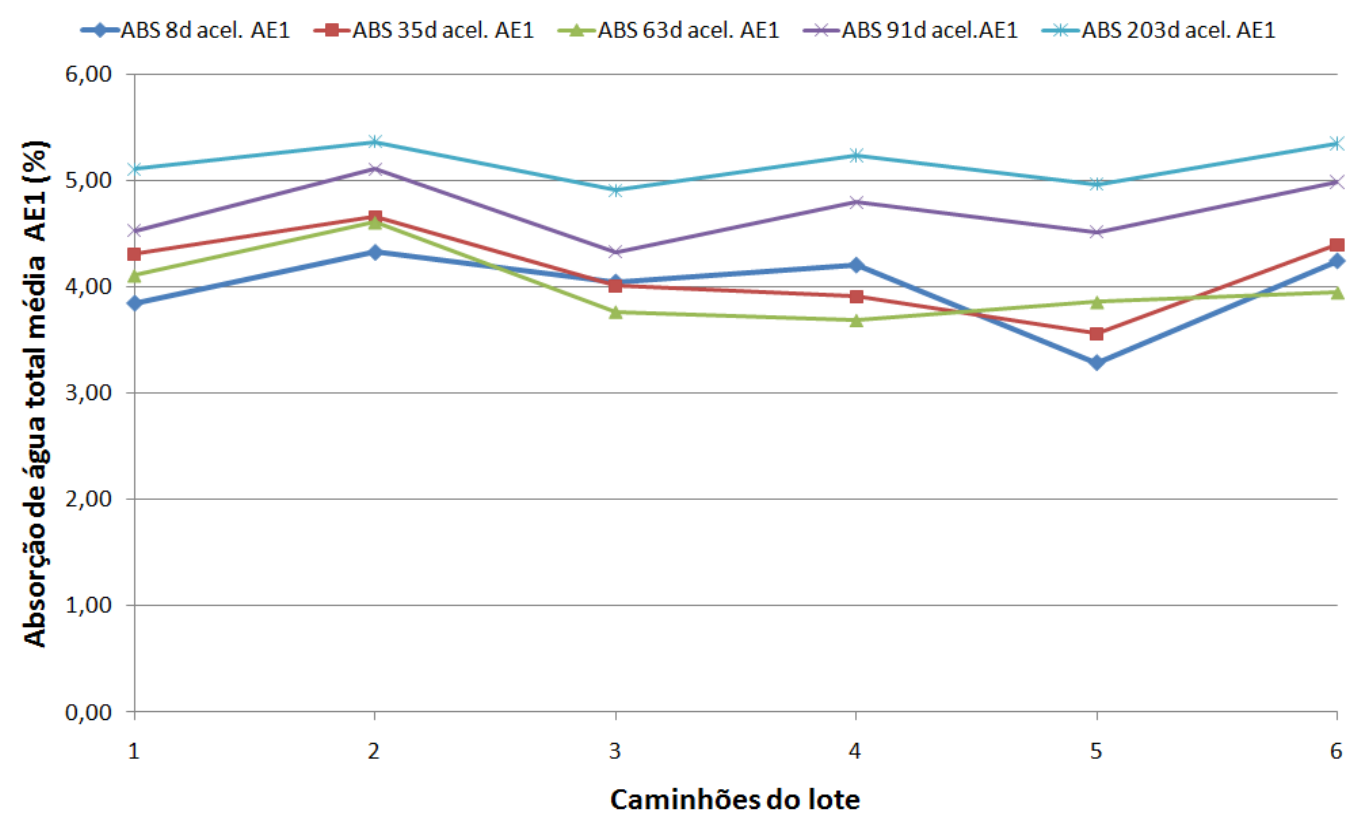

FIGURA 80 - Variação da absorção de água média dos corpos-de-prova, submetidos à cura acelerada de $24 / 72 \mathrm{~h}$ e imersão em água até 7 dias e depois a ciclos de $24 \mathrm{~h}$ de exposição em câmara de $\mathrm{CO}_{2}$ seguida por 27 dias de secagem em estufa a $40^{\circ} \mathrm{C}$ (AE1).

\section{F.2) Cura acelerada de $24 / 72$ horas seguida por imersão em água até 7 dias e ciclos de 24 horas de imersão em tanque com água seguida por 27 dias de secagem em estufa (AE2).}

\section{F.2a) Absorção de água a 8 dias}

A Tabela 64 apresenta os resultados das medidas individuais em metade de corposde-prova partidos por compressão diametral, as médias, o desvio padrão, os valores máximo e mínimo, as amplitudes e o coeficiente de variação do ensaio de absorção de água dos concretos com cura acelerada de 24/72 horas seguida de cura imersa em água até 7 dias. Os corpos-de-prova íntegros foram ainda submetidos por a 24 horas de imersão em tanque de água, antes da realização do ensaio.

Pode-se observar que os concretos dos caminhões $1 \mathrm{~A}$ e $5 \mathrm{E}$ mostraram menores resultados de absorção de água total, em relação aos demais concretos do lote, concordando com a resistência à compressão, que para estes caminhões foi maior. 
TABELA 64 - Resultados do ensaio de absorção de água a 8 dias (AE2) dos concretos do lote analisado. ABNT NBR 9778 (2005).

\begin{tabular}{|c|c|c|c|c|c|c|c|c|c|c|c|c|}
\hline \multirow[b]{2}{*}{ סُ } & \multicolumn{5}{|c|}{ Medidas por amostra } & \multicolumn{7}{|c|}{ Cálculos para o lote } \\
\hline & $\begin{array}{l}\text { Absorção } \\
\text { total } \\
(\%)\end{array}$ & $\begin{array}{l}\text { Média } \\
(\%)\end{array}$ & $\begin{array}{c}\text { Valor } \\
\text { Máximo (\%) }\end{array}$ & $\begin{array}{c}\text { Valor } \\
\text { Minimo (\%) }\end{array}$ & $\begin{array}{c}\text { Amplitude } \\
(\%)\end{array}$ & Média (\%) & $\begin{array}{c}\text { Desvio } \\
\text { padrão (\%) }\end{array}$ & $\begin{array}{c}\text { Coeficiente } \\
\text { de } \\
\text { variação } \\
(\%)\end{array}$ & $\begin{array}{c}\text { Valor } \\
\text { Máximo } \\
(\%)\end{array}$ & $\begin{array}{c}\text { Valor } \\
\text { Mínimo (\%) }\end{array}$ & $\begin{array}{c}\text { Amplitude } \\
(\%)\end{array}$ & $\begin{array}{l}\text { Intervalo de } \\
\text { confiança da } \\
\text { média } 95 \% \\
(\%)\end{array}$ \\
\hline $1 \mathrm{~A}$ & $\begin{array}{l}3,8 \\
4,0\end{array}$ & 3,9 & 4,0 & 3,8 & 0,2 & \multirow{6}{*}{4,1} & \multirow{6}{*}{0,2} & \multirow{6}{*}{$4 \%$} & \multirow{6}{*}{4,3} & \multirow{6}{*}{3,9} & \multirow{6}{*}{0,4} & \multirow{6}{*}{ $\pm 0,14$} \\
\hline 2B & $\begin{array}{l}4,2 \\
4,4\end{array}$ & 4,3 & 4,4 & 4,2 & 0,2 & & & & & & & \\
\hline $3 C$ & $\begin{array}{l}4,1 \\
4,2\end{array}$ & 4,1 & 4,2 & 4,1 & 0,1 & & & & & & & \\
\hline 4D & $\begin{array}{l}4,4 \\
4,3\end{array}$ & 4,3 & 4,4 & 4,3 & 0,1 & & & & & & & \\
\hline $5 E$ & $\begin{array}{l}4,0 \\
3,9\end{array}$ & 4,0 & 4,0 & 3,9 & 0,1 & & & & & & & \\
\hline $6 \mathrm{~F}$ & $\begin{array}{l}4,0 \\
4,2\end{array}$ & 4,1 & 4,2 & 4,0 & 0,3 & & & & & & & \\
\hline
\end{tabular}

\section{F.2b) Absorção de água a 35 dias}

A Tabela 65 apresenta os resultados das medidas individuais em metade de corposde-prova partidos por compressão diametral, as médias, o desvio padrão, os valores máximo e mínimo, as amplitudes e o coeficiente de variação do ensaio de absorção de água dos concretos com cura acelerada de 24/72 horas seguida de cura imersa em água até 7 dias. Os corpos-de-prova íntegros foram ainda submetidos por 24 horas de imersão em tanque de água, seguida de 27 dias de secagem em estufa a $(40 \pm 1)^{\circ} \mathrm{C}$, antes da realização do ensaio.

Pode-se observar que os concretos dos caminhões $3 \mathrm{C}$ e $5 \mathrm{E}$ mostraram menores resultados de absorção de água, em relação aos demais caminhões do lote. O concreto do caminhão 2B mostrou novamente maior resultado médio de absorção de água, para este tipo de condicionamento. 
TABELA 65 - Resultados do ensaio de absorção de água a 35 dias (AE2) dos concretos do lote analisado. ABNT NBR 9778 (2005).

\begin{tabular}{|c|c|c|c|c|c|c|c|c|c|c|c|c|}
\hline \multirow[b]{2}{*}{ 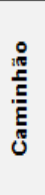 } & \multicolumn{5}{|c|}{ Medidas por amostra } & \multicolumn{7}{|c|}{ Cálculos para o lote } \\
\hline & $\begin{array}{c}\text { Absorção } \\
\text { total } \\
(\%) \\
(\%)\end{array}$ & Média (\%) & $\begin{array}{c}\text { Valor } \\
\text { Máximo (\%) }\end{array}$ & $\begin{array}{c}\text { Valor } \\
\text { Mínimo (\%) }\end{array}$ & $\begin{array}{c}\text { Amplitude } \\
(\%)\end{array}$ & Média (\%) & $\begin{array}{c}\text { Desvio } \\
\text { padrão (\%) }\end{array}$ & $\begin{array}{l}\text { Coeficiente } \\
\text { de } \\
\text { variaçăa } \\
(\%)\end{array}$ & $\begin{array}{l}\text { Valor } \\
\text { Máximo } \\
(\%)\end{array}$ & $\begin{array}{l}\text { Valor } \\
\text { Mínimo (\%) }\end{array}$ & $\begin{array}{c}\text { Amplitude } \\
(\%)\end{array}$ & $\begin{array}{l}\text { Intervalo de } \\
\text { confiança da } \\
\text { média } 95 \% \\
(\%)\end{array}$ \\
\hline $1 \mathrm{~A}$ & $\begin{array}{l}4,3 \\
4,1\end{array}$ & 4,2 & 4,3 & 4,1 & 0,1 & \multirow{6}{*}{4,2} & \multirow{6}{*}{0,3} & \multirow{6}{*}{$7 \%$} & \multirow{6}{*}{4,6} & \multirow{6}{*}{3,8} & \multirow{6}{*}{0,8} & \multirow{6}{*}{ $\pm 0,24$} \\
\hline $2 B$ & $\begin{array}{l}4,6 \\
4,5\end{array}$ & 4,6 & 4,6 & 4,5 & 0,1 & & & & & & & \\
\hline $3 \mathrm{C}$ & $\begin{array}{l}3,9 \\
3,7\end{array}$ & 3,8 & 3,9 & 3,7 & 0,2 & & & & & & & \\
\hline 4D & $\begin{array}{l}4,0 \\
4,7\end{array}$ & 4,3 & 4,7 & 4,0 & 0,7 & & & & & & & \\
\hline $5 E$ & $\begin{array}{l}4,0 \\
3,7\end{array}$ & 3,8 & 4,0 & 3,7 & 0,3 & & & & & & & \\
\hline $6 \mathrm{~F}$ & $\begin{array}{l}4,3 \\
4,2\end{array}$ & 4,3 & 4,3 & 4,2 & 0,1 & & & & & & & \\
\hline
\end{tabular}

\section{F.2c) Absorção de água a 63 dias}

A Tabela 66 apresenta os resultados das medidas individuais em metade de corposde-prova partidos por compressão diametral, as médias, o desvio padrão, os valores máximo e mínimo, as amplitudes e o coeficiente de variação do ensaio de absorção de água dos concretos com cura acelerada de 24/72 horas seguida de cura imersa em água até 7 dias. Os corpos-de-prova íntegros foram ainda submetidos a dois ciclos de 24 horas de imersão em tanque de água e 27 dias de secagem em estufa a $(40 \pm 1)^{\circ} \mathrm{C}$, antes da realização do ensaio.

Pode-se observar que os concretos dos caminhões $5 \mathrm{E}$ e $6 \mathrm{~F}$ mostraram menores resultados de absorção de água total, em relação aos demais caminhões do lote. O concreto do caminhão 2B mostrou novamente maior resultado médio de absorção de água total, para este tipo de condicionamento. 
TABELA 66 - Resultados do ensaio de absorção de água a 63 dias (AE2) dos concretos do lote analisado. ABNT NBR 9778 (2005).

\begin{tabular}{|c|c|c|c|c|c|c|c|c|c|c|c|c|}
\hline \multirow[b]{2}{*}{ סُ } & \multicolumn{5}{|c|}{ Medidas por amostra } & \multicolumn{7}{|c|}{ Cálculos para o lote } \\
\hline & $\begin{array}{l}\text { Absorçăo } \\
\text { total } \\
(\%)\end{array}$ & $\begin{array}{l}\text { Média } \\
(\%)\end{array}$ & $\begin{array}{c}\text { Valor } \\
\text { Máximo (\%) }\end{array}$ & $\begin{array}{c}\text { Valor } \\
\text { Minimo (\%) }\end{array}$ & $\begin{array}{c}\text { Amplitude } \\
(\%)\end{array}$ & Média (\%) & $\begin{array}{c}\text { Desvio } \\
\text { padrão (\%) }\end{array}$ & $\begin{array}{c}\text { Coeficiente } \\
\text { de } \\
\text { variaçāo } \\
(\%)\end{array}$ & $\begin{array}{l}\text { Valor } \\
\text { Máximo } \\
\text { (\%) }\end{array}$ & $\begin{array}{l}\text { Valor } \\
\text { Minimo (\%) }\end{array}$ & $\begin{array}{c}\text { Amplitude } \\
(\%)\end{array}$ & $\begin{array}{l}\text { Intervalo de } \\
\text { confiança da } \\
\text { média } 95 \% \\
(\%)\end{array}$ \\
\hline $1 \mathrm{~A}$ & $\begin{array}{l}4,0 \\
4,2\end{array}$ & 4,1 & 4,2 & 4,0 & 0,2 & \multirow{6}{*}{4,1} & \multirow{6}{*}{0,3} & \multirow{6}{*}{$6 \%$} & \multirow{6}{*}{4,6} & \multirow{6}{*}{3,9} & \multirow{6}{*}{0,7} & \multirow{6}{*}{ $\pm 0,21$} \\
\hline $2 \mathrm{~B}$ & $\begin{array}{l}4,6 \\
4,6\end{array}$ & 4,6 & 4,6 & 4,6 & 0,0 & & & & & & & \\
\hline $3 \mathrm{C}$ & $\begin{array}{l}4,1 \\
4,2\end{array}$ & 4,1 & 4,2 & 4,1 & 0,1 & & & & & & & \\
\hline $4 \mathrm{D}$ & $\begin{array}{l}4,0 \\
4,1\end{array}$ & 4,1 & 4,1 & 4,0 & 0,0 & & & & & & & \\
\hline $5 \mathrm{E}$ & $\begin{array}{l}3,9 \\
3,9\end{array}$ & 3,9 & 3,9 & 3,9 & 0,1 & & & & & & & \\
\hline $6 \mathrm{~F}$ & $\begin{array}{l}3,9 \\
3,9\end{array}$ & 3,9 & 3,9 & 3,9 & 0,0 & & & & & & & \\
\hline
\end{tabular}

\section{F.2d) Absorção de água a 91 dias}

A Tabela 67 apresenta os resultados das medidas individuais em metade de corposde-prova partidos por compressão diametral, as médias, o desvio padrão, os valores máximo e mínimo, as amplitudes e o coeficiente de variação do ensaio de absorção de água dos concretos com cura acelerada de 24/72 horas seguida de cura imersa em água até 7 dias. Os corpos-de-prova íntegros e originais foram ainda submetidos a três ciclos de 24 horas de imersão em tanque de água e 27 dias de secagem em estufa a $(40 \pm 1)^{\circ} \mathrm{C}$, antes da realização deste ensaio.

Pode-se observar que os concretos dos caminhões 3C e 6F mostraram menores resultados de absorção de água total, em relação aos demais caminhões do lote. O concreto do caminhão $2 \mathrm{~B}$ mostrou novamente maior resultado médio de absorção de água total, para este tipo de condicionamento.

TABELA 67 - Resultados do ensaio de absorção de água a 91 dias (AE2) dos concretos do lote analisado. ABNT NBR 9778 (2005).

\begin{tabular}{|c|c|c|c|c|c|c|c|c|c|c|c|c|}
\hline \multirow[b]{2}{*}{ 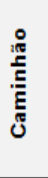 } & \multicolumn{5}{|c|}{ Medidas por amostra } & \multicolumn{7}{|c|}{ Cálculos para o lote } \\
\hline & $\begin{array}{c}\text { Absorç̧ão } \\
\text { total } \\
(\%)\end{array}$ & Média (\%) & $\begin{array}{c}\text { Valor } \\
\text { Máximo (\%) }\end{array}$ & $\begin{array}{c}\text { Valor } \\
\text { Mínimo (\%) }\end{array}$ & $\begin{array}{c}\text { Amplitude } \\
(\%)\end{array}$ & Média $(\%)$ & $\begin{array}{c}\text { Desvio } \\
\text { padrão (\%) }\end{array}$ & $\begin{array}{c}\text { Coeficiente } \\
\text { de } \\
\text { variação } \\
(\%)\end{array}$ & $\begin{array}{l}\text { Valor } \\
\text { Máximo } \\
(\%)\end{array}$ & $\begin{array}{c}\text { Valor } \\
\text { Mínimo (\%) }\end{array}$ & $\begin{array}{c}\text { Amplitude } \\
(\%)\end{array}$ & $\begin{array}{c}\text { Intervalo de } \\
\text { confiança da } \\
\text { média } 95 \% \\
(\%)\end{array}$ \\
\hline $1 \mathrm{~A}$ & $\begin{array}{l}4,3 \\
4,8\end{array}$ & 4,5 & 4,8 & 4,3 & 0,6 & \multirow{6}{*}{4,6} & \multirow{6}{*}{0,3} & \multirow{6}{*}{$6 \%$} & \multirow{6}{*}{5,1} & \multirow{6}{*}{4,4} & \multirow{6}{*}{0,7} & \multirow{6}{*}{ $\pm 0,21$} \\
\hline $2 B$ & $\begin{array}{l}5,3 \\
4,9\end{array}$ & 5,1 & 5,3 & 4,9 & 0,4 & & & & & & & \\
\hline $3 C$ & $\begin{array}{l}4,5 \\
4,4\end{array}$ & 4,5 & 4,5 & 4,4 & 0,1 & & & & & & & \\
\hline $4 \mathrm{D}$ & $\begin{array}{l}4,2 \\
4,7\end{array}$ & 4,5 & 4,7 & 4,2 & 0,5 & & & & & & & \\
\hline $5 \mathrm{E}$ & $\begin{array}{l}4,6 \\
4,6\end{array}$ & 4,6 & 4,6 & 4,6 & 0,0 & & & & & & & \\
\hline $6 \mathrm{~F}$ & $\begin{array}{l}4,3 \\
4,5\end{array}$ & 4,4 & 4,5 & 4,3 & 0,3 & & & & & & & \\
\hline
\end{tabular}




\section{F.2e) Absorção de água a 203 dias}

A Tabela 68 apresenta os resultados das medidas individuais em metade de corposde-prova partidos por compressão diametral, as médias, o desvio padrão, os valores máximo e mínimo, as amplitudes e o coeficiente de variação do ensaio de absorção de água dos concretos com cura acelerada de 24/72 horas seguida de cura imersa em água até 7 dias. Os corpos-de-prova íntegros e originais foram ainda submetidos a sete ciclos de imersão de 24 horas em tanque de água e 27 dias de secagem em estufa a $(40 \pm 1)^{\circ} \mathrm{C}$, antes da realização deste ensaio.

Pode-se observar que os caminhões $3 \mathrm{C}$ e $5 \mathrm{E}$ mostraram menores resultados de absorção de água total, em relação aos demais caminhões do lote. O concreto do caminhão 2B mostrou novamente maior resultado médio de absorção de água total, para este tipo de condicionamento.

TABELA 68 - Resultados do ensaio de absorção de água a 203 dias (AE2) dos concretos do lote analisado. ABNT NBR 9778 (2005).

\begin{tabular}{|c|c|c|c|c|c|c|c|c|c|c|c|c|c|}
\hline \multirow[b]{2}{*}{ 选 } & \multicolumn{5}{|c|}{ Medidas por amostra } & \multicolumn{8}{|c|}{ Cálculos para o lote } \\
\hline & $\begin{array}{c}\text { Absorção } \\
\text { total } \\
(\%)\end{array}$ & $\begin{array}{c}\text { Média } \\
(\%)\end{array}$ & $\begin{array}{c}\text { Valor } \\
\text { Máximo (\%) }\end{array}$ & $\begin{array}{c}\text { Valor } \\
\text { Mínimo (\%) }\end{array}$ & $\begin{array}{c}\text { Amplitude } \\
(\%)\end{array}$ & Média & $(\%)$ & $\begin{array}{c}\text { Desvio } \\
\text { padrão (\%) }\end{array}$ & $\begin{array}{c}\text { Coeficiente } \\
\text { de } \\
\text { variação } \\
(\%)\end{array}$ & $\begin{array}{c}\text { Valor } \\
\text { Máximo } \\
(\%)\end{array}$ & $\begin{array}{c}\text { Valor } \\
\text { Mínimo (\%) }\end{array}$ & $\begin{array}{c}\text { Amplitude } \\
(\%)\end{array}$ & $\begin{array}{c}\text { Intervalo de } \\
\text { confiança da } \\
\text { média } 95 \% \\
(\%)\end{array}$ \\
\hline $1 A$ & $\begin{array}{l}5,2 \\
5,1\end{array}$ & 5,1 & 5,2 & 5,1 & 0,1 & \multirow{6}{*}{\multicolumn{2}{|c|}{5,3}} & \multirow{6}{*}{0,4} & \multirow{6}{*}{$7 \%$} & \multirow{6}{*}{5,7} & \multirow{6}{*}{4,8} & \multirow{6}{*}{0,9} & \multirow{6}{*}{ $\pm 0,28$} \\
\hline $2 \mathrm{~B}$ & $\begin{array}{l}5,8 \\
5,7\end{array}$ & 5,7 & 5,8 & 5,7 & 0,1 & & & & & & & & \\
\hline $3 \mathrm{C}$ & $\begin{array}{l}5,0 \\
5,1\end{array}$ & 5,0 & 5,1 & 5,0 & 0,1 & & & & & & & & \\
\hline 4D & $\begin{array}{l}5,2 \\
5,5\end{array}$ & 5,3 & 5,5 & 5,2 & 0,3 & & & & & & & & \\
\hline $5 \mathrm{E}$ & $\begin{array}{l}4,8 \\
4,9\end{array}$ & 4,8 & 4,9 & 4,8 & 0,2 & & & & & & & & \\
\hline $6 \mathrm{~F}$ & $\begin{array}{l}5,8 \\
5,5\end{array}$ & 5,6 & 5,8 & 5,5 & 0,4 & & & & & & & & \\
\hline
\end{tabular}

A Figura 81 a seguir ilustra a absorção de água média para as idades de ensaio e para a condição de envelhecimento acelerado tipo AE2, com ciclos de imersão de $24 \mathrm{~h}$ em tanque de água seguida de 27 dias de secagem em estufa. Verificou-se valores mais altos de absorção de água a partir de 91 dias, da mesma forma que ocorreu para os corpos-de-prova ensaiados na condição AE1. 


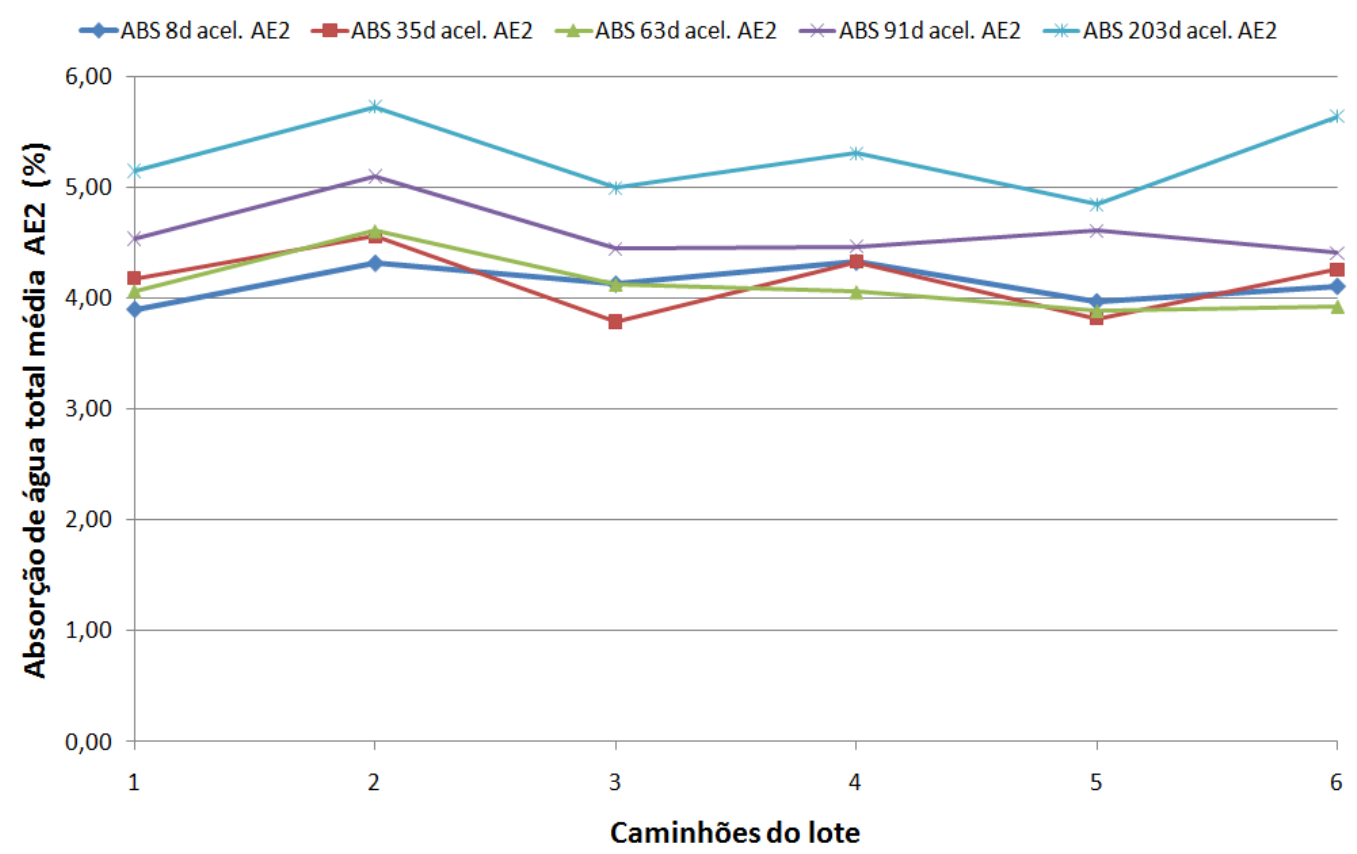

FIGURA 81 - Variação da absorção de água média dos corpos-de-prova, submetidos à cura acelerada de $24 / 72 \mathrm{~h}$ e imersão em água até 7 dias e depois a ciclos de $24 \mathrm{~h}$ de imersão em tanque de água seguida por 27 dias de secagem em estufa a $40^{\circ} C$ (AE2).

F.3) Cura acelerada de 24/72 horas seguida por imersão em água até 7 dias e ciclos de 28 dias de secagem contínua (AE3).

\section{F.3a) Absorção de água a 91 dias}

A Tabela 69 apresenta os resultados das medidas individuais em metade de corposde-prova partidos por compressão diametral, as médias, o desvio padrão, os valores máximo e mínimo, as amplitudes e o coeficiente de variação do ensaio de absorção de água dos concretos com cura acelerada de 24/72 horas seguida de cura imersa em água até 7 dias. Os corpos-de-prova íntegros e originais foram ainda mantidos em secagem contínua em estufa a $(40 \pm 1)^{\circ} \mathrm{C}$, antes da realização do ensaio.

Pode-se observar que os concretos dos caminhões $1 \mathrm{~A}$ e $5 \mathrm{E}$ mostraram menores resultados de absorção de água total, em relação aos demais do lote. O concreto do caminhão 2B mostrou novamente maior resultado médio de absorção de água, também para este tipo de condicionamento. 
TABELA 69 - Resultados do ensaio de absorção de água a 91 dias (AE3) dos concretos do lote analisado. ABNT NBR 9778 (2005).

\begin{tabular}{|c|c|c|c|c|c|c|c|c|c|c|c|c|}
\hline \multirow[b]{2}{*}{ 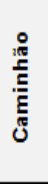 } & \multicolumn{5}{|c|}{ Medidas por amostra } & \multicolumn{7}{|c|}{ Cálculos para o lote } \\
\hline & $\begin{array}{c}\text { Absorçãao } \\
\text { total } \\
(\%)\end{array}$ & $\begin{array}{l}\text { Média } \\
(\%)\end{array}$ & $\begin{array}{c}\text { Valor } \\
\text { Máximo (\%) }\end{array}$ & $\begin{array}{c}\text { Valor } \\
\text { Mínimo (\%) }\end{array}$ & $\begin{array}{c}\text { Amplitude } \\
(\%)\end{array}$ & Média $(\%)$ & $\begin{array}{c}\text { Desvio } \\
\text { padrão (\%) }\end{array}$ & $\begin{array}{c}\text { Coeficiente } \\
\text { de } \\
\text { variação } \\
(\%)\end{array}$ & $\begin{array}{c}\text { Valor } \\
\text { Máximo } \\
(\%)\end{array}$ & $\begin{array}{c}\text { Valor } \\
\text { Mínimo (\%) }\end{array}$ & $\begin{array}{l}\text { Amplitude } \\
(\%)\end{array}$ & $\begin{array}{l}\text { Intervalo de } \\
\text { confiança da } \\
\text { média 95\% } \\
(\%)\end{array}$ \\
\hline $1 \mathrm{~A}$ & $\begin{array}{l}4,6 \\
4,7\end{array}$ & 4,6 & 4,7 & 4,6 & 0,1 & \multirow{6}{*}{4,8} & \multirow{6}{*}{0,2} & \multirow{6}{*}{$5 \%$} & \multirow{6}{*}{5,2} & \multirow{6}{*}{4,6} & \multirow{6}{*}{0,6} & \multirow{6}{*}{ $\pm 0,19$} \\
\hline $2 \mathrm{~B}$ & $\begin{array}{l}5,1 \\
5,3\end{array}$ & 5,2 & 5,3 & 5,1 & 0,2 & & & & & & & \\
\hline $3 \mathrm{C}$ & $\begin{array}{l}4,6 \\
4,9\end{array}$ & 4,7 & 4,9 & 4,6 & 0,2 & & & & & & & \\
\hline $4 \mathrm{D}$ & $\begin{array}{l}4,7 \\
4,7\end{array}$ & 4,7 & 4,7 & 4,7 & 0,0 & & & & & & & \\
\hline $5 \mathrm{E}$ & $\begin{array}{l}4,7 \\
4,6\end{array}$ & 4,7 & 4,7 & 4,6 & 0,0 & & & & & & & \\
\hline $6 \mathrm{~F}$ & $\begin{array}{l}4,8 \\
5,1\end{array}$ & 4,9 & 5,1 & 4,8 & 0,3 & & & & & & & \\
\hline
\end{tabular}

\section{F.3b) Absorção de água a 203 dias}

A Tabela 70 apresenta os resultados das medidas individuais em metade de corposde-prova partidos por compressão diametral, as médias, o desvio padrão, os valores máximo e mínimo, as amplitudes e o coeficiente de variação do ensaio de absorção de água dos concretos com cura acelerada de 24/72 horas seguida de cura imersa em água até 7 dias. Os corpos-de-prova ínegros e originais foram ainda mantidos em secagem contínua em estufa $\mathrm{a}(40 \pm 1)^{\circ} \mathrm{C}$, antes deste ensaio.

Pode-se observar que os concretos dos caminhões $3 \mathrm{C}$ e $5 \mathrm{E}$ mostraram menores resultados de absorção de água, em relação aos demais caminhões do lote. O concreto do caminhão 6F mostrou maior resultado médio de absorção de água total, para este tipo de condicionamento. Para esta idade e este tipo de condicionamento os resultados mostraram menores variações.

TABELA 70 - Resultados do ensaio de absorção de água a 203 dias (AE3) dos concretos do lote analisado. ABNT NBR 9778 (2005).

\begin{tabular}{|c|c|c|c|c|c|c|c|c|c|c|c|c|}
\hline \multirow{2}{*}{ 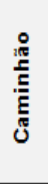 } & \multicolumn{5}{|c|}{ Medidas por amostra } & \multicolumn{7}{|c|}{ Cálculos para o lote } \\
\hline & $\begin{array}{c}\text { Absorção } \\
\text { total } \\
(\%)\end{array}$ & Média (\%) & $\begin{array}{c}\text { Valor } \\
\text { Máximo (\%) }\end{array}$ & $\begin{array}{c}\text { Valor } \\
\text { Mínimo (\%) }\end{array}$ & $\begin{array}{l}\text { Amplitude } \\
(\%)\end{array}$ & Média $(\%)$ & $\begin{array}{c}\text { Desvio } \\
\text { padrão }(\%)\end{array}$ & $\begin{array}{c}\text { Coeficiente } \\
\text { de } \\
\text { variação } \\
(\%)\end{array}$ & $\begin{array}{c}\text { Valor } \\
\text { Máximo } \\
(\%)\end{array}$ & $\begin{array}{c}\text { Valor } \\
\text { Mínimo (\%) }\end{array}$ & $\begin{array}{c}\text { Amplitude } \\
(\%)\end{array}$ & $\begin{array}{c}\text { Intervalo de } \\
\text { confiança da } \\
\text { média 95\% } \\
(\%)\end{array}$ \\
\hline $1 \mathrm{~A}$ & $\begin{array}{l}5,5 \\
5,5\end{array}$ & 5,5 & 5,5 & 5,5 & 0,0 & \multirow{6}{*}{5,4} & \multirow{6}{*}{0,2} & \multirow{6}{*}{$4 \%$} & \multirow{6}{*}{5,7} & \multirow{6}{*}{5,1} & \multirow{6}{*}{0,6} & \multirow{6}{*}{ $\pm 0,17$} \\
\hline $2 B$ & $\begin{array}{l}5,5 \\
5,7\end{array}$ & 5,6 & 5,7 & 5,5 & 0,2 & & & & & & & \\
\hline $3 C$ & $\begin{array}{l}5,1 \\
5,2 \\
5\end{array}$ & 5,1 & 5,2 & 5,1 & 0,1 & & & & & & & \\
\hline $4 \mathrm{D}$ & $\begin{array}{l}5,5 \\
5,2\end{array}$ & 5,4 & 5,5 & 5,2 & 0,3 & & & & & & & \\
\hline $5 \mathrm{E}$ & $\begin{array}{l}5,1 \\
5,4\end{array}$ & 5,3 & 5,4 & 5,1 & 0,3 & & & & & & & \\
\hline $6 \mathrm{~F}$ & $\begin{array}{l}5,8 \\
5,6\end{array}$ & 5,7 & 5,8 & 5,6 & 0,3 & & & & & & & \\
\hline
\end{tabular}


A Figura 82 a seguir ilustra a absorção de água média para as idades de ensaio e para a condição de envelhecimento AE3 com ciclos de 28 dias de secagem contínua em estufa ventilada a $(40 \pm 1)^{\circ} \mathrm{C}$.

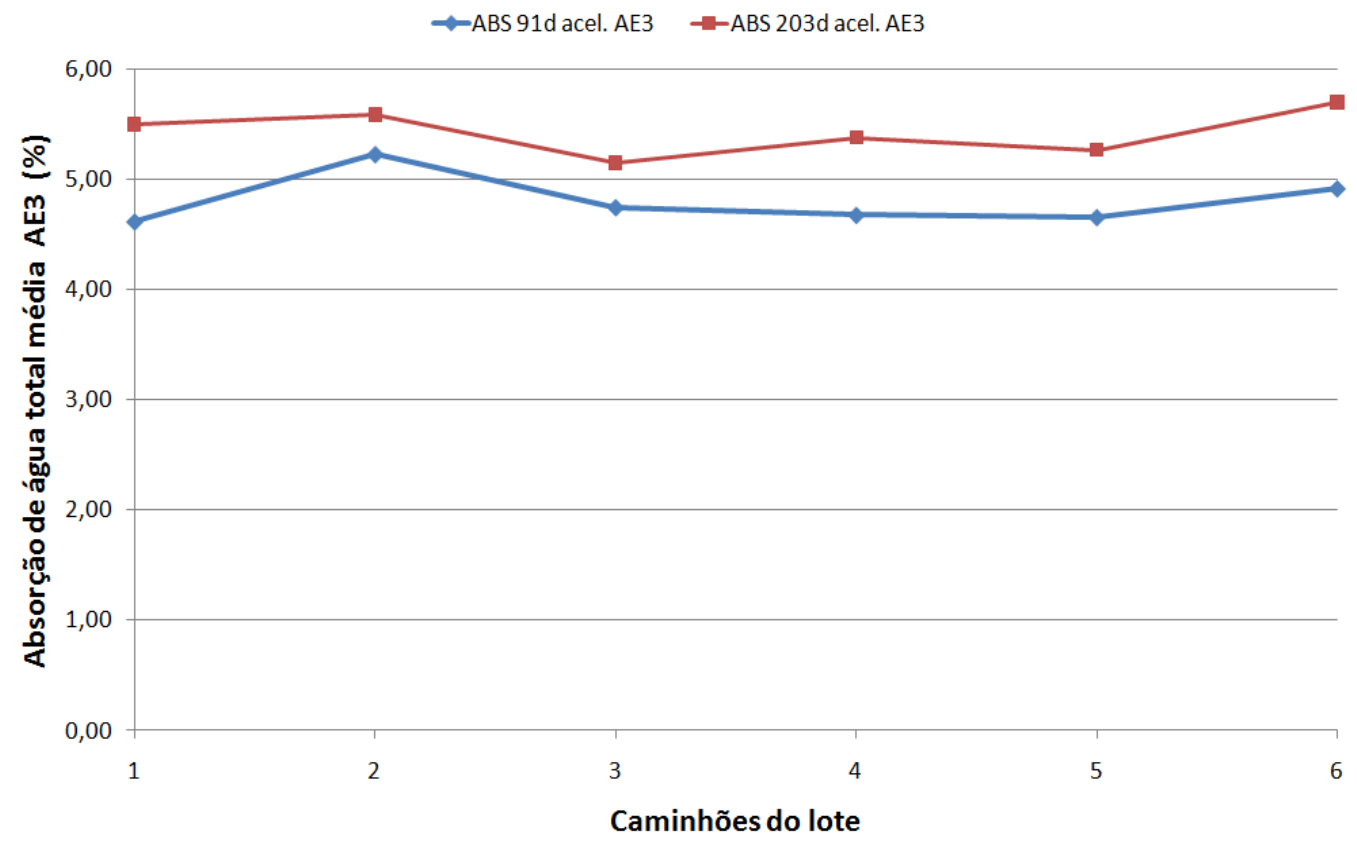

FIGURA 82 - Variação da absorção de água média dos corpos-de-prova, submetidos à cura acelerada $24 / 72 \mathrm{~h}$ e imersão em água até 7 dias e depois a ciclos de 28 dias de secagem contínua em estufa ventilada a $(40 \pm 1)^{\circ} \mathrm{C}$, na condição AE3. 


\section{F.4) Análise conjunta da absorção de água, para todas as idades e condições de envelhecimento acelerado}

A Tabela 71 apresenta as medidas individuais, as médias, os desvios padrão, os valores máximos e mínimos e os coeficientes de variação dos resultados para o lote analisado, quanto ao ensaio de absorção de água, para os concretos com cura acelerada 24/72 horas seguida de cura imersa em água até 7 dias, sendo depois os corpos-de-prova originais mantidos respectivamente nas três seguintes condições de envelhecimento acelerado:

$\checkmark$ AE1 (ciclos de $24 \mathrm{~h}$ de exposição em câmara de $\mathrm{CO}_{2}$ seguida de 27 dias de secagem em estufa a $40 \pm 1 \stackrel{\circ}{ }$ );

$\checkmark$ AE2 (ciclos de $24 \mathrm{~h}$ de imersão em tanque de água seguida de 27 dias de secagem em estufa a $40 \pm 1^{\circ} \mathrm{C}$ ); $\mathrm{e}$,

$\checkmark$ AE3 (ciclos de 28 dias de secagem contínua em estufa a $40 \pm 5^{\circ} \mathrm{C}$ ).

Pela Tabela 71, observa-se que a absorção de água mostrou valores próximos e constantes para as idades de 8, 35 e 63 dias, e um ligeiro aumento desses valores aos 91 dias, para os três tipos de condicionamento. Aos 203 dias, obteve-se ainda um aumento ligeiramente maior em relação aos resultados de 91 dias e significativamente maior que os resultados das demais idades. A absorção de água aos 203 dias teve resultado um pouco maior para o condicionamento de secagem contínua.

Para os concretos de todos os caminhões, para todas as idades e tipo de condição de envelhecimento acelerado, os coeficientes de variação dos resultados foram baixos, sendo que a maioria deles foi menor que 10\%, com exceção do resultado de 8 dias (AE1) e 35 dias $\mathrm{AE} 1$, que foram de $10 \%$ e $11 \%$ respectivamente. 
TABELA 71 - Resultados do ensaio de absorção de água nos concretos amostrados do lote, considerando média dos 12 resultados. ABNT NBR 9778 (2005).

\begin{tabular}{|c|c|c|c|c|c|c|c|c|c|c|c|c|}
\hline \multirow{2}{*}{ 题 } & \multicolumn{2}{|c|}{8 dias } & \multicolumn{2}{|c|}{35 dias } & \multicolumn{2}{|c|}{63 dias } & \multicolumn{3}{|c|}{91 dias } & \multicolumn{3}{|c|}{203 dias } \\
\hline & $\begin{array}{c}\text { Abs.total } 8 \\
\text { dias - AE1 } \\
\text { (\%) }\end{array}$ & $\begin{array}{c}\text { Abs.total } 8 \\
\text { dias - AE2 } \\
\text { (\%) }\end{array}$ & $\begin{array}{c}\text { Abs.total } 35 \\
\text { dias - AE1 } \\
\text { (\%) }\end{array}$ & $\begin{array}{c}\text { Abs.total } 35 \\
\text { dias - AE2 } \\
(\%)\end{array}$ & $\begin{array}{c}\text { Abs.total } 63 \\
\text { dias - AE1 } \\
\text { (\%) }\end{array}$ & $\begin{array}{c}\text { Abs.total } 63 \\
\text { dias - AE2 } \\
(\%)\end{array}$ & $\begin{array}{c}\text { Abs.total } 91 \\
\text { dias - AE1 } \\
(\%)\end{array}$ & $\begin{array}{c}\text { Abs.total } \\
91 \text { dias - } \\
\text { AE2 (\%) }\end{array}$ & $\begin{array}{c}\text { Abs.total } 91 \\
\text { dias - AE3 } \\
(\%)\end{array}$ & $\begin{array}{l}\text { Abs.total } \\
203 \text { dias - } \\
\text { AE1 (\%) }\end{array}$ & $\begin{array}{l}\text { Abs.total } \\
203 \text { dias - } \\
\text { AE2 (\%) }\end{array}$ & $\begin{array}{c}\text { Abs.total } 203 \\
\text { dias - AE3 } \\
\text { (\%) }\end{array}$ \\
\hline \multirow{2}{*}{$1 \mathrm{~A}$} & 4,1 & 3,8 & 4,5 & 4,3 & 4,1 & 4,0 & 4,5 & 4,3 & 4,6 & 5,1 & 5,2 & 5,5 \\
\hline & 3,6 & 4,0 & 4,2 & 4,1 & 4,1 & 4,2 & 4,6 & 4,8 & 4,7 & 5,2 & 5,1 & 5,5 \\
\hline \multirow{2}{*}{$2 B$} & 4,4 & 4,2 & 4,6 & 4,6 & 4,8 & 4,6 & 4,9 & 5,3 & 5,1 & 5,5 & 5,8 & 5,5 \\
\hline & 4,3 & 4,4 & 4,8 & 4,5 & 4,4 & 4,6 & 5,3 & 4,9 & 5,3 & 5,2 & 5,7 & 5,7 \\
\hline \multirow{2}{*}{$3 C$} & 4,3 & 4,1 & 4,2 & 3,9 & 3,6 & 4,1 & 4,4 & 4,5 & 4,6 & 5,0 & 5,0 & 5,1 \\
\hline & 3,8 & 4,2 & 3,8 & 3,7 & 3,9 & 4,2 & 4,3 & 4,4 & 4,9 & 4,8 & 5,1 & 5,2 \\
\hline \multirow{2}{*}{ 4D } & 4,2 & 4,4 & 4,4 & 4,0 & 4,0 & 4,0 & 4,8 & 4,2 & 4,7 & 5,2 & 5,2 & 5,5 \\
\hline & 4,2 & 4,3 & 3,4 & 4,7 & 3,4 & 4,1 & 4,8 & 4,7 & 4,7 & 5,3 & 5,5 & 5,2 \\
\hline \multirow{2}{*}{$5 \mathrm{E}$} & 3,3 & 4,0 & 3,6 & 4,0 & 3,9 & 3,9 & 4,6 & 4,6 & 4,7 & 5,0 & 4,8 & 5,1 \\
\hline & 3,3 & 3,9 & 3,5 & 3,7 & 3,8 & 3,9 & 4,4 & 4,6 & 4,6 & 4,9 & 4,9 & 5,4 \\
\hline \multirow{2}{*}{$6 \mathrm{~F}$} & 4,2 & 4,0 & 4,5 & 4,3 & 3,9 & 3,9 & 4,9 & 4,3 & 4,8 & 5,2 & 5,8 & 5,8 \\
\hline & 4,3 & 4,2 & 4,3 & 4,2 & 4,0 & 3,9 & 5,1 & 4,5 & 5,1 & 5,5 & 5,5 & 5,6 \\
\hline $\begin{array}{l}\text { Média do } \\
\text { lote (\%) }\end{array}$ & 4,0 & 4,1 & 4,1 & 4,2 & 4,0 & 4,1 & 4,7 & 4,6 & 4,8 & 5,2 & 5,3 & 5,4 \\
\hline $\begin{array}{c}\text { Valor } \\
\text { máximo (\%) }\end{array}$ & 4,4 & 4,4 & 4,8 & 4,7 & 4,8 & 4,6 & 5,3 & 5,3 & 5,3 & 5,5 & 5,8 & 5,8 \\
\hline $\begin{array}{c}\text { Valor } \\
\text { mínimo (\%) }\end{array}$ & 3,3 & 3,8 & 3,4 & 3,7 & 3,4 & 3,9 & 4,3 & 4,2 & 4,6 & 4,8 & 4,8 & 5,1 \\
\hline $\begin{array}{c}\text { Desvio } \\
\text { padrão (\%) }\end{array}$ & 0,4 & 0,2 & 0,4 & 0,3 & 0,4 & 0,3 & 0,3 & 0,3 & 0,2 & 0,2 & 0,4 & 0,2 \\
\hline $\begin{array}{c}\text { Coeficientes } \\
\text { de variação } \\
(\%)\end{array}$ & 9,9 & 4,6 & 10,7 & 8,0 & 9,0 & 6,1 & 6,5 & 6,8 & 5,1 & 4,1 & 6,7 & 4,2 \\
\hline
\end{tabular}


G) Índice de vazios

Os corpos-de-prova e procedimentos foram simultâneos aos de medida de absorção de água, já analisados no item F).

\section{G.1) Cura acelerada 24/72 horas seguida por imersão em água até 7 dias e ciclos de 24 horas em câmara de carbonatação e 27 dias de secagem em estufa (AE1).}

Os itens a seguir apresentam os resultados dos cálculos de índice de vazios a 8, 35, 63, 91 e 203 dias dos concretos do lote analisado, para o condicionamento AE1.

\section{G.1a) Índice de vazios a 8 dias}

A Tabela 72 apresenta os resultados das medidas individuais, as médias, o desvio padrão, os valores máximo e mínimo, as amplitudes e o coeficiente de variação do ensaio de índice de vazios dos concretos com cura acelerada de 24/72 horas seguida de cura imersa em água até 7 dias. Os corpos-de-prova originais foram ainda submetidos a 24 horas em câmara de carbonatação a $5 \%$ de $\mathrm{CO}_{2}$, antes da realização deste ensaio.

Observa-se que os concretos dos caminhões 2B, 4D e 6E mostraram valores iguais de índice de vazios médio a 8 dias para este tipo de condicionamento.

TABELA 72 - Resultados do ensaio de índice de vazios a 8 dias (AE1) dos concretos do lote analisado. ABNT NBR 9778 (2005).

\begin{tabular}{|c|c|c|c|c|c|c|c|c|c|c|c|c|}
\hline \multirow[b]{2}{*}{ 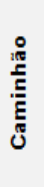 } & \multicolumn{5}{|c|}{ Medidas por amostra } & \multicolumn{7}{|c|}{ Cálculos para o lote } \\
\hline & $\begin{array}{c}\text { Índice de } \\
\text { vazios } \\
(\%)\end{array}$ & $\begin{array}{c}\text { Média } \\
(\%)\end{array}$ & $\begin{array}{c}\text { Valor } \\
\text { Máximo }(\%)\end{array}$ & $\begin{array}{c}\text { Valor } \\
\text { Mínimo } \\
(\%)\end{array}$ & $\begin{array}{c}\text { Amplitude } \\
(\%)\end{array}$ & Média (\%) & $\begin{array}{c}\text { Desvio } \\
\text { padrão } \\
(\%)\end{array}$ & $\begin{array}{c}\text { Coeficiente } \\
\text { de } \\
\text { variação } \\
(\%)\end{array}$ & $\begin{array}{c}\text { Valor } \\
\text { Máximo } \\
(\%)\end{array}$ & $\begin{array}{c}\text { Valor } \\
\text { Mínimo } \\
(\%)\end{array}$ & $\begin{array}{c}\text { Amplitude } \\
(\%)\end{array}$ & $\begin{array}{c}\text { Intervalo de } \\
\text { confiança da } \\
\text { média 95\% } \\
(\%)\end{array}$ \\
\hline $1 \mathrm{~A}$ & $\begin{array}{l}9,6 \\
8,6\end{array}$ & 9,1 & 9,6 & 8,6 & 1,0 & \multirow{6}{*}{9,4} & \multirow{6}{*}{0,8} & \multirow{6}{*}{$9 \%$} & \multirow{6}{*}{10,0} & \multirow{6}{*}{7,9} & \multirow{6}{*}{2,2} & \multirow{6}{*}{ $\pm 0,67$} \\
\hline $2 B$ & $\begin{array}{c}10,0 \\
9,9\end{array}$ & 10,0 & 10,0 & 9,9 & 0,1 & & & & & & & \\
\hline $3 C$ & $\begin{array}{c}10,1 \\
9,0\end{array}$ & 9,6 & 10,1 & 9,0 & 1,1 & & & & & & & \\
\hline $4 \mathrm{D}$ & $\begin{array}{c}10,1 \\
9,9\end{array}$ & 10,0 & 10,1 & 9,9 & 0,1 & & & & & & & \\
\hline $5 \mathrm{E}$ & $\begin{array}{l}8,0 \\
7,7\end{array}$ & 7,9 & 8,0 & 7,7 & 0,3 & & & & & & & \\
\hline $6 \mathrm{~F}$ & $\begin{array}{c}9,9 \\
10,2\end{array}$ & 10,0 & 10,2 & 9,9 & 0,3 & & & & & & & \\
\hline
\end{tabular}


O concreto do caminhão $5 \mathrm{E}$ obteve mostrou menor resultado médio de índice de vazios, para este tipo de condicionamento, e isto concorda com o maior resultado de resistência à compressão desse concreto, na mesma idade.

\section{G.1b) Índice de vazios a 35 dias}

A Tabela 73 apresenta os resultados das medidas individuais, as médias, o desvio padrão, os valores máximo e mínimo, as amplitudes e o coeficiente de variação do ensaio de índice de vazios dos concretos com cura acelerada de 24/72 horas seguida de cura imersa em água até 7 dias. Os corpos-de-prova originais foram submetidos a um ciclo de 24 horas em câmara de carbonatação a $5 \%$ de $\mathrm{CO}_{2}$, e 27 dias de secagem em estufa a (40 \pm $1)^{\circ} \mathrm{C}$, antes da realização deste ensaio.

Observa-se que os concretos dos caminhões $1 \mathrm{~A}$ e $6 \mathrm{E}$ mostraram valores próximos de índice de vazios médio a 35 dias para este tipo de condicionamento. O concreto do caminhão 5E mostrou novamente menor resultado de índice de vazios entre os resultados.

TABELA 73 - Resultados do ensaio de índice de vazios a 35 dias (AE1) dos concretos do lote analisado. ABNT NBR 9778 (2005).

\begin{tabular}{|c|c|c|c|c|c|c|c|c|c|c|c|c|}
\hline \multirow[b]{2}{*}{ "ृ. } & \multicolumn{5}{|c|}{ Medidas por amostra } & \multicolumn{7}{|c|}{ Cálculos para o lote } \\
\hline & $\begin{array}{l}\text { Indice de } \\
\text { vazios } \\
(\%)\end{array}$ & $\begin{array}{l}\text { Média } \\
(\%)\end{array}$ & $\begin{array}{c}\text { Valor } \\
\text { Máximo } \\
(\%)\end{array}$ & $\begin{array}{c}\text { Valor } \\
\text { Minimo } \\
(\%)\end{array}$ & $\begin{array}{c}\text { Amplitude } \\
(\%)\end{array}$ & Média (\%) & $\begin{array}{c}\text { Desvio } \\
\text { padrão } \\
(\%)\end{array}$ & $\begin{array}{c}\text { Coeficiente } \\
\text { de } \\
\text { variação } \\
(\%)\end{array}$ & $\begin{array}{l}\text { Valor } \\
\text { Máximo } \\
(\%)\end{array}$ & $\begin{array}{l}\text { Valor } \\
\text { Minimo } \\
(\%)\end{array}$ & $\begin{array}{c}\text { Amplitude } \\
(\%)\end{array}$ & $\begin{array}{l}\text { Intervalo de de } \\
\text { confiança da } \\
\text { média } 95 \% \\
(\%)\end{array}$ \\
\hline $1 \mathrm{~A}$ & $\begin{array}{l}10,6 \\
10,0\end{array}$ & 10,3 & 10,6 & 10,0 & 0,6 & \multirow{6}{*}{9,9} & \multirow{6}{*}{0,8} & \multirow{6}{*}{$8 \%$} & \multirow{6}{*}{11,0} & \multirow{6}{*}{8,7} & \multirow{6}{*}{2,3} & \multirow{6}{*}{ $\pm 0,66$} \\
\hline 2B & $\begin{array}{l}10,7 \\
11,2\end{array}$ & 11,0 & 11,2 & 10,7 & 0,4 & & & & & & & \\
\hline $3 C$ & $\begin{array}{c}10,1 \\
9,2\end{array}$ & 9,7 & 10,1 & 9,2 & 0,8 & & & & & & & \\
\hline 4D & $\begin{array}{c}10,4 \\
8,4\end{array}$ & 9,4 & 10,4 & 8,4 & 2,0 & & & & & & & \\
\hline $5 \mathrm{E}$ & $\begin{array}{l}8,7 \\
8,6\end{array}$ & 8,7 & 8,7 & 8,6 & 0,1 & & & & & & & \\
\hline $6 \mathrm{~F}$ & $\begin{array}{l}10,9 \\
10,3\end{array}$ & 10,6 & 10,9 & 10,3 & 0,6 & & & & & & & \\
\hline
\end{tabular}

\section{G.1c) Índice de vazios a 63 dias}

A Tabela 74 apresenta os resultados das medidas individuais, as médias, o desvio padrão, valores máximo e mínimo, as amplitudes e o coeficiente de variação do ensaio de índice de vazios dos concretos com cura acelerada de 24/72 horas seguida de cura imersa em água até 7 dias. Os corpos-de-prova originais foram submetidos a dois ciclos de 
exposição de 24 horas em câmara de carbonatação a 5\% de $\mathrm{CO}_{2}$ e 27 dias de secagem em estufa a $(40 \pm 1)^{\circ} \mathrm{C}$, antes da realização deste ensaio.

Pode-se observar que os concretos dos caminhões $3 \mathrm{C}$ e $4 \mathrm{D}$ mostraram menores resultados de índice de vazios, em relação aos demais do lote. O concreto do caminhão 2B apresentou maior resultado de índice de vazios, como na maioria dos casos dos ensaios de absorção de água, onde mostrou obteve também maiores resultados.

TABELA 74 - Resultados do ensaio de índice de vazios a 63 dias (AE1) dos concretos do lote analisado. ABNT NBR 9778 (2005).

\begin{tabular}{|c|c|c|c|c|c|c|c|c|c|c|c|c|c|}
\hline \multirow{2}{*}{ 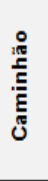 } & \multicolumn{5}{|c|}{ Medidas por amostra } & \multicolumn{8}{|c|}{ Cálculos para o lote } \\
\hline & $\begin{array}{c}\text { Índice de } \\
\text { vazios } \\
\text { (\%) }\end{array}$ & $\begin{array}{l}\text { Média } \\
(\%)\end{array}$ & $\begin{array}{c}\text { Valor } \\
\text { Máximo (\%) }\end{array}$ & $\begin{array}{c}\text { Valor } \\
\text { Minimo (\%) }\end{array}$ & $\begin{array}{c}\text { Amplitude } \\
(\%)\end{array}$ & Média & $(\%)$ & $\begin{array}{c}\text { Desvio } \\
\text { padrão (\%) }\end{array}$ & $\begin{array}{c}\text { Coeficiente } \\
\text { de } \\
\text { variação } \\
(\%)\end{array}$ & $\begin{array}{c}\text { Valor } \\
\text { Máximo } \\
(\%)\end{array}$ & $\begin{array}{c}\text { Valor } \\
\text { Minimo } \\
(\%)\end{array}$ & $\begin{array}{c}\text { Amplitude } \\
(\%)\end{array}$ & $\begin{array}{c}\text { Intervalo de } \\
\text { confiança da } \\
\text { média 95\% } \\
(\%)\end{array}$ \\
\hline $1 \mathrm{~A}$ & $\begin{array}{l}9,9 \\
9,8\end{array}$ & 9,8 & 9,9 & 9,8 & 0,1 & \multirow{6}{*}{9,5} & \multirow{6}{*}{\multicolumn{2}{|c|}{0,7}} & \multirow{6}{*}{$8 \%$} & \multirow{6}{*}{10,8} & \multirow{6}{*}{8,9} & \multirow{6}{*}{2,0} & \multirow{6}{*}{ $\pm 0,58$} \\
\hline $2 \mathrm{~B}$ & $\begin{array}{l}11,3 \\
10,4\end{array}$ & 10,8 & 11,3 & 10,4 & 0,9 & & & & & & & & \\
\hline $3 \mathrm{C}$ & $\begin{array}{l}8,3 \\
9,4\end{array}$ & 8,9 & 9,4 & 8,3 & 1,1 & & & & & & & & \\
\hline $4 D$ & $\begin{array}{l}9,6 \\
8,3\end{array}$ & 8,9 & 9,6 & 8,3 & 1,3 & & & & & & & & \\
\hline $5 \mathrm{E}$ & $\begin{array}{l}9,4 \\
9,2\end{array}$ & 9,3 & 9,4 & 9,2 & 0,2 & & & & & & & & \\
\hline $6 \mathrm{~F}$ & $\begin{array}{l}9,5 \\
9,6\end{array}$ & 9,5 & 9,6 & 9,5 & 0,1 & & & & & & & & \\
\hline
\end{tabular}

\section{G.1d) Índice de vazios a 91 dias}

A Tabela 75 apresenta os resultados das medidas individuais, as médias, o desvio padrão, valores máximo e mínimo, as amplitudes e o coeficiente de variação do ensaio de índice de vazios dos concretos com cura acelerada de 24/72 horas seguida de cura imersa em água até 7 dias. Os corpos-de-prova originais foram ainda submetidos a três ciclos de 24 horas em câmara de carbonatação a $5 \%$ de $\mathrm{CO}_{2}$ e 27 dias de secagem em estufa a (40 \pm $1)^{\circ} \mathrm{C}$, antes da realização deste ensaio.

Pode-se observar que os concretos dos caminhões $1 \mathrm{~A}, 3 \mathrm{C}$ e $5 \mathrm{E}$ mostraram menores resultados de índice de vazios, em relação aos demais amostrados do lote. 
TABELA 75 - Resultados do ensaio de índice de vazios a 91 dias (AE1) dos concretos do lote analisado. ABNT NBR 9778 (2005).

\begin{tabular}{|c|c|c|c|c|c|c|c|c|c|c|c|c|}
\hline \multirow{2}{*}{ 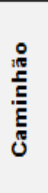 } & \multicolumn{5}{|c|}{ Medidas por amostra } & \multicolumn{7}{|c|}{ Cálculos para o lote } \\
\hline & $\begin{array}{c}\text { Índice de } \\
\text { vazios } \\
(\%)\end{array}$ & $\begin{array}{l}\text { Média } \\
(\%)\end{array}$ & $\begin{array}{c}\text { Valor } \\
\text { Máximo (\%) }\end{array}$ & $\begin{array}{l}\text { Valor } \\
\text { Minimo } \\
(\%)\end{array}$ & $\begin{array}{c}\text { Amplitude } \\
(\%)\end{array}$ & Média (\%) & $\begin{array}{c}\text { Desvio } \\
\text { padrão } \\
(\%)\end{array}$ & $\begin{array}{c}\text { Coeficiente } \\
\text { de } \\
\text { variação } \\
(\%)\end{array}$ & $\begin{array}{c}\text { Valor } \\
\text { Máximo } \\
(\%)\end{array}$ & $\begin{array}{c}\text { Valor } \\
\text { Mínimo } \\
(\%)\end{array}$ & $\begin{array}{l}\text { Amplitude } \\
(\%)\end{array}$ & $\begin{array}{c}\text { Intervalo de } \\
\text { confiança da } \\
\text { média } 95 \% \\
(\%)\end{array}$ \\
\hline $1 \mathrm{~A}$ & $\begin{array}{l}10,4 \\
10,7\end{array}$ & 10,6 & 10,7 & 10,4 & 0,3 & \multirow{6}{*}{11,0} & \multirow{6}{*}{0,6} & \multirow{6}{*}{$6 \%$} & \multirow{6}{*}{11,7} & \multirow{6}{*}{10,2} & \multirow{6}{*}{1,6} & \multirow{6}{*}{ $\pm 0,50$} \\
\hline $2 B$ & $\begin{array}{l}11,4 \\
12,1\end{array}$ & 11,7 & 12,1 & 11,4 & 0,7 & & & & & & & \\
\hline $3 \mathrm{C}$ & $\begin{array}{l}10,2 \\
10,1\end{array}$ & 10,2 & 10,2 & 10,1 & 0,1 & & & & & & & \\
\hline $4 \mathrm{D}$ & $\begin{array}{l}11,3 \\
11,1\end{array}$ & 11,2 & 11,3 & 11,1 & 0,2 & & & & & & & \\
\hline $5 \mathrm{E}$ & $\begin{array}{l}10,9 \\
10,3\end{array}$ & 10,6 & 10,9 & 10,3 & 0,5 & & & & & & & \\
\hline $6 \mathrm{~F}$ & $\begin{array}{l}11,4 \\
11,8\end{array}$ & 11,6 & 11,8 & 11,4 & 0,4 & & & & & & & \\
\hline
\end{tabular}

O concreto do caminhão $2 \mathrm{~B}$ apresentou novamente maior resultado de índice de vazios, como na maioria dos casos dos ensaios de absorção de água.

\section{G.1e) Índice de vazios a 203 dias}

A Tabela 76 apresenta os resultados das medidas individuais, as médias, o desvio padrão, os valores máximo e mínimo, as amplitudes e o coeficiente de variação do ensaio de índice de vazios dos concretos com cura acelerada de 24/72 horas seguida de cura imersa em água até 7 dias. Os corpos-de-prova originais foram ainda submetidos a sete ciclos de 24 horas em câmara de carbonatação a $5 \%$ de $\mathrm{CO}_{2}$, e 27 dias de secagem em estufa a $(40 \pm 1)^{\circ} \mathrm{C}$, antes da realização deste ensaio.

Pode-se observar que os concretos dos caminhões $1 \mathrm{~A}, 3 \mathrm{C}$ e $5 \mathrm{E}$ mostraram menores resultados de índice de vazios, em relação aos demais caminhões do lote. Os concretos dos caminhões 2B e 6F apresentaram maiores resultados de índice de vazios. 
TABELA 76 - Resultados do ensaio de índice de vazios a 203 dias (AE1) dos concretos do lote analisado. ABNT NBR 9778 (2005).

\begin{tabular}{|c|c|c|c|c|c|c|c|c|c|c|c|c|}
\hline \multirow[b]{2}{*}{ 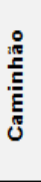 } & \multicolumn{5}{|c|}{ Medidas por amostra } & \multicolumn{7}{|c|}{ Cálculos para o lote } \\
\hline & $\begin{array}{c}\text { Índice de } \\
\text { vazios } \\
(\%)\end{array}$ & $\begin{array}{c}\text { Média } \\
(\%)\end{array}$ & $\begin{array}{c}\text { Valor } \\
\text { Máximo } \\
(\%)\end{array}$ & $\begin{array}{c}\text { Valor } \\
\text { Mínimo } \\
(\%)\end{array}$ & $\begin{array}{c}\text { Amplitude } \\
(\%)\end{array}$ & Média (\%) & $\begin{array}{c}\text { Desvio } \\
\text { padrão } \\
(\%)\end{array}$ & $\begin{array}{c}\text { Coeficiente } \\
\text { de } \\
\text { variação } \\
(\%)\end{array}$ & $\begin{array}{c}\text { Valor } \\
\text { Máximo } \\
(\%)\end{array}$ & $\begin{array}{c}\text { Valor } \\
\text { Mínimo } \\
(\%)\end{array}$ & $\begin{array}{c}\text { Amplitude } \\
(\%)\end{array}$ & $\begin{array}{l}\text { Intervalo de } \\
\text { confiança da } \\
\text { média } 95 \% \\
\text { (\%) }\end{array}$ \\
\hline $1 \mathrm{~A}$ & $\begin{array}{l}11,9 \\
12,0\end{array}$ & 11,9 & 12,0 & 11,9 & 0,1 & \multirow{6}{*}{12,1} & \multirow{6}{*}{0,4} & \multirow{6}{*}{$3 \%$} & \multirow{6}{*}{12,5} & \multirow{6}{*}{11,6} & \multirow{6}{*}{1,0} & \multirow{6}{*}{ $\pm 0,34$} \\
\hline $2 \mathrm{~B}$ & $\begin{array}{l}12,7 \\
12,3\end{array}$ & 12,5 & 12,7 & 12,3 & 0,4 & & & & & & & \\
\hline $3 \mathrm{C}$ & $\begin{array}{l}11,7 \\
11,4\end{array}$ & 11,6 & 11,7 & 11,4 & 0,2 & & & & & & & \\
\hline $4 \mathrm{D}$ & $\begin{array}{l}12,2 \\
12,3\end{array}$ & 12,2 & 12,3 & 12,2 & 0,1 & & & & & & & \\
\hline $5 \mathrm{E}$ & $\begin{array}{l}11,8 \\
11,5\end{array}$ & 11,6 & 11,8 & 11,5 & 0,3 & & & & & & & \\
\hline $6 \mathrm{~F}$ & $\begin{array}{l}12,2 \\
12,8\end{array}$ & 12,5 & 12,8 & 12,2 & 0,6 & & & & & & & \\
\hline
\end{tabular}

A Figura 83 a seguir ilustra a variação dos resultados do ensaio de índice de vazios médio para as idades de ensaio e para as condições de envelhecimento tipo AE1, por exposição de $24 \mathrm{~h}$ em câmara de $\mathrm{CO}_{2}$ e 27 dias de secagem em estufa.

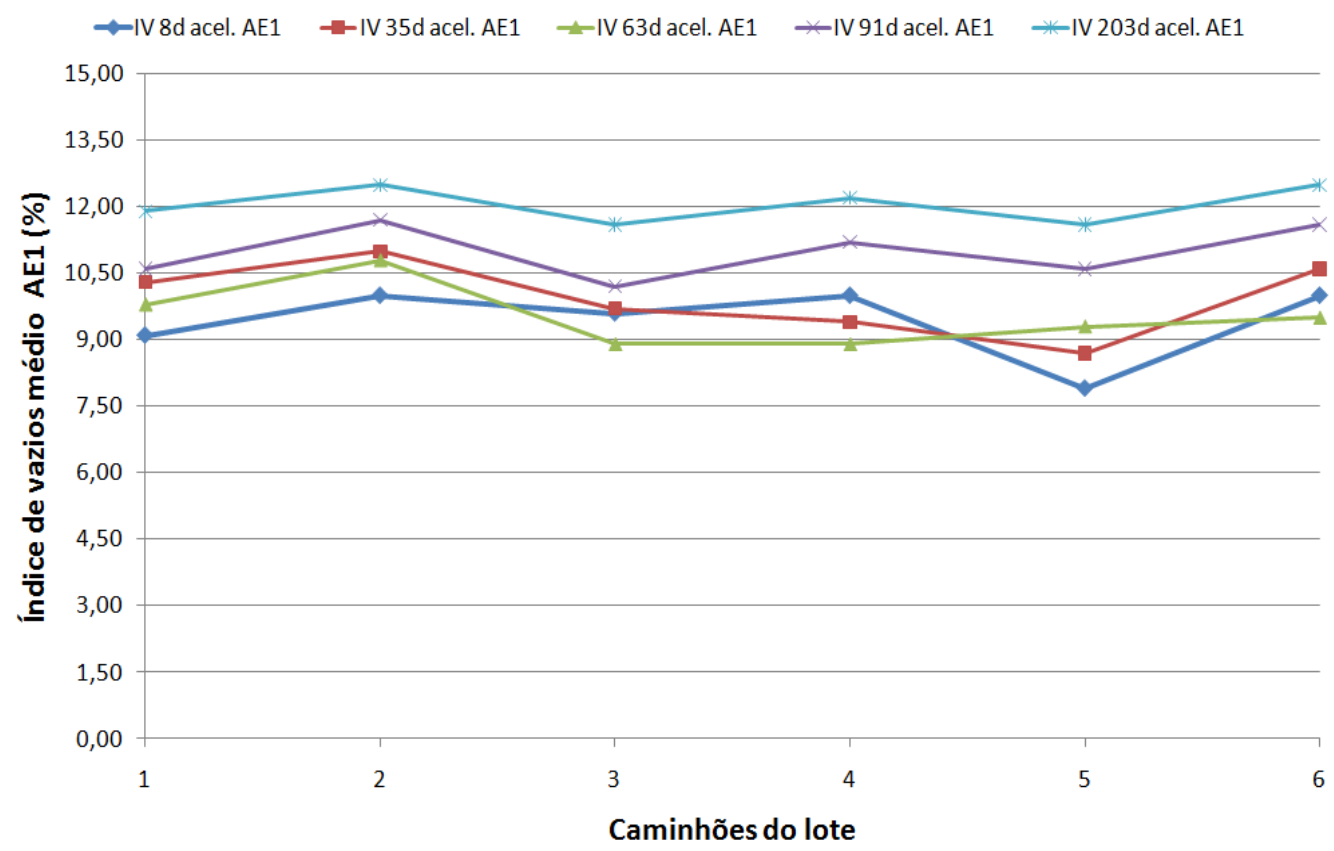

FIGURA 83 - Variação do índice de vazios médio dos corpos-de-prova, submetidos à cura acelerada de $24 / 72 \mathrm{~h}$ e imersão em água até 7 dias e à ciclagem de $24 \mathrm{~h}$ de exposição em câmara de $\mathrm{CO}_{2}$ seguida por 27 dias de secagem em estufa ventilada a 40 ㅇ (AE1). 


\section{G.2) Cura acelerada $24 / 72$ horas seguida por imersão em água até 7 dias e ciclos 24 horas de imersão em tanque com água seguida por 27 dias de secagem em estufa (AE2).}

\section{G.2a) Índice de vazios a 8 dias}

A Tabela 77 apresenta os resultados das medidas individuais, as médias, o desvio padrão, os valores máximo e mínimo, as amplitudes e o coeficiente de variação do ensaio de índice de vazios dos concretos com cura acelerada de 24/72 horas seguida de cura imersa em água até 7 dias. Os corpos-de-prova originais foram ainda submetidos a 24 horas de imersão em tanque de água, antes da realização deste ensaio.

Pode-se observar que não existiram grandes variações entre os resultados. O concreto do caminhão $1 \mathrm{~A}$ mostrou menor resultado de índice de vazios, mas muito próximo dos resultados do concreto do caminhão $5 \mathrm{E}$.

TABELA 77 - Resultados do ensaio de índice de vazios a 8 dias (AE2) dos concretos do lote analisado. ABNT NBR 9778 (2005).

\begin{tabular}{|c|c|c|c|c|c|c|c|c|c|c|c|c|}
\hline \multirow[b]{2}{*}{ Dִ } & \multicolumn{5}{|c|}{ Medidas por amostra } & \multicolumn{7}{|c|}{ Cálculos para o lote } \\
\hline & $\begin{array}{l}\text { İndice de } \\
\text { vazios } \\
(\%)\end{array}$ & $\begin{array}{l}\text { Média } \\
(\%)\end{array}$ & $\begin{array}{l}\text { Valor } \\
\text { Máximo } \\
(\%)\end{array}$ & $\begin{array}{l}\text { Valor } \\
\text { Minimo } \\
(\%)\end{array}$ & $\begin{array}{c}\text { Amplitude } \\
(\%)\end{array}$ & Média (\%) & $\begin{array}{c}\text { Desvio } \\
\text { padrão (\%) }\end{array}$ & $\begin{array}{c}\text { Coeficiente } \\
\text { de } \\
\text { variação } \\
(\%)\end{array}$ & $\begin{array}{l}\text { Valor } \\
\text { Máximo } \\
(\%)\end{array}$ & $\begin{array}{l}\text { Valor } \\
\text { Minimo } \\
(\%)\end{array}$ & $\begin{array}{c}\text { Amplitude } \\
(\%)\end{array}$ & $\begin{array}{l}\text { Intervalo de } \\
\text { confiança da } \\
\text { média } 95 \% \\
\text { (\%) }\end{array}$ \\
\hline $1 \mathrm{~A}$ & $\begin{array}{l}9,0 \\
9,4\end{array}$ & 9,2 & 9,4 & 9,0 & 0,4 & \multirow{6}{*}{9,7} & \multirow{6}{*}{0,4} & \multirow{6}{*}{$4 \%$} & \multirow{6}{*}{10,2} & \multirow{6}{*}{9,2} & \multirow{6}{*}{1,0} & \multirow{6}{*}{ $\pm 0,29$} \\
\hline 2B & $\begin{array}{l}9,8 \\
10,2\end{array}$ & 10,0 & 10,2 & 9,8 & 0,3 & & & & & & & \\
\hline $3 c$ & $\begin{array}{l}9,7 \\
9,8\end{array}$ & 9,8 & 9,8 & 9,7 & 0,1 & & & & & & & \\
\hline $4 \mathrm{D}$ & $\begin{array}{l}10,3 \\
10,1\end{array}$ & 10,2 & 10,3 & 10,1 & 0,2 & & & & & & & \\
\hline $5 \mathrm{E}$ & $\begin{array}{l}9,5 \\
9,3\end{array}$ & 9,4 & 9,5 & 9,3 & 0,2 & & & & & & & \\
\hline $6 \mathrm{~F}$ & $\begin{array}{c}9,4 \\
10,0\end{array}$ & 9,7 & 10,0 & 9,4 & 0,6 & & & & & & & \\
\hline
\end{tabular}

\section{G.2b) Índice de vazios a 35 dias}

A Tabela 78 apresenta os resultados das medidas individuais, as médias, o desvio padrão, os valores máximo e mínimo, as amplitudes e o coeficiente de variação do ensaio de índice de vazios dos concretos com cura acelerada de 24/72 horas seguida de cura imersa em água até 7 dias. Os corpos-de-prova originais foram ainda submetidos a um ciclo de 24 horas de imersão em tanque de água seguida de 27 dias de secagem em estufa a (40 $\pm 1)^{\circ} \mathrm{C}$, antes da realização deste ensaio. 
Observa-se que os concretos dos caminhões 1A, 4D e 6F mostraram valores próximos de índice de vazios médio a 35 dias para este tipo de condicionamento. O concreto do caminhão $3 \mathrm{C}$ mostrou menor valor de índice de vazios.

TABELA 78 - Resultados do ensaio de índice de vazios a 35 dias (AE2) dos concretos do lote analisado. ABNT NBR 9778 (2005).

\begin{tabular}{|c|c|c|c|c|c|c|c|c|c|c|c|c|c|}
\hline \multirow[b]{2}{*}{ 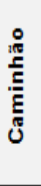 } & \multicolumn{5}{|c|}{ Medidas por amostra } & \multicolumn{8}{|c|}{ Cálculos para o lote } \\
\hline & $\begin{array}{c}\text { Índice de } \\
\text { vazios } \\
(\%)\end{array}$ & $\begin{array}{c}\text { Média } \\
(\%)\end{array}$ & \begin{tabular}{c}
\multicolumn{2}{c}{ Valor } \\
Máximo $(\%)$
\end{tabular} & $\begin{array}{c}\text { Valor } \\
\text { Mínimo } \\
(\%)\end{array}$ & $\begin{array}{c}\text { Amplitude } \\
(\%)\end{array}$ & Média & $(\%)$ & $\begin{array}{c}\text { Desvio } \\
\text { padrão } \\
(\%)\end{array}$ & $\begin{array}{c}\text { Coeficiente } \\
\text { de } \\
\text { variação } \\
(\%)\end{array}$ & $\begin{array}{c}\text { Valor } \\
\text { Máximo } \\
(\%)\end{array}$ & $\begin{array}{c}\text { Valor } \\
\text { Mínimo } \\
(\%)\end{array}$ & $\begin{array}{c}\text { Amplitude } \\
(\%)\end{array}$ & $\begin{array}{c}\text { Intervalo de } \\
\text { confiança da } \\
\text { média 95\% } \\
(\%)\end{array}$ \\
\hline $1 \mathrm{~A}$ & $\begin{array}{c}10,1 \\
9,8\end{array}$ & 10,0 & 10,1 & 9,8 & 0,3 & \multirow{6}{*}{9,9} & & \multirow{6}{*}{0,8} & \multirow{6}{*}{$8 \%$} & \multirow{6}{*}{10,8} & \multirow{6}{*}{8,7} & \multirow{6}{*}{2,1} & \multirow{6}{*}{ $\pm 0,63$} \\
\hline $2 B$ & $\begin{array}{l}10,9 \\
10,7\end{array}$ & 10,8 & 10,9 & 10,7 & 0,2 & & & & & & & & \\
\hline $3 \mathrm{C}$ & $\begin{array}{l}8,4 \\
8,9\end{array}$ & 8,7 & 8,9 & 8,4 & 0,6 & & & & & & & & \\
\hline 4D & $\begin{array}{c}9,6 \\
11,1\end{array}$ & 10,3 & 11,1 & 9,6 & 1,4 & & & & & & & & \\
\hline $5 \mathrm{E}$ & $\begin{array}{l}9,6 \\
8,8\end{array}$ & 9,2 & 9,6 & 8,8 & 0,7 & & & & & & & & \\
\hline $6 \mathrm{~F}$ & $\begin{array}{l}10,4 \\
10,1\end{array}$ & 10,2 & 10,4 & 10,1 & 0,3 & & & & & & & & \\
\hline
\end{tabular}

\section{G.2c) Índice de vazios a 63 dias}

A Tabela 79 apresenta os resultados das medidas individuais, as médias, o desvio padrão, os valores máximo e mínimo, as amplitudes e o coeficiente de variação do ensaio de índice de vazios dos concretos com cura acelerada de 24/72 horas seguida de cura imersa em água até 7 dias. Os corpos-de-prova foram ainda submetidos a dois ciclos de 24 horas de imersão em tanque de água e 27 dias de secagem em estufa a $(40 \pm 1)^{\circ} \mathrm{C}$, antes da realização deste ensaio.

Observa-se que os concretos mostraram valores próximos de índice de vazios médio a 63 dias para este tipo de condicionamento. O concreto do caminhão 5E mostrou menor resultado de índice de vazios. O concreto do caminhão 2B apresentou novamente maior resultado de índice de vazios, como na maioria dos casos dos ensaios de absorção de água. 
TABELA 79 - Resultados do ensaio de índice de vazios a 63 dias (AE2) dos concretos do lote analisado. ABNT NBR 9778 (2005).

\begin{tabular}{|c|c|c|c|c|c|c|c|c|c|c|c|c|c|}
\hline \multirow{2}{*}{ 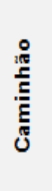 } & \multicolumn{5}{|c|}{ Medidas por amostra } & \multicolumn{8}{|c|}{ Cálculos para o lote } \\
\hline & $\begin{array}{l}\text { İ́ndice de } \\
\text { vazios } \\
(\%)\end{array}$ & $\begin{array}{l}\text { Média } \\
(\%)\end{array}$ & $\begin{array}{l}\text { Valor } \\
\text { Máximo } \\
(\%)\end{array}$ & $\begin{array}{l}\text { Valor } \\
\text { Minimo } \\
\text { (\%) }\end{array}$ & $\begin{array}{c}\text { Amplitude } \\
(\%)\end{array}$ & Média & $(\%)$ & $\begin{array}{c}\text { Desvio } \\
\text { padrão } \\
(\%)\end{array}$ & $\begin{array}{c}\text { Coeficiente } \\
\text { de } \\
\text { variação } \\
(\%)\end{array}$ & $\begin{array}{l}\text { Valor } \\
\text { Máximo } \\
(\%)\end{array}$ & $\begin{array}{l}\text { Valor } \\
\text { Minimo } \\
\text { (\%) }\end{array}$ & $\begin{array}{c}\text { Amplitude } \\
(\%)\end{array}$ & $\begin{array}{l}\text { Intervalo de de } \\
\text { confiança da } \\
\text { média 95\% } \\
\text { (\%) }\end{array}$ \\
\hline $1 \mathrm{~A}$ & $\begin{array}{c}9,5 \\
10,0\end{array}$ & 9,7 & 10,0 & 9,5 & 0,5 & \multirow{6}{*}{\multicolumn{2}{|c|}{9,8}} & \multirow{6}{*}{0,5} & \multirow{6}{*}{$5 \%$} & \multirow{6}{*}{10,8} & \multirow{6}{*}{9,4} & \multirow{6}{*}{1,5} & \multirow{6}{*}{ $\pm 0,42$} \\
\hline $2 B$ & $\begin{array}{l}10,9 \\
10,8\end{array}$ & 10,8 & 10,9 & 10,8 & 0,1 & & & & & & & & \\
\hline $3 C$ & $\begin{array}{c}9,9 \\
10,0\end{array}$ & 9,9 & 10,0 & 9,9 & 0,1 & & & & & & & & \\
\hline 4D & $\begin{array}{l}9,5 \\
9,8\end{array}$ & 9,6 & 9,8 & 9,5 & 0,4 & & & & & & & & \\
\hline $5 E$ & $\begin{array}{l}9,3 \\
9,4\end{array}$ & 9,4 & 9,4 & 9,3 & 0,1 & & & & & & & & \\
\hline $6 \mathrm{~F}$ & $\begin{array}{l}9,6 \\
95\end{array}$ & 9,5 & 9,6 & 9,5 & 0,1 & & & & & & & & \\
\hline
\end{tabular}

\section{G.2d) Índice de vazios a 91 dias}

A Tabela 80 apresenta os resultados das medidas individuais, as médias, o desvio padrão, os valores máximo e mínimo, as amplitudes e o coeficiente de variação do ensaio de índice de vazios dos concretos com cura acelerada de 24/72 horas seguida de cura imersa em água até 7 dias. Os corpos-de-prova originais foram ainda submetidos a três ciclos de 24 horas de imersão em tanque de água e 27 dias de secagem em estufa a (40 \pm 1) ${ }^{\circ} \mathrm{C}$, antes da realização deste ensaio.

Observa-se que os concretos mostraram valores próximos de índice de vazios médio a 91 dias para este tipo de condicionamento, exceto o concreto do caminhão $2 \mathrm{~B}$, que mostrou maior resultado de índice de vazios entre os demais.

TABELA 80 - Resultados do ensaio de índice de vazios a 91 dias (AE2) dos concretos do lote analisado. ABNT NBR 9778 (2005).

\begin{tabular}{|c|c|c|c|c|c|c|c|c|c|c|c|c|}
\hline \multirow[b]{2}{*}{ 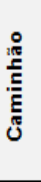 } & \multicolumn{5}{|c|}{ Medidas por amostra } & \multicolumn{7}{|c|}{ Cálculos para o lote } \\
\hline & $\begin{array}{c}\text { Índice de } \\
\text { vazios } \\
(\%)\end{array}$ & $\begin{array}{l}\text { Média } \\
(\%)\end{array}$ & $\begin{array}{c}\text { Valor } \\
\text { Máximo }(\%)\end{array}$ & $\begin{array}{c}\text { Valor } \\
\text { Mínimo } \\
(\%)\end{array}$ & $\begin{array}{c}\text { Amplitude } \\
(\%)\end{array}$ & Média (\%) & $\begin{array}{c}\text { Desvio } \\
\text { padrão } \\
(\%)\end{array}$ & $\begin{array}{c}\text { Coeficiente } \\
\text { de } \\
\text { variação } \\
(\%)\end{array}$ & $\begin{array}{c}\text { Valor } \\
\text { Máximo } \\
(\%)\end{array}$ & $\begin{array}{c}\text { Valor } \\
\text { Mínimo } \\
(\%)\end{array}$ & $\begin{array}{c}\text { Amplitude } \\
(\%)\end{array}$ & $\begin{array}{c}\text { Intervalo de } \\
\text { confiança da } \\
\text { média } 95 \% \\
(\%)\end{array}$ \\
\hline $1 \mathrm{~A}$ & $\begin{array}{l}10,0 \\
11,1\end{array}$ & 10,6 & 11,1 & 10,0 & 1,1 & \multirow{6}{*}{10,7} & \multirow{6}{*}{0,5} & \multirow{6}{*}{$5 \%$} & \multirow{6}{*}{11,7} & \multirow{6}{*}{10,4} & \multirow{6}{*}{1,3} & \multirow{6}{*}{ $\pm 0,39$} \\
\hline $2 B$ & $\begin{array}{l}12,2 \\
11,3\end{array}$ & 11,7 & 12,2 & 11,3 & 0,9 & & & & & & & \\
\hline $3 \mathrm{C}$ & $\begin{array}{l}10,6 \\
10,4\end{array}$ & 10,5 & 10,6 & 10,4 & 0,2 & & & & & & & \\
\hline $4 D$ & $\begin{array}{l}10,0 \\
11,1\end{array}$ & 10,5 & 11,1 & 10,0 & 1,1 & & & & & & & \\
\hline $5 \mathrm{E}$ & $\begin{array}{l}10,7 \\
10,8\end{array}$ & 10,7 & 10,8 & 10,7 & 0,0 & & & & & & & \\
\hline $6 \mathrm{~F}$ & $\begin{array}{l}10,1 \\
10,7 \\
\end{array}$ & 10,4 & 10,7 & 10,1 & 0,6 & & & & & & & \\
\hline
\end{tabular}


A Tabela 81 apresenta os resultados das medidas individuais, as médias, o desvio padrão, os valores máximo e mínimo, as amplitudes e o coeficiente de variação do ensaio de índice de vazios dos concretos com cura acelerada de 24/72 horas seguida de cura imersa em água até 7 dias. Os corpos-de-prova originais foram ainda submetidos a sete ciclos de 24 horas de imersão em tanque de água e 27 dias de secagem em estufa a (40 \pm 1) ${ }^{\circ} \mathrm{C}$, antes da realização deste ensaio.

Observa-se que os concretos dos caminhões $2 \mathrm{~B}$ e $6 \mathrm{~F}$ apresentaram maiores valores de índice de vazios. O resultado do concreto do caminhão $2 \mathrm{~B}$ voltou a ter destaque em relação aos demais, porém muito próximos ao resultado médio do concreto do caminhão $6 \mathrm{~F}$.

TABELA 81 - Resultados do ensaio de índice de vazios a 203 dias (AE2) dos concretos do lote analisado. ABNT NBR 9778 (2005).

\begin{tabular}{|c|c|c|c|c|c|c|c|c|c|c|c|c|}
\hline \multirow[b]{2}{*}{ 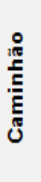 } & \multicolumn{5}{|c|}{ Medidas por amostra } & \multicolumn{7}{|c|}{ Cálculos para o lote } \\
\hline & $\begin{array}{c}\text { Índice de } \\
\text { vazios } \\
(\%)\end{array}$ & $\begin{array}{c}\text { Média } \\
(\%)\end{array}$ & \begin{tabular}{c}
\multicolumn{2}{c}{ Valor } \\
Máximo $(\%)$
\end{tabular} & $\begin{array}{c}\text { Valor } \\
\text { Mínimo } \\
(\%)\end{array}$ & $\begin{array}{c}\text { Amplitude } \\
(\%)\end{array}$ & Média (\%) & $\begin{array}{c}\text { Desvio } \\
\text { padrão } \\
(\%)\end{array}$ & $\begin{array}{c}\text { Coeficiente } \\
\text { de } \\
\text { variação } \\
(\%)\end{array}$ & $\begin{array}{c}\text { Valor } \\
\text { Máximo } \\
(\%)\end{array}$ & $\begin{array}{c}\text { Valor } \\
\text { Mínimo } \\
(\%)\end{array}$ & $\begin{array}{c}\text { Amplitude } \\
(\%)\end{array}$ & $\begin{array}{l}\text { Intervalo de } \\
\text { confiança da } \\
\text { média } 95 \% \\
(\%)\end{array}$ \\
\hline $1 \mathrm{~A}$ & $\begin{array}{l}12,1 \\
11,8\end{array}$ & 12,0 & 12,1 & 11,8 & 0,3 & \multirow{6}{*}{12,3} & \multirow{6}{*}{0,7} & \multirow{6}{*}{$6 \%$} & \multirow{6}{*}{13,2} & \multirow{6}{*}{11,4} & \multirow{6}{*}{1,8} & \multirow{6}{*}{ $\pm 0,58$} \\
\hline $2 \mathrm{~B}$ & $\begin{array}{l}13,2 \\
13,1\end{array}$ & 13,2 & 13,2 & 13,1 & 0,2 & & & & & & & \\
\hline $3 \mathrm{C}$ & $\begin{array}{l}11,7 \\
11,8\end{array}$ & 11,8 & 11,8 & 11,7 & 0,2 & & & & & & & \\
\hline $4 \mathrm{D}$ & $\begin{array}{l}12,1 \\
12,7\end{array}$ & 12,4 & 12,7 & 12,1 & 0,6 & & & & & & & \\
\hline $5 \mathrm{E}$ & $\begin{array}{l}11,2 \\
11,5\end{array}$ & 11,4 & 11,5 & 11,2 & 0,4 & & & & & & & \\
\hline $6 \mathrm{~F}$ & $\begin{array}{l}13,4 \\
12,8\end{array}$ & 13,1 & 13,4 & 12,8 & 0,7 & & & & & & & \\
\hline
\end{tabular}

A Figura 84 a seguir ilustra a variação dos resultados do ensaio de índice de vazios médio para as idades de ensaio e para as condições de envelhecimento por imersão de 24h em tanque de água seguida de 27 dias de secagem em estufa. As variações observadas na Figura 84 para 91 e 203 dias são menos evidentes do que as da Figura 83, relativa à condição AE1. 


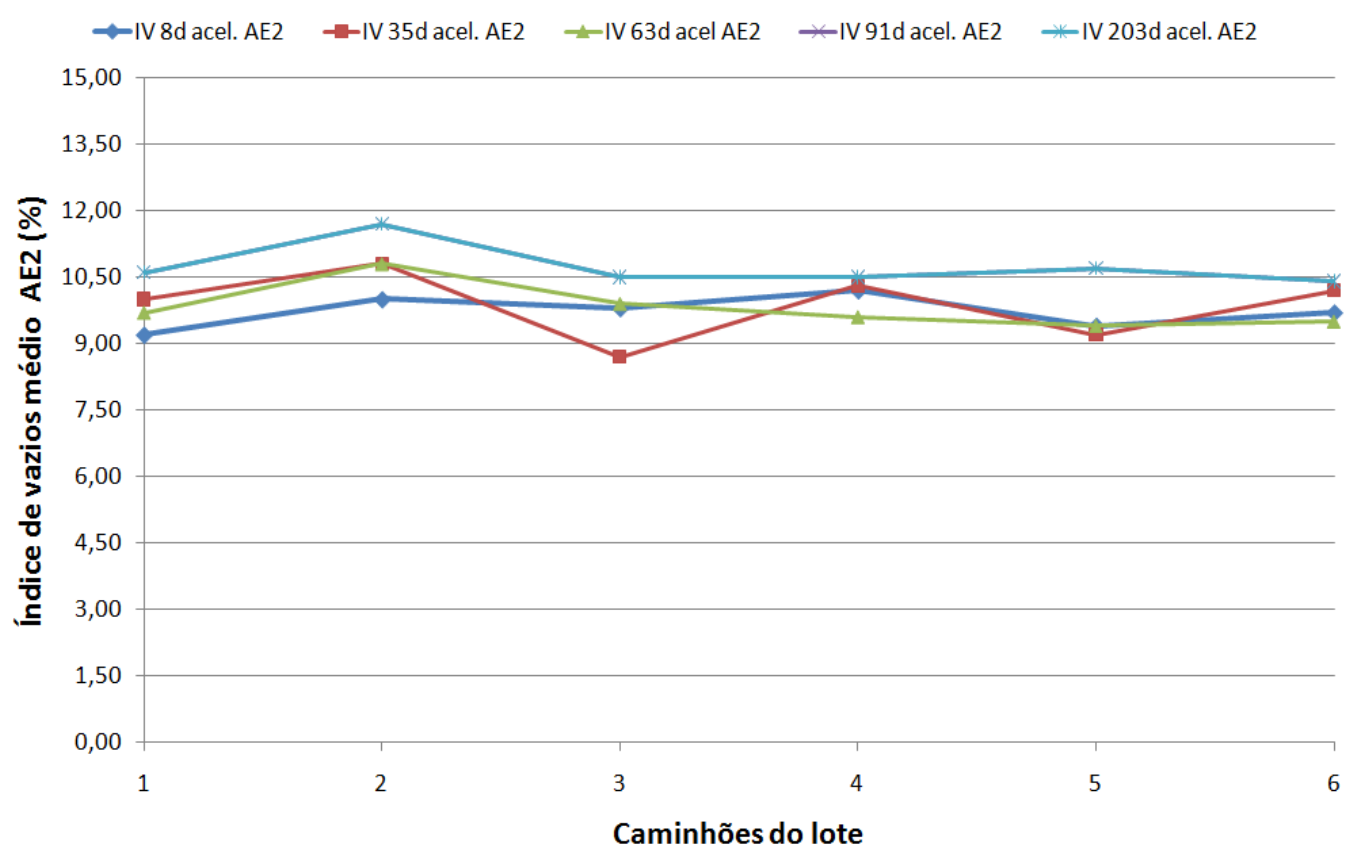

FIGURA 84 - Variação do índice de vazios médio dos corpos-de-prova, submetidos à cura acelerada de $24 / 72 \mathrm{~h}$ e imersão em água até 7 dias e ciclagem de $24 \mathrm{~h}$ de imersão em tanque de água seguida por 27 dias de secagem em estufa ventilada a 40ㄷ (AE2).

\section{G.3) Cura acelerada 24/72 horas seguida por imersão em água até 7 dias e ciclos de 28 dias de secagem contínua (AE3).}

\section{G.3a) Índice de vazios a 91 dias}

A Tabela 82 apresenta os resultados das medidas individuais, as médias, o desvio padrão, os valores máximo e mínimo, as amplitudes e o coeficiente de variação do ensaio de índice de vazios dos concretos com cura acelerada de 24/72 horas seguida de cura imersa em água até 7 dias. Os corpos-de-prova íntegros e originais foram ainda submetidos a três ciclos de 28 dias de secagem contínua em estufa a $(40 \pm 1)^{\circ} \mathrm{C}$ antes da realização deste ensaio.

Observa-se que os concretos mostraram valores próximos de índice de vazios médio a 91 dias para este tipo de condicionamento, exceto o concreto do caminhão 2B, que mostrou maior resultado de índice de vazios entre os demais. 
TABELA 82 - Resultados do ensaio de índice de vazios a 91 dias (AE3) dos concretos do lote analisado. ABNT NBR 9778 (2005).

\begin{tabular}{|c|c|c|c|c|c|c|c|c|c|c|c|c|}
\hline \multirow[b]{2}{*}{ סُ } & \multicolumn{5}{|c|}{ Medidas por amostra } & \multicolumn{7}{|c|}{ Cálculos para o lote } \\
\hline & $\begin{array}{l}\text { İndice de } \\
\text { vazios } \\
(\%)\end{array}$ & $\begin{array}{l}\text { Média } \\
(\%)\end{array}$ & $\begin{array}{l}\text { Valor } \\
\text { Máximo } \\
(\%)\end{array}$ & $\begin{array}{l}\text { Valor } \\
\text { Minimo } \\
(\%)\end{array}$ & $\begin{array}{c}\text { Amplitude } \\
(\%)\end{array}$ & Média (\%) & $\begin{array}{c}\text { Desvio } \\
\text { padrão } \\
(\%)\end{array}$ & $\begin{array}{c}\text { Coeficiente } \\
\text { de } \\
\text { variação } \\
(\%) \\
\end{array}$ & $\begin{array}{c}\text { Valor } \\
\text { Máximo } \\
(\%) \\
\end{array}$ & $\begin{array}{l}\text { Valor } \\
\text { Minimo } \\
(\%)\end{array}$ & $\begin{array}{c}\text { Amplitude } \\
(\%)\end{array}$ & $\begin{array}{l}\text { Intervalo de } \\
\text { confiança da } \\
\text { média } 95 \% \\
(\%)\end{array}$ \\
\hline $1 \mathrm{~A}$ & $\begin{array}{l}10,7 \\
10,9\end{array}$ & 10,8 & 10,9 & 10,7 & 0,2 & \multirow{6}{*}{11,2} & \multirow{6}{*}{0,4} & \multirow{6}{*}{$4 \%$} & \multirow{6}{*}{12,0} & \multirow{6}{*}{10,8} & \multirow{6}{*}{1,2} & \multirow{6}{*}{ $\pm 0,35$} \\
\hline $2 B$ & $\begin{array}{l}11,8 \\
12,2\end{array}$ & 12,0 & 12,2 & 11,8 & 0,4 & & & & & & & \\
\hline $3 \mathrm{C}$ & $\begin{array}{l}10,9 \\
11,3\end{array}$ & 11,1 & 11,3 & 10,9 & 0,4 & & & & & & & \\
\hline 4D & $\begin{array}{l}10,9 \\
11,0\end{array}$ & 11,0 & 11,0 & 10,9 & 0,1 & & & & & & & \\
\hline $5 \mathrm{E}$ & $\begin{array}{l}10,9 \\
11,2\end{array}$ & 11,1 & 11,2 & 10,9 & 0,3 & & & & & & & \\
\hline $6 \mathrm{~F}$ & $\begin{array}{l}11,2 \\
11,8\end{array}$ & 11,5 & 11,8 & 11,2 & 0,6 & & & & & & & \\
\hline
\end{tabular}

\section{G.3b) Índice de vazios a 203 dias}

A Tabela 83 apresenta os resultados das medidas individuais, as médias, o desvio padrão, os valores máximo e mínimo, as amplitudes e o coeficiente de variação do ensaio de índice de vazios dos concretos com cura acelerada de 24/72 horas seguida de cura imersa em água até 7 dias. Os corpos-de-prova íntegros e originais foram ainda submetidos a sete ciclos de 28 dias de secagem contínua em estufa a $(40 \pm 1)^{\circ} \mathrm{C}$, antes da realização deste ensaio. Observa-se que os concretos apresentaram resultados médios muito próximos e com pouca variação de índice de vazios, exceto para o concreto do caminhão $6 \mathrm{~F}$ que mostrou maior resultado entre os demais.

TABELA 83 - Resultados do ensaio de índice de vazios a 203 dias (AE3) dos concretos do lote analisado. ABNT NBR 9778 (2005).

\begin{tabular}{|c|c|c|c|c|c|c|c|c|c|c|c|c|}
\hline \multirow[b]{2}{*}{ 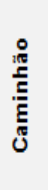 } & \multicolumn{5}{|c|}{ Medidas por amostra } & \multicolumn{7}{|c|}{ Cálculos para o lote } \\
\hline & $\begin{array}{l}\text { Índice de } \\
\text { vazios } \\
(\%)\end{array}$ & $\begin{array}{l}\text { Média } \\
(\%)\end{array}$ & $\begin{array}{l}\text { Valor } \\
\text { Máximo } \\
(\%)\end{array}$ & $\begin{array}{c}\text { Valor } \\
\text { Mínimo } \\
(\%)\end{array}$ & $\begin{array}{l}\text { Amplitude } \\
(\%)\end{array}$ & Média (\%) & $\begin{array}{c}\text { Desvio } \\
\text { padrão } \\
\text { (\%) }\end{array}$ & $\begin{array}{c}\text { Coeficiente } \\
\text { de } \\
\text { variação } \\
(\%)\end{array}$ & $\begin{array}{l}\text { Valor } \\
\text { Máximo } \\
(\%)\end{array}$ & $\begin{array}{c}\text { Valor } \\
\text { Mínimo } \\
(\%)\end{array}$ & $\begin{array}{l}\text { Amplitude } \\
(\%)\end{array}$ & $\begin{array}{c}\text { Intervalo de } \\
\text { confiança da } \\
\text { média } 95 \% \\
(\%)\end{array}$ \\
\hline $1 \mathrm{~A}$ & $\begin{array}{l}12,6 \\
12,8\end{array}$ & 12,7 & 12,8 & 12,6 & 0,1 & \multirow{6}{*}{12,6} & \multirow{6}{*}{0,4} & \multirow{6}{*}{$3 \%$} & \multirow{6}{*}{13,2} & \multirow{6}{*}{12,0} & \multirow{6}{*}{1,2} & \multirow{6}{*}{ $\pm 0,34$} \\
\hline $2 B$ & $\begin{array}{l}12,7 \\
13,1\end{array}$ & 12,9 & 13,1 & 12,7 & 0,4 & & & & & & & \\
\hline $3 \mathrm{C}$ & $\begin{array}{l}11,9 \\
12,2\end{array}$ & 12,0 & 12,2 & 11,9 & 0,3 & & & & & & & \\
\hline $4 \mathrm{D}$ & $\begin{array}{l}12,9 \\
12,3\end{array}$ & 12,6 & 12,9 & 12,3 & 0,6 & & & & & & & \\
\hline $5 \mathrm{E}$ & $\begin{array}{l}12,0 \\
12,5\end{array}$ & 12,2 & 12,5 & 12,0 & 0,5 & & & & & & & \\
\hline $6 \mathrm{~F}$ & $\begin{array}{l}13,5 \\
13,0\end{array}$ & 13,2 & 13,5 & 13,0 & 0,5 & & & & & & & \\
\hline
\end{tabular}

A Figura 85 ilustra a variação dos resultados do ensaio de índice de vazios médio para as idades de ensaio e para as condições de envelhecimento por ciclos de 28 dias de secagem contínua em estufa ventilada a $(40 \pm 1)^{\circ} \mathrm{C}$. 


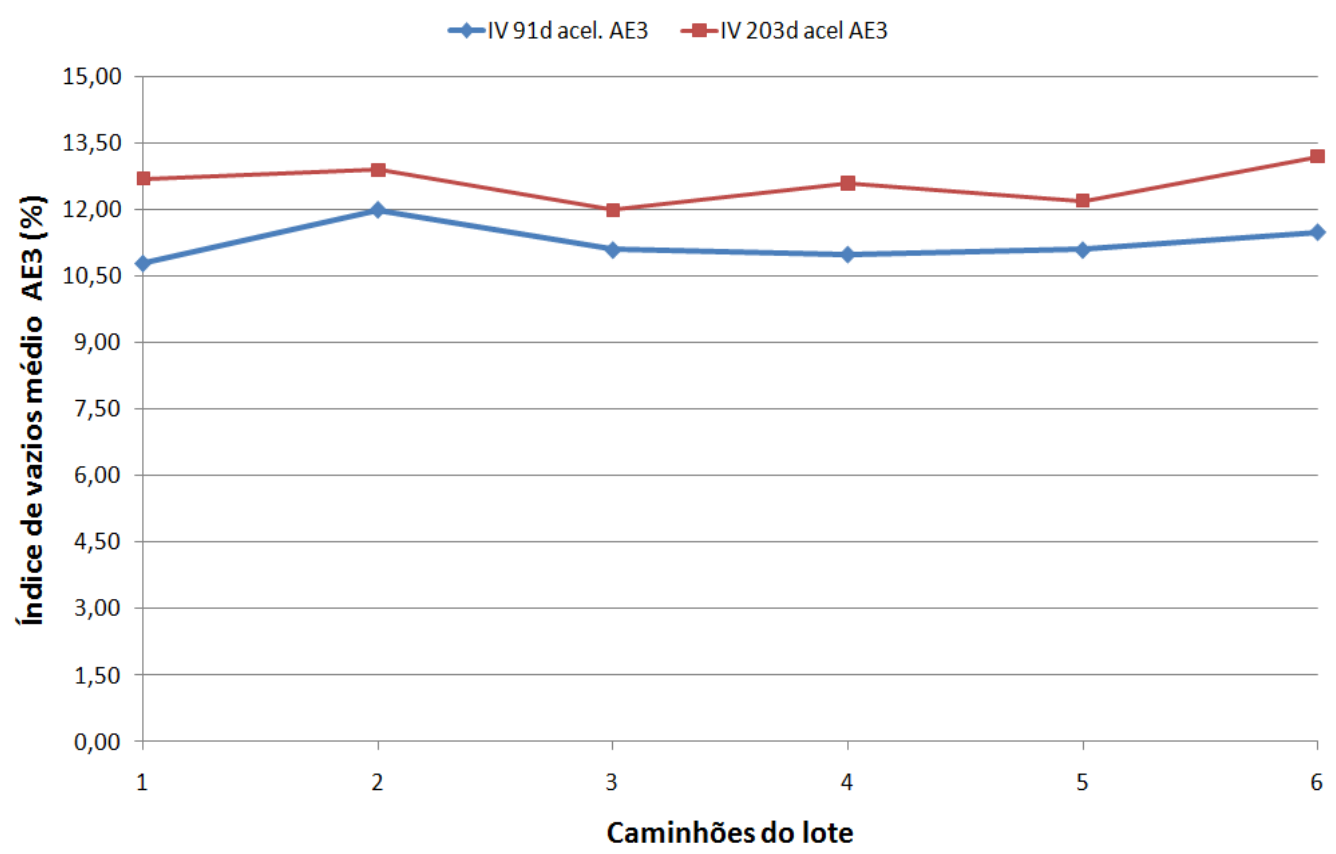

FIGURA 85 - Variação do índice de vazios médio dos corpos-de-prova, submetidos à cura acelerada de $24 / 72 \mathrm{~h}$ e imersão em água até 7 dias e depois a ciclos de 28 dias de secagem contínua em estufa a $(40 \pm 1)^{\circ} \mathrm{C}(\mathrm{AE} 3)$.

G.4) Análise conjunta do índice de vazios em todas as idades e condições de envelhecimento acelerado

A Tabela 84 apresenta as medidas individuais, as médias, os desvios padrão, os valores máximos e mínimos e os coeficientes de variação dos resultados do ensaio de índice de vazios, por cura acelerada 24/72 horas seguida de cura imersa em água até 7 dias, sendo os corpos-de-prova originais depois mantidos respectivamente nas três seguintes condições de envelhecimento acelerado:

$\checkmark$ AE1 (ciclos de $24 \mathrm{~h}$ de exposição em câmara de $\mathrm{CO}_{2}$ seguida por 27 dias de secagem em estufa);

$\checkmark$ AE2 (ciclos de $24 \mathrm{~h}$ de imersão em tanque de água seguida por 27 dias de secagem em estufa) $e$;

$\checkmark$ AE3 (ciclos de 28 dias de secagem contínua em estufa a $40 \pm 1^{\circ} \mathrm{C}$ ).

Pela Tabela 84 observa-se que os resultados de índice de vazios foram próximos e constantes nas idades de 8, 35 e 63 dias, com um ligeiro aumento de valores aos 91 dias, para os três tipos de condicionamento, o mesmo comportamento dos ensaios de absorção de água. Aos 203 dias mostrou-se ainda um aumento ligeiramente maior em relação aos resultados de 91 dias e significativamente maiores que os resultados das demais idades. Os 
resultados de índice de vazios aos 203 dias foram ainda um pouco maiores para o condicionamento de secagem contínua, sendo que a mesma observação foi feita para os resultados de absorção de água, neste tipo de condicionamento e idade.

Para os concretos de todos os caminhões, para todas as idades e tipo de condição de envelhecimento acelerado, os coeficientes de variação entre os resultados foram baixos e menores que $10 \%$, ligeiramente menores do que os coeficientes de variação da absorção de água. 
TABELA 84 - Resultados do ensaio de índice de vazios nos concretos do lote amostrado, considerando média de 12 resultados. ABNT NBR 9778 (2005).

\begin{tabular}{|c|c|c|c|c|c|c|c|c|c|c|c|c|}
\hline \multirow[b]{2}{*}{ 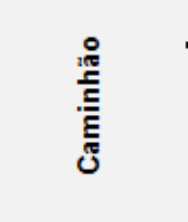 } & \multicolumn{2}{|c|}{8 dias } & \multicolumn{2}{|c|}{35 dias } & \multicolumn{2}{|c|}{63 dias } & \multicolumn{3}{|c|}{91 dias } & \multicolumn{3}{|c|}{203 dias } \\
\hline & $\begin{array}{c}\text { Índ. Vazios } \\
8 \text { dias - AE1 } \\
\text { (\%) }\end{array}$ & $\begin{array}{c}\text { Índ. Vazios } \\
8 \text { dias - AE2 } \\
(\%)\end{array}$ & $\begin{array}{l}\text { Índ. Vazios } \\
35 \text { dias - } \\
\text { AE1 (\%) }\end{array}$ & $\begin{array}{c}\text { Índ. Vazios } \\
35 \text { dias - } \\
\text { AE2 (\%) }\end{array}$ & $\begin{array}{c}\text { Índ. Vazios } \\
63 \text { dias - } \\
\text { AE1 (\%) }\end{array}$ & $\begin{array}{c}\text { Índ. Vazios } \\
63 \text { dias - } \\
\text { AE2 (\%) }\end{array}$ & $\begin{array}{c}\text { Índ. Vazios } \\
91 \text { dias - } \\
\text { AE1 (\%) }\end{array}$ & $\begin{array}{c}\text { Índ. } \\
\text { Vazios } 91 \\
\text { dias - AE2 } \\
(\%)\end{array}$ & $\begin{array}{l}\text { Índ. Vazios } \\
91 \text { dias - } \\
\text { AE3 (\%) }\end{array}$ & $\begin{array}{c}\text { Índ. Vazios } \\
203 \text { dias - } \\
\text { AE1 (\%) }\end{array}$ & $\begin{array}{c}\text { Índ. Vazios } \\
203 \text { dias - } \\
\text { AE2 (\%) }\end{array}$ & $\begin{array}{c}\text { Índ. Vazios } \\
203 \text { dias - } \\
\text { AE3 (\%) }\end{array}$ \\
\hline \multirow{2}{*}{$1 A$} & 9,6 & 9,0 & 10,6 & 10,1 & 9,9 & 9,5 & 10,4 & 10,0 & 10,7 & 11,9 & 12,1 & 12,6 \\
\hline & 8,6 & 9,4 & 10,0 & 9,8 & 9,8 & 10,0 & 10,7 & 11,1 & 10,9 & 12,0 & 11,8 & 12,8 \\
\hline \multirow{2}{*}{$2 B$} & 10,0 & 9,8 & 10,7 & 10,9 & 11,3 & 10,9 & 11,4 & 12,2 & 11,8 & 12,7 & 13,2 & 12,7 \\
\hline & 9,9 & 10,2 & 11,2 & 10,7 & 10,4 & 10,8 & 12,1 & 11,3 & 12,2 & 12,3 & 13,1 & 13,1 \\
\hline \multirow{2}{*}{$3 C$} & 10,1 & 9,7 & 10,1 & 8,4 & 8,3 & 9,9 & 10,2 & 10,6 & 10,9 & 11,7 & 11,7 & 11,9 \\
\hline & 9,0 & 9,8 & 9,2 & 8,9 & 9,4 & 10,0 & 10,1 & 10,4 & 11,3 & 11,4 & 11,8 & 12,2 \\
\hline \multirow{2}{*}{$4 \mathrm{D}$} & 10,1 & 10,3 & 10,4 & 9,6 & 9,6 & 9,5 & 11,3 & 10,0 & 10,9 & 12,2 & 12,1 & 12,9 \\
\hline & 9,9 & 10,1 & 8,4 & 11,1 & 8,3 & 9,8 & 11,1 & 11,1 & 11,0 & 12,3 & 12,7 & 12,3 \\
\hline \multirow{2}{*}{$5 \mathrm{E}$} & 8,0 & 9,5 & 8,7 & 9,6 & 9,4 & 9,3 & 10,9 & 10,7 & 10,9 & 11,8 & 11,2 & 12,0 \\
\hline & 7,7 & 9,3 & 8,6 & 8,8 & 9,2 & 9,4 & 10,3 & 10,8 & 11,2 & 11,5 & 11,5 & 12,5 \\
\hline \multirow{2}{*}{$6 \mathrm{~F}$} & 9,9 & 9,4 & 10,9 & 10,4 & 9,5 & 9,6 & 11,4 & 10,1 & 11,2 & 12,2 & 13,4 & 13,5 \\
\hline & 10,2 & 10,0 & 10,3 & 10,1 & 9,6 & 9,5 & 11,8 & 10,7 & 11,8 & 12,8 & 12,8 & 13,0 \\
\hline $\begin{array}{c}\text { Média do } \\
\text { lote (\%) }\end{array}$ & 9,4 & 9,7 & 9,9 & 9,9 & 9,5 & 9,8 & 11,0 & 10,7 & 11,2 & 12,1 & 12,3 & 12,6 \\
\hline $\begin{array}{c}\text { Valor } \\
\text { máximo (\%) }\end{array}$ & 10,2 & 10,3 & 11,2 & 11,1 & 11,3 & 10,9 & 12,1 & 12,2 & 12,2 & 12,8 & 13,4 & 13,5 \\
\hline $\begin{array}{c}\text { Valor } \\
\text { mínimo (\%) }\end{array}$ & 7,7 & 9,0 & 8,4 & 8,4 & 8,3 & 9,3 & 10,1 & 10,0 & 10,7 & 11,4 & 11,2 & 11,9 \\
\hline $\begin{array}{c}\text { Desvio } \\
\text { padrão (\%) }\end{array}$ & 0,9 & 0,4 & 0,9 & 0,8 & 0,8 & 0,5 & 0,6 & 0,6 & 0,5 & 0,4 & 0,7 & 0,5 \\
\hline $\begin{array}{c}\text { Coeficientes } \\
\text { de variação } \\
(\%)\end{array}$ & 9,2 & 4,0 & 9,5 & 8,5 & 8,5 & 5,3 & 5,8 & 5,7 & 4,1 & 3,7 & 5,9 & 3,7 \\
\hline
\end{tabular}


A Tabela 85 apresenta os resultados das medidas individuais em corpos-de-prova inteiros, as médias, o desvio padrão, os valores máximo e mínimo, as amplitudes e o coeficiente de variação do ensaio de absorção de água por capilaridade por cura normal, de $24 \mathrm{~h}$ até 91 dias nos concretos do lote analisado.

Pela Tabela 85 pode-se perceber que os resultados apresentados obtiveram pequenas variações e baixos desvios padrão e coeficientes de variação.

TABELA 85 - Resultados dos ensaios de absorção de água por capilaridade, ao final de 72 horas, nos concretos com cura normal de 1 até 91 dias. ABNT NBR 9779 (1995).

\begin{tabular}{|c|c|c|c|c|c|c|c|c|c|c|c|c|}
\hline \multirow[b]{2}{*}{ 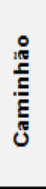 } & \multicolumn{5}{|c|}{ Medidas por amostra } & \multicolumn{7}{|c|}{ Cálculos para o lote } \\
\hline & $\begin{array}{c}\text { Absorção } \\
\left(\mathrm{g} / \mathrm{cm}^{2}\right)\end{array}$ & $\begin{array}{l}\text { Média } \\
\left(\mathrm{g} / \mathrm{cm}^{2}\right)\end{array}$ & $\begin{array}{c}\text { Valor } \\
\text { Máximo } \\
\left(\mathrm{g} / \mathrm{cm}^{2}\right)\end{array}$ & $\begin{array}{l}\text { Valor } \\
\text { Mínimo } \\
\left(\mathrm{g} / \mathrm{cm}^{2}\right)\end{array}$ & $\begin{array}{c}\text { Amplitude } \\
\left(\mathrm{g} / \mathrm{cm}^{2}\right)\end{array}$ & $\begin{array}{l}\text { Média } \\
\left(\mathrm{g} / \mathrm{cm}^{2}\right)\end{array}$ & $\begin{array}{l}\text { Desvio } \\
\text { padrão } \\
\left(\mathrm{g} / \mathrm{cm}^{2}\right)\end{array}$ & $\begin{array}{c}\text { Coeficiente } \\
\text { de } \\
\text { variação } \\
(\%)\end{array}$ & $\begin{array}{c}\text { Valor } \\
\text { Máximo } \\
\left(\mathrm{g} / \mathrm{cm}^{2}\right)\end{array}$ & $\begin{array}{c}\text { Valor } \\
\text { Mínimo } \\
\left(\mathrm{g} / \mathrm{cm}^{2}\right)\end{array}$ & $\begin{array}{l}\text { Amplitude } \\
\left(\mathrm{g} / \mathrm{cm}^{2}\right)\end{array}$ & $\begin{array}{c}\text { Intervalo de } \\
\text { confiança } \\
\text { da média } \\
95 \%\left(\mathrm{~g} / \mathrm{cm}^{2}\right)\end{array}$ \\
\hline $1 \mathrm{~A}$ & $\begin{array}{l}0,47 \\
0,47\end{array}$ & 0,47 & 0,47 & 0,47 & 0,00 & \multirow{6}{*}{0,47} & \multirow{6}{*}{0,01} & \multirow{6}{*}{$2 \%$} & \multirow{6}{*}{0,5} & \multirow{6}{*}{0,46} & \multirow{6}{*}{0,02} & \multirow{6}{*}{ $\pm 0,01$} \\
\hline $2 \mathrm{~B}$ & $\begin{array}{l}0,47 \\
0,46\end{array}$ & 0,47 & 0,47 & 0,46 & 0,01 & & & & & & & \\
\hline $3 \mathrm{C}$ & $\begin{array}{l}0,46 \\
0,46\end{array}$ & 0,46 & 0,46 & 0,46 & 0,00 & & & & & & & \\
\hline $4 \mathrm{D}$ & $\begin{array}{l}0,48 \\
0,48\end{array}$ & 0,48 & 0,48 & 0,48 & 0,00 & & & & & & & \\
\hline $5 \mathrm{E}$ & $\begin{array}{l}0,48 \\
0,47\end{array}$ & 0,48 & 0,48 & 0,47 & 0,01 & & & & & & & \\
\hline $6 \mathrm{~F}$ & $\begin{array}{l}0,48 \\
0,46 \\
\end{array}$ & 0,47 & 0,48 & 0,46 & 0,02 & & & & & & & \\
\hline
\end{tabular}

A Figura 86 ilustra a variação dos resultados de absorção de água por capilaridade para corpos-de-prova com 91 dias de cura normal. Observa-se que resultados de absorção resultaram praticamente iguais para todos os caminhões que representam o lote em análise. 


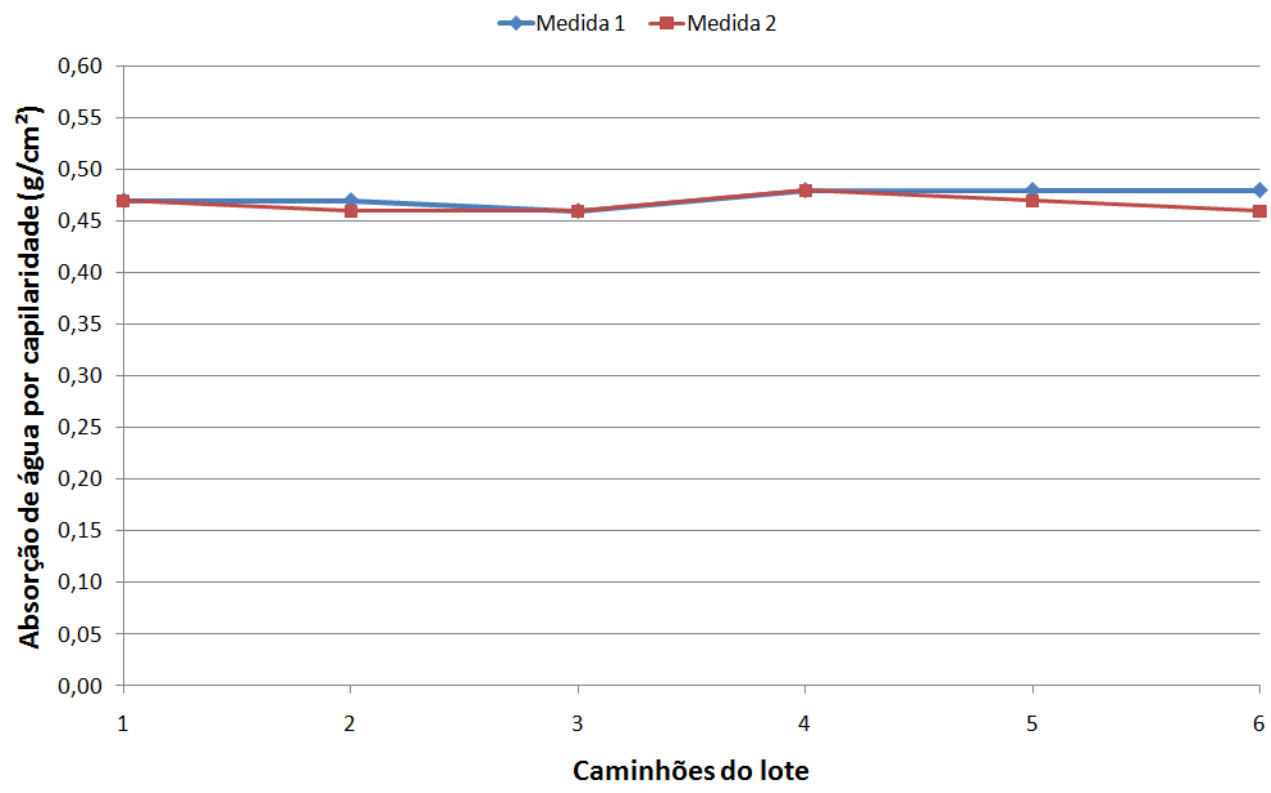

FIGURA 86 - Variação da absorção de água por capilaridade média nos concretos amostrados, submetidos à cura normal, do lote analisado. ABNT NBR 9779 (1995).

\section{I) Profundidade de carbonatação}

As medidas de profundidade de carbonatação foram feitas por três métodos de medição:

$\checkmark$ Medida linear42 - método tradicional utilizando paquímetro digital com resolução de $0,01 \mathrm{~mm}\left(^{*}\right)$;

$\checkmark$ Medida relativa da área carbonatada pelo programa de processamento de análises de imagens de domínio público - "Image $\int$ "43;

$\checkmark$ Medida relativa de área carbonatada pelo programa de processamento de análises de imagens "Leica Qwin".

\footnotetext{
42 Foi considerado neste estudo como medida linear as medidas realizadas com paquímetro nas faces partidas dos corpos-de-prova, através da observação visual e escolha aleatória de pontos em que a fenolftaleína detectou franja de carbonatação.

${ }^{*}$ ) Os cálculos / resultados de profundidade de carbonatação foram mantidos com o mesmo número de algarismos de leitura do paquímetro digital utilizado, mas devem ser arredondados para a precisão de $1 \mathrm{~mm}$, face às incertezas da medida linear.
}

43 As medidas realizadas com o Imaje J, foram feitas somente para os corpos-de-prova com fenolftaleína. 
Os itens a seguir mostram os resultados para cada idade de ensaio e por tipo de envelhecimento acelerado.

\section{I.1) Cura acelerada de 24/72 horas seguida por imersão em água até 7 dias e ciclos de 24 horas em câmara de carbonatação e 27 dias de secagem em estufa (AE1).}

Os itens a seguir apresentam os resultados dos ensaios de profundidade de carbonatação a 8, 35, 63, 91 e 203 dias dos concretos do lote analisado, para este tipo de condicionamento.

\section{I.1A) Profundidade de carbonatação a 8 e 35 dias}

Para melhor fazer a predição do comportamento do concreto quanto à sua resistência à carbonatação é que este trabalho propôs-se a fazer medidas iniciando-se a 8 dias de idade. Porém para os 3 (três) tipos de condicionamento: (AE1) ciclagem de exposição a $24 \mathrm{~h}$ câmara de carbonatação a $5 \%$ de $\mathrm{CO}_{2}$ seguido por 27 dias de secagem em estufa, (AE2) ciclagem de $24 \mathrm{~h}$ de imersão em tanque de água seguido por 27 dias de secagem em estufa e (AE3) ciclos de 28 dias de secagem contínua em estufa, não foi possível fazer medições de profundidade de carbonatação, por soluções indicadoras, conforme observa-se no Apêndice fotográfico. Este resultado já era esperado e os corpos-de-prova foram abertos principalmente para registros da não carbonatação e respectiva resistência à tração por compressão diametral.

\section{I.1b) Profundidade de carbonatação a 63 dias}

A Tabela 86, Tabela 87 e Tabela 88 apresentam os resultados das medidas médias em faces diametrais partidas de dois corpos-de-prova de $10 \times 20 \mathrm{~cm}$, as médias, o desvio padrão, os valores máximos e mínimos, as amplitudes, o coeficiente de variação e as taxas de carbonatação, para os concretos com cura acelerada de 24/72 horas seguida de cura imersa em água até 7 dias. Os corpos-de-prova originais foram ainda submetidos a dois ciclos de 24 horas em câmara de carbonatação a $5 \%$ de $\mathrm{CO}_{2}$ seguida por 27 dias de secagem em estufa a $(40 \pm 1)^{\circ} \mathrm{C}$, antes das análises, por timoftaleína e fenolftaleína respectivamente. As tabelas completas com todas as medidas realizadas, e os gráficos de taxa de carbonatação constam no Apêndice B.

Pela timolftaleína não se obteve as maiores profundidades de carbonatação a 63 dias, apesar de sua faixa de $\mathrm{pH}$ ser mais elevada. A Tabela 86 e Tabela 87 referem-se a medidas 
lineares pelo método tradicional, e a Tabela 88 refere-se aos cálculos por análise de imagem pelo software Image $\mathrm{J}$.

TABELA 86 - Resultados do ensaio de resistência à carbonatação por câmara de $\mathrm{CO} 2$ ( $5 \%$; 24 horas) a 63 dias (AE1) dos concretos do lote analisado, por timolftaleína medida linear (Interpretar espessuras de carbonatação em valor inteiro de $\mathrm{mm}^{*}$ ).

\begin{tabular}{|c|c|c|c|c|c|c|c|c|c|c|c|c|c|}
\hline \multirow[b]{2}{*}{ 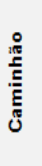 } & \multicolumn{6}{|c|}{ Medidas por amostra } & \multicolumn{7}{|c|}{ Cálculos para o lote } \\
\hline & $\begin{array}{c}\text { Profundidade } \\
\text { de } \\
\text { carbonatação } \\
\text { (mm) }\end{array}$ & $\begin{array}{l}\text { Média } \\
(\mathrm{mm})\end{array}$ & $\begin{array}{l}\text { Valor } \\
\text { Máximo } \\
(\mathrm{mm})\end{array}$ & $\begin{array}{c}\text { Valor } \\
\text { Minimo } \\
(\mathrm{mm})\end{array}$ & $\begin{array}{c}\text { Amplitude } \\
\text { (mm) }\end{array}$ & $\begin{array}{c}\text { Taxa de } \\
\text { carbonatação } \\
\left(\mathrm{mm} / \mathrm{Ino}^{-1 / 2}\right)\end{array}$ & Média (mm) & $\begin{array}{l}\text { Desvio } \\
\text { padrão } \\
(\mathrm{mm})\end{array}$ & $\begin{array}{l}\text { Coeficiente } \\
\text { de variação } \\
(\%)\end{array}$ & $\begin{array}{l}\text { Valor } \\
\text { Máximo } \\
(\mathrm{mm})\end{array}$ & $\begin{array}{c}\text { Valor } \\
\text { Minimo } \\
(\mathrm{mm})\end{array}$ & $\begin{array}{c}\text { Amplitude } \\
\text { (mm) }\end{array}$ & $\begin{array}{c}\text { Intervalo de } \\
\text { confiança da } \\
\text { média 95\% } \\
(\mathrm{mm})\end{array}$ \\
\hline $1 \mathrm{~A}$ & $\begin{array}{l}2,56 \\
245\end{array}$ & 2,51 & 2,56 & 2,45 & 0,11 & 0,32 & & & & & & & \\
\hline $2 B$ & $\begin{array}{l}2,55 \\
2,64\end{array}$ & 2,60 & 2,64 & 2,55 & 0,09 & 0,33 & & & & & & & \\
\hline $3 \mathrm{C}$ & $\begin{array}{l}2,51 \\
2,49\end{array}$ & 2,50 & 2,51 & 2,49 & 0,02 & 0,31 & 263 & 022 & $8 \%$ & 302 & 242 & 0 . & +17 \\
\hline 4D & $\begin{array}{l}2,96 \\
3,07\end{array}$ & 3,02 & 3,07 & 2,96 & 0,11 & 0,38 & $2,0 \mathrm{~J}$ & 0,22 & $8 \%$ & $5,0 \mathrm{C}$ & 2,42 & 0,00 & $\{0,11$ \\
\hline $5 E$ & $\begin{array}{l}2,56 \\
2,27\end{array}$ & 2,42 & 2,56 & 2,27 & 0,29 & 0,30 & & & & & & & \\
\hline $6 \mathrm{~F}$ & $\begin{array}{l}2,55 \\
2.91\end{array}$ & 2,73 & 2,91 & 2,55 & 0,36 & 0,34 & & & & & & & \\
\hline
\end{tabular}

TABELA 87 - Resultados do ensaio de resistência à carbonatação por câmara de CO2 ( $5 \%$; 24 horas) a 63 dias (AE1) dos concretos do lote analisado, por fenolftaleína medida linear (Interpretar espessuras de carbonatação em valor inteiro de $\mathrm{mm}^{\star}$ ).

\begin{tabular}{|c|c|c|c|c|c|c|c|c|c|c|c|c|c|}
\hline \multirow[b]{2}{*}{ 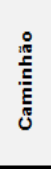 } & \multicolumn{6}{|c|}{ Medidas por amostra } & \multicolumn{7}{|c|}{ Cálculos para o lote } \\
\hline & $\begin{array}{c}\text { Profundidade } \\
\text { de } \\
\text { carbonatação } \\
(\mathrm{mm})\end{array}$ & $\begin{array}{l}\text { Média } \\
(\mathrm{mm})\end{array}$ & $\begin{array}{l}\text { Valor } \\
\text { Máximo } \\
(\mathrm{mm})\end{array}$ & $\begin{array}{c}\text { Valor } \\
\text { Minimo } \\
(\mathrm{mm})\end{array}$ & $\begin{array}{c}\text { Amplitude } \\
(\mathrm{mm})\end{array}$ & $\begin{array}{c}\text { Taxa de } \\
\text { carbonatação } \\
\left(\mathrm{mm} / \mathrm{ano}^{-1 / 2}\right)\end{array}$ & Média (mm) & $\begin{array}{c}\text { Desvio } \\
\text { padrão } \\
(\mathrm{mm})\end{array}$ & $\begin{array}{l}\text { Coeficiente } \\
\text { de variação } \\
(\%)\end{array}$ & $\begin{array}{l}\text { Valor } \\
\text { Máximo } \\
(\mathrm{mm})\end{array}$ & $\begin{array}{c}\text { Valor } \\
\text { Minimo } \\
(\mathrm{mm})\end{array}$ & $\begin{array}{c}\text { Amplitude } \\
\text { (mm) }\end{array}$ & $\begin{array}{c}\text { Intervalo de } \\
\text { confiança da } \\
\text { média } 95 \% \\
\text { (mm) }\end{array}$ \\
\hline $1 \mathrm{~A}$ & $\begin{array}{l}2,49 \\
2,72\end{array}$ & 2,61 & 2,72 & 2,49 & 0,23 & 0,33 & & & & & & & \\
\hline $2 B$ & $\begin{array}{l}2,37 \\
2,45\end{array}$ & 2,41 & 2,45 & 2,37 & 0,08 & 0,30 & & & & & & & \\
\hline $3 C$ & $\begin{array}{l}2,69 \\
2,62\end{array}$ & 2,66 & 2,69 & 2,62 & 0,07 & 0,33 & 268 & 034 & $13 \%$ & 321 & 230 & 0.91 & +027 \\
\hline 4D & $\begin{array}{l}3,01 \\
3,41\end{array}$ & 3,21 & 3,41 & 3,01 & 0,40 & 0,40 & & & $10 \%$ & & & & \\
\hline $5 E$ & $\begin{array}{l}2,38 \\
2,22\end{array}$ & 2,30 & 2,38 & 2,22 & 0,16 & 0,29 & & & & & & & \\
\hline $6 \mathrm{~F}$ & $\begin{array}{l}2,81 \\
3,04\end{array}$ & 2,93 & 3,04 & 2,81 & 0,23 & 0,37 & & & & & & & \\
\hline
\end{tabular}

TABELA 88 - Resultados do ensaio de resistência à carbonatação por câmara de CO2 (5\%; 24 horas) a 63 dias (AE1) dos concretos do lote analisado, por fenolftaleína medida através do software Image $\mathbf{J}$ (Interpretar espessuras de carbonatação em valor inteiro de $\mathrm{mm}^{\star}$ ).

\begin{tabular}{|c|c|c|c|c|c|c|c|c|c|c|c|c|c|}
\hline \multirow[b]{2}{*}{ 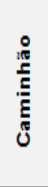 } & \multicolumn{6}{|c|}{ Medidas por amostra } & \multicolumn{7}{|c|}{ Cálculos para o lote } \\
\hline & $\begin{array}{c}\text { Profundidade } \\
\text { de } \\
\text { carbonatação } \\
(\mathrm{mm})\end{array}$ & $\begin{array}{r}\text { Média } \\
(\mathrm{mm})\end{array}$ & $\begin{array}{l}\text { Valor } \\
\text { Máximo } \\
(\mathrm{mm})\end{array}$ & $\begin{array}{l}\text { Valor } \\
\text { Minimo } \\
(\mathrm{mm})\end{array}$ & $\begin{array}{c}\text { Amplitude } \\
\text { (mm) }\end{array}$ & $\begin{array}{c}\text { Taxa de } \\
\text { carbonataçāa } \\
\left(\mathrm{mm} / \mathrm{ano}^{-1 / 2}\right)\end{array}$ & Média (mm) & $\begin{array}{l}\text { Desvio } \\
\text { padrão } \\
(\mathrm{mm})\end{array}$ & $\begin{array}{l}\text { Coeficiente } \\
\text { de variaçãao } \\
(\%)\end{array}$ & $\begin{array}{l}\text { Valor } \\
\text { Máximo } \\
\text { (mm) }\end{array}$ & $\begin{array}{c}\text { Valor } \\
\text { Minimo } \\
(\mathrm{mm})\end{array}$ & $\begin{array}{c}\text { Amplitude } \\
(\mathrm{mm})\end{array}$ & $\begin{array}{c}\text { Intervalo de } \\
\text { confiança da } \\
\text { média 95\% } \\
\text { (mm) }\end{array}$ \\
\hline $1 \mathrm{~A}$ & $\begin{array}{l}1,68 \\
1,70\end{array}$ & 1,69 & 1,70 & 1,68 & 0,02 & 0,21 & \multirow{6}{*}{2,37} & \multirow{6}{*}{0,47} & \multirow{6}{*}{$20 \%$} & \multirow{6}{*}{3,06} & \multirow{6}{*}{1,69} & \multirow{6}{*}{1,37} & \multirow{6}{*}{ $\pm 0,38$} \\
\hline $2 B$ & $\begin{array}{l}2,12 \\
2,13\end{array}$ & 2,13 & 2,13 & 2,12 & 0,01 & 0,27 & & & & & & & \\
\hline $3 C$ & $\begin{array}{l}2,32 \\
2,10\end{array}$ & 2,21 & 2,32 & 2,10 & 0,22 & 0,28 & & & & & & & \\
\hline $4 \mathrm{D}$ & $\begin{array}{l}2,49 \\
2,67\end{array}$ & 2,58 & 2,67 & 2,49 & 0,18 & 0,33 & & & & & & & \\
\hline $5 E$ & $\begin{array}{l}2,54 \\
2,60\end{array}$ & 2,57 & 2,60 & 2,54 & 0,06 & 0,32 & & & & & & & \\
\hline $6 \mathrm{~F}$ & $\begin{array}{l}3,25 \\
2,86\end{array}$ & 3,06 & 3,25 & 2,86 & 0,40 & 0,39 & & & & & & & \\
\hline
\end{tabular}


Todos os caminhões apresentaram resultados próximos e com variações mínimas entre corpos-de-prova do mesmo caminhão, para os dois indicadores utilizados, conforme se observa pela ilustração da Figura 87, para as medidas lineares. Já para as medidas realizadas com a ferramenta Image $\mathrm{J}$, os resultados médios ficaram inferiores para os concretos dos caminhões de 1A a 4D. Para os concretos dos caminhões 5E e 6F, os resultados médios ficaram próximos, porém ligeiramente maiores para a leitura realizada através do Image $\mathrm{J}$.

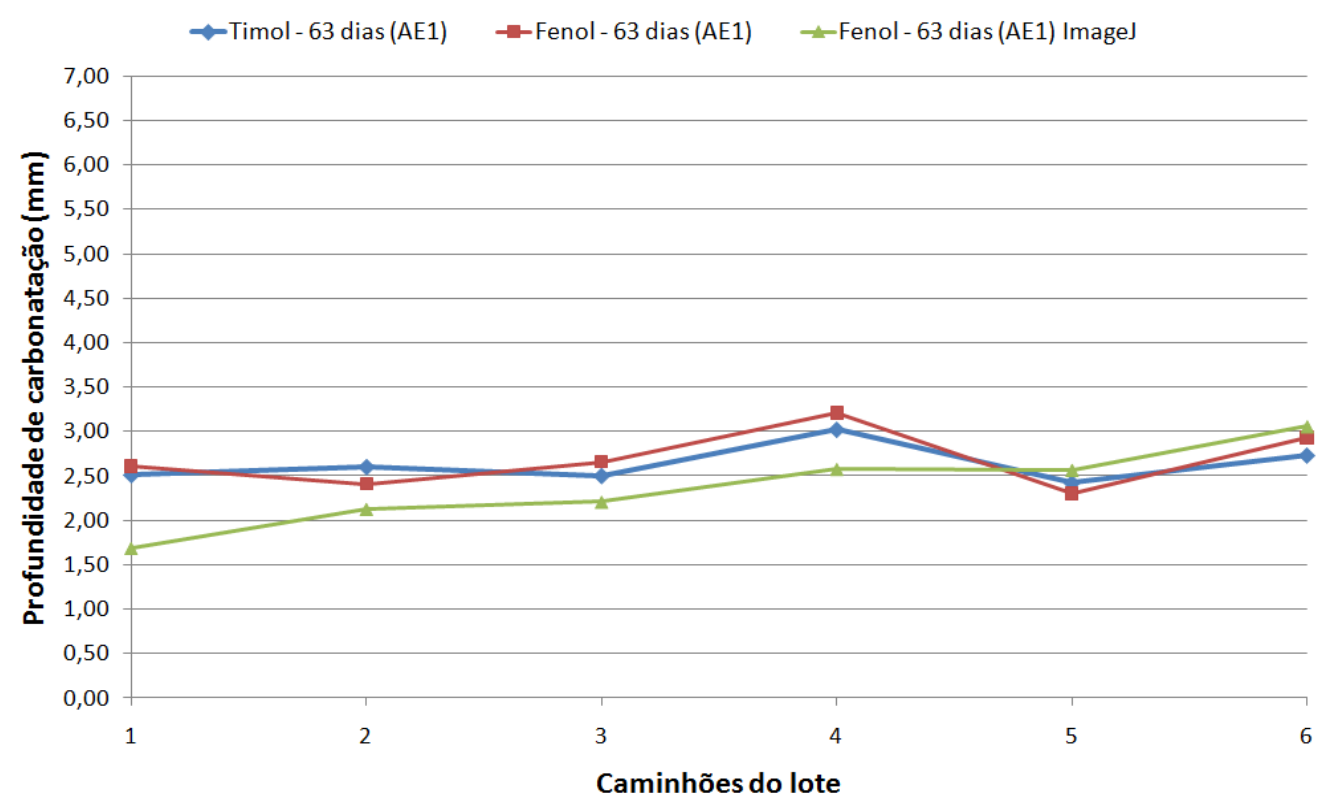

FIGURA 87 - Variação da profundidade de carbonatação média após dois ciclos em câmara de $\operatorname{CO2}\left(5 \%\right.$; 24h) e 27 dias de secagem a $40^{\circ} C$ (AE1), por timolftaleína e fenolftaleína, nas metades seccionadas de dois corpos-de-prova de concreto por caminhão a 63 dias - medida linear e pelo programa Image J.

O concreto do caminhão 4D mostrou maior profundidade de carbonatação e o concreto do caminhão $5 \mathrm{E}$ mostrou menor profundidade, para os dois tipos de indicadores, neste tipo de condicionamento e idade dos corpos-de-prova, nas medidas lineares. Pode-se observar na Figura 87 a mesma tendência de profundidade de carbonatação para os dois tipos de indicadores utilizados, para as medidas lineares.

\section{I.1c) Profundidade de carbonatação a 91 dias}

A Tabela 89 apresenta os resultados das medidas lineares médias de faces diametrais partidas de dois corpos-de-prova de $10 \times 20 \mathrm{~cm}$, as médias, o desvio padrão, os valores máximos e mínimos, as amplitudes, o coeficiente de variação e taxas de carbonatação, para 
concretos com cura acelerada de 24/72 horas seguida de cura imersa em água até 7 dias. Os corpos-de-prova originais foram ainda submetidos a três ciclos de 24 horas em câmara de carbonatação a $5 \%$ de $\mathrm{CO}_{2}$ seguida por 27 dias de secagem em estufa a $(40 \pm 1)^{\circ} \mathrm{C}$, antes da ruptura e análise por fenolftaleína. A tabela completa com todas as medidas realizadas consta no Apêndice B. A Tabela 90 apresenta os resultados das medidas realizadas com o software Image $\mathrm{J}$.

TABELA 89 - Resultados do ensaio de resistência à carbonatação por três ciclos de $24 \mathrm{~h}$ de exposição em câmara de carbonatação $(5 \%, 24 \mathrm{~h})$ e por 27 dias de secagem a $40^{\circ} \mathrm{C}$, a 91 dias (AE1) dos concretos do lote analisado, por fenolftaleína - medida linear (Interpretar espessuras de carbonatação em valor inteiro de $\mathrm{mm}$ ).

\begin{tabular}{|c|c|c|c|c|c|c|c|c|c|c|c|c|c|}
\hline \multirow[b]{2}{*}{ 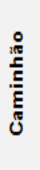 } & \multicolumn{6}{|c|}{ Medidas por amostra } & \multicolumn{7}{|c|}{ Cálculos para o lote } \\
\hline & $\begin{array}{c}\text { Profundidade } \\
\text { de } \\
\text { carbonatação } \\
\text { (mm) }\end{array}$ & $\begin{array}{l}\text { Média } \\
(\mathrm{mm})\end{array}$ & $\begin{array}{l}\text { Valor } \\
\text { Máximo } \\
(\mathrm{mm})\end{array}$ & $\begin{array}{l}\text { Valor } \\
\text { Minimo } \\
(\mathrm{mm})\end{array}$ & $\begin{array}{c}\text { Amplitude } \\
(\mathrm{mm})\end{array}$ & $\begin{array}{c}\text { Taxa de } \\
\text { carbonatação I } \\
\left(\text { mm/ano }{ }^{-1 / 2}\right)\end{array}$ & Média (mm) & $\begin{array}{c}\text { Desvio } \\
\text { padrão } \\
\text { (mm) }\end{array}$ & $\begin{array}{c}\text { Coeficiente } \\
\text { de variaçãao } \\
(\%)\end{array}$ & $\begin{array}{l}\text { Valor } \\
\text { Máximo } \\
(\mathrm{mm})\end{array}$ & $\begin{array}{l}\text { Valor } \\
\text { Minimo } \\
(\mathrm{mm})\end{array}$ & $\begin{array}{c}\text { Amplitude } \\
\text { (mm) }\end{array}$ & $\begin{array}{l}\text { Intervalo de } \\
\text { confiança da } \\
\text { média 95\% } \\
\text { (mm) }\end{array}$ \\
\hline $1 \mathrm{~A}$ & $\begin{array}{l}3,07 \\
2,46\end{array}$ & 2,77 & 3,07 & 2,46 & 0,61 & 0,29 & & & & & & & \\
\hline $2 \mathrm{~B}$ & $\begin{array}{l}3,06 \\
2,75\end{array}$ & 2,91 & 3,06 & 2,75 & 0,31 & 0,30 & & & & & & & \\
\hline $3 \mathrm{C}$ & $\begin{array}{l}3,19 \\
2,65\end{array}$ & 2,92 & 3,19 & 2,65 & 0,54 & 0,31 & 3,10 & 0,51 & $16 \%$ & 3,98 & 2,61 & 1,37 & $\pm 0,40$ \\
\hline $4 \mathrm{D}$ & $\begin{array}{l}4,15 \\
3,80\end{array}$ & 3,98 & 4,15 & 3,80 & 0,35 & 0,42 & $J, 10$ & 0,01 & $10 \%$ & $J, 00$ & 2,01 & (,T) & $\{0,40$ \\
\hline $5 E$ & $\begin{array}{l}2,78 \\
2,44\end{array}$ & 2,61 & 2,78 & 2,44 & 0,34 & 0,27 & & & & & & & \\
\hline $6 \mathrm{~F}$ & $\begin{array}{l}3,44 \\
3,35\end{array}$ & 3,40 & 3,44 & 3,35 & 0,09 & 0,36 & & & & & & & \\
\hline
\end{tabular}

TABELA 90 - Resultados do ensaio de resistência à carbonatação por três ciclos de $24 \mathrm{~h}$ de exposição em câmara de carbonatação $(5 \%, 24 \mathrm{~h})$ e 27 dias de secagem, a 91 dias (AE1) dos concretos do lote analisado, por fenolftaleína- medida por Image $\mathbf{J}$ (Interpretar espessuras de carbonatação em valor inteiro de $\mathrm{mm}$ ).

\begin{tabular}{|c|c|c|c|c|c|c|c|c|c|c|c|c|c|}
\hline \multirow[b]{2}{*}{ 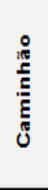 } & \multicolumn{6}{|c|}{ Medidas por amostra } & \multicolumn{7}{|c|}{ Cálculos para o lote } \\
\hline & $\begin{array}{l}\text { Profundidade } \\
\text { de } \\
\text { carbonatação } \\
(\mathrm{mm})\end{array}$ & $\begin{array}{r}\text { Média } \\
(\mathrm{mm})\end{array}$ & $\begin{array}{l}\text { Valor } \\
\text { Máximo } \\
(\mathrm{mm})\end{array}$ & $\begin{array}{l}\text { Valor } \\
\text { Minimo } \\
(\mathrm{mm})\end{array}$ & $\begin{array}{l}\text { Amplitude } \\
(\mathrm{mm})\end{array}$ & $\begin{array}{c}\text { Taxa de } \\
\text { carbonataçãa } \\
\left(\mathrm{mm} / \mathrm{ano}^{-1 / 2}\right)\end{array}$ & Média (mm) & $\begin{array}{c}\text { Desvio } \\
\text { padrão } \\
(\mathrm{mm})\end{array}$ & $\begin{array}{c}\text { Coeficiente } \\
\text { de variaçãa } \\
(\%)\end{array}$ & $\begin{array}{l}\text { Valor } \\
\text { Máximo } \\
\text { (mm) }\end{array}$ & $\begin{array}{c}\text { Valor } \\
\text { Minimo } \\
(\mathrm{mm})\end{array}$ & $\begin{array}{c}\text { Amplitude } \\
(\mathrm{mm})\end{array}$ & $\begin{array}{l}\text { Intervalo de } \\
\text { confiança da } \\
\text { média 95\% } \\
\text { (mm) }\end{array}$ \\
\hline $1 \mathrm{~A}$ & $\begin{array}{l}2,26 \\
1,82\end{array}$ & 2,04 & 2,26 & 1,82 & 0,44 & 0,21 & \multirow{6}{*}{2,90} & \multirow{6}{*}{0,63} & \multirow{6}{*}{$22 \%$} & \multirow{6}{*}{3,50} & \multirow{6}{*}{2,04} & \multirow{6}{*}{1,46} & \multirow{6}{*}{ $\pm 0,50$} \\
\hline $2 \mathrm{~B}$ & $\begin{array}{l}2,95 \\
2,54\end{array}$ & 2,75 & 2,95 & 2,54 & 0,41 & 0,29 & & & & & & & \\
\hline $3 C$ & $\begin{array}{l}3,33 \\
3,41\end{array}$ & 3,37 & 3,41 & 3,33 & 0,08 & 0,35 & & & & & & & \\
\hline $4 D$ & $\begin{array}{l}2,75 \\
4,12\end{array}$ & 3,44 & 4,12 & 2,75 & 1,36 & 0,36 & & & & & & & \\
\hline $5 E$ & $\begin{array}{l}2,62 \\
2,02\end{array}$ & 2,32 & 2,62 & 2,02 & 0,59 & 0,24 & & & & & & & \\
\hline $6 \mathrm{~F}$ & $\begin{array}{l}2,85 \\
4,16\end{array}$ & 3,50 & 4,16 & 2,85 & 1,32 & 0,37 & & & & & & & \\
\hline
\end{tabular}

A Figura 88 apresenta os resultados de profundidade de carbonatação a 91 dias para análise com fenolftaleína e utilizando medidas lineares e Image J. Os resultados entre os dois tipos de medidas foram bem próximos para os concretos dos caminhões 2B, 5E e $6 \mathrm{~F}$. 


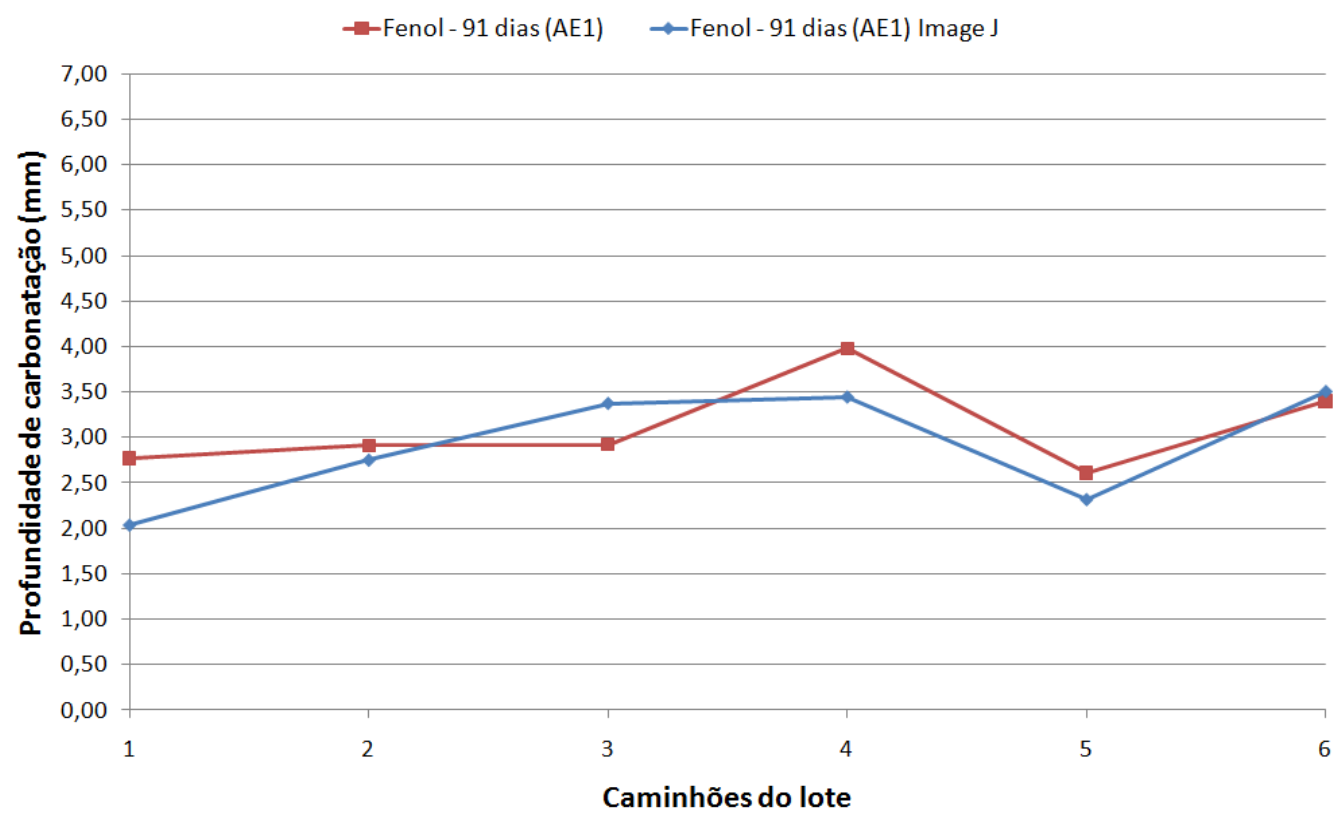

FIGURA 88 - Variação da profundidade de carbonatação média após três ciclos em câmara de $\mathrm{CO}_{2}(5 \% ; 24 \mathrm{~h})$ e 27 dias de secagem a $40^{\circ} \mathrm{C}$ (AE1), por fenolftaleína, nas metades seccionadas de dois corpos-de-prova de concreto, por caminhão a 91 dias medida linear e pelo programalmage $\mathrm{J}$.

\section{I.1d) Profundidade de carbonatação a 203 dias}

A Tabela 91 apresenta os resultados das medidas lineares médias em faces diametrais partidas de dois corpos-de-prova de $10 \times 20 \mathrm{~cm}$, as médias, o desvio padrão, os valores máximos e mínimos, as amplitudes, o coeficiente de variação e as taxas de carbonatação, para os concretos com cura acelerada de 24/72 horas seguida de cura imersa em água até 7 dias. Os corpos-de-prova originais foram ainda submetidos a sete ciclos de 24 horas em câmara de carbonatação a $5 \%$ de $\mathrm{CO}_{2}$ seguida por 27 dias de secagem em estufa a $(40 \pm 1)^{\circ} \mathrm{C}$, antes das análises por fenolftaleína.

A Tabela 92 apresenta os resultados das medidas realizadas com o programa Image $J$ e a Tabela 93 apresenta os resultados das medidas realizadas com o programa Leica Qwin. A tabela completa com todas as medidas realizadas consta no Apêndice B.

Através das medidas lineares, os resultados das medidas não mostraram variabilidade significativa entre os corpos-de-prova de mesmo caminhão. O concreto do caminhão $1 \mathrm{~A}$ mostrou menor profundidade média de carbonatação e os concretos de 4D e $6 \mathrm{~F}$ resultaram com maiores profundidades de carbonatação e maiores taxas de carbonatação, inclusive o valor médio foi igual, com baixas amplitudes. 
TABELA 91 - Resultados do ensaio de resistência à carbonatação por sete ciclos de $24 \mathrm{~h}$ de exposição em câmara de carbonatação $(5 \%, 24 \mathrm{~h})$ e 27 dias de secagem, a 203 dias (AE1) dos concretos do lote analisado, por fenolftaleína -medida linear (Interpretar espessuras de carbonatação em valor inteiro de $\mathrm{mm}$ ).

\begin{tabular}{|c|c|c|c|c|c|c|c|c|c|c|c|c|c|}
\hline \multirow[b]{2}{*}{ 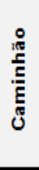 } & \multicolumn{6}{|c|}{ Medidas por amostra } & \multicolumn{7}{|c|}{ Cálculos para o lote } \\
\hline & $\begin{array}{c}\text { Profundidade } \\
\text { de } \\
\text { carbonatação } \\
(\mathrm{mm})\end{array}$ & $\begin{array}{r}\text { Média } \\
(\mathrm{mm})\end{array}$ & $\begin{array}{l}\text { Valor } \\
\text { Máximo } \\
(\mathrm{mm})\end{array}$ & $\begin{array}{c}\text { Valor } \\
\text { Mínimo } \\
(\mathrm{mm})\end{array}$ & $\begin{array}{l}\text { Amplitude } \\
\text { (mm) }\end{array}$ & $\begin{array}{c}\text { Taxa de } \\
\text { carbonataçãa } \\
\left(\mathrm{mm} / \mathrm{ano}^{-1 / 2}\right)\end{array}$ & Média (mm) & $\begin{array}{c}\text { Desvio } \\
\text { padrão } \\
(\mathrm{mm})\end{array}$ & $\begin{array}{c}\text { Coeficiente } \\
\text { de variação } \\
(\%)\end{array}$ & $\begin{array}{l}\text { Valor } \\
\text { Máximo } \\
(\mathrm{mm})\end{array}$ & $\begin{array}{c}\text { Valor } \\
\text { Mínimo } \\
(\mathrm{mm})\end{array}$ & $\begin{array}{l}\text { Amplitude } \\
\text { (mm) }\end{array}$ & $\begin{array}{c}\text { Intervalo de } \\
\text { confiança da } \\
\text { média 95\% } \\
\text { (mm) }\end{array}$ \\
\hline $1 \mathrm{~A}$ & $\begin{array}{l}3,38 \\
3,38\end{array}$ & 3,38 & 3,38 & 3,38 & 0,00 & 0,24 & \multirow{6}{*}{4,15} & \multirow{6}{*}{0,84} & \multirow{6}{*}{$20 \%$} & \multirow{6}{*}{5,20} & \multirow{6}{*}{3,38} & \multirow{6}{*}{1,82} & \multirow{6}{*}{ $\pm 0,67$} \\
\hline $2 \mathrm{~B}$ & $\begin{array}{l}3,90 \\
4,14\end{array}$ & 4,02 & 4,14 & 3,90 & 0,24 & 0,28 & & & & & & & \\
\hline $3 \mathrm{C}$ & $\begin{array}{l}3,82 \\
3,28\end{array}$ & 3,55 & 3,82 & 3,28 & 0,54 & 0,24 & & & & & & & \\
\hline $4 \mathrm{D}$ & $\begin{array}{l}5,29 \\
5,11\end{array}$ & 5,20 & 5,29 & 5,11 & 0,18 & 0,36 & & & & & & & \\
\hline $5 \mathrm{E}$ & $\begin{array}{l}3,39 \\
3,67\end{array}$ & 3,53 & 3,67 & 3,39 & 0,28 & 0,25 & & & & & & & \\
\hline $6 \mathrm{~F}$ & $\begin{array}{l}5,17 \\
5,22\end{array}$ & 5,20 & 5,22 & 5,17 & 0,05 & 0,36 & & & & & & & \\
\hline
\end{tabular}

TABELA 92 - Resultados do ensaio de resistência à carbonatação por sete ciclos de exposição em câmara de carbonatação $(5 \%, 24 \mathrm{~h})$ e 27 dias de secagem, a 203 dias (AE1) dos concretos do lote analisado, por fenolftaleína- medida por Image J (Interpretar espessuras de carbonatação em valor inteiro de $\mathrm{mm}$ ).

\begin{tabular}{|c|c|c|c|c|c|c|c|c|c|c|c|c|c|}
\hline \multirow[b]{2}{*}{ 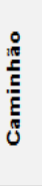 } & \multicolumn{6}{|c|}{ Medidas por amostra } & \multicolumn{7}{|c|}{ Cálculos para o lote } \\
\hline & $\begin{array}{l}\text { Profundidade } \\
\text { de } \\
\text { carbonatação } \\
\text { (mm) }\end{array}$ & $\begin{array}{l}\text { Média } \\
(\mathrm{mm})\end{array}$ & $\begin{array}{l}\text { Valor } \\
\text { Máximo } \\
(\mathrm{mm})\end{array}$ & $\begin{array}{l}\text { Valor } \\
\text { Mínimo } \\
(\mathrm{mm})\end{array}$ & $\begin{array}{c}\text { Amplitude } \\
(\mathrm{mm})\end{array}$ & $\begin{array}{c}\text { Taxa de } \\
\text { carbonatação } \\
\left(\mathrm{mm} / \mathrm{ano}^{-1 / 2}\right)\end{array}$ & Média (mm) & $\begin{array}{c}\text { Desvio } \\
\text { padrão } \\
(\mathrm{mm})\end{array}$ & $\begin{array}{c}\text { Coeficiente } \\
\text { de variação } \\
(\%)\end{array}$ & $\begin{array}{l}\text { Valor } \\
\text { Máximo } \\
\text { (mm) }\end{array}$ & $\begin{array}{l}\text { Valor } \\
\text { Mínimo } \\
(\mathrm{mm})\end{array}$ & $\begin{array}{c}\text { Amplitude } \\
\text { (mm) }\end{array}$ & $\begin{array}{l}\text { Intervalo de } \\
\text { confiança da } \\
\text { média 95\% } \\
(\mathrm{mm})\end{array}$ \\
\hline $1 \mathrm{~A}$ & $\begin{array}{l}3,96 \\
4,09\end{array}$ & 4,03 & 4,09 & 3,96 & 0,13 & 0,28 & & & & & & & \\
\hline $2 \mathrm{~B}$ & $\begin{array}{l}3,79 \\
3,26\end{array}$ & 3,53 & 3,79 & 3,26 & 0,53 & 0,25 & & & & & & & \\
\hline $3 \mathrm{C}$ & $\begin{array}{l}4,16 \\
4,91\end{array}$ & 4,54 & 4,91 & 4,16 & 0,75 & 0,32 & 466 & 0.94 & $20 \%$ & 627 & 353 & 275 & +075 \\
\hline $4 \mathrm{D}$ & $\begin{array}{l}6,66 \\
5,88\end{array}$ & 6,27 & 6,66 & 5,88 & 0,78 & 0,44 & & & & & & & \\
\hline $5 \mathrm{E}$ & $\begin{array}{l}5,08 \\
4,79\end{array}$ & 4,94 & 5,08 & 4,79 & 0,29 & 0,35 & & & & & & & \\
\hline $6 \mathrm{~F}$ & $\begin{array}{l}5,24 \\
4,05\end{array}$ & 4,65 & 5,24 & 4,05 & 1,19 & 0,33 & & & & & & & \\
\hline
\end{tabular}


TABELA 93 - Resultados do ensaio de resistência à carbonatação por sete ciclos de $24 \mathrm{~h}$ de exposição em câmara de carbonatação $(5 \%, 24 \mathrm{~h})$ e 27 dias de secagem, a 203 dias (AE1) dos concretos do lote analisado, por fenolftaleína- medida por Leica Qwin (Interpretar espessuras de carbonatação em valor inteiro de $\mathrm{mm}$ ).

\begin{tabular}{|c|c|c|c|c|c|c|c|c|c|c|c|c|c|}
\hline \multirow[b]{2}{*}{ 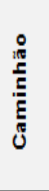 } & \multicolumn{6}{|c|}{ Medidas por amostra } & \multicolumn{7}{|c|}{ Cálculos para o lote } \\
\hline & $\begin{array}{l}\text { Profundidade } \\
\text { de } \\
\text { carbonatação } \\
\text { (mm) }\end{array}$ & $\begin{array}{l}\text { Média } \\
(\mathrm{mm})\end{array}$ & $\begin{array}{l}\text { Valor } \\
\text { Máximo } \\
(\mathrm{mm})\end{array}$ & $\begin{array}{l}\text { Valor } \\
\text { Mínimo } \\
(\mathrm{mm})\end{array}$ & $\begin{array}{c}\text { Amplitude } \\
\text { (mm) }\end{array}$ & $\begin{array}{c}\text { Taxa de } \\
\text { carbonatação } \\
\left(\mathrm{mm} / \mathrm{ano}^{-1 / 2}\right)\end{array}$ & Média (mm) & $\begin{array}{c}\text { Desvio } \\
\text { padrão } \\
\text { (mm) }\end{array}$ & $\begin{array}{c}\text { Coeficiente } \\
\text { de variação } \\
(\%)\end{array}$ & $\begin{array}{l}\text { Valor } \\
\text { Máximo } \\
(\mathrm{mm})\end{array}$ & $\begin{array}{c}\text { Valor } \\
\text { Mínimo } \\
(\mathrm{mm})\end{array}$ & $\begin{array}{l}\text { Amplitude } \\
\text { (mm) }\end{array}$ & $\begin{array}{l}\text { Intervalo de } \\
\text { confiança da } \\
\text { média 95\% } \\
(\mathrm{mm})\end{array}$ \\
\hline $1 \mathrm{~A}$ & $\begin{array}{l}4,32 \\
5,93\end{array}$ & 5,13 & 5,93 & 4,32 & 1,61 & 0,36 & \multirow{6}{*}{5,33} & \multirow{6}{*}{0,92} & \multirow{6}{*}{$17 \%$} & \multirow{6}{*}{6,55} & \multirow{6}{*}{4,04} & \multirow{6}{*}{2,51} & \multirow{6}{*}{ $\pm 0,73$} \\
\hline $2 B$ & $\begin{array}{l}4,08 \\
4,00\end{array}$ & 4,04 & 4,08 & 4,00 & 0,08 & 0,28 & & & & & & & \\
\hline $3 C$ & $\begin{array}{l}5,75 \\
3,49\end{array}$ & 4,62 & 5,75 & 3,49 & 2,26 & 0,32 & & & & & & & \\
\hline $4 D$ & $\begin{array}{l}5,49 \\
6,21\end{array}$ & 5,85 & 6,21 & 5,49 & 0,72 & 0,41 & & & & & & & \\
\hline $5 \mathrm{E}$ & $\begin{array}{l}5,52 \\
6,08\end{array}$ & 5,80 & 6,08 & 5,52 & 0,56 & 0,41 & & & & & & & \\
\hline $6 \mathrm{~F}$ & $\begin{array}{l}6,42 \\
6,68\end{array}$ & 6,55 & 6,68 & 6,42 & 0,26 & 0,46 & & & & & & & \\
\hline
\end{tabular}

A Figura 89 ilustra os resultados dos três métodos utilizados para as medidas de profundidade de carbonatação para a idade de 203 dias, nesta condição de envelhecimento acelerado. Para as medidas lineares, os resultados apresentados foram em média menores que para as outras duas formas de medição, no caso para os concretos dos caminhões $1 \mathrm{~A}$, 3C, 4D e 5E. Os resultados apresentados pelas medidas realizadas pelo programa Leica Qwin foram em média maiores do que para os outros dois métodos, exceto para o concreto do caminhão 4D.

As maiores profundidades de carbonatação entre os três métodos de medição foram: para medidas lineares - concretos dos caminhões 4D e 6F, para Image $\mathrm{J}$ - concreto do caminhão 4D e para o Leica Qwin - concreto do caminhão 6F. 


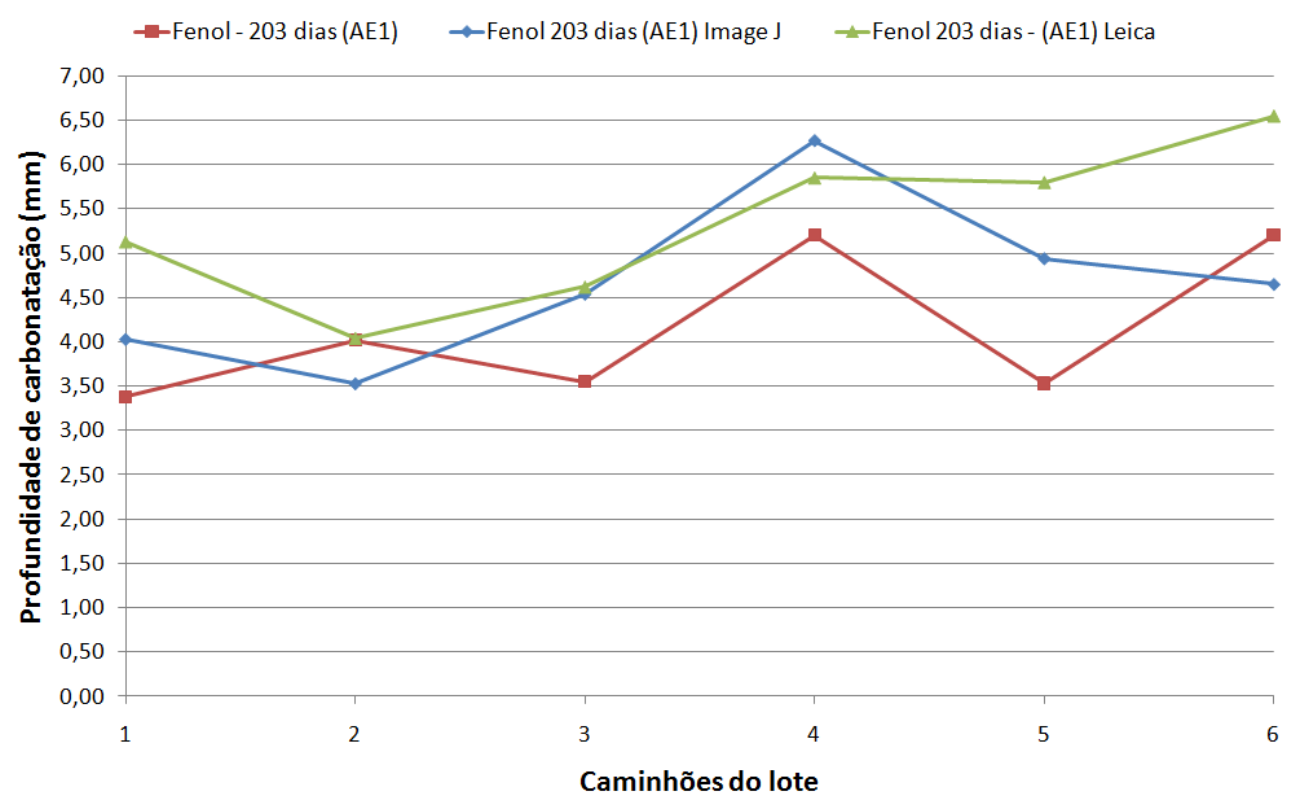

FIGURA 89 - Variação da profundidade de carbonatação média por sete ciclos de $24 \mathrm{~h}$ de exposição em câmara de carbonatação $(5 \%, 24 \mathrm{~h})$ e 27 dias de secagem (AE1), por fenolftaleína, nas metades seccionadas de dois corpos-de-prova de concreto por caminhão a 203 dias - medida linear, programa Image J e programa Leica Qwin.

I.2) Cura acelerada de 24/72 horas seguida por imersão em água até 7 dias e ciclos de 24 horas de imersão em tanque com água e 27 dias de secagem (AE2).

\section{I.2a) Profundidade de carbonatação a 63 dias}

A Tabela 94 e a Tabela 95 apresentam os resultados das medidas lineares médias em faces diametrais partidas de dois corpos-de-prova de $10 \times 20 \mathrm{~cm}$, as médias, o desvio padrão, os valores máximos e mínimos, as amplitudes, o coeficiente de variação e as taxas de carbonatação, para os concretos com cura acelerada de 24/72 horas seguida de cura imersa em água até 7 dias. Os corpos-de-prova originais foram ainda submetidos a dois ciclos de 24 horas de imersão em tanque de água seguida por 27 dias de secagem em estufa a $(40 \pm 1)^{\circ} \mathrm{C}$, antes das análises, por timoftaleína e fenolftaleína respectivamente. A tabela completa com todas as medidas realizadas consta no Apêndice B. 
TABELA 94 - Resultados do ensaio de resistência à carbonatação por dois ciclos de $24 \mathrm{~h}$ de imersão em água, seguido por 27 dias de secagem, a 63 dias (AE2) dos concretos do lote analisado, por timolftaleína - medida linear (Interpretar espessuras de carbonatação em valor inteiro de $\mathrm{mm}$ ).

\begin{tabular}{|c|c|c|c|c|c|c|c|c|c|c|c|c|c|}
\hline \multirow[b]{2}{*}{ 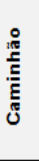 } & \multicolumn{6}{|c|}{ Medidas por amostra } & \multicolumn{7}{|c|}{ Cálculos para o lote } \\
\hline & $\begin{array}{l}\text { Profundidade } \\
\text { de } \\
\text { carbonatação } \\
\text { (mm) }\end{array}$ & $\begin{array}{r}\text { Média } \\
(\mathrm{mm})\end{array}$ & $\begin{array}{l}\text { Valor } \\
\text { Máximo } \\
(\mathrm{mm})\end{array}$ & $\begin{array}{c}\text { Valor } \\
\text { Mínimo } \\
(\mathrm{mm})\end{array}$ & $\begin{array}{c}\text { Amplitude } \\
\text { (mm) }\end{array}$ & $\begin{array}{c}\text { Taxa de } \\
\text { carbonatação } \\
\left(\mathrm{mm} / \mathrm{ano}^{-1 / 2}\right)\end{array}$ & Média (mm) & $\begin{array}{c}\text { Desvio } \\
\text { padrão } \\
(\mathrm{mm})\end{array}$ & $\begin{array}{l}\text { Coeficiente } \\
\text { de variação } \\
(\%)\end{array}$ & $\begin{array}{l}\text { Valor } \\
\text { Máximo } \\
(\mathrm{mm})\end{array}$ & $\begin{array}{c}\text { Valor } \\
\text { Mínimo } \\
(\mathrm{mm})\end{array}$ & $\begin{array}{l}\text { Amplitude } \\
\text { (mm) }\end{array}$ & $\begin{array}{l}\text { Intervalo de } \\
\text { confiança da } \\
\text { média 95\% } \\
(\mathrm{mm})\end{array}$ \\
\hline $1 \mathrm{~A}$ & $\begin{array}{l}2,48 \\
2,40\end{array}$ & 2,44 & 2,48 & 2,40 & 0,08 & 0,31 & & & & & & & \\
\hline $2 \mathrm{~B}$ & $\begin{array}{l}2,58 \\
2,64\end{array}$ & 2,61 & 2,64 & 2,58 & 0,06 & 0,33 & & & & & & & \\
\hline $3 \mathrm{C}$ & $\begin{array}{l}2,22 \\
2,25\end{array}$ & 2,24 & 2,25 & 2,22 & 0,03 & 0,28 & 264 & 029 & $11 \%$ & 302 & 224 & 079 & +023 \\
\hline $4 \mathrm{D}$ & $\begin{array}{l}3,00 \\
3,04\end{array}$ & 3,02 & 3,04 & 3,00 & 0,04 & 0,38 & & & & & 2,24 & & \\
\hline $5 \mathrm{E}$ & $\begin{array}{l}2,59 \\
2,65\end{array}$ & 2,62 & 2,65 & 2,59 & 0,06 & 0,33 & & & & & & & \\
\hline $6 \mathrm{~F}$ & $\begin{array}{l}2,84 \\
2,93\end{array}$ & 2,89 & 2,93 & 2,84 & 0,09 & 0,36 & & & & & & & \\
\hline
\end{tabular}

TABELA 95 - Resultados do ensaio de resistência à carbonatação por dois ciclos de $24 \mathrm{~h}$ imersão em água, seguido por 27 dias de secagem, a 63 dias (AE2) dos concretos do lote analisado, por fenolftaleína - medida linear (Interpretar espessuras de carbonatação em valor inteiro de $\mathrm{mm}$ ).

\begin{tabular}{|c|c|c|c|c|c|c|c|c|c|c|c|c|c|}
\hline \multirow[b]{2}{*}{ 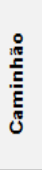 } & \multicolumn{6}{|c|}{ Medidas por amostra } & \multicolumn{7}{|c|}{ Cálculos para o lote } \\
\hline & $\begin{array}{c}\text { Profundidade } \\
\text { de } \\
\text { carbonatação } \\
(\mathrm{mm})\end{array}$ & $\begin{array}{l}\text { Média } \\
(\mathrm{mm})\end{array}$ & $\begin{array}{l}\text { Valor } \\
\text { Máximo } \\
(\mathrm{mm})\end{array}$ & $\begin{array}{l}\text { Valor } \\
\text { Mínimo } \\
(\mathrm{mm})\end{array}$ & $\begin{array}{c}\text { Amplitude } \\
\text { (mm) }\end{array}$ & $\begin{array}{c}\text { Taxa de } \\
\text { carbonataçãa } \\
\left(\mathrm{mm} / \mathrm{ano}^{-1 / 2}\right)\end{array}$ & Média (mm) & $\begin{array}{c}\text { Desvio } \\
\text { padrão } \\
(\mathrm{mm})\end{array}$ & $\begin{array}{c}\text { Coeficiente } \\
\text { de variação } \\
(\%)\end{array}$ & $\begin{array}{l}\text { Valor } \\
\text { Máximo } \\
(\mathrm{mm})\end{array}$ & $\begin{array}{c}\text { Valor } \\
\text { Mínimo } \\
(\mathrm{mm})\end{array}$ & $\begin{array}{l}\text { Amplitude } \\
\text { (mm) }\end{array}$ & $\begin{array}{l}\text { Intervalo de } \\
\text { confiança da } \\
\text { média } 95 \% \\
\text { (mm) }\end{array}$ \\
\hline $1 \mathrm{~A}$ & $\begin{array}{l}1,88 \\
2,07\end{array}$ & 1,98 & 2,07 & 1,88 & 0,19 & 0,25 & & & & & & & \\
\hline $2 \mathrm{~B}$ & $\begin{array}{l}2,36 \\
2,72\end{array}$ & 2,54 & 2,72 & 2,36 & 0,36 & 0,32 & & & & & & & \\
\hline $3 C$ & $\begin{array}{l}2,10 \\
2,76\end{array}$ & 2,43 & 2,76 & 2,10 & 0,66 & 0,31 & & & & & & & \\
\hline 4D & $\begin{array}{l}2,01 \\
2,74\end{array}$ & 2,38 & 2,74 & 2,01 & 0,73 & 0,30 & 2,30 & 0,26 & $11 \%$ & 2,54 & 1,97 & 0,58 & $\pm 0,21$ \\
\hline $5 \mathrm{E}$ & $\begin{array}{l}1,92 \\
2,01\end{array}$ & 1,97 & 2,01 & 1,92 & 0,09 & 0,25 & & & & & & & \\
\hline $6 \mathrm{~F}$ & $\begin{array}{l}2,60 \\
2,45\end{array}$ & 2,53 & 2,60 & 2,45 & 0,15 & 0,32 & & & & & & & \\
\hline
\end{tabular}

A Figura 90 apresenta os resultados de profundidade de carbonatação a 63 dias para as soluções de timolftaleína e fenolftaleína. Os concretos apresentaram resultados próximos e com variações mínimas entre corpos-de-prova do mesmo caminhão, quando utilizada a fenolftaleína, e o concreto do caminhão $5 \mathrm{E}$ mostrou menor profundidade de carbonatação. 


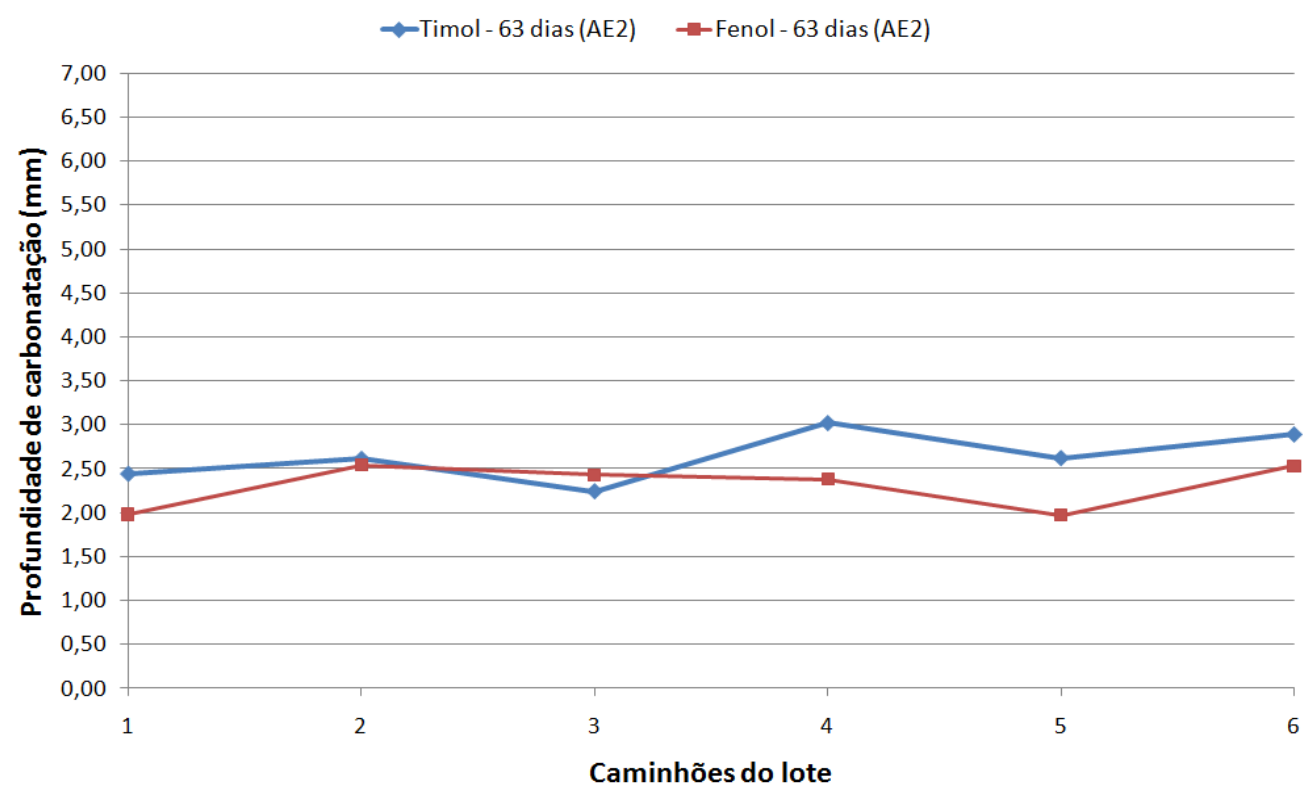

FIGURA 90 - Variação da profundidade de carbonatação média em dois ciclos de $24 \mathrm{~h}$ de imersão em água, seguido por 27 dias de secagem (AE2), por timolftaleína e fenolftaleína, nas metades seccionadas de dois corpos-de-prova de concreto, por caminhão a 63 dias.

Observando-se os resultados quando utilizada a timolftaleína, verificam-se maiores variações entre os resultados, sendo que o concreto do caminhão 4D apresentou maior profundidade de carbonatação neste caso. Para essa idade e esse tipo de condicionamento não foram feitas medidas pelos programas de análise de imagens.

\section{I.2b) Profundidade de carbonatação a 91 dias}

A Tabela 96 e a Tabela 97 apresentam os resultados das medidas médias em faces diametrais partidas de dois corpos-de-prova de $10 \times 20 \mathrm{~cm}$, as médias, o desvio padrão, os valores máximos e mínimos, as amplitudes, o coeficiente de variação e as taxas de carbonatação, para os concretos com cura acelerada de 24/72 horas seguida de cura imersa em água até 7 dias. Os corpos-de-prova originais foram ainda submetidos a três ciclos de 24 horas de imersão em tanque de água seguido por 27 dias de secagem em estufa a $(40 \pm 1)^{\circ} \mathrm{C}$, antes das análises por fenolftaleína. 
TABELA 96 - Resultados do ensaio de resistência à carbonatação por três ciclos de $24 \mathrm{~h}$ de imersão em água e 27 dias de secagem, a 91 dias (AE2) dos concretos do lote analisado, por fenolftaleína - medida linear (Interpretar espessuras de carbonatação em valor inteiro de $\mathrm{mm}$ ).

\begin{tabular}{|c|c|c|c|c|c|c|c|c|c|c|c|c|c|}
\hline \multirow[b]{2}{*}{ 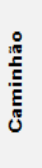 } & \multicolumn{6}{|c|}{ Medidas por amostra } & \multicolumn{7}{|c|}{ Cálculos para o lote } \\
\hline & $\begin{array}{c}\text { Profundidade } \\
\text { de } \\
\text { carbonatação } \\
(\mathrm{mm})\end{array}$ & $\begin{array}{l}\text { Média } \\
(\mathrm{mm})\end{array}$ & $\begin{array}{l}\text { Valor } \\
\text { Máximo } \\
(\mathrm{mm})\end{array}$ & $\begin{array}{l}\text { Valor } \\
\text { Mínimo } \\
(\mathrm{mm})\end{array}$ & $\begin{array}{l}\text { Amplitude } \\
\text { (mm) }\end{array}$ & $\begin{array}{c}\text { Taxa de } \\
\text { carbonatação } \\
\left(\mathrm{mm} / \mathrm{ano}^{-1 / 2}\right)\end{array}$ & Média (mm) & $\begin{array}{c}\text { Desvio } \\
\text { padrão } \\
(\mathrm{mm})\end{array}$ & $\begin{array}{c}\text { Coeficiente } \\
\text { de variação } \\
(\%)\end{array}$ & $\begin{array}{l}\text { Valor } \\
\text { Máximo } \\
(\mathrm{mm})\end{array}$ & $\begin{array}{l}\text { Valor } \\
\text { Mínimo } \\
(\mathrm{mm})\end{array}$ & $\begin{array}{l}\text { Amplitude } \\
(\mathrm{mm})\end{array}$ & $\begin{array}{l}\text { Intervalo de } \\
\text { confiança da } \\
\text { média } 95 \% \\
\text { (mm) }\end{array}$ \\
\hline $1 \mathrm{~A}$ & $\begin{array}{l}2,31 \\
2,62\end{array}$ & 2,47 & 2,62 & 2,31 & 0,31 & 0,26 & & & & & & & \\
\hline $2 \mathrm{~B}$ & $\begin{array}{l}2,42 \\
1,99\end{array}$ & 2,21 & 2,42 & 1,99 & 0,43 & 0,23 & & & & & & & \\
\hline $3 C$ & $\begin{array}{l}2,32 \\
2,71\end{array}$ & 2,52 & 2,71 & 2,32 & 0,39 & 0,26 & & & & & & & \\
\hline 4D & $\begin{array}{l}2,58 \\
2,55\end{array}$ & 2,57 & 2,58 & 2,55 & 0,03 & 0,27 & 2,51 & 0,23 & $9 \%$ & 2,90 & 2,21 & 0,69 & $\pm 0,18$ \\
\hline $5 \mathrm{E}$ & $\begin{array}{l}2,62 \\
2,22\end{array}$ & 2,42 & 2,62 & 2,22 & 0,40 & 0,25 & & & & & & & \\
\hline $6 \mathrm{~F}$ & $\begin{array}{l}2,60 \\
3,19\end{array}$ & 2,90 & 3,19 & 2,60 & 0,59 & 0,30 & & & & & & & \\
\hline
\end{tabular}

TABELA 97- Resultados do ensaio de resistência à carbonatação por três ciclos de $24 \mathrm{~h}$ de imersão em água e 27 dias de secagem, a 91 dias (AE2) dos concretos do lote analisado, por fenolftaleína - medida por Image J (Interpretar espessuras de carbonatação em valor inteiro de $\mathrm{mm}$ ).

\begin{tabular}{|c|c|c|c|c|c|c|c|c|c|c|c|c|c|}
\hline \multirow[b]{2}{*}{ 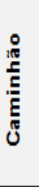 } & \multicolumn{6}{|c|}{ Medidas por amostra } & \multicolumn{7}{|c|}{ Cálculos para o lote } \\
\hline & $\begin{array}{l}\text { Profundidade } \\
\text { de } \\
\text { carbonatação } \\
(\mathrm{mm})\end{array}$ & $\begin{array}{l}\text { Média } \\
(\mathrm{mm})\end{array}$ & $\begin{array}{l}\text { Valor } \\
\text { Máximo } \\
(\mathrm{mm})\end{array}$ & $\begin{array}{l}\text { Valor } \\
\text { Mínimo } \\
(\mathrm{mm})\end{array}$ & $\begin{array}{c}\text { Amplitude } \\
\text { (mm) }\end{array}$ & $\begin{array}{c}\text { Taxa de } \\
\text { carbonatação } \\
\left(\mathrm{mm} / \mathrm{ano}^{-1 / 2}\right)\end{array}$ & Média (mm) & $\begin{array}{c}\text { Desvio } \\
\text { padrão } \\
(\mathrm{mm})\end{array}$ & $\begin{array}{c}\text { Coeficiente } \\
\text { de variação } \\
(\%)\end{array}$ & $\begin{array}{l}\text { Valor } \\
\text { Máximo } \\
(\mathrm{mm})\end{array}$ & $\begin{array}{l}\text { Valor } \\
\text { Mínimo } \\
(\mathrm{mm})\end{array}$ & $\begin{array}{l}\text { Amplitude } \\
\text { (mm) }\end{array}$ & $\begin{array}{c}\text { Intervalo de } \\
\text { confiança da } \\
\text { média 95\% } \\
(\mathrm{mm})\end{array}$ \\
\hline $1 \mathrm{~A}$ & $\begin{array}{l}1,29 \\
1,12\end{array}$ & 1,21 & 1,29 & 1,12 & 0,17 & 0,26 & & & & & & & \\
\hline $2 \mathrm{~B}$ & $\begin{array}{l}1,54 \\
1,29\end{array}$ & 1,41 & 1,54 & 1,29 & 0,25 & 0,27 & & & & & & & \\
\hline $3 C$ & $\begin{array}{l}1,33 \\
1,44\end{array}$ & 1,38 & 1,44 & 1,33 & 0,11 & 0,23 & 1.24 & 0.33 & $27 \%$ & 1,63 & 0.67 & 0.96 & \pm 0.26 \\
\hline 40 & $\begin{array}{l}2,00 \\
1,26\end{array}$ & 1,63 & 2,00 & 1,26 & 0,74 & 0,32 & & & & & & & \\
\hline $5 \mathrm{E}$ & $\begin{array}{l}1,03 \\
0,31\end{array}$ & 0,67 & 1,03 & 0,31 & 0,72 & 0,27 & & & & & & & \\
\hline $6 \mathrm{~F}$ & $\begin{array}{l}1,49 \\
0,76 \\
\end{array}$ & 1,12 & 1,49 & 0,76 & 0,73 & 0,30 & & & & & & & \\
\hline
\end{tabular}

A Tabela 96 apresenta os resultados de profundidade de carbonatação a 91 dias utilizando fenolftaleína, por medidas lineares. A Tabela 97 apresenta os resultados das medidas realizadas pelo programa de análise de imagem Image $\mathrm{J}$. Os resultados com as leituras feitas com Image $\mathrm{J}$ foram menores que as leituras lineares.

Para as medidas lineares, os concretos apresentaram resultados com poucas variações médias, porém obteve-se variabilidade entre os corpos-de-prova de mesmo caminhão, resultando assim valores significativos de amplitude e coeficiente de variação acima de 10\%, como nos resultados dos concretos dos caminhões $2 \mathrm{~B}, 3 \mathrm{C}, 5 \mathrm{E}$ e $6 \mathrm{~F}$.

O concreto do caminhão 2B mostrou menor profundidade média de carbonatação e o concreto do caminhão 6F resultou com maior profundidade e taxa de carbonatação. Para as medidas pelo Image $\mathrm{J}$, o coeficiente de variação obtido com as médias das medidas foi maior que o coeficiente de variação para as medidas médias lineares. A Tabela 96 e Tabela 
97 apresentam também os resultados de taxa de carbonatação a 91 dias para a fenolftaleína, para as medidas lineares e pelo programa Image J.

A Figura 91 apresenta os resultados de profundidade de carbonatação a 91 dias para a fenolftaleína, utilizando medidas lineares e Image $\mathrm{J}$.

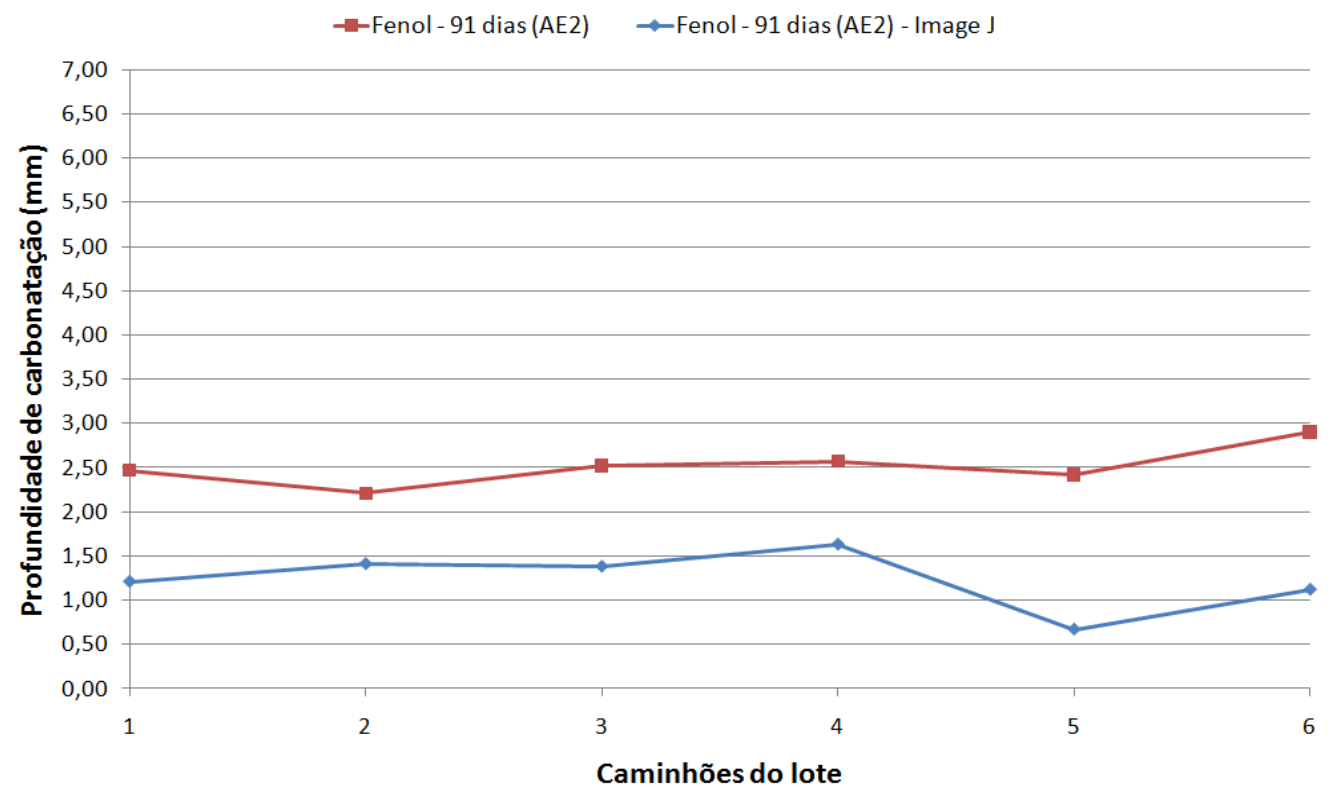

FIGURA 91 - Variação da profundidade de carbonatação média por três ciclos de $24 \mathrm{~h}$ de imersão em água e 27 dias de secagem (AE2), por fenolftaleína, nas metades seccionadas de dois corpos-de-prova de concreto, por caminhão a 91 dias - medida linear e programa Image $\mathrm{J}$.

\section{I.2c) Profundidade de carbonatação a 203 dias}

A Tabela 98 apresenta os resultados das medidas lineares médias em faces diametrais partidas de dois corpos-de-prova de $10 \times 20 \mathrm{~cm}$, as médias, o desvio padrão, os valores máximos e mínimos, as amplitudes, o coeficiente de variação e as taxas de carbonatação, para os concretos com cura acelerada de 24/72 horas seguida de cura imersa em água até 7 dias. Os corpos-de-prova originais foram ainda submetidos a sete ciclos de 24 horas de imersão em tanque de água seguido por 27 dias de secagem em estufa a $(40 \pm 1)^{\circ} \mathrm{C}$, antes das análises por fenolftaleína. Os concretos apresentaram resultados com variações entre as médias, mas sem variabilidade significativa entre os corpos-de-prova de mesmo caminhão, o que pode ser observado pelos baixos valores de amplitude. O concreto do caminhão 5E mostrou menor profundidade média de carbonatação, e o concreto do caminhão 4D resultou com maior profundidade e taxa de carbonatação, com baixa amplitude. 
A Tabela 99 apresenta os resultados das profundidades de carbonatação por medidas de análise de imagem pelo programa Image $J$ e a Tabela 100 apresenta os resultados por análise de imagem pelo programa Leica Qwin. A tabela completa com todas as medidas realizadas consta no Apêndice $B$.

TABELA 98 - Resultados do ensaio de resistência à carbonatação por sete ciclos de $24 \mathrm{~h}$ de imersão em água e 27 dias de secagem, a 203 dias (AE2) dos concretos do lote analisado, por fenolftaleína - medida linear (Interpretar espessuras de carbonatação em valor inteiro de $\mathrm{mm}$ ).

\begin{tabular}{|c|c|c|c|c|c|c|c|c|c|c|c|c|c|}
\hline \multirow[b]{2}{*}{ 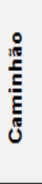 } & \multicolumn{6}{|c|}{ Medidas por amostra } & \multicolumn{7}{|c|}{ Cálculos para o lote } \\
\hline & $\begin{array}{l}\text { Profundidade } \\
\text { de } \\
\text { carbonatação } \\
(\mathrm{mm})\end{array}$ & $\begin{array}{l}\text { Média } \\
(\mathrm{mm})\end{array}$ & $\begin{array}{l}\text { Valor } \\
\text { Máximo } \\
(\mathrm{mm})\end{array}$ & $\begin{array}{l}\text { Valor } \\
\text { Mínimo } \\
(\mathrm{mm})\end{array}$ & $\begin{array}{l}\text { Amplitude } \\
\text { (mm) }\end{array}$ & $\begin{array}{c}\text { Taxa de } \\
\text { carbonataçãa } \\
\left(\mathrm{mm}^{-} \mathrm{ano}^{-1 / 2}\right)\end{array}$ & Média (mm) & $\begin{array}{c}\text { Desvio } \\
\text { padrão } \\
(\mathrm{mm})\end{array}$ & $\begin{array}{c}\text { Coeficiente } \\
\text { de variação } \\
(\%)\end{array}$ & $\begin{array}{l}\text { Valor } \\
\text { Máximo } \\
(\mathrm{mm})\end{array}$ & $\begin{array}{l}\text { Valor } \\
\text { Mínimo } \\
(\mathrm{mm})\end{array}$ & $\begin{array}{l}\text { Amplitude } \\
(\mathrm{mm})\end{array}$ & $\begin{array}{l}\text { Intervalo de } \\
\text { confiança da } \\
\text { média 95\% } \\
(\mathrm{mm})\end{array}$ \\
\hline $1 \mathrm{~A}$ & $\begin{array}{l}3,14 \\
3,56\end{array}$ & 3,35 & 3,56 & 3,14 & 0,42 & 0,24 & \multirow{6}{*}{3,64} & \multirow{6}{*}{0,57} & \multirow{6}{*}{$16 \%$} & \multirow{6}{*}{4,37} & \multirow{6}{*}{2,78} & \multirow{6}{*}{1,59} & \multirow{6}{*}{ $\pm 0,46$} \\
\hline $2 B$ & $\begin{array}{l}4,37 \\
3,53\end{array}$ & 3,95 & 4,37 & 3,53 & 0,84 & 0,28 & & & & & & & \\
\hline $3 C$ & $\begin{array}{l}3,21 \\
3,63\end{array}$ & 3,42 & 3,63 & 3,21 & 0,42 & 0,24 & & & & & & & \\
\hline 4D & $\begin{array}{l}4,27 \\
4,47\end{array}$ & 4,37 & 4,47 & 4,27 & 0,20 & 0,31 & & & & & & & \\
\hline $5 \mathrm{E}$ & $\begin{array}{l}2,63 \\
2,93\end{array}$ & 2,78 & 2,93 & 2,63 & 0,30 & 0,20 & & & & & & & \\
\hline $6 \mathrm{~F}$ & $\begin{array}{l}3,99 \\
4,00\end{array}$ & 4,00 & 4,00 & 3,99 & 0,01 & 0,28 & & & & & & & \\
\hline
\end{tabular}

TABELA 99 - Resultados do ensaio de resistência à carbonatação por sete ciclos de $24 \mathrm{~h}$ de imersão em água e 27 dias de secagem, a 203 dias (AE2) dos concretos do lote analisado, por fenolftaleína - medida por Image J (Interpretar espessuras de carbonatação em valor inteiro de $\mathrm{mm}$ ).

\begin{tabular}{|c|c|c|c|c|c|c|c|c|c|c|c|c|c|}
\hline \multirow{2}{*}{ 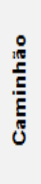 } & \multicolumn{6}{|c|}{ Medidas por amostra } & \multicolumn{7}{|c|}{ Cálculos para o lote } \\
\hline & $\begin{array}{l}\text { Profundidade } \\
\text { de } \\
\text { carbonatação } \\
\text { (mm) }\end{array}$ & $\begin{array}{l}\text { Média } \\
(\mathrm{mm})\end{array}$ & $\begin{array}{l}\text { Valor } \\
\text { Máximo } \\
(\mathrm{mm})\end{array}$ & $\begin{array}{l}\text { Valor } \\
\text { Mínimo } \\
(\mathrm{mm})\end{array}$ & $\begin{array}{c}\text { Amplitude } \\
\text { (mm) }\end{array}$ & $\begin{array}{c}\text { Taxa de } \\
\text { carbonatação } \\
\left(\mathrm{mm} / \mathrm{ano}^{-1 / 2}\right)\end{array}$ & Média (mm) & $\begin{array}{c}\text { Desvio } \\
\text { padrão } \\
\text { (mm) }\end{array}$ & $\begin{array}{c}\text { Coeficiente } \\
\text { de variação } \\
(\%)\end{array}$ & $\begin{array}{l}\text { Valor } \\
\text { Máximo } \\
(\mathrm{mm})\end{array}$ & $\begin{array}{l}\text { Valor } \\
\text { Mínimo } \\
(\mathrm{mm})\end{array}$ & $\begin{array}{l}\text { Amplitude } \\
\text { (mm) }\end{array}$ & $\begin{array}{c}\text { Intervalo de } \\
\text { confiança da } \\
\text { média 95\% } \\
\text { (mm) }\end{array}$ \\
\hline $1 \mathrm{~A}$ & $\begin{array}{l}3,15 \\
3,46\end{array}$ & 3,31 & 3,46 & 3,15 & 0,31 & 0,23 & \multirow{6}{*}{3,57} & \multirow{6}{*}{0,55} & \multirow{6}{*}{$15 \%$} & \multirow{6}{*}{4,39} & \multirow{6}{*}{2,92} & \multirow{6}{*}{1,48} & \multirow{6}{*}{0,44} \\
\hline $2 \mathrm{~B}$ & $\begin{array}{l}3,39 \\
3,17\end{array}$ & 3,28 & 3,39 & 3,17 & 0,22 & 0,23 & & & & & & & \\
\hline $3 C$ & $\begin{array}{l}3,31 \\
3,65\end{array}$ & 3,48 & 3,65 & 3,31 & 0,34 & 0,24 & & & & & & & \\
\hline 40 & $\begin{array}{l}4,19 \\
4,59\end{array}$ & 4,39 & 4,59 & 4,19 & 0,40 & 0,31 & & & & & & & \\
\hline $5 E$ & $\begin{array}{l}3,04 \\
2,79\end{array}$ & 2,92 & 3,04 & 2,79 & 0,25 & 0,20 & & & & & & & \\
\hline $6 \mathrm{~F}$ & $\begin{array}{l}4,14 \\
3,98\end{array}$ & 4,06 & 4,14 & 3,98 & 0,16 & 0,28 & & & & & & & \\
\hline
\end{tabular}


TABELA 100 - Resultados do ensaio de resistência à carbonatação por sete ciclos de 24h de imersão em água e 27 dias de secagem, a 203 dias (AE2) dos concretos do lote analisado, por fenolftaleína - medida por Leica Qwin (Interpretar espessuras de carbonatação em valor inteiro de $\mathrm{mm}$ ).

\begin{tabular}{|c|c|c|c|c|c|c|c|c|c|c|c|c|c|}
\hline \multirow[b]{2}{*}{ 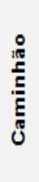 } & \multicolumn{6}{|c|}{ Medidas por amostra } & \multicolumn{7}{|c|}{ Cálculos para o lote } \\
\hline & $\begin{array}{l}\text { Profundidade } \\
\text { de } \\
\text { carbonatação } \\
(\mathrm{mm})\end{array}$ & $\begin{array}{c}\text { Média } \\
(\mathrm{mm})\end{array}$ & $\begin{array}{l}\text { Valor } \\
\text { Máximo } \\
(\mathrm{mm})\end{array}$ & $\begin{array}{l}\text { Valor } \\
\text { Minimo } \\
(\mathrm{mm})\end{array}$ & $\begin{array}{c}\text { Amplitude } \\
\text { (mm) }\end{array}$ & $\begin{array}{c}\text { Taxa de } \\
\text { carbonatação } \\
\left(\mathrm{mm} / \mathrm{ano}^{-1 / 2}\right)\end{array}$ & Média (mm) & $\begin{array}{c}\text { Desvio } \\
\text { padrão } \\
(\mathrm{mm})\end{array}$ & $\begin{array}{c}\text { Coeficiente } \\
\text { de variação } \\
(\%)\end{array}$ & $\begin{array}{l}\text { Valor } \\
\text { Máximo } \\
(\mathrm{mm})\end{array}$ & $\begin{array}{l}\text { Valor } \\
\text { Mínimo } \\
(\mathrm{mm})\end{array}$ & $\begin{array}{c}\text { Amplitude } \\
\text { (mm) }\end{array}$ & $\begin{array}{c}\text { Intervalo de } \\
\text { confiança da } \\
\text { média 95\% } \\
(\mathrm{mm})\end{array}$ \\
\hline $1 \mathrm{~A}$ & $\begin{array}{l}3,93 \\
3,57\end{array}$ & 3,75 & 3,93 & 3,57 & 0,36 & 0,26 & \multirow{6}{*}{4,08} & \multirow{6}{*}{0,51} & \multirow{6}{*}{$13 \%$} & \multirow{6}{*}{4,93} & \multirow{6}{*}{3,69} & \multirow{6}{*}{1,24} & \multirow{6}{*}{ $\pm 0,41$} \\
\hline $2 \mathrm{~B}$ & $\begin{array}{l}3,95 \\
3,86\end{array}$ & 3,91 & 3,95 & 3,86 & 0,09 & 0,27 & & & & & & & \\
\hline $3 C$ & $\begin{array}{l}3,64 \\
3,78\end{array}$ & 3,71 & 3,78 & 3,64 & 0,14 & 0,26 & & & & & & & \\
\hline 40 & $\begin{array}{l}4,77 \\
5,08\end{array}$ & 4,93 & 5,08 & 4,77 & 0,31 & 0,35 & & & & & & & \\
\hline $5 \mathrm{E}$ & $\begin{array}{l}3,72 \\
3,65\end{array}$ & 3,69 & 3,72 & 3,65 & 0,07 & 0,26 & & & & & & & \\
\hline $6 \mathrm{~F}$ & $\begin{array}{l}4,85 \\
4,14\end{array}$ & 4,50 & 4,85 & 4,14 & 0,71 & 0,32 & & & & & & & \\
\hline
\end{tabular}

A Figura 92 ilustra os resultados dos três métodos utilizados para as medidas de profundidade de carbonatação. Os três métodos apresentaram perfil semelhante para os resultados. Para as medidas lineares, os resultados apresentados foram em média iguais às medidas realizadas através do programa Image $\mathrm{J}$, exceto para o concreto do caminhão $2 \mathrm{~B}$, cujo resultado obtido pelo Image $\mathrm{J}$ foi menor.

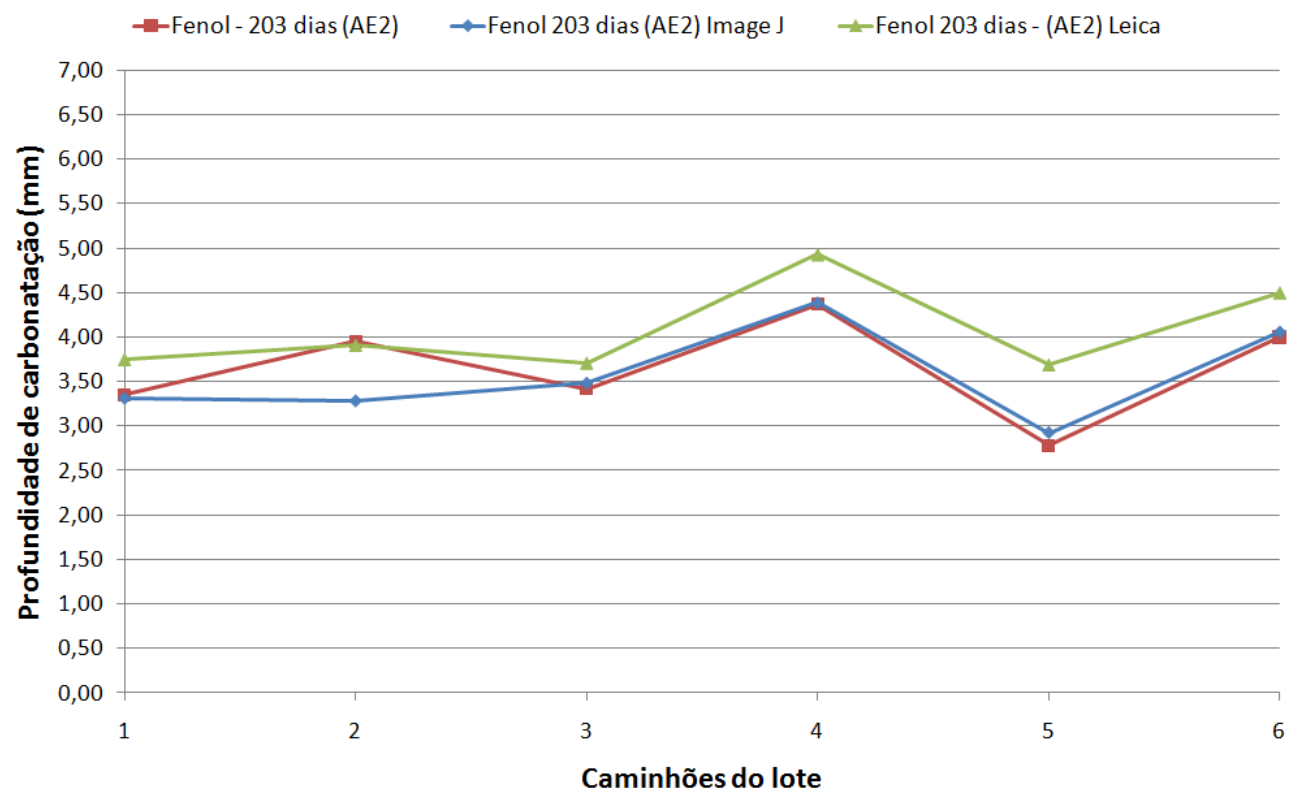

FIGURA 92 - Variação da profundidade de carbonatação média por sete ciclos de $24 \mathrm{~h}$ de imersão em água e 27 dias de secagem (AE2), por fenolftaleína, nas metades seccionadas de dois corpos-de-prova de concreto por caminhão a 203 dias - medida linear, programa Image J e programa Leica Qwin. 
Os resultados apresentados pelas medidas realizadas pelo programa Leica Qwin foram em média maiores que para os outros dois métodos, exceto para o concreto do caminhão 2B, cujo resultado foi aproximadamente igual ao da medida linear.

\section{I.3) Cura acelerada de 24/72 horas seguida por imersão em água até 7 dias e ciclos de 28 dias de secagem contínua (AE3).}

\section{I.3a) Profundidade de carbonatação até 91 dias}

Para as idades de 8, 35, 63 e 91 dias para este tipo de condicionamento, não foi possível obter medidas de profundidade de carbonatação, conforme pode ser verificado em fotos disponíveis no Apêndice $C$.

\section{I.3b) Profundidade de carbonatação a 203 dias}

A Tabela 101 apresenta os resultados das medidas lineares médias em faces diametrais partidas de dois corpos-de-prova de $10 \times 20 \mathrm{~cm}$, as médias, o desvio padrão, os valores máximos e mínimos, as amplitudes, o coeficiente de variação e as taxas de carbonatação, para os concretos com cura acelerada de 24/72 horas seguida de cura imersa em água até 7 dias. Os corpos-de-prova originais foram ainda submetidos a sete ciclos de 28 dias de secagem contínua em estufa a $(40 \pm 1)^{\circ} \mathrm{C}$, antes da análise por fenolftaleína. A Tabela 102 apresenta os resultados das profundidades de carbonatação por medidas de análise de imagem pelo programa Image $\mathrm{J}$, e a Tabela 103 apresenta os resultados por análise de imagem pelo programa Leica Qwin. 
TABELA 101 - Resultados do ensaio de resistência à carbonatação por sete ciclos de 28 dias de secagem contínua, a 203 dias (AE3) dos concretos do lote analisado, por fenolftaleína - medida linear (Interpretar espessuras de carbonatação em valor inteiro de $\mathrm{mm}$ ).

\begin{tabular}{|c|c|c|c|c|c|c|c|c|c|c|c|c|c|}
\hline \multirow[b]{2}{*}{ : } & \multicolumn{6}{|c|}{ Medidas por amostra } & \multicolumn{7}{|c|}{ Cálculos para o lote } \\
\hline & $\begin{array}{c}\text { Profundidade } \\
\text { de } \\
\text { carbonatação } \\
\text { (mm) }\end{array}$ & $\begin{array}{l}\text { Média } \\
(\mathrm{mm})\end{array}$ & $\begin{array}{l}\text { Valor } \\
\text { Máximo } \\
(\mathrm{mm})\end{array}$ & $\begin{array}{c}\text { Valor } \\
\text { Mínimo } \\
(\mathrm{mm})\end{array}$ & $\begin{array}{c}\text { Amplitude } \\
\text { (mm) }\end{array}$ & $\begin{array}{c}\text { Taxa de } \\
\text { carbonatação } \\
\left(\mathrm{mm} / \mathrm{ano}^{-1 / 2}\right)\end{array}$ & Média (mm) & $\begin{array}{c}\text { Desvio } \\
\text { padrão } \\
(\mathrm{mm})\end{array}$ & $\begin{array}{c}\text { Coeficiente } \\
\text { de variação } \\
(\%)\end{array}$ & $\begin{array}{l}\text { Valor } \\
\text { Máximo } \\
(\mathrm{mm})\end{array}$ & $\begin{array}{c}\text { Valor } \\
\text { Mínimo } \\
(\mathrm{mm})\end{array}$ & $\begin{array}{l}\text { Amplitude } \\
\text { (mm) }\end{array}$ & $\begin{array}{l}\text { Intervalo de } \\
\text { confiança da } \\
\text { média 95\% } \\
\text { (mm) }\end{array}$ \\
\hline $1 \mathrm{~A}$ & $\begin{array}{l}4,33 \\
4,08\end{array}$ & 4,21 & 4,33 & 4,08 & 0,25 & 0,29 & & & & & & & \\
\hline $2 B$ & $\begin{array}{l}4,43 \\
4,76\end{array}$ & 4,60 & 4,76 & 4,43 & 0,33 & 0,32 & & & & & & & \\
\hline $3 C$ & $\begin{array}{l}4,26 \\
4,76\end{array}$ & 4,51 & 4,76 & 4,26 & 0,50 & 0,32 & & & & & & & \\
\hline 4D & $\begin{array}{l}5,95 \\
5,52\end{array}$ & 5,74 & 5,95 & 5,52 & 0,43 & 0,40 & 4,66 & 0,58 & $12 \%$ & 5,74 & 4,14 & 1,60 & $\pm 0,46$ \\
\hline $5 \mathrm{E}$ & $\begin{array}{l}3,87 \\
4,41\end{array}$ & 4,14 & 4,41 & 3,87 & 0,54 & 0,29 & & & & & & & \\
\hline $6 \mathrm{~F}$ & $\begin{array}{l}4,81 \\
4,71\end{array}$ & 4,76 & 4,81 & 4,71 & 0,10 & 0,33 & & & & & & & \\
\hline
\end{tabular}

TABELA 102 - Resultados do ensaio de resistência à carbonatação por sete ciclos de 28 dias de secagem contínua, a 203 dias (AE3) dos concretos do lote analisado, por fenolftaleína - medida por Image J (Interpretar espessuras de carbonatação em valor inteiro de $\mathrm{mm}$ ).

\begin{tabular}{|c|c|c|c|c|c|c|c|c|c|c|c|c|c|}
\hline \multirow[b]{2}{*}{ 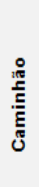 } & \multicolumn{6}{|c|}{ Medidas por amostra } & \multicolumn{7}{|c|}{ Cálculos para o lote } \\
\hline & $\begin{array}{l}\text { Profundidade } \\
\text { de } \\
\text { carbonatação } \\
\text { (mm) }\end{array}$ & $\begin{array}{r}\text { Média } \\
(\mathrm{mm})\end{array}$ & $\begin{array}{l}\text { Valor } \\
\text { Máximo } \\
(\mathrm{mm})\end{array}$ & $\begin{array}{c}\text { Valor } \\
\text { Minimo } \\
(\mathrm{mm})\end{array}$ & $\begin{array}{l}\text { Amplitude } \\
\text { (mm) }\end{array}$ & $\begin{array}{c}\text { Taxa de } \\
\text { carbonatação } \\
\left(\mathrm{mm} / \mathrm{ano}^{-1 / 2}\right)\end{array}$ & Média (mm) & $\begin{array}{c}\text { Desvio } \\
\text { padrão } \\
(\mathrm{mm})\end{array}$ & $\begin{array}{c}\text { Coeficiente } \\
\text { de variação } \\
(\%)\end{array}$ & $\begin{array}{l}\text { Valor } \\
\text { Máximo } \\
(\mathrm{mm})\end{array}$ & $\begin{array}{c}\text { Valor } \\
\text { Mínimo } \\
(\mathrm{mm})\end{array}$ & $\begin{array}{l}\text { Amplitude } \\
\text { (mm) }\end{array}$ & $\begin{array}{l}\text { Intervalo de } \\
\text { confiança da } \\
\text { média 95\% } \\
\text { (mm) }\end{array}$ \\
\hline $1 \mathrm{~A}$ & $\begin{array}{l}3,69 \\
3,13\end{array}$ & 3,41 & 3,69 & 3,13 & 0,56 & 0,24 & & & & & & & \\
\hline $2 B$ & $\begin{array}{l}3,24 \\
4,41\end{array}$ & 3,83 & 4,41 & 3,24 & 1,17 & 0,27 & & & & & & & \\
\hline $3 \mathrm{C}$ & $\begin{array}{l}4,87 \\
4,95\end{array}$ & 4,91 & 4,95 & 4,87 & 0,08 & 0,34 & & & & & & & \\
\hline 4D & $\begin{array}{l}5,74 \\
5,01\end{array}$ & 5,38 & 5,74 & 5,01 & 0,73 & 0,38 & 4,22 & 0,81 & $21 \%$ & 5,38 & 3,21 & 2,17 & $\pm 0,69$ \\
\hline $5 \mathrm{E}$ & $\begin{array}{l}2,86 \\
3,55\end{array}$ & 3,21 & 3,55 & 2,86 & 0,69 & 0,23 & & & & & & & \\
\hline $6 \mathrm{~F}$ & $\begin{array}{l}4,41 \\
4,72\end{array}$ & 4,57 & 4,72 & 4,41 & 0,31 & 0,32 & & & & & & & \\
\hline
\end{tabular}

TABELA 103 - Resultados do ensaio de resistência à carbonatação por sete ciclos de 28 dias de secagem contínua, a 203 dias (AE3) dos concretos do lote analisado, por fenolftaleína - medida por Leica Qwin (Interpretar espessuras de carbonatação em valor inteiro de $\mathrm{mm}$ ).

\begin{tabular}{|c|c|c|c|c|c|c|c|c|c|c|c|c|c|}
\hline \multirow[b]{2}{*}{ 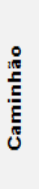 } & \multicolumn{6}{|c|}{ Medidas por amostra } & \multicolumn{7}{|c|}{ Cálculos para o lote } \\
\hline & $\begin{array}{l}\text { Profundidade } \\
\text { de } \\
\text { carbonatação } \\
\text { (mm) }\end{array}$ & $\begin{array}{l}\text { Média } \\
(\mathrm{mm})\end{array}$ & $\begin{array}{l}\text { Valor } \\
\text { Máximo } \\
(\mathrm{mm})\end{array}$ & $\begin{array}{l}\text { Valor } \\
\text { Mínimo } \\
(\mathrm{mm})\end{array}$ & $\begin{array}{l}\text { Amplitude } \\
\text { (mm) }\end{array}$ & $\begin{array}{c}\text { Taxa de } \\
\text { carbonatação } \\
\left(\mathrm{mm} / \mathrm{ano}^{-1 / 2}\right)\end{array}$ & Média (mm) & $\begin{array}{c}\text { Desvio } \\
\text { padrão } \\
(\mathrm{mm})\end{array}$ & $\begin{array}{c}\text { Coeficiente } \\
\text { de variação } \\
(\%)\end{array}$ & $\begin{array}{l}\text { Valor } \\
\text { Máximo } \\
(\mathrm{mm})\end{array}$ & $\begin{array}{l}\text { Valor } \\
\text { Mínimo } \\
(\mathrm{mm})\end{array}$ & $\begin{array}{l}\text { Amplitude } \\
\text { (mm) }\end{array}$ & $\begin{array}{l}\text { Intervalo de } \\
\text { confiança da } \\
\text { média 95\% } \\
\text { (mm) }\end{array}$ \\
\hline $1 \mathrm{~A}$ & $\begin{array}{l}2,70 \\
2,29\end{array}$ & 2,50 & 2,70 & 2,29 & 0,41 & 0,18 & \multirow{6}{*}{5,42} & \multirow{6}{*}{1,98} & \multirow{6}{*}{$37 \%$} & \multirow{6}{*}{7,96} & \multirow{6}{*}{2,50} & \multirow{6}{*}{5,47} & \multirow{6}{*}{ $\pm 1,58$} \\
\hline $2 B$ & $\begin{array}{l}4,59 \\
4,83\end{array}$ & 4,71 & 4,83 & 4,59 & 0,24 & 0,33 & & & & & & & \\
\hline $3 \mathrm{C}$ & $\begin{array}{l}4,85 \\
3,59\end{array}$ & 4,22 & 4,85 & 3,59 & 1,26 & 0,30 & & & & & & & \\
\hline $4 \mathrm{D}$ & $\begin{array}{l}6,96 \\
6,05\end{array}$ & 6,51 & 6,96 & 6,05 & 0,91 & 0,46 & & & & & & & \\
\hline $5 \mathrm{E}$ & $\begin{array}{l}10,74 \\
5,18\end{array}$ & 7,96 & 10,74 & 5,18 & 5,56 & 0,56 & & & & & & & \\
\hline $6 \mathrm{~F}$ & $\begin{array}{l}6,63 \\
6,62\end{array}$ & 6,63 & 6,63 & 6,62 & 0,01 & 0,47 & & & & & & & \\
\hline
\end{tabular}


A Figura 93 ilustra os resultados dos três métodos utilizados para as medidas de profundidade de carbonatação. Para as medidas lineares e medidas por análise de imagem pelo programa Image J, as médias estão próximas e com menores coeficientes de variação quando comparadas às medidas realizadas com o auxílio do programa Leica Qwin. As medidas pelo programa Leica Qwin ficaram discrepantes em relação aos outros dois métodos, para os concretos dos caminhões $5 \mathrm{E}$ e $6 \mathrm{~F}$, tornando assim o coeficiente de variação de suas médias bem superiores aos dos demais métodos.

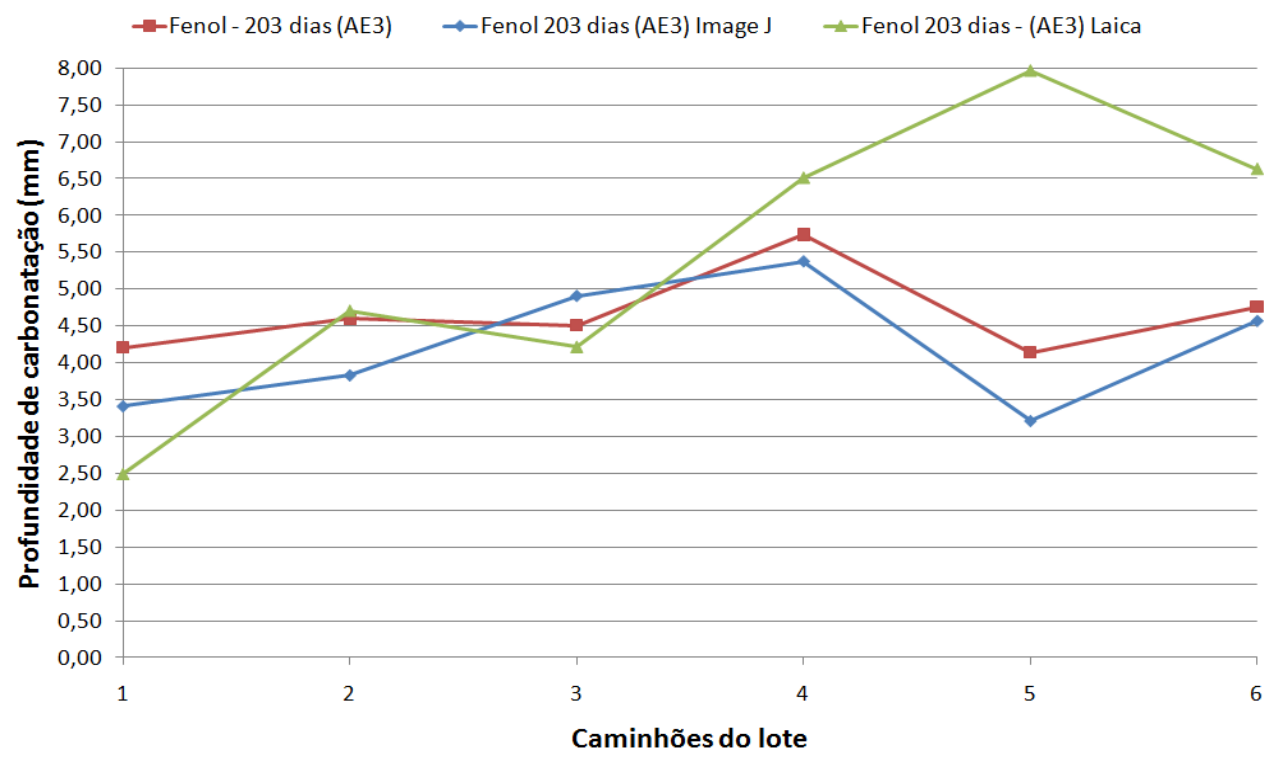

FIGURA 93 - Variação da profundidade de carbonatação média por sete ciclos de 28 dias de secagem contínua a 40C (AE3), por fenolftaleína, nas metades seccionadas de dois corpos-de-prova de concreto por caminhão a 203 dias - medida linear, programa Image J e programa Leica Qwin.

A Figura 94 ilustra os resultados das taxas de carbonatação para as três condições de condicionamento e três metodologias de medidas, por método linear e análise de imagem. 


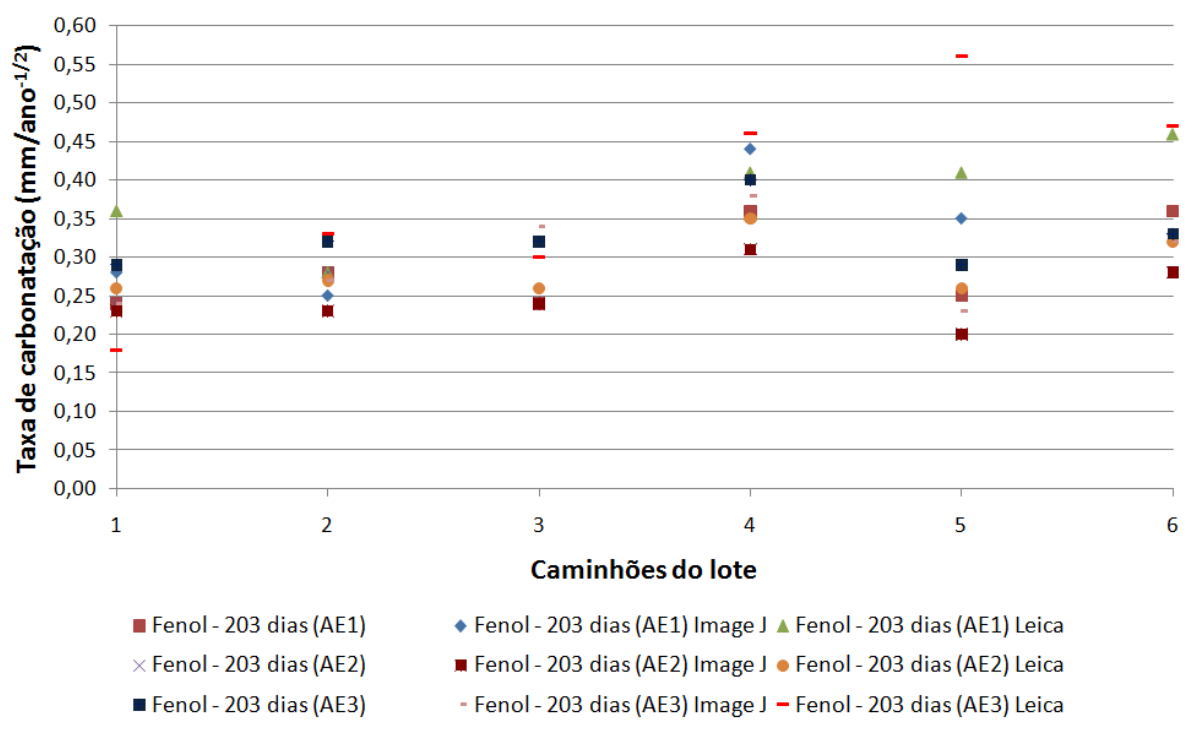

FIGURA 94 - Variação da taxa de carbonatação média para os três tipos de condicionamento, por fenolftaleína, nas metades seccionadas de dois corpos-deprova de concreto por caminhão a 203 dias - medida linear, programa Image J e programa Leica.

\section{I.4) Análise conjunta da profundidade de carbonatação, para todas as idades e condições de envelhecimento acelerado}

Os concretos dos caminhões 4D e 5E são destaques em resultados que diferem dos demais, o primeiro por menor qualidade e o segundo por melhor qualidade de suas propriedades, pois verifica-se comparação análoga entre várias propriedades. O concreto do caminhão 4D mostrou menores resistências à compressão e menores resistências à tração em quase todas as idades ensaiadas, porém não mostrou menores resultados de absorção de água e índice de vazios para a maioria dessas idades e condicionamentos, ficando a cargo do concreto do caminhão $2 \mathrm{~B}$, a obtenção dos menores resultados, Quanto ao concreto do caminhão $5 \mathrm{E}$, foi possível obter comparação das profundidades de carbonatação entre resistência à compressão, resistência à tração, absorção de água e índice de vazios. Este concreto foi referência de bons resultados em todas as propriedades, apesar de apresentar o menor resultado de abatimento na central entre os demais caminhões, fato que também chamou atenção no dia da concretagem.

Quanto ao concreto fresco, o concreto do caminhão 4D mostrou menor valor de teor de ar pelo método pressométrico e menores espessuras compactadas, em ambos os procedimentos, adensado e não adensado. O concreto do caminhão $5 \mathrm{E}$ mostrou maior valor de teor de ar pelo método pressométrico e maiores espessuras compactadas, em ambos os 
procedimentos, adensado e não adensado. O concreto do caminhão 2B, que foi destaque em maiores valores de absorção de água total e índice de vazios, não apresentou nenhum diferencial em suas profundidades de carbonatação, sendo destaque ainda para algumas idades, em boas resistências à compressão e carbonatação. Quanto ao concreto fresco, este concreto apresentou maiores resultados de umidade e teor de finos.

A Tabela 104 ilustra o resumo de todas as idades dos ensaios de profundidade de carbonatação, para os respectivos tipos de condição de envelhecimento acelerado e para os três métodos de leitura de medidas de profundidade por: medidas lineares, medidas por análise de imagem pelos programas Image $\mathrm{J}$ e Leica Qwin. Observa-se que os resultados de profundidade de carbonatação permaneceram próximos a 63 e 91 dias, mesmo para os diferentes métodos de medidas, observando-se um ligeiro aumento desses valores aos 91 dias. Aos 203 dias os resultados apresentados pelos corpos-de-prova expostos a câmara de carbonatação (AE1) estão muito próximos aos resultados dos corpos-de-prova expostos a secagem contínua (AE3), que até 91 dias, não havia apresentado nenhuma frente de carbonatação. 
TABELA 104 - Resultados do ensaio de profundidade de carbonatação nos concretos do lote amostrado, considerando médias de 12 resultados (Interpretar espessuras de carbonatação em valor inteiro de $\mathrm{mm}$ ).

\begin{tabular}{|c|c|c|c|c|c|c|c|c|c|c|c|c|c|c|c|c|}
\hline \multirow[b]{2}{*}{ 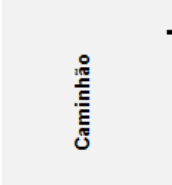 } & \multicolumn{3}{|c|}{63 dias } & \multicolumn{4}{|c|}{91 dias } & \multicolumn{9}{|c|}{203 dias } \\
\hline & $\begin{array}{c}63 \text { dias } \\
\text { Carbonatação } \\
\text { AE1- linear } \\
(\mathrm{mm})\end{array}$ & $\begin{array}{c}63 \text { dias } \\
\text { Carbonatação } \\
\text { AE1- ImageJ } \\
(\mathrm{mm})\end{array}$ & $\begin{array}{c}63 \text { dias } \\
\text { Carbonatação } \\
\text { AE2- linear } \\
(\mathrm{mm})\end{array}$ & $\begin{array}{c}91 \text { dias } \\
\text { Carbonatação } \\
\text { AE1- linear } \\
(\mathrm{mm})\end{array}$ & $\begin{array}{c}91 \text { dias } \\
\text { Carbonatação } \\
\text { AE1- ImageJ } \\
(\mathrm{mm})\end{array}$ & $\begin{array}{c}91 \text { dias } \\
\text { Carbonatação } \\
\text { AE2- linear } \\
(\mathrm{mm})\end{array}$ & $\begin{array}{c}91 \text { dias } \\
\text { Carbonatação } \\
\text { AE2- Image J } \\
(\mathrm{mm})\end{array}$ & $\begin{array}{c}203 \text { dias } \\
\text { Carbonatação } \\
\text { AE1- linear } \\
(\mathrm{mm})\end{array}$ & $\begin{array}{c}203 \text { dias } \\
\text { Carbonatação } \\
\text { AE1- ImageJ } \\
(\mathrm{mm})\end{array}$ & $\begin{array}{c}203 \text { dias } \\
\text { o Carbonatação } \\
\text { AE1- Leica } \\
\text { (mm) }\end{array}$ & $\begin{array}{c}203 \text { dias } \\
\text { o Carbonatação } \\
\text { AE2- linear } \\
\text { (mm) }\end{array}$ & $\begin{array}{c}203 \text { dias } \\
\text { Carbonatação } \\
\text { AE2- ImageJ } \\
(\mathrm{mm})\end{array}$ & $\begin{array}{c}203 \text { dias } \\
\text { Carbonatação } \\
\text { AE2- Leica } \\
(\mathrm{mm})\end{array}$ & $\begin{array}{c}203 \text { dias } \\
\text { o Carbonatação } \\
\text { AE3- linear } \\
\text { (mm) }\end{array}$ & $\begin{array}{c}203 \text { dias } \\
\text { Carbonatação } \\
\text { AE3-ImageJ } \\
\text { (mm) }\end{array}$ & $\begin{array}{c}203 \text { dias } \\
\text { Carbonatação } \\
\text { AE3- Leica } \\
\text { (mm) }\end{array}$ \\
\hline \multirow[t]{2}{*}{$1 \mathrm{~A}$} & 2,49 & 1,68 & 1,88 & 3,07 & 2,26 & 2,31 & 1,29 & 3,38 & 3,96 & 4,32 & 3,14 & 3,15 & 3,93 & 4,33 & 3,69 & 2,70 \\
\hline & 2,72 & 1,70 & 2,07 & 2,46 & 1,82 & 2,62 & 1,12 & 3,38 & 4,09 & 5,93 & 3,56 & 3,46 & 3,57 & 4,08 & 3,13 & 2,29 \\
\hline \multirow[t]{2}{*}{$2 \mathrm{~B}$} & 2,37 & 2,12 & 2,36 & 3,06 & 2,95 & 2,42 & 1,54 & 3,90 & 3,79 & 4,08 & 4,37 & 3,39 & 3,95 & 4,43 & 3,24 & 4,59 \\
\hline & 2,45 & 2,13 & 2,72 & 2,75 & 2,54 & 1,99 & 1,29 & 4,14 & 3,26 & 4,00 & 3,53 & 3,17 & 3,86 & 4,76 & 4,41 & 4,83 \\
\hline \multirow{2}{*}{$3 c$} & 2,69 & 2,32 & 2,10 & 3,19 & 3,33 & 2,32 & 1,33 & 3,82 & 4,16 & 5,75 & 3,21 & 3,31 & 3,64 & 4,26 & 4,87 & 4,85 \\
\hline & 2,62 & 2,10 & 2,76 & 2,65 & 3,41 & 2,71 & 1,44 & 3,28 & 4,91 & 3,49 & 3,63 & 3,65 & 3,78 & 4,76 & 4,95 & 3,59 \\
\hline \multirow{2}{*}{$4 \mathrm{D}$} & 3,01 & 2,49 & 2,01 & 4,15 & 2,75 & 2,58 & 2,00 & 5,29 & 6,66 & 5,49 & 4,27 & 4,19 & 4,77 & 5,95 & 5,74 & 6,96 \\
\hline & 3,41 & 2,67 & 2,74 & 3,80 & 4,12 & 2,55 & 1,26 & 5,11 & 5,88 & 6,21 & 4,47 & 4,59 & 5,08 & 5,52 & 5,01 & 6,05 \\
\hline \multirow{2}{*}{$5 E$} & 2,38 & 2,54 & 1,92 & 2,78 & 2,62 & 2,62 & 1,03 & 3,39 & 5,08 & 5,52 & 2,63 & 3,04 & 3,72 & 3,87 & 2,86 & 10,74 \\
\hline & 2,22 & 2,60 & 2,01 & 2,44 & 2,02 & 2,22 & 0,31 & 3,67 & 4,79 & 6,08 & 2,93 & 2,79 & 3,65 & 4,41 & 3,55 & 5,18 \\
\hline \multirow{2}{*}{$6 \mathrm{~F}$} & 2,81 & 3,25 & 2,60 & 3,44 & 2,85 & 2,60 & 1,49 & 5,17 & 5,24 & 6,42 & 3,99 & 4,14 & 4,85 & 4,81 & 4,41 & 6,63 \\
\hline & 3,04 & 2,86 & 2,45 & 3,35 & 4,16 & 3,19 & 0,76 & 5,22 & 4,05 & 6,68 & 4,00 & 3,98 & 4,14 & 4,71 & 4,72 & 6,62 \\
\hline Média do lote (\%) & 2,7 & 2,4 & 2,3 & 3,1 & 2,9 & 2,5 & 1,2 & 4,1 & 4,7 & 5,3 & 3,6 & 3,6 & 4,1 & 4,7 & 4,2 & 5,4 \\
\hline $\begin{array}{c}\text { Valor máximo } \\
(\%)\end{array}$ & 3,4 & 3,3 & 2,8 & 4,2 & 4,2 & 3,2 & 2,0 & 5,3 & 6,7 & 6,7 & 4,5 & 4,6 & 5,1 & 6,0 & 5,7 & 10,7 \\
\hline Valor mínimo (\%) & 2,2 & 1,7 & 1,9 & 2,4 & 1,8 & 2,0 & 0,3 & 3,3 & 3,3 & 3,5 & 2,6 & 2,8 & 3,6 & 3,9 & 2,9 & 2,3 \\
\hline $\begin{array}{c}\text { Desvio padrão } \\
\quad(\%)\end{array}$ & 0,3 & 0,5 & 0,3 & 0,5 & 0,7 & 0,3 & 0,4 & 0,8 & 1,0 & 1,1 & 0,6 & 0,5 & 0,5 & 0,6 & 0,9 & 2,3 \\
\hline $\begin{array}{l}\text { Coeficientes de } \\
\text { variação (\%) }\end{array}$ & $13 \%$ & $19 \%$ & $15 \%$ & $17 \%$ & $26 \%$ & $12 \%$ & $34 \%$ & $20 \%$ & $21 \%$ & $20 \%$ & $16 \%$ & $15 \%$ & $13 \%$ & $13 \%$ & $21 \%$ & $42 \%$ \\
\hline
\end{tabular}




\section{J) Comparação dos resultados de carbonatação com a predição pelo modelo de Helene (1997)}

Conforme já abordado no item 2.1.4 (E), do Capítulo 2, Helene (1997) propõe a adoção de um ábaco (Figura 15) para representar o seu modelo, e naquele a determinação de cobrimentos de armaduras de estruturas expostas à carbonatação é feita em função da vida útil de projeto desejada, ou seja, do período de passivação das armaduras, também dito período de iniciação da corrosão. Embora o resultado do ábaco seja a espessura de cobrimento, os valores de $\mathrm{k}_{\mathrm{CO} 2}$ podem ser deduzidos para cada tipo de concreto, em função da vida útil de projeto e do cobrimento indicado utilizando-se a equação: $\mathbf{e}=\mathbf{k}_{\mathrm{cO} 2} \sqrt{ } \mathbf{t}$. Os ajustes dos valores de $\mathrm{k}_{\mathrm{CO} 2}$ em função do tipo de concreto estão explicitados no item 2.1.4.

Para este estudo o tipo de cimento utilizado foi CP II E 40, composto por escória de alto forno, utiliza-se para o cálculo de $\mathrm{k}_{\mathrm{CO} 2}$ a equação ajustada abaixo, sendo a previsão original de Helene (1997) feita para carbonatação natural de concretos com cimento Portland comum:

$k_{\mathrm{CO}_{2 A F}}=1,2 \cdot\left(6,7882-0,1131 . f_{c k}\right)$

Onde:

$\mathrm{k}_{\mathrm{CO} 2 \mathrm{AF}}=$ Coeficiente de carbonatação para cimentos de alto forno $\left(\mathrm{mm} / \mathrm{ano}^{1 / 2}\right)$;

$\mathrm{f}_{\mathrm{ck}}=$ Resistência à compressão característica do concreto $(\mathrm{MPa})$.

Então, para o concreto deste estudo, com $\mathrm{f}_{\mathrm{ck}}$ de $30 \mathrm{MPa}$, o valor do coeficiente natural de carbonatação $\left(\boldsymbol{k}_{\mathrm{CO} 2}\right)$ seria igual a $4,1 \mathrm{~mm} / \mathrm{ano}^{1 / 2}$

A Tabela 105 e a Figura 95 apresentam os resultados médios da profundidade de carbonatação e o respectivo cálculo de $\mathrm{k}_{\mathrm{CO} 2}$, considerando para ot (tempo) de 0,55 ano (203 dias). Observar que os resultados estão coerentes, já que a predição de Helene (1997) é para carbonatação natural e, portanto, o valor de $\mathbf{k}$ deveria mesmo ser menor do que os coeficientes calculados em qualquer uma das condições explícitas na Tabela 105.

Foi cogitado também aplicar o programa CARAMBOLA, desenvolvido por Carmona (2005), para confirmar a comparação com os resultados da Tabela 105, porém não foi possível devido à rotina do programa não prever concretos com o cimento utilizado neste estudo, o CP II E 40. 
TABELA 105 - Resultados de $\mathrm{K}_{\mathrm{CO} 2}$ para a espessura média de carbonatação a 203 dias de idade para diferentes condicionamentos e métodos de medida.

\begin{tabular}{|c|c|c|c|c|c|c|c|c|c|}
\hline 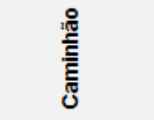 & $\begin{array}{c}203 \text { dias } \\
\text { Carbonatação } \\
\text { AE1- linear } \\
(\mathrm{mm})\end{array}$ & $\begin{array}{c}203 \text { dias } \\
\text { Carbonatação } \\
\text { AE1- ImageJ } \\
(\mathrm{mm})\end{array}$ & $\begin{array}{c}203 \text { dias } \\
\text { Carbonatação } \\
\text { AE1- Leica } \\
(\mathrm{mm})\end{array}$ & $\begin{array}{c}203 \text { dias } \\
\text { Carbonatação } \\
\text { AE2- linear } \\
(\mathrm{mm})\end{array}$ & $\begin{array}{c}203 \text { dias } \\
\text { Carbonatação } \\
\text { AE2- ImageJ } \\
(\mathrm{mm})\end{array}$ & $\begin{array}{c}203 \text { dias } \\
\text { Carbonatação } \\
\text { AE2- Leica } \\
(\mathrm{mm})\end{array}$ & $\begin{array}{c}203 \text { dias } \\
\text { Carbonatação } \\
\text { AE3- linear } \\
(\mathrm{mm})\end{array}$ & $\begin{array}{c}203 \text { dias } \\
\text { Carbonatação } \\
\text { AE3- ImageJ } \\
(\mathrm{mm})\end{array}$ & $\begin{array}{c}203 \text { dias } \\
\text { Carbonatação } \\
\text { AE3- Leica } \\
(\mathrm{mm})\end{array}$ \\
\hline \multirow{2}{*}{$1 \mathrm{~A}$} & 3,38 & 3,96 & 4,32 & 3,14 & 3,15 & 3,93 & 4,33 & 3,69 & 2,70 \\
\hline & 3,38 & 4,09 & 5,93 & 3,56 & 3,46 & 3,57 & 4,08 & 3,13 & 2,29 \\
\hline \multirow{2}{*}{$2 \mathrm{~B}$} & 3,90 & 3,79 & 4,08 & 4,37 & 3,39 & 3,95 & 4,43 & 3,24 & 4,59 \\
\hline & 4,14 & 3,26 & 4,00 & 3,53 & 3,17 & 3,86 & 4,76 & 4,41 & 4,83 \\
\hline \multirow{2}{*}{$3 C$} & 3,82 & 4,16 & 5,75 & 3,21 & 3,31 & 3,64 & 4,26 & 4,87 & 4,85 \\
\hline & 3,28 & 4,91 & 3,49 & 3,63 & 3,65 & 3,78 & 4,76 & 4,95 & 3,59 \\
\hline \multirow{2}{*}{$4 D$} & 5,29 & 6,66 & 5,49 & 4,27 & 4,19 & 4,77 & 5,95 & 5,74 & 6,96 \\
\hline & 5,11 & 5,88 & 6,21 & 4,47 & 4,59 & 5,08 & 5,52 & 5,01 & 6,05 \\
\hline \multirow{2}{*}{$5 E$} & 3,39 & 5,08 & 5,52 & 2,63 & 3,04 & 3,72 & 3,87 & 2,86 & 10,74 \\
\hline & 3,67 & 4,79 & 6,08 & 2,93 & 2,79 & 3,65 & 4,41 & 3,55 & 5,18 \\
\hline \multirow[t]{2}{*}{$6 \mathrm{~F}$} & 5,17 & 5,24 & 6,42 & 3,99 & 4,14 & 4,85 & 4,81 & 4,41 & 6,63 \\
\hline & 5,22 & 4,05 & 6,68 & 4,00 & 3,98 & 4,14 & 4,71 & 4,72 & 6,62 \\
\hline $\begin{array}{l}\text { Média do lote } \\
\qquad(\mathrm{mm})\end{array}$ & 4,1 & 4,7 & 5,3 & 3,6 & 3,6 & 4,1 & 4,7 & 4,2 & 5,4 \\
\hline $\begin{array}{c}\mathrm{KCO}_{2} \\
\left(\mathrm{~mm} / \mathrm{ano}^{1 / 2}\right)\end{array}$ & 5,6 & 6,3 & 7,2 & 4,9 & 4,8 & 5,5 & 6,3 & 5,7 & 7,3 \\
\hline
\end{tabular}

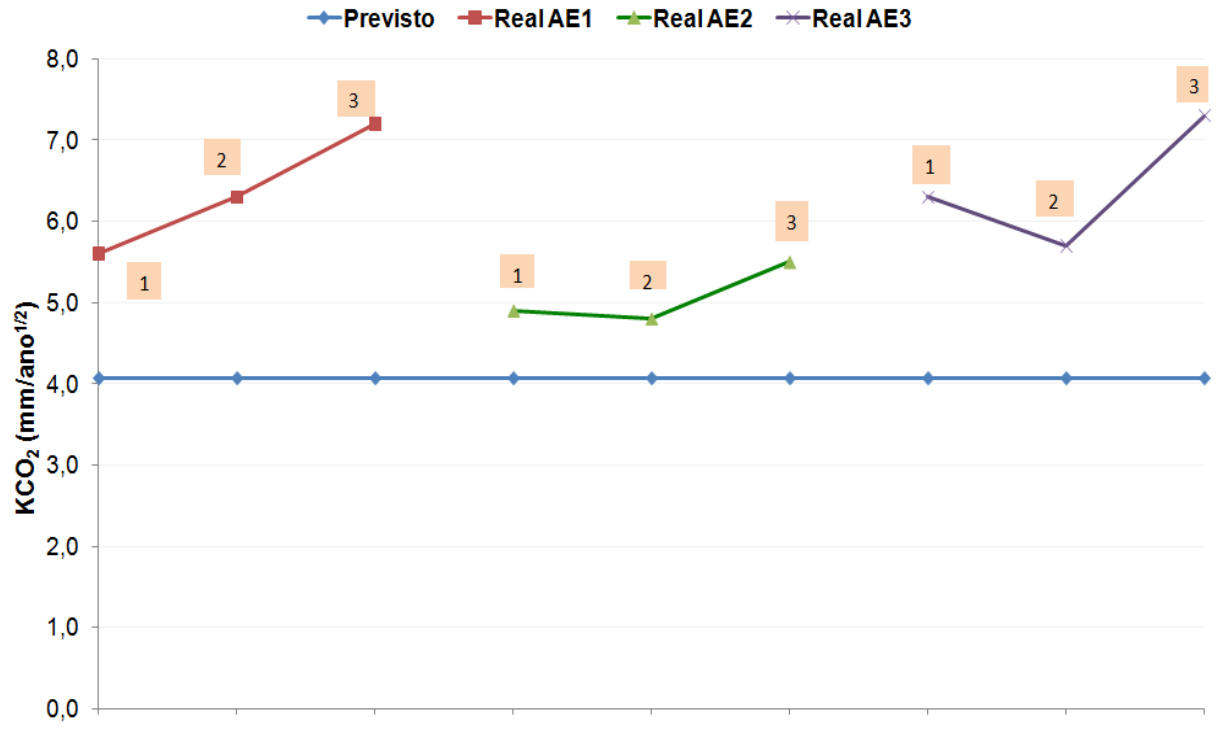

Média do lote

FIGURA 95 - Valores de $\mathbf{k}_{\mathrm{CO} 2}$ calculados para os resultados deste trabalho a 203 dias de idade, sendo (1) medida linear; (2) medida ImageJ e (3) medida Leica Qwin. O valor de $\mathrm{k}_{\mathrm{cO} 2}$ igual a $4,1 \mathrm{~mm} / \mathrm{ano}^{1 / 2}$ é a previsão de Helene (1997) para carbonatação natural de um concreto classe 30 com cimento de alto-forno. 
Os ensaios de módulo de elasticidade foram feitos com duas idades: 91 e 203 dias, para corpos-de-prova que permaneceram em cura normal e por cura acelerada seguida de exposição nas três condições de envelhecimento acelerado, conforme dados e resultados apresentados na Tabela 106.

TABELA 106- Condições e resultados dos ensaios de módulo de elasticidade.

\begin{tabular}{|c|c|c|c|c|c|}
\hline $\begin{array}{l}\text { Idade de } \\
\text { ensaio }\end{array}$ & $\begin{array}{l}\text { Caminhão } \\
\text { amostrado }\end{array}$ & Tipo de cura e condicionamento & $\begin{array}{l}\text { Corpo-de- } \\
\text { prova }\end{array}$ & $\begin{array}{l}\text { Módulo de } \\
\text { Elasticidade } \\
\text { para } \sim \sigma_{\mathrm{a}} \\
30 \%(\mathrm{GPa})\end{array}$ & $\begin{array}{l}\text { Módulo de } \\
\text { Elasticidade } \\
\text { para } 10 \% \text { - } \\
30 \%(\mathrm{GPa})\end{array}$ \\
\hline \multirow{5}{*}{91 dias } & \multirow{8}{*}{$\mathrm{F}$} & \begin{tabular}{|c|} 
Cura acelerada de $24 / 72 \mathrm{~h}$ a $35+3$ \\
${ }^{\circ} \mathrm{C}$ seguida de cura imersa em \\
tanque saturado de cal até 7 dias, e \\
cura normal de 7 a 91 dias. \\
\end{tabular} & $\begin{array}{l}35 \\
36\end{array}$ & $\begin{array}{l}40,0 \\
39,0\end{array}$ & $\begin{array}{l}38,0 \\
38,0\end{array}$ \\
\hline & & Cura úmida normal de $24 \mathrm{~h}$ a 91 dias & $\begin{array}{l}39 \\
40\end{array}$ & $\begin{array}{l}41,0 \\
40,0\end{array}$ & $\begin{array}{l}40,0 \\
38,0\end{array}$ \\
\hline & & $\begin{array}{c}\text { Cura acelerada / Ciclagem por } \\
\text { secagem alternada com } 24 \mathrm{~h} \text { CO2 } \\
\text { (AE1) }\end{array}$ & $\begin{array}{l}49 \\
50\end{array}$ & $\begin{array}{l}37,0 \\
31,0\end{array}$ & $\begin{array}{l}34,0 \\
29,0\end{array}$ \\
\hline & & $\begin{array}{c}\text { Cura acelerada / Ciclagem por } \\
\text { secagem alternada com } 24 \mathrm{~h} \text { imerso } \\
\text { água (AE2) }\end{array}$ & $\begin{array}{l}61 \\
62\end{array}$ & $\begin{array}{l}34,0 \\
35,0\end{array}$ & $\begin{array}{l}34,0 \\
34,0\end{array}$ \\
\hline & & $\begin{array}{l}\text { Cura acelerada / Ciclagem por } \\
\text { secagem contínua (AE3) }\end{array}$ & $\begin{array}{l}73 \\
74\end{array}$ & $\begin{array}{l}35,0 \\
35,0\end{array}$ & $\begin{array}{l}33,0 \\
33,0\end{array}$ \\
\hline \multirow{3}{*}{203 dias } & & $\begin{array}{c}\text { Cura acelerada / Ciclagem por } \\
\text { secagem alternada com } 24 \mathrm{~h} \text { CO2 } \\
\text { (AE1) }\end{array}$ & 55 & $\begin{array}{l}38,0 \\
36,0\end{array}$ & $\begin{array}{l}36,0 \\
30,0\end{array}$ \\
\hline & & $\begin{array}{c}\text { Cura acelerada / Ciclagem por } \\
\text { secagem alternada com } 24 \mathrm{~h} \text { imerso } \\
\text { água (AE2) }\end{array}$ & $\begin{array}{l}67 \\
68\end{array}$ & $\begin{array}{l}39,0 \\
38,0\end{array}$ & $\begin{array}{l}35,0 \\
37,0\end{array}$ \\
\hline & & $\begin{array}{l}\text { Cura acelerada / Ciclagem por } \\
\text { secagem contínua (AE3) }\end{array}$ & $\begin{array}{l}79 \\
80\end{array}$ & $\begin{array}{l}36,0 \\
39,0\end{array}$ & $\begin{array}{l}34,0 \\
36,0\end{array}$ \\
\hline
\end{tabular}

O módulo de elasticidade aumentou conforme a idade, para os corpos-de-prova submetidos à cura e envelhecimento acelerados. O módulo para os corpos-de-prova 39, 40 e 35, 36 com cura úmida normal de $24 \mathrm{~h}$ a 91 dias e com cura acelerada inicial seguida de 
imersão até 91 dias, respectivamente, mas sem envelhecimento acelerado, resultou cerca de $10 \%$ maior que os demais dentro da mesma idade de ensaio (91 dias), o que poderia ser esperado, mas caberia ser confirmado e melhor interpretado.

A Figura 96 ilustra a curva de tensão-deformação para os corpos-de-prova ensaiados a 91 dias. A Figura 126 ilustra a curva de tensão-deformação para os corpos-de-prova ensaiados a 203 dias.

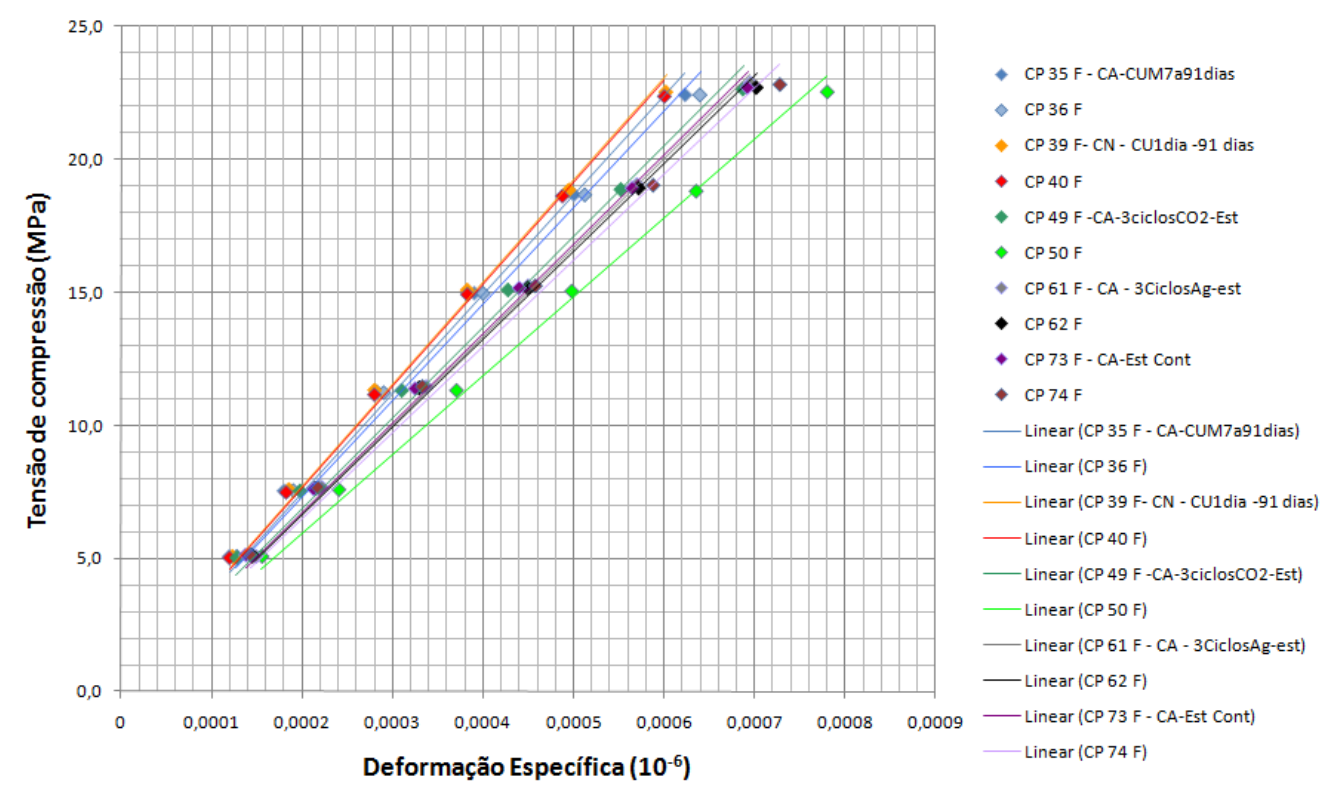

FIGURA 96 - Curva tensão-deformação para os corpos-de-prova ensaiados a 91 dias.

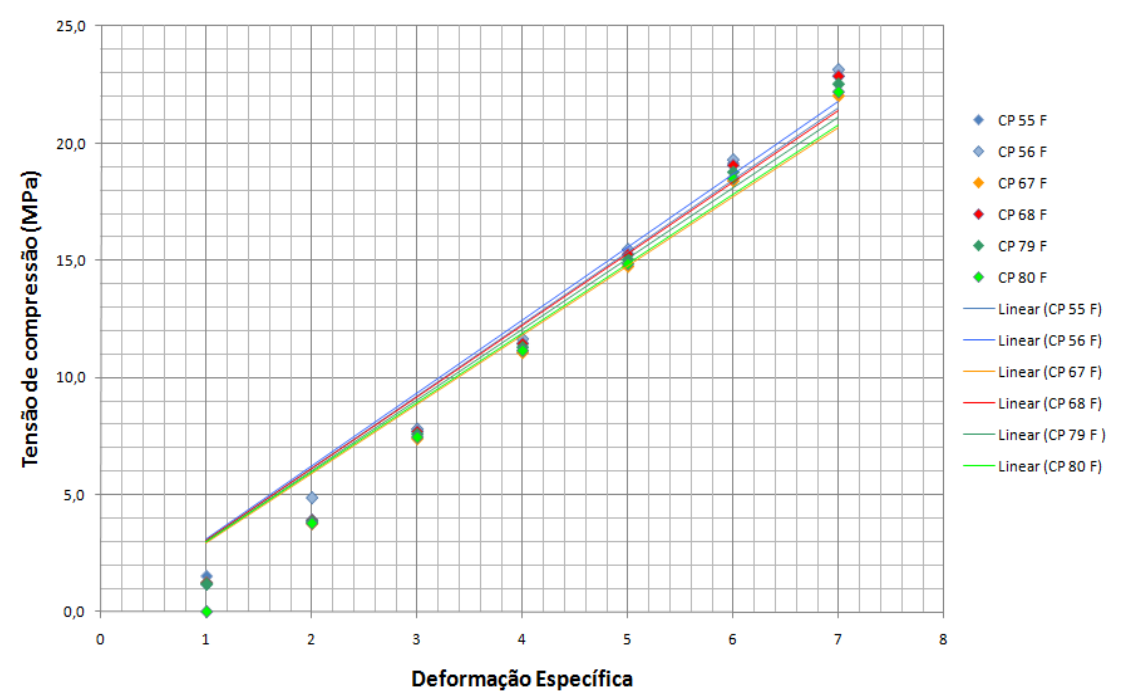

FIGURA 97 - Curva tensão-deformação para os corpos-de-prova ensaiados a 203 dias. 


\section{M) Ultrassom}

Os ensaios de ultrassom foram úteis para a comparação do grau de umidade interna dos corpos-de-prova, pois se observa que aqueles submetidos à condição de envelhecimento acelerado por secagem contínua apresentaram as menores velocidades de propagação, para sete das oito idades e ciclos comparados na Figura 98, ou seja, como estes corpos-de-prova estavam mais secos, as ondas atravessavam mais lentamente a massa analisada. Já na comparação entre os grupos com $24 \mathrm{~h}$ de molhagem ou $24 \mathrm{~h}$ de exposição à câmara de $\mathrm{CO}_{2}$, alternados com 27 dias de secagem, a umidade diminuiu de modo mais lento para o grupo ciclado em água, como ilustra a Figura 98 e em geral o ponto central dos corpos-de-prova deste grupo proporcionou uma velocidade do ultrassom ligeiramente maior, como ilustra a Figura 99, de modo coerente e esperado.

É interessante observar que a partir de 6 ciclos (175 dias) houve uma tendência geral nos três grupos à redução da velocidade do ultrassom, podendo ser isto causado pela influência das leituras dos quatro pontos periféricos, em cada corpo-de-prova, e pelas alterações decorrentes da secagem, na sua microestrutura, muito similar nas três condições, ficando difícil concluir sobre a influência da carbonatação além do comentário que segue.

Não houve aparente relação da velocidade do ultrassom com o grau de saturação estimado para cada tipo de ciclagem, conforme apresentado no item 4.1.2.2. Isto pode ser indicativo de que a propagação das ondas se dá preferencialmente por meso e microporos do concreto, possivelmente, os mais afetados pela secagem e carbonatação periférica dos quatro pontos indicados nas Figura 99 e Figura 100. A maior influência da ciclagem tipo AE2, que envolveu imersão em água por $24 \mathrm{~h}$, alternada com 27 dias de secagem, apenas se manifestou no ponto central dos seus corpos-de-prova (ver Figura 99 e Figura 100). 


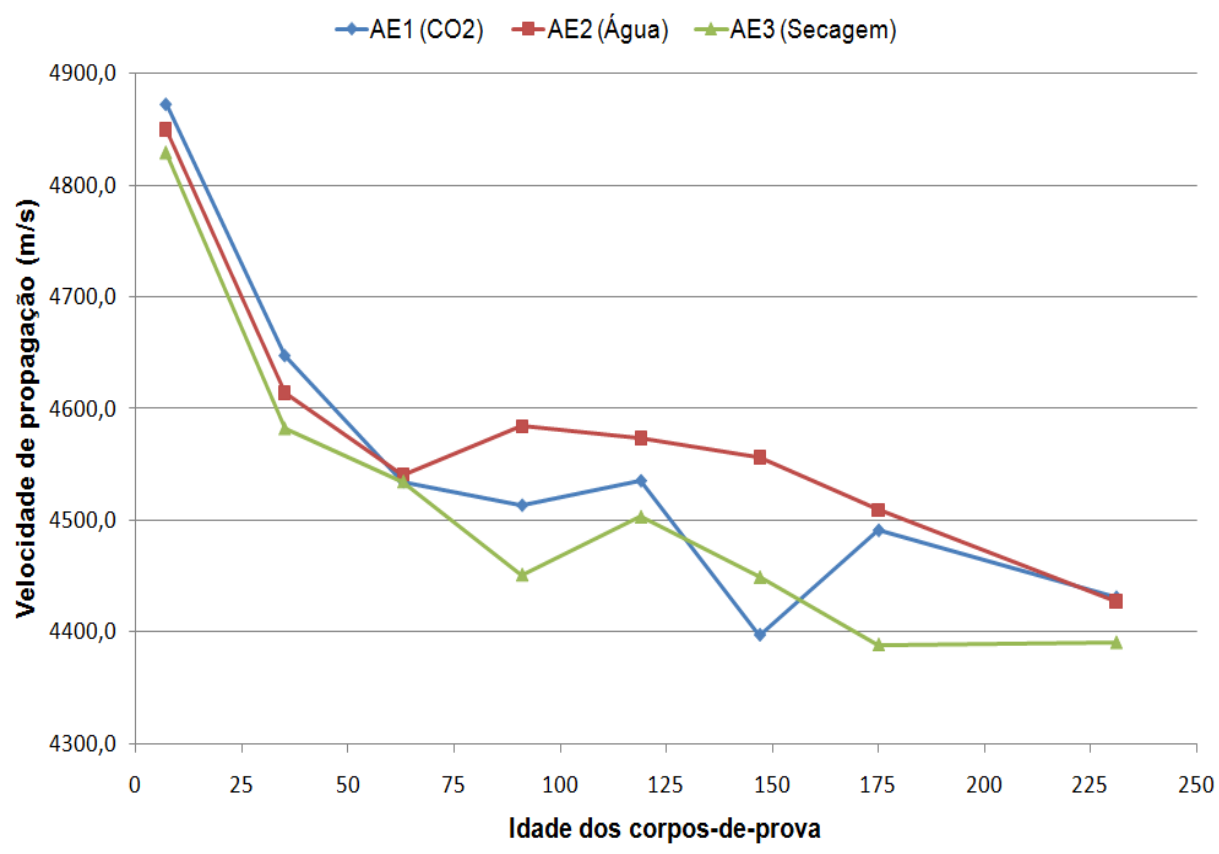

FIGURA 98 - Variação da velocidade média de ultra-som com a idade de ensaio e tipo de condição de envelhecimento acelerado, para velocidade com 5 pontos, que inclui 0 ponto central do corpo-de-prova.

Em resumo, a análise das Figuras 99, 100 e 101 permite destacar que:

- a velocidade do ultrassom tende a estabilizar com a constância da massa, pela secagem, e o efeito da umidade sobre a velocidade da onda ultrassônica parece até aqui ser muito maior do que o dito refinamento dos poros pela carbonatação. Mas, é necessário prosseguir os ciclos para aumentar a profundidade de carbonatação até alcançar pelo menos o diâmetro dos transdutores do ultrassom;

- uma vez confirmado que a influência da umidade na velocidade da onda ultrassônica é superior ao efeito da carbonatação, isto pode exigir a extração de testemunhos específicos do concreto de uma estrutura, em casos de mapeamento específico dessas variáveis;

- a secagem contínua do concreto levou a diferentes taxas de variação da velocidade da onda ultrassônica nos pontos periféricos e no central dos corpos-de-prova, sendo isto bem evidenciado pelas relações destacadas na Figura 100. A igualdade de velocidade para as idades mais avançadas, como 175 dias, pode ser indicativa de um melhor equilíbrio interno de umidade, o que precisaria ser confirmado por leituras em idades mais avançadas ainda. 


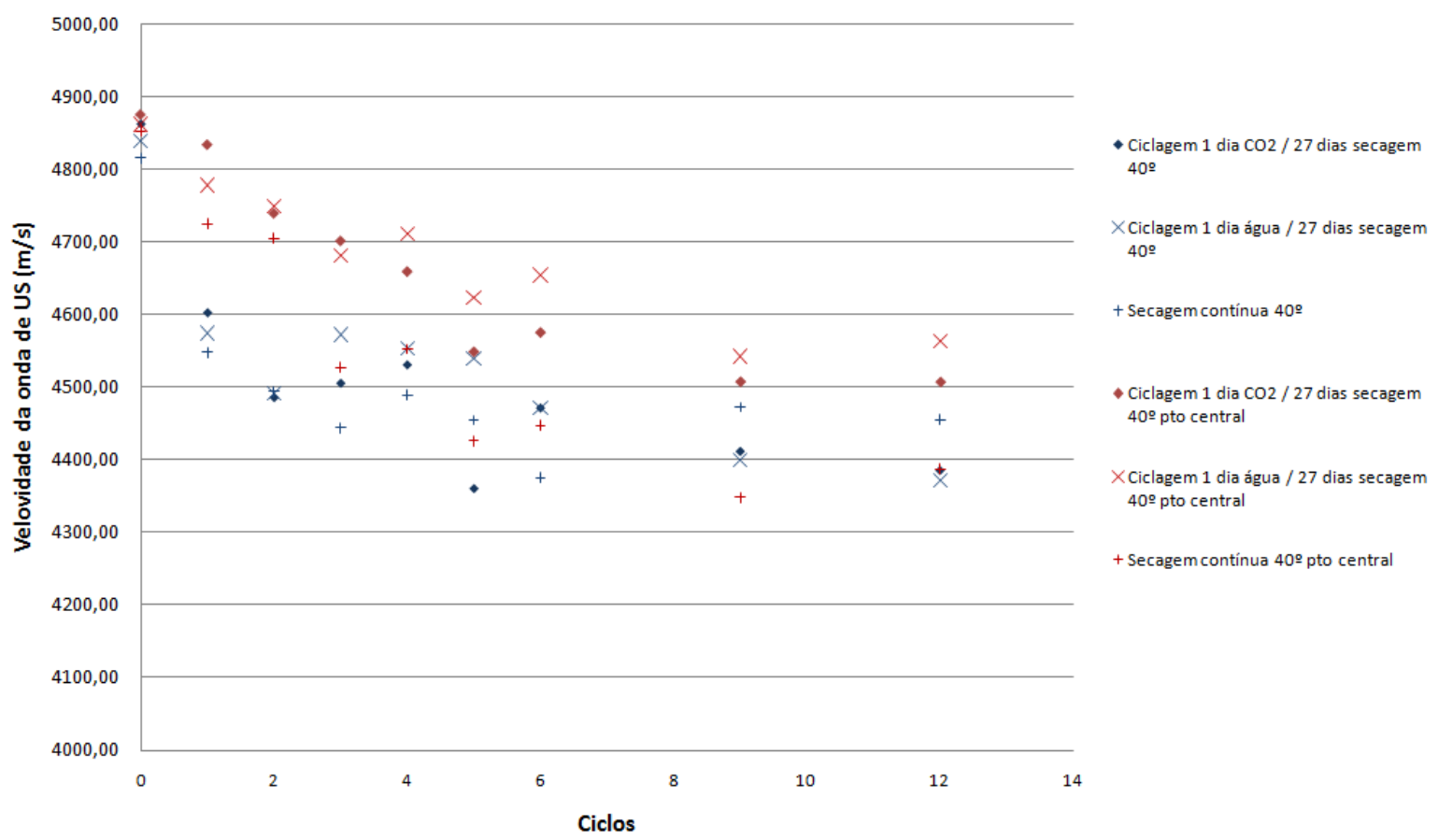

FIGURA 99 - Comparação da velocidade de propagação da onda ultrassônica no ponto central com os 4 periféricos em função do número de ciclos, para cada ambiente de envelhecimento acelerado, sempre antes do $1^{\circ}$ dia do ciclo.

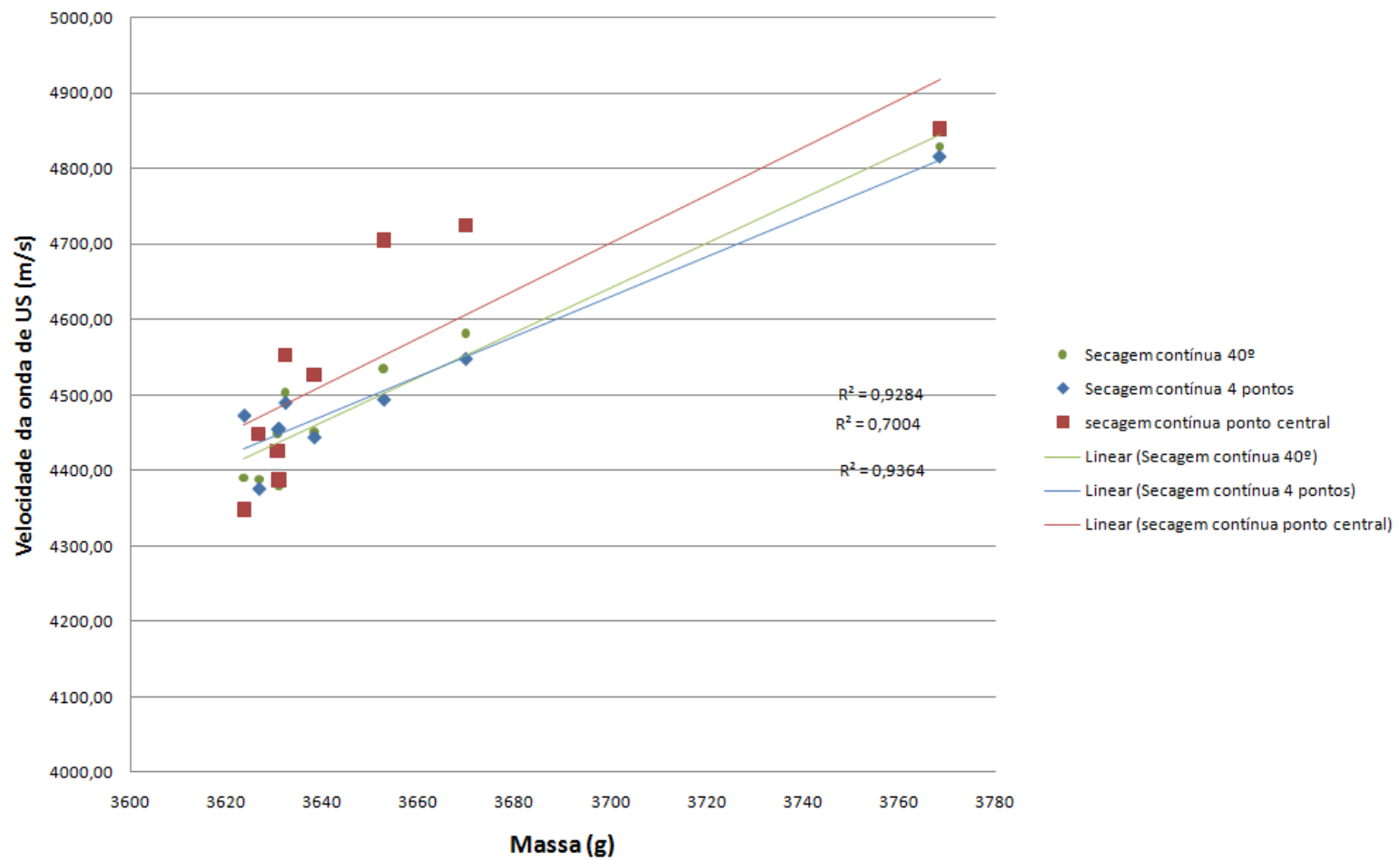

FIGURA 100 - Comparação da velocidade de propagação da onda ultrassônica de cada CP em função da massa, para o ambiente de secagem contínua (AE3). 


\subsection{Análises Estatísticas}

Os resultados do programa experimental apresentados no item 4.1 foram submetidos a algumas análises estatísticas, de modo análogo e com alguns estudos complementares em relação às sugestões do CEA - IME, USP em Cavalcanti Filho (2010)

\subsubsection{Correlações entre as propriedades}

A partir da teoria de associação entre variáveis quantitativas e fazendo uso do programa Minitab, versão 15, inicialmente foi elaborada uma matriz de correlações lineares. As correlações foram feitas entre as propriedades medidas para as amostras de concreto dos seis caminhões de concreto analisados, cabendo destacar que este pequeno número de observações do lote restringe conclusões e a análise aqui é específica ao estudo de caso. As correlações são interpretadas pelos coeficientes de Pearson e podem ser identificadas conforme a Tabela 107.

TABELA 107 - Interpretação das correlações lineares entre as propriedades medidas.

\begin{tabular}{|ll|l|}
\hline \multicolumn{2}{|c|}{ Coeficiente de Pearson } & \multicolumn{1}{c|}{$\begin{array}{c}\text { Então } \\
\text { correlação é: }\end{array}$} \\
\hline maior que & $|0,75|$ & Forte \\
\hline entre & $|0,5|$ e $|0,75|$ & Razoável \\
\hline menor & $|0,5|$ & Fraca \\
\hline
\end{tabular}

Os itens a seguir destacam separadamente as melhores correlações obtidas e que poderiam ser classificadas como fortes a razoáveis, para os ensaios de carbonatação, em relação a todas às demais propriedades caracterizadas, no estado fresco e endurecido, para os concretos dos seis caminhões do lote.

\section{A) Estudo da matriz de correlações das propriedades analisadas em relação às medidas de profundidade de carbonatação}

Para a interpretação dos resultados de correlações neste item, segue a legenda das descrições das condições de exposição, na Tabela 108 e Figura 101, para melhor 
entendimento das matrizes de correlações resumidas em seqüência a partir da matriz principal no Apêndice E.

TABELA 108 - Descrição da legenda, conforme Figura 101.

\begin{tabular}{|c|c|c|}
\hline PROPRIEDADE & MEDIDA & DESCRIÇÃO DAS CONDIÇÕES DE EXPOSIÇÃO \\
\hline Carb $63 \mathrm{CO} 2 \mathrm{~T}(\mathrm{~mm})$ & & $\begin{array}{l}\text { Profundidade de carbonatação a } 63 \text { dias de idade por } 2 \text { ciclos de exposição a } 24 \mathrm{~h} \text { de } \mathrm{CO}_{2} \\
-5 \% \text { e } 27 \text { dias secagem forçada a } 40 \pm 1^{\circ} \mathrm{C} \text { (medidas por solução de timol). }\end{array}$ \\
\hline Carb $63 \mathrm{CO} 2 \mathrm{~F}(\mathrm{~mm})$ & & $\begin{array}{l}\text { Profundidade de carbonatação a } 63 \text { dias de idade por } 2 \text { ciclos de exposição a } 24 \mathrm{~h} \text { de } \mathrm{CO}_{2} \\
-5 \% \text { e } 27 \text { dias secagem forçada a } 40 \pm 1^{\circ} \mathrm{C} \text { (medidas por solução de fenol). }\end{array}$ \\
\hline Carb $63 \mathrm{H} 2 \mathrm{O}$ T(mm & & $\begin{array}{l}\text { Profundidade de carbonatação a } 63 \text { dias de idade por } 2 \text { ciclos de } 24 \mathrm{~h} \text { de imersão em } \\
\text { tanque de água e } 27 \text { dias de secagem forçada a } 40 \pm 1^{\circ} \mathrm{C} \text { (medidas por solução de timol). }\end{array}$ \\
\hline Carb 63 H2O (mm) & 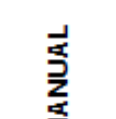 & $\begin{array}{l}\text { Profundidade de carbonatação a } 63 \text { dias de idade por } 2 \text { ciclos de } 24 \mathrm{~h} \text { de imersão em } \\
\text { tanque de água seguido e } 27 \text { dias de secagem forçada a } 40 \pm 1^{\circ} \mathrm{C} \text { (medidas por solução } \\
\text { de fenol). }\end{array}$ \\
\hline Carb $91 \mathrm{CO} 2(\mathrm{~mm})$ & $\underset{\underline{\alpha}}{\underline{\alpha}}$ & $\begin{array}{l}\text { Profundidade de carbonatação a } 91 \text { dias de idade por } 3 \text { ciclos de exposição a } 24 \mathrm{~h} \text { de } \mathrm{CO}_{2} \\
-5 \% \text { e } 27 \text { dias secagem forçada a } 40 \pm 1{ }^{\circ} \mathrm{C} \text { (medidas por solução de fenol) }\end{array}$ \\
\hline Carb 91 H2O (mm) & & $\begin{array}{l}\text { Profundidade de carbonatação a } 91 \text { dias de idade por } 3 \text { ciclos de } 24 \mathrm{~h} \text { de imersão em } \\
\text { tanque de água e } 27 \text { dias de secagem forçada a } 40 \pm 1^{\circ} \mathrm{C} \text { (medidas por solução de fenol) }\end{array}$ \\
\hline Carb $203 \mathrm{CO} 2(\mathrm{~mm})$ & & $\begin{array}{l}\text { Profundidade de carbonatação a } 203 \text { dias de idade por } 7 \text { ciclos de exposição a } 24 \mathrm{~h} \text { de } \mathrm{CO}_{2} \\
-5 \% \text { e } 27 \text { dias secagem forçada a } 40 \pm 1^{\circ} \mathrm{C} \text { (medidas por solução de fenol). }\end{array}$ \\
\hline Carb 203 H2O (mm) & & $\begin{array}{l}\text { Profundidade de carbonatação a } 203 \text { dias de idade por } 7 \text { ciclos de } 24 \mathrm{~h} \text { de imersão em } \\
\text { tanque de água e } 27 \text { dias de secagem forçada a } 40 \pm 1^{\circ} \mathrm{C} \text { (medidas por solução de fenol) }\end{array}$ \\
\hline Carb 203 SEC (mm) & & $\begin{array}{l}\text { Profundidade de carbonatação a } 203 \text { dias de idade por } 7 \text { ciclos de } 28 \text { dias de secagem } \\
\text { contínua forçada a } 40 \pm 1^{\circ} \mathrm{C} \text { (medidas por solução de fenol) }\end{array}$ \\
\hline IMJ C02 63 (\%) & & $\begin{array}{l}\text { Profundidade de carbonatação a } 63 \text { dias de idade por } 2 \text { ciclos de exposição a } 24 \mathrm{~h} \text { de } \mathrm{CO}_{2} \\
-5 \% \text { e } 27 \text { dias secagem forçada a } 40 \pm 1{ }^{\circ} \mathrm{C} \text { (medidas de área pelo software Image J). }\end{array}$ \\
\hline IMJ C02 91(\%) & & $\begin{array}{l}\text { Profundidade de carbonatação a } 91 \text { dias de idade por } 3 \text { ciclos de exposição a } 24 \mathrm{~h} \text { de } \mathrm{CO}_{2} \\
-5 \% \text { e } 27 \text { dias secagem forçada a } 40 \pm 1^{\circ} \mathrm{C} \text { (medidas de área pelo software Image } \mathrm{J} \text { ). }\end{array}$ \\
\hline IMJ H20 91 (\%) & 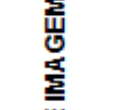 & $\begin{array}{l}\text { Profundidade de carbonatação a } 91 \text { dias de idade por } 3 \text { ciclos de } 24 \mathrm{~h} \text { de imersão em } \\
\text { água e } 27 \text { dias de secagem forçada a } 40 \pm 1{ }^{\circ} \mathrm{C} \text { (medidas de área pelo software Image } \mathrm{J} \text { ). }\end{array}$ \\
\hline LC CO2 $203(\%)$ & 崖 & $\begin{array}{l}\text { Profundidade de carbonatação a } 203 \text { dias de idade por } 7 \text { ciclos de exposição a } 24 \mathrm{~h} \text { de } \mathrm{CO}_{2} \\
-5 \% \text { e } 27 \text { dias secagem forçada a } 40 \pm 1{ }^{\circ} \mathrm{C} \text { (medidas de área pelo software Leica Qwin). }\end{array}$ \\
\hline IMJ CO2 203 (\%) & 萦 & $\begin{array}{l}\text { Profundidade de carbonatação a } 203 \text { dias de idade por } 7 \text { ciclos de exposição a } 24 \mathrm{~h} \text { de } \mathrm{CO}_{2} \\
-5 \% \text { e } 27 \text { dias secagem forçada a } 40 \pm 1{ }^{\circ} \mathrm{C} \text { (medidas de área pelo software Image J). }\end{array}$ \\
\hline LC H20 $203(\%)$ & $\frac{5}{\frac{5}{5}}$ & $\begin{array}{l}\text { Profundidade de carbonatação a } 203 \text { dias de idade por } 7 \text { ciclos de } 24 \mathrm{~h} \text { de imersão em } \\
\text { água e } 27 \text { dias de secagem forçada a } 40 \pm 1^{\circ} \mathrm{C} \text { (medidas de área pelo software Leica } \\
\text { Qwin). }\end{array}$ \\
\hline IMJ H2O 203 (\%) & $\alpha$ & $\begin{array}{l}\text { Profundidade de carbonatação a } 203 \text { dias de idade por } 7 \text { ciclos de } 24 \mathrm{~h} \text { de imersão em } \\
\text { água e } 27 \text { dias de secagem forçada a } 40 \pm 1{ }^{\circ} \mathrm{C} \text { (medidas de área pelo software Image J). }\end{array}$ \\
\hline LC SEC 203(\%) & & $\begin{array}{l}\text { Profundidade de carbonatação a } 203 \text { dias de idade por } 7 \text { ciclos de } 28 \text { dias de secagem } \\
\text { contínua forçada a } 40 \pm 1^{\circ} \mathrm{C} \text { (medidas de área pelo software Leica Qwin). }\end{array}$ \\
\hline IMJ SEC 203(\%) & & $\begin{array}{l}\text { Profundidade de carbonatação a } 203 \text { dias de idade por } 7 \text { ciclos de } 28 \text { dias de secagem } \\
\text { contínua forçada a } 40 \pm 1^{\circ} \mathrm{C} \text { (medidas de área pelo software Image } \mathrm{J} \text { ). }\end{array}$ \\
\hline
\end{tabular}


As legendas seguiram o seguinte exemplo da Figura 101, e ainda a letra T, que vai aparecer ao final da legenda em algumas tabelas, indica para a medida manual as medidas encontradas utilizando solução de timolftaleína para 63 dias, enquanto todas as demais medidas foram realizadas com fenolftaleína.

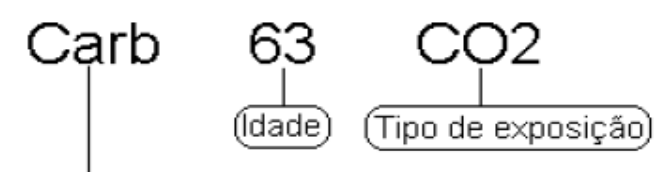

Método de medida da carbonataçẫo
em área relativa:
Carb:Medida manual linear.
IMJ: Medida pelo software ImageJ
LC: Medida pelo software Leica

FIGURA 101 - Legenda das descrições das condições de exposição, nas tabelas de correlação das propriedades.

\section{A.1) Concreto Fresco}

As correlações encontradas entre as propriedades analisadas no concreto fresco e os resultados de profundidade de carbonatação estão apresentadas na Tabela 109.

TABELA 109 - Correlações entre as propriedades no estado fresco e resultados de medidas de profundidade de carbonatação.

\begin{tabular}{|c|c|c|c|c|c|c|c|c|c|c|c|}
\hline Item & Medida & PROPRIEDADE & $\begin{array}{c}\text { Slump na } \\
\text { Central } \\
\text { (cm) }\end{array}$ & $\begin{array}{l}\text { Slump na } \\
\text { Obra } \\
\text { (cm) } \\
\end{array}$ & $\begin{array}{c}\text { Compact. } \\
\text { Adensada } \\
(\mathrm{mm}) \\
\end{array}$ & $\begin{array}{l}\text { Compact. Não- } \\
\text { Adensada (mm) }\end{array}$ & $\begin{array}{c}\text { Teor de ar } \\
\text { Pressométrico } \\
(\%) \\
\end{array}$ & $\begin{array}{c}\text { Densidade } \\
\left(\mathrm{kg} / \mathrm{m}^{3}\right)\end{array}$ & $\begin{array}{c}\begin{array}{c}\text { Teor de ar } \\
\text { gravimétrico } \\
(\%)\end{array} \\
\end{array}$ & $\begin{array}{c}\text { Teor de } \\
\text { Umidade } \\
(\%) \\
\end{array}$ & $\begin{array}{c}\begin{array}{c}\text { Teor de } \\
\text { Finos } \\
(\%)\end{array} \\
\end{array}$ \\
\hline 1 & \multirow{6}{*}{ 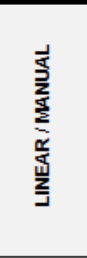 } & Carb $63 \mathrm{CO} 2 \mathrm{~T}(\mathrm{~mm})$ & 0,416 & $-0,251$ & $-0,838$ & \begin{tabular}{l|l|}
$-0,38$ \\
\end{tabular} & $-0,769$ & $-0,362$ & 0,25 & \begin{tabular}{|l|}
$-0,084$ \\
\end{tabular} & $-0,204$ \\
\hline 2 & & Carb $63 \mathrm{CO} 2(\mathrm{~mm})$ & 0,475 & 0,152 & $-0,814$ & $-0,396$ & $-0,968$ & $-0,112$ & 0,019 & $-0,402$ & $-0,448$ \\
\hline 4 & & Carb $63 \mathrm{H} 2 \mathrm{O}(\mathrm{mm})$ & 0,797 & 0,035 & $-0,23$ & 0,128 & $-0,274$ & $-0,587$ & 0,358 & 0,496 & $-0,104$ \\
\hline 5 & & Carb $91 \mathrm{CO} 2(\mathrm{~mm})$ & 0,427 & $-0,148$ & $-0,802$ & $-0,317$ & $-0,845$ & $-0,337$ & 0,198 & $-0,184$ & $-0,351$ \\
\hline 6 & & Carb $91 \mathrm{H} 2 \mathrm{O}(\mathrm{mm})$ & 0,223 & 0,557 & $-0,503$ & 0,244 & $-0,744$ & 0,435 & $-0,656$ & $-0,657$ & $-0,539$ \\
\hline 9 & & Carb 203 SEC(mm) & 0,394 & $-0,315$ & $-0,7$ & \begin{tabular}{l|l|}
$-0,382$ \\
\end{tabular} & $-0,739$ & $-0,528$ & 0,42 & $-0,044$ & $-0,315$ \\
\hline 10 & \multirow{5}{*}{ 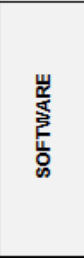 } & IMJ C02 $63(\%)$ & $-0,054$ & $-0,125$ & $-0,266$ & 0,652 & $-0,38$ & $-0,076$ & $-0,305$ & \begin{tabular}{l|l|}
$-0,237$ \\
\end{tabular} & $-0,487$ \\
\hline 11 & & \begin{tabular}{|l|} 
IMJ C02 91(\%) \\
\end{tabular} & 0,469 & $-0,092$ & $-0,48$ & $-0,093$ & $-0,76$ & $-0,551$ & 0,341 & $-0,103$ & $-0,597$ \\
\hline 12 & & IMJ H20 91 (\%) & 0,781 & 0,002 & $-0,472$ & $-0,69$ & $-0,513$ & $-0,567$ & 0,638 & 0,285 & $-0,029$ \\
\hline 13 & & LC C02 $203(\%)$ & $-0,283$ & 0,117 & $-0,508$ & 0,302 & $-0,572$ & 0,48 & $-0,683$ & $-0,736$ & $-0,427$ \\
\hline 14 & & \begin{tabular}{|l|l|} 
IMJ CO2 $203(\%)$ \\
\end{tabular} & $-0,245$ & $-0,301$ & $-0,426$ & $-0,154$ & $-0,698$ & $-0,205$ & 0,106 & $-0,585$ & $-0,672$ \\
\hline & & $12>0,7$ & 3 & 0 & 0 & 0 & 0 & 0 & 0 & 0 & 0 \\
\hline & & $r 2>0,8$ & 0 & 0 & 0 & 0 & 0 & 0 & 0 & 0 & 0 \\
\hline & & $r 2>0,9$ & 0 & 0 & 0 & 이 & 0 & 0 & 0 & 이 & 0 \\
\hline & & $r 2<-0,5$ & 1 & 1 & 11 & 1 & 14 & 5 & 2 & 3 & 4 \\
\hline & & $r 2<-0,7$ & 0 & 0 & 9 & 0 & 9 & 0 & 0 & 1 & 0 \\
\hline & & $r 2<-0,8$ & 0 & 0 & 5 & 0 & 4 & 0 & 0 & 0 & 0 \\
\hline & & $r 2<-0,9$ & 0 & 0 & 0 & 0 & 2 & 0 & 0 & o: & 0 \\
\hline & & $r 2>10,5 \mid$ & 6 & 2 & 11 & 3 & 14 & 5 & 3 & 3 & 4 \\
\hline & & {$[2>10,7$} & 3 & 0 & 9 & 0 & 9 & 0 & 0 & 1 & 0 \\
\hline & & {$[2>|0,8|$} & 0 & 0 & 5 & 0 & 4 & 0 & 0 & : & -1.-0. \\
\hline & & $\mathrm{r} 2>|0,9|$ & 0 & 0 & 0 & 0 & 2 & 0 & 0 & 0 & 0 \\
\hline
\end{tabular}

As seguintes observações podem ser destacadas da Tabela 109: 
$\checkmark$ No tocante ao concreto fresco, chama atenção que o baixo teor de ar deste concreto provavelmente introduziu melhorias na sua microestrutura, como sugere e discute Martin (2005), com base em gráfico de Mindess; Young (1981), na Figura 25 do item 2.3.2C);

$\checkmark$ A profundidade de carbonatação linear a 63 dias por 2 ciclos de $24 \mathrm{~h}$ de exposição a $5 \%$ de $\mathrm{CO}_{2}$ seguido por secagem forçada (na medida com fenolftaleína) teve relação inversa forte com o teor de ar pressométrico $\left(r^{2}=-0,968\right)$;

$\checkmark$ A profundidade de carbonatação linear a 91 dias por 3 ciclos de $24 \mathrm{~h}$ em tanque de água seguido por secagem forçada obteve maior número de correlações com as propriedades do concreto fresco;

$\checkmark$ A profundidade de carbonatação pelo software Leica a 203 dias, por ciclos de molhagem e secagem, obteve relação inversa forte com a compactabilidade adensada $\left(r^{2}=-0,853\right)$ e teor de ar pressométrico $\left(r^{2}=-0,792\right)$;

$\checkmark$ A profundidade de carbonatação pelo software Image $\mathrm{J}$ a 203 dias, por ciclos de molhagem e secagem, obteve relação inversa forte com a compactabilidade adensada $\left(r^{2}=-0,816\right)$ e teor de ar pressométrico $\left(r^{2}=-0,915\right)$;

$\checkmark$ A profundidade de carbonatação pelo software Image $\mathrm{J}$ a 203 dias por ciclos de secagem contínua, obteve relação inversa forte com o teor de ar pressométrico $\left(r^{2}=-0,800\right)$.

\section{A.2) Concreto Endurecido - Resistência à compressão}

As correlações encontradas entre os resultados de resistência à compressão e profundidade de carbonatação estão apresentadas na Tabela 110. 
TABELA 110 - Correlações entre as resistências à compressão e os resultados de medidas de profundidade de carbonatação.

\begin{tabular}{|c|c|c|c|c|c|c|c|}
\hline Item & Medida & PROPRIEDADE & $\begin{array}{c}\text { fc1 acel } \\
\text { (MPa) }\end{array}$ & $\begin{array}{c}\text { fc2 acel } \\
\text { (MPa) }\end{array}$ & $\begin{array}{c}\text { fc3 acel } \\
\text { (MPa) }\end{array}$ & $\begin{array}{c}\text { fc7 acel } \\
\text { (MPa) }\end{array}$ & $\begin{array}{l}\text { fc28 n } \\
(\mathrm{MPa})\end{array}$ \\
\hline 1 & \multirow{9}{*}{ 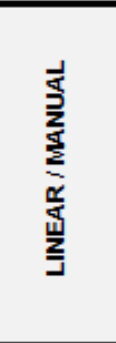 } & Carb $63 \mathrm{CO} 2 \mathrm{~T}(\mathrm{~mm})$ & $-0,299$ & $-0,769$ & $-0,928$ & $-0,914$ & $-0,909$ \\
\hline 2 & & Carb $63 \mathrm{CO} 2(\mathrm{~mm})$ & $-0,413$ & $-0,81$ & $-0,986$ & $-0,859$ & $-0,949$ \\
\hline 3 & & \begin{tabular}{|l|} 
Carb $63 \mathrm{H} 2 \mathrm{O} \mathrm{T}(\mathrm{mm})$ \\
\end{tabular} & $-0,503$ & $-0,718$ & $-0,719$ & \begin{tabular}{|l|}
$-0,753$ \\
\end{tabular} & $-0,616$ \\
\hline 4 & & Carb $63 \mathrm{H} 2 \mathrm{O}(\mathrm{mm})$ & $-0,055$ & $-0,18$ & $-0,451$ & $-0,496$ & $-0,671$ \\
\hline 5 & & Carb $91 \mathrm{CO} 2(\mathrm{~mm})$ & $-0,407$ & $-0,833$ & $-0,959$ & $-0,95$ & $-0,952$ \\
\hline 6 & & Carb $91 \mathrm{H} 2 \mathrm{O}(\mathrm{mm})$ & $-0,73$ & $-0,618$ & $-0,659$ & \begin{tabular}{|l|}
$-0,463$ \\
\end{tabular} & $-0,579$ \\
\hline 7 & & Carb $203 \mathrm{CO} 2(\mathrm{~mm})$ & $-0,531$ & $-0,757$ & $-0,883$ & $-0,864$ & $-0,872$ \\
\hline 8 & & \begin{tabular}{|l|} 
Carb $203 \mathrm{H} 2 \mathrm{O}(\mathrm{mm})$ \\
\end{tabular} & $-0,01$ & $-0,454$ & $-0,829$ & $-0,733$ & $-0,889$ \\
\hline 9 & & Carb 203 SEC $(\mathrm{mm})$ & $-0,297$ & $-0,782$ & $-0,87$ & \begin{tabular}{|l|}
$-0,947$ \\
\end{tabular} & $-0,901$ \\
\hline 10 & \multirow{9}{*}{ 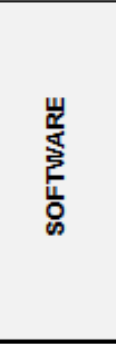 } & IMJ C02 $63(\%)$ & $-0,886$ & $-0,695$ & $-0,461$ & $-0,632$ & $-0,473$ \\
\hline 11 & & \begin{tabular}{|l|} 
IMJ C02 91(\%) \\
\end{tabular} & $-0,496$ & $-0,801$ & $-0,816$ & $-0,945$ & $-0,928$ \\
\hline 12 & & IMJ H20 $91(\%)$ & 0,328 & $-0,22$ & $-0,604$ & $-0,523$ & $-0,726$ \\
\hline 13 & & \begin{tabular}{|l|} 
LC CO2 $203(\%)$ \\
\end{tabular} & $-0,845$ & $-0,725$ & $-0,534$ & $-0,468$ & $-0,348$ \\
\hline 14 & & \begin{tabular}{|l|} 
IMJ CO2 203 (\%) \\
\end{tabular} & $-0,684$ & $-0,946$ & $-0,641$ & $-0,828$ & $-0,569$ \\
\hline 15 & & $\begin{array}{|lc|}\text { LC H20 } 203(\%) \\
\end{array}$ & $-0,47$ & $-0,833$ & $-0,944$ & $-0,922$ & $-0,9$ \\
\hline 16 & & IMJ H2O 203 (\%) & $-0,418$ & $-0,788$ & $-0,99$ & $-0,889$ & $-0,985$ \\
\hline 17 & & LC SEC 203(\%) & $-0,807$ & $-0,602$ & $-0,133$ & \begin{tabular}{|l|}
$-0,487$ \\
\end{tabular} & $-0,116$ \\
\hline \multirow[t]{13}{*}{18} & & IMJ SEC 203(\%) & $-0,373$ & $-0,704$ & $-0,787$ & $-0,849$ & $-0,916$ \\
\hline & & $r 2>0,5$ & 0 & 0 & 0 & 0 & 0 \\
\hline & & $22>0,7$ & 0 & 0 & 0 & 0: & 0 \\
\hline & & {$[2>0,8$} & 0 & 0 & 0 & 0 & 0 \\
\hline & & $r 2>0,9$ & 0 & 0 & 0 & 0 & 0 \\
\hline & & $r 2<-0,5$ & 7 & 15 & 15 & 14 & 15 \\
\hline & & $r 2<-0,7$ & 4 & 12 & 11 & 12 & 11 \\
\hline & & $r 2<-0,8$ & 3 & 5 & 9 & 10 & 10 \\
\hline & & $12<-0,9$ & 0 & 1 & 5 & 5 & 8 \\
\hline & & $r 2>10,5$ & 7 & 15 & 15 & 14 & 15 \\
\hline & & $12>10,7$ & 4 & 12 & 11 & 12 & 11 \\
\hline & & $12>10,8$ & 3 & 5 & 9 & 10 & 10 \\
\hline & & $12>\mid 0,9$ & 0 & 1 & 5 & 5 & 8 \\
\hline
\end{tabular}

As seguintes observações podem ser destacadas na Tabela 110:

De modo resumido cabe destacar que a profundidade de carbonatação linear a 63 dias por ciclagem 24h de exposição a 5\% de CO2 seguido de secagem forçada (timol) teve relação inversa forte, principalmente com a resistência à compressão a 3 dias por cura acelerada 24/72h $\left(r^{2}=-0,928\right)$, resistência à compressão a 7 dias por cura acelerada $24 / 72 h$, seguida de cura imersa em água até 7 dias $\left(r^{2}=-0,914\right)$ e resistência à compressão a 28 dias por cura normal $\left(r^{2}=-0,909\right)$;

$\checkmark$ A profundidade de carbonatação linear a 63 dias por 2 ciclos de $24 \mathrm{~h}$ de exposição a $5 \%$ de $\mathrm{CO}_{2}$ seguido de secagem forçada (fenol) teve relação inversa forte, principalmente com a resistência à compressão a 3 dias por cura acelerada $24 / 72 \mathrm{~h}$ $\left(r^{2}=-0,986\right)$ e resistência à compressão a 28 dias por cura normal $\left(r^{2}=-0,949\right)$;

$\checkmark$ A profundidade de carbonatação linear a 91 dias por 3 ciclos de 24h de exposição a $5 \%$ de $\mathrm{CO}_{2}$ seguido de secagem forçada (fenol) teve relação inversa forte, principalmente com a resistência à compressão a 3 dias por cura acelerada $24 / 72 \mathrm{~h}$ 
( $\left.r^{2}=-0,959\right)$, a resistência à compressão a 3 dias por cura acelerada 24/72h seguida de cura imersa até 7 dias $\left(r^{2}=-0,950\right)$ e a resistência à compressão a 28 dias por cura normal $\left(r^{2}=-0,952\right)$;

$\checkmark$ A profundidade de carbonatação linear a 91 dias por ciclagem de $24 \mathrm{~h}$ de exposição a $5 \%$ de $\mathrm{CO}_{2}$ seguido de secagem forçada (fenol) teve relação inversa forte com a resistência à compressão a 3 dias por cura acelerada 24/72h $\left(r^{2}=-0,883\right)$, resistência à compressão a 28 dias por cura normal $\left(r^{2}=-0,872\right)$ e resistência à compressão a 7 dias por cura acelerada $24 / 72 \mathrm{~h}$, seguida de cura imersa em água até 7 dias $\left(r^{2}=-0,864\right)$;

$\checkmark$ A profundidade de carbonatação linear a 203 dias por 7 ciclos de 28 dias de secagem forçada contínua, teve relação inversa forte, principalmente com a resistência à compressão a 3 dias por cura acelerada $24 / 72 \mathrm{~h}$ seguida de cura imersa até 7 dias $\left(r^{2}=-0,947\right)$ e resistência à compressão a 28 dias por cura normal $\left(r^{2}=-0,901\right)$;

$\checkmark$ A profundidade de carbonatação pelo programa Image $\mathrm{J}$ a 63 dias por 2 ciclos de 24h de exposição a $5 \%$ de $\mathrm{CO}_{2}$ seguido de 27 dias de secagem forçada (fenol) teve relação inversa forte, com a resistência à compressão a 1 dia por cura acelerada $0 / 24 h\left(r^{2}=-0,886\right)$;

$\checkmark$ A profundidade de carbonatação pelo programa Image $\mathrm{J}$ a 91 dias por ciclagem de $24 \mathrm{~h}$ de exposição a $5 \%$ de $\mathrm{CO}_{2}$ seguido de secagem forçada (fenol) teve relação inversa forte com a resistência à compressão a 2 dias por cura acelerada 24/48h $\left(r^{2}=-0,801\right)$, resistência à compressão a 3 dias por cura acelerada $24 / 72 h\left(r^{2}=-\right.$ 0,816), resistência à compressão a 3 dias por cura acelerada 24/72h seguida de cura imersa até 7 dias $\left(r^{2}=-0,945\right)$ e resistência à compressão a 28 dias por cura normal $\left(r^{2}=-0,928\right)$;

$\checkmark$ A profundidade de carbonatação pelo programa Image $\mathrm{J}$ a 203 dias por ciclagem de $24 \mathrm{~h}$ de exposição a $5 \%$ de $\mathrm{CO}_{2}$ seguido de secagem forçada (fenol) teve relação inversa forte com a resistência à compressão a 2 dias por cura acelerada 24/48h $\left(r^{2}=-0,946\right)$ e resistência à compressão a 3 dias por cura acelerada $24 / 72 \mathrm{~h}$ seguida de cura imersa até 7 dias $\left(r^{2}=-0,828\right)$;

$\checkmark$ A profundidade de carbonatação pelo programa Leica a 203 dias por ciclagem de $24 \mathrm{~h}$ de imersão em tanque de água seguido de 27 dias de secagem forçada, teve relação inversa forte com a resistência à compressão a 2 dias por cura acelerada $24 / 48 \mathrm{~h}\left(r^{2}=-0,833\right)$, resistência à compressão a 3 dias por cura acelerada $24 / 72 \mathrm{~h}$ 
$\left(r^{2}=-0,944\right)$, resistência à compressão a 3 dias por cura acelerada 24/72h seguida de cura imersa até 7 dias $\left(r^{2}=-0,922\right)$ e resistência à compressão a 28 dias por cura normal $\left(r^{2}=-0,900\right)$;

$\checkmark$ A profundidade de carbonatação pelo programa Image J a 203 dias por ciclagem de $24 \mathrm{~h}$ de imersão em tanque de água seguido de 27 dias de secagem forçada, teve relação inversa forte com a resistência à compressão a 3 dias por cura acelerada 24/72h $\left(\mathrm{r}^{2}=-0,99\right)$, resistência à compressão a 3 dias por cura acelerada 24/72h seguida de cura imersa até 7 dias $\left(r^{2}=-0,889\right)$ e resistência à compressão a 28 dias por cura normal $\left(r^{2}=-0,985\right)$;

$\checkmark$ A profundidade de carbonatação pelo programa Leica a 203 dias por ciclos de 28 dias de secagem contínua forçada, teve relação inversa forte com resistência à compressão a 1 dia por cura acelerada $0 / 24 h\left(r^{2}=-0,807\right)$;

$\checkmark$ A profundidade de carbonatação pelo programa Image $\mathrm{J}$ a 203 dias por ciclos de 28 dias de secagem contínua forçada, teve relação inversa forte com resistência à compressão a 3 dias por cura acelerada 24/72h seguida de cura imersa até 7 dias $\left(r^{2}=-0,849\right)$ e resistência à compressão a 28 dias por cura normal $\left(r^{2}=-0,916\right)$.

Em resumo, foram evidentes e muito elevadas as correlações, o que confirma as expectativas de normas de projeto ao usarem a resistência à compressão para controle indireto da capacidade de proteção de armaduras pelo concreto. Mas, não necessariamente esta variável pode ser adequada para analisar em conjunto, diferentes lotes, como ocorreu em Cavalcanto Filho (2010).

As correlações foram em maior número tanto para os concretos com cura acelerada entre $24 / 72 \mathrm{~h}$ quanto para o concreto com cura normal até 28 dias.

\section{A.3) Concreto Endurecido - Resistência à tração por compressão diametral}

As correlações encontradas entre os resultados de resistência à tração por compressão diametral e os resultados de profundidade de carbonatação estão apresentadas na Tabela 111. 
TABELA 111 - Correlações entre as resistências à tração por compressão diametral e medidas de profundidade de carbonatação.

\begin{tabular}{|c|c|c|c|c|c|c|c|c|c|c|c|c|c|c|}
\hline Item & Medida & PROPRIEDADE & $\begin{array}{c}\text { fct, sp } \\
\text { 8acel CO2 }\end{array}$ & $\begin{array}{c}\text { fct, sp } \\
\text { 8acel H2O }\end{array}$ & $\begin{array}{c}\text { fct, sp } \\
\text { 35acel C02 }\end{array}$ & $\begin{array}{c}\text { fct, sp } \\
\text { 35acel H2O }\end{array}$ & $\begin{array}{c}\text { fct, sp } \\
\text { 63acel C02 }\end{array}$ & $\begin{array}{c}\text { fct, sp } \\
\text { 63acel H2O }\end{array}$ & $\begin{array}{c}\text { fct, sp } \\
\text { 91acel CO2 }\end{array}$ & $\begin{array}{c}\text { fct, sp } \\
\text { 91acel H2O }\end{array}$ & $\begin{array}{c}\text { fct, sp } \\
\text { 91acel Sec }\end{array}$ & $\begin{array}{c}\text { fct, sp } \\
\text { 203acel } \\
\text { CO2 }\end{array}$ & $\begin{array}{c}\text { fct, sp } \\
\text { 203acel } \\
\text { H2O }\end{array}$ & $\begin{array}{c}\text { fct, sp } \\
\text { 203acelSec }\end{array}$ \\
\hline 1 & \multirow{9}{*}{ 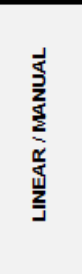 } & Carb $63 \mathrm{CO} 2 \mathrm{~T}(\mathrm{~mm})$ & $-0,807$ & $-0,676$ & $-0,397$ & $-0,536$ & $-0,335$ & $-0,521$ & $-0,556$ & $-0,851$ & $-0,663$ & \begin{tabular}{r|}
$-0,594$ \\
\end{tabular} & $-0,768$ & $-0,15$ \\
\hline 2 & & Carb $63 \mathrm{CO} 2(\mathrm{~mm})$ & $-0,804$ & $-0,795$ & $-0,271$ & $-0,621$ & $-0,333$ & $-0,608$ & $-0,718$ & $-0,785$ & $-0,65$ & $-0,704$ & $-0,952$ & $-0,257$ \\
\hline 3 & & Carb 63 H2O T(mm) & $-0,365$ & $-0,454$ & $-0,625$ & $-0,494$ & 0,216 & $-0,684$ & $-0,179$ & $-0,713$ & $-0,576$ & $-0,568$ & $-0,473$ & $-0,372$ \\
\hline 4 & & Carb $63 \mathrm{H} 2 \mathrm{O}(\mathrm{mm})$ & $-0,7$ & 0,11 & $-0,691$ & 0,187 & $-0,256$ & 0,276 & 0,182 & $-0,059$ & $-0,09$ & $-0,688$ & $-0,156$ & 0,65 \\
\hline 5 & & \begin{tabular}{|l|l|l} 
Carb 91 C02(mm) \\
\end{tabular} & $-0,809$ & $-0,668$ & $-0,4$ & $-0,602$ & $-0,336$ & $-0,524$ & $-0,575$ & $-0,852$ & $-0,6$ & $-0,677$ & $-0,831$ & $-0,131$ \\
\hline 6 & & Carb $91 \mathrm{H} 2 \mathrm{O}(\mathrm{mm})$ & $-0,24$ & $-0,433$ & $-0,464$ & $-0,456$ & 0,345 & $-0,654$ & $-0,248$ & $-0,28$ & $-0,338$ & $-0,846$ & $-0,649$ & $-0,401$ \\
\hline 7 & & Carb 203 C02(mm) & $-0,641$ & $-0,462$ & $-0,739$ & $-0,437$ & 0,046 & $-0,554$ & $-0,225$ & $-0,651$ & $-0,558$ & $-0,848$ & $-0,629$ & $-0,132$ \\
\hline 8 & & Carb 203 H2O(mm) & $-0,923$ & $-0,503$ & $-0,549$ & $-0,121$ & $-0,36$ & $-0,248$ & $-0,338$ & $-0,534$ & $-0,658$ & $-0,639$ & $-0,564$ & 0,13 \\
\hline 9 & & Carb 203 SEC(mm) & $-0,821$ & $-0,585$ & $-0,301$ & $-0,579$ & $-0,492$ & $-0,366$ & $-0,563$ & $-0,875$ & $-0,505$ & $-0,527$ & $-0,747$ & 0,008 \\
\hline 10 & \multirow{9}{*}{ 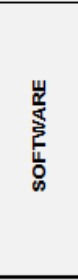 } & IMJ C02 63 (\%) & $-0,064$ & 0,047 & $-0,741$ & $-0,478$ & 0,427 & $-0,38$ & 0,21 & $-0,363$ & 0,027 & $-0,775$ & $-0,281$ & $-0,046$ \\
\hline 11 & & \begin{tabular}{|l|l|} 
IMJ C02 91(\%) \\
\end{tabular} & $-0,775$ & $-0,358$ & $-0,404$ & $-0,566$ & $-0,447$ & $-0,192$ & $-0,397$ & $-0,709$ & $-0,224$ & $-0,723$ & $-0,715$ & 0,236 \\
\hline 12 & & \begin{tabular}{|l|l|} 
IMJ H20 91 (\%) \\
\end{tabular} & $-0,951$ & $-0,469$ & $-0,036$ & $-0,037$ & $-0,803$ & 0,093 & $-0,538$ & $-0,425$ & $-0,459$ & $-0,262$ & $-0,522$ & 0,335 \\
\hline 13 & & \begin{tabular}{|l|l} 
LC CO2 $203(\%)$ \\
\end{tabular} & 0,077 & $-0,434$ & $-0,362$ & $-0,674$ & 0,534 & $-0,858$ & $-0,223$ & $-0,482$ & $-0,323$ & $-0,574$ & $-0,538$ & $-0,691$ \\
\hline 14 & & \begin{tabular}{|l|l|} 
IMJ C02 $203(\%)$ \\
\end{tabular} & $-0,294$ & $-0,534$ & 0,049 & $-0,978$ & $-0,262$ & $-0,558$ & $-0,627$ & $-0,938$ & $-0,191$ & $-0,304$ & $-0,753$ & $-0,334$ \\
\hline 15 & & LC H20 $203(\%)$ & $-0,707$ & $-0,646$ & $-0,519$ & $-0,583$ & $-0,138$ & $-0,629$ & $-0,471$ & $-0,826$ & $-0,646$ & $-0,712$ & $-0,768$ & $-0,239$ \\
\hline 16 & & \begin{tabular}{|l|l|} 
IMJ H2O $203(\%)$ \\
\end{tabular} & $-0,836$ & $-0,694$ & $-0,44$ & $-0,533$ & $-0,28$ & $-0,544$ & $-0,575$ & $-0,738$ & $-0,631$ & $-0,791$ & $-0,874$ & $-0,146$ \\
\hline 17 & & \begin{tabular}{|l|} 
LC SEC 203(\%) \\
\end{tabular} & \begin{tabular}{l|l|}
0,268 \\
\end{tabular} & 0,229 & $-0,457$ & $-0,543$ & 0,412 & $-0,263$ & 0,293 & $-0,397$ & 0,263 & $-0,324$ & $-0,019$ & $-0,073$ \\
\hline 18 & & IMJ SEC 203(\%) & $-0,832$ & $-0,406$ & $-0,238$ & $-0,506$ & $-0,588$ & $-0,11$ & $-0,509$ & $-0,625$ & $-0,212$ & $-0,666$ & $-0,761$ & 0,275 \\
\hline & & $r 2>0,5$ & 0 & 0 & 0 & 0 & 1 & 0 & 0 & 0 & 0 & 0 & 0 & 1 \\
\hline & & $12>0,7$ & i: & 0 & 0 & 0 & 0 & 0 & 0 & 0 & 0 & 0 & 0 & 0 \\
\hline & & $12>0,8$ & 0 & 0 & 0 & 0 & 0 & 0 & 0 & 0 & 0 & 0 & 0 & 0 \\
\hline & & $12>0,9$ & 0 & 0 & 0 & 0 & 0 & 0 & 0 & 0 & 0 & 0 & 0 & 0 \\
\hline & & $12<-0,5$ & 12 & 8 & 6 & 11 & 2 & 10 & 8 & 12 & 9 & 15 & 14 & 1 \\
\hline & & $12<-0,7$ & 11 & 1 & 2 & 1 & 1 & 1 & 1 & 9 & 0 & 7 & 9 & 0 \\
\hline & & $12<-0,8$ & 8 & 0 & 0 & 1 & 1 & 1 & 0 & 5 & 0 & 2 & 3 & 0 \\
\hline & & $12<-0,9$ & 2 & 0 & 0 & 1 & 0 & 0 & 0 & 1 & 0 & 0 & 1 & 0 \\
\hline & & {$[2>\mid 0,5$} & 12 & 8 & 6 & 11 & 3 & 10 & 8 & 12 & 9 & 15 & 14 & 2 \\
\hline & & {$[2>\mid 0,7]$} & 11 & 1 & 2 & 1 & 1 & 1 & 1 & 9 & 0 & 7 & 9 & 0 \\
\hline & & $12>10,8$ & 8 & 0 & 0 & 1 & 1 & 1 & 0 & 5 & 0 & 2 & 3 & 0 \\
\hline & & $r 2>|0,9|$ & 2 & 0 & 0 & 1 & 0 & 0 & 0 & 1 & 0 & 0 & 1 & 0 \\
\hline
\end{tabular}

As seguintes observações podem ser destacadas na TABELA 111:

$\checkmark$ A profundidade de carbonatação linear a 63 dias por ciclagem $24 \mathrm{~h}$ de exposição a $5 \%$ de $\mathrm{CO}_{2}$ seguido de de secagem forçada (fenol) teve relação inversa forte com a resistência à tração por compressão diametral a 203 dias de idade, por cura acelerada 24/72h seguida de cura imersa em água até 7 dias e expostos a ciclagem por secagem alternada com $24 \mathrm{~h}$ em tanque de água $\left(r^{2}=-0,952\right)$;

$\checkmark$ A profundidade de carbonatação linear a 91 dias por ciclagem 24h de exposição em tanque de água seguido de de secagem forçada (fenol) teve relação inversa forte com resistência à tração por compressão diametral a 203 dias de idade, por cura acelerada 24/72h seguida de cura imersa em água até 7 dias e expostos a ciclagem por secagem alternada com $24 \mathrm{~h}$ de $\mathrm{CO}_{2}\left(\mathrm{r}^{2}=-0,846\right)$.

$\checkmark$ A profundidade de carbonatação linear a 203 dias por ciclagem 24h de exposição em tanque de água seguido de 27 dias de de secagem forçada (fenol) teve relação inversa forte com a resistência à tração por compressão diametral a 8 dias de idade, por cura acelerada 24/72h seguida de cura imersa em água até 7 dias e expostos a ciclagem por secagem alternada com $24 \mathrm{~h}$ de $\mathrm{CO}_{2}\left(\mathrm{r}^{2}=-0,923\right)$; 
$\checkmark$ A profundidade de carbonatação pelo programa Image $\mathrm{J}$ a 91 dias por ciclagem de $24 \mathrm{~h}$ de exposição em tanque de água seguido de secagem forçada (fenol) tem relação inversa forte com resistência à tração por compressão diametral a 8 e 63 dias de idade por cura acelerada 24/72h seguida de cura imersa em água até 7 dias e expostos a ciclagem por secagem alternada com $24 \mathrm{~h}$ de $\mathrm{CO}_{2}\left(\mathrm{r}^{2}=-0,951\right)$ e $\left(r^{2}=0,803\right)$ respectivamente;

$\checkmark$ A profundidade de carbonatação pelo programa Leica a 203 dias por ciclagem de $24 \mathrm{~h}$ de exposição em $5 \%$ de $\mathrm{CO}_{2}$ seguido de 27 dias de secagem forçada, teve relação inversa forte com resistência à tração por compressão diametral a 63 dias de idade por cura acelerada 24/72h seguida de cura imersa em água até 7 dias e expostos a ciclagem por secagem alternada com $24 \mathrm{~h}$ de imersão em água $\left(r^{2}=-\right.$ $0,858)$;

$\checkmark$ A profundidade de carbonatação pelo programa Image $\mathrm{J}$ a 203 dias por ciclagem de $24 \mathrm{~h}$ de exposição em $5 \%$ de $\mathrm{CO}_{2}$ seguido de secagem forçada, teve relação inversa forte com resistência à tração por compressão diametral a 35 e 91 dias de idade por cura acelerada $24 / 72 \mathrm{~h}$ seguida de cura imersa em água até 7 dias e expostos a ciclagem por secagem alternada com 24 h de imersão em água $\left(r^{2}=-0,978\right)$ e $(-0,938)$ respectivamente;

$\checkmark$ A profundidade de carbonatação pelo programa Leica a 203 dias por ciclagem de $24 \mathrm{~h}$ de imersão em água seguido de secagem forçada teve relação inversa forte com resistência à tração por compressão diametral a 91 dias de idade por cura acelerada 24/72h seguida de cura imersa em água até 7 dias e expostos a ciclagem por secagem alternada com $24 \mathrm{~h}$ de imersão em água $\left(r^{2}=-0,826\right)$;

$\checkmark$ A profundidade de carbonatação pelo programa Image $\mathrm{J}$ a 203 dias por ciclagem de $24 \mathrm{~h}$ de imersão em água seguido de 27 dias de secagem forçada, teve relação inversa forte com resistência à tração por compressão diametral a 8 dias de idade por cura acelerada 24/72h seguida de cura imersa em água até 7 dias e expostos a ciclagem por secagem alternada com $24 \mathrm{~h}$ de exposição a $5 \%$ de $\mathrm{CO}_{2}\left(\mathrm{r}^{2}=-0,836\right)$ e a 203 dias a por cura acelerada 24/72h seguida de cura imersa em água até 7 dias e expostos a ciclagem por secagem alternada com $24 \mathrm{~h}$ de imersão em água $\left(\mathrm{r}^{2}=-\right.$ $0,874)$;

$\checkmark$ A profundidade de carbonatação pelo programa Image $J$ a 203 dias por secagem contínua forçada teve relação inversa forte com resistência à tração por compressão diametral a 8 dias de idade por cura acelerada 24/72h seguida de cura imersa em 
água até 7 dias e expostos a ciclagem por secagem alternada com $24 \mathrm{~h}$ de exposição a $5 \%$ de $\mathrm{CO}_{2}\left(\mathrm{r}^{2}=-0,832\right)$.

Em resumo, como seria coerente, a resistência à tração por compressão diametral também mostrou correlação com as medidas de carbonatação, mas apenas destacou-se em número de correlações fortes as medidas de tração a 8 dias, pela exposição de $24 \mathrm{~h}$ a $\mathrm{CO}_{2}$ após maturação acelerada.

\section{A.4) Concreto Endurecido - Índice de vazios}

As correlações encontradas entre os resultados de índice de vazios e as medidas de profundidade de carbonatação estão apresentadas na Tabela 112.

TABELA 112 - Correlações entre os resultados de índice de vazios e os resultados de ensaios de profundidade de carbonatação.

\begin{tabular}{|c|c|c|c|c|c|c|c|c|c|c|c|c|c|c|}
\hline Item & Medida & PROPRIEDADE & $\begin{array}{c}\text { IV CO2 } 8 \\
(\%)\end{array}$ & $\begin{array}{c}\text { IV H20 } 8 \\
(\%)\end{array}$ & $\begin{array}{c}\text { IV C02 } 35 \\
(\%)\end{array}$ & $\begin{array}{c}\text { IV H20 } 35 \\
(\%)\end{array}$ & $\begin{array}{c}\text { IV CO2 } 63 \\
(\%)\end{array}$ & $\begin{array}{c}\text { IV H20 } 63 \\
(\%)\end{array}$ & $\begin{array}{c}\text { IV C02 } 91 \\
(\%)\end{array}$ & $\begin{array}{c}\text { IV H20 } 91 \\
(\%)\end{array}$ & $\begin{array}{c}\text { IV sec } 91 \\
(\%)\end{array}$ & $\begin{array}{c}\text { IV CO2 } 203 \\
(\%)\end{array}$ & $\begin{array}{c}\text { IV H20 } 203 \\
(\%)\end{array}$ & $\begin{array}{c}\text { IV sec } 203 \\
(\%)\end{array}$ \\
\hline 1 & \multirow{9}{*}{ 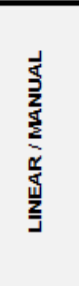 } & Carb $63 \mathrm{CO} 2 \mathrm{~T}(\mathrm{~mm})$ & 0,662 & 0,731 & 0,078 & 0,533 & $-0,243$ & $-0,098$ & 0,532 & $-0,189$ & 0,021 & 0,578 & 0,484 & 0,416 \\
\hline 2 & & Carb 63 C02(mm) & 0,638 & 0,529 & 0,03 & 0,252 & $-0,504$ & $-0,343$ & 0,258 & $-0,542$ & $-0,249$ & 0,375 & 0,315 & 0,304 \\
\hline 3 & & Carb $63 \mathrm{H} 20 \mathrm{~T}(\mathrm{~mm})$ & 0,312 & 0,467 & $-0,019$ & 0,609 & $-0,081$ & $-0,264$ & 0,705 & $-0,116$ & 0,159 & 0,635 & 0,474 & 0,583 \\
\hline 4 & & \begin{tabular}{|l|} 
Carb $63 \mathrm{H} 2 \mathrm{O}(\mathrm{mm})$ \\
\end{tabular} & 0,867 & 0,787 & 0,563 & 0,355 & 0,166 & 0,493 & 0,599 & 0,251 & 0,689 & 0,666 & 0,775 & 0,399 \\
\hline 5 & & \begin{tabular}{|l|l|} 
Carb 91 C02(mm) \\
\end{tabular} & 0,662 & 0,721 & 0,025 & 0,407 & $-0,371$ & $-0,189$ & 0,451 & $-0,315$ & $-0,035$ & 0,509 & 0,43 & 0,352 \\
\hline 6 & & \begin{tabular}{|l|} 
Carb $91 \mathrm{H} 20(\mathrm{~mm})$ \\
\end{tabular} & 0,253 & $-0,03$ & 0,002 & $-0,093$ & $-0,531$ & $-0,672$ & 0,117 & $-0,782$ & $-0,23$ & 0,196 & 0,166 & 0,34 \\
\hline 7 & & \begin{tabular}{|l|} 
Carb $203 \mathrm{CO}(\mathrm{mm})$ \\
\end{tabular} & 0,634 & 0,637 & 0,175 & 0,519 & $-0,182$ & $-0,181$ & 0,696 & $-0,224$ & 0,237 & 0,709 & 0,629 & 0,601 \\
\hline 8 & & Carb 203 H2O(mm) & 0,915 & 0,791 & 0,491 & 0,687 & 0,089 & 0,278 & 0,7 & 0,093 & 0,35 & 0,797 & 0,781 & 0,598 \\
\hline 9 & & Carb $203 \mathrm{SEC}(\mathrm{mm})$ & 0,647 & 0,827 & $-0,025$ & 0,405 & $-0,324$ & $-0,046$ & 0,422 & $-0,165$ & 0,01 & 0,459 & 0,388 & 0,23 \\
\hline 10 & \multirow{9}{*}{$\begin{array}{l}\frac{w}{\alpha} \\
\frac{w}{\alpha} \\
\frac{\tilde{p}}{0} \\
\frac{0}{0}\end{array}$} & \begin{tabular}{|l|l|} 
IMJ C02 63 (\%) \\
\end{tabular} & 0,133 & 0,339 & $-0,19$ & 0,028 & $-0,354$ & $-0,433$ & 0,421 & $-0,344$ & 0,232 & 0,322 & 0,266 & 0,274 \\
\hline 11 & & IMJ C02 91(\%) & 0,672 & 0,837 & $-0,049$ & 0,116 & $-0,487$ & $-0,101$ & 0,3 & $-0,305$ & 0,076 & 0,347 & 0,349 & 0,098 \\
\hline 12 & & IMJ H20 91 (\%) & 0,852 & 0,738 & 0,4 & 0,392 & 0,006 & 0,444 & 0,258 & 0,129 & 0,117 & 0,415 & 0,468 & 0,168 \\
\hline 13 & & LC C02 $203(\%)$ & $-0,148$ & $-0,15$ & $-0,355$ & $-0,027$ & $-0,532$ & $-0,861$ & 0,13 & $-0,725$ & $-0,352$ & 0,086 & $-0,057$ & 0,269 \\
\hline 14 & & IMJ C02 203 (\%) & 0,001 & 0,39 & $-0,667$ & $-0,134$ & $-0,783$ & $-0,631$ & $-0,091$ & $-0,6$ & $-0,502$ & $-0,136$ & $-0,265$ & $-0,222$ \\
\hline 15 & & \begin{tabular}{|l|} 
LC H20 203 (\%) \\
\end{tabular} & 0,595 & 0,646 & 0,044 & 0,496 & $-0,293$ & $-0,243$ & 0,566 & $-0,294$ & 0,025 & 0,593 & 0,486 & 0,48 \\
\hline 16 & & IMJ H2O 203 (\%) & 0,728 & 0,63 & 0,137 & 0,352 & $-0,392$ & $-0,23$ & 0,416 & $-0,422$ & $-0,056$ & 0,519 & 0,47 & 0,41 \\
\hline 17 & & LC SEC 203(\%) & $-0,276$ & 0,241 & $-0,532$ & $-0,066$ & $-0,315$ & $-0,421$ & 0,256 & $-0,156$ & 0,145 & 0,051 & $-0,055$ & $-0,019$ \\
\hline 18 & & IMJ SEC 203(\%) & 0,711 & 0,767 & $-0,002$ & $-0,005$ & $-0,537$ & $-0,075$ & 0,125 & $-0,372$ & $-0,041$ & 0,23 & 0,269 & $-0,005$ \\
\hline & & $12>0,5$ & 12 & 12 & 1 & 4 & 0 & 0 & 6 & 0 & 1 & 8 & 3 & 3 \\
\hline & & $12>0,7$ & 5 & 8 & 0 & 0 & 0 & 0 & 2 & 0 & 0 & 2 & 2 & 0 \\
\hline & & $12>0,8$ & 3 & 2 & 0 & 0 & 0 & 0 & 0 & 0 & 0 & 0 & 0 & 0 \\
\hline & & $12>0,9$ & 1 & 0 & 0 & 0 & 0 & 0 & 0 & 0 & 0 & 0 & 0 & 0 \\
\hline & & $12<-0,5$ & 0 & 0 & 2 & 0 & 5 & 3 & 0 & 4 & 1 & 0 & 0 & 0 \\
\hline & & $12<-0,7$ & 0 & 0 & 0 & 0 & 1 & 1 & 0 & 2 & 0 & 0 & 0 & 0 \\
\hline & & $12<-0,8$ & 0 & 0 & 0 & 0 & 0 & 1 & 0 & 0 & 0 & 0 & 0 & 0 \\
\hline & & $12<-0,9$ & 0 & 0 & 0 & 0 & 0 & 0 & 0 & 0 & 0 & 0 & 0 & 0 \\
\hline & & $12>10,5$ & 12 & 12 & 3 & 4 & 5 & 3 & 6 & 4 & 2 & 8 & 3 & 3 \\
\hline & & {$[2>10,7 \mid$} & 5 & 8 & 0 & 0 & 1 & 1 & 2 & 2 & 0 & 2 & 2 & 0 \\
\hline & & {$[2>10,8$} & 3 & 2 & 0 & 0 & 0 & 1 & 0 & 0 & 0 & 0 & 0 & 0 \\
\hline & & $12>|0,9|$ & 1 & 0 & 0 & 0 & 0 & 0 & 0 & 0 & 0 & 0 & 0 & 0 \\
\hline
\end{tabular}

A Tabela 112 evidencia que o índice de vazios para a idade inicial de 8 dias mostrou fortes correlações com as franjas de carbonatação. A título de predição é um bom resultado, mas não se verificou esta correlação para as demais idades de ensaio do índice de vazios. Cabe prosseguir investigações para outros lotes. De qualquer forma, comportamento análogo foi observado no estudo de Cavalcanti Filho (2010). 


\section{A.5) Concreto Endurecido - Absorção de água por capilaridade e total}

As correlações encontradas entre os resultados de absorção de água e as medidas de profundidade de carbonatação estão apresentadas na Tabela 113.

TABELA 113 - Correlações entre os resultados absorção de água e os resultados de ensaios de profundidade de carbonatação

\begin{tabular}{|c|c|c|c|c|c|c|c|c|c|c|c|c|c|c|c|}
\hline Item & Medida & PROPRIEDADE & $\begin{array}{c}\text { abs cap. } 91 \\
\mathrm{n}(\mathrm{g} / \mathrm{c}\end{array}$ & $\begin{array}{c}\text { ABS CO2 } 8 \\
(\%)\end{array}$ & $\begin{array}{c}\text { ABS H20 } 8 \\
(\%)\end{array}$ & $\begin{array}{c}\text { ABS CO2 } \\
35(\%)\end{array}$ & $\begin{array}{c}\text { ABS H20 } 35 \\
(\%)\end{array}$ & $\begin{array}{l}\text { ABS CO2 } \\
63(\%)\end{array}$ & $\begin{array}{c}\text { ABS H20 } 63 \\
(\%)\end{array}$ & $\begin{array}{c}\text { ABS CO2 } \\
91(\%)\end{array}$ & $\begin{array}{c}\text { ABS H20 } 91 \\
(\%)\end{array}$ & $\begin{array}{l}\text { ABS sec } \\
91(\%)\end{array}$ & $\begin{array}{l}\text { ABS CO2 } \\
203(\%)\end{array}$ & $\begin{array}{l}\text { ABS H20 } \\
203(\%)\end{array}$ & $\begin{array}{l}\text { ABS sec } \\
203(\%)\end{array}$ \\
\hline 1 & \multirow{9}{*}{ 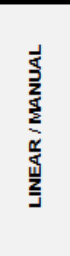 } & Carb 63 C02 T(mm) & 0,377 & 0,611 & 0,684 & 0,091 & 0,553 & $-0,27$ & $-0,015$ & 0,49 & $-0,215$ & 0,039 & 0,578 & 0,462 & 0,287 \\
\hline 2 & & \begin{tabular}{|l|} 
Carb $63 \mathrm{CO} 2(\mathrm{~mm})$ \\
\end{tabular} & 0,129 & 0,561 & 0,428 & 0,021 & 0,282 & $-0,52$ & $-0,277$ & 0,2 & $-0,574$ & $-0,214$ & 0,351 & 0,277 & 0,172 \\
\hline 3 & & \begin{tabular}{|l|} 
Carb 63 H2O T(mm) \\
\end{tabular} & 0,71 & 0,284 & 0,455 & $-0,015$ & 0,532 & $-0,159$ & $-0,201$ & 0,656 & $-0,11$ & 0,092 & 0,67 & 0,469 & 0,495 \\
\hline 4 & & \begin{tabular}{|l|} 
Carb $63 \mathrm{H} 2 \mathrm{O}(\mathrm{mm})$ \\
\end{tabular} & $-0,389$ & 0,873 & 0,794 & 0,554 & 0,482 & 0,208 & 0,478 & 0,599 & 0,185 & 0,718 & 0,578 & 0,74 & 0,336 \\
\hline 5 & & \begin{tabular}{|l|} 
Carb 91 C02(mm) \\
\end{tabular} & 0,3 & 0,599 & 0,647 & 0,028 & 0,434 & $-0,391$ & $-0,115$ & 0,402 & $-0,346$ & $-0,024$ & 0,494 & 0,398 & 0,217 \\
\hline 6 & & Carb $91 \mathrm{H} 2 \mathrm{O}(\mathrm{mm})$ & $-0,053$ & 0,187 & $-0,146$ & $-0,055$ & $-0,131$ & $-0,571$ & $-0,69$ & 0,044 & $-0,8$ & $-0,269$ & 0,153 & 0,125 & 0,272 \\
\hline 7 & & \begin{tabular}{|l|} 
Carb $203 \mathrm{CO}(\mathrm{mm})$ \\
\end{tabular} & 0,325 & 0,593 & 0,593 & 0,163 & 0,512 & $-0,226$ & $-0,138$ & 0,642 & $-0,25$ & 0,205 & 0,69 & 0,601 & 0,49 \\
\hline 8 & & Carb 203 H2O(mm) & 0,04 & 0,897 & 0,8 & 0,503 & 0,76 & 0,088 & 0,338 & 0,681 & 0,046 & 0,412 & 0,768 & 0,76 & 0,494 \\
\hline 9 & & Carb $203 \mathrm{SEC}(\mathrm{mm})$ & 0,326 & 0,592 & 0,764 & $-0,008$ & 0,452 & $-0,33$ & 0,037 & 0,385 & $-0,195$ & 0,027 & 0,448 & 0,36 & 0,096 \\
\hline 10 & \multirow{9}{*}{ 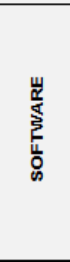 } & IMJ C02 $63(\%)$ & 0,322 & 0,094 & 0,257 & $-0,227$ & $-0,024$ & $-0,402$ & $-0,454$ & 0,362 & $-0,353$ & 0,1 & 0,292 & 0,232 & 0,208 \\
\hline 11 & & IMJ C02 91(\%) & 0,039 & 0,607 & 0,731 & $-0,055$ & 0,195 & $-0,469$ & $-0,063$ & 0,257 & $-0,353$ & 0,07 & 0,289 & 0,299 & $-0,035$ \\
\hline 12 & & IMJ H20 91 (\%) & $-0,26$ & 0,831 & 0,733 & 0,427 & 0,533 & 0,059 & 0,508 & 0,266 & 0,074 & 0,244 & 0,374 & 0,447 & 0,077 \\
\hline 13 & & LC C02 203 (\%) & 0,503 & $-0,211$ & $-0,251$ & $-0,393$ & $-0,155$ & $-0,617$ & $-0,85$ & 0,053 & $-0,702$ & $-0,454$ & 0,108 & $-0,076$ & 0,212 \\
\hline 14 & & \begin{tabular}{|l} 
IMJ CO2 $203(\%)$ \\
\end{tabular} & 0,577 & $-0,088$ & 0,248 & $-0,664$ & $-0,172$ & $-0,814$ & $-0,562$ & $-0,151$ & $-0,593$ & $-0,564$ & $-0,118$ & $-0,294$ & $-0,338$ \\
\hline 15 & & LC H20 203 (\%) & 0,422 & 0,54 & 0,587 & 0,044 & 0,489 & $-0,335$ & $-0,172$ & 0,511 & $-0,315$ & 0,013 & 0,592 & 0,461 & 0,355 \\
\hline 16 & & \begin{tabular}{|l|l|} 
IMJ H2O 203 (\%) \\
\end{tabular} & 0,116 & 0,662 & 0,546 & 0,127 & 0,389 & $-0,408$ & $-0,173$ & 0,362 & $-0,461$ & $-0,03$ & 0,486 & 0,431 & 0,28 \\
\hline 17 & & LC SEC 203(\%) & 0,645 & $-0,301$ & 0,18 & $-0,545$ & $-0,158$ & $-0,37$ & $-0,427$ & 0,215 & $-0,133$ & $-0,025$ & 0,066 & $-0,067$ & $-0,058$ \\
\hline 18 & & IMJ SEC 203(\%) & $-0,177$ & 0,641 & 0,65 & $-0,011$ & 0,106 & $-0,498$ & $-0,041$ & 0,087 & $-0,429$ & $-0,009$ & 0,157 & 0,216 & $-0,133$ \\
\hline & & $r 2>0,5$ & 4 & 12 & 11 & 2 & 5 & 0 & 1 & 5 & 0 & 1 & 6 & 3 & 0 \\
\hline & & $12>0,7$ & 1 & 3 & 5 & 0 & 1 & 0 & 0 & 0 & 0 & 1 & 1 & 2 & 0 \\
\hline & & $12>0,8$ & 0 & 3 & 1 & 0 & 0 & 0 & 0 & 0 & 0 & 0 & 0 & 0 & 0 \\
\hline & & $12>0,9$ & 0 & 0 & 0 & 0 & 0 & 0 & 0 & 0 & 0 & 0 & 0 & 0 & 0 \\
\hline & & $12<-0,5$ & 0 & 0 & 0 & 2 & 0 & 4 & 3 & 0 & 4 & 1: & 0 & 0 & 0 \\
\hline & & $12<-0,7$ & 0 & 0 & 0 & 0 & 0 & 1 & 1 & 0 & 2 & 0 & 0 & 0 & 0 \\
\hline & & $12<-0,8$ & 0 & 0 & 0 & 0 & 0 & 1 & 1) & 0 & 1] & 0 & 0 & 0 & 0 \\
\hline & & $12<-0,9$ & 0 & 0 & 0 & 0 & 0 & 0 & 0 & 0 & 0 & 0 & 0 & 0 & 0 \\
\hline & & $12>10,5$ & 4 & 12 & 11 & 4 & 5 & 4 & 4 & 5 & 4 & 2 & 6 & 3 & 0 \\
\hline & & $12>10,7]$ & 1 & 3 & 5 & 0 & 1 & 1 & 1) & 0 & 2 & 1 & 1 & 2 & 0 \\
\hline & & $r 2>10,8$ & 0 & 3 & 1 & 0 & 0 & 1. & 1 & 0 & 1 & 0 & 0 & 0 & 0 \\
\hline & & $12>10,9$ & 0 & 0 & 0 & 0 & 0 & 0 & 0 & 0 & 0 & 0 & 0 & 0 & 0 \\
\hline
\end{tabular}

Novamente a Tabela 113 demonstra algumas correlações para idades iniciais, mas apenas com a propriedade de absorção de água e de modo similar ao que ocorreu para o índice de vazios, mas com valores mais altos do coeficiente de Pearson para índice de vazios.

\section{A.6) Concreto Endurecido - Carbonatação}

As correlações encontradas entre as medidas de profundidade de carbonatação, entre si, estão apresentadas na Tabela 114. 
TABELA 114 - Correlações entre os resultados carbonatação linear e os resultados de ensaios de profundidade de carbonatação

\begin{tabular}{|c|c|c|c|c|c|c|c|c|c|c|c|c|c|c|c|c|c|c|c|c|}
\hline Item & Medida & PROPRIEDADE & $\begin{array}{c}\text { Carb 63 } \\
\text { C02 } \\
T(m m)\end{array}$ & $\begin{array}{c}\text { Carb 63 } \\
\text { C02 } \\
(\mathrm{mm}) \\
\end{array}$ & \begin{tabular}{c|} 
Carb 63 \\
H2O \\
T(mm)
\end{tabular} & $\begin{array}{c}\text { Carb 63 } \\
\text { H20 } \\
(\mathrm{mm})\end{array}$ & $\begin{array}{c}\text { Carb } 91 \\
\text { C02 } \\
(\mathrm{mm})\end{array}$ & $\begin{array}{c}\text { Carb } 91 \\
\text { H20 } \\
(\mathrm{mm})\end{array}$ & \begin{tabular}{|c} 
Carb 203 \\
C02 \\
$(\mathrm{mm})$
\end{tabular} & \begin{tabular}{|c} 
Carb 203 \\
H20 \\
$(\mathrm{mm})$
\end{tabular} & \begin{tabular}{|c} 
Carb 203 \\
SEC \\
$(\mathrm{mm})$ \\
\end{tabular} & \begin{tabular}{|c|} 
IMJ C02 \\
$63(\%)$
\end{tabular} & \begin{tabular}{|c|} 
IMJ C Co2 \\
$91(\%)$
\end{tabular} & $\begin{array}{c}\text { IMJ H20 } \\
91 \text { (\%) }\end{array}$ & $\begin{array}{l}\text { LC CO2 } \\
203(\%)\end{array}$ & \begin{tabular}{|c|} 
IMJ CO2 \\
$203(\%)$
\end{tabular} & $\begin{array}{l}\mathrm{LC} \mathrm{H} 20 \\
203(\%)\end{array}$ & \begin{tabular}{|c|} 
IMJ H2O \\
203 (\%)
\end{tabular} & $\begin{array}{l}\text { LC SEC } \\
203(\%)\end{array}$ & \begin{tabular}{|c|} 
IMJ SEC \\
$203(\%)$
\end{tabular} \\
\hline 1 & \multirow{9}{*}{$\begin{array}{l}\frac{1}{5} \\
\frac{2}{2} \\
\frac{2}{2} \\
\frac{2}{2} \\
\frac{d}{5} \\
\frac{d}{2} \\
\frac{2}{J}\end{array}$} & Carb 63 C02 T(mm) & & 0,9 & 0,815 & 0,481 & 0,986 & 0,38 & 0,889 & 0,891 & 0,974 & 0,424 & 0,833 & 0,671 & 0,379 & 0,678 & 0,973 & 0,929 & 0,24 & 0,749 \\
\hline 2 & & Carb $63302(\mathrm{~mm})$ & 0,9 & & 0,628 & 0,408 & 0,946 & 0,65 & 0,814 & 0,775 & 0,869 & 0,408 & 0,837 & 0,63 & 0,503 & 0,695 & 0,903 & 0,98 & 0,091 & 0,839 \\
\hline 3 & & Carb 63 H2O T(mm) & 0,815 & 0,628 & & 0,265 & 0,778 & 0,419 & 0,889 & 0,639 & 0,723 & 0,677 & 0,558 & 0,162 & 0,652 & 0,604 & 0,889 & 0,693 & 0,613 & 0,349 \\
\hline 4 & & Carb 63 H2O(mm) & 0,481 & 0,408 & 0,265 & & 0,508 & 0,223 & 0,602 & 0,751 & 0,514 & 0,399 & 0,693 & 0,613 & $-0,16$ & $-0,055$ & 0,461 & 0,556 & 0,049 & 0,672 \\
\hline 5 & & Carb 91 Co2(mm) & 0,986 & 0,946 & 0,778 & 0,508 & & 0,494 & 0,903 & 0,863 & 0,97 & 0,497 & 0,896 & 0,651 & 0,442 & 0,724 & 0,976 & 0,969 & 0,268 & 0,828 \\
\hline 6 & & Carb 91 H2O(mm) & 0,38 & 0,65 & 0,419 & 0,223 & 0,494 & & 0,621 & 0,276 & 0,283 & 0,679 & 0,473 & $-0,048$ & 0,817 & 0,397 & 0,542 & 0,645 & 0,278 & 0,462 \\
\hline 7 & & Carb $203 \mathrm{CO} 2(\mathrm{~mm})$ & 0,889 & 0,814 & 0,889 & 0,602 & 0,903 & 0,621 & & 0,827 & 0,821 & 0,74 & 0,805 & 0,406 & 0,582 & 0,552 & 0,957 & 0,898 & 0,46 & 0,668 \\
\hline 8 & & Carb 203 H2O(mm) & 0,891 & 0,775 & 0,639 & 0,751 & 0,863 & 0,276 & 0,827 & & 0,857 & 0,285 & 0,765 & 0,816 & 0,079 & 0,292 & 0,837 & 0,858 & $-0,019$ & 0,721 \\
\hline 9 & & Carb 203 SEC(mm) & 0,974 & 0,869 & 0,723 & 0,514 & 0,97 & 0,283 & 0,821 & 0,857 & & 0,393 & 0,895 & 0,725 & 0,267 & 0,724 & 0,922 & 0,894 & 0,254 & 0,827 \\
\hline 10 & \multirow{9}{*}{$\begin{array}{l}\frac{w}{\alpha} \\
\frac{\alpha}{5} \\
\frac{\partial}{0} \\
\frac{0}{\infty}\end{array}$} & IMJ C02 63 (\%) & 0,424 & 0,408 & 0,677 & 0,399 & 0,497 & 0,679 & 0,74 & 0,285 & 0,393 & & 0,58 & $-0,195$ & 0,735 & 0,491 & 0,594 & 0,501 & 0,843 & 0,399 \\
\hline 11 & & IMJ C02 91(\%) & 0,833 & 0,837 & 0,558 & 0,693 & 0,896 & 0,473 & 0,805 & 0,765 & 0,895 & 0,58 & & 0,641 & 0,294 & 0,67 & 0,824 & 0,884 & 0,331 & 0,962 \\
\hline 12 & & IMJ H20 91 (\%) & 0,671 & 0,63 & 0,162 & 0,613 & 0,651 & $-0,048$ & 0,406 & 0,816 & 0,725 & $-0,195$ & 0,641 & & $-0,348$ & 0,185 & 0,512 & 0,646 & $-0,422$ & 0,733 \\
\hline 13 & & LC C02 $203(\%)$ & 0,379 & 0,503 & 0,652 & $-0,16$ & 0,442 & 0,817 & 0,582 & 0,079 & 0,267 & 0,735 & 0,294 & $-0,348$ & & 0,614 & 0,561 & 0,477 & 0,612 & 0,171 \\
\hline 14 & & IIMJ C02 203 (\%) & 0,678 & 0,695 & 0,604 & $-0,055$ & 0,724 & 0,397 & 0,552 & 0,292 & 0,724 & 0,491 & 0,67 & 0,185 & 0,614 & & 0,701 & 0,63 & 0,551 & 0,59 \\
\hline 15 & & LC H2O $203(\%)$ & 0,973 & 0,903 & 0,889 & 0,461 & 0,976 & 0,542 & 0,957 & 0,837 & 0,922 & 0,594 & 0,824 & 0,512 & 0,561 & 0,701 & & 0,941 & 0,379 & 0,711 \\
\hline 16 & & IMJ H2O $203(\%)$ & 0,929 & 0,98 & 0,693 & 0,556 & 0,969 & 0,645 & 0,898 & 0,858 & 0,894 & 0,501 & 0,884 & 0,646 & 0,477 & 0,63 & 0,941 & & 0,159 & 0,856 \\
\hline 17 & & LC SEC 203(\%) & 0,24 & 0,091 & 0,613 & 0,049 & 0,268 & 0,278 & 0,46 & $-0,019$ & 0,254 & 0,843 & 0,331 & $-0,422$ & 0,612 & 0,551 & 0,379 & 0,159 & & 0,098 \\
\hline 18 & & IMJ SEC 203(\%) & 0,749 & 0,839 & 0,349 & 0,672 & 0,828 & 0,462 & 0,668 & 0,721 & 0,827 & 0,399 & 0,962 & 0,733 & 0,171 & 0,59 & 0,711 & 0,856 & 0,098 & \\
\hline & & $2>0,5$ & 12 & 14 & 13 & 8 & 13 & 6 & 15 & 12 & 13 & 8 & 14 & 10 & 8 & 12 & 15 & 15 & 4 & 12 \\
\hline & & $12>0,7$ & 10 & 9 & 5 & 1 & 11 & 1 & 10 & 11 & 12 & 3 & 9 & 3 & 2 & 3 & 11 & 9 & 1 & $x^{\prime}$ \\
\hline & & $2>0,8$ & 9 & 8 & 3 & of & 9 & 1 & 9 & 7 & 9 & 1 & 8 & 1 & 1 & 0 & 9 & 9 & 1 & 5 \\
\hline & & $12>0,9$ & 5 & 4 & 0 & 0 & 6 & 0 & 2 & 0 & 3 & 0 & 1 & 0 & 0 & 0 & 6 & 4 & 01 & 1 \\
\hline & & $12<-0,5$ & 0 & 0 & 0 & 0 & 0 & 0 & 0 & 0 & 0 & 0 & 0 & 0 & 0 & 0 & 0 & 0 & 0 & 0 \\
\hline & & $12<-0,7$ & 0 & 0 & 0 & 0 & 0 & 0 & 0 & 0 & 0 & 0 & 0 & 0 & 0 & 0 & 0 & 0 & 0 & 0 \\
\hline & & $12<-0,8$ & 0 & 0 & 0 & 0 & 0 & 0 & 0 & 0 & 0 & 0 & 0 & 0 & 0 & 0 & 0 & 0 & 0 & 0 \\
\hline & & $12<-0,9$ & 0 & 0 & 0 & 0 & 0 & 0 & 0 & 0 & 0 & 0 & 0 & 0 & 0 & 0 & of & 0 & 0 & Oi \\
\hline & & $12>10,5$ & 12 & 14 & 13 & 8 & 13 & 6 & 15 & 12 & 13 & 8 & 14 & 10 & 8 & 12 & 15 & 15 & 4 & 12 \\
\hline & & {$[2>10,7$} & 10 & 9 & 5 & 1 & 11 & 1 & 10 & 11 & 12 & 3 & 9 & 3 & 2 & 3 & 11 & 9 & 1 & 9 \\
\hline & & $12>10,8$ & 9 & 8 & 3 & 0 & 9 & 1 & 9 & 7 & 9 & 1 & 8 & 1 & 1 & 0 & 9 & 9 & 1 & 5 \\
\hline & & $12>0,9$ & 5 & 4 & 0 & of & 6 & of & 2 & 0 & 3 & 0 & 1 & 0 & 0 & 0 & 6 & 4 & 0 & \\
\hline
\end{tabular}

Observam-se boas correlações quando se compara a profundidade de carbonatação entre si, demonstrando que as diferenças de exposição seguem algum padrão. O método de medida pelo programa Leica Qwin permitiu as melhores correlações e foi o mesmo que apresentou as piores correlações em uma diferente ciclagem, tal fato pode ser explicado devido percepção visual dos operadores. As medidas com ciclagem em água, que apresentaram maior quantidade de correlações, são as que possuíam a franja de carbonatação mais definida. O ambiente com secagem permanente (LC SEC 203 (\%) da Tabela 114) apresentou uma franja com menor definição e as poucas correlações ocorridas para essas medidas caberiam ser investigadas.

Em três idades comparativas o método de medida linear mostrou correlações do que as medidas pelo programa Image $\mathrm{J}$, mas isto pode ter ocorrido por desvios no plano central de análise da imagem do corpo-de-prova e tal plano cabe ser melhor controlado em futuras pesquisas. As medidas lineares de franja de carbonatação por apenas dois ciclos do tipo $A E 1$ foram suficientes para predizer o comportamento da carbonatação por sete ciclos (203 dias) nos três ambientes de exposição. 


\subsubsection{Teste de hipótese e normalidade quanto às propriedades}

A ferramenta de análise "Anderson-Darling", segundo os estatísticos, é um bom caminho para realizar testes de normalidade. O teste de Anderson-Darling para normalidade detecta os desvios da normalidade.

Embora seja por vezes apresentado como o teste mais poderoso, entre três mais comuns, nenhum teste é um dos melhores contra todas as alternativas e os outros dois testes são de potência comparável. O teste rejeita a hipótese de normalidade, quando o valor-p é menor ou igual a $0,05.44$

$\mathrm{Na}$ falta de normalidade permite afirmar com 95\% de confiança que os dados não tem a distribuição normal. Passando, o teste de normalidade só permite afirmar que nenhum desvio significativo da normalidade foi encontrado.

Se o valor de $P$ (P-value) do Teste de Anderson-Darling $(A D)$ é maior que 0,05 , não se rejeita a hipótese H0, ou seja, os erros têm uma distribuição normal.

P-valor é a probabilidade que a amostra a ser testada foi retirada de uma população com uma distribuição normal, se o P-valor é menor do que o padrão geralmente aceite de 0,05, a hipótese nula é provável que seja falsa e diferenças entre as amostras é provável que existam.

Autores internacionais destacam patamares diferenciados para aceitação ou rejeição da hipótese, conforme significado do tamanho do P-Valor 45 citado na apresentação sobre testes de hipóteses de Campos $^{46}$, apresentado na Tabela 115:

44

http://www.minasjr.demin.ufmg.br/pdf/Tratamento estatistico da expectativa de carga em caminhoes fora de estrada Rodrigo Barbosa.pdf, consultado em 17/11/2010.

http://www.fcav.unesp.br/gener/Aula Prat 2.pdf, consultado em 17/11/2010.

45 Wild,C.J.; Seber, G.A.F. “ Chance Encounters: A first course in data analysis and inference”.Wiley, New York, 2000, 611p.

${ }^{46}$ Campos,M.R. Estatística usando o SPSS - apresentação em Power Point pelo site: www.enap.gov.br/downloads/ec43ea4fTeste de hipoteses.pdf, consultado em 23/05/2010. 
TABELA 115 - Significado do tamanho do P-valor conforme Wild; Seber (2000).

\begin{tabular}{cc}
\hline \multicolumn{2}{c}{ Interpretação do tamanho de um P-Valor } \\
\hline $\begin{array}{c}\text { Aproximação do tamanho do } \\
\text { P-Valor }\end{array}$ & Significado \\
\hline$>0,12(12 \%)$ & Não há evidência contra Ho \\
$0,10(10 \%)$ & Evidência fraca contra Ho \\
$0,05(5 \%)$ & Alguma evidência contra Ho \\
$0,01(1 \%)$ & Forte evidência contra Ho \\
$0,001(0,1 \%)$ & Muito forte evidência contra Ho \\
\hline
\end{tabular}

Para o estudo foi utilizado o nível de significância de $5 \%$ e se o P-valor do teste de Anderson-Darling for menor que o nível de significância $(0,05)$ rejeita-se a normalidade e o ttest será considerado inválido.

\section{A) Concreto fresco}

A Tabela 116 apresenta os valores de Anderson-Darling, $P$-Valor e se os resultados apresentados mostram normalidade entre as medidas ou não, para os ensaios do concreto fresco.

TABELA 116 - Resultados da análise de normalidade das propriedades do concreto no estado fresco, das amostras de seis caminhões de concreto do lote analisado

\begin{tabular}{|c|c|c|c|c|c|c|}
\hline $\begin{array}{c}\text { Estado do } \\
\text { concreto }\end{array}$ & Identificação & PROPRIEDADE & Abreviatura/Gráficos & $\begin{array}{c}\text { Anderson- } \\
\text { Darling }\end{array}$ & P-Valor & Normalidade \\
\hline \multirow{9}{*}{ FRESCO } & 1 & Slump na central $(\mathrm{cm})$ & slumpCT $(\mathrm{cm})$ & 0,756 & 0,022 & Não \\
\hline & 2 & Slump na obra $(\mathrm{cm})$ & slumpOB $(\mathrm{cm})$ & 0,927 & 0,007 & Não \\
\hline & 3 & Compactabilidade adensada (mm) & compact ad (mm) & 0,3 & 0,6 & Sim \\
\hline & 4 & Compactabilidade não adensada(mm) & compact nad(mm) & 0,3 & 0,4 & Sim \\
\hline & 5 & Teor de ar pressométrico (\%) & pressometrico (\%) & 0,2 & 0,8 & Sim \\
\hline & 6 & Densidade de massa especifica $\left(\mathrm{kg} / \mathrm{m}^{3}\right)$ & Densidade $\left(\mathrm{kg} / \mathrm{m}^{3}\right)$ & 0,3 & 0,5 & Sim \\
\hline & 7 & Teor de ar gravimétrico (\%) & gravimétrico (\%) & 0,3 & 0,5 & Sim \\
\hline & 8 & Umidade do concreto fresco $(\%)$ & umidade $(\%)$ & 1,218 & 0 & Não \\
\hline & 9 & Teor de finos (\%) & Fino (\%) & 0,3 & 0,5 & Sim \\
\hline
\end{tabular}

As Figuras 102 a 110 ilustram os gráficos feitos utilizando o Minitab, para os testes de normalidade das variáveis analisadas para o concreto fresco. 


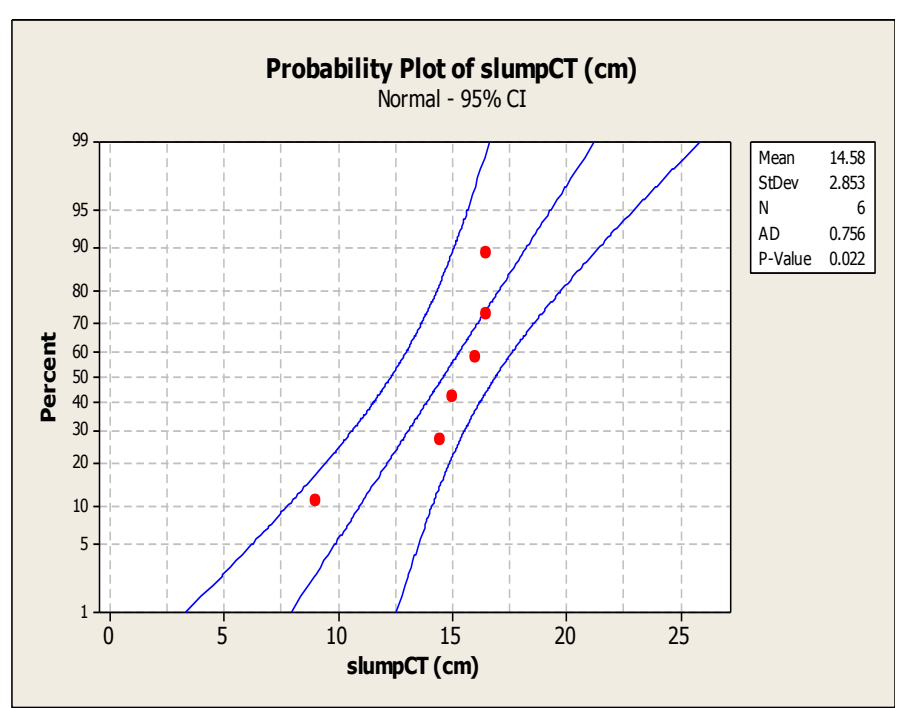

FIGURA 102- Slump na Central (1)

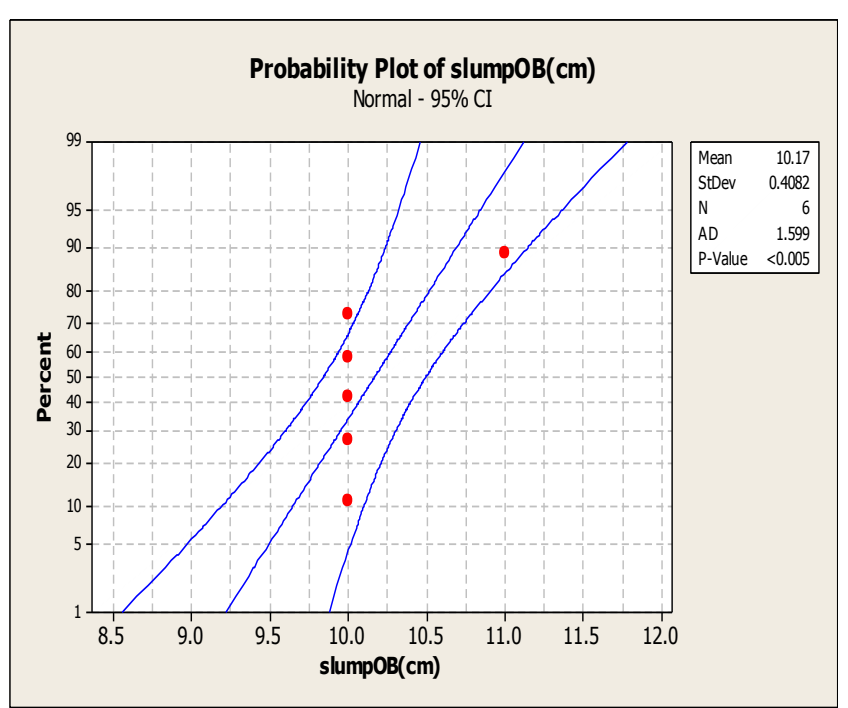

FIGURA 103 -Slump na Obra (2)

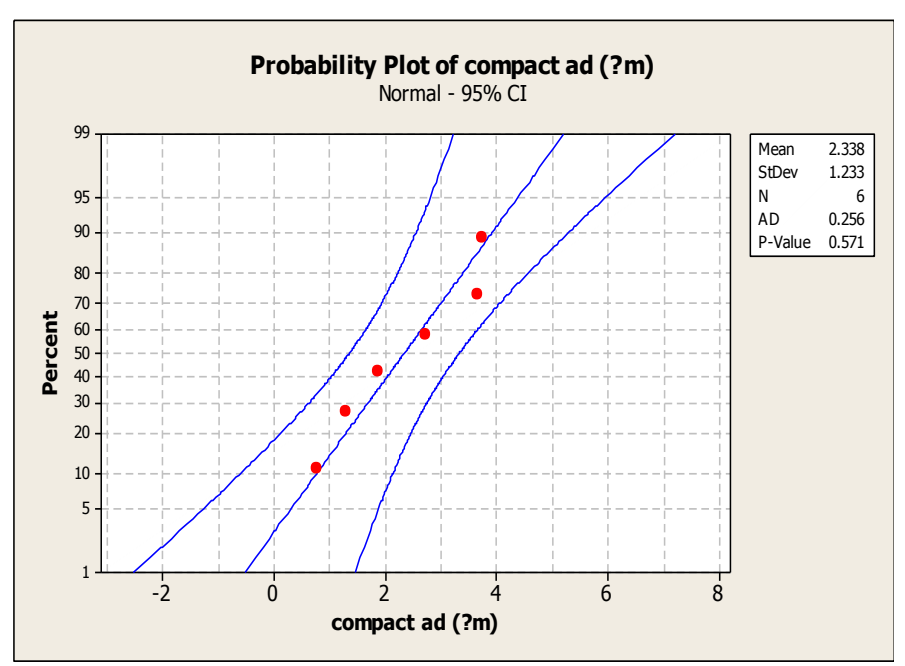

FIGURA 104-Compactabilidade adensada (3)

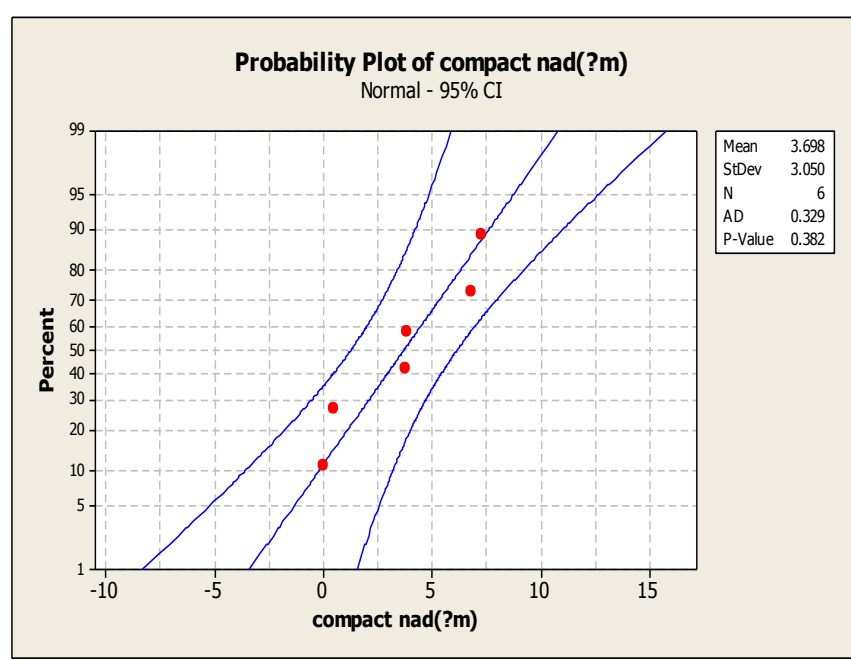

FIGURA 105- Compactabilidade não-adensada (4)
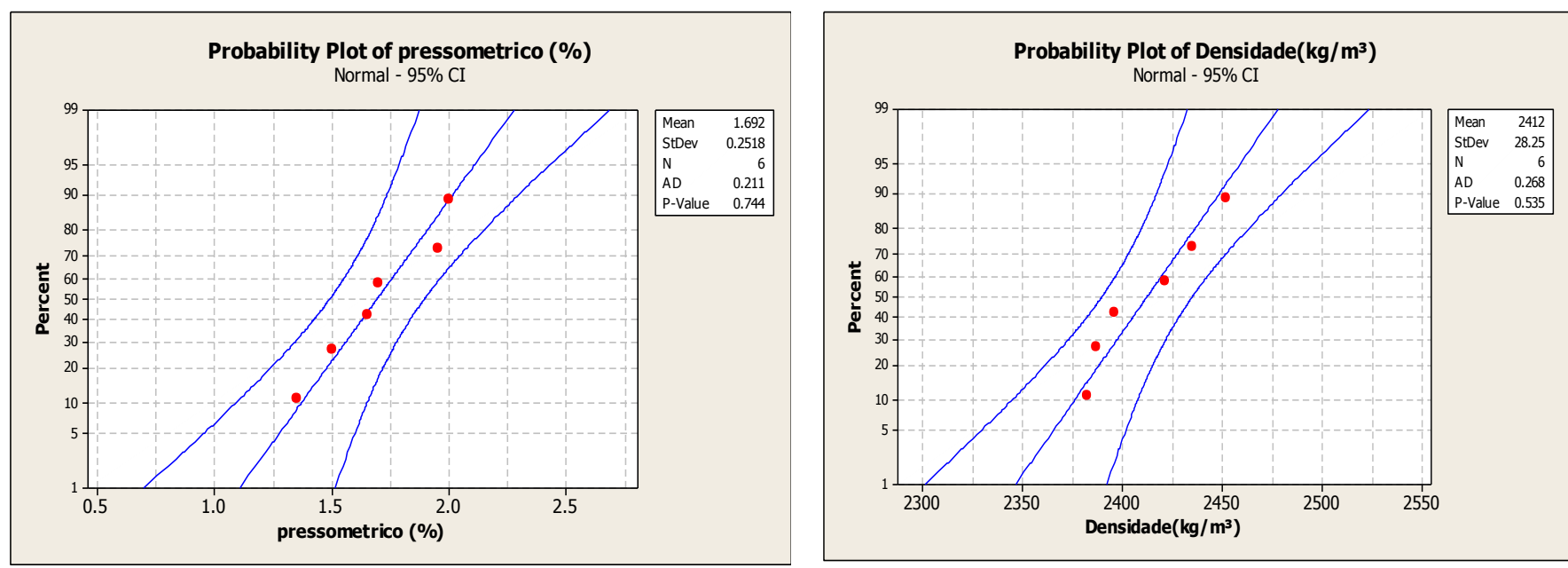

FIGURA 107-Teor de ar pressométrico (5) 


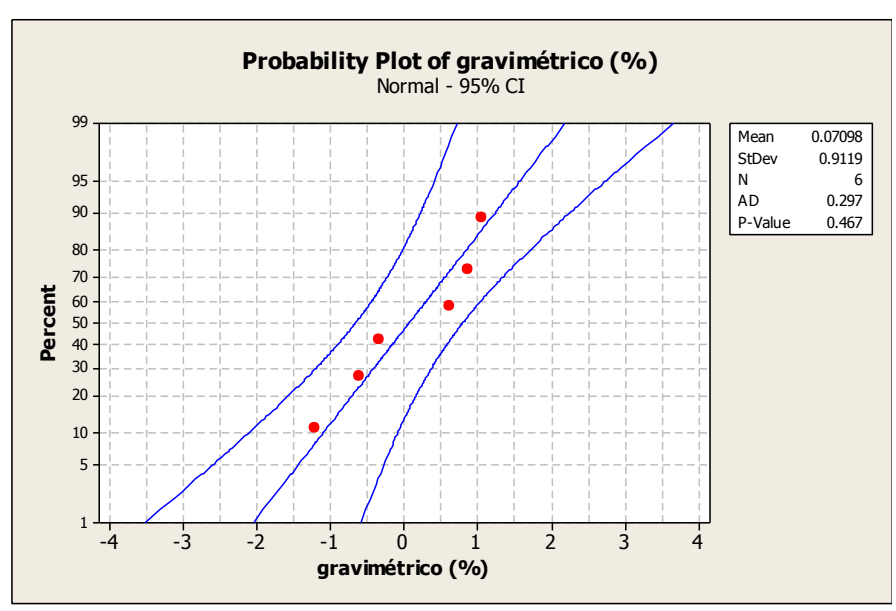

FIGURA 108 - Teor de ar gravimétrico (7)

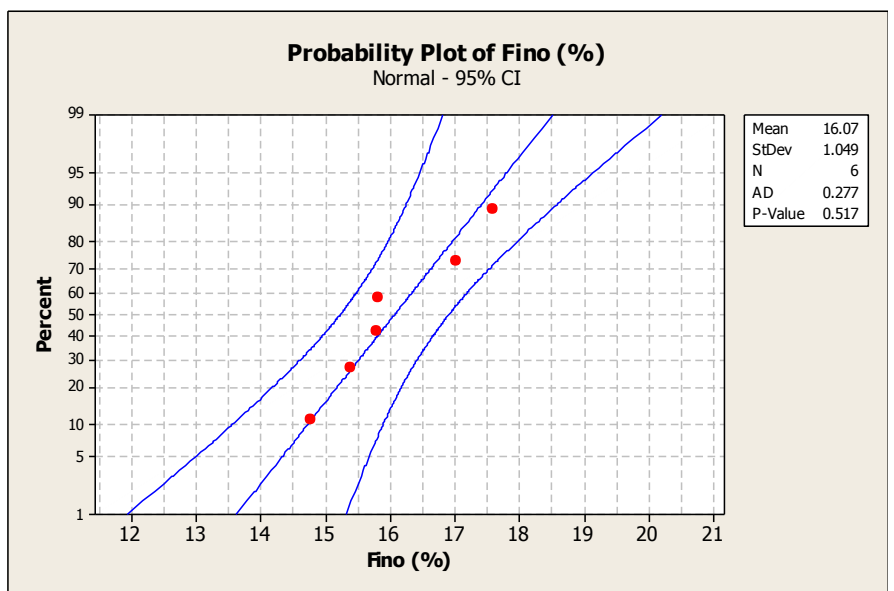

FIGURA 110 - Teor de finos (9)

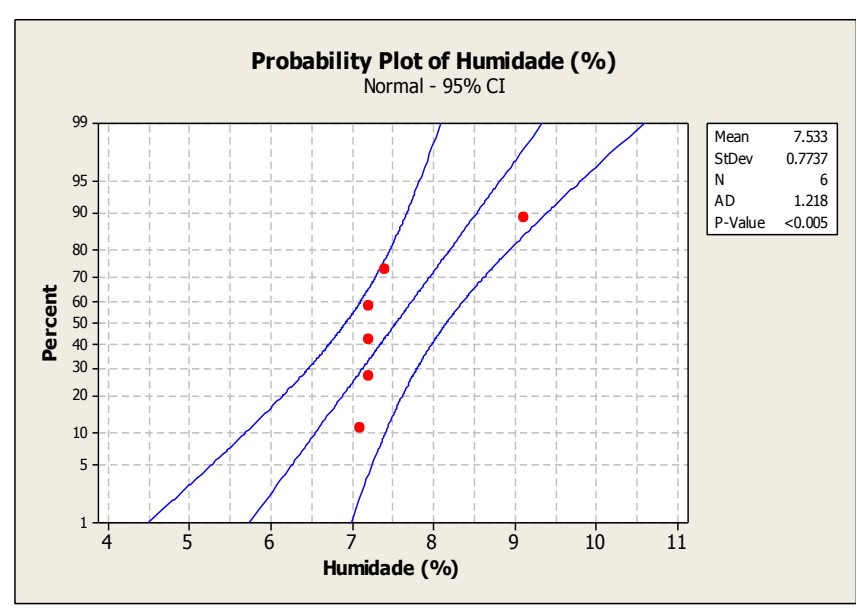

FIGURA 109 - Teor de umidade (8)

A um nível de significância de 5\%, para as variáveis 1, 2 e 8 há evidências para se rejeitar a suposição de normalidade. Para as demais propriedades não há evidências para se rejeitar a suposição de normalidade, portanto as variáveis são consideradas normais.

\section{A) Análise conjunta das propriedades do concreto no estado endurecido}

A Tabela 117 apresenta os valores de Anderson-Darling, P-Valor e se os resultados apresentados mostram normalidade ou não, para os ensaios do concreto endurecido. 
TABELA 117 - Resultados da análise de normalidade das propriedades do concreto no estado endurecido, das amostras de seis caminhões de concreto do lote

\begin{tabular}{|c|c|c|c|c|c|c|}
\hline $\begin{array}{l}\text { Estado do } \\
\text { concreto }\end{array}$ & Identificação & PROPRIEDADE & Abreviatura/Gráficos & $\begin{array}{c}\text { Anderson- } \\
\text { Darling }\end{array}$ & P-Valor & Normalidade \\
\hline \multirow{69}{*}{ ENDURECIDO } & 10 & Res. compressão cura acelerada 0/1 dia (MPa) & fc1 acel (MPa) & 0,3 & 0,4 & Sim \\
\hline & 11 & Res. compressão cura acelerada $1 / 2$ dias $(\mathrm{MPa})$ & fc2 acel (MPa) & 0,2 & 0,8 & Sim \\
\hline & 12 & Res. compressão cura acelerada $1 / 3$ dias (MPa) & fc3 acel (MPa) & 0,3 & 0,4 & Sim \\
\hline & 13 & Res. compressão cura acelerada $1 / 7$ dias $(\mathrm{MPa})$ & fc7 acel $(\mathrm{MPa})$ & 0,3 & 0,4 & Sim \\
\hline & 14 & Res. compressão cura normal 28 dias (MPa) & $\mathrm{fc} 28 \mathrm{n}(\mathrm{MPa})$ & 0,147 & 0,925 & Sim \\
\hline & 15 & Res. tração 8 dias/ cura acelerada exp. $\mathrm{CO} 2(\mathrm{MPa})$ & fct, sp 8acel CO2 (MPa) & 0,497 & 0,124 & Sim \\
\hline & 16 & Res. tração 8 dias/ cura acelerada exp. água ( $\mathrm{MPa}$ ) & fct, sp 8acel H2O (MPa) & 0,3 & 0,3 & Sim \\
\hline & 17 & Res. tração 35 dias/ cura acelerada exp.CO2 (MPa) & fct, sp 35acel CO2 (MPa) & 0,2 & 0,6 & Sim \\
\hline & 18 & Res. tração 35 dias/ cura acelerada exp.água (MPa) & fct, sp 35acel H2O (MPa) & 0,2 & 0,7 & Sim \\
\hline & 19 & Res. tração 63 dias/ cura acelerada exp.CO2 (MPa) & fct, sp 63acel CO2 (MPa) & 0,3 & 0,5 & Sim \\
\hline & 20 & Res. tração 63 dias/ cura acelerada exp. água ( $\mathrm{MPa}$ ) & fct, sp 63acel H2O (MPa) & 0,503 & 0,118 & Sim \\
\hline & 21 & Res. tração 91 dias/ cura acelerada exp. CO2 (MPa) & fct, sp 91acel CO2 (MPa) & 0,2 & 0,8 & Sim \\
\hline & 22 & Res. tração 91 dias/ cura acelerada exp. água ( $\mathrm{MPa}$ ) & fct, sp 91acel H2O (MPa) & 0,9 & 0,01 & Não \\
\hline & 23 & Res. tração 91 dias/ cura acelerada exp. secagem (MPa) & fct, sp 91acel SEC (MPa) & 0,46 & 0,16 & Sim \\
\hline & 24 & Res. tração 203 dias/cura acelerada exp. CO2 (MPa) & fct, sp 203acel CO2 (MPa) & 0,4 & 0,3 & Sim \\
\hline & 25 & Res. tração 203 dias/cura acelerada exp. água (MPa) & fct, sp 203acel H2O (MPa) & 0,3 & 0,6 & Sim \\
\hline & 26 & Res. tração 203 dias/ cura acelerada exp.secagem (MPa) & fct, sp 203acel SEC (MPa) & 0,589 & 0,068 & Sim \\
\hline & 27 & Absorção Capilar 91 dias cura normal $(\mathrm{g} / \mathrm{cm} 2)$ & abs cap91 $\mathrm{n}(\mathrm{g} / \mathrm{cm} 2)$ & 0,477 & 0,143 & Sim \\
\hline & 28 & Absorção Total 8 dias/ cura acelerada exp. CO2 (\%) & ABS CO2 $8(\%)$ & 0,461 & 0,2 & Sim \\
\hline & 29 & Absorção Total 8 dias/ cura acelerada exp. água (\%) & ABS H20 $8(\%)$ & 0,3 & 0,5 & Sim \\
\hline & 30 & Absorção Total 35 dias/ cura acelerada exp. CO2 (\%) & ABS CO2 $35(\%)$ & 0,2 & 0,9 & Sim \\
\hline & 31 & Absorção Total 35 dias/ cura acelerada exp. água (\%) & ABS H2O $35(\%)$ & 0,3 & 0,5 & Sim \\
\hline & 32 & Absorção Total 63 dias/ cura acelerada exp. CO2 (\%) & ABS CO2 $63(\%)$ & 0,4 & 0,2 & Sim \\
\hline & 33 & Absorção Total 63 dias/cura acelerada exp. água (\%) & ABS H2O $63(\%)$ & 0,6 & 0,07 & Sim \\
\hline & 34 & Absorção Total 91 dias/ cura acelerada exp. CO2 (\%) & ABS CO2 $91(\%)$ & 0,3 & 0,6 & Sim \\
\hline & 35 & Absorção Total 91 dias/cura acelerada exp. água (\%) & ABS H2O $91(\%)$ & 0,8 & 0,02 & Não \\
\hline & 36 & Absorção Total 91 dias/cura acelerada exp. secagem (\%) & ABS sec $91(\%)$ & 0,515 & 0,112 & Sim \\
\hline & 37 & Absorção Total 203 dias/ cura acelerada exp. CO2 (\%) & ABS CO2 $203(\%)$ & 0,3 & 0,5 & Sim \\
\hline & 38 & Absorção Total 203 dias/ cura acelerada exp. água (\%) & ABS H20 $203(\%)$ & 0,3 & 0,7 & Sim \\
\hline & 39 & Absorção Total 203 dias/ cura acelerada exp. secagem (\%) & ABS sec $203(\%)$ & 0,1 & 0,9 & Sim \\
\hline & 40 & Indice de Vazios 8 dias/ cura acelerada exp. CO2 (\%) & IV CO2 $8(\%)$ & 0,6 & 0,05 & Não \\
\hline & 41 & Indice de Vazios 8 dias/cura acelerada exp. água (\%) & IV H20 $8(\%)$ & 0,2 & 0,9 & Sim \\
\hline & 42 & Indice de Vazios 35 dias/cura acelerada exp. $\mathrm{CO} 2(\%)$ & IV CO2 $35(\%)$ & 0,2 & 0,9 & Sim \\
\hline & 43 & Indice de Vazios 35 dias/cura acelerada exp. água (\%) & IV H2O $35(\%)$ & 0,3 & 0,5 & Sim \\
\hline & 44 & Indice de Vazios 63 dias/cura acelerada exp. CO2 (\%) & IV CO2 $63(\%)$ & 0,4 & 0,3 & Sim \\
\hline & 45 & Índice de Vazios 63 dias/ cura acelerada exp. água (\%) & IV H2O $63(\%)$ & 0,606 & 0,061 & Sim \\
\hline & 46 & Indice de Vazios 91 dias/cura acelerada exp. CO2 (\%) & IV CO2 $91(\%)$ & 0,3 & 0,4 & Sim \\
\hline & 47 & Indice de Vazios 91 dias/ cura acelerada exp. água (\%) & IV H20 $91(\%)$ & 0,924 & 0,007 & Não \\
\hline & 48 & Índice de Vazios 91 dias/cura acelerada exp. secagem (\%) & IV sec $91(\%)$ & 0,4 & 0,2 & Sim \\
\hline & 49 & Indice de Vazios 203 dias/cura acelerada exp. CO2 (\%) & IV CO2 203 (\%) & 0,4 & 0,3 & Sim \\
\hline & 50 & IIndice de Vazios 203 dias/cura acelerada exp. água (\%) & IV H2O 203 (\%) & 0,3 & 0,6 & Sim \\
\hline & 51 & Indice de Vazios 203 dias/cura acelerada exp. secagem (\%) & IV sec $203(\%)$ & 0,2 & 0,9 & Sim \\
\hline & 52 & Carbonatação 63 dias -ciclagem CO2 -timol (mm) & Carb $63 \mathrm{CO} 2 \mathrm{~T}(\mathrm{~mm})$ & 0,4 & 0,3 & Sim \\
\hline & 53 & Carbonatação 63 dias -ciclagem CO2- fenol (mm) & Carb $63 \mathrm{CO} 2(\mathrm{~mm})$ & 0,2 & 0,8 & Sim \\
\hline & 54 & Carbonatação 63 dias-ciclagem água -timol T (mm) & Carb $63 \mathrm{H} 2 \mathrm{O} \mathrm{T}(\mathrm{mm})$ & 0,2 & 0,8 & Sim \\
\hline & 55 & Carbonatação 63 dias- ciclagem água -fenol (mm) & Carb $63 \mathrm{H} 2 \mathrm{O}(\mathrm{mm})$ & 0,577 & 0,073 & Sim \\
\hline & 56 & Carbonatação 91 dias- ciclagem $\mathrm{CO} 2(\mathrm{~mm})$ & Carb $91 \mathrm{CO} 2(\mathrm{~mm})$ & 0,4 & 0,2 & Sim \\
\hline & 57 & Carbonatação 91 dias- ciclagem água $(\mathrm{mm})$ & Carb $91 \mathrm{H} 2 \mathrm{O}(\mathrm{mm})$ & 0,3 & 0,4 & Sim \\
\hline & 58 & Carbonatação 203 dias- ciclagem $\mathrm{CO} 2(\mathrm{~mm})$ & Carb $203 \mathrm{CO} 2(\mathrm{~mm})$ & 0,6 & 0,06 & Sim \\
\hline & 59 & Carbonatação 203 dias- ciclagem água (mm) & Carb $203 \mathrm{H} 2 \mathrm{O}(\mathrm{mm})$ & 0,2 & 0,7 & Sim \\
\hline & 60 & Carbonatação 203 dias- ciclagem secagem (mm) & Carb 203 SEC(mm) & 0,47 & 0,14 & Sim \\
\hline & 61 & Taxa Carbonatação 63 dias-ciclagem $\mathrm{CO} 2 \mathrm{~T}\left(\mathrm{~mm} / \mathrm{ano}^{\wedge} 1 / 2\right)$ & TAXA Carb $63 \mathrm{CO} 2 \mathrm{~T}\left(\mathrm{~mm} / \mathrm{ano}^{\wedge} 1 / 2\right)$ & 0,3 & 0,5 & Sim \\
\hline & 62 & Taxa Carbonatação 63 dias-ciclagem $\mathrm{CO} 2\left(\mathrm{~mm} / \mathrm{ano}^{\wedge} 1 / 2\right)$ & TAXA Carb $63 \mathrm{CO} 2\left(\mathrm{~mm} / \mathrm{ano}^{\wedge} 1 / 2\right)$ & 0,3 & 0,6 & Sim \\
\hline & 63 & Taxa Carbonatação 63 dias- ciclagem água $\mathrm{T}\left(\mathrm{mm} / \mathrm{ano}^{\wedge} 1 / 2\right)$ & TAXA Carb $63 \mathrm{H} 2 \mathrm{O} \mathrm{T}\left(\mathrm{mm} / \mathrm{ano}^{\wedge} 1 / 2\right)$ & 0,184 & 0,838 & Sim \\
\hline & 64 & Taxa Carb 63 dias- ciclagem água (mm/ano^1/2) & TAXA Carb $63 \mathrm{H} 2 \mathrm{O}\left(\mathrm{mm} / \mathrm{ano}^{\wedge} 1 / 2\right)$ & 0,618 & 0,058 & Sim \\
\hline & 65 & Taxa Carbonatação 91 dias- ciclagem $\mathrm{CO} 2$ (mm/ano^1/2) & TAXA Carb $91 \mathrm{CO} 2\left(\mathrm{~mm} / \mathrm{ano}^{\wedge} 1 / 2\right)$ & 0,4 & 0,3 & Sim \\
\hline & 66 & Taxa Carbonatação 91dias -ciclagem água ( $\left.\mathrm{mm} / \mathrm{ano}^{\wedge} 1 / 2\right)$ & TAXA Carb $91 \mathrm{H} 2 \mathrm{O}\left(\mathrm{mm} / \mathrm{ano}^{\wedge} 1 / 2\right)$ & 0,3 & 0,53 & Sim \\
\hline & 67 & Taxa Carbonatação 203 dias-ciclagem $\mathrm{CO} 2\left(\mathrm{~mm} / \mathrm{ano}^{\wedge} 1 / 2\right)$ & TAXA Carb $203 \mathrm{CO} 2\left(\mathrm{~mm} / \mathrm{ano}^{\wedge} 1 / 2\right)$ & 0,6 & 0,058 & Sim \\
\hline & 68 & Taxa Carbonatação 203 dias- ciclagem água ( $\left.\mathrm{mm} / \mathrm{ano}^{\wedge} 1 / 2\right)$ & TAXA Carb $203 \mathrm{H} 2 \mathrm{O}\left(\mathrm{mm} / \mathrm{ano}^{\wedge} 1 / 2\right)$ & 0,3 & 0,5 & Sim \\
\hline & 69 & Taxa Carbonatação 203 dias- ciclagem secagem $\left(\mathrm{mm} / \mathrm{ano}^{\wedge} 1 / 2\right)$ & TAXA Carb $203 \mathrm{SEC}\left(\mathrm{mm} / \mathrm{ano}^{\wedge} 1 / 2\right)$ & 0,535 & 0,097 & Sim \\
\hline & 70 & Carbonatação Image J 63 dias- ciclagem $\mathrm{CO} 2(\%)$ & IMJ C02 $63(\%)$ & 0,2 & 0,8 & Sim \\
\hline & 71 & Carbonatação Image J 91 dias- ciclagem CO2 (\%) & IMJ C02 91(\%) & 0,2 & 0,8 & Sim \\
\hline & 72 & Carbonatação Image J 91 dias- ciclagem água (\%) & IMJ H2O $91(\%)$ & 0,3 & 0,5 & Sim \\
\hline & 73 & Carbonatação Laica 203 dias - ciclagem CO2 (\%) & LC CO2 $203(\%)$ & 0,2 & 0,8 & Sim \\
\hline & 74 & Carbonatação Image J 203 dias - ciclagem CO2 (\%) & IMJ CO2 $203(\%)$ & 0,3 & 0,5 & Sim \\
\hline & 75 & Carbonatação Laica 203 dias - ciclagem água (\%) & LC H20 $203(\%)$ & 0,6 & 0,065 & Sim \\
\hline & 76 & Carbonatação Image J 203 dias - ciclagem água (\%) & IMJ H2O $203(\%)$ & 0,3 & 0,5 & Sim \\
\hline & 77 & Carbonatação Laica 203 dias - ciclagem secagem (\%) & LC SEC $203(\%)$ & 0,2 & 0,8 & Sim \\
\hline & 78 & Carbonatação Image J 203 dias - ciclagem secagem (\%) & IMJ SEC 203(\%) & 0,3 & 0,7 & Sim \\
\hline
\end{tabular}

Nota-se que apenas três propriedades relativas à exposição em água não resultaram normais, uma propriedade para exposição de $\mathrm{CO}_{2}$ e nenhuma para secagem contínua. A rejeição de normalidade parece estar ainda relacionada ao tipo de ensaio, no caso de absorção de água e índice de vazios. 
As Figuras 111 a 119 ilustram os gráficos de ensaios de carbonatação feitos utilizando o programa Minitab. Essas figuras representam as medidas de profundidade de carbonatação realizadas de maneira tradicional por medidas lineares.

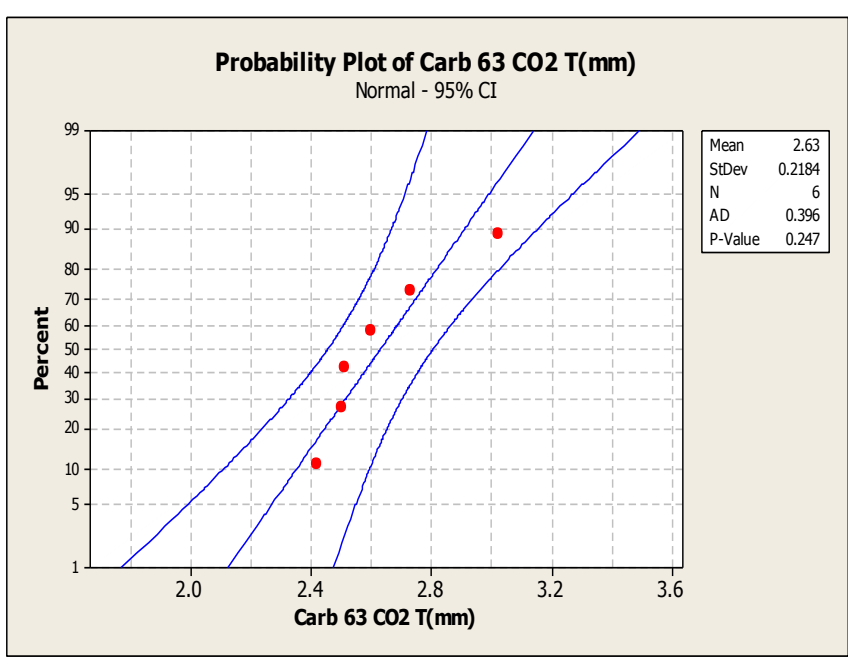

FIGURA 111 - Carbonatação 63 dias/ timolCO2 (52)

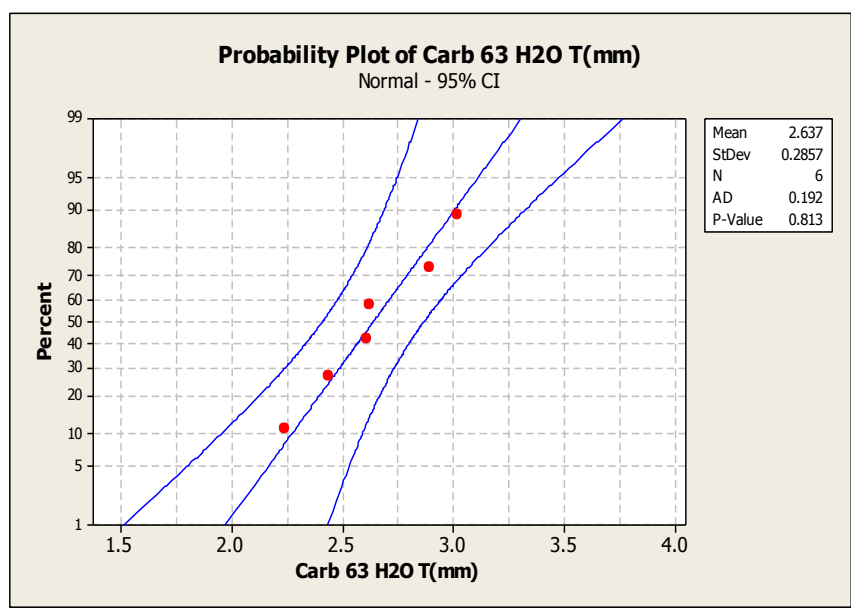

FIGURA 113 - Carbonatação 63 dias/timol Água (54)

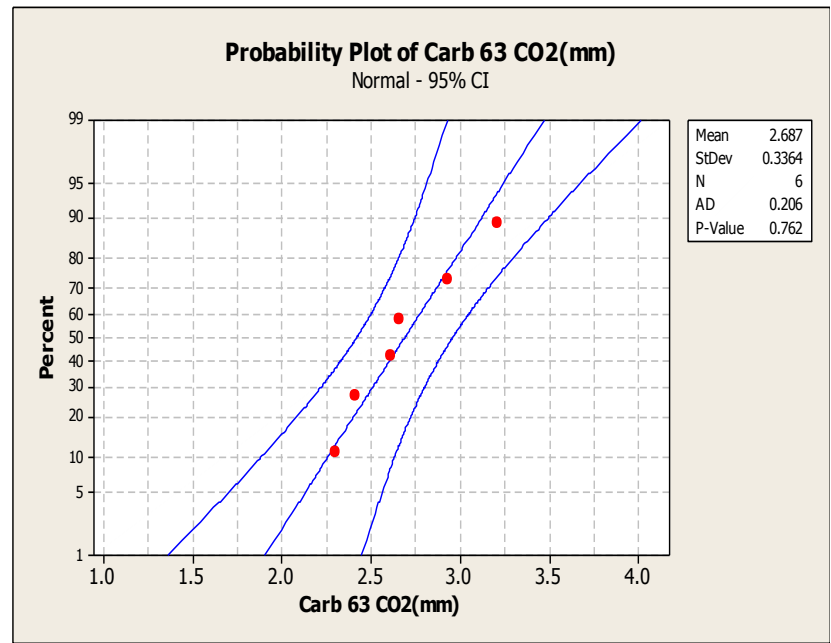

FIGURA 112- Carbonatação 63 dias /fenol CO2 (53)

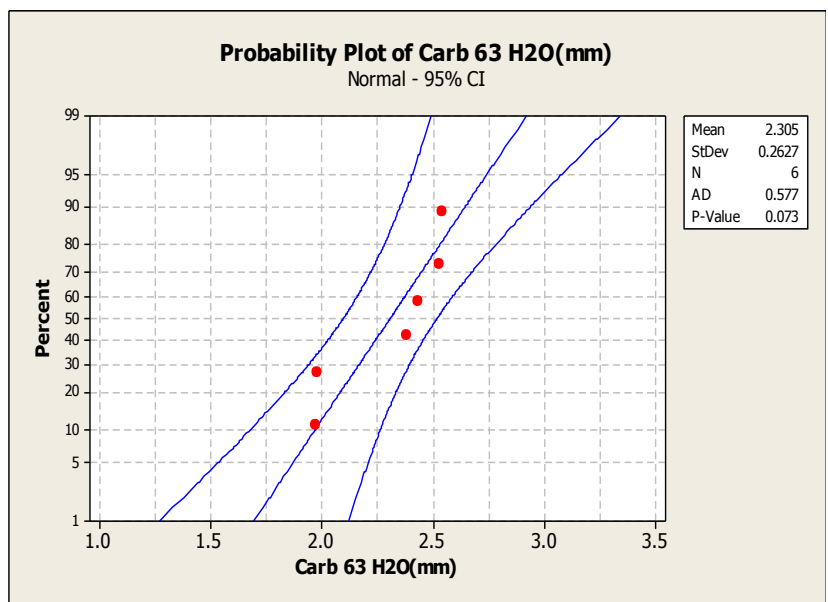

FIGURA 114 - Carbonatação 63 dias/fenol Água (55) 


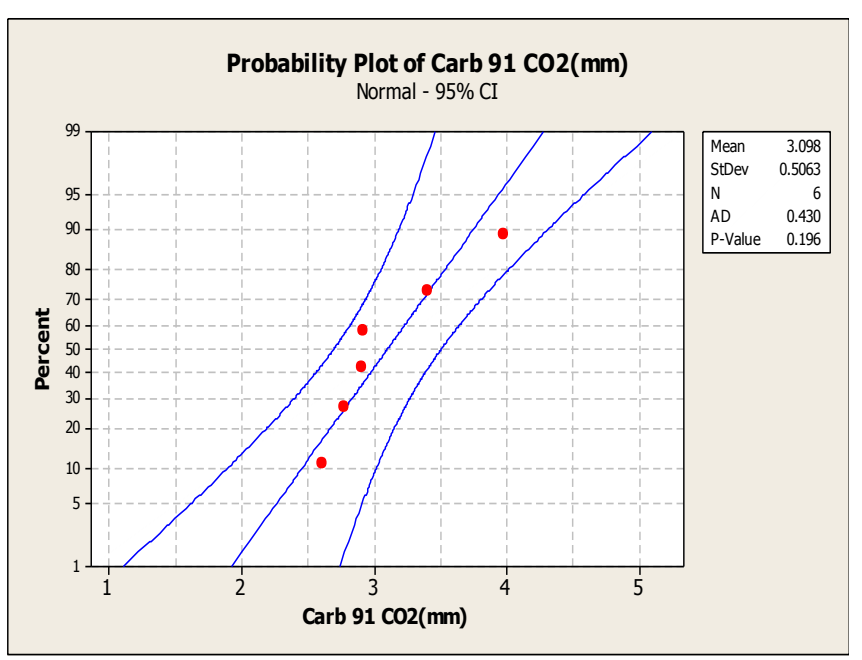

FIGURA 115 - Carbonatação 91 dias - CO2 (56)

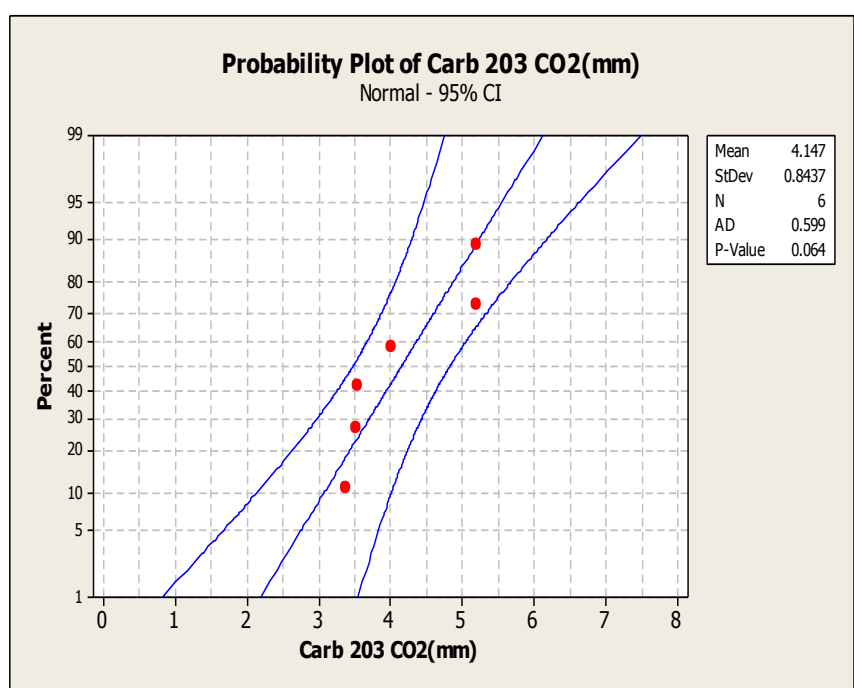

FIGURA 117 - Carbonatação 203 dias - CO2 (58)

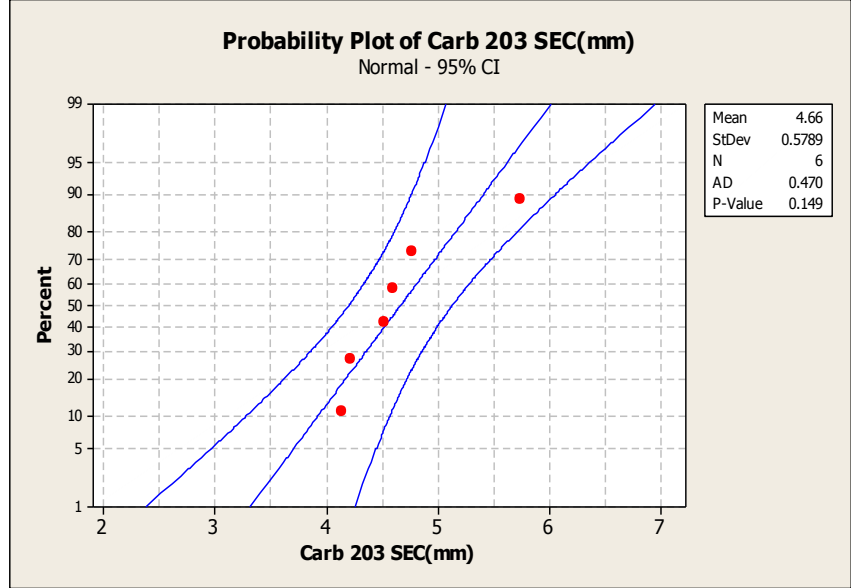

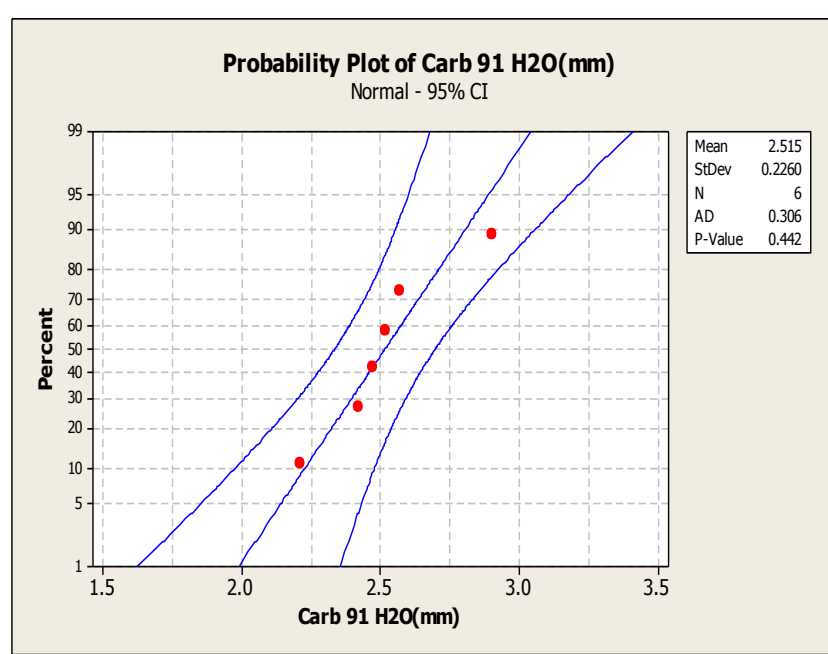

FIGURA 116 - Carbonatação 91 dias - Água (57)

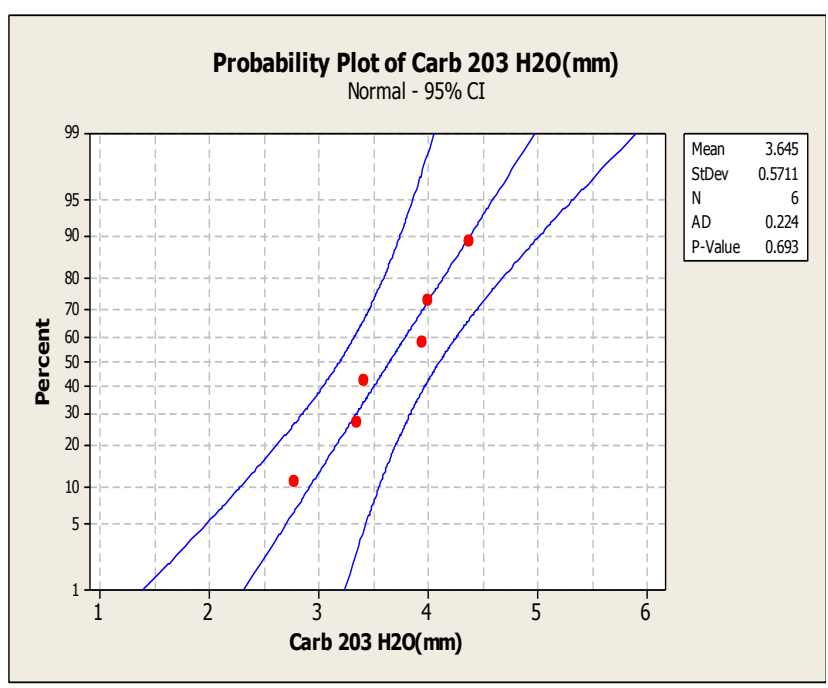

FIGURA 118 - Carbonatação 203 dias - Água (59)

FIGURA 119- Carbonatação Image J 203 dias - Secagem

As Figuras 120 a 128 ilustram os gráficos de ensaios de carbonatação feitos utilizando o programa Minitab. Essas figuras representam as medidas de profundidade de carbonatação realizadas através dos softwares Image $\mathrm{J}$ e Leica, conforme descrito no 
Capítulo 3. Os demais gráficos para os ensaios de concreto endurecido constam no Apêndice D.

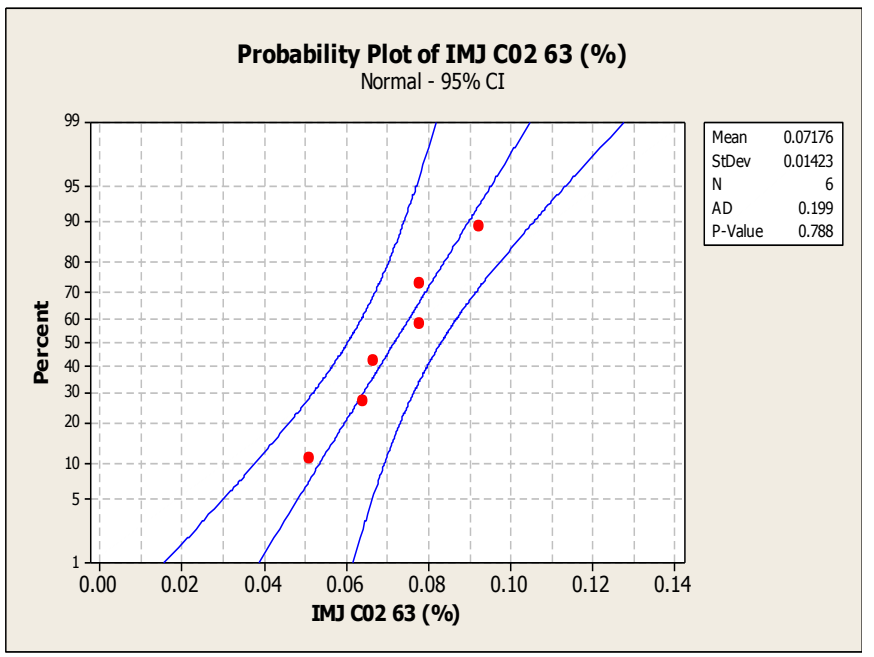

FIGURA 120 - Carbonatação Image J 63 dias $\operatorname{CO2}(70)$

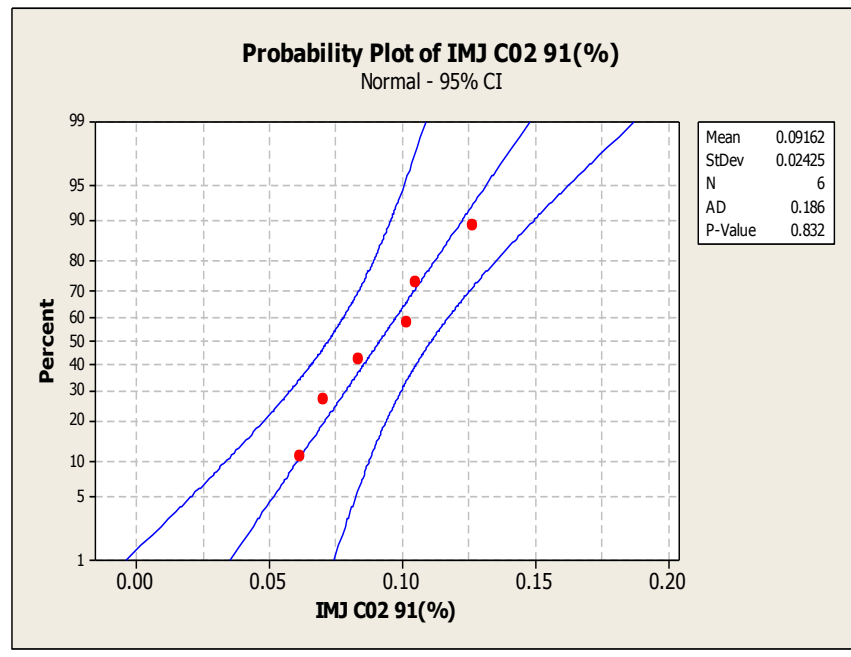

FIGURA 121- Carbonatação Image J 91 dias CO2 (71)

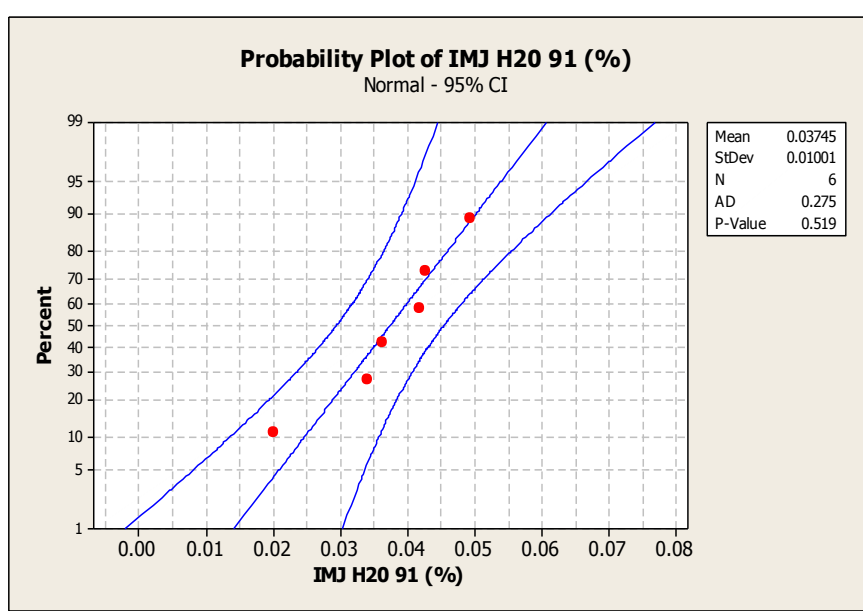

FIGURA 122 - Carbonatação Image J 91 dias Água (72)

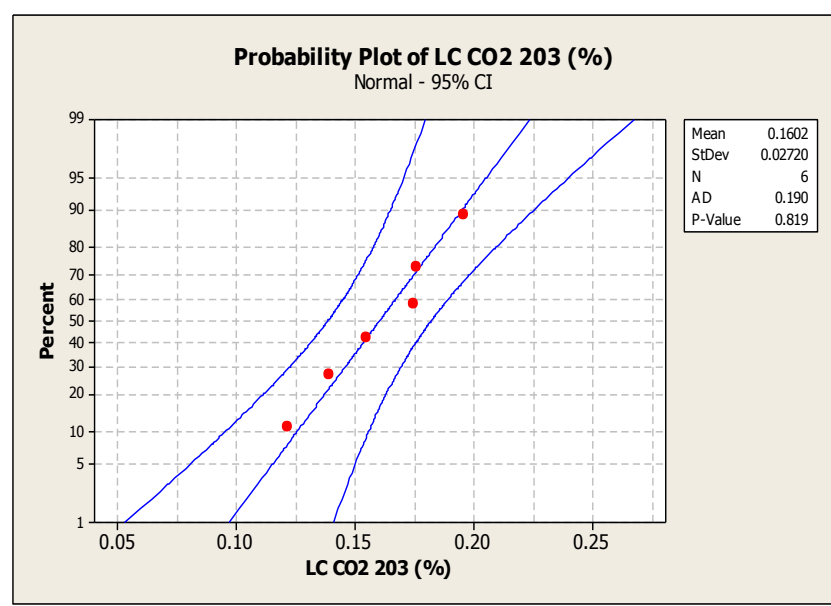

FIGURA 123 - Carbonatação Leica 203 dias CO2 (73) 


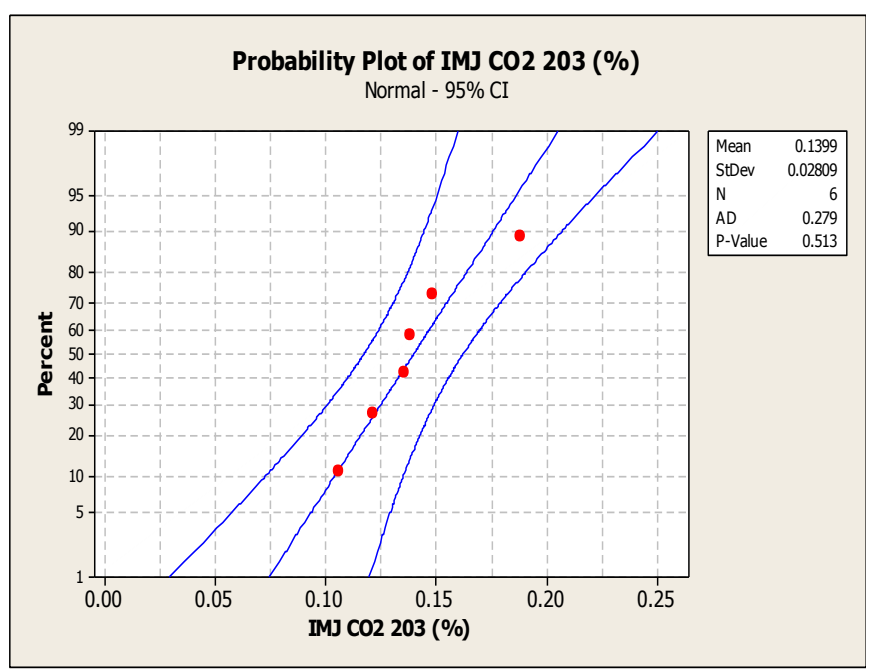

FIGURA 124 - Carbonatação Image J 203 dias - CO2 (74)

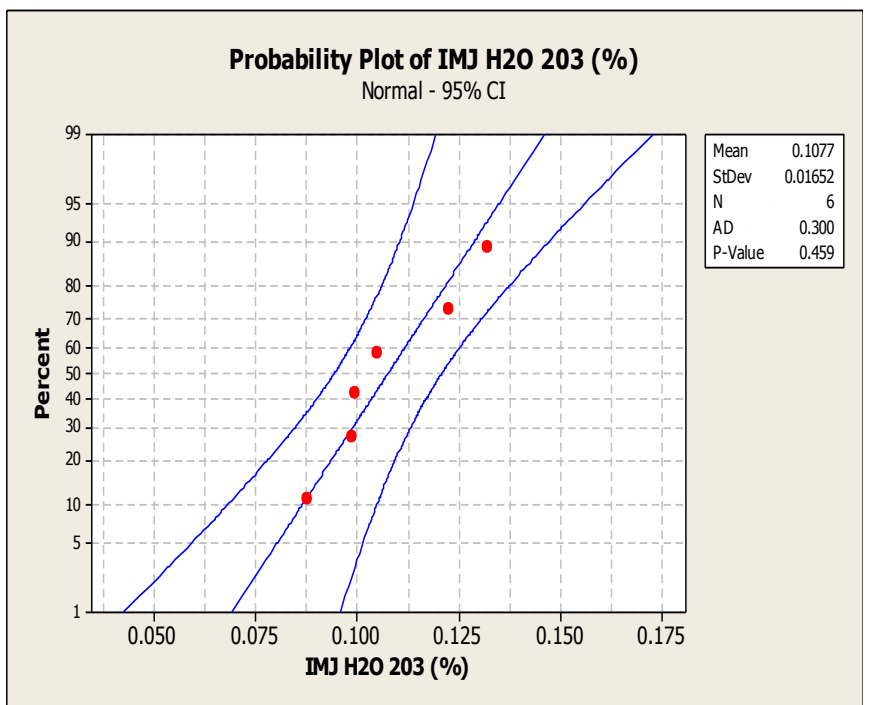

FIGURA 126 - Carbonatação Image J 203 dias - Água (76)

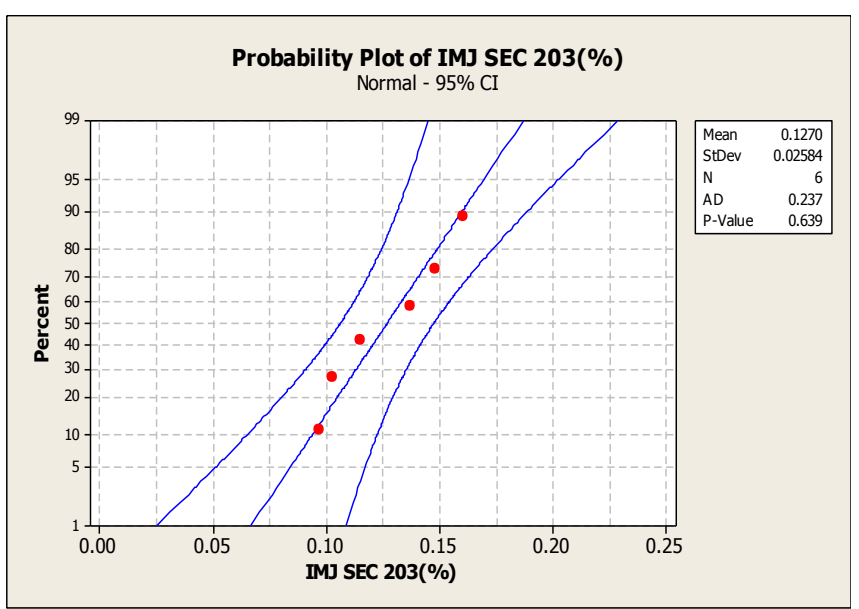

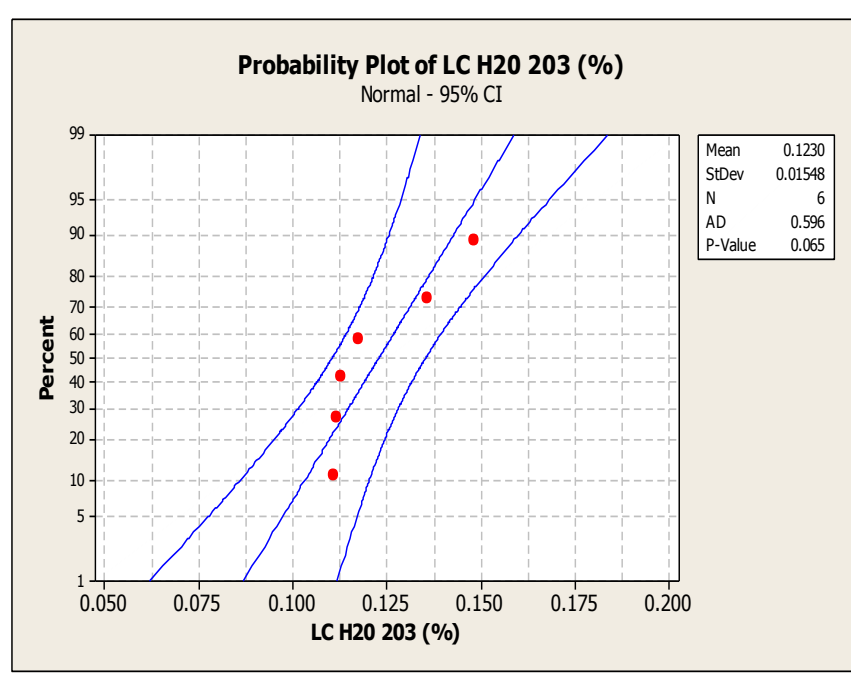

FIGURA 125 - Carbonatação Leica 203 dias Água (75)

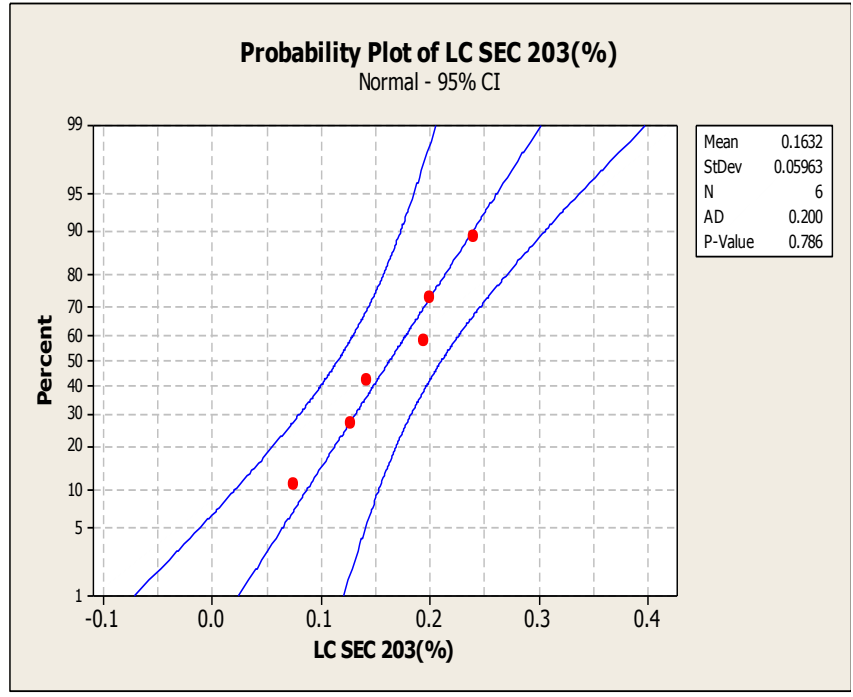

FIGURA 127- Carbonatação Leica 203 dias Secagem (77)

FIGURA 128- Carbonatação Image J 203 dias - Secagem

Para as medidas de profundidade de carbonatação foram realizados os testes de normalidade, e os valores de Anderson-Darling para os respectivos testes permitem concluir que: 
$\checkmark$ Ao nível de 5\%, para as medidas lineares de carbonatação, não há evidências para se rejeitar a suposição de normalidade em nenhum dos casos;

$\checkmark$ Ao nível de $5 \%$, para as medidas de área relativa de carbonatação realizadas pelo software Image $\mathrm{J}$, não há evidências para se rejeitar a suposição de normalidade para todas as idades e nas três condições de exposição analisadas. Quando os valores são analisados dentro do lote, os dados aparentam apresentar normalidade;

$\checkmark$ Ao nível de 5\%, para as medidas de área relativa de carbonatação realizadas pelo software Leica Qwin, não há evidências para se rejeitar a suposição de normalidade;

$\checkmark$ Observa-se que entre 26 propriedades medidas pelos ensaios com exposição cíclica à água, três não apresentaram normalidade e isto cabe ser investigado em pesquisas futuras, pois pode ser devido à falta de repetição na rotina de imersão dos corpos-de-prova, na etapa do ciclo com $24 \mathrm{~h}$ ou em eventual problema de uso da água da rede de abastecimento pública para este fim.

Ao analisar os gráficos e os valores da estatística de Anderson-Darling para o teste de normalidade, é possível concluir que:

$\checkmark$ De 78 propriedades analisadas no estudo, 74 foram consideradas normais e quatro delas foram consideradas não-normais.

\subsubsection{Análise de Variância (ANOVA)}

A Análise de Variância (ANOVA) é um procedimento utilizado para comparar tratamentos em diferentes experimentos objeto de uma investigação. Existem muitas variações da ANOVA devido aos diferentes tipos de experimentos que podem ser realizados.

Um tratamento é uma condição imposta ou objeto que se deseja medir ou avaliar em um experimento. Normalmente, em um experimento, é utilizado mais de um tratamento. Cada tipo de tratamento também pode ser chamado de um fator.

Os tratamentos são chamados de variáveis independentes. Quando, em um experimento, pretende-se estudar apenas um tipo de variável independente, diz-se que há apenas um fator.

Repetição é o número de vezes que um tratamento aparece no experimento. 
O número de repetições, em um experimento, vai depender também dos recursos disponíveis, do tipo de experimento (delineamento) e, também, da variabilidade do experimento ou da variável resposta.

Em um experimento, existe o interesse em testar se há diferenças entre as médias dos tratamentos, o que equivale a testar as hipóteses:

$$
\begin{aligned}
& H 0: \mu_{1}=\mu_{2} \\
& H 1: \mu_{1} \neq \mu_{2}
\end{aligned}
$$

Se a hipótese nula for verdadeira, todos os tratamentos terão uma média comum $\mu$. Esta análise é feita através de alguns parâmetros que são objeto de resultado da ANOVA, quais sejam: valor $\mathrm{F}$ e valor $\mathrm{p}$.

Se Fcalculado for maior que Fcrítico, rejeita-se a hipótese de nulidade $\mathrm{H}$, ou seja, existem evidências de diferença significativa entre pelo menos um par de médias de tratamentos, ao nível a de significância escolhido. Caso contrário, não se rejeita a hipótese de nulidade $\mathrm{H} 0$, ou seja, não há evidências de diferença significativa entre tratamentos, ao nível $\alpha$ de significância escolhido.

A outra maneira de avaliar a significância da estatística $F$ é utilizando o p-valor. Se o pvalor for menor que $\alpha$ - nível de significância ou erro rejeita-se a hipótese de nulidade H0. Caso contrário, não se rejeita a hipótese de nulidade $\mathrm{H} 0$, ou seja, não há evidências de diferenças significativas entre os tratamentos, ao nível a de significância escolhido.

\section{A) Testes ANOVA das propriedades analisadas (Fator duplo)}

Inicialmente e de modo simplificado, foram adotados testes de análise de variância de fator duplo com repetição para as propriedades investigadas neste trabalho, com o objetivo de verificar a influência dos seguintes fatores isolados e combinados entre si, no programa experimental:

$\checkmark$ Mistura (betonada de concreto, reunindo todas as variações relativas aos materiais, pesagem, equipamento e procedimento de mistura);

$\checkmark$ Ciclagem, ou seja, tipo de condicionamento para carbonatação dos corpos-de-prova, conforme item 3.3.4 e assim resumida:

a. AE1 ou $\mathbf{C O}_{2}$ - ciclagem de $24 \mathrm{~h}$ de exposição em câmara de carbonatação a $5 \%$ e 27 dias de secagem em estufa ventilada a $40 \pm 1^{\circ} \mathrm{C}$; 
b. AE2 ou $\mathrm{H}_{2} \mathrm{O}$ - ciclagem de $24 \mathrm{~h}$ de imersão em tanque de água e 27 dias de secagem em estufa ventilada a $40 \pm 1^{\circ} \mathrm{C}$;

c. AE3 ou SEC - ciclos de 28 dias de secagem contínua em estufa a $40 \pm 5^{\circ} \mathrm{C}$.

Para este trabalho foram feitos estudos de análise do fator duplo inicialmente, porém após avaliação dos dados por comparações múltiplas, verificou-se maior conveniência em apresentar e discutir somente este último método juntamente com a análise de Tukey, por serem métodos mais didáticos e de melhor compreensão da avaliação estatística. As tabelas da análise de fator duplo com repetição encontram-se no Apêndice D.

\section{B) Testes ANOVA por comparações múltiplas (fator quádruplo)}

Para o estudo em questão, foram realizados testes de análise de variância de fator quádruplo com repetição para as propriedades investigadas neste trabalho, com o objetivo de verificar a influência dos fatores descritos abaixo nos resultados obtidos:

$\checkmark$ Idade de ensaio;

$\checkmark$ Mistura, reunindo influência dos materiais (caminhão e pesagem de concreto);

$\checkmark$ Ciclagem (tipo de condicionamento dos corpos-de-prova) e combinação desses fatores;

$\checkmark$ Método de medida da carbonatação.

\section{B.1) Análise complementar pelo método de Tukey}

A análise inicia-se após concluir que existe diferença significativa entre tratamentos, por meio do teste $\mathrm{F}$, pode-se avaliar a magnitude destas diferenças utilizando um teste de comparações múltiplas pelo método de Tukey.

O teste proposto por Tukey (1953) - Teste de Tukey (TSD - Tukey Significant Difference permite testar qualquer contraste, combinação linear das médias dos níveis do fator. Em particular, podem-se comparar as médias dos níveis duas a duas.

O teste de Tukey permite testar qualquer contraste, sempre, entre duas médias de tratamentos, ou seja, não permite comparar grupos entre si.

O teste baseia-se na Diferença Mínima Significativa (DMS ) $\Delta$. A estatística do teste é dada da seguinte forma: 


$$
\Delta=q \sqrt{\frac{Q M \operatorname{Re} s}{r}}
$$

Em que, q é a amplitude total studentizada, da tabela do teste de Tukey, QMRes é o quadrado médio do resíduo, e r é o número de repetições. O valor de q depende do número de tratamentos e do número de graus de liberdade do resíduo.

Também, em um teste de comparações de médias, deve-se determinar um nível de significância a para o teste. Normalmente, utiliza-se o nível de $5 \%$ ou $1 \%$ de significância. Como o teste de Tukey é de certa forma, independente do teste $F$, é possível que, mesmo sendo significativo o valor de Fcalculado, não se encontrem diferenças significativas entre contrastes de médias.

Aplicando o teste de Tukey às médias dos tratamentos de um exemplo, tem-se:

$$
\Delta(5 \%)=3,85 \sqrt{\frac{0,00242}{8}}=0,06696
$$

Sendo $q=3,85$ e $\alpha=0,05$ (para o exemplo)

Se o contraste for maior do que $\Delta$, então as médias diferem ao nível $\alpha$ de significância. Utilizar-se-á o método de letras para exemplificar o uso do teste, mas existem outras maneiras de representação como, por exemplo, o uso de tabelas ou barras. Inicialmente, ordenam-se as médias de forma crescente ou decrescente, para facilitar as comparações. Coloca-se uma letra do alfabeto na primeira média (normalmente a letra 'a') e, em seguida, compara-se a diferença com as médias seguintes. Se a diferença for superior ao valor de $\Delta$ ( $5 \%)=0,06696$, a diferença entre duas médias será considerada significativa. A diferença entre duas médias é representada pela presença de letras diferentes. O resultado final é o seguinte:

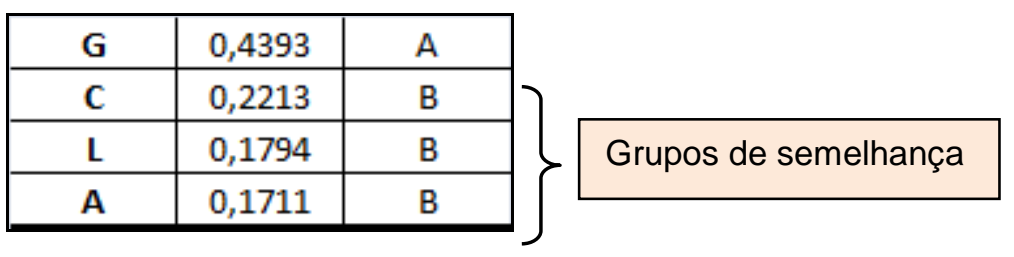

Tem-se que, médias de crescimento, seguidas de letras iguais, não diferem significativamente entre si, pelo teste de Tukey ao nível de $5 \%$ de probabilidade. 


\section{B.2) Análise de resultados por fator triplo ou quádruplo e método de Tukey}

Uma das avaliações deste estudo é a análise de variância (ANOVA) por comparações múltiplas, seguida de comparações das médias por Tukey. Para este trabalho, foram considerados como fatores: idade, a mistura (caminhão) e a ciclagem de modo separado, dois a dois e os três em conjunto e também em alguns casos incluindo o método de medida da área carbonatada.

As tabelas a seguir demonstram os resultados obtidos através desta ferramenta estatística. Para cada tabela de análise de Tukey originou-se uma análise de variância fator triplo que será demonstrada na seqüência. As análises utilizando Tukey resumem com importância as comparações das médias, de maneira simplificada.

TABELA 118 - Comparação das médias dos ensaios de carbonatação por Tukey.

\begin{tabular}{|c|c|c|c|c|c|c|c|c|}
\hline \multicolumn{5}{|c|}{ TUKEY } & A & B & $\mathrm{C}$ & D \\
\hline Propriedade & \multicolumn{2}{|c|}{ Fatores } & $N^{\circ}$ cp's & $\begin{array}{l}\text { Média } \\
\text { (mm) }\end{array}$ & \multicolumn{4}{|c|}{ Grupo de semelhança } \\
\hline \multirow{11}{*}{$\begin{array}{c}\text { CARBONATAÇÃO } \\
\text { MANUAL } 91 \text { e } 203 \\
\text { (todas as } \\
\text { ciclagens) }\end{array}$} & \multirow{2}{*}{ IDADE } & 203 & 36 & 4,1 & $\mathrm{~A}$ & & & \\
\hline & & 91 & 36 & 1,9 & & $\mathrm{~B}$ & & \\
\hline & \multirow{6}{*}{$\begin{array}{c}\text { MISTURA } \\
\text { (CAMINHÄO) }\end{array}$} & $4 \mathrm{D}$ & 12 & 3,6 & $\mathrm{~A}$ & & & \\
\hline & & $6 \mathrm{~F}$ & 12 & 3,4 & $\mathrm{~A}$ & & & \\
\hline & & 2B & 12 & 2,9 & & $\mathrm{~B}$ & & \\
\hline & & $3 C$ & 12 & 2,8 & & $\mathrm{~B}$ & C & \\
\hline & & $1 \mathrm{~A}$ & 12 & 2,7 & & $\mathrm{~B}$ & C & \\
\hline & & $5 E$ & 12 & 2,6 & & & C & \\
\hline & \multirow{3}{*}{ CICLAGEM } & $\mathrm{CO} 2$ & 24 & 3,6 & A & & & \\
\hline & & $\mathrm{H} 2 \mathrm{O}$ & 24 & 3,1 & & $\mathrm{~B}$ & & \\
\hline & & SEC & 24 & 2,3 & & & $\mathrm{C}$ & \\
\hline \multirow{11}{*}{$\begin{array}{c}\text { CARBONATAÇÃO } \\
\text { MANUAL CO2 e } \\
\mathrm{H} 2 \mathrm{O} \text { (todas as } \\
\text { idades) }\end{array}$} & \multirow{3}{*}{ IDADE } & 203 & 24 & 3,9 & $\mathrm{~A}$ & & & \\
\hline & & 91 & 24 & 2,8 & & $\mathrm{~B}$ & & \\
\hline & & 63 & 24 & 2,5 & & & C & \\
\hline & \multirow{6}{*}{$\begin{array}{c}\text { MISTURA } \\
\text { (CAMINHÄO) }\end{array}$} & $4 \mathrm{D}$ & 12 & 3,6 & $\mathrm{~A}$ & & & \\
\hline & & $6 \mathrm{~F}$ & 12 & 3,5 & $A$ & & & \\
\hline & & $2 \mathrm{~B}$ & 12 & 3,0 & & $\mathrm{~B}$ & & \\
\hline & & $3 C$ & 12 & 2,9 & & $\mathrm{~B}$ & C & \\
\hline & & $1 \mathrm{~A}$ & 12 & 2,8 & & $\mathrm{~B}$ & C & \\
\hline & & $5 \mathrm{E}$ & 12 & 2,6 & & & C & \\
\hline & \multirow{2}{*}{ CICLAGEM } & $\mathrm{CO} 2$ & 36 & 3,3 & $\mathrm{~A}$ & & & \\
\hline & & $\mathrm{H} 2 \mathrm{O}$ & 36 & 2,8 & & $\mathrm{~B}$ & & \\
\hline \multirow{11}{*}{$\begin{array}{c}\text { CARBONATAÇÃO } \\
\text { por IMJ } 91 \text { e } 203 \\
\text { (todas as } \\
\text { ciclagens) }\end{array}$} & \multirow{2}{*}{ IDADE } & 203 & 36 & 4,1 & $\mathrm{~A}$ & & & \\
\hline & & 91 & 36 & 1,4 & & $\mathrm{~B}$ & & \\
\hline & \multirow{6}{*}{$\begin{array}{c}\text { MISTURA } \\
\text { (CAMINHÄO) }\end{array}$} & $4 \mathrm{D}$ & 12 & 3,5 & A & & & \\
\hline & & $6 \mathrm{~F}$ & 12 & 3,0 & & $\mathrm{~B}$ & & \\
\hline & & $3 C$ & 12 & 2,9 & & B & C & \\
\hline & & $2 \mathrm{~B}$ & 12 & 2,5 & & & C & $\mathrm{D}$ \\
\hline & & $5 \mathrm{E}$ & 12 & 2,3 & & & & $\mathrm{D}$ \\
\hline & & $1 \mathrm{~A}$ & 12 & 2,3 & & & & $\mathrm{D}$ \\
\hline & \multirow{3}{*}{ CICLAGEM } & $\mathrm{CO} 2$ & 24 & 3,8 & $A$ & & & \\
\hline & & $\mathrm{H} 2 \mathrm{O}$ & 24 & 2,4 & & $\mathrm{~B}$ & & \\
\hline & & SEC & 24 & 2,1 & & & C & \\
\hline \multirow{11}{*}{$\begin{array}{c}\text { CARBONATAÇÃO } \\
\text { por IMJ CO2 e } \\
\mathrm{H} 2 \mathrm{O} \text { (todas as } \\
\text { idades) }\end{array}$} & \multirow{3}{*}{ IDADE } & 203 & 24 & 4,1 & $A$ & & & \\
\hline & & 91 & 24 & 2,1 & & $\mathrm{~B}$ & & \\
\hline & & 63 & 24 & - & & & C & \\
\hline & \multirow{6}{*}{$\begin{array}{c}\text { MISTURA } \\
\text { (CAMINHÄO) }\end{array}$} & $4 \mathrm{D}$ & 12 & 2,6 & A & & & \\
\hline & & $6 \mathrm{~F}$ & 12 & 2,2 & A & $\mathrm{B}$ & & \\
\hline & & $3 C$ & 12 & 2,1 & & $\mathrm{~B}$ & C & \\
\hline & & $2 \mathrm{~B}$ & 12 & 1,8 & & $\mathrm{~B}$ & $\mathrm{C}$ & \\
\hline & & $5 \mathrm{E}$ & 12 & 1,8 & & $\mathrm{~B}$ & C & \\
\hline & & $1 \mathrm{~A}$ & 12 & 1,8 & & & C & \\
\hline & \multirow{2}{*}{ CICLAGEM } & $\mathrm{CO} 2$ & 36 & 2,5 & A & & & \\
\hline & & $\mathrm{H} 2 \mathrm{O}$ & 36 & 1,6 & & $\mathrm{~B}$ & & \\
\hline
\end{tabular}


Pela Tabela 118 e como seria esperado, verifica-se que somente as misturas (caminhões) apresentaram alguma semelhança entre si conforme o número da mistura, pelas comparações de Tukey. Observar que essa análise foi sensível para diferenciar as idades e os três tipos de ambiente de exposição na carbonatação, para todos os métodos de medida da franja.

$\mathrm{Na}$ Tabela 119 verifica-se que a ANOVA acusou bem a influência das variáveis de forma isolada, mas tende a não diferenciar as três variáveis quando analisadas de forma conjunta.

TABELA 119 - Resultados das análises dos resultados de carbonatação por ANOVA ( fator triplo)

\begin{tabular}{|c|c|c|c|c|}
\hline Propriedade & Resumo & Influenciou? & $\mathrm{F}$ & P-Valor \\
\hline \multirow{7}{*}{$\begin{array}{c}\text { CARBONATAÇÃO } \\
\text { MANUAL } 91 \text { e } 203 \\
\text { (todas as } \\
\text { ciclagens) }\end{array}$} & IDADE & SIM & 1495,500 & 0,00000 \\
\hline & MISTURA (CAMINHÃ̃) & SIM & 32,700 & 0,00000 \\
\hline & CICLAGEM & SIM & 161,200 & 0,00000 \\
\hline & IDADE*MISTURA & SIM & 9,200 & 0,00000 \\
\hline & IDADE ${ }^{*}$ CICLAGEM & SIM & 406,300 & 0,00000 \\
\hline & MISTURA*CICLAGEM & SIM & 3,600 & 0,00200 \\
\hline & IDADE* MISTURA*CICLAGEM & NÃO & 2,000 & 0,05500 \\
\hline \multirow{7}{*}{$\begin{array}{l}\text { CARBONATAÇÃO } \\
\text { MANUAL } \mathrm{CO}_{2} \text { e } \\
\mathrm{H}_{2} \mathrm{O} \text { (todas as } \\
\text { idades) }\end{array}$} & IDADE & SIM & 85,000 & 0,00000 \\
\hline & MISTURA (CAMINHÃO) & SIM & 27,940 & 0,00000 \\
\hline & CICLAGEM & SIM & 61,280 & 0,00000 \\
\hline & IDADE*MISTURA & SIM & 3,800 & 0,00100 \\
\hline & IDADE ${ }^{*}$ CICLAGEM & NÃO & 0,880 & 0,42500 \\
\hline & MISTURA $^{*} \mathrm{CICLAGEM}$ & SIM & 4,230 & 0,00400 \\
\hline & IDADE* MISTURA*CICLAGEM & NÃO & 1,770 & 0,10300 \\
\hline \multirow{7}{*}{$\begin{array}{c}\text { CARBONATAÇÃO } \\
\text { por IMJ } 91 \text { e } 203 \\
\text { (todas as } \\
\text { ciclagens) }\end{array}$} & IDADE & SIM & 806,680 & 0,00000 \\
\hline & MISTURA (CAMINHÃO) & SIM & 15,500 & 0,00000 \\
\hline & CICLAGEM & SIM & 111,720 & 0,00000 \\
\hline & \begin{tabular}{|l|l} 
IDADE*MISTURA \\
\end{tabular} & SIM & 4,410 & 0,00300 \\
\hline & IDADE ${ }^{*}$ CICLAGEM & $\mathrm{NÃO}$ & 58,160 & 0,00000 \\
\hline & MISTURA*CICLAGEM & NÃO & 1,630 & 0,13700 \\
\hline & IDADE*MISTURA*CICLAGEM & SIM & 2,640 & 0,01600 \\
\hline \multirow{7}{*}{$\begin{array}{l}\text { CARBONATAÇÃOO } \\
\text { por IMJ } \mathrm{CO}_{2} \text { e } \mathrm{H}_{2} \mathrm{O} \\
\text { (todas as idades) }\end{array}$} & IDADE & SIM & 755,520 & 0,00000 \\
\hline & MISTURA (CAMINHÃO) & SIM & 10,110 & 0,00000 \\
\hline & CICLAGEM & SIM & 120,480 & 0,00000 \\
\hline & IDADE*MISTURA & SIM & 4,600 & 0,00000 \\
\hline & IDADE ${ }^{*} \mathrm{CICLAGEM}$ & SIM & 29,520 & 0,00000 \\
\hline & MISTURA ${ }^{*} \mathrm{CICLAGEM}$ & NÃO & 2,390 & 0,05700 \\
\hline & IDADE ${ }^{\star}$ MISTURA ${ }^{*}$ CICLAGEM & NÃO & 1,850 & 0,08600 \\
\hline
\end{tabular}


TABELA 120 - Comparação das médias dos ensaios de porcentagem de área carbonatada a 203 dias por método de Tukey

\begin{tabular}{|c|c|c|c|c|c|c|c|c|}
\hline \multicolumn{5}{|c|}{ TUKEY } & A & B & $\mathrm{C}$ & D \\
\hline Propriedade & \multicolumn{2}{|c|}{ Fatores } & $\mathrm{N}^{\circ} \mathrm{cp}$ 's & $\begin{array}{c}\text { Média } \\
\text { (\% área) }\end{array}$ & & $\mathrm{OC}$ & elh & \\
\hline \multirow{13}{*}{$\begin{array}{l}203 \text { dias TODOS os } \\
\text { Métodos - \% Área } \\
\text { Carbonatada }\end{array}$} & \multirow{4}{*}{ MÉTODO } & Leica & 36 & 0,1 & $\mathrm{~A}$ & & & \\
\hline & & IMJ & 36 & 0,1 & & $B$ & & \\
\hline & & Manual & 36 & 0,1 & & $B$ & & \\
\hline & & Manual2 & 36 & 0,1 & & & $\mathrm{C}$ & \\
\hline & \multirow{6}{*}{ 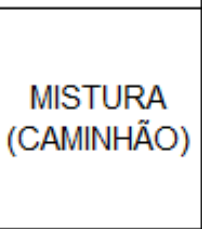 } & $4 \mathrm{D}$ & 24 & 0,2 & $\mathrm{~A}$ & & & \\
\hline & & $6 \mathrm{~F}$ & 24 & 0,1 & & $B$ & & \\
\hline & & $3 \mathrm{C}$ & 24 & 0,1 & & $\mathrm{~B}$ & $\mathrm{C}$ & \\
\hline & & $5 \mathrm{E}$ & 24 & 0,1 & & & C & \\
\hline & & $2 \mathrm{~B}$ & 24 & 0,1 & & & $\mathrm{C}$ & \\
\hline & & $1 \mathrm{~A}$ & 24 & 0,1 & & & C & \\
\hline & \multirow{3}{*}{ CICLAGEM } & SEC & 48 & 0,1 & $\mathrm{~A}$ & & & \\
\hline & & $\mathrm{CO} 2$ & 48 & 0,1 & $\mathrm{~A}$ & & & \\
\hline & & $\mathrm{H} 2 \mathrm{O}$ & 48 & 0,1 & & $B$ & & \\
\hline
\end{tabular}

Verifica-se que para a Tabela 120 o teste de Tukey agrupou a ciclagem de secagem contínua e ciclagem de exposição a $\mathrm{CO}_{2}$, também os métodos de leitura da porcentagem de área carbonatada por medidas manuais e pelo software Image $\mathrm{J}$, que foram realizados para as idades de 91 e 63 dias, porém devido à qualidade da foto a 63 dias, não foi possível verificar essa semelhança, e para essa idade, foi eliminada da análise. Devido a isto, apresenta-se a Tabela 121 com ANOVA de quatro fatores, para melhor confirmação da semelhança dos métodos. Mesmo com 2 operadores distintos e métodos completamente diferentes de medidas, obteve-se resultados semelhantes conforme demonstrado abaixo.

TABELA 121 - Comparação das médias dos ensaios de carbonatação a 91 e 203 dias por ANOVA (fator quádruplo).

\begin{tabular}{|c|c|c|c|c|}
\hline Propriedade & Resumo & Influenciou? & $\mathrm{F}$ & P-Valor \\
\hline \multirow{13}{*}{$\begin{array}{c}\text { \% Área Carbonatada } \\
\text { (91 e } 203 \text { dias; IMJ e } \\
\text { Manual 1; Todas as } \\
\text { ciclagens) }\end{array}$} & IDADE & SIM & 682,75 & 0 \\
\hline & MISTURA (CAMINHÃO) & SIM & 15,89 & 0 \\
\hline & CICLAGEM & SIM & 54,84 & 0 \\
\hline & MÉTODO & $\mathrm{NÃO}$ & 3,17 & 0,079 \\
\hline & IDADE*MISTURA & NÄO & 1,86 & 0,111 \\
\hline & IDADE*CICLAGEM & SIM & 127,4 & 0 \\
\hline & IDADE*MÉTODO & SIM & 9,35 & 0,003 \\
\hline & MISTURA*CICLAGEM & NÃO & 0,67 & 0,751 \\
\hline & MISTURA*METODO & NÃO & 0,96 & 0,446 \\
\hline & CICLAGEM*METODO & SIM & 6,44 & 0,003 \\
\hline & IDADE*MISTURA*CICLAGEM & NÃO & 1,66 & 0,104 \\
\hline & IDADE*MISTURA*METODO & NÄO & 0,9 & 0,486 \\
\hline & MISTURA*CICLAGEM*METODO & NÃO & 0,63 & 0,782 \\
\hline
\end{tabular}

As Tabelas 123 a 125 demonstram os resultados das comparações das médias pelo método de Tukey para os ensaios de resistência à tração por compressão diametral, absorção de água total e índice de vazios. Para esses três ensaios não serão demonstradas as ANOVAS - fator triplo, pois o método de Tukey pode melhor resumir onde houve as semelhanças. 
TABELA 122 - Comparação das médias dos ensaios de tração por compressão diametral pelo método de Tukey.

\begin{tabular}{|c|c|c|c|c|c|c|c|c|c|}
\hline \multicolumn{5}{|c|}{ TUKEY } & A & B & $\mathrm{C}$ & D & $E$ \\
\hline Propriedade & \multicolumn{2}{|c|}{ Fatores } & $\begin{array}{l}\mathrm{N}^{\circ} \mathrm{de} \\
\text { cp's }\end{array}$ & $\begin{array}{l}\text { Média } \\
\text { (MPa) }\end{array}$ & \multicolumn{5}{|c|}{ Grupo de semelhança } \\
\hline \multirow{11}{*}{$\begin{array}{c}\mathrm{f}_{\mathrm{ct}, \mathrm{sp}} 91 \text { e } 203 \\
\text { (todas as } \\
\text { ciclagens) }\end{array}$} & \multirow{2}{*}{ IDADE } & 203 & 36 & 4,3 & $\mathrm{~A}$ & & & & \\
\hline & & 91 & 36 & 4,1 & & $\mathrm{~B}$ & & & \\
\hline & \multirow{6}{*}{$\begin{array}{c}\text { MISTURA } \\
\text { (CAMINHÄO) }\end{array}$} & $2 \mathrm{~B}$ & 12 & 4,4 & $\mathrm{~A}$ & & & & \\
\hline & & $5 \mathrm{E}$ & 12 & 4,4 & A & & & & \\
\hline & & $3 \mathrm{C}$ & 12 & 4,3 & $\mathrm{~A}$ & & & & \\
\hline & & $1 \mathrm{~A}$ & 12 & 4,2 & A & $\mathrm{B}$ & & & \\
\hline & & $6 \mathrm{~F}$ & 12 & 4,1 & $\mathrm{~A}$ & $\mathrm{~B}$ & & & \\
\hline & & $4 \mathrm{D}$ & 12 & 3,9 & & $\mathrm{~B}$ & & & \\
\hline & \multirow{3}{*}{ CICLAGEM } & $\mathrm{H} 2 \mathrm{O}$ & 24 & 4,6 & $\mathrm{~A}$ & & & & \\
\hline & & $\mathrm{CO} 2$ & 24 & 4,1 & & $\mathrm{~B}$ & & & \\
\hline & & SEC & 24 & 3,9 & & $\mathrm{~B}$ & & & \\
\hline \multirow{13}{*}{$\begin{array}{l}\mathrm{f}_{\mathrm{ct}, \mathrm{sp}} \mathrm{CO} 2 \text { e H2O } \\
\text { (todas as idades) }\end{array}$} & \multirow{5}{*}{ IDADE } & 203 & 24 & 4,5 & $A$ & & & & \\
\hline & & 91 & 24 & 4,2 & & $\mathrm{~B}$ & & & \\
\hline & & 35 & 24 & 4,2 & & $\mathrm{~B}$ & & & \\
\hline & & 63 & 24 & 3,9 & & & $\mathrm{C}$ & & \\
\hline & & 8 & 24 & 3,8 & & & $\mathrm{C}$ & & \\
\hline & \multirow{6}{*}{$\begin{array}{c}\text { MISTURA } \\
\text { (CAMINHÄO) }\end{array}$} & $2 \mathrm{~B}$ & 20 & 4,3 & $\mathrm{~A}$ & & & & \\
\hline & & $5 \mathrm{E}$ & 20 & 4,3 & $\mathrm{~A}$ & & & & \\
\hline & & $3 \mathrm{C}$ & 20 & 4,2 & $\mathrm{~A}$ & & & & \\
\hline & & $1 \mathrm{~A}$ & 20 & 4,1 & $\mathrm{~A}$ & & & & \\
\hline & & $6 \mathrm{~F}$ & 20 & 4,1 & $\mathrm{~A}$ & $\mathrm{~B}$ & & & \\
\hline & & $4 \mathrm{D}$ & 20 & 3,8 & & $\mathrm{~B}$ & & & \\
\hline & \multirow{2}{*}{ CICLAGEM } & $\mathrm{H} 2 \mathrm{O}$ & 60 & 4,3 & $\mathrm{~A}$ & & & & \\
\hline & & $\mathrm{CO} 2$ & 60 & 4,0 & & $\mathrm{~B}$ & & & \\
\hline
\end{tabular}

Nota-se semelhança das ciclagens de $\mathrm{CO}_{2}$ e SEC para as idades de 91 e 203 dias.

TABELA 123 - Comparação das médias dos ensaios de absorção de água pelo método de Tukey.

\begin{tabular}{|c|c|c|c|c|c|c|c|c|c|}
\hline \multicolumn{5}{|c|}{ TUKEY } & A & B & $\mathrm{C}$ & D & $\mathrm{E}$ \\
\hline Propriedade & \multicolumn{2}{|c|}{ Fatores } & $\begin{array}{l}N^{\circ} \text { de } \\
\text { cp's }\end{array}$ & $\begin{array}{l}\text { Média } \\
(\%)\end{array}$ & \multicolumn{5}{|c|}{ Grupo de semelhança } \\
\hline \multirow{11}{*}{$\begin{array}{c}\text { ABS } 91 \text { e } 203 \\
\text { (todas as } \\
\text { ciclagens) }\end{array}$} & \multirow{2}{*}{ IDADE } & 203 & 36 & 5,3 & $\mathrm{~A}$ & & & & \\
\hline & & 91 & 36 & 4,7 & & $\mathrm{~B}$ & & & \\
\hline & \multirow{6}{*}{$\begin{array}{c}\text { MISTURA } \\
\text { (CAMINHÄO) }\end{array}$} & $2 \mathrm{~B}$ & 12 & 5,4 & $\mathrm{~A}$ & & & & \\
\hline & & $6 \mathrm{~F}$ & 12 & 5,2 & $\mathrm{~A}$ & $\mathrm{~B}$ & & & \\
\hline & & $4 \mathrm{D}$ & 12 & 5,0 & & $\mathrm{~B}$ & $\mathrm{C}$ & & \\
\hline & & $1 \mathrm{~A}$ & 12 & 4,9 & & & $\mathrm{C}$ & $\mathrm{D}$ & \\
\hline & & $5 \mathrm{E}$ & 12 & 4,8 & & & $\mathrm{C}$ & $\mathrm{D}$ & \\
\hline & & $3 \mathrm{C}$ & 12 & 4,8 & & & & $\mathrm{D}$ & \\
\hline & \multirow{3}{*}{ CICLAGEM } & SEC & 24 & 5,1 & A & & & & \\
\hline & & $\mathrm{H} 2 \mathrm{O}$ & 24 & 4,9 & & $\mathrm{~B}$ & & & \\
\hline & & $\mathrm{CO} 2$ & 24 & 4,9 & & $\mathrm{~B}$ & & & \\
\hline \multirow{13}{*}{$\begin{array}{c}\text { ABS } \mathrm{CO} 2 \mathrm{e} \\
\mathrm{H} 2 \mathrm{O} \text { (todas as } \\
\text { idades) }\end{array}$} & \multirow{5}{*}{ IDADE } & 203 & 24 & 5,2 & $\mathrm{~A}$ & & & & \\
\hline & & 91 & 24 & 4,7 & & $\mathrm{~B}$ & & & \\
\hline & & 35 & 24 & 4,1 & & & $\mathrm{C}$ & & \\
\hline & & 8 & 24 & 4,1 & & & $\mathrm{C}$ & & \\
\hline & & 63 & 24 & 4,1 & & & $\mathrm{C}$ & & \\
\hline & \multirow{6}{*}{$\begin{array}{c}\text { MISTURA } \\
\text { (CAMINHÄO) }\end{array}$} & $2 \mathrm{~B}$ & 20 & 4,8 & $\mathrm{~A}$ & & & & \\
\hline & & $6 \mathrm{~F}$ & 20 & 4,5 & & $\mathrm{~B}$ & & & \\
\hline & & $4 \mathrm{D}$ & 20 & 4,4 & & $\mathrm{~B}$ & $\mathrm{C}$ & & \\
\hline & & $1 \mathrm{~A}$ & 20 & 4,4 & & $\mathrm{~B}$ & $\mathrm{C}$ & & \\
\hline & & $3 \mathrm{C}$ & 20 & 4,3 & & & $\mathrm{C}$ & $\mathrm{D}$ & \\
\hline & & $5 \mathrm{E}$ & 20 & 4,1 & & & & $\mathrm{D}$ & \\
\hline & \multirow{2}{*}{ CICLAGEM } & $\mathrm{H} 2 \mathrm{O}$ & 60 & 10,5 & $\mathrm{~A}$ & & & & \\
\hline & & $\mathrm{CO} 2$ & 60 & 10,4 & $\mathrm{~A}$ & & & & \\
\hline
\end{tabular}


Nota-se para os ensaios de absorção uma semelhança das ciclagens de $\mathrm{CO}_{2}$ e $\mathrm{H}_{2} \mathrm{O}$ para todas as idades, inclusive o mesmo ocorreu para os ensaios de índice de vazios conforme apresentado na Tabela 124, mas não houve semelhança de média para a exposição em secagem forçada contínua (SEC). Isto é um indício que a camada de carbonatação formada pela curta exposição dos corpos-de-prova em câmara de $\mathrm{CO}_{2}$ pode ter alterado a miscroestrutura superficial do concreto e aprisionado a umidade inicial existente no seu interior, assemelhando os resultados aos corpos-de-prova ciclados em umidade. Todavia, isto precisaria ser melhor investigado e também verificado se haveria o mesmo tipo de semelhança em idades avançadas.

TABELA 124 - Comparação das médias dos ensaios de índice de vazios por Tukey.

\begin{tabular}{|c|c|c|c|c|c|c|c|c|c|}
\hline \multicolumn{5}{|c|}{ TUKEY } & $\mathrm{A}$ & $\mathrm{B}$ & $\mathrm{C}$ & D & $\mathrm{E}$ \\
\hline Propriedade & Fatore & & $\begin{array}{l}N^{0} \text { de } \\
\text { cp's }\end{array}$ & $\begin{array}{l}\text { Média } \\
(\%)\end{array}$ & \multicolumn{5}{|c|}{ Grupo de semelhança } \\
\hline \multirow{11}{*}{$\begin{array}{l}\text { IV } 91 \text { E } 203 \\
\text { (todas as } \\
\text { ciclagens) }\end{array}$} & \multirow{2}{*}{ IDADE } & 203 & 36 & 12,3 & $\mathrm{~A}$ & & & & \\
\hline & & 91 & 36 & 11,0 & & $B$ & & & \\
\hline & \multirow{6}{*}{$\begin{array}{c}\text { MISTURA } \\
\text { (CAMINHÕES) }\end{array}$} & 2 & 12 & 12,3 & $\mathrm{~A}$ & & & & \\
\hline & & 6 & 12 & 12,1 & $\mathrm{~A}$ & $\mathrm{~B}$ & & & \\
\hline & & 4 & 12 & 11,6 & & $\mathrm{~B}$ & $\mathrm{C}$ & & \\
\hline & & 1 & 12 & 11,4 & & & $\mathrm{C}$ & $\mathrm{D}$ & \\
\hline & & 5 & 12 & 11,3 & & & $\mathrm{C}$ & D & \\
\hline & & 3 & 12 & 11,2 & & & & $\mathrm{D}$ & \\
\hline & \multirow{3}{*}{ CICLAGEM } & SEC & 24 & 11,9 & $\mathrm{~A}$ & & & & \\
\hline & & $\mathrm{CO} 2$ & 24 & 11,5 & & $\mathrm{~B}$ & & & \\
\hline & & $\mathrm{H} 2 \mathrm{O}$ & 24 & 11,5 & & $\mathrm{~B}$ & & & \\
\hline \multirow{13}{*}{$\begin{array}{l}\text { IV CO2 E H2O } \\
\text { (todas as } \\
\text { idades) }\end{array}$} & \multirow{5}{*}{ IDADE } & 203 & 24 & 12,2 & $\mathrm{~A}$ & & & & \\
\hline & & 91 & 24 & 10,9 & & $\mathrm{~B}$ & & & \\
\hline & & 35 & 24 & 9,9 & & & $\mathrm{C}$ & & \\
\hline & & 63 & 24 & 9,7 & & & $\mathrm{C}$ & & \\
\hline & & 8 & 24 & 9,6 & & & $\mathrm{C}$ & & \\
\hline & \multirow{6}{*}{$\begin{array}{c}\text { MISTURA } \\
\text { (CAMINHÕES) }\end{array}$} & 2 & 20 & 11,2 & $\mathrm{~A}$ & & & & \\
\hline & & 6 & 20 & 10,7 & & $\mathrm{~B}$ & & & \\
\hline & & 4 & 20 & 10,5 & & $\mathrm{~B}$ & $\mathrm{C}$ & & \\
\hline & & 1 & 20 & 10,3 & & & $\mathrm{C}$ & D & \\
\hline & & 3 & 20 & 10,0 & & & & $\mathrm{D}$ & $\mathrm{E}$ \\
\hline & & 5 & 20 & 9,8 & & & & & $\mathrm{E}$ \\
\hline & \multirow{2}{*}{ CICLAGEM } & $\mathrm{H} 2 \mathrm{O}$ & 60 & 4,5 & $\mathrm{~A}$ & & & & \\
\hline & & $\mathrm{CO} 2$ & 60 & 4,4 & A & & & & \\
\hline
\end{tabular}




\section{CONSIDERACÕES E CONCLUSÕES FINAIS}

A pesquisa de Cavalcanti Filho (2010) e as conclusões principais desta dissertação, a seguir destacadas, confirmam que é importante e possível estudar novas práticas de controle tecnológico do concreto fresco, para a evolução contínua de métodos e critérios de predição de vida útil das estruturas, no tocante ao controle de carbonatação e vida útil de projeto de armaduras.

\subsection{QUANTO AO PROGRAMA EXPERIMENTAL}

O programa experimental foi realizado em São Paulo/SP, com a parte de campo principal realizada em 13 de agosto de 2009, com o apoio das entidades e pessoas especialmente citadas nos Agradecimentos desta dissertação.

O objetivo geral foi evoluir na investigação de novas metodologias para controlar a qualidade do concreto, com vistas à durabilidade de armaduras, partindo dos estudos iniciados por Cavalcanti Filho (2010).

Quanto aos objetivos específicos, o principal foi observar a influência do teor de ar do concreto no estado fresco na sua resistência à carbonatação e ainda testar métodos alternativos de antecipar a cura e de carbonatar o concreto, e de ao final realizar medidas de áreas relativas de carbonatação, por dois programas de análise de imagem.

Assim, no estado endurecido, foram realizados estudos de cura acelerada do concreto em temperatura amena e comparados métodos e medidas auxiliares para a avaliação de resistência à carbonatação a partir de 8 dias de idade. Foram investigados três processos de carbonatação do concreto, sendo um deles por molhagem e secagem, uma condição também mais favorável à corrosão de armaduras, hoje em foco por pesquisas avançadas de modelagem e outros dois, sem envolver a exposição à umidade, sendo comum aos três métodos um período prolongado de secagem em estufa ventilada a $40^{\circ} \mathrm{C}$.

Para tanto, foram caracterizadas seis amassadas aleatórias, de um dado lote de concreto pré-misturado, em condições de produção e amostragem dentro do pátio de uma central dosadora, mas sem a interferência ou controle dos pesquisadores na composição, dosagem e pesagem das misturas.

O lote de concreto estrutural pré-misturado estudado era destinado a uma dada obra de edifício de múltiplos andares, de localização muito próxima à central dosadora, era do tipo bombeado, com abatimento $10 \pm 2 \mathrm{~cm}$, resistência característica à compressão de 30 MPa, para estrutura em ambiente classe II da ABNT NBR 6118 (2003), ou seja, com relação 
água/cimento igual ou menor do que 0,60 e consumo mínimo de cimento de aproximadamente $300 \mathrm{~kg} / \mathrm{m}^{3}$.

Os objetivos principais de comparar as propriedades de seis betonadas do concreto que compunham o lote em estudo, desde o estado fresco e evidenciar os efeitos do teor de ar em características relacionadas à sua capacidade de resistência à carbonatação, foram alcançados; e foi possível avançar na interpretação da correlação entre propriedades, com base em análises estatísticas apresentadas no Capítulo 4, item 4.2. Os itens que seguem destacam os resultados mais importantes para a aplicação deste trabalho, no campo do controle tecnológico do concreto estrutural.

\subsubsection{Sobre a cura acelerada em temperatura amena}

De acordo com Mindess; Young (1981), temperaturas de cura até 45드 não são prejudiciais à estrutura química e física do concreto.

Em geral as temperaturas de cura acelerada discutidas em trabalhos nacionais e internacionais alcançam valores bem mais elevados e que precisam ser adotados com maior cautela, pelo menos em estudos relacionados a indicadores de durabilidade para a proteção de armaduras, pois a temperatura de cura pode prejudicar a microestrutura e introduzir alguma microfissuração no concreto.

No programa experimental desta dissertação, foi adaptado o procedimento de cura acelerada do concreto em temperatura amena do Tipo A da ASTM C 684 (1999), para ser iniciado em dia seguinte à moldagem do concreto em campo, e aqui foi estudada a sua duração entre 24 e 48 h; entre 24 e 72 h; entre 24 h e 72 h e esta ainda seguida do resfriamento natural da água e a manutenção da cura imersa à temperatura ambiente até 7 dias. A quarta situação foi a inicial do estudo de carbonatação dos corpos-de-prova, nesta pesquisa. Dois conjuntos de dois corpos-de-prova de cada mistura foram testados ainda pelo procedimento mais próximo ao método ASTM citado e pelo procedimento usual de cura até 28 dias, como referências para a análise de eficiência dos outros quatro.

As resistências à compressão entre 1 e 7 dias das misturas, pelos procedimentos descritos de cura acelerada em temperatura amena, se relacionaram bem tanto com propriedades do estado fresco do concreto, quanto com propriedades físicas e mecânicas em idades posteriores. Como exemplo, cabe citar a relação entre a resistência acelerada a 7 dias e a resistência à compressão a 28 dias, por cura normal da ABNT NBR 5738 (2003), que resultou igual a 84,1\%, segundo a Tabela 44, no Capítulo 4.

Por outro lado, esta relação é indicativa de que pode ser necessário ampliar a duração da cura em temperatura amena, entre 3 e 7 dias, no caso do concreto em 
caracterização ser de endurecimento mais lento, por efeito de aditivo ou por ficar exposto a temperaturas mais baixas em campo, nas primeiras $24 \mathrm{~h}$. No caso desta pesquisa, ambos os fatores ocorreram, pois além do concreto conter aditivo polifuncional com efeito retardador, posteriormente interpretado; os corpos-de-prova também ficaram expostos, nas primeiras 24 horas, à temperatura média em campo de $17{ }^{\circ} \mathrm{C}$, com máxima de $26^{\circ} \mathrm{C}$ e mínima de $12{ }^{\circ} \mathrm{C}$.

Não obstante a ocorrência citada confirmou-se o potencial do método de cura acelerada em temperatura amena com adaptação para iniciar em dia seguinte à produção e moldagem do concreto. Aqui, inclusive, testou-se um cimento de maior resistência inicial e uma condição mais adversa de temperatura dos corpos-de-prova em campo, do que nos ensaios iniciais já bem sucedidos de Cavalcanti Filho (2010), para três lotes de concreto com dois tipos de cimento, em João Pessoa/PB.

Observar que este tipo de cura também pode servir para medidas de propriedades mecânicas com maior agilidade, tanto para estudos de dosagem, de controle de produção ou de recebimento do concreto. Por pesquisas complementares para refinamento da metodologia, acredita-se ser possível evoluir para um procedimento brasileiro normalizado e sugestão para isto está salientada no item 5.2.

\subsubsection{Correlações entre propriedades do estado fresco e endurecido}

No total, oito propriedades foram medidas no estado fresco de cada uma das seis misturas de concreto fresco amostradas. Essas propriedades foram relacionadas entre si e a outras 59 medidas no estado endurecido das misturas, com idades desde 1 dia até 203 dias, em sete tipos de ensaios de caracterização física e mecânica, por procedimentos normais ou acelerados.

Segundo discutido no Capítulo 4 e na matriz de resumo das correlações no Apêndice $\mathrm{F}$, o número de correlações fortes e acima de 0,7 variaram da seguinte forma para as propriedades no estado fresco:

$\checkmark 19$ correlações no caso do teor de ar pelo método pressométrico (nove acima de 0,8$)$;

$\checkmark 17$ correlações no caso da compactabilidade adensada (oito acima de 0,8 ), método este introduzido de forma original por esta pesquisa e pela de Cavalcanti Filho (2010) a partir de adaptação da BS EN 12350-4:2009;

$\checkmark 10$ correlações no caso do abatimento do tronco de cone (três acima de 0,8 ); 
$\checkmark 10$ correlações no caso do teor de umidade ou relação água/materiais secos (oito acima de 0,8 );

$\checkmark$ seis correlações no caso do teor de finos total abaixo de $75 \mu \mathrm{m}$ (duas acima de $0,8)$;

$\checkmark$ quatro correlações no caso da densidade de massa aparente (três acima de $0,8)$;

$\checkmark$ três correlações no caso do teor de ar pelo método gravimétrico (uma acima de $0,8)$;

$\checkmark$ duas correlações no caso da compactabilidade não adensada.

Assim, esta pesquisa conclui que o controle do teor de ar dos concretos no estado fresco deve ser priorizado, de modo rotineiro, para a comparação ou o controle de propriedades de concretos estruturais de consistência plástica, seja em estudos de dosagem, produção ou recebimento.

O teor de ar pelo método pressométrico já é um ensaio conhecido e com norma brasileira de procedimento a ABNT NBR NM 47 (2002), mas é ainda pouco utilizado no controle tecnológico de concretos em campo, no Brasil. Neste programa, esta medida apresentou excelentes correlações com propriedades mecânicas e as indicadoras de resistência à carbonatação das seis misturas de concreto que foram caracterizadas. Portanto, essa propriedade deve passar a ser mais bem discutida e interpretada em resultados de pesquisas e estudos de dosagem.

O teor de ar pelo método pressométrico mostrou correlação forte e direta, por exemplo:

$\checkmark$ com as resistências à compressão desde iniciais e aceleradas até 28 dias por cura normal $\left(r^{2}=0,802\right.$ para $\mathrm{fc}_{2 \text { acel }}, \mathrm{r}^{2}=0,930$ para $\mathrm{fc}_{\text {3acel. }}, \mathrm{r}^{2}=0,769$ para $\mathrm{fc}_{7 \text { acel. }} \mathrm{e}$ $\mathrm{r}^{2}=0,872$ para $\left.\mathrm{fc}_{28 n}\right)$;

$\checkmark$ com a medida linear de profundidade de carbonatação a 63 dias, após dois ciclos de $24 \mathrm{~h}$ de exposição em câmara de carbonatação alternada com 27 dias de secagem forçada a $40{ }^{\circ} \mathrm{C}\left(\mathrm{r}^{2}=-0,968\right)$;

$\checkmark$ com a medida linear de profundidade de carbonatação a 91 dias, após três ciclos de $24 \mathrm{~h}$ de exposição em câmara de carbonatação alternada com 27 dias de secagem forçada a $40{ }^{\circ} \mathrm{C}\left(\mathrm{r}^{2}=-0,845\right)$;

$\checkmark$ com as medidas relativas de área carbonatada pelo software Image $\mathrm{J}$ a 203 dias, após 7 ciclos de $24 \mathrm{~h}$ de imersão em $\mathrm{H}_{2} \mathrm{O}$ alternada com 27 dias de 
secagem forçada a $40{ }^{\circ} \mathrm{C}\left(r^{2}=-0,915\right)$ e também para 203 dias de secagem forçada contínua a $40{ }^{\circ} \mathrm{C}\left(\mathrm{r}^{2}=-0,800\right)$;

$\checkmark$ com a resistência à tração por compressão diametral a 203 dias após sete ciclos de $24 \mathrm{~h}$ de imersão em água alternada com 27 dias de secagem forçada a $40{ }^{\circ} \mathrm{C}\left(r^{2}=0,985\right)$.

O ensaio de compactabilidade do concreto adensado, adaptado da BS EN 123504:2009, embora aplicado sem estudos mais aprofundados de refinamento da metodologia, apresentou correlações fortes com diversas propriedades e chama atenção a relação ser direta com propriedades mecânicas, o que pode significar ser uma medida indicadora do assentamento plástico do concreto, por exemplo:

$$
\begin{aligned}
& \checkmark \quad \operatorname{com~} f_{\text {c3-acel }} r^{2}=0,878 ; \\
& \checkmark \quad \operatorname{com~} f_{c t, 8-a c e l-H 2 O} r^{2}=0,848 ; \\
& \checkmark \quad \operatorname{com~} f_{\text {ct,63-acel-H2O }} r^{2}=0,785 \text { e } \\
& \checkmark \quad \operatorname{com~} f_{\text {ct,91-acel-Sec }} r^{2}=0,946 .
\end{aligned}
$$

Em relação às correlações da compactabilidade adensada com as medidas lineares de profundidade de carbonatação, várias correlações foram fortes e inversas, por exemplo:

$\checkmark$ com a espessura carbonatada a 63 dias para a condição AE1 (ou seja, após dois ciclos de $24 \mathrm{~h}$ de exposição em câmara de carbonatação alternada com 27 dias de secagem forçada a $40{ }^{\circ} \mathrm{C}$ ), os valores de $r^{2}$ foram de $-0,838$ e $-0,814$ conforme o indicador usado;

$\checkmark$ com a área relativa carbonatada, medida pelos software Leica e Image J, a 203 dias de idade na condição AE2 (ou seja, após sete ciclos 24 h de imersão em água alternada com 27 dias de secagem forçada a $40^{\circ} \mathrm{C}$, respectivamente, $\mathrm{r}^{2}=$ $-0,853$ e $r^{2}=-0,816$.

Portanto, a expectativa é de que vindo a ser aperfeiçoado o método de ensaio, a medida de compactabilidade do concreto adensado pode resultar num excelente método prático de comparação de misturas em estudos de dosagem. Também cabe salientar que esse tipo de ensaio pode permitir um cálculo ainda mais preciso de perdas de concreto, por seu assentamento plástico natural em formas da estrutura, ou pela incorporação de ar por aditivos.

Assim, todas as correlações medidas nesta pesquisa confirmam a influência do teor de ar no mapa da microestrutura inicial do concreto. Mas, o sinal negativo das correlações 
entre o teor de ar e a espessura ou área da franja carbonatação nos corpos-de-prova são, em princípio, indicativos de duas hipóteses antagônicas:

$\checkmark$ de que houve assentamento plástico excessivo do concreto fresco, percebido visualmente na desforma dos corpos-de-prova, e a causa pode ter sido de retardo excessivo de pega por efeito colateral de aditivo polifuncional (isto foi confirmado posteriormente para outras partidas dos mesmos cimento e aditivo). Desta forma, mais ar no estado fresco pode ter levado a maior assentamento e compactação que depois se refletiu em menor espessura de carbonatação;

$\checkmark$ de que não houve assentamento plástico excessivo do concreto fresco, e então um teor de ar até $2 \%$ no concreto fresco poderia melhorar a zona de transição entre agregados e a matriz de cimento, o que concordaria com o modelo de MINDESS; YOUNG (1981) e caberia então aprofundar esse modelo para a resistência à carbonatação.

A favor da primeira hipótese recai o fato de que na pesquisa de Cavalcanti Filho (2010) as correlações entre teor de ar do concreto fresco e espessura de carbonatação e de ingresso de cloretos foram diretas e não inversas, e os três lotes caracterizados naquele trabalho tinham teor de ar médio na faixa de $3 \%$.

Observa-se que livros atuais e muito abrangentes no campo da tecnologia do concreto, como são os de Isaia (2005), Mehta; Monteiro (2008) e Fusco (2009) dão pouca ênfase à influência do teor de ar do concreto fresco nas propriedades relacionadas à durabilidade e vida útil de armaduras, mas as correlações obtidas neste trabalho apontam que tal propriedade deve ser mais estudada e controlada.

Tal como visto na pesquisa de Cavalcanti Filho (2010), o abatimento do tronco de cone também mostrou possibilidades de correlação com propriedades do concreto no estado endurecido, por exemplo:

$\checkmark$ com a resistência à tração por compressão diametral a 8 dias por cura acelerada de 24/72h em água a temperatura amena e seguida de cura imersa em água em temperatura ambiente até 7 dias e mais $24 \mathrm{~h}$ em câmara de carbonatação $\left(r^{2}=-0,825\right)$;

$\checkmark$ com medidas de absorção de água e índice de vazios nesses mesmos corposde-prova $\left(r^{2}=0,953\right.$ e $r^{2}=0,947$, respectivamente);

$\checkmark$ com a medida linear de carbonatação na condição AE1 a 63 dias (após dois ciclos de $24 \mathrm{~h}$ de imersão em água alternada com 27 dias de secagem forçada a $\left.40{ }^{\circ} \mathrm{C}, r^{2}=0,797\right)$ e para sete ciclos a 203 dias $\left(r^{2}=0,749\right)$; 
$\checkmark$ com as medidas de área relativa de carbonatação pelo software Image $\mathrm{J}$ na condição AE2 a 91 dias de idade (após três ciclos de 24 h de imersão em água alternada com 27 dias de secagem forçada a $40^{\circ} \mathrm{C}, \mathrm{r}^{2}=0,781$ ).

Mas, diferente das medidas de teor de ar, o abatimento não apresentou correlações com as resistências à compressão acelerada do concreto (1, 2, 3 e 7 dias).

A caracterização da umidade dos concretos no estado fresco, ou seja, a relação água/materiais secos $(H)$, apenas apresentou coeficientes de correlação $\left(r^{2}\right)$ superior a 0,75 com as propriedades físicas de absorção de água e índice de vazios, em idades a 63 e 91 dias. Mesmo a determinação tendo sido aplicada em caráter experimental, o valor médio resultante de $7,5 \%$ não ficou muito distante do valor teórico para o traço informado pela central dosadora, em que $\mathrm{H}=8,1 \%$. Mas, cabe ser bem melhor estudada a sua forma de determinação, em especial para outros patamares de temperatura de secagem, acima de $105 \pm 5^{\circ} \mathrm{C}$.

Pela determinação de $\mathrm{H}$, também foi possível estimar o teor de finos total das misturas com dimensão inferior a $75 \mu \mathrm{m}$ e o valor médio foi de $16 \%$, com coeficiente de variação de 7. Quando se observa o valor teórico do teor de finos de $15 \%$, verifica-se que o procedimento de ensaio utilizado nesta pesquisa foi adequado, e praticamente igual ao que foi obtido no ensaio.

Mas, tanto para $\mathrm{H}$ quanto para as medidas de teor de finos total inferior a $75 \mu \mathrm{m}$, cabe confirmar o método de determinação no que diz respeito à quantidade de massa das amostras de ensaio que foi pequena, no caso desta pesquisa, com o objetivo de facilitar e aperfeiçoar o tempo de duração do ensaio. Mas, esses dois ensaios são mais difíceis de serem realizados em campo, e a metodologia precisaria evoluir para facilitar tal fim. Além disto, o número de correlações razoáveis a fortes observadas entre essas duas propriedades e o estado endurecido não foram tão expressivas como ocorreu para as duas propriedades relacionadas ao teor de ar.

No que diz respeito à medida de densidade de massa aparente do concreto fresco, confirmando o mesmo observado em Cavalcanti Filho (2010), esta propriedade não foi adequada para se relacionar bem com as do estado endurecido e nem para estimar o teor de ar dos concretos estudados, pelo método gravimétrico. Mas, apresentou coeficiente de variação aceitável entre os concretos amostrados e pode ser útil para verificações do consumo efetivo de cimento por metro cúbico.

Em resumo, os resultados permitem orientar, estimular e justificar novas práticas de controle tecnológico de concretos estruturais, em estudos de dosagem, seleção, produção ou recebimento, com maior ênfase no controle do teor de ar do concreto fresco e na sua 
compactabilidade adensada, que também pode ser interpretada com a sua propensão ao assentamento plástico.

\subsubsection{Quanto aos métodos e medidas de carbonatação estudados e suas correlações com outras propriedades}

Os três métodos acelerados de carbonatação e os três métodos de medida dos resultados possibilitaram um conjunto de dados de profundidade de carbonatação com distribuição normal.

Em princípio, as medidas de área relativa carbonatada por análise de imagem, introduzidas de forma inédita nesta dissertação, para corpos-de-prova cilíndricos de $10 \mathrm{~cm} \mathrm{x}$ $20 \mathrm{~cm}$, são mais representativas do que o método manual até hoje aplicado e mais simples de serem realizadas do que o procedimento de análise de imagem de Pauletti (2004), que foi apenas testado para argamassas.

Observar que o método manual linear apenas promove medidas pontuais e em número bem limitado de repetições por operador (seis a doze). O software Leica Qwin estudado com a cooperação do LCT- PMI - EPUSP tem maior resolução para estudos mais avançados, enquanto o software Image $\mathrm{J}$ é de acesso público e pode ser usado em trabalhos mais correntes. A análise de imagem pode viabilizar melhores registros para pesquisas do que as medidas manuais.

Assim, o procedimento testado nesta pesquisa tanto permite medir a resistência à tração do concreto, através dos corpos-de-prova cilíndricos de $10 \mathrm{~cm}$ de diâmetro por $20 \mathrm{~cm}$ de altura, quanto analisar a da profundidade de carbonatação na sua seção diametral plena. A partir de volume e área com extensão representativa do concreto, é possível que seja melhor para analisar a influência das características do concreto no estado fresco, na carbonatação. Inclusive, observar melhor os fenômenos de sedimentação plástica, que podem aumentar a compacidade dos corpos-de-prova e gerar medidas de correlação inversa entre teor de ar no estado fresco e a profundidade de carbonatação, como se constatou ter ocorrido tanto no ato da desforma dos corpos-de-prova moldados para esta pesquisa, quanto pela análise da matriz de correlações discutida no Capítulo 4.

Também os corpos-de-prova em dimensões mais adequadas ao concreto estrutural e com ruptura induzida que facilite a obtenção de uma superfície mais plana, para análise do fenômeno de carbonatação do concreto, podem permitir realizar cálculos porcentuais de área carbonatada, pelas técnicas de análise de imagem testadas nesta pesquisa, e isto ser extrapolado à previsão de carbonatação em peças com outras relações de área e volume, uma vez que evoluam pesquisas sobre o efeito de geometria das peças na carbonatação. Assim, é recomendável fazer o ensaio de compressão diametral com uma indução da 
superfície de fratura, pelo uso de algum dispositivo ou de outro método de fragilização de superfície central ao eixo dos corpos-de-prova.

Portanto, a forma de medir a resistência à carbonatação adotada nesta pesquisa parece ser promissora para o desenvolvimento de modelagens de predição da vida útil de armaduras do concreto e também para futura normalização, mas cabe ainda avaliar a repetibilidade e a reprodutibilidade dos ensaios, com algum aperfeiçoamento no que diz respeito ao controle da seção de fratura no ensaio de compressão diametral.

Pela análise dos coeficientes de variação de profundidade de carbonatação para as seis misturas, nas diversas idades, métodos de envelhecimento e três formas de medida constatou-se que os métodos de análise de imagem apresentaram maior dispersão do que as medidas lineares e isto pode ter relação com a forma de ruptura não exatamente diametral no ensaio à tração de cada corpo-de-prova, pois as áreas relativas são afetadas pela mesma.

A 203 dias, a espessura média das franjas de carbonatação pelos três métodos de envelhecimento acelerado resultou entre 4 e $5 \mathrm{~mm}$, com coeficiente de variação entre $13 \%$ e $21 \%$ para oito dos nove grupos de doze corpos-de-prova (dois por mistura), no caso diferenciados pelo método de envelhecimento ou de medida da carbonatação.

Os coeficientes de variação para a profundidade média de carbonatação linear de cada uma das seis misturas variaram entre $8 \%$ e $20 \%$, sendo oito medidas para cada dois corpos-de-prova por mistura.

Para a profundidade de carbonatação por área relativa através dos programas Image $\mathrm{J}$ e Leica, os coeficientes de variação foram de no máximo $21 \%$, exceto para as medidas realizadas com o software Leica para 203 dias de idades submetidos à secagem contínua, que apresentou um coeficiente de variação de $42 \%$ (em decorrência de uma medida anômala e que pode ter origem no afastamento da seção em análise do plano diametral de ruptura ideal, no ensaio de tração por compressão diametral). O software Leica mostrou maiores espessuras de carbonatação, possivelmente pela sua maior resolução.

As medidas de carbonatação em corpos-de-prova submetidos ao método envolvendo apenas imersão em água e secagem a 203 dias resultaram com ótimo contraste com o indicador de fenolftaleína e foram as que mostraram maiores probabilidades de igualdade de médias, independente do método de medida da franja. As outras franjas obtidas por exposição a $\mathrm{CO}_{2}(\mathrm{AE} 1)$ ou secagem contínua (AE3) foram mais difusas e difíceis de ver. Mas, o Leica Qwin tem resolução suficiente para eliminar essas dúvidas e só não foi aplicado de modo totalmente confiável devido à não linearidade da superfície das fotos, o que pode ser melhorado por indução da superfície de fratura ou por evolução de rotinas do 
programa que efetue uma correção relativa do resultado, de modo automático e proporcional ao desvio médio da superfície analisada em relação ao eixo central do corpo-de-prova.

Por análise de variância para três fatores a 203 dias de idade, foram observadas equivalência entre as medidas de carbonatação, por dois dos métodos acelerados - um de secagem contínua a $40^{\circ} \mathrm{C}$ em estufa ventilada e outro de um dia de exposição a $\mathrm{CO}_{2}(5 \%$ e U.R. $75 \%$ ) alternado por 27 dias de secagem a $40^{\circ} \mathrm{C}$ em estufa ventilada, mas ambos não mostraram semelhança com o terceiro método, que foi de um dia de imersão em água alternada por 27 dias de secagem a $40^{\circ} \mathrm{C}$ em estufa ventilada.

As curvas de monitoração dos corpos-de-prova em secagem contínua forçada são indicativas de que a carbonatação ocorreu em um terceiro período de velocidade de secagem do concreto, superior a 90 dias, possivelmente devido ao fato da saída de água na rede de macroporos, com maior estabilização da perda de massa e como evidenciam as curvas de secagem no item 4.1.2 D3). Idades mais avançadas de análise se tornariam necessárias para visualizar a influência da perda final de água na faixa de meso e microporos e quando seria esperado estabilizar a franja de exposição pelos ciclos de $\mathrm{CO}_{2} \mathrm{e}$ pela secagem contínua.

Neste estudo, verificou-se tanto pela análise de fator duplo, quanto a análise por fator triplo, que a combinação de fatores como idade do concreto, mistura e condição de envelhecimento pode dificultar a diferenciação de diferentes lotes de concreto, pois em geral os fatores apenas mostraram influência significativa quando analisados isoladamente.

Para as análises de variância por fator triplo e verificadas pelo método de Tukey, em relação aos resultados de profundidade de carbonatação para os métodos manuais e pelo software ImageJ, quando se compara diferentes idades e os três tipos de ciclagem, não se observa grupos de semelhança entre esses fatores, ou seja não há igualdade. Verifica-se que somente as misturas (caminhões) apresentaram certa semelhança entre si dentro das análises de fatores.

Para os resultados de carbonatação utilizando porcentagem de área carbonatada, que foi calculada para as medidas lineares para viabilizar a comparação com as medidas de análise de imagem, verificou-se semelhança entre os métodos de medidas manual e pelo software ImageJ para 203 dias. Mas, observou-se diferença entre as medidas manuais de dois operadores diferentes (Manual 1 e Manual 2). Em princípio, isto poderia ter sido causado pela falta de treinamento do operador 2 , em medição manual, pois o operador 1 tinha realizado várias medidas manuais precedentes. No entanto, foi esse mesmo operador 2, quem realizou as medidas no software ImageJ, que apresentou semelhança com as medidas manuais realizadas pelo operador 1 . Ou seja, as semelhanças e diferenças entre 
os métodos não foram conclusivas. Assim, cabe prosseguir a investigação dos métodos de análise de imagem, tanto para confirmação das correlações aqui obtidas, quanto para contribuição à evolução da modelagem desse mecanismo.

As medidas de profundidade de carbonatação pelos três métodos de envelhecimento acelerado mostraram excelentes correlações inversas com as resistências à compressão por cura acelerada em idades iniciais e também por resistência à compressão a 28 dias por cura normal, como também para as resistências à tração por compressão diametral principalmente a 8 dias do concreto com cura acelerada.

Para os ensaios de tração para as idades de 91 e 203 dias também se observou semelhança quando se verifica as ciclagens de secagem contínua e câmara de carbonatação, e para a ciclagem de molhagem e secagem resultou maior valor médio.

Já para os ensaios de absorção de água e índice de vazios, o grupo de semelhança entre os tipos de ciclagens foi entre a ciclagem de molhagem e secagem e exposição à câmara de carbonatação. Isto pode ser explicado devido às propriedades físicas apenas terem influência principal de macroporos, enquanto que a tração tem influência de meso e microporos, que devido à condição submersa, melhora a hidratação e as propriedades mecânicas então aumentam. Pode ser explicado também pela influência do dióxido de carbono em realizar a colmatação inicial e superficial de poros na superfície dos corpos-deprova, e isto cabe ser mais bem estudado.

Portanto, esta pesquisa por hora conclui e propõe que, além das medidas do teor de ar no estado fresco, a resistência à tração por compressão diametral e a resistência à compressão a 1, 2, 3 ou 7 dias por cura acelerada sejam propriedades que também passem a ser avaliadas em concretos, com vistas a melhorar ou controlar a sua resistência à carbonatação.

Quanto às propriedades físicas relacionadas à porosidade do concreto, como a absorção de água e índice de vazios, estas também podem ser caracterizadas de forma acessória e complementar, em idades iniciais ou mais avançadas dos concretos, mas aqui não mostraram muitas correlações razoáveis a fortes, com as medidas de profundidade de carbonatação entre 63 e 203 dias de idade. Os resultados de ensaios de absorção de água e índice de vazios parecem ter sido mais afetados pela idade de secagem dos concretos do que pela hidratação, já que esta foi inicialmente acelerada.

Assim, os objetivos desta dissertação foram alcançados, independente da interferência aleatória e desconhecida de todas as variáveis previsíveis e atuantes em um processo real de produção do concreto, como foi o estudo de caso realizado. 
Espera-se com estes resultados estimular novas práticas de qualificação e recebimento de concretos pré-misturados, por laboratórios especializados com vistas à futura evolução de procedimentos da ABNT 12655 (2006) e ainda para o desenvolvimento de novas normas de ensaio, que possam contribuir para a previsão e modelagem de vida útil das armaduras em estruturas.

\subsection{SUGESTÕES PARA FUTURAS PESQUISAS}

Esta dissertação procurou iniciar e incentivar pesquisas que possam contribuir para a evolução do controle tecnológico da resistência à carbonatação de concretos estruturais, em condições muito próximas às reais de fornecimento em campo, para novas práticas em estudos de dosagem e de produção ou recebimento.

A amostragem e caracterização do concreto fresco e a moldagem dos corpos-de-prova desta pesquisa foram realizadas para porções de primeira descarga, em curto prazo de amassamento do concreto de seis caminhões betoneira de $8 \mathrm{~m}^{3}$, dentro do pátio da central produtora, sendo que a obra de destino situava-se ao lado da central.

Como todos os resultados aqui discutidos são indicativos de que esse procedimento de amostragem não foi prejudicial à caracterização do concreto, cabe sugerir, inicialmente, o estudo de metodologias alternativas de amostragem do concreto fresco e possam ser contempladas em uma futura revisão da ABNT NBR NM 33 (1998), pois podem servir em algumas circunstâncias a rotinas de controle de processo.

Do ponto de vista do aperfeiçoamento dos métodos e medidas de carbonatação estudados e das suas correlações com outras propriedades do concreto, o prosseguimento das seguintes pesquisas deve se dar:

$\checkmark$ Pelo prosseguimento do envelhecimento acelerado do concreto deste estudo, para uma última avaliação em idade por volta de 500 dias;

$\checkmark$ Continuar estudos da influência do teor de ar por método pressométrico no concreto fresco na resistência à carbonatação do concreto, com vistas a verificar a proposição de Mindess; Young (1981) e assim refinar critérios de variação aceitáveis para o controle das propriedades físicas e mecânicas do concreto endurecido, sem prejuízo à durabilidade das estruturas;

$\checkmark$ Continuar estudos sobre a compactabilidade do concreto adensado, no caso de ser plástico, ou de compactabilidade não adensada, no caso de ser fluido, para quantificar os melhores volumes e tempo de duração deste ensaio e os seus limites de especificação, para a predição de propriedades físicas e mecânicas a 
baixas idades, como a resistência à tração, compressão e resistência à carbonatação;

$\checkmark$ Realizar estudos de repetibilidade e de reprodutibilidade dos ensaios de teor de ar do concreto fresco, pelos métodos pressométrico e gravimétrico respectivamente ABNT NBR 47 (2002) e ABNT NBR 9833 (1987);

$\checkmark$ Prosseguir em estudo de metodologias para a caracterização de umidade e teor de finos total em concretos no estado fresco, avaliando equipamentos e métodos, que possam ser aplicados a condições de campo com mais facilidade do que os procedimentos testados nesta pesquisa;

$\checkmark$ Prosseguir em estudos de cura acelerada em temperatura amena do tipo A da ASTM C 684 (1999), mas para duração progressiva entre 1-3, 1-5 e 1-7 dias de idade do concreto, prevendo-se o complemento da cura em temperatura ambiente até 7 dias, no caso dos períodos acelerados entre 1-3 e 1-5 dias;

$\checkmark$ Investigar os limites mínimos de maturação acelerada do concreto, para não prejudicar ou falsear o seu comportamento em ensaios de envelhecimento acelerado, por exemplo, na situação de exposição a métodos mais agressivos de carbonatação como ocorre para exposição à $\mathrm{CO}_{2}$ sob pressão;

$\checkmark$ Verificar a influência de aditivos fluidificantes e da temperatura de exposição dos corpos-de-prova até $24 \mathrm{~h}$ de moldagem, na duração da cura acelerada citada, com vistas a compensar eventuais efeitos de retardo de pega e endurecimento e para se alcançar de modo mais garantido a maturação equivalente a 28 dias;

$\checkmark$ Prosseguir em estudos de envelhecimento acelerado de concretos prematurados até 7 dias em temperatura amena e sem precondicionamento, baseado na secagem forçada do concreto a $40^{\circ} \mathrm{C}$, alternada por ciclos de imersão em água, como feito neste trabalho, pois é uma condição inicial mais comparativa com o concreto em envelhecimento natural. A exposição contínua ou alternada a $\mathrm{CO}_{2}$ sob pressão sempre pode ser também comparada para uma resposta mais rápida do estudo. Tanto propriedades físicas quanto mecânicas cabem ser caracterizadas e continuar a ser interpretadas quanto às suas correlações;

Desenvolver estudos comparativos de secagem natural e carbonatação de concretos, em ambientes internos, em relação à secagem forçada em estufa ventilada a $40 \pm 5{ }^{\circ} \mathrm{C}$, ou por outras técnicas ainda mais aceleradas de secagem, verificando seus efeitos na retração por secagem e no surgimento de microfissuras na microestrutura; 
$\checkmark$ Estudar a influência e a eficiência de dispositivos para melhorar a superfície do corpo-de-prova rompido à tração por compressão diametral e a ser usado nas análises de imagem;

$\checkmark$ Prosseguir na aplicação de conceitos estatísticos e das técnicas de análise de imagem testadas por esta pesquisa, fazendo um interlaboratorial entre métodos e diferentes operadores, para se avançar em interpretações de profundidade ou área relativa característica de carbonatação e nas suas aplicações para a modelagem do período de passivação de armaduras, isto é da sua vida útil em projetos de estruturas;

$\checkmark$ Investigar e tentar evidenciar pela microestrutura, hidratação e secagem do concreto, as razões para que as medidas de absorção de água por imersão dos concretos mostrem valores maiores a partir de 91 dias, ainda que em todas as idades iniciais (8, 35 e 63 dias) e finais (91 e 203 dias) a massa seca de referência dos corpos-de-prova seja sempre medida da mesma forma e a $100^{\circ} \mathrm{C}$;

$\checkmark$ Ampliar estudos para verificar a possibilidade de correlação entre a absorção de água por capilaridade e a resistência à carbonatação do concreto por efeitos de ciclos de molhagem/secagem. Estudar procedimentos de lubrificação de formas em moldagem de corpos-de-prova que possam ter pouca ou nenhuma influência na sua capilaridade superficial.

\subsection{TRANSFERÊNCIAS AO MEIO TÉCNICO}

As seguintes publicações divulgaram resultados parciais desta pesquisa:

$\checkmark$ CAFANGE, D.M.P.J.; CAVALCANTI FILHO, A.N.; MIRANDA, D.A.; SELMO, S.M.S. Prosseguimento de estudos de cura acelerada em temperatura moderada de concreto estrutural em condições de campo. In: CONGRESSO BRASILEIRO DO CONCRETO, 52으, 2010, Fortaleza. Anais: IBRACON, 2010;

$\checkmark$ MATAR, M.R. Estudo da velocidade da onda ultrasônica em concreto classe $30 \mathrm{em}$ diferentes ambientes de envelhecimento. In: SIMPÓSIO DE INICIAÇÃO CIENTÍFICA DA USP, 18ํ, 2010, São Paulo. Anais: SIICUSP, 2010;

$\checkmark$ MIRANDA, D.A. Análise de imagem na tecnologia do concreto. In: SIMPÓSIO DE INICIAÇÃO CIENTÍFICA DA USP, 18ํ, 2010, São Paulo. Anais: SIICUSP, 2010;

$\checkmark$ MIRANDA, D.A. Monitoração de propriedades físicas de concretos estruturais em envelhecimento acelerado. Relatório de Iniciação Científica com bolsa USP no período de 2009/2010. 


\section{REFERÊNCIAS BIBLIOGRÁFICAS}

ABREU, A.G. Estudo da corrosão da armadura induzida por carbonatação em concretos com cinza volante. 2004. 169p. Tese (Doutorado). Universidade Federal, Rio Grande do Sul, Porto Alegre. 2004.

AMERICAN CONCRETE INSTITUTE. ACI Committee 316: guide for construction of concrete pavements and concrete, 1997.

ACI Committee 350: Environmental engineering concrete structures, 1987.

1997.

ACI Committee 350: Concrete structures for containment of hazardous materials,

ACI Committee 357: Guide for the design and construction of fixed offshores concrete structures, 1997.

AITCIN, P.C. Concreto de alto desempenho; São Paulo: PINI, 2000. 662p.

AMERICAN SOCIETY FOR TESTING AND MATERIALS. Standard practice for making and curing concrete test specimens in the field.: ASTM C $31 \mathrm{M}-06$. PA, 2006, 6p.

Standard test method for making accelerated curing, and testing concrete compression test specimens: ASTM C 684 - 99. Philadelphia, 1999. 10p.

Standard test method for electrical indication of concrete's ability to resist chloride ion penetration. ASTM C 1202-05. Philadelphia, 2005, 6p.

ANDRADE, C. Manual para diagnóstico de obras deterioradas por corrosão de armaduras. Trad. Carmona Filho, A.; Helene, P. São Paulo, PINI, nov. 1992. 105p. ISBN 85-7266-040-2.

ANDRADE, C. et al. Carbonation effect on reinforced concrete durability in Iberoamerican countries: Duracon Project/Cyted. In: Congresso Latino Americano de Corrosão. Anais. Fortaleza, LATINCORR, 2006.

ANDRADE, J. J. O. Contribuição à Previsão da Vida Útil das Estruturas de Concreto Armado Atacadas pela Corrosão das Armaduras: Iniciação por Cloretos. Tese (Doutorado em Engenharia). Universidade Federal, Rio Grande do Sul, Porto Alegre, 2001.

ANDRADE, P. A. Os caminhos do comprometimento. Revista recuperar no 63, Rio de Janeiro: Thomastec, 2005.

ANDRADE, W. P. Concretos: massa, estrutural, projetado e compactado com rolo: ensaios e propriedades. São Paulo: Pini, 1997. (várias paginações) ISBN 85-7266-069-0.

ARAÚJO, F.W.; FIGUEIREDO, E. P.; HELENE, P. Contribuição para a viabilização da técnica de realcalinização do concreto carbonatado: repassivação da armadura. In: 40은 Congresso Brasileiro do Concreto. Anais. Bento Gonçalves, IBRACON, 2007.

ASSOCIAÇÃO BRASILEIRA DE NORMAS TÉCNICAS. NBR NM 248: Agregados determinação da composição granulométrica. Rio de Janeiro. 2001. 6p.

$5 p$.

NBR NM 033: Concreto - amostragem do concreto fresco. Rio de Janeiro, 1998.

NBR NM 047: Concreto fresco - determinação do teor de ar em concreto fresco método pressiométrico. Rio de Janeiro, 2003.

NBR NM 067: Concreto fresco - determinação da consistência pelo abatimento de

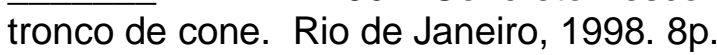


NBR 12654: Controle tecnológico de materiais componentes do concreto. Rio de Janeiro, 1992. 6p.

NBR 7222: Argamassa e concreto - determinação da resistência à tração por compressão diametral de corpos de prova cilíndricos. Rio de Janeiro, 1994.

NBR 8802: Concreto endurecido - determinação da velocidade de propagação de onda ultra-sônica. Rio de Janeiro, 1994. 1995. $2 \mathrm{p}$.

NBR 9779: Determinação da absorção de água por capilaridade. Rio de Janeiro,

NBR 5738: Concreto - procedimento para moldagem e cura de corpos de prova. Rio de Janeiro, 2003. 6p.

NBR 9778: Argamassa e concreto endurecidos - determinação da absorção de água, índice de vazios e massa específica. Rio de Janeiro, 2005.4p.

NBR 12655: Concreto - preparo, controle e recebimento. Rio de Janeiro, 2006. $18 p$. 2007. 221p.

NBR 6118: Projetos de Estruturas de Concreto - procedimento. Rio de Janeiro,

NBR 5739: Concreto - ensaio de compressão de corpo-de-prova cilíndrico. Rio de Janeiro, 2007. 9p.

NBR 9833: Concreto fresco - determinação da massa específica e do teor de ar pelo método gravimétrico. Rio de Janeiro, 2008. 8p.

NBR 8522: Determinação dos módulos estáticos de elasticidade e de deformação e da curva tensão de deformação. Rio de Janeiro, 2008. 16p.

ASSOCIAÇÃO BRASILEIRA DAS EMPRESAS DE TECNOLOGIA DA CONSTRUÇÃO CIVIL (ABRATEC). Procedimentos recomendados para controle tecnológico do concreto. Procedimento - D 0510 - 1ª edição. São Paulo, 2005.

BARBOSA, D.C.; BARDELLA, P.S.; CAMARINI, G. Avaliação da carbonatação natural em concretos produzidos com e sem sílica ativa submetido a diferentes procedimentos de cura. In: CONGRESSO BRASILEIRO DO CONCRETO, 47², 2005, Rio de Janeiro. Anais: IBRACON, 2005.

BARKER, A.P.; MATTHEWS, J.D. Concrete durability specification by water/cement or compressive strength for European cement types. DURABILITY OF CONCRETE INTERNATIONAL CONFERENCE, 3., Detroit. 1994. Proceedings....American Concrete Institute, 1994, p. 1135-1159.

BASSHER, L.; KROPP, J.; CLELAND, D.J. Assessment of the durability of concrete form its permeation properties: a review. Construction and Building Materials, v.15, n2/3, p. 93103, Mar/Apr. 2001.

BATTAGIN, A. F.; CURTI, R.; SILVA, C. O.; MUNHOZ, F. A. C. Influência das condições de cura em algumas propriedades dos concretos convencionais e de alto desempenho.In: CONGRESSO BRASILEIRO DO CONCRETO, 44, 2002, Belo Horizonte. Anais: IBRACON, 2002.

BAUER, E; NEPOMUCENO, A.A.; LARA, P. L. O.; PEREIRA, C. H.A.F. Avaliação da carbontação de concretos produzidos no DF. In: CONGRESSO BRASILEIRO DO CONCRETO, 48 , 2006, Rio de Janeiro. Anais. IBRACON, 2006.

BAUER L.A.F. Materiais de construção, 5. ed. Rio de Janeiro: Ed. LTC, 1994, v.2.

BERTOLO, R.S.B. Contribuição ao desenvolvimento de programas de durabilidade de reparos de argamassa, em estruturas de concreto com corrosão de armaduras. 2006. 
237p. Dissertação (Mestrado). Escola Politécnica, Universidade de São Paulo, São Paulo, 2006.

BRITISH STANDARD INSTITUTE. Testing fresh concrete. Degree of compactability. BS EN 12350-4 (2009).

CADORE, W.W.; ISAIA, G.C.; GASTALDINI, A.L.G.; DIESEL, F.B. Ensaios acelerados e naturais na carbonatação de concretos com altos teores de adição mineral. In: CONGRESSO BRASILEIRO DO CONCRETO, 49ํ, 2007, Bento Gonçalves. Anais: IBRACON, 2007.

CAMARINI, G.; CINCOTTO, M.A. Efeito da cura térmica na resistência de argamassas de cimento Portland comum e de alto-forno. Boletim Técnico da Escola Politécnica da USP. BT/PCC/156. São Paulo, 1995.

CAMARINI, G; BARBOSA, D.C; BARDELLA, P.S. Avaliação da carbonatação natural em concretos produzidos com e sem sílica ativa submetidos a diferentes procedimentos de cura. In: CONGRESSO BRASILEIRO DO CONCRETO, 47², 2005, Recife. Anais: IBRACON 2005.

CARMONA, T.G. Modelos de previsão da despassivação das armaduras em estruturas de concreto sujeitas à carbonatação. São Paulo, 2005. 93p. Dissertação (Mestrado) Escola Politécnica, Universidade de São Paulo, São Paulo, 2005.

CASCUDO, O. O controle da corrosão de armaduras em concreto - inspeção e técnicas eletroquímicas. Goiânia: Editora UFG, 1997. 237p.

CASCUDO, O. Influência das características do aço carbono destinado ao uso como armaduras para concreto armado no comportamento frente à corrosão. São Paulo, 2000. Tese (Doutorado) - Escola Politécnica, Universidade de São Paulo, São Paulo, 2000.

CASCUDO, O. Inspeção e diagnóstico de estrutura de concreto com problemas de corrosão de armaduras. In: Isaia, G.C. Concreto: ensino, pesquisa e realizações, São Paulo: Ibracon, 2005. v.2, cap. 35, p.1071-1108.

CASTELLOTE, M.; ANDRADE, C. Modelling the carbonation of cementitious matrixes by means of the unreacted-core model, UR-CORE. Cement and Concrete Research, v.38, n.12, p. 1374-1384, 2008.

CASTELlOTE, M.; FERNANDEZ, L.; ANDRADE, C.; ALONSO, C. Chemical changes and phase analysis of OPC pastes carbonated at different $\mathrm{CO}_{2}$ concentrations. Materials and Structures, v. 42, n. 4, p. 515-524, 2009.

CASTRO, A.; CASCUDO, O.; CARASEK, H.; LOPES, A.N.M. Avaliação da carbonatação no concreto de cobrimento com adições minerais e diferentes relações água/aglomerante. In: CONGRESSO BRASILEIRO DO CONCRETO, 45, 2003, Vitória. Anais: IBRACON, 2003.

CAVALCANTI FILHO, A.N.; CAVALCANTI, G.A.D.; SELMO, S.M.S. Estudo de propriedades mecânicas de concretos estruturais em cura acelerada com temperatura moderada. In: CONGRESSO BRASILEIRO DO CONCRETO, 51ํ, 2009, Curitiba. Anais: IBRACON, 2009.

CAVALCANTI FILHO, A.N. Contribuição ao controle tecnológico de concretos estruturais de cimento Portland, em ambientes marítimos. 2010. Dissertação (Mestrado) - Escola Politécnica, Universidade de São Paulo, São Paulo, 2010.

CHANG, C.F; CHEN, J.W. The experimental investigation of concrete carbonation depth. Cement and Concrete Research. n. 36, p. 1760 - 1767, 2006.

CLAISSE, P.; EL-SAYAD, H.; SHAABAN, I., Permeability and pore volume of carbonated concrete. ACl materials Journal, v.96, n.3, p.378-381, May-June 1999. 
COMITÉ EURO-INTERNACIONAL DU BETÓN. New approach to durability design: an example for carbonation induced corrosion. Bulletin d' Information $n^{\circ} 238$. Suecis, May 1997, $138 \mathrm{p}$.

COSTA JUNIOR, M.P et al.; Concretos com altos teores de escória de alto-forno: avaliação da carbonatação e da difusão de íons cloreto. In: CONGRESSO BRASILEIRO DO CONCRETO, 47ํㅜ 2005, Recife. Anais: IBRACON, 2005.

CRUZ NETO, J.M.; SILVA, A.J.C.; ANDRADE, A. S. A. C.; ANDRADE, T. W. C. O. Avaliação da despassivação da armadura por meio do perfil de cloretos e carbonatação em estruturas de concreto em região agressiva com 20 anos de idade - Porto do Recife. In: CONGRESSO BRASILEIRO DO CONCRETO, 47º, 2005, Recife. Anais: IBRACON, 2005.

CUNHA, A.C.C. Despassivação das armaduras de concreto por ação da carbonatação. 2001. Dissertação (Mestrado). Escola Politécnica, Universidade de São Paulo, São Paulo, 2001.

CUNHA, A.C.Q.; HELENE, P.R.L.; Despassivação das armaduras de concreto por ação da carbonatação. São Paulo: EPUSP, 2001. Boletim Técnico, Escola Politécnica da USP Departamento de Engenharia de Construção Civil, BT/PCC/283.

DAL MOLIN, D.C.C.; PAULETTI, C.; KAZMIERCZAK, C.S. Comparação entre diferentes precondicionamentos de corpos-de-prova para ensaios acelerados de carbonatação. In: CONGRESSO BRASILEIRO DO CONCRETO IBRACON, 49, 2007, Bento Gonçalves. Anais: IBRACON, 2007.

D-HAINAUT L. Conceitos e Métodos da Estatística. Volume I | Uma variável a uma dimensão. 2.ed. Lisboa: Fundação Calouste Gulbenkian; 1997.p.16-17; 25; 162-163.

DIAS, W.P.S. Reduction of concrete sorptivity with age though carbonation. Cement and Concrete Research, v.30, p.1255-1261, 2000.

DIAZ, N.E. Avaliação do grau de corrosão das armaduras em estruturas com concreto carbonatadas. 1997. Dissertação (Mestrado). Escola Politécnica, Universidade de São Paulo, São Paulo, 1997.

FIGUEIREDO, C.R. Estudo da carbonatação em estruturas de concreto armado em Brasília: avaliação de pilares. 2004. 222p. Tese (Doutorado). Universidade de Brasília, Brasília, 2004.

FIGUEIREDO, E.P. Efeitos da carbonatação e de cloretos no concreto. In: Isaia, G.C. Concreto: ensino, pesquisa e realizações. São Paulo: Ibracon, 2005. V.2, cap. 27, p.829 $-855$.

FORTES, L.R. Corrosão na armadura do concreto armado e sua avaliação pela técnica do potencial de eletrodo. 1995. 228p. Dissertação (Mestrado). Universidade Federal do Ceará. Fortaleza, 1995.

FUSCO, P.B. Tecnologia do Concreto Estrutural: tópicos aplicados. São Paulo: Pini, 2008. 179p.

GASTALDINI, A.L.G.; Influência da finura da escória na carbonatação de concretos com adições minerais. In: CONGRESSO BRASILEIRO DE CIMENTO, 5ㅜ, 1999, Florianópolis. Anais: 1999.

GENTIL, V. Corrosão. $4^{\mathrm{a}}$ ed. Rio de Janeiro: Editora LTC, 2003. 341p.

GEYER, A.L.B.; SÁ, R.R. Importância do controle da qualidade do concreto no estado fresco. Informativo técnico Realmix, ano 2, №2, 2006. Disponível em: www.realmixconcreto.com.br. Acesso em: 12 ago. 2008. 
GIANOTTI, F.S; HELENE, P. Carbonatação acelerada e medida da carbonatação: fatores intervenientes nos ensaios. In: CONGRESSO BRASILEIRO DO CONCRETO, 49, 2007, Bento Gonçalves. Anais: IBRACON, 2007.

GLASSER, F.; MATSCHEI, T. Interactions between Portland cement and carbon dioxide. In: $12^{\text {th }}$ International Congress on the Chemistry of Cement. Proceedings.... Montreal, 2007.

GOMES, N.A. Estruturas de concreto armado interrompidas em ambiente urbano: Avaliação da carbonatação à luz das recomendações da NBR 6118/03. 2006. Dissertação (Mestrado). Universidade Federal de São Carlos, São Carlos, 2006.

GONEN, T.; YAZICIOGLU, S. The influence of compaction pores on sorptivity and carbonation of concrete. Construction and Building Materials v.21 (2007) 1040-1045.

GRICOLI, A.S. Porosidade dos Concretos. 2001. Apresentação de trabalho à Escola Politécnica da USP. Departamento de estruturas e fundações.

HELENE, P.R.L. Corrosão em armaduras para concreto armado. São Paulo: Editora Pini, Instituto de Pesquisas Tecnológicas IPT, 1986. 47p.

HELENE, P.R.L. Tecnologia de edificações. Corrosão de armaduras para concreto armado. São Paulo: Editora Pini, p. 597-602 1988.

HELENE, P.R.L. Contribuição ao estudo da corrosão em armaduras de concreto armado. 1993. 231p. Tese (Livre Docente), Escola Politécnica da Universidade de São Paulo, Departamento de Engenharia Civil.

HELENE, P.R.L. Durabilidade das Estruturas de Concreto Armado. In: I SEMINÁRIO SOBRE CORROSÃO NORTE NORDESTE, 1995, Fortaleza. Anais: ABRACO, 1995.

HELENE, P.R.L. Vida útil das Estruturas de Concreto. In: IV Congresso Iberoamericano de Patologia das Construções. Anais... Porto Alegre, RS, 1997.

HELENE, P.R.L.; TERZIAN, P.R. Manual de dosagem e controle do concreto. São Paulo: Editora Pini, São Paulo, 1992.

HELENE, P.; VIEIRA. J.O.; ANDRADE, T.; DELGADO, C.; JUST, A. Influência da relação água / cimento e abatimento na carbonatação do concreto. In: CONGRESSO BRASILEIRO DO CONCRETO. Anais: IBRACON 1999.

HELENE, P.R. Manual de estruturas de concreto. Reparo, reforço e proteção. São Paulo: Red Rehabilitar, São Paulo, 2003.

HERVÉ, E.N. Controle em Centrais Dosadoras. Téchne. 1995, p. 24 - 25.

HO, D.W.S.; LEWIS, R.K. Carbonation of concrete and its prediction. Cement and Concrete Research, v.17, p.489-504, 1987.

HOPPE FILHO, J. Sistemas cimento Portland, cinza volante e cal hidratada: mecanismo de hidratação, microestrutura e carbonatação do concreto. 2008. 247p. Tese (Doutorado) Escola Politécnica, Universidade de São Paulo, São Paulo, 2008.

HOUST, Y.F.; WITTMANN, F.H. Influence of porosity and water content on the diffusivity of $\mathrm{CO}_{2}$ and $\mathrm{O}_{2}$ through hydrated cement paste. Cement and Concrete Research, v. 24, n. 6, 1994.

HOUST, Y.F.; WITTMANN, F.H. Depth profiles carbonates formed during natural carbonation. Cement Concrete Research. n. 32, 2002, p. 1923-1930.

HOOTON, R.D; MINDESS, S.; ROUMAIN, J.C.; BOYD, A.J.; REAR, K.B. Proportioning and Testing Concrete for Durability. Concrete International. 2006. p. 38-41.

ISAIA, G.C.; VAGHETTI, M.; GASTALDINI, A. Carbonatação acelerada e natural de concreto com alto teor de pozolanas: um estudo preliminar. In: CONGRESSO BRASILEIRO DO CONCRETO, 43, Foz do Iguaçu, 2001. Anais: IBRACON, 2001. 
ISAIA, G.C. Concreto: Ensino, Pesquisa e Realizações. São Paulo: IBRACON, 2005. vol. 01 e 02.

ISAIA, G.C. Carbonatação do concreto: Uma Revisão. Santa Maria, 1999.

ISHIDA, T.; MAEKAWA, K. Modeling of $\mathrm{pH}$ profile in pore water based on mass transport and chemical equilibrium theory. (translation on proceedings of JSCE, n.648/V.47, May 2000).

JERGA, J.; Physico-mechanical properties of carbonated concrete. Construction and Building Materials. v. 18 (2004) 645-652.

JIANG, L.; LIN, B.; CAI, Y.A. A model for predicting carbonation of high-volume fly ash concrete. Cement and Concrete Research, v.30, p.669-702, 2000.

LO,T.Y; NADEEM,A.; TANG,W.C.P.; YU,P.C. The effect high temperature curing on the strength and carbonation of pozzolanic structural lightweight concretes. Construction and Buildings Materials. 23 (2009) 1306-1310.

KAZMIERCZAK, C. S. Contribuição para a análise da eficiência de películas aplicadas sobre estruturas de concreto armado com o objetivo de proteção contra a carbonatação. 1995. 168p. Tese (Doutorado). Escola Politécnica, Universidade de São Paulo, São Paulo, 1995.

KUHN, M.C.; WILLRICH, F.L.; LIMA JR, H.C. Efeito da resistência à compressão na resistência à carbonatação do concreto. In: CONGRESSO BRASILEIRO DO CONCRETO, 47ํ, 2005, Recife. Anais: IBRACON, 2005.

KULAKOWSKI, M.P.; DAL MOLIN, D.C.C. Estudo da porosidade como condicionante da durabilidade da carbonatação em concretos. In: CONGRESSO BRASILEIRO DO CONCRETO, 48, 2006, Rio de Janeiro. Anais. IBRACON, 2006.

LO, T.Y.; NADEEM, A.; TANG, W.C.P.; YU, P.C. The effect high temperature curing on the strength and carbonation of pozzolanic structural lightweight concretes. Construction and Buildings Materials. 23 (2009) 1306-1310.

LYRA, F.N.P. Influência da Dosagem na Carbonatação dos Concretos. 1999. Dissertação (Mestrado) - Escola Politécnica, Universidade de São Paulo, São Paulo, 1999.

MATHER, B. - Concrete durability. Cement \& Concrete Composites 26 (2004) 3-4.

MARTIN, J.F.M. Aditivos para concreto. In: Isaia, G.C. Concreto: ensino, pesquisa e realizações, São Paulo: Ibracon, 2005. v.1, cap. 13, p.381-406.

MEDEIROS, M.H.F.; Estruturas de concreto com corrosão de armaduras por carbonatação: comparação de argamassas de reparo quanto à proteção do aço. 2002. 193 p. Dissertação (Mestrado) Escola Politécnica, Universidade de São Paulo, São Paulo, 2002.

MEDEIROS, M.H.F., SELMO, S.M.S. Estruturas de concreto com corrosão de armaduras por carbonatação: comparação de argamassas de reparo quanto à proteção do aço. São Paulo: EPUSP, 2003. (Boletim Técnico da Escola Politécnica da USP. Departamento de Engenharia de Construção Civil, BT./PCC/344).

MEHTA, P. K. Concrete Structure, Properties and Materials. New Jersey: Prentice Hall, 1986.

MEHTA, P.K.; MONTEIRO, P.J.M. Concreto: Estrutura, Propriedades e Materiais. - São Paulo: Pini, 1994. 573p.

MEHTA, P.K.; MONTEIRO, P.J.M. Concreto: Microestrutura, Propriedades e Materiais. São Paulo: IBRACON, 2008. 674p. 
MEIRA, G.R. Agressividade por cloretos em zona de atmosfera marinha frente ao problema da corrosão em estruturas de concreto armado. 2004. 346p. Tese (Doutorado). Universidade Federal de Santa Catarina, Florianópolis, 2004.

MEIRA, G.R.; PADARATZ, I.J.; BORBA, J.C.J. Carbonatação natural de concretos: Resultados de cerca de quatro anos de monitoramento. In: XI Encontro Nacional de Tecnologia no Ambiente Construído, Florianópolis. Anais: ENTAC, 2006.

MELO NETO, A.A. Influência de aditivos redutores e compensadores de retração em argamassas e pastas com cimento de escória ativada. 2007. Tese (Doutorado). Universidade de São Paulo, São Paulo, 2007.

MEYER, A. Investigation on the carbonation of concrete. In: INTERNATIONAL SYMPOSIUM ON THE CHEMISTRY OF CEMENT, $5^{\text {th }}, 1968$. Proceedings.... (Supplementary Paper III 52). v. III, p.394-401.Tokyo, 1969.

MINDESS, S.; YOUNG, J.F. Concrete. USA: Prentice-Hall, 1981. 671p.

MONÇÃO JR, A.; PEREIRA, M.; SANTOS, J.; MONTEIRO, E.; HELENE, P.R. Análise da carbonatação ao natural com diferentes traços. In: CONGRESSO BRASILEIRO DO CONCRETO, 48, 2006, Rio de Janeiro. Anais. IBRACON, 2006.

MUNTEAN, A.; BÖHM, M. A moving - boundary problem of concrete carbonation: global existence and uniqueness of weak solutions. Journal of Mathematical Analysis and Application, v. 350, p.234-251, 2009.

NAKAO, R.; BERTOCINI, S.R.; ALMEIDA NETO, J.A. Avaliação "in loco" da profundidade de carbonatação em estruturas de concreto armado. In: CONGRESSO BRASILEIRO DO CONCRETO, 48 , 2006, Rio de Janeiro. Anais. IBRACON, 2006.

NEPOMUCENO, A.A. Comportamiento de morteros de reparacion frente a la carbonatacion y la penetracion de cloruros en estructuras de hormigon armado dañadas por corrosion de armaduras. Estúdio mediant la tecnica de resistencia de polarizacion. 1992. Tese (Doutorado). Universid Politécnica de Madrid, Instituto de Ciências de la Construcion "Eduardo Torroja" - CSIC. Madrid, 1992.

NEVILLE, A.M. Propriedades do concreto. São Paulo: Editora Pini, 1982.

NEVILLE, A.M. Propriedades do concreto. ํe ed. São Paulo: Editora Pini, 1997.

NOGUEIRA, R.P. A Corrosão do Aço em Concreto: Influência do pH e do Potencial de Eletrodo. 1989. Tese (Mestrado). Universidade Federal do Rio de Janeiro, Rio de Janeiro, 1989.

OLIVEIRA, P.A.P. Avaliação da influência do consumo de cimento na corrosão de armaduras em estruturas de concreto carbonatadas. 2002. Dissertação (Mestrado). Universidade de Brasília, Brasília, 2002.

OBLA, K. H.; LOBO, C. L. Acceptance criteria for durability tests. Concrete International. v. 29, n. 5, May 2007, p. $43-48$.

OKOCHI, H.; KAMEDA, H.; HASEGAWA, S.I.; SAITO, N.; KUBOTA, K.; IGAWA, M. Deterioration of concrete structures by acid deposition an assessment of the role of the rainwater on deterioration by laboratory and field experiments using mortar specimens. Atmospheric Environment, v.34, p.2937-2945, 2000.

OZKUL, M.H. Efficiency of accelerated curing in concrete. Cement and Concrete Research, v.3, p. 1351-1357, 2001.

PADE, C.; GUIMARÃES, M. The $\mathrm{CO}_{2}$ uptake of concrete in a 100 year perspective. Cement and Concrete Research, v. 37, p.1348-1356, 2007. 
PAPADAKIS, V.G. Effect of supplementary cementing materials on concrete resistance against carbonation and chloride ingress. Cement and Concrete Research, v. 30, n. 2, p.291-299, 2000.

PARROT, L.J. A review of carbonation in reinforced concrete. Wexham Springs, Cement and Concrete Association. 1986, 69p.

PAULETTI, C. Análise comparativa de procedimentos para ensaios acelerados de carbonatação. 2004. 176p. Dissertação (Mestrado). Universidade Federal do Rio Grande do Sul, Porto Alegre, 2004.

PAULETTI, C. Estimativa da carbonatação natural de materiais cimenticios a partir de ensaios acelerados e de modelos de predição. 2009. 233p. Tese (Doutorado). Universidade Federal do Rio Grande do Sul, Porto Alegre, 2009.

PAULETTI, C; DAL MOLIN, D; KAZMIERCZAK, C. Ensaios acelerados de carbonatação com diferentes tempos de sazonamento. In: CONGRESSO BRASILEIRO DO CONCRETO, 48, 2006, Rio de Janeiro. Anais. IBRACON, 2006.

PAULETTI, C.; POSSAN, E.; DAL MOLIN, D. Carbonatação aceleradada: estado da artedas pesquisas no Brasil. Ambiente Construído, Porto Alegre, v. 7, n. 4, p. 7-20, out./dez. 2007. ISSN 1678-8621.

PESSÔA, P.O.A. Avaliação da influência do consumo de cimento na corrosão de armaduras em estruturas de concreto carbonatadas. 2002. 153p. Dissertação (Mestrado). Universidade de Brasília, Brasília, 2002.

PETER, M.; MUNTEAN, A.; MEIER, S.; BÖHM, M. Competition of several carbonation reactions in concrete: A parametric study. Cement and Concrete Research, v.38, n. 12, p. 1385-1393, 2008.

PLEAU, R., PIGEON M., LAURENCOT J.L. Some findings on the usefulness of image analysis for determining the characteristics of the air-void system on hardened concrete. Cement and Concrete Composites v. 23, p.237-246, 2001.

POLITO, G. Corrosão em estruturas de concreto armado: causas, mecanismos, prevenção e recuperação. 2006. 191p. TCC (Especialização). Universidade Federal de Minas Gerais, Belo Horizonte, 2006.

POSSAN, E. Contribuição ao estudo da carbonatação do concreto com adição de sílica ativa em ambiente natural e acelerado. 2004. Dissertação (Mestrado). Universidade Federal do Rio Grande do Sul, Porto Alegre, 2004.

PRISZKULNIKI, S.; KIRILOS, J.P.; ABREU, J.V. Especificar ou não o consumo de cimento do concreto. In: CONGRESSO BRASILEIRO DO CONCRETO, 47, 2005, Recife. Anais: IBRACON, 2005.

RAMOS, A.W. Aplicação de controle estatístico de processo à fabricação de pequenos lotes. 1990. Dissertação (Mestrado) Escola Politécnica, Universidade de São Paulo, São Paulo, 1990.

REGATTIERI, C.E.X. Contribuição ao estudo da influência da dosagem do concreto na absorção capilar e penetração de íons cloreto. 1998. Dissertação (Mestrado). Escola Politécnica, Universidade de São Paulo, São Paulo, 1998.

RODRIGUES, J. Carbonatação. O inimigo esquecido do concreto. Revista recuperar. v. 25, Rio de Janeiro: Ed. Thomastec, 1998.

RODRIGUES, J. E a recuperação do concreto da edificação? Revista recuperar. v. 64, p. 12-17, Rio de Janeiro: Ed. Thomastec, 2005.

ROY, S.K.; POH, K.B.; NORTHWOOD, D.O. Durability of concrete-accelerated carbonation and weathering studies. Building and Environment, v.34, p.597-606, 1999. 
RUIZ, L.A.; PLATRET, G.; MASSIEU, E.; EHRLACHER, A. The Use of Thermal Analysis in Assessing the Effect of Temperature on Cement Paste. Cement and Concrete Research. p. $609-613,2004$.

SAETTA A.V.; VITALIANI, R.V. Investigation and numerical modeling of carbonation process in reinforced concrete structures. Part I: Theorical formulation. Cement and Concrete Research, v. 34, p. 571-579, 2004.

SAETTA A.V.; VITALIANI, R.V. Investigation and numerical modeling of carbonation process in reinforced concrete structures. Part I: Practical applications. Cement and Concrete Research, v. 35, p. 958-967, 2005.

SATO, N.M.N. Análise da porosidade e de propriedades de transporte de massa em concretos. 1998. 163 p. Tese (Doutorado) - Escola Politécnica, Universidade de São Paulo, São Paulo, 1998.

SCHOLZ, S.; SEIDLER, P.; JACOSKI, C. Procedimentos para ensaios de concreto fresco: um comparartivo entre técnicas utilizadas no Brasil e Alemanha. Chapecó: Argos, 2008. 55p.

SELMO, S.M.S. Aço carbono em pastas de gesso de construção: estimativas de taxas de corrosão por impedância e por método gravimétrico conjugado à análise de imagem. 1997. Dissertação (Mestrado). Escola Politécnica, Universidade de São Paulo, São Paulo, 1997.

SELMO, S.M.S.; BUONAPANE, R.S.B.; RIBEIRO, J.L.S.; MEDEIROS, M.H.F.; GALENI, P.C.; SILVA, T. F. Contribution to the macro and microstructure analysis of repair mortars for corroded reinforced concrete structures. In: International Essen Workshop Transport in Concrete: Nano-to Macrostructure, 5ํㅜ, TRANSCON 07, 2007, Essen. Proceedings..... Freiburg : Aedificatio Publishers, 2007. p. 241-250.

SILVA, P.F.A.. Durabilidade das estruturas de concreto aparente em atmosfera urbana. 1ํ ed. São Paulo: Editora Pini - Serrana, 1995 152p.

SILVA, P.F. Concreto Projetado para Túneis - São Paulo, PINI, 1997.

SILVA, V.M. Ação da carbonatação em vigas de concreto armado em serviço, construídas em escala natural e reduzida. 2007. Tese (Doutorado). Universidade de São Carlos, São Carlos, 2007.

SILVA, V.M.C.; LIBÓRIO, J.B.L. Comportamento da frente de carbonatação em elementos estruturais e suas conseqüências. In: CONGRESSO BRASILEIRO DO CONCRETO, 49ª 2007, Bento Gonçalves. Anais: IBRACON, 2007.

SIMAS, M.S.L. Sistemas de protecção do betão face à carbonatação. 2007. 81p. Dissertação (Mestrado). Universidade Técnica de Lisboa, Lisboa, 2007.

SONG, H.W.; KWON, S.J. Permeability characteristics of carbonated concrete considering capillary pore structure. Cement and Concrete Research, v. 37, p.909-915, 2007.

STEFFENS, A.; DINKLER, D.; AHRENS, H. Modeling carbonation for corrosion risk prediction of concrete structures. Cement and Concrete Research, v. 32, p.935-941, 2002.

TANGO, C.E.S. Contribuição ao estudo da previsão de resistência à compressão de cimentos e concretos. 1983. 462 p. Dissertação (Mestrado). Escola Politécnica, Universidade de São Paulo, São Paulo, 1983.

THIÉRY, M. Modélisation de la carbonatation atmosphérique des bétons - Prose en compte des effects cinétiques et de létat hydrique. Thèse (Doctorat). École Nationale des Ponts et Chaussées, Paris, 2005.

THIÉRY, M.; BAROGHEL-BOUNY, V.; CRÉMONA, C. An engineering approach to the problem of natural carbonation accompanied by drying-wetting cycles. In: INTERNATIONAL 
RILEM SYMPOSIUM ON CONCRETE MODELING, 2008. Proceedings... Netherlands: CONMOD, 2008. p.265-273.

THOMAZ, E. Requisitos técnicos e operacionais visando a qualidade na construção de edificios. 1999. Tese (Doutorado) - Escola Politécnica, Universidade de São Paulo, São Paulo, 1999.

TOKYAY, M. Strength prediction of fly ash concretes by accelerated testing. Cement and Concrete Research, v. 29, p.1737-1741, 1999.

UEMOTO, T; TAKADA, Y. Factors affecting concrete carbonation rate. Durability of Building Materials and Components. v.6, 1993.

VIEIRA, D.V; PELISSER, F. Influência do processo de carbonatação em concretos com diferentes tipos de cimento e classes de resistência comparados a um estudo de caso de uma estrutura de concreto de uma edificação com 23 anos. In: CONGRESSO BRASILEIRO DO CONCRETO, 49, 2007, Bento Gonçalves. Anais: IBRACON, 2007.

VIANA, M.M. Materiais porosos. 2004. 33p. Monografia de licenciatura. Universidade Federal de Minas Gerais, Belo Horizonte, 2004. 


\section{APÊNDICES}


APÊNDICE A - CARACTERIZAÇÃO DOS MATERIAIS COLETADOS NAS CENTRAIS DOSADORAS DE CONCRETO

A seguir estão apresentadas as características dos materiais utilizados na produção dos concretos, segundo informações da central dosadora de concreto. 


\subsection{Areia de quartzo}

\begin{tabular}{|c|c|c|c|c|c|c|}
\hline & & & \\
\hline
\end{tabular}




\subsection{Areia de brita}

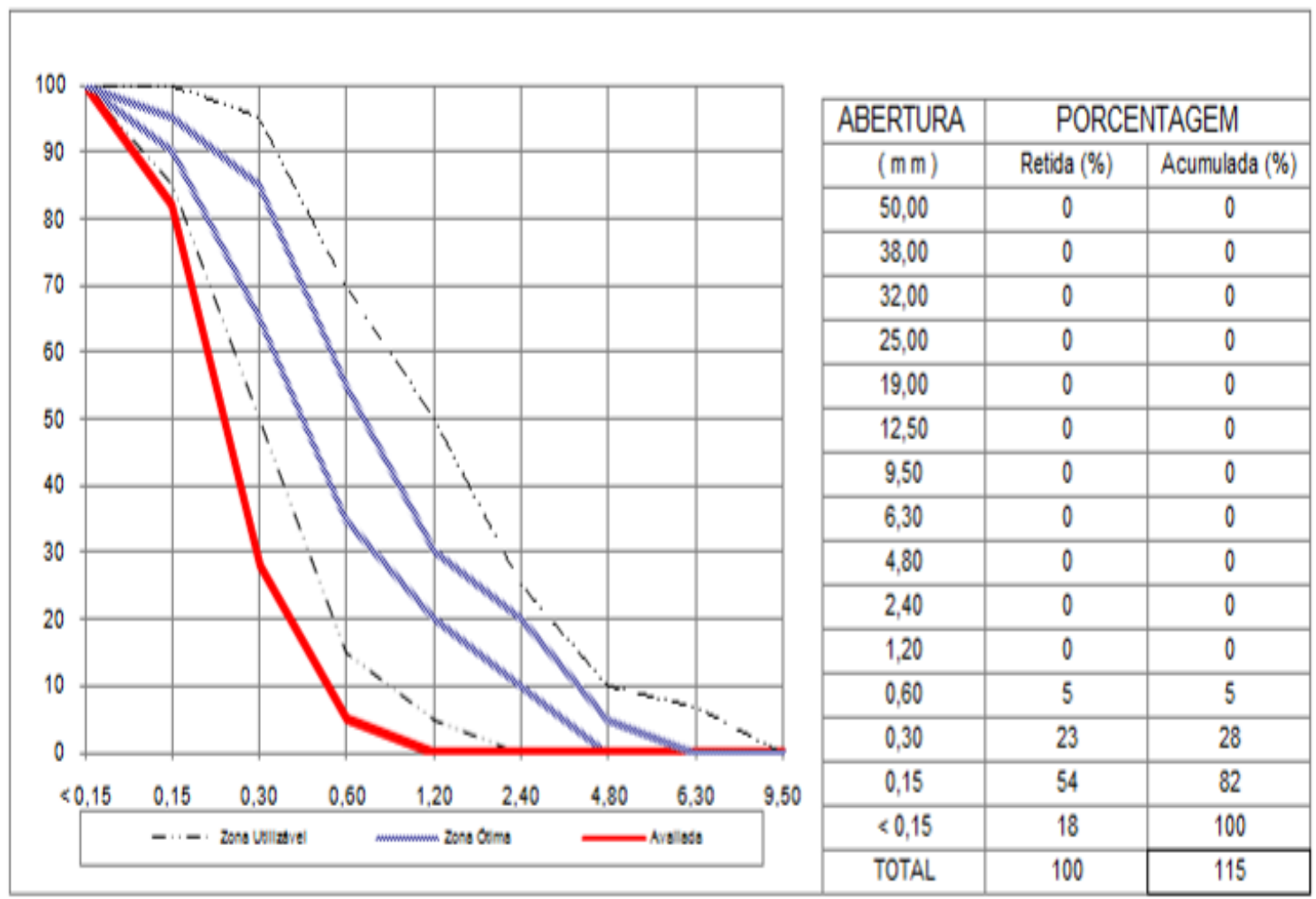

\begin{tabular}{|c|c|c|c|c|c|}
\hline & Caracteristicas do Material & Unidade & Obtidas & Especificadas & Metodologia de Ensaio \\
\hline 2 & - Módulo de finura & $(\%)$ & 1,14 & $1,35 \cdot 1,70$ & NBR - NM 248 \\
\hline 3 & - Dimensão Máxima & $\mathrm{mm}$ & 0,60 & $1,20-4,80$ & NBR - NM 248 \\
\hline 4 & - Massa Especifica & $\mathrm{g} / \mathrm{cm}^{3}$ & 2,63 & $2,60 \cdot 2,70$ & NBR-NM 052 \\
\hline 5 & - Massa Especifica Aparente & $\mathrm{g} / \mathrm{cm}^{2}$ & 2,65 & - & NBR - NM 052 \\
\hline 6 & - Massa Esp. Saturada Superf. Seca & $\mathrm{g} / \mathrm{cm}^{2}$ & 2,66 & - & NBR - NM 052 \\
\hline 7 & - Massa Unitária & $\mathrm{Kg} / \mathrm{dm}^{3}$ & 1,25 & $1,35 \cdot 1,65$ & NBR $\cdot 7251$ \\
\hline 8 & - Material Pulverulento & $(\%)$ & 1,9 & $\leq 3,0$ & NBR NM - 46 \\
\hline
\end{tabular}




\subsection{Brita 0}

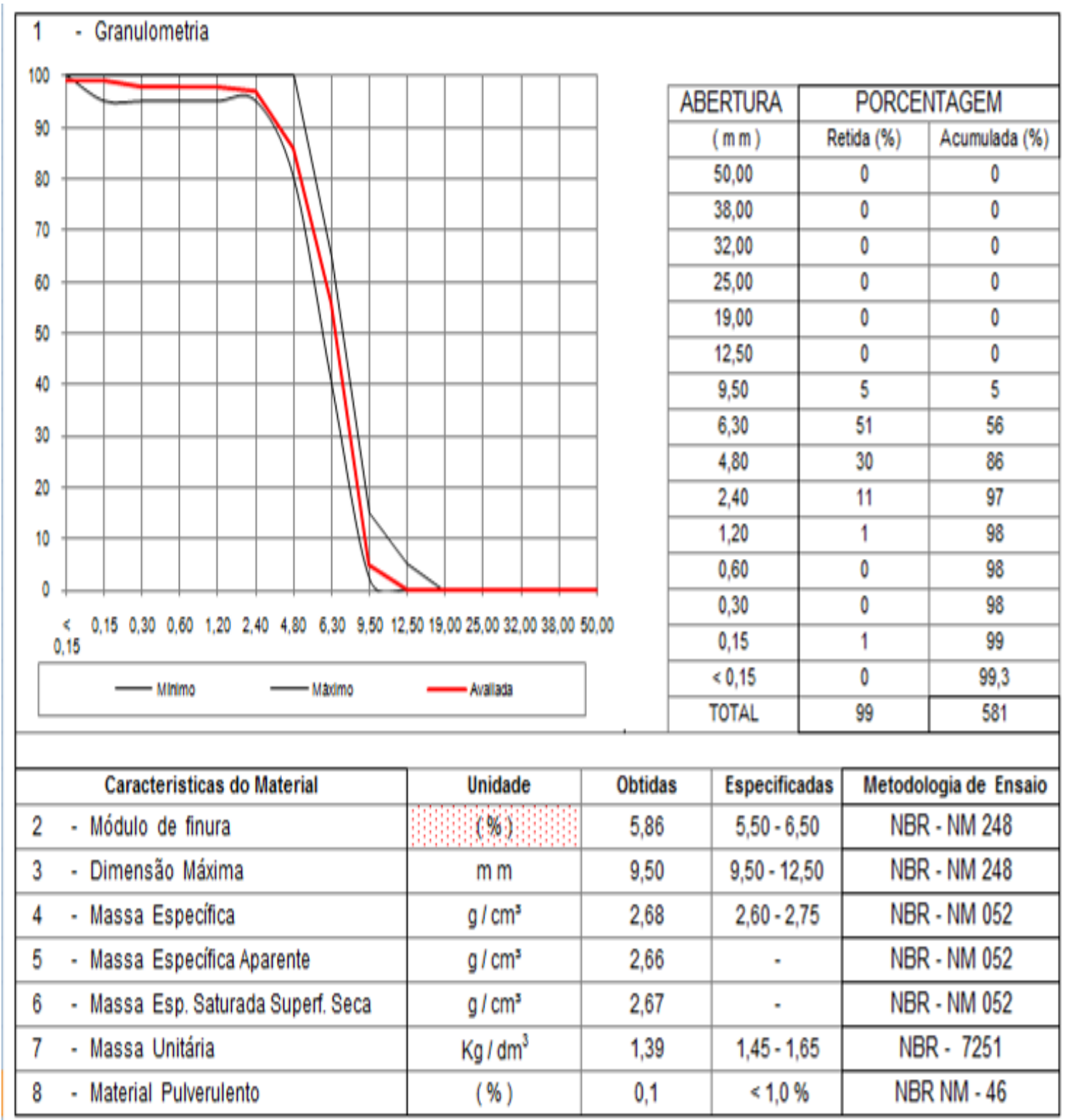




\subsection{Brita 1}

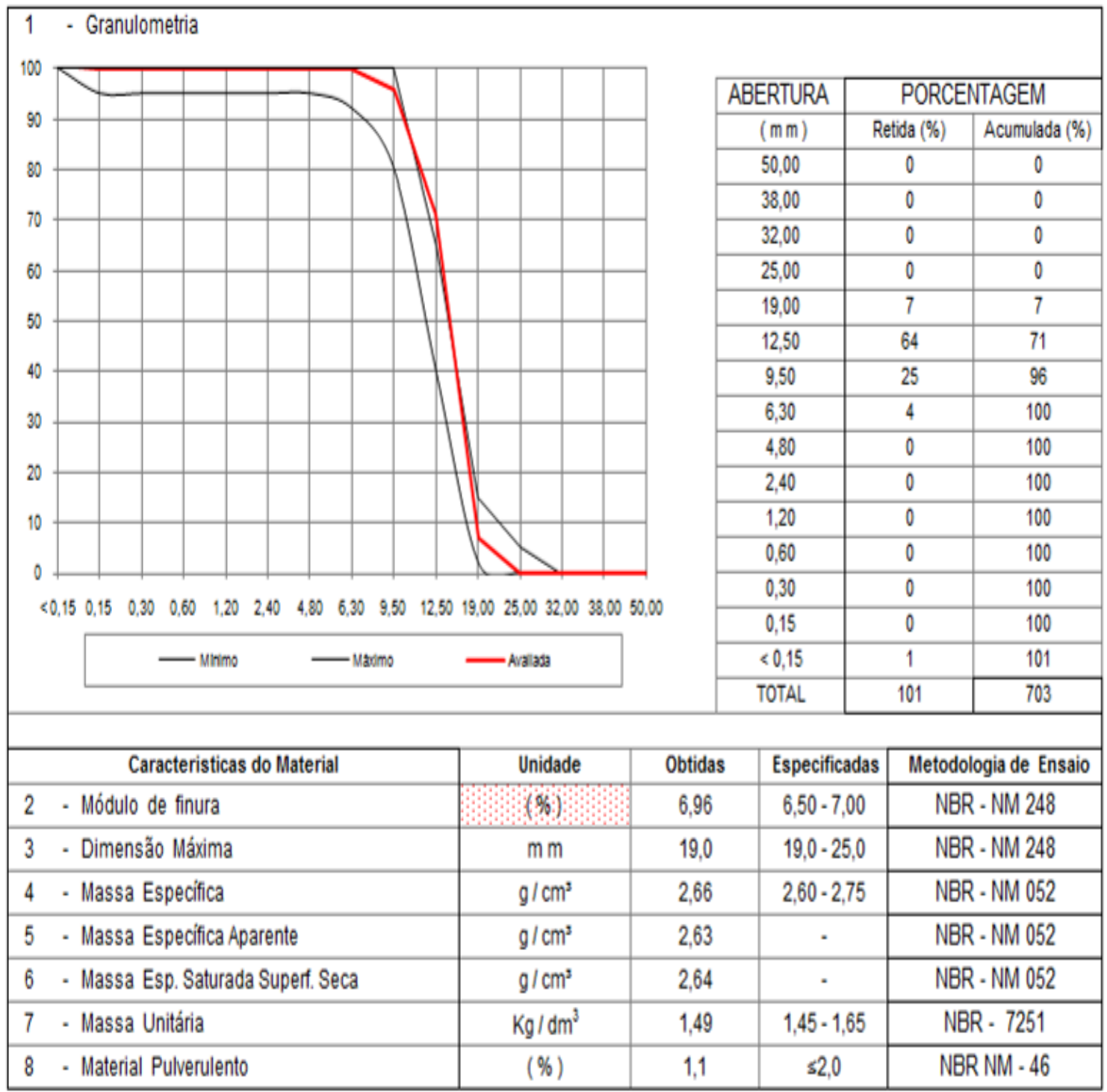

1.5 Cimento CP II E 40 


\begin{tabular}{|c|c|c|c|c|c|c|c|c|c|c|c|c|c|c|c|c|c|c|c|}
\hline \multirow{3}{*}{$\begin{array}{l}\text { Lumies } \\
\text { da Norma }\end{array}$} & \multicolumn{7}{|c|}{ ENSANOS QUIMICOS } & \multicolumn{12}{|c|}{ ENSANOS FISICOS E MECÃNICOS } \\
\hline & \multicolumn{7}{|c|}{ TEORES (\$/) } & \multicolumn{4}{|c|}{ Resist.a compreesac(MPa) } & \multicolumn{3}{|c|}{ Finura(46) } & \multirow{2}{*}{$\begin{array}{l}\text { Blalne } \\
\geq \geq 2800 \\
\end{array}$} & \multirow{2}{*}{$\begin{array}{l}\text { Agus do } \\
\text { Nollos } \\
\text { Aclosvel }\end{array}$} & \multicolumn{2}{|c|}{ Tempo Poga(h:min) } & \multirow{2}{*}{$\begin{array}{c}\text { Exp. Quvent } \\
\leq 5,0\end{array}$} \\
\hline & $\leq 6,5$ & $\leq 6,5$ & $\leq 40$ & $\leq 5,0$ & $\leq 2,5$ & 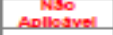 & Aollostrol & Aoliosturel & $\geq 15,0$ & $\geq 25,0$ & $\geq 40,0$ & $\leq 10,0$ & 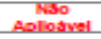 & 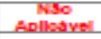 & & & $\geq 1$ & $\leq 10$ & \\
\hline & PF & Mgo & sos & $\mathrm{cos}$ & F & Eq Aloalino & CaO Lvro & 1 Diss & 3 Dlas & 7 Dlas & 28 Di3s & \pm 200 & \pm 25 & $\$ 400$ & cmerg & Conc. (20) & INICIO & FIM & $(\mathrm{mm})$ \\
\hline 01/08/09 & 4,03 & 5,47 & 2,99 & 3,70 & 1,03 & & & & 27,60 & 35,40 & 47,10 & 0,30 & & 7,60 & 4230 & 29,00 & $2: 45$ & 3:55 & \\
\hline \multicolumn{20}{|l|}{$02,08 / 09$} \\
\hline 03/08/09 & 4.25 & 5,50 & 2.95 & 3,15 & 0,98 & & & & 27,70 & 35,80 & 47,50 & 0.20 & & 6,00 & 4489 & 28,30 & $2: 45$ & 4:05 & $0, \infty$ \\
\hline $04 / 08 / 09$ & 4,45 & 5,33 & 2,85 & 4,12 & 1,10 & & & & 27,60 & 35,50 & 44,50 & 0,30 & & 5,80 & 4452 & 28,00 & 3.05 & $4: 20$ & \\
\hline $05 / 08 / 09$ & 1,51 & 5,53 & 3,17 & 4,49 & 1,09 & & & & 28,00 & 36,00 & 45,30 & 0,08 & & 4,60 & 4462 & 28,80 & $2: 45$ & 3:55 & $0, \infty$ \\
\hline $06 / 08 / 09$ & 4,65 & 5,62 & 3,15 & 4,85 & 0,84 & & & & 27,80 & 35,20 & 44,80 & 0,40 & & 6.20 & 4387 & 28,60 & $2: 50$ & 4:00 & \\
\hline 07/08/09 & 5,50 & 5,41 & 3,00 & 4,55 & 0,97 & & & & 27,50 & $35, \infty 0$ & 45,00 & 0,40 & & 6.20 & 4225 & 28,60 & 3.00 & 4:10 & $0, \infty$ \\
\hline $08 / 08 / 09$ & 4,00 & 5,51 & 2.94 & 3,12 & 1,10 & & & & 27,90 & 34,80 & 44,50 & 0,40 & & 6.20 & 4269 & 28,60 & $2: 50$ & 4:00 & \\
\hline \multicolumn{20}{|l|}{$09 / 08 / 09$} \\
\hline $10108 / 09$ & 4,56 & 5,39 & 3,08 & 4,87 & 0,82 & & & & 28,00 & 35,80 & 45,60 & 0,30 & & 6,80 & 4126 & 28,86 & 2.45 & 3.55 & $0, \infty$ \\
\hline $11 / 08 / 09$ & 4,56 & 5,94 & 3,15 & 4,17 & 1,02 & & & & 28,00 & 35,50 & 45,20 & 0,30 & & 7,60 & 4462 & 28,70 & 2.55 & $3: 55$ & \\
\hline $12 / 08 / 09$ & 4,97 & 5,41 & 2,84 & 4.25 & 1,13 & & & & 27,70 & $36, \infty 0$ & 47,10 & 0,30 & & 6.50 & 4043 & 28,60 & 3.00 & 4:05 & $0, \infty$ \\
\hline $13 / 08 / 09$ & 4,21 & 5,64 & 2,97 & 2.21 & 1,13 & & & & 27,30 & 35,80 & 47,40 & 0,30 & & 7,00 & 4457 & 28,70 & $2: 50$ & 4:00 & \\
\hline $14 / 08 / 09$ & 5,65 & 5,78 & 2,98 & 5,00 & 0,84 & & & & 27,50 & 35,10 & 46,70 & 0,30 & & 7,00 & 4312 & 28,70 & 3.00 & 4:10 & $0, \infty$ \\
\hline $15 / 08 / 09$ & 4,67 & 5,70 & 3,02 & 4,62 & 1,05 & & & & 27,90 & 35,90 & 46,50 & 0,30 & & 7,00 & 4259 & 28,70 & 3.05 & 4:10 & \\
\hline \multicolumn{20}{|l|}{$16 / 08 / 09$} \\
\hline $17 / 08 / 09$ & 4.25 & 5,76 & 2,91 & 3,68 & 1,07 & & & & 27,60 & 35,60 & 46,30 & 0.30 & & 7,30 & 4253 & 28,90 & $2: 40$ & 4:00 & $0, \infty$ \\
\hline $18 / 08 / 09$ & 6,35 & 5,53 & 3.17 & 4,49 & 1,29 & & & & 27,80 & 35,80 & 44,50 & 0,08 & & 4,60 & 4425 & 28,80 & $2: 45$ & $3: 50$ & \\
\hline $19 / 08 / 09$ & 5,65 & 5,78 & 2,98 & 3,56 & 0,84 & & & & 27,10 & 35,80 & 46,50 & 0,30 & & 7,70 & 4312 & 28.26 & $2: 45$ & 4:05 & $0, \infty$ \\
\hline $20108 / 09$ & 4,78 & 5,37 & 2,85 & 3,16 & 0,65 & & & & 28,00 & $36, \infty 0$ & 45,80 & 0,30 & & 6,00 & 4212 & 28,00 & 3.00 & 4:10 & \\
\hline $21,08 / 09$ & 4,89 & 5,49 & 2,86 & 2.68 & 1,02 & & & & 27,30 & 35,70 & 46,30 & 0,30 & & 6,00 & 4383 & 28,00 & $2: 50$ & $4: 00$ & $0, \infty$ \\
\hline $2208 / 09$ & 4,48 & 5,57 & 2.92 & 2.75 & 1,07 & & & & 27,80 & 35,90 & 46,70 & 0,30 & & 6,00 & 4415 & 28,00 & $2: 45$ & $3: 55$ & \\
\hline $23108 / 09$ & & & & & & & & & & & & & & & & & & & $0, \infty$ \\
\hline $24 / 08 / 09$ & 4,67 & 5,54 & 2,64 & 3,40 & 0,99 & & & & 26,60 & 35,60 & 46,50 & 0,30 & & 6,40 & 4325 & 28.20 & $2: 40$ & 4:00 & $0, \infty$ \\
\hline $25 / 08 / 09$ & 4.56 & 5,39 & 3.08 & 4,87 & 0,82 & & & & 26,40 & 35,80 & 46,90 & 0,30 & & 7,10 & 4126 & 28,10 & $2: 45$ & 4:05 & \\
\hline $26 / 08 / 09$ & 4.21 & 5,64 & 2.97 & 2.21 & 1,13 & & & & 27,70 & 35,20 & 46,30 & 0,30 & & 7,30 & 4457 & 28,06 & $2: 55$ & $4: 20$ & $0, \infty$ \\
\hline $27 / 08 / 09$ & 5,75 & 5,63 & 2,66 & 3,48 & 1,09 & & & & 26,60 & 35,60 & 44,80 & 0,30 & & 7,00 & 4402 & 28,00 & $2: 45$ & 3.55 & \\
\hline $28 / 08 / 09$ & 4,52 & 5,65 & 2,70 & 2.92 & 1,11 & & & & 26,00 & 34,80 & 44,50 & 0,30 & & 7,00 & 4212 & 28,00 & 3.00 & 4:05 & $0, \infty$ \\
\hline $29108 / 09$ & 4,98 & 5,58 & 2,68 & $5, \infty 0$ & 1,14 & & & & 26,30 & 34,60 & 45,10 & 0,30 & & 7.00 & 4169 & 28,00 & $2: 45$ & $3: 50$ & \\
\hline \multicolumn{20}{|l|}{$30 / 08 / 09$} \\
\hline $31 / 08 / 09$ & 4,78 & 5,50 & 3,04 & 4,63 & 1,14 & & & & 26,90 & 35,90 & 46,70 & 0,30 & & 6,00 & 4326 & 28.20 & $2: 45$ & $3: 45$ & $0, \infty$ \\
\hline & & & & & & & & & & & & & & & & & & & \\
\hline Medla & 4.65 & 556 & 295 & 3.84 & 1,02 & - & - & - & 274 & 35.5 & 459 & 0.3 & & 6.5 & 4315 & 28.4 & $2: 50$ & $4: 01$ & - \\
\hline D.Padrao & 0,86 & 0,15 & 0,15 & 0,88 & 0,14 & . & - & - & 0.59 & 0.41 & 1,00 & 0,07 & - & 0,81 & 124,05 & 0,35 & 0.01 & 0,01 & - \\
\hline Coet.var. & 18,50 & 2,70 & 5,09 & 22,90 & 13,76 & - & - & - & 2,15 & 1,15 & 2,18 & 24,07 & - & 12,40 & 2,87 & 1,23 & 8.44 & 5,96 & - \\
\hline Minimo & 1,51 & 5,33 & 2,64 & 2,21 & 0.65 & - & - & - & 26,0 & 34,6 & 44.5 & 0.1 & - & 4,6 & 4043 & 28,0 & $2: 40$ & 3:45 & - \\
\hline Maximo & 6,35 & 5,94 & 3.17 & 5,00 & 1,29 & - & - & - & 28,0 & 36,0 & 47,5 & 0,4 & - & 7.7 & 4489 & 29,0 & $3: 05$ & 4:20 & - \\
\hline
\end{tabular}


1.6 Resultados dos ensaios de calorimetria do cimento sem e com aditivo

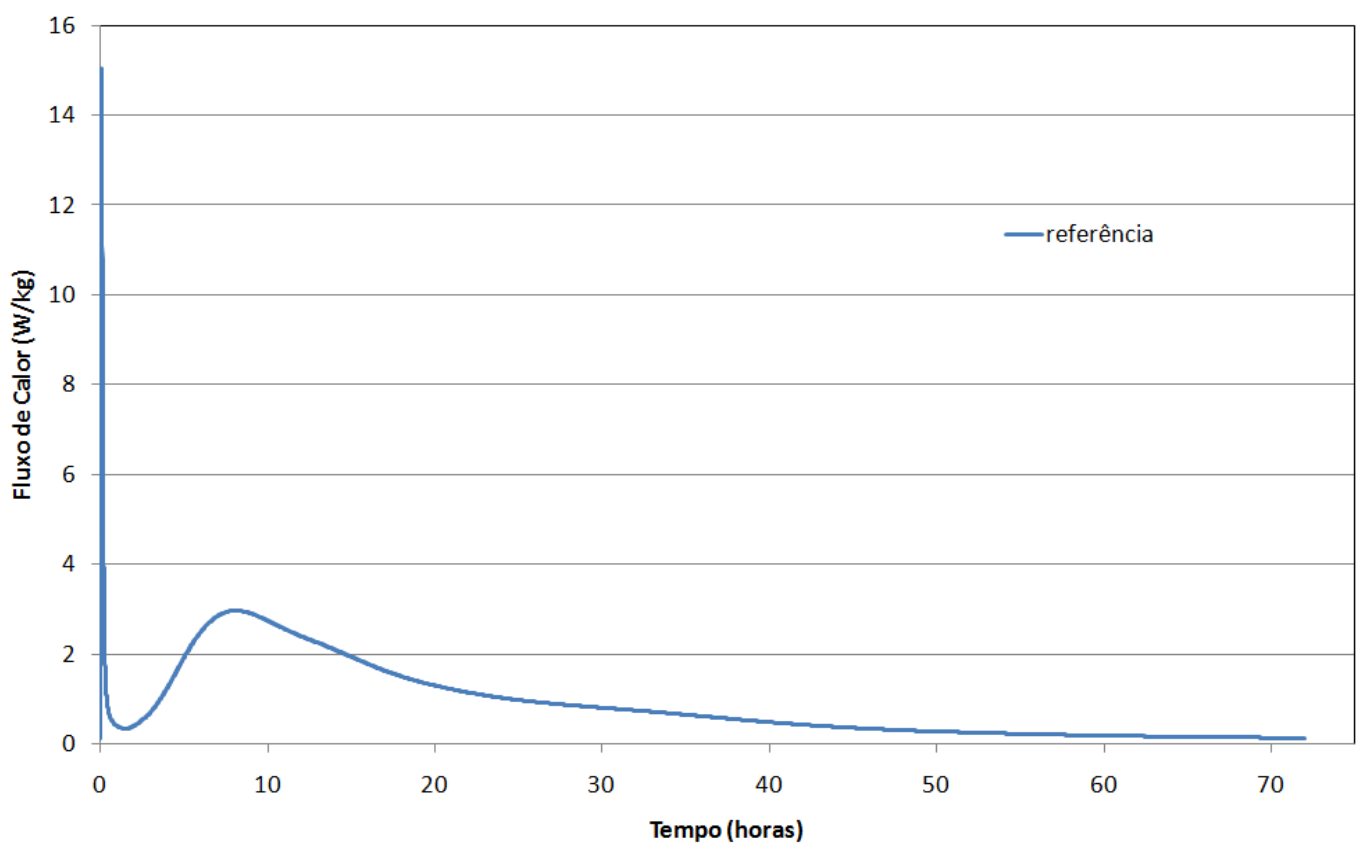

FIGURA 129 - Calorimetria da pasta de cimento.

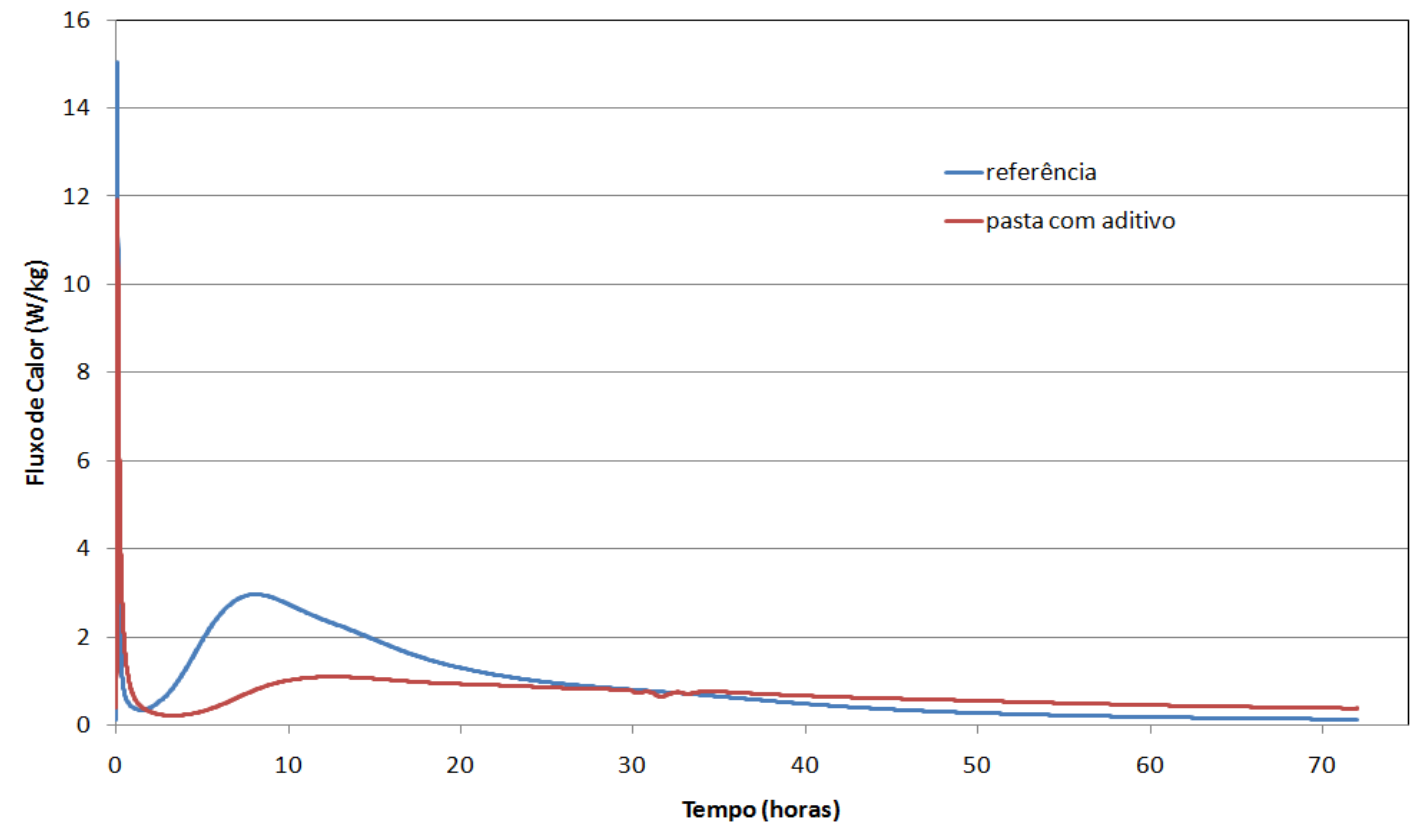

FIGURA 130 - Calorimetria da pasta de cimento com e sem aditivo. 


\section{APÊNDICE B - RESULTADOS COMPLETOS DE ENSAIOS}

A seguir estão apresentadas as figuras e tabelas com resultados completos dos ensaios realizados. 

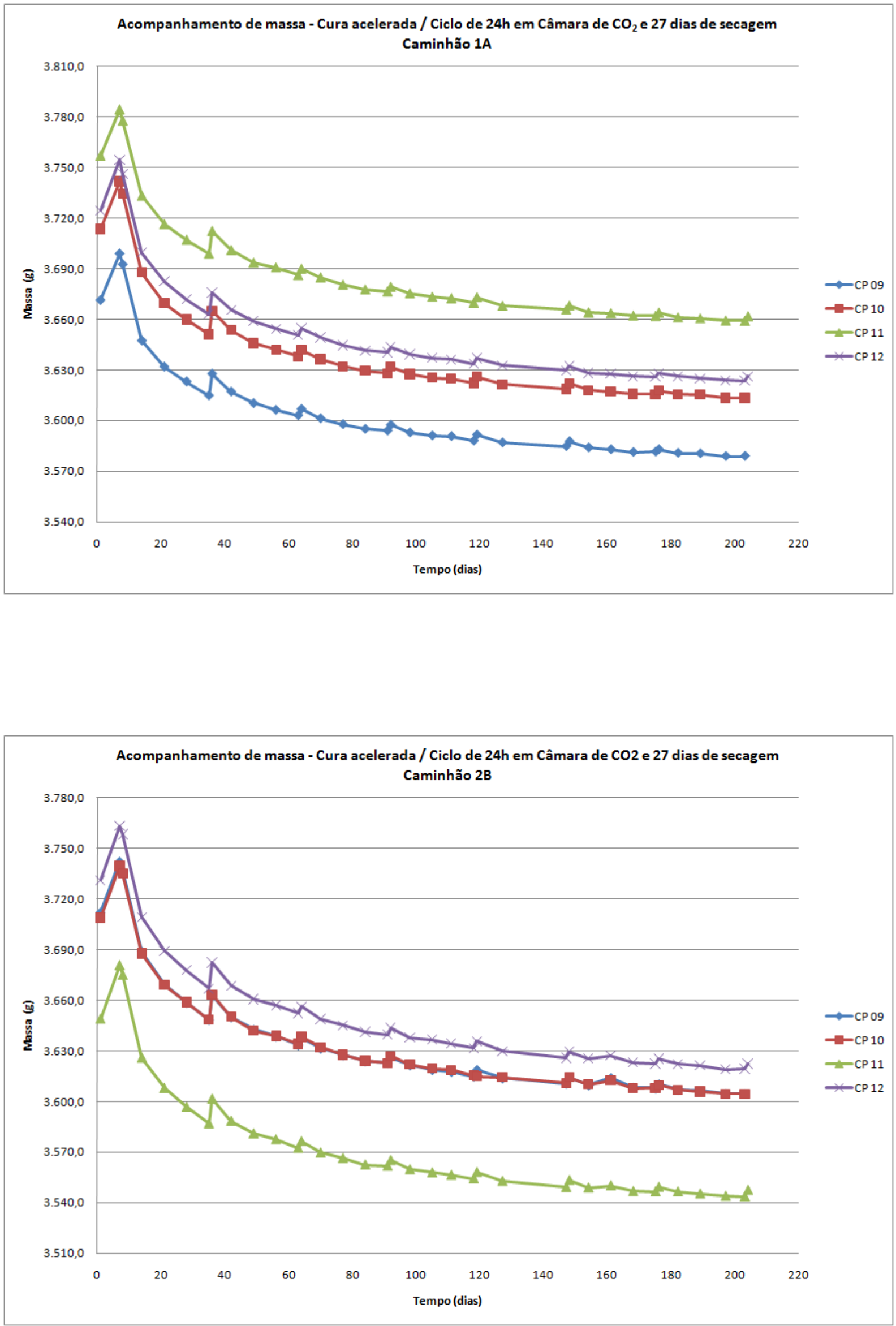

FIGURA 131 - Controle de massa dos corpos-de-prova 9, 10, 11 e 12 (AE1) das misturas C1 A e C2B. 

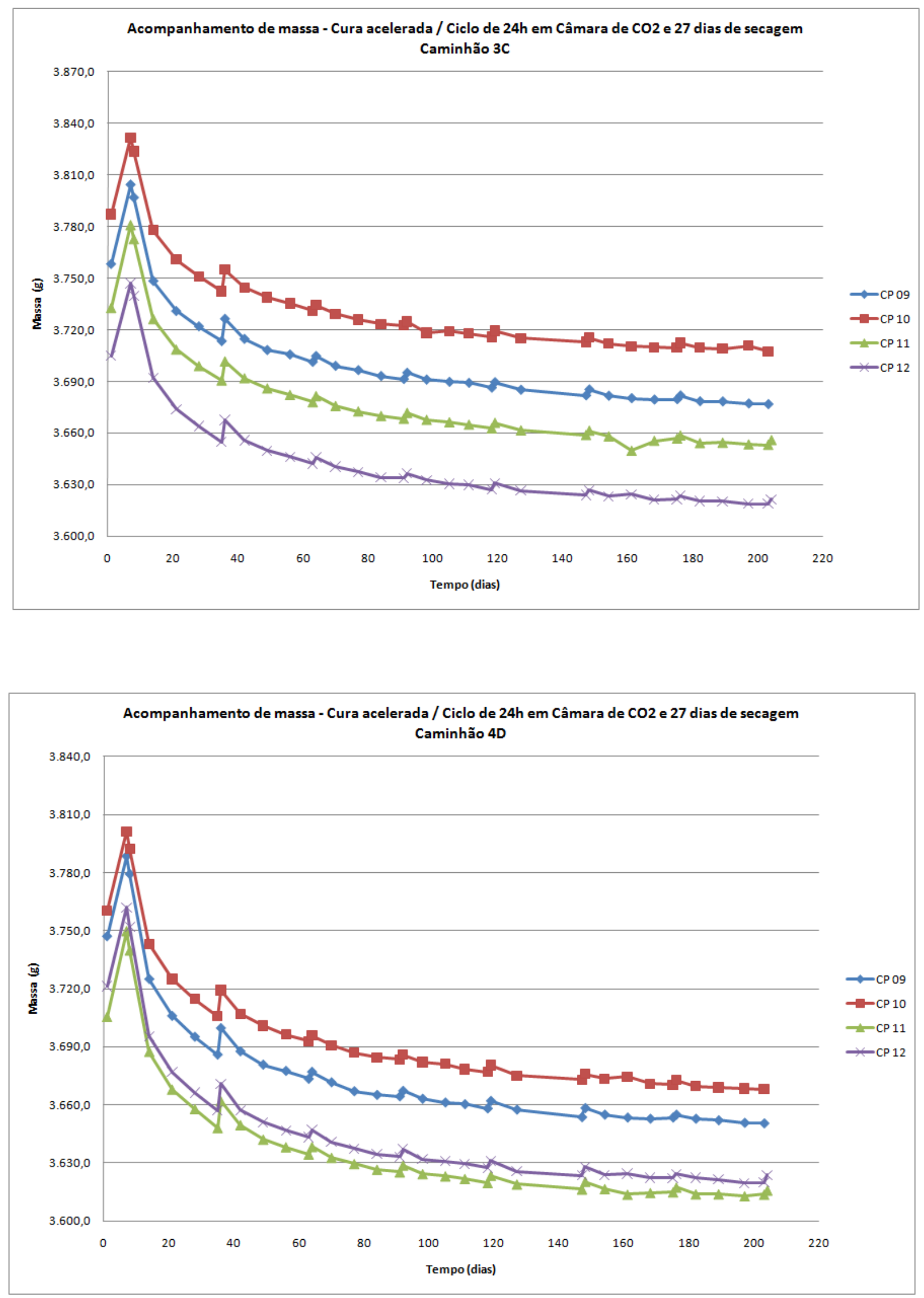

FIGURA 132 - Controle de massa dos corpos-de-prova 9, 10, 11 e 12 (AE1) e das misturas C3C e C4D. 

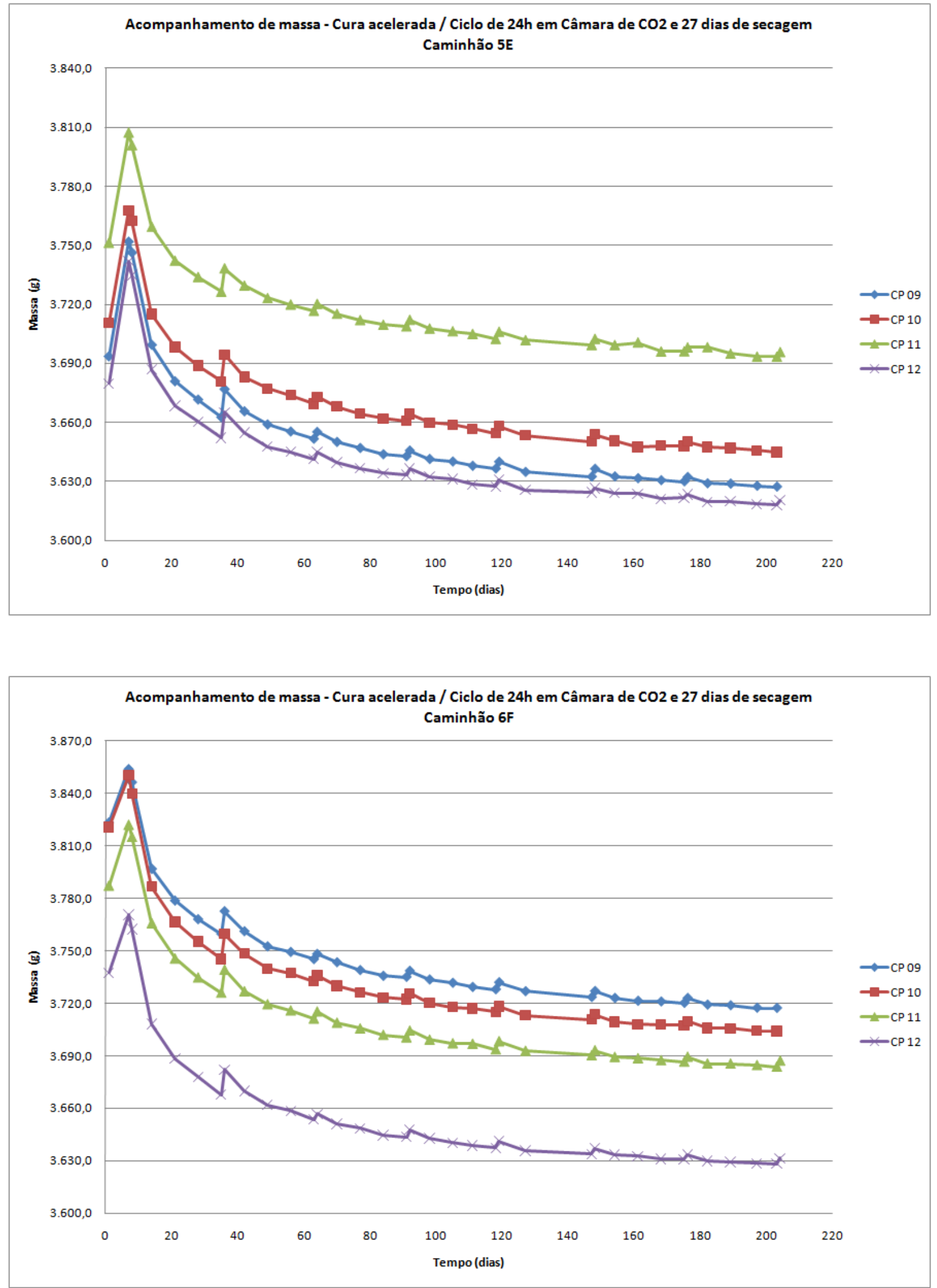

FIGURA 133 - Controle de massa dos corpos-de-prova 9, 10, 11 e 12 (AE1) e das misturas C5E e C6F. 

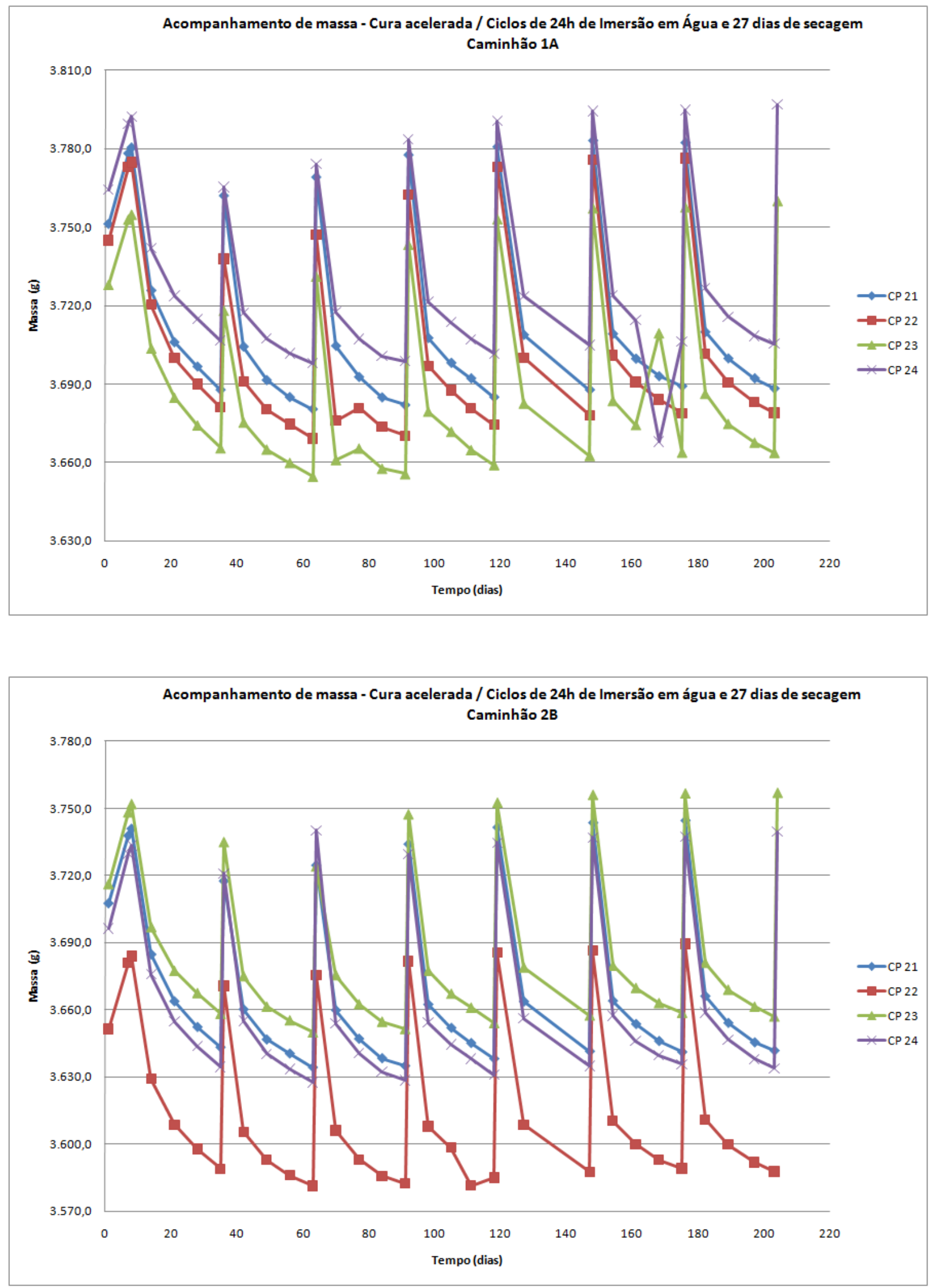

FIGURA 134 - Controle de massa de corpos-de-prova21, 22, 23 e 24 (AE2) das misturas C1A e C2B. 

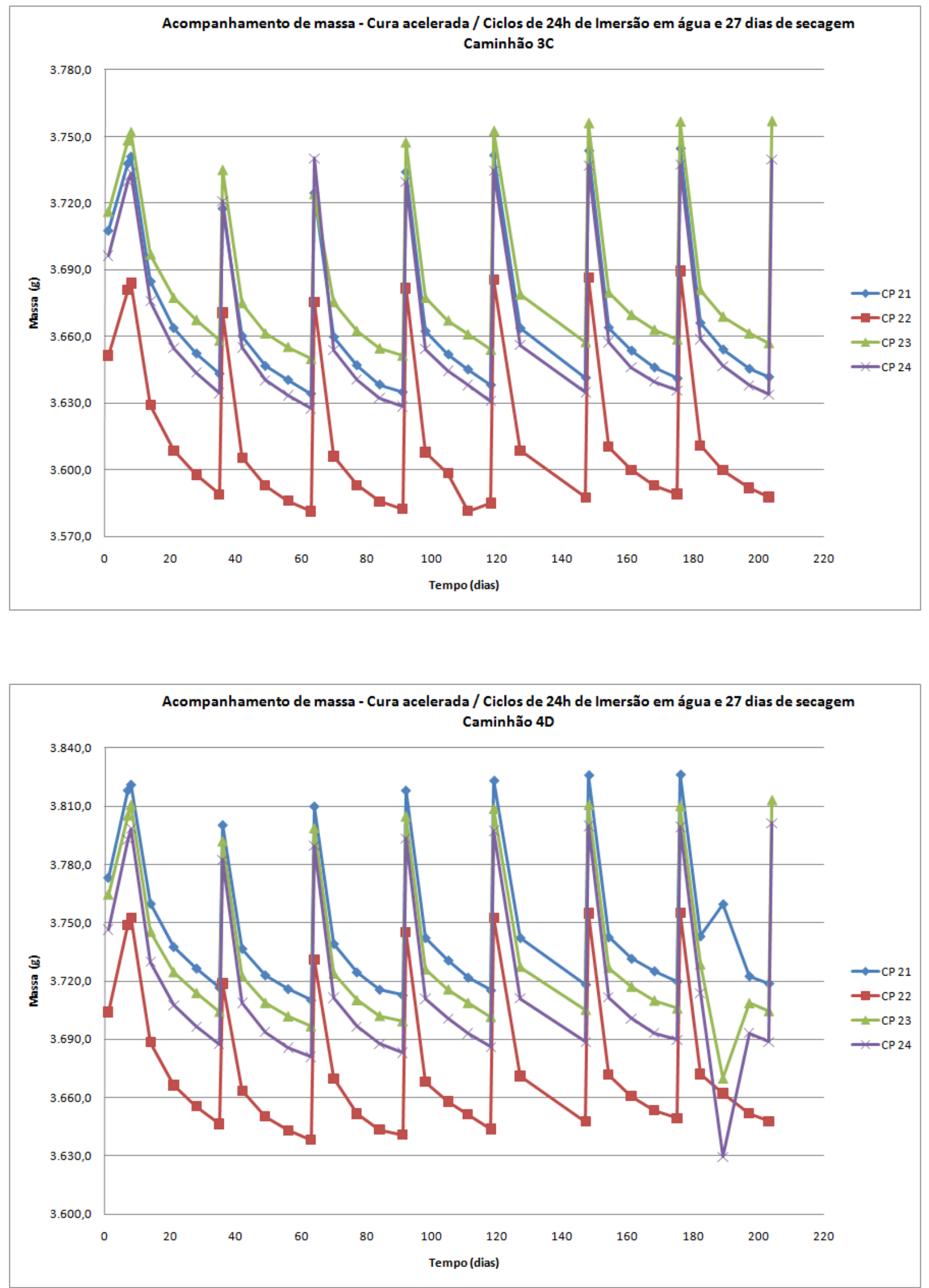

FIGURA 135 - Controle de massa de corpos-de-prova 21, 22, 23 e 24 (AE2) das misturas C3C e C4D. 

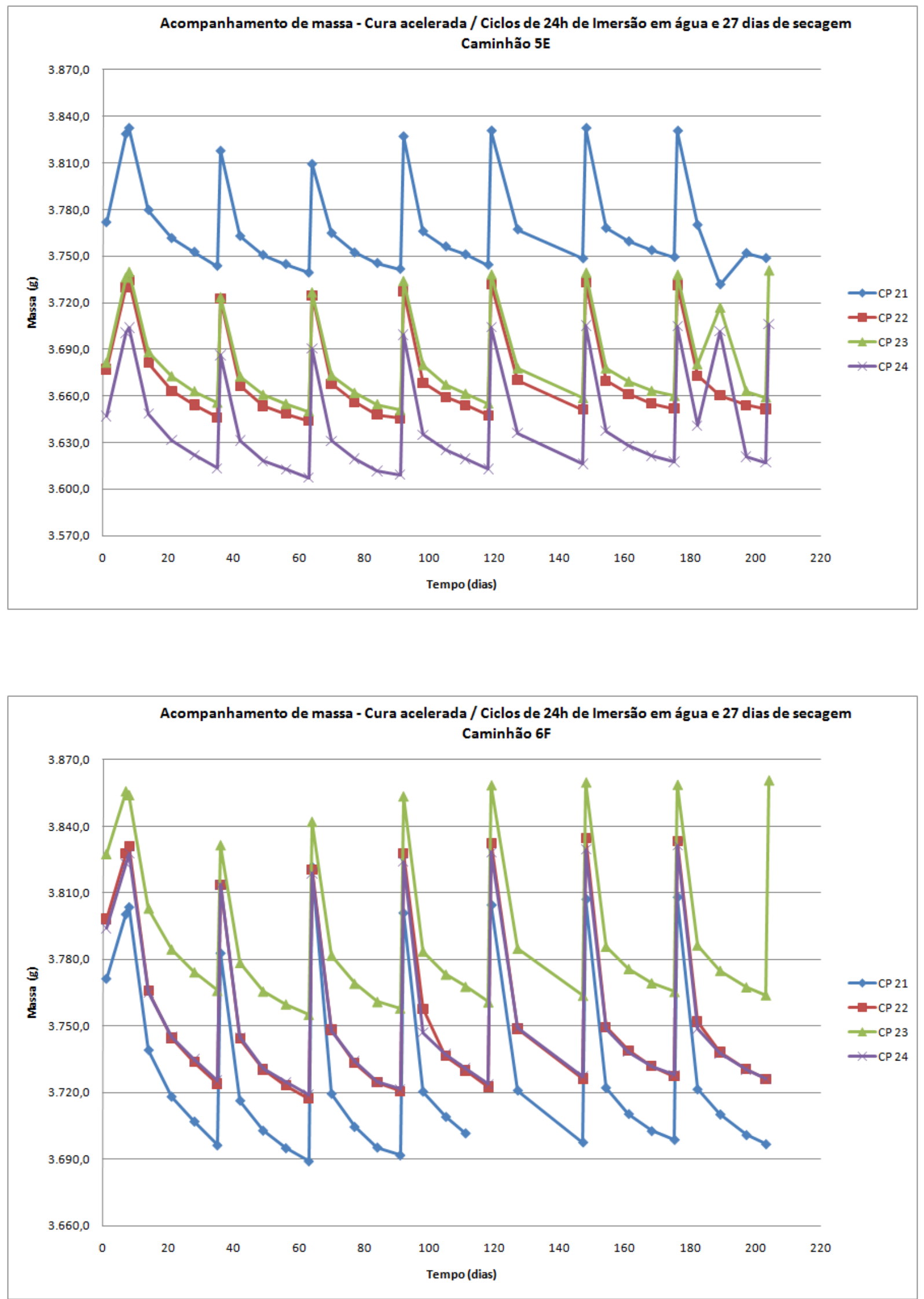

FIGURA 136 - Controle de massa de corpos-de-prova 21, 22, 23 e 24 (AE2) das misturas C5E e C6F. 

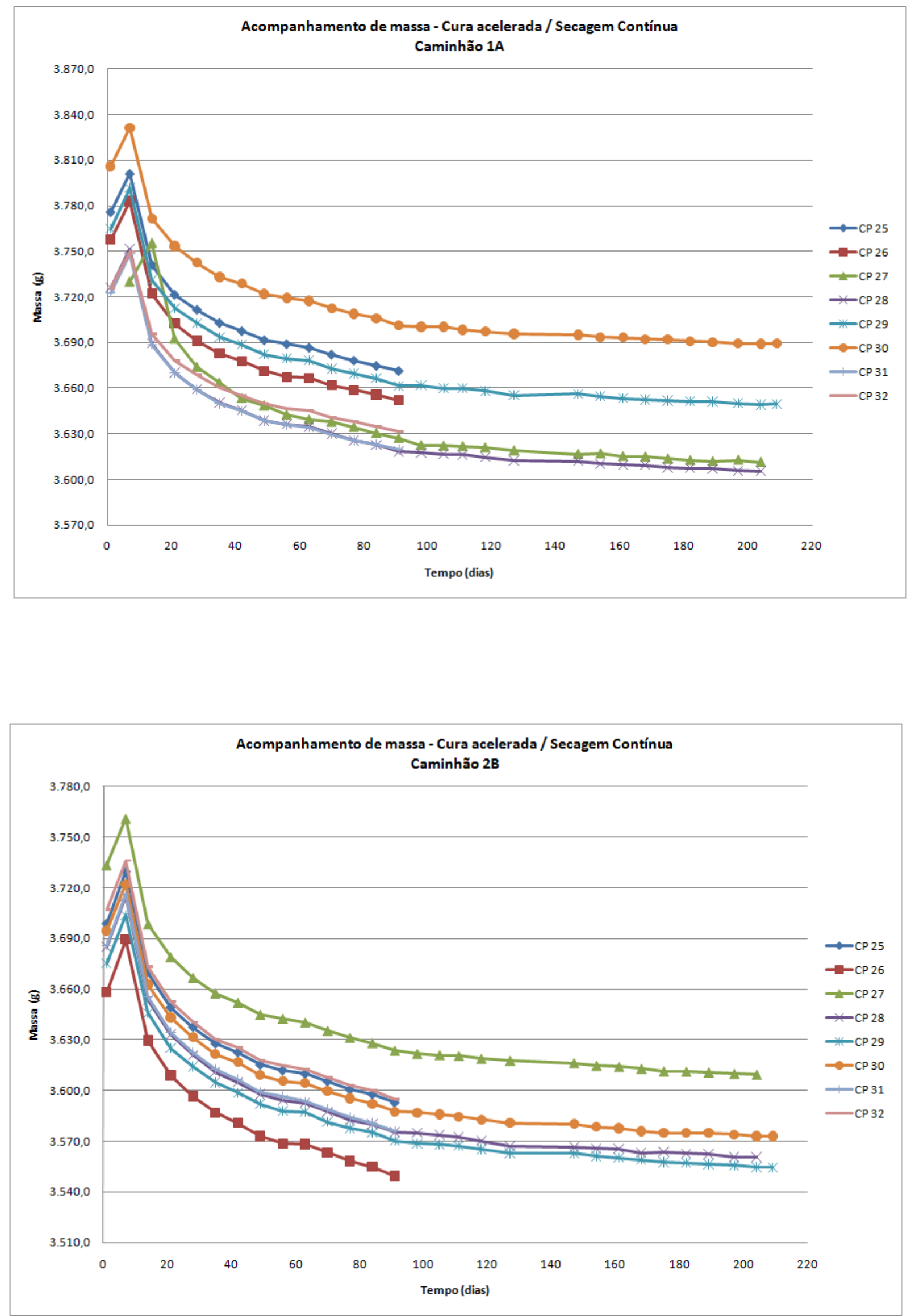

FIGURA 137 - Controle de massa de corpos-de-prova 25 a 32 (AE3) das misturas C1A e C2B. 

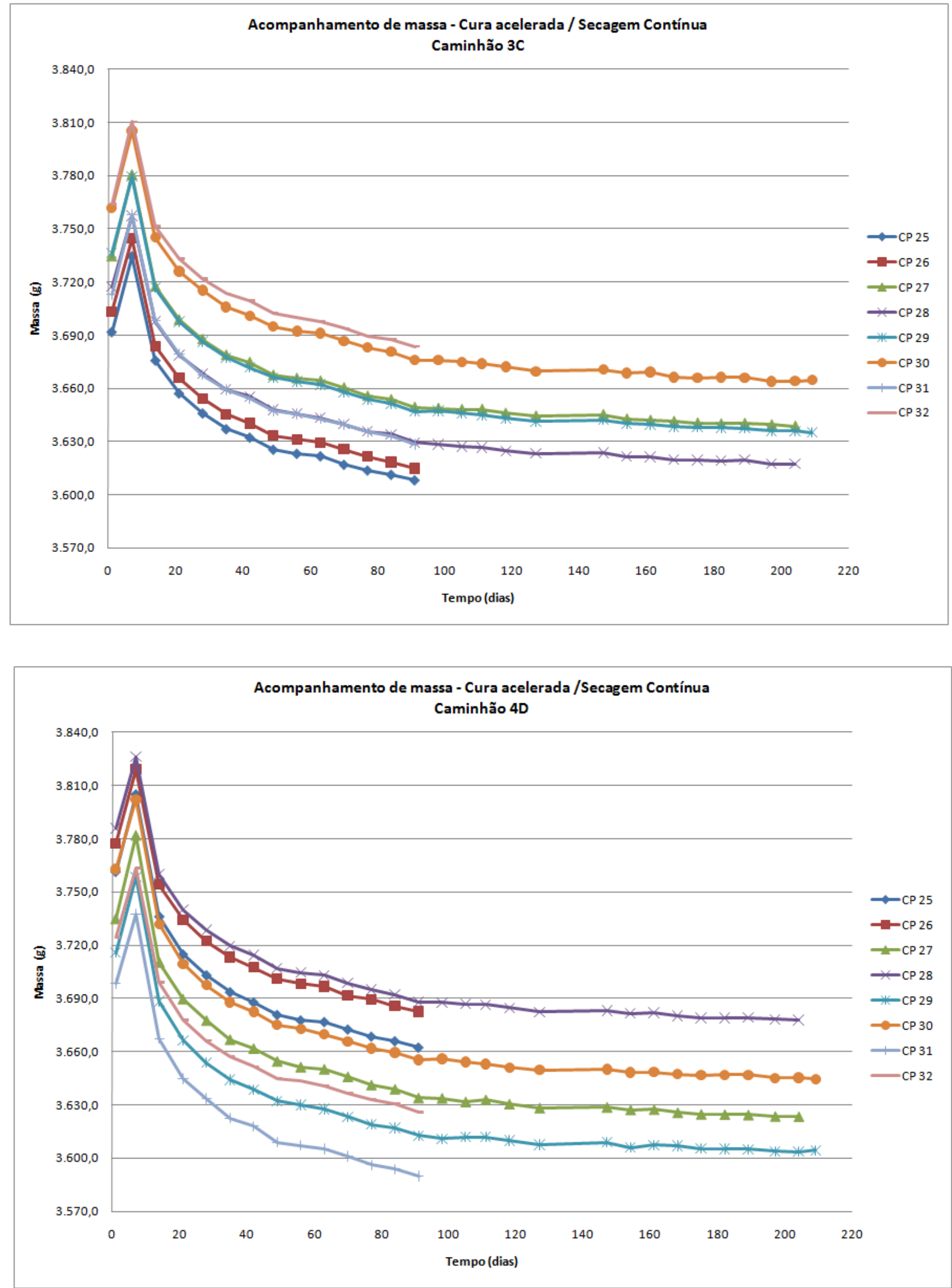

FIGURA 138 - Controle de massa de corpos-de-prova 25 a 32 (AE3) das misturas C3C e C4D. 

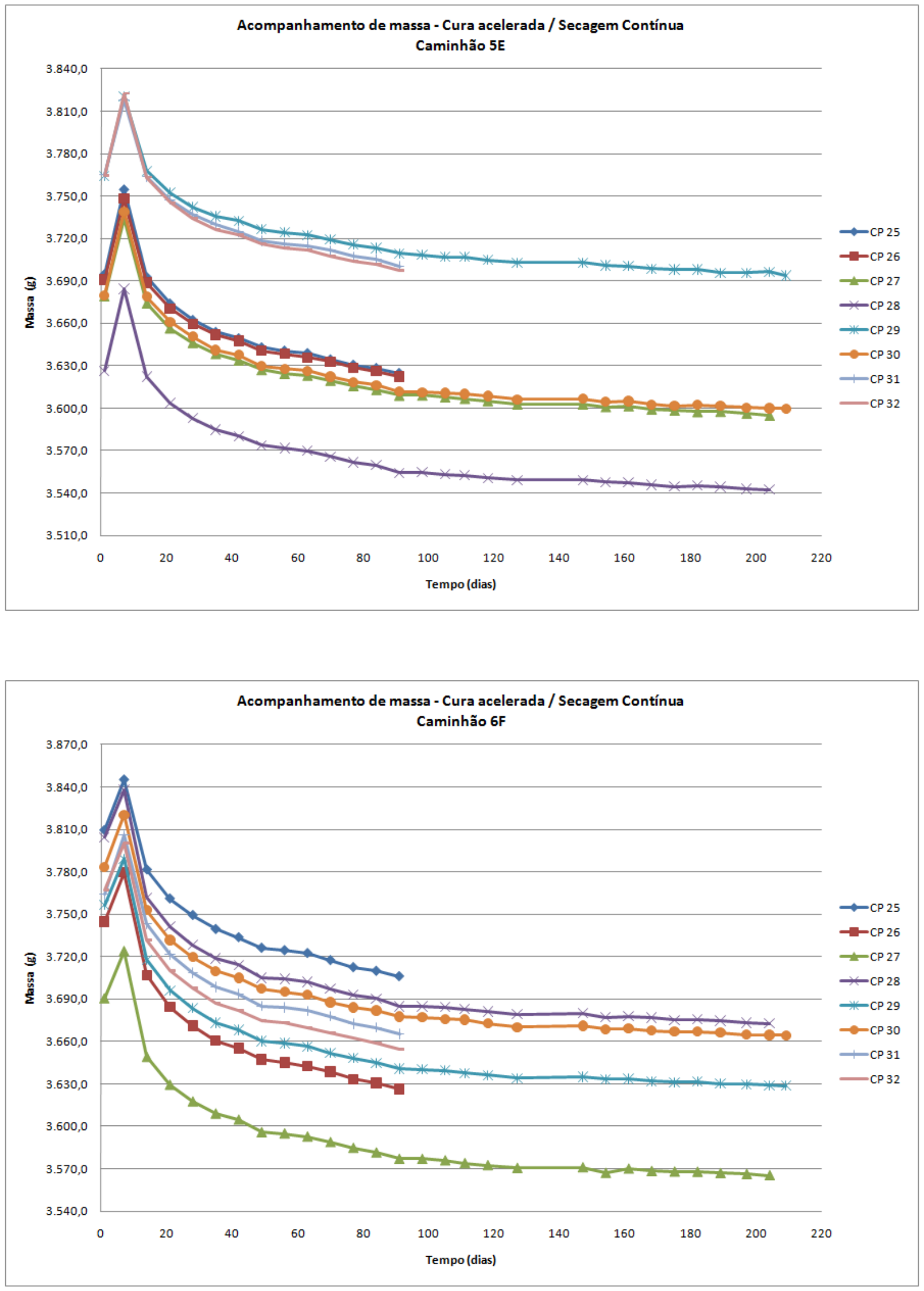

FIGURA 139- Controle de massa de corpos-de-prova (AE3) C5E e C6F. 
TABELA 125 - Dados completos sobre resistência à tração por compressão diametral.

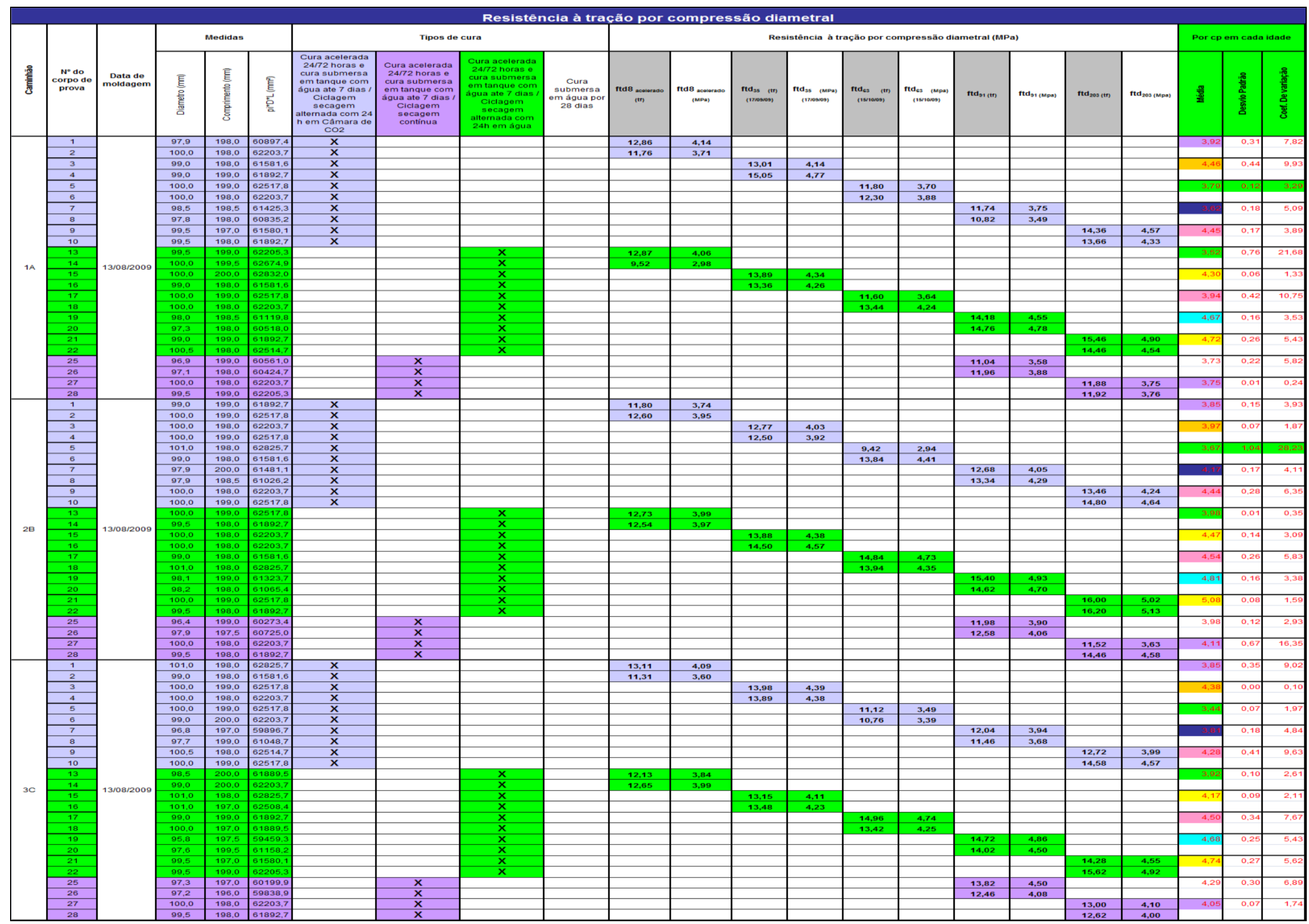




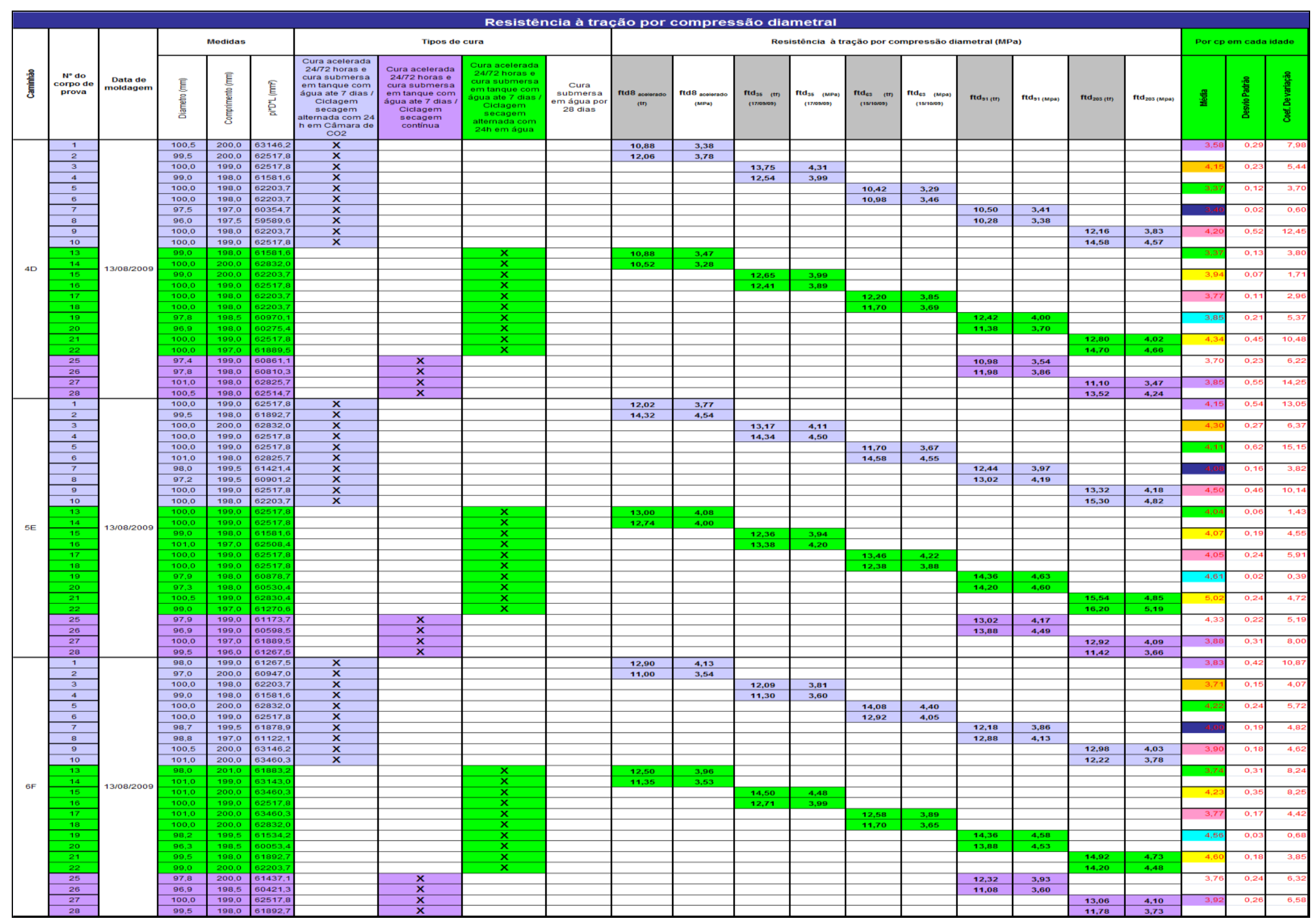


TABELA 126 - Dados completos sobre ensaios de profundidade de carbonatação.

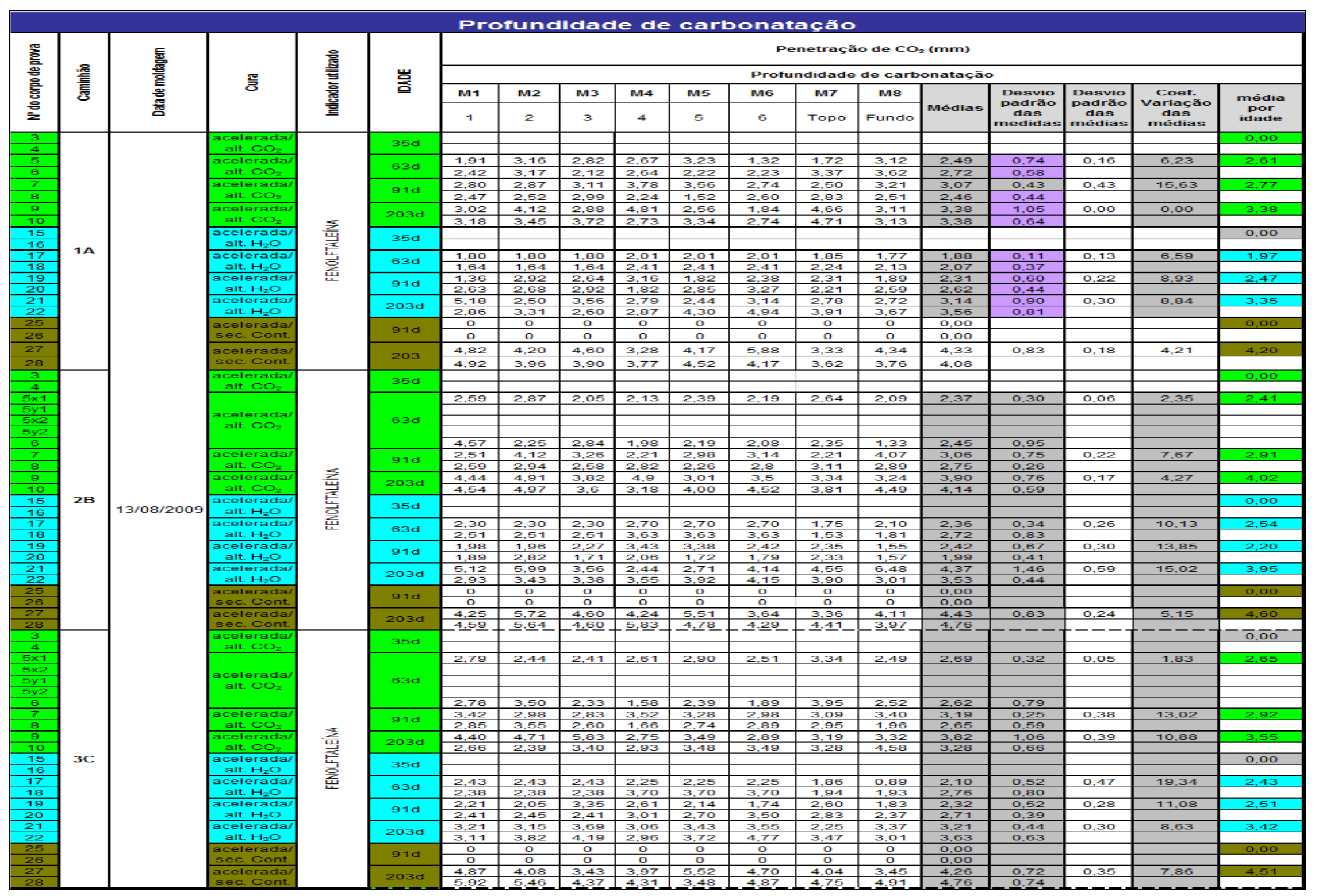




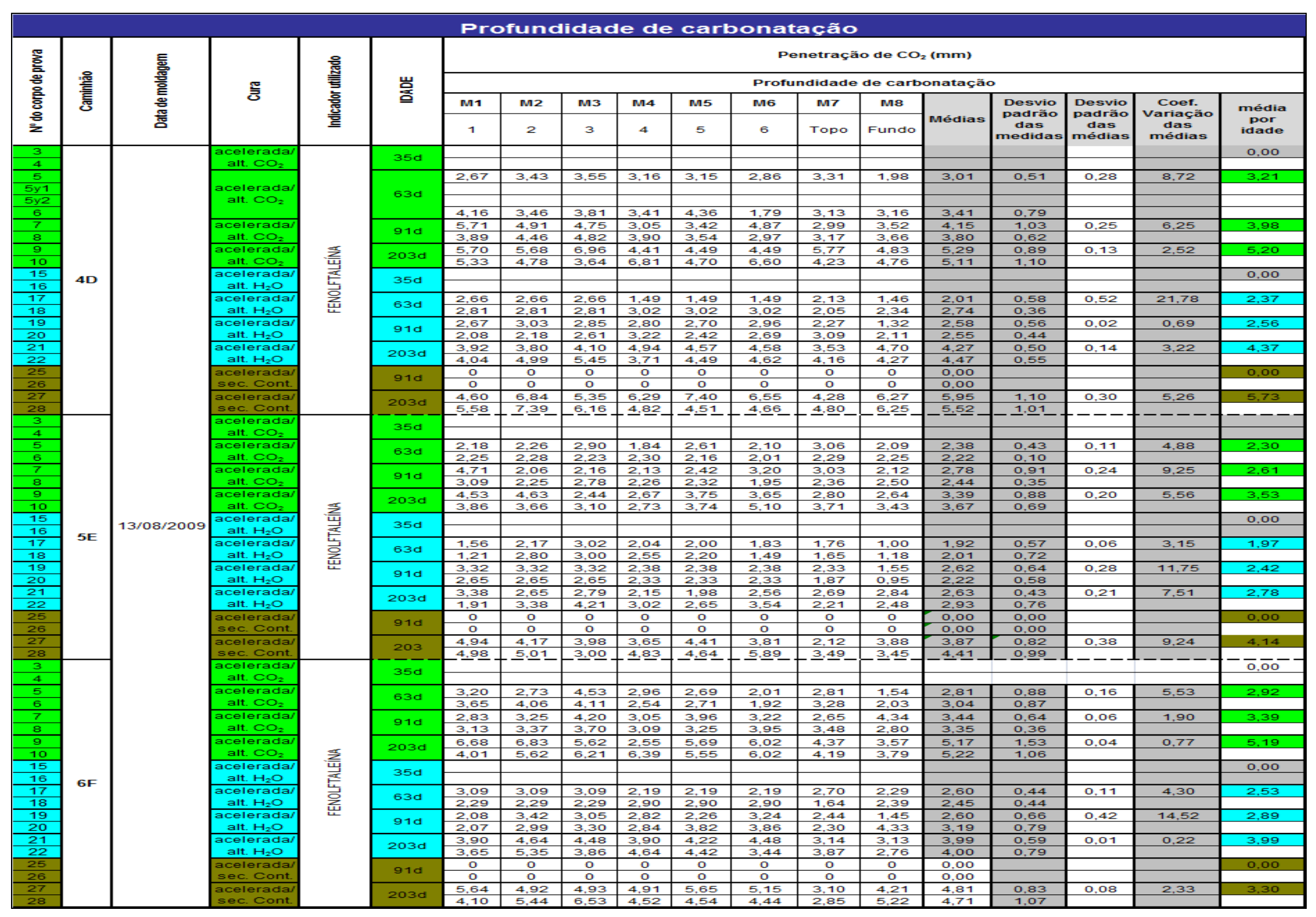




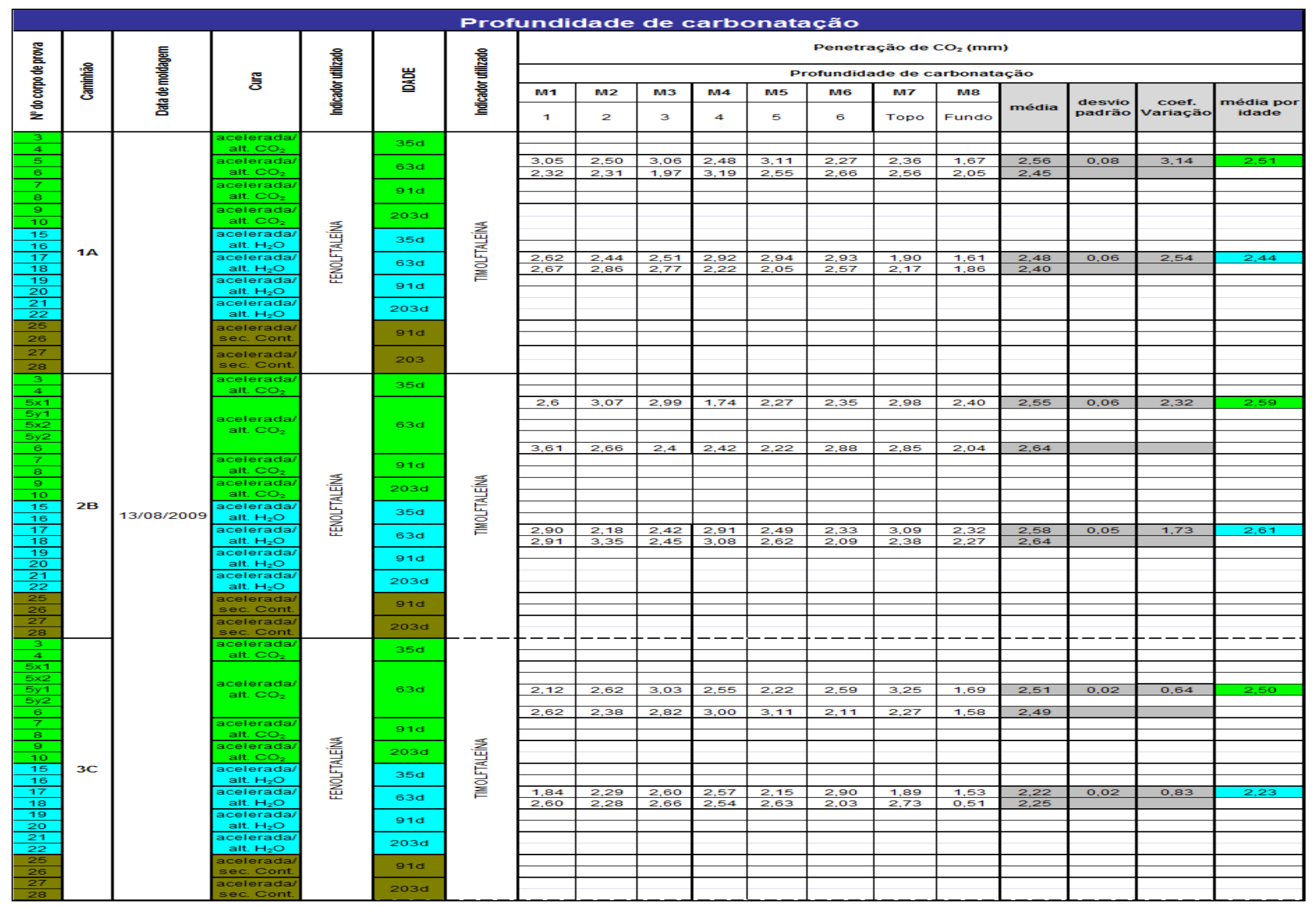




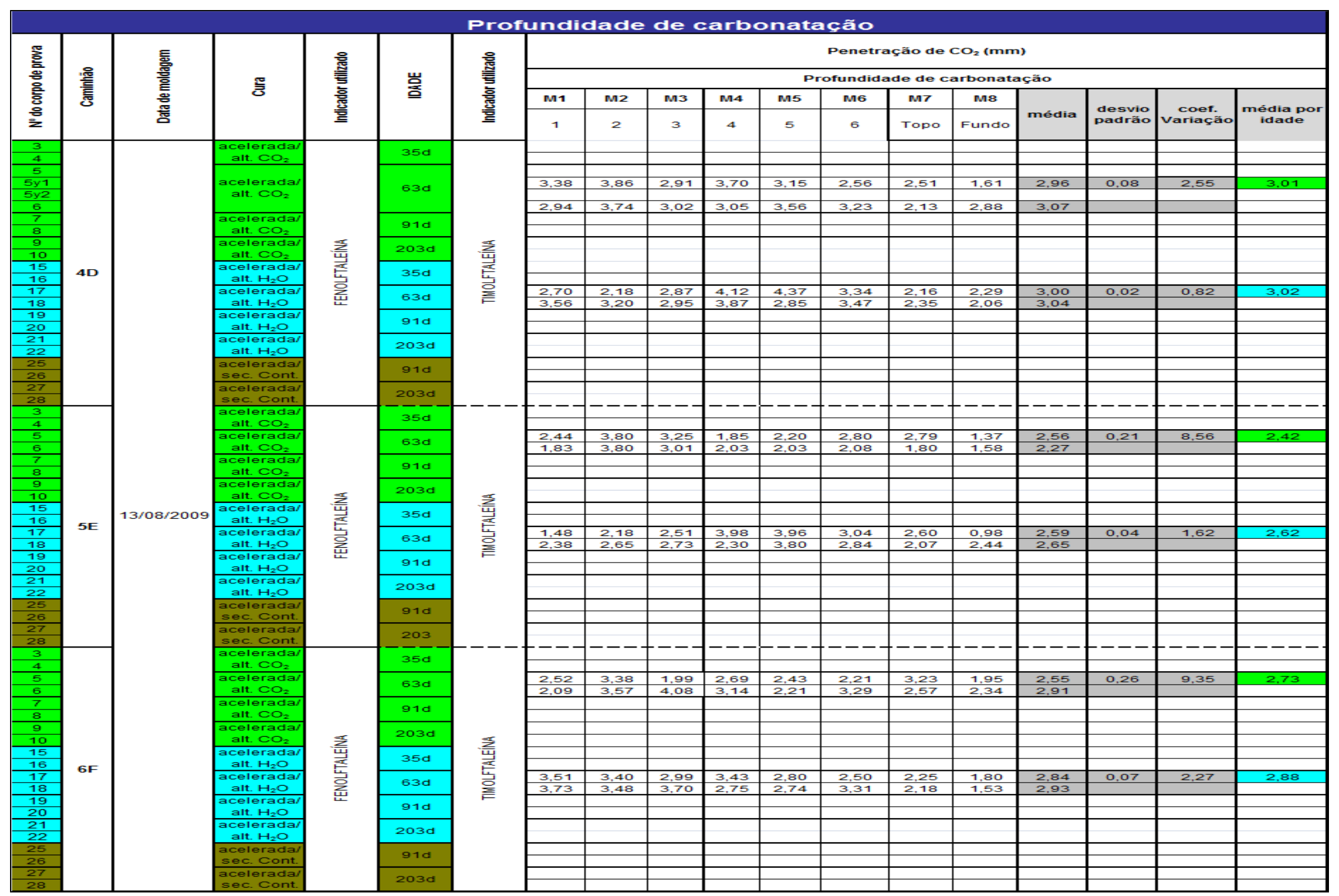




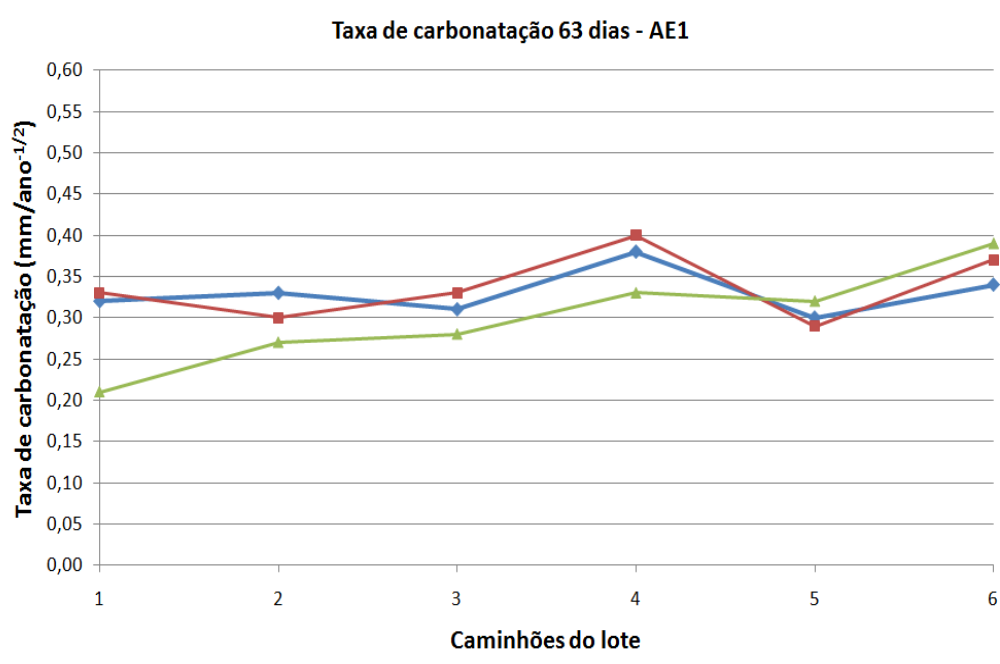

$\rightarrow$ Timol-63dias (AE1) $\rightarrow$-Fenol- 63 dias (AE1) $\rightarrow$ Fenol- 63 dias (AE1) - Image J

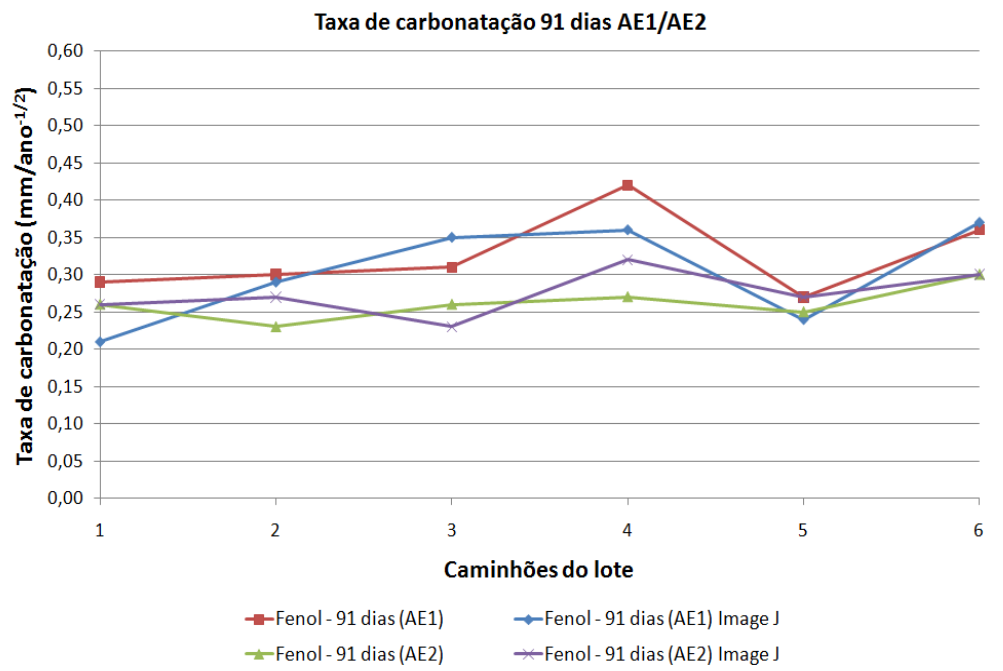

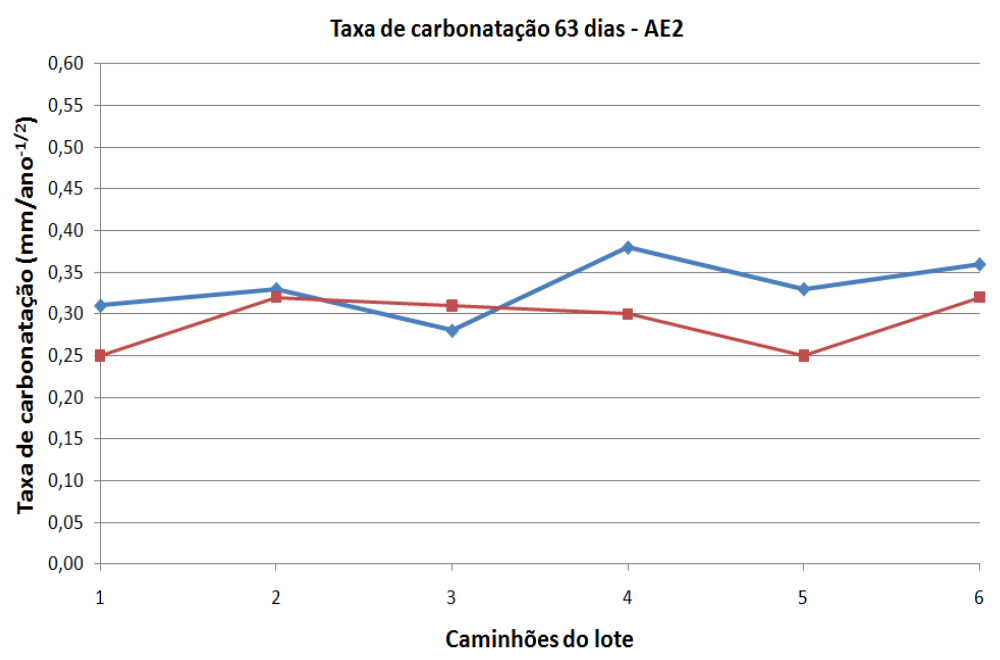

$\rightarrow$-Timol - 63 dias (AE2) $\rightarrow$-Fenol - 63 dias (AE2)

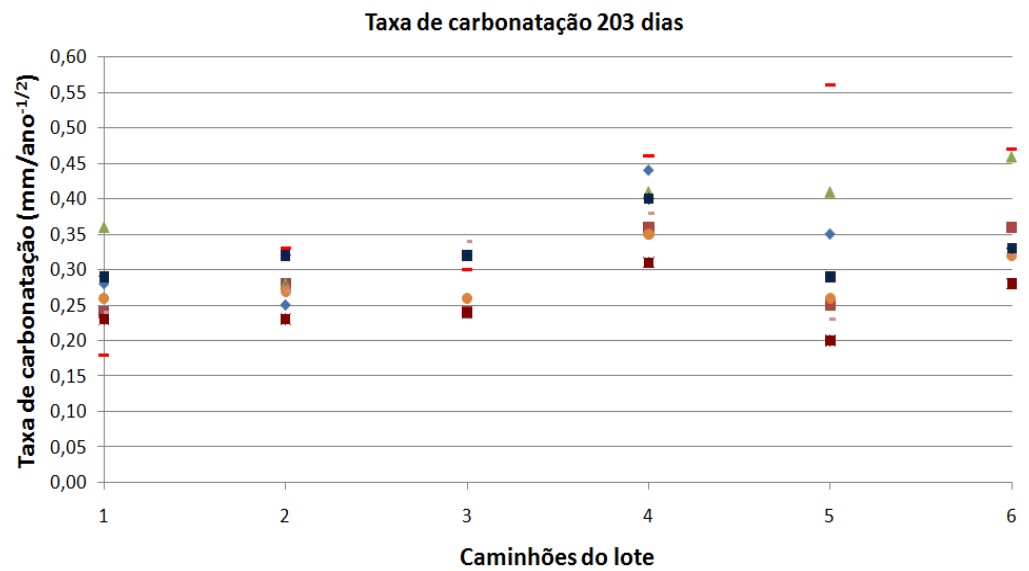

- Fenol- 203 dias (AE1) • Fenol-203 dias (AE1) Image J A Fenol - 203 dias (AE1) Laica $\times$ Fenol - 203 dias (AE2) $\quad$ Fenol - 203 dias (AE2) Image J • Fenol - 203 dias (AE2) Laica
- Fenol - 203 dias (AE3) 
TABELA 127 - Dados completos sobre ensaios de módulo de elasticidade a 91 dias.

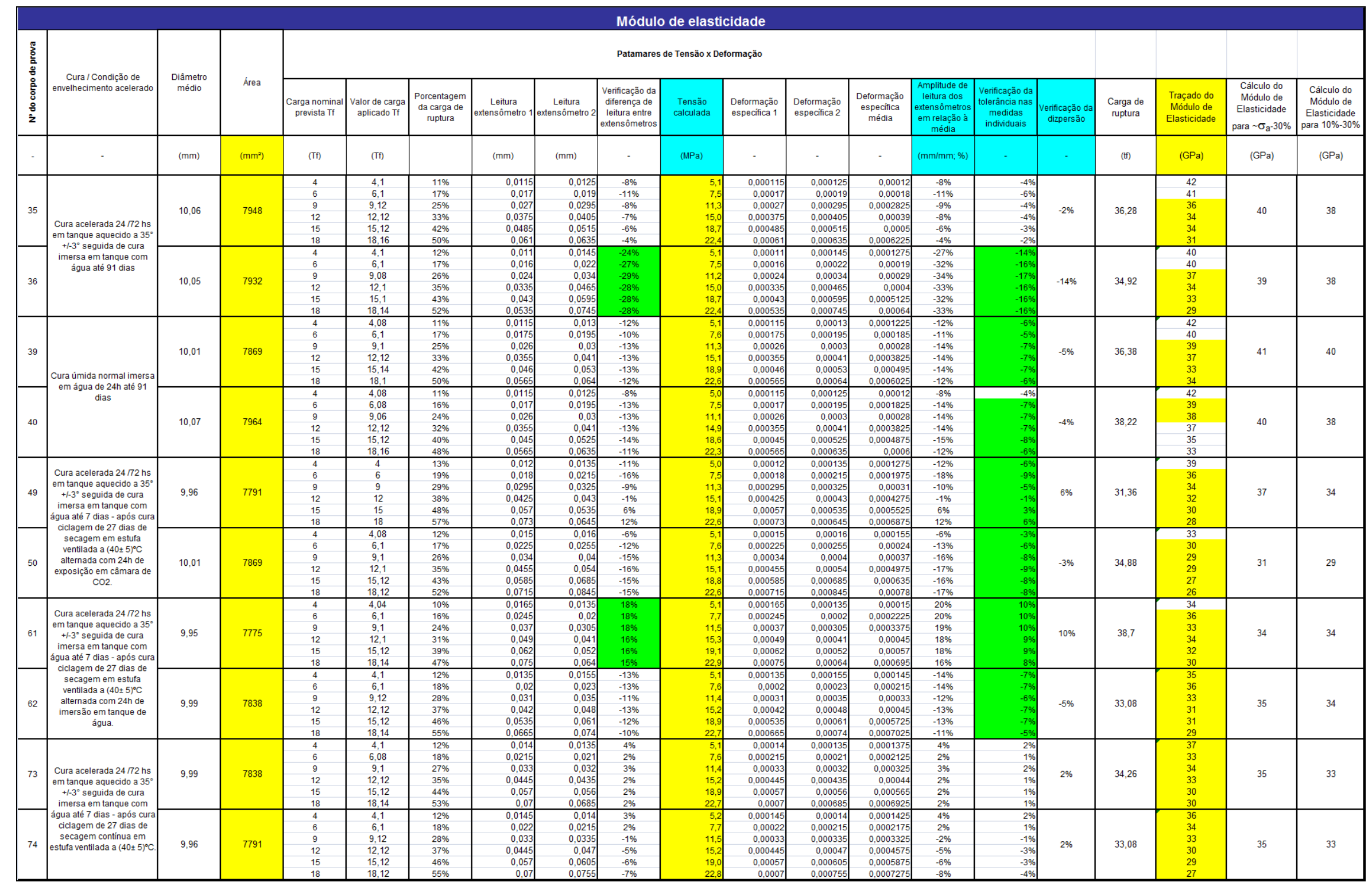


TABELA 128 - Dados completos sobre ensaios de módulo de elasticidade a 203 dias.

\begin{tabular}{|c|c|c|c|c|c|c|c|c|c|c|c|c|c|c|c|c|c|c|c|c|}
\hline \multicolumn{21}{|c|}{ Módulo de elasticidade 203 dias } \\
\hline \multirow{2}{*}{ 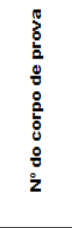 } & \multirow{2}{*}{$\begin{array}{l}\text { Cura / Condiç̃ão de } \\
\text { envelhecimento } \\
\text { acelerado }\end{array}$} & \multirow{2}{*}{$\begin{array}{c}\text { Diâmetro } \\
\text { médio }\end{array}$} & \multirow[b]{2}{*}{ Area } & \multicolumn{17}{|c|}{ Patamares de Tensão x Deformação } \\
\hline & & & & $\begin{array}{c}\text { Carga nominal } \\
\text { prevista Tf }\end{array}$ & \begin{tabular}{|} 
Valor de carga \\
aplicado Tf
\end{tabular} & $\begin{array}{c}\text { Porcentagem } \\
\text { da carga de } \\
\text { ruppura }\end{array}$ & $\begin{array}{c}\text { Leitura } \\
\text { extensômetro } 1\end{array}$ & $\begin{array}{c}\text { Leitura } \\
\text { extensómetro } 2\end{array}$ & \begin{tabular}{|l|} 
Verificacẵo da \\
differnça de \\
eletura entre \\
extensômetros
\end{tabular} & $\begin{array}{l}\text { Tensão } \\
\text { calculada }\end{array}$ & $\begin{array}{l}\text { Deformação } \\
\text { especticas } 1\end{array}$ & $\begin{array}{l}\text { Deformaçãa } \\
\text { espectifca } 2\end{array}$ & \begin{tabular}{|c|} 
Deformaçăo \\
espectíca \\
média
\end{tabular} & \begin{tabular}{c|} 
Ampilitude de \\
eletura dos \\
extensómetros \\
em relaçáco à \\
média
\end{tabular} & 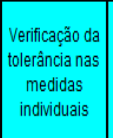 & \begin{tabular}{|c|} 
Verificacąão da \\
dizpersäo
\end{tabular} & $\begin{array}{l}\text { Carga de } \\
\text { ruptura }\end{array}$ & $\begin{array}{l}\text { Traçado do } \\
\text { Módulo de } \\
\text { Elasticidade }\end{array}$ & \begin{tabular}{|c|} 
Cálculo do \\
Módulo de \\
Elasticidade \\
para $\sim \sigma_{\mathrm{a}}-30 \%$ \\
\end{tabular} & \begin{tabular}{|c|} 
Cálculo do \\
Módulo de \\
Elasticiade \\
para 10\%-30\%
\end{tabular} \\
\hline Unidades & - & $(\mathrm{mm})$ & $\mathrm{mm}^{2}$ & Tf & Tf & & $(\mathrm{mm})$ & $(\mathrm{mm})$ & & (MPa) & - & - & . & $(\mathrm{mm} / \mathrm{mm} ; \%)$ & & & (ti) & (GPa) & (GPa) & (GPa) \\
\hline \multirow{7}{*}{55} & \multirow{14}{*}{ 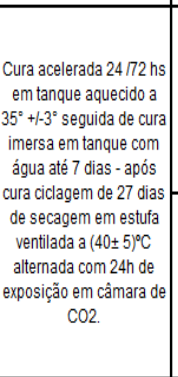 } & \multirow{7}{*}{99,55} & \multirow{7}{*}{7783} & 1 & 1,2 & $3 \%$ & 0,001 & 0,0025 & $-60 \%$ & 1,5 & & & & & & \multirow{7}{*}{$26 \%$} & \multirow{7}{*}{37,88} & & \multirow{7}{*}{38} & \multirow{7}{*}{36} \\
\hline & & & & 3 & 3,1 & $8 \%$ & 0,0110 & 0,0065 & $41 \%$ & 3,9 & 0,00011 & 0,000065 & 0,0000875 & $51 \%$ & $26 \%$ & & & 45 & & \\
\hline & & & & 6 & 6,1 & $16 \%$ & 0,0215 & 0,017 & $21 \%$ & 7,7 & 0,000215 & 0,00017 & \begin{tabular}{|l|l|}
0,0001925 \\
\end{tabular} & $23 \%$ & $12 \%$ & & & 36 & & \\
\hline & & & & 9 & $\begin{array}{l}0,1 \\
9,1\end{array}$ & $24 \%$ & 0,0325 & 0,0275 & $15 \%$ & $\begin{array}{l}1,1 \\
11,5\end{array}$ & $\begin{array}{l}0,000215 \\
0,000325\end{array}$ & 0,000275 & $\mid$\begin{tabular}{|l|}
0,000003 \\
\end{tabular} & $17 \%$ & $8 \%$ & & & 35 & & \\
\hline & & & & 12 & 12,12 & $32 \%$ & 0,0440 & 0,039 & $11 \%$ & 15,3 & 0,00044 & 0,00039 & 0,000415 & $12 \%$ & $6 \%$ & & & 33 & & \\
\hline & & & & 15 & 15,2 & $40 \%$ & 0,0560 & 0,051 & $9 \%$ & 19,2 & 0,00056 & 0,00051 & 0,000535 & $9 \%$ & $5 \%$ & & & 32 & & \\
\hline & & & & 18 & 18,16 & $48 \%$ & 0,0685 & 0,063 & $8 \%$ & 22,9 & 0,000685 & 0.00063 & 0,0006575 & $8 \%$ & $4 \%$ & & & 30 & & \\
\hline \multirow{7}{*}{56} & & \multirow{7}{*}{98,9} & & 1 & 0,92 & $2 \%$ & 0,002 & 0,0025 & $-20 \%$ & 1,2 & & & & & & & & & & \\
\hline & & & & 3 & 3,8 & $10 \%$ & 0,0085 & 0,0115 & $-26 \%$ & 4,9 & 0,000085 & 0,000115 & 0,0001 & $-30 \%$ & $-15 \%$ & & & 49 & & \\
\hline & & & & 6 & 6,1 & $16 \%$ & 0,0185 & 0,0235 & $-21 \%$ & 7,8 & 0,000185 & 0,000235 & 0,00021 & $-24 \%$ & $-12 \%$ & & & 27 & & \\
\hline & & & 7682 & 9 & 9,12 & $24 \%$ & 0,0295 & 0,036 & $-18 \%$ & 11,6 & 0,000295 & 0,00036 & 0,0003275 & $-20 \%$ & $-10 \%$ & $.7 \%$ & 35,78 & 33 & 36 & 30 \\
\hline & & & & 12 & 12,12 & $32 \%$ & 0,0410 & 0,0485 & $-15 \%$ & 15,5 & 0,00041 & 0,000485 & \begin{tabular}{|l|}
0,0004475 \\
\end{tabular} & $-17 \%$ & $-8 \%$ & & & 32 & & \\
\hline & & & & 15 & 15,12 & $40 \%$ & 0,0525 & 0,0615 & $-15 \%$ & 19,3 & 0,000525 & 0,000615 & 0,00057 & $-16 \%$ & $-8 \%$ & & & 31 & & \\
\hline & & & & 18 & 18,14 & $48 \%$ & 0,0645 & 0,0745 & $-13 \%$ & $\begin{array}{l}23,2 \\
\end{array}$ & 0,000645 & 0,000745 & 0,000695 & $-14 \%$ & $.7 \%$ & & & 31 & & \\
\hline & & & & 1 & 0,98 & $3 \%$ & 0,006 & 0,001 & $83 \%$ & 1,3 & & & & & & & & & & \\
\hline & & & & 3 & 3,1 & $8 \%$ & 0,0115 & 0,0035 & $70 \%$ & 3,8 & 0,000115 & 0,000035 & 0,000075 & $107 \%$ & $53 \%$ & & & 50 & & \\
\hline & Cura acelerada $2472 \mathrm{hs}$ & & & 6 & 6,08 & $16 \%$ & 0,0175 & 0,02 & $-13 \%$ & 7,4 & 0,000175 & 0,0002 & 0,0001875 & $-13 \%$ & $.7 \%$ & & & 32 & & \\
\hline 67 & em tanque aquecido a & 101,35 & 8067 & 9 & 9,1 & $24 \%$ & 0,026 & 0,031 & $-16 \%$ & 11,1 & 0,00026 & 0,00031 & 0,000285 & $-18 \%$ & $-9 \%$ & $53 \%$ & 42,55 & 38 & 39 & 35 \\
\hline & $35^{5}+1-3^{\circ}$ seguida de cura & & & 12 & 12,12 & $32 \%$ & 0,0355 & 0,0425 & $-16 \%$ & 14,7 & 0,000355 & 0,000425 & 0,00039 & $-18 \%$ & $-9 \%$ & & & 35 & & \\
\hline & imersa em tanque com & & & 15 & 15,12 & $40 \%$ & 0.046 & 0.054 & $-15 \%$ & 18.4 & 0,00046 & 0.00054 & 0,0005 & $-16 \%$ & $-8 \%$ & & & 33 & & \\
\hline & água até 7 dias - após & & & 18 & $\begin{array}{l}18,12 \\
18,1\end{array}$ & $48 \%$ & 0,0565 & 0,065 & $-13 \%$ & $\begin{array}{l}20,4 \\
22.0\end{array}$ & 0,000565 & 0,00065 & 0 & $-14 \%$ & $.7 \%$ & & & 34 & & \\
\hline & 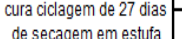 & & & 1 & 0,98 & $3 \%$ & 0,003 & 0,0025 & $17 \%$ & 1,2 & & & & & & & & & & \\
\hline & 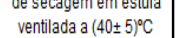 & & & 3 & 3,1 & $8 \%$ & 0,0095 & 0,01 & $-5 \%$ & 3,9 & 0,000095 & 0,0001 & 0,0000975 & $-5 \%$ & $-3 \%$ & & & 40 & & \\
\hline & alternada com $24 \mathrm{~d}$ de & & & 6 & 6,1 & $16 \%$ & 0,019 & 0,0205 & $.7 \%$ & 7,7 & 0,00019 & 0,000205 & 0,0001975 & $-8 \%$ & $-4 \%$ & & & 38 & & \\
\hline 68 & 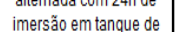 & 99,55 & 7783 & 9 & 9,08 & $24 \%$ & 0,0285 & 0,0315 & $-10 \%$ & 11,4 & 0,000285 & 0,000315 & 0,0003 & $-10 \%$ & $.5 \%$ & $-3 \%$ & 45,75 & 37 & 38 & 37 \\
\hline & & & & 12 & 12,1 & $32 \%$ & 0,038 & 0,0425 & $.11 \%$ & 15,2 & 0,00038 & 0,000425 & 0,0004025 & $-11 \%$ & $-6 \%$ & & & 37 & & \\
\hline & & & & 15 & 15,12 & $40 \%$ & 0,047 & 0.054 & $-13 \%$ & 19,0 & 0,00047 & 0.00054 & 0,000505 & $-14 \%$ & $-7 \%$ & & & 37 & & \\
\hline & & & & 18 & 18,14 & $48 \%$ & 0,058 & 0,066 & $-12 \%$ & 22,8 & 0.00058 & 0,00066 & 0,00062 & $-13 \%$ & $-6 \%$ & & & 33 & & \\
\hline & & & & 1 & 0,92 & $2 \%$ & 0,003 & 0 & $100 \%$ & 1,2 & & & & & & & & & & \\
\hline & & & & 3 & 3,08 & $8 \%$ & 0,0105 & 0,008 & $24 \%$ & 3,8 & 0,000105 & 0,00008 & 0,0000925 & $27 \%$ & $14 \%$ & & & 41 & & \\
\hline & & & & 6 & 6,08 & $16 \%$ & 0,0215 & 0,018 & $16 \%$ & 7,6 & 0,000215 & 0,00018 & 0,0001975 & $18 \%$ & $9 \%$ & & & 36 & & \\
\hline 79 & & 100,2 & 7885 & 9 & 9,08 & $24 \%$ & 0,0335 & 0,0295 & $12 \%$ & 11,3 & 0,000335 & 0,000295 & 0,000315 & $13 \%$ & $6 \%$ & $14 \%$ & 35,54 & 32 & 36 & 34 \\
\hline & Cura acelerada $24 / 2 \mathrm{hs}$ & & & 12 & 12,1 & $32 \%$ & 0,0465 & 0,041 & $12 \%$ & 15,0 & 0,000465 & 0,00041 & 0,0004375 & $13 \%$ & $6 \%$ & & & 31 & & \\
\hline & em tanque aquecido a & & & 15 & 15,1 & $40 \%$ & 0,06 & 0,0535 & $11 \%$ & 18,8 & 0,0006 & 0,000535 & 0,0005675 & $11 \%$ & $6 \%$ & & & 29 & & \\
\hline & $35^{5}+1-3^{3}$ seguida de cura & & & 18 & 18,13 & $48 \%$ & 0,074 & 0,066 & $11 \%$ & 22,5 & 0,00074 & 0,00066 & 0,0007 & $11 \%$ & $6 \%$ & & & 28 & & \\
\hline & 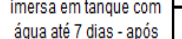 & & & 1 & 0,9 & $2 \%$ & 0,001 & 0,003 & $-67 \%$ & & & & & & & & & & & \\
\hline & 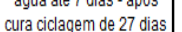 & & & 3 & 3,08 & $8 \%$ & 0,008 & 0,0075 & $6 \%$ & 3,8 & 0,00008 & 0,000075 & 0,0000775 & $6 \%$ & $3 \%$ & & & 49 & & \\
\hline & de secagem. & & & 6 & 6,08 & $16 \%$ & 0,0185 & 0,0165 & $11 \%$ & 7,5 & 0,000185 & 0,000165 & 0,000175 & $11 \%$ & $6 \%$ & & & 38 & & \\
\hline 80 & & 100,9 & 7996 & 9 & 9,1 & $24 \%$ & 0,03 & 0,027 & $10 \%$ & 11,2 & 0,0003 & 0,00027 & 0,000285 & $11 \%$ & $5 \%$ & $6 \%$ & 35,14 & 34 & 39 & 36 \\
\hline & & & & 12 & 12,12 & $32 \%$ & 0,042 & 0,038 & $10 \%$ & 14,9 & 0,00042 & 0,00038 & 0,0004 & $10 \%$ & $5 \%$ & & & 32 & & \\
\hline & & & & 15 & 15,1 & $40 \%$ & 0,0535 & 0,049 & $8 \%$ & 18,5 & 0,000535 & 0,00049 & 0,0005125 & $9 \%$ & $4 \%$ & & & 32 & & \\
\hline & & & & 18 & 18,12 & $48 \%$ & 0,066 & 0,061 & $8 \%$ & $\begin{array}{l}22,2 \\
22 \\
\end{array}$ & $\begin{array}{l}0,000066 \\
0,006\end{array}$ & 0,00061 & \begin{tabular}{|l|}
0,000635 \\
\end{tabular} & $8 \%$ & $4 \%$ & & & 30 & & \\
\hline
\end{tabular}


Dados completos sobre ensaios de ultra-som e módulo.

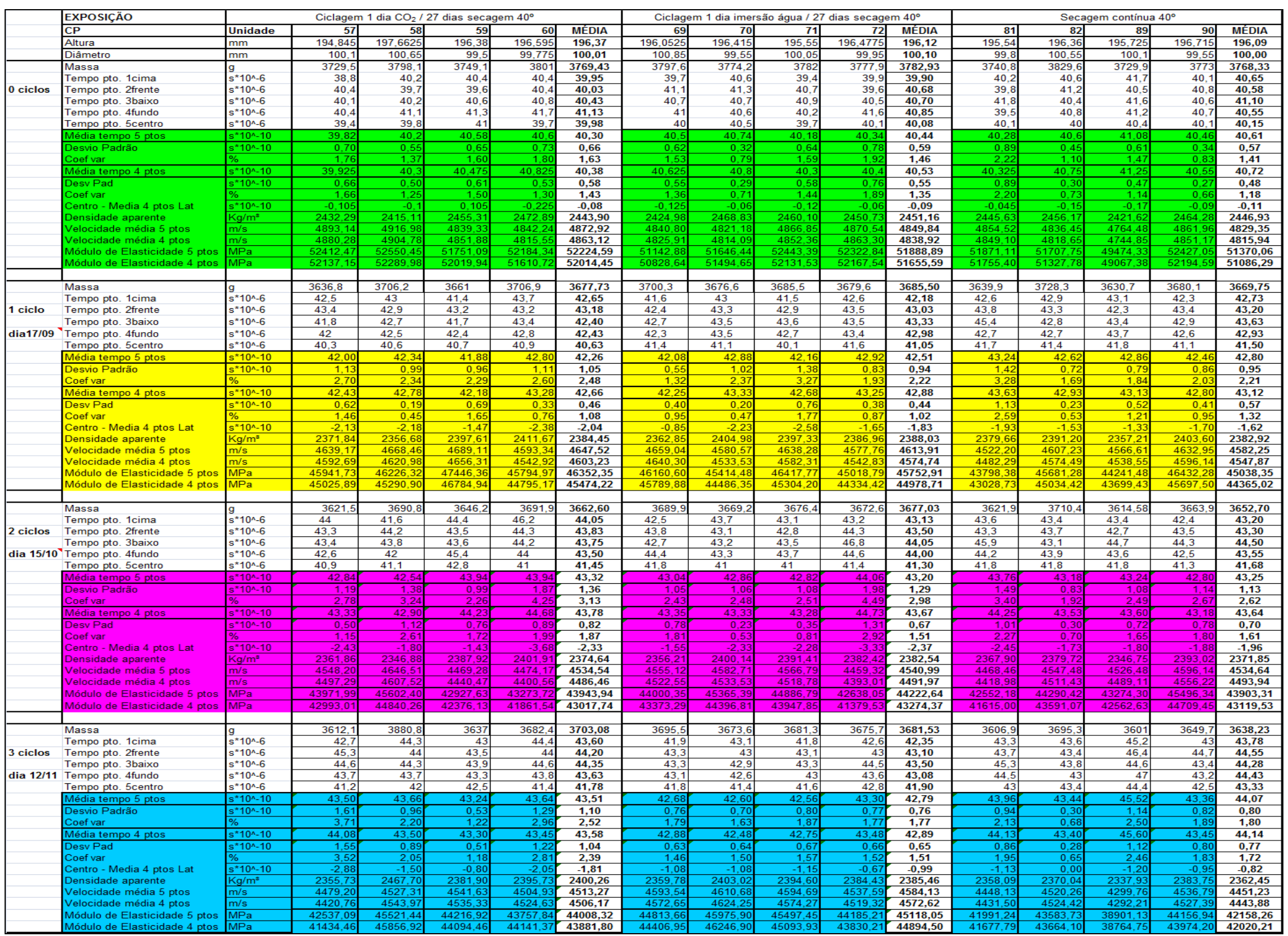




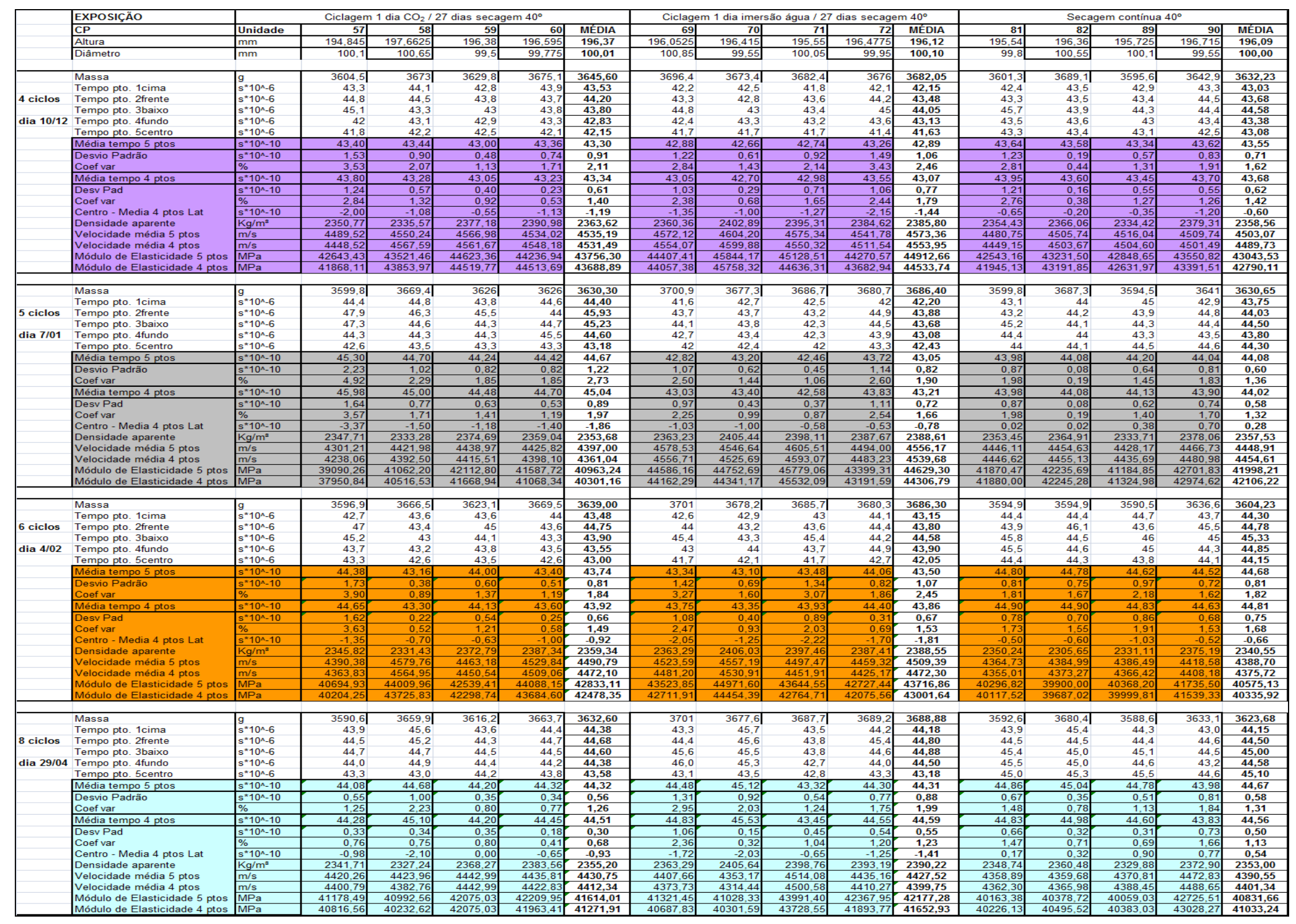




\section{Dados climáticos}

\section{SÃO PAULO - AGOSTO DE 2009}
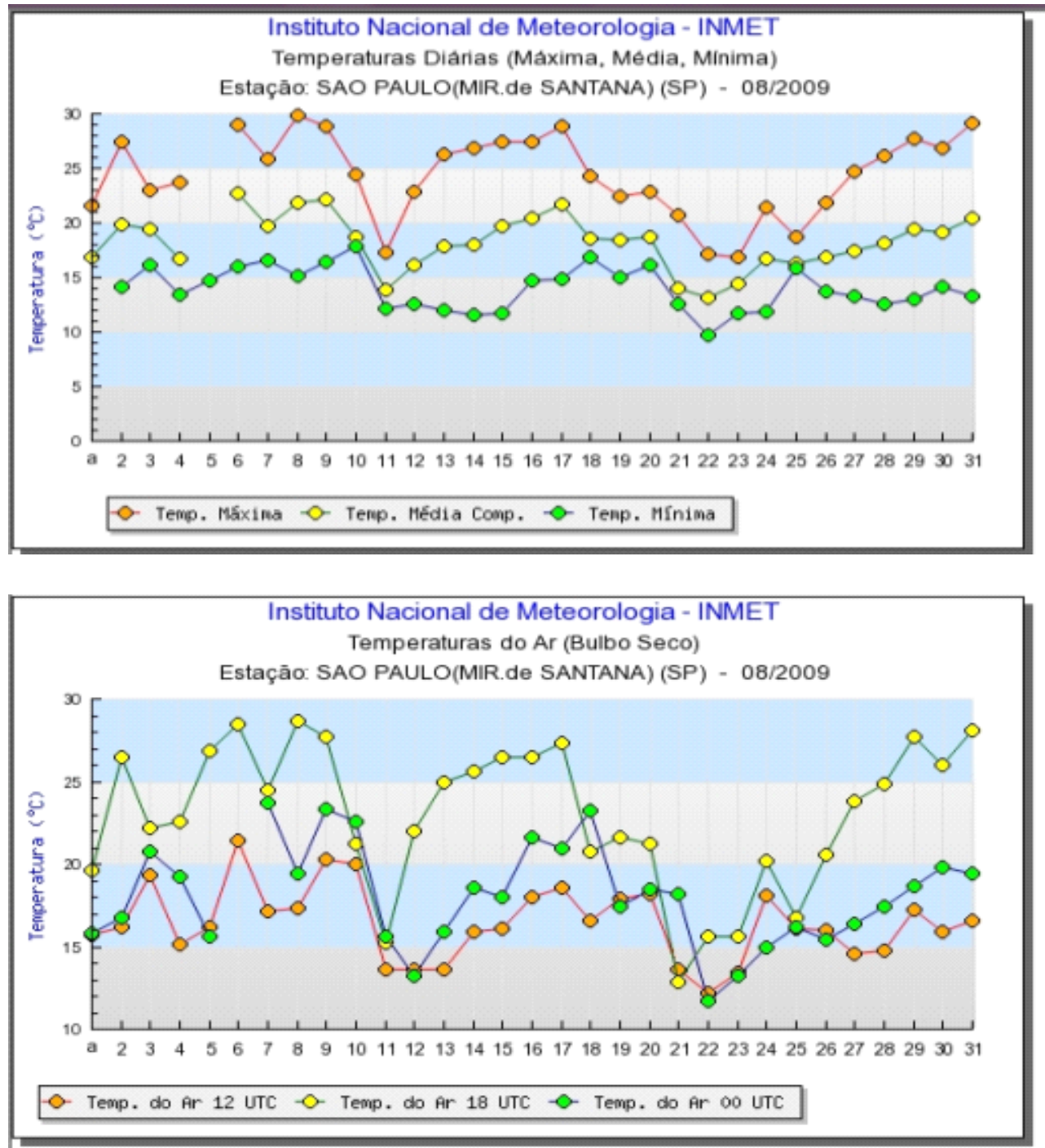

FIGURA 141 - Dados climáticos da época da concretagem. 
APÊNDICE C - CORPOS-DE-PROVA- ENSAIOS DE CARBONATAÇÃO (AE1, AE2 - 35D)

Data de moldagem dos corpos-de-prova: 13/08/2009

$\checkmark$ Idade de ensaio: 35 dias

$\checkmark$ (AE1) Corpos-de-prova 3 e 4 - expostos em câmara a $5 \%$ de $\mathrm{CO}_{2}$;

$\checkmark$ (AE2) Corpos-de-prova 15 e 16 - ciclagem secagem 24h em tanque com água;

$\checkmark$ Ensaiados com fenolftaleína - Pm = profundidade de penetração em $\mathrm{mm}$

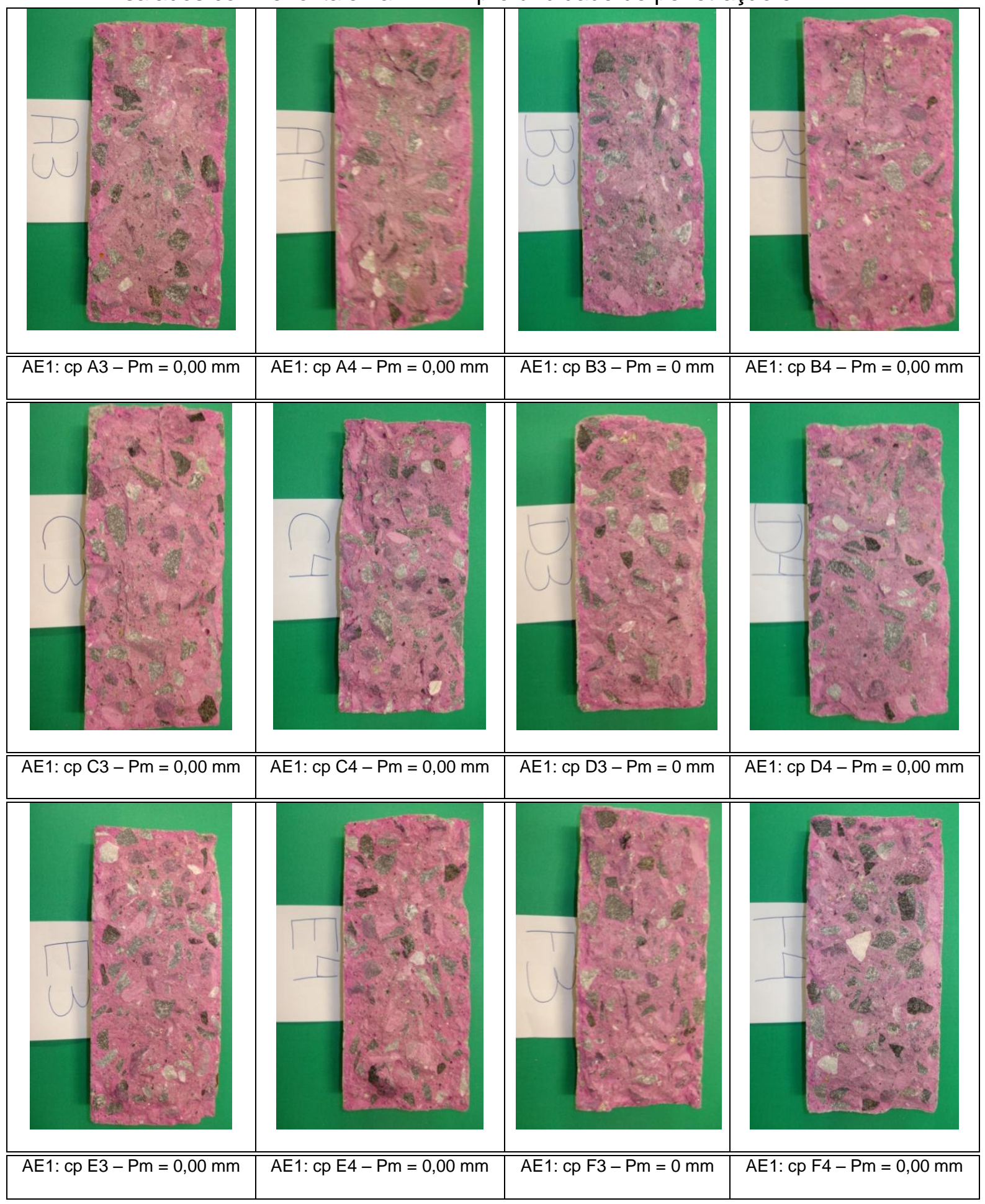




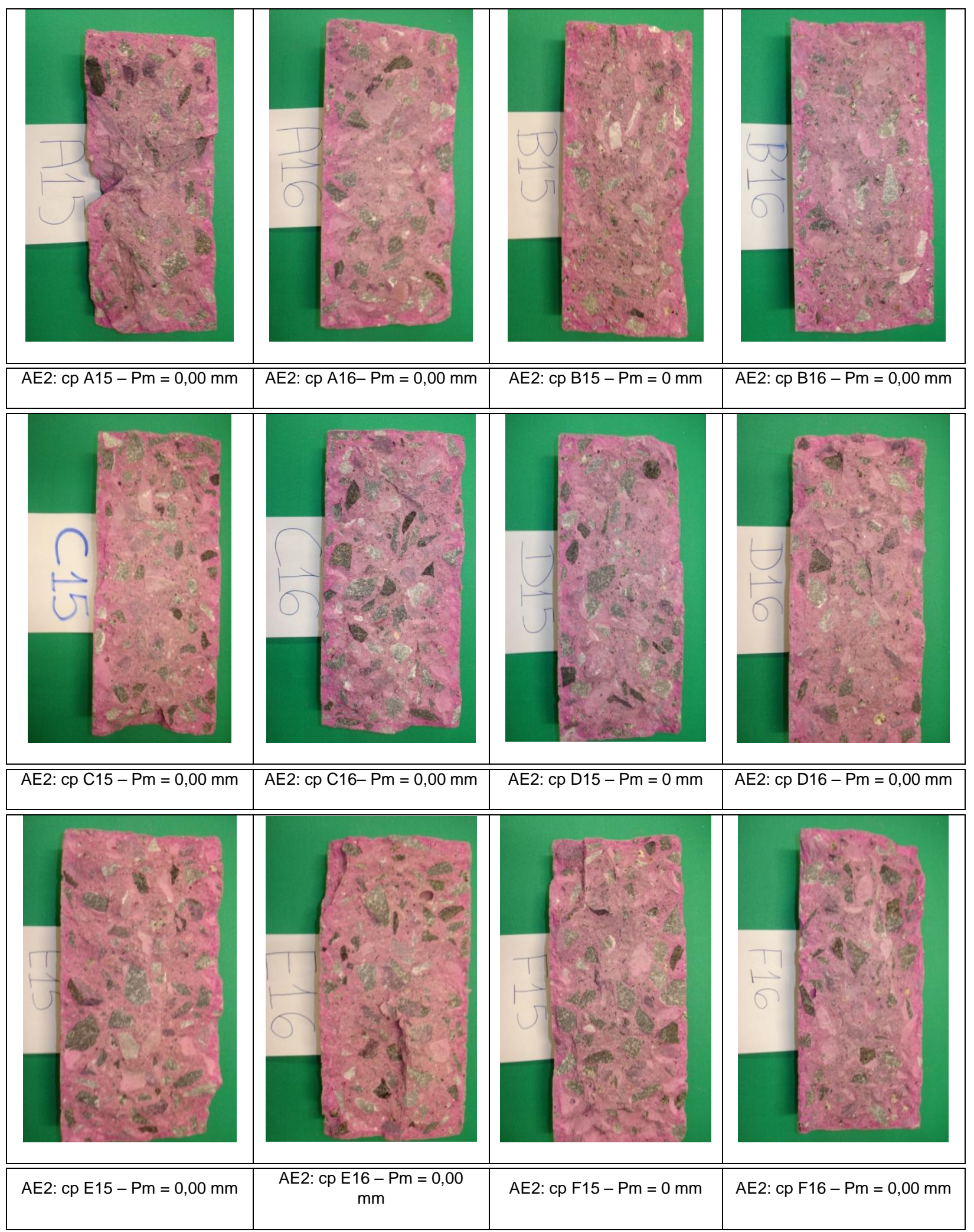




\section{APÊNDICE C - CORPOS-DE-PROVA- FRENTE DE SECAGEM (AE1, AE2 - 63D)}

Data de moldagem dos corpos-de-prova: 13/08/2009

$\checkmark$ Idade de ensaio: 63 dias

$\checkmark$ (AE1) Corpos-de-prova 5 e 6 - expostos em câmara a $5 \%$ de $\mathrm{CO}_{2}$;

$\checkmark$ (AE2) Corpos-de-prova 17 e 18 - ciclagem secagem 24h em tanque com água; $\mathrm{Pm}=$ profundidade de penetração em $\mathrm{mm}$.
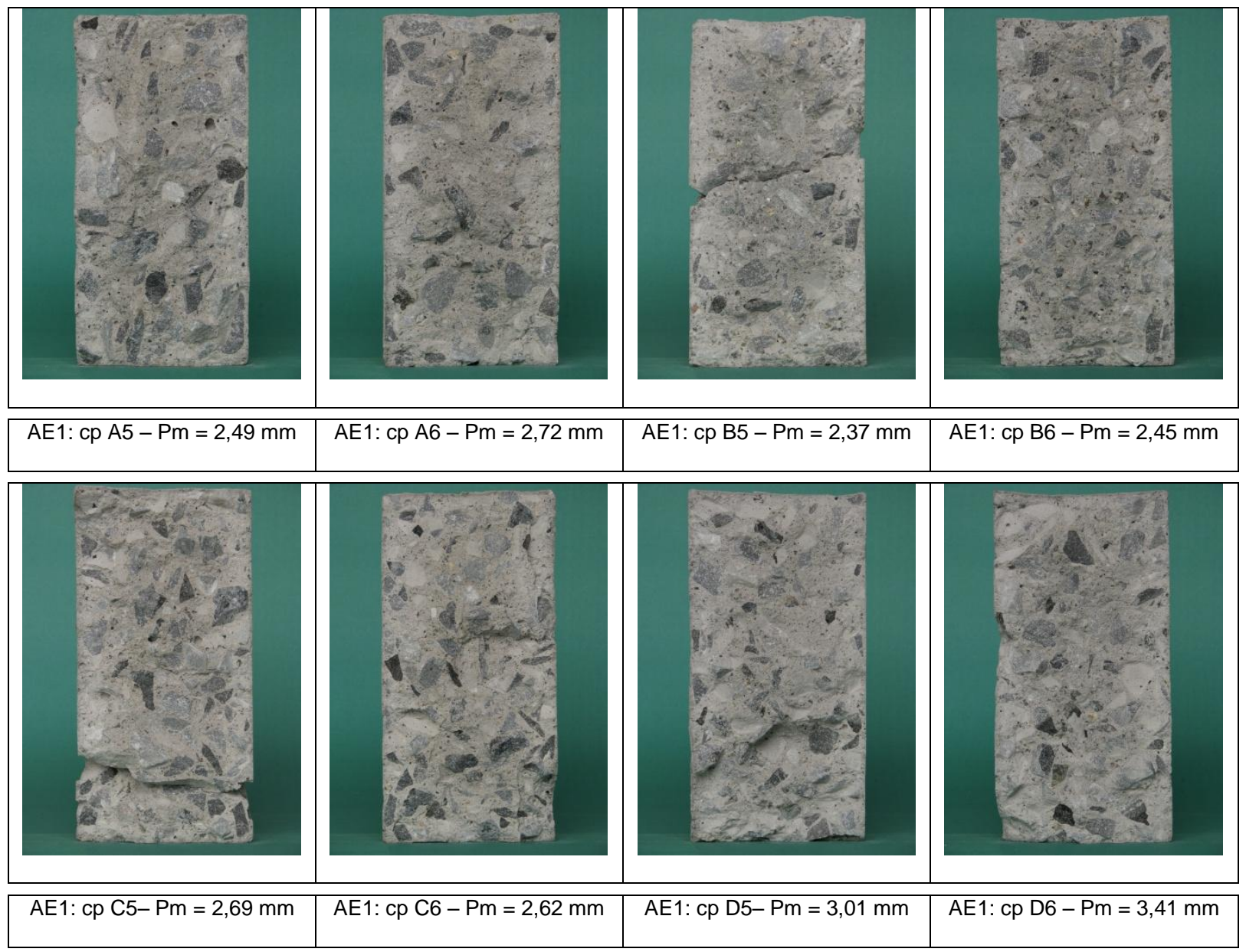

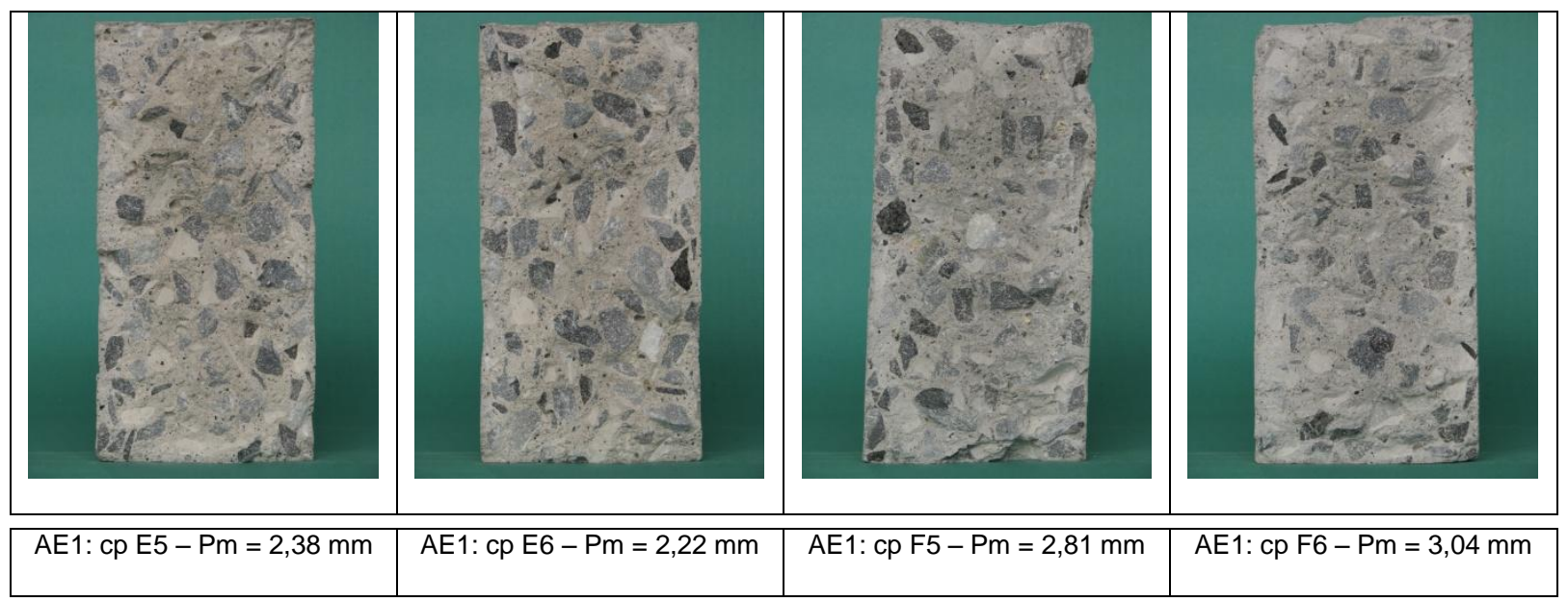




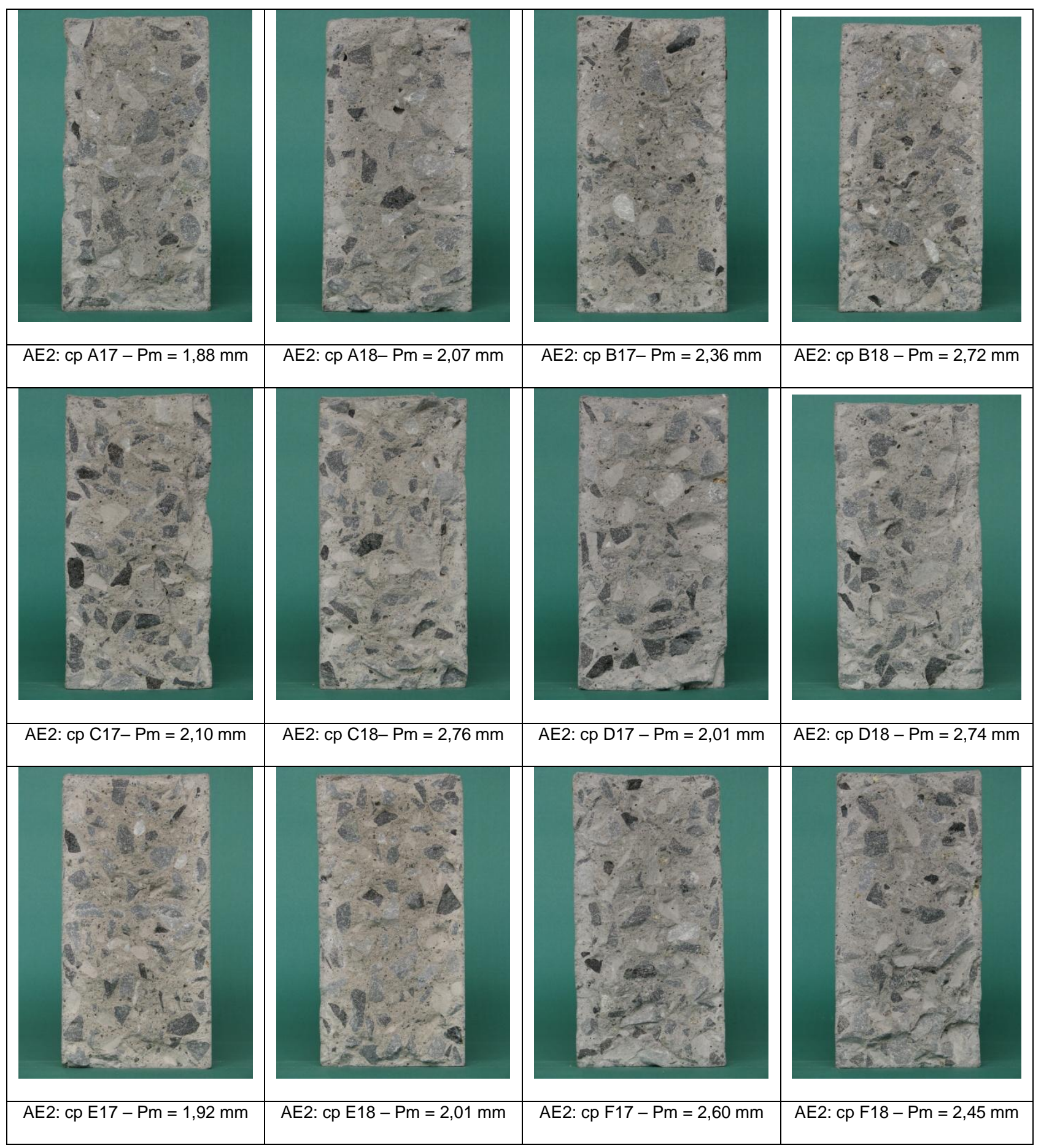


APÊNDICE C - CORPOS-DE-PROVA- ENSAIOS DE CARBONATAÇÃO (AE1, AE2 - 63D)

Data de moldagem dos corpos-de-prova: 13/08/2009

$\checkmark$ Idade de ensaio: 63 dias

$\checkmark$ (AE1) Corpos-de-prova 5 e 6 - expostos em câmara a $5 \%$ de $\mathrm{CO}_{2}$;

$\checkmark$ (AE2) Corpos-de-prova 17 e 18 - ciclagem secagem 24h em tanque com água;

$\checkmark$ Ensaiados com fenolftaleína $-\mathrm{Pm}=$ profundidade de penetração em $\mathrm{mm}$

\begin{tabular}{|c|c|c|c|}
\hline $\mathrm{AE} 1: \mathrm{cp} A 5-\mathrm{Pm}=2,49 \mathrm{~mm}$ & $\mathrm{AE} 1 \mathrm{cp} \mathrm{A} 6-\mathrm{Pm}=2,72 \mathrm{~mm}$ & $\mathrm{AE} 1: \mathrm{cp} B 5-\mathrm{Pm}=2,37 \mathrm{~mm}$ & $\mathrm{AE} 1: \mathrm{cp} \mathrm{B6}-\mathrm{Pm}=2,45 \mathrm{~mm}$ \\
\hline 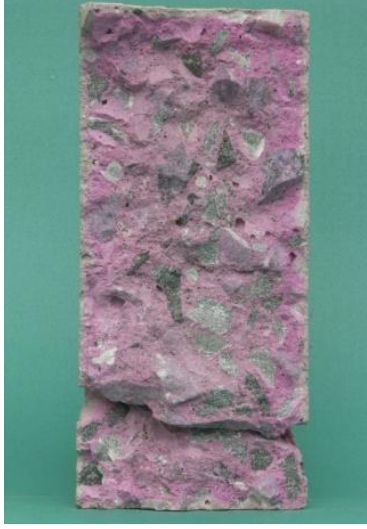 & 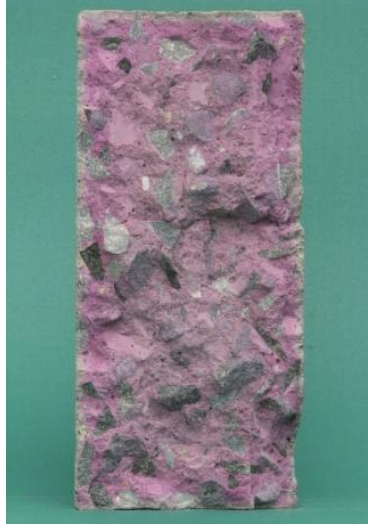 & 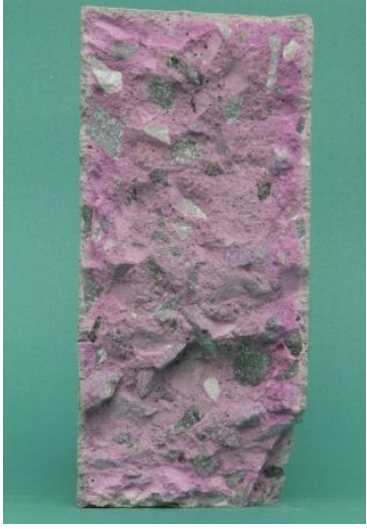 & 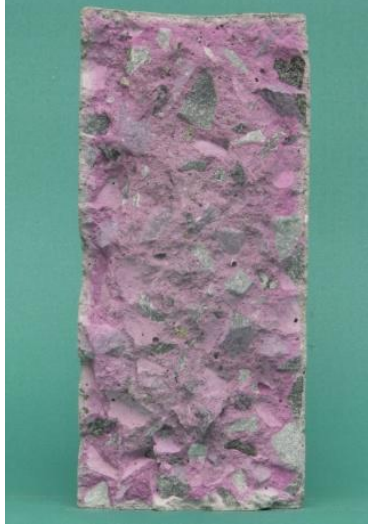 \\
\hline AE1: cp C5- Pm = 2,69 mm & $\overline{A A E 1: c p ~ C 6-P m ~=~ 2,62 ~ m m ~}$ & AE1: cp D5- Pm = 3,01 mm & $\overline{\mathrm{AEE} 1: \mathrm{cp} \mathrm{D6}-\mathrm{Pm}=3,41 \mathrm{~mm}}$ \\
\hline 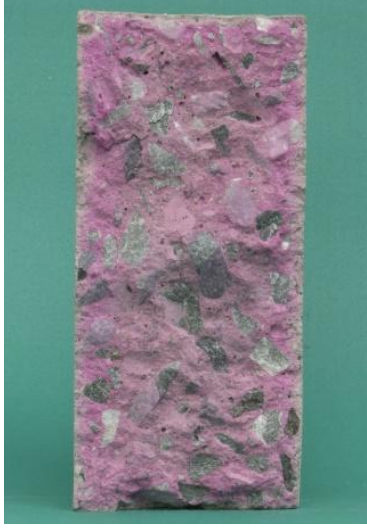 & 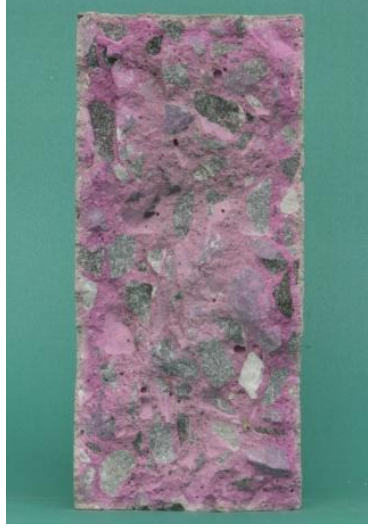 & 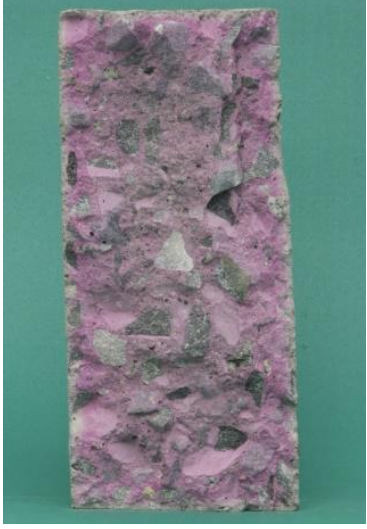 & 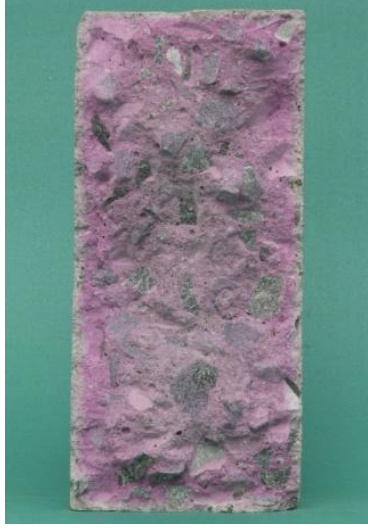 \\
\hline $\mathrm{AE} 1: \mathrm{cp} \mathrm{E} 5-\mathrm{Pm}=2,38 \mathrm{~mm}$ & $\mathrm{AE} 1 \mathrm{cp} \mathrm{E} 6-\mathrm{Pm}=2,22 \mathrm{~mm}$ & $\mathrm{AE} 1: \mathrm{cp} \mathrm{F5}-\mathrm{Pm}=2,81 \mathrm{~mm}$ & $\mathrm{AE} 1 \mathrm{cp} F 6-\mathrm{Pm}=3,04 \mathrm{~mm}$ \\
\hline
\end{tabular}




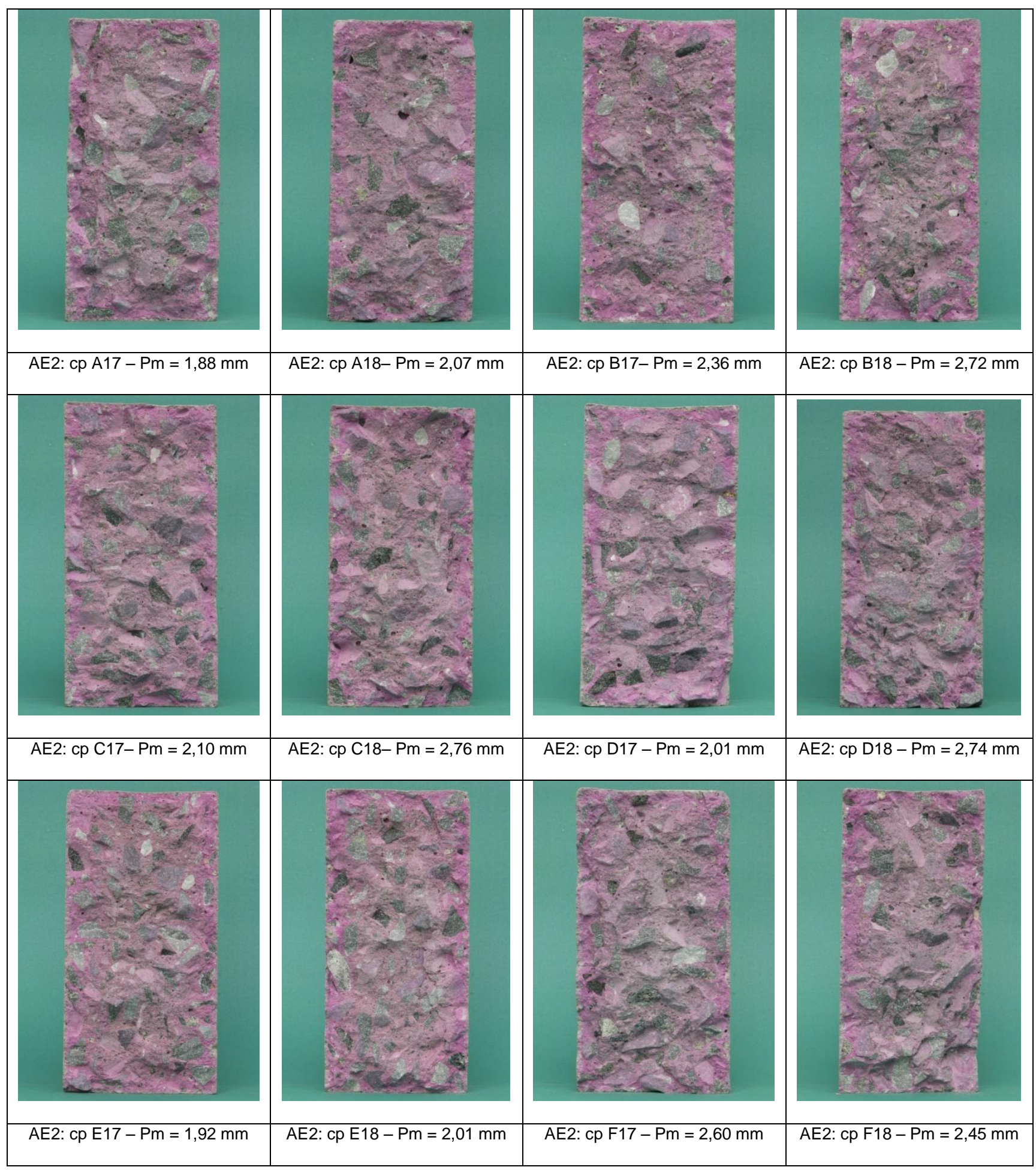


APÊNDICE C - CORPOS-DE-PROVA- FRENTE DE SECAGEM (AE1, AE2, AE3 - 91D)

Data de moldagem dos corpos-de-prova: 13/08/2009

$\checkmark$ Idade de ensaio: 91 dias

$\checkmark$ (AE1) Corpos-de-prova 7 e 8 - expostos em câmara a $5 \%$ de $\mathrm{CO}_{2}$;

$\checkmark$ (AE2) Corpos-de-prova 19 e 20 - ciclagem secagem 24h em tanque com água;

$\checkmark$ (AE3) Corpos-de-prova 25 e 26 - ciclagem secagem contínua.

$\mathrm{Pm}=$ profundidade de penetração em $\mathrm{mm}$.

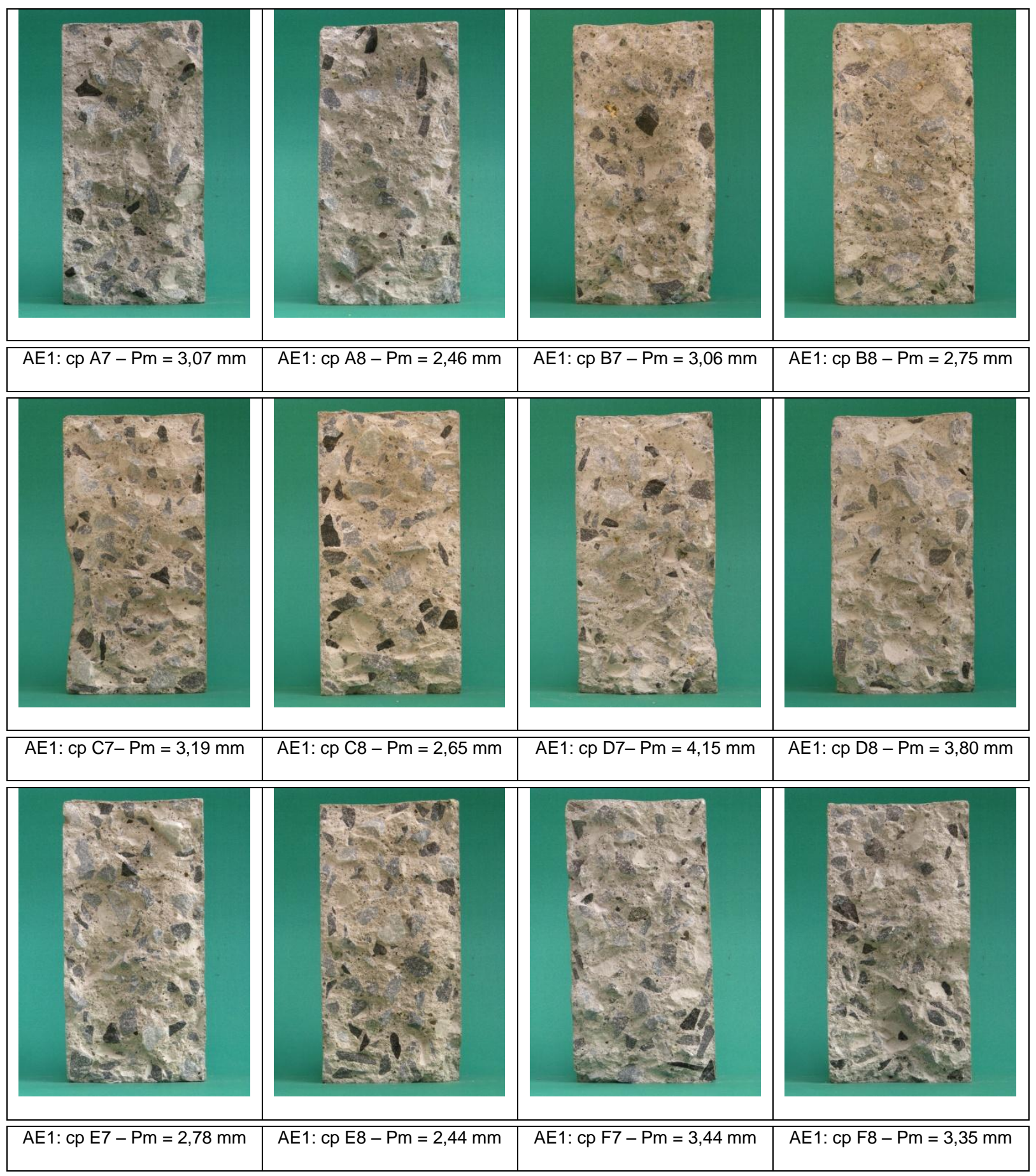




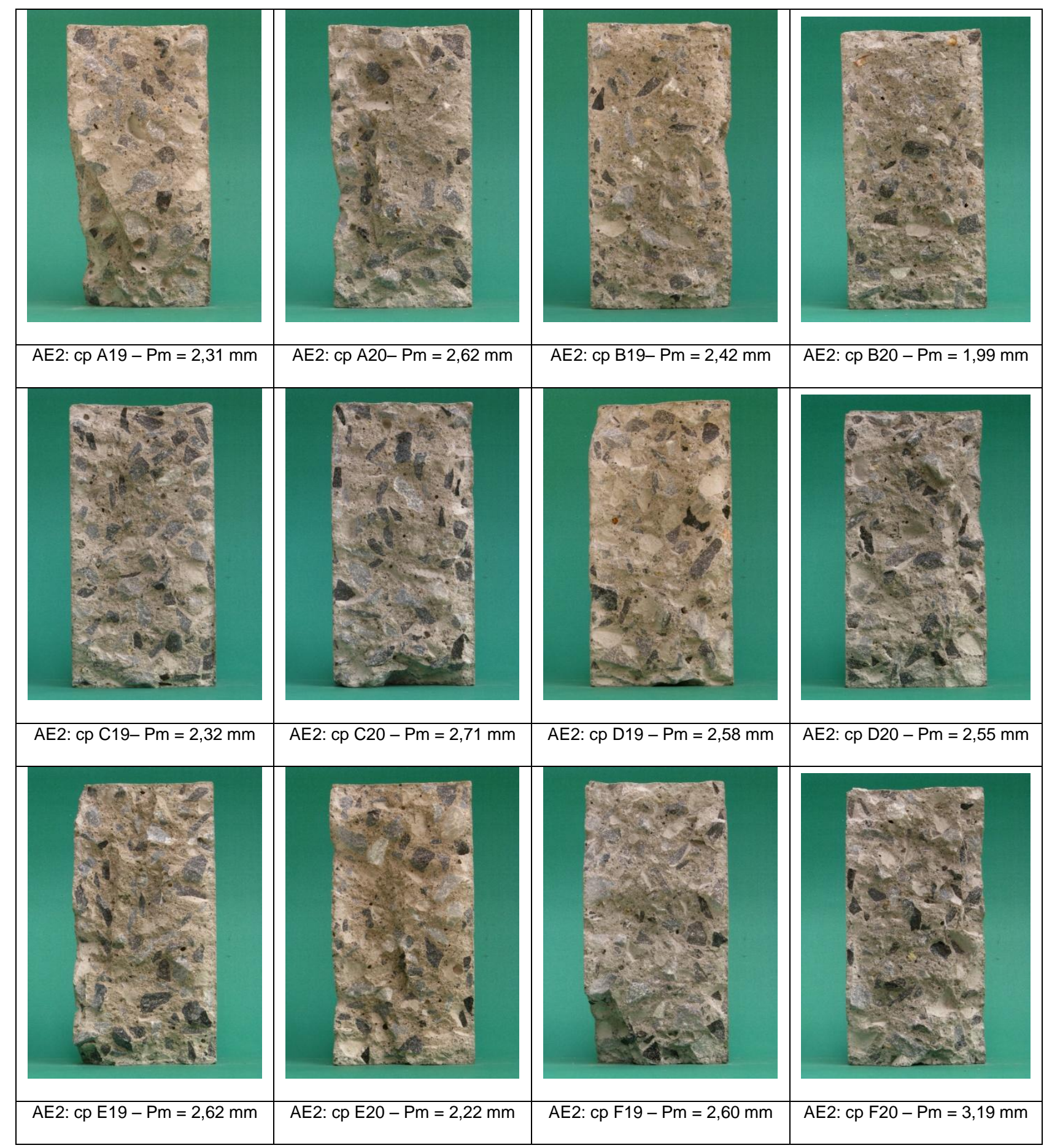




\begin{tabular}{|c|c|c|c|}
\hline 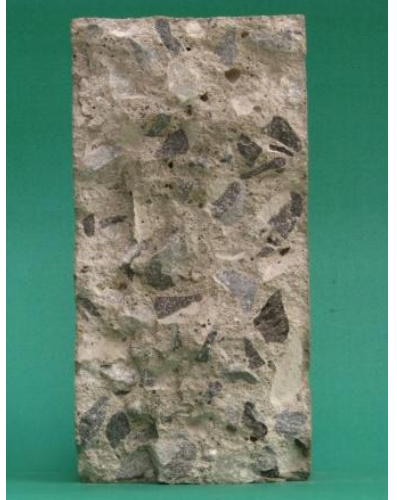 & 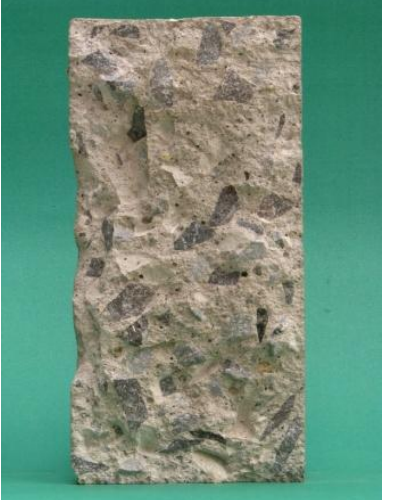 & 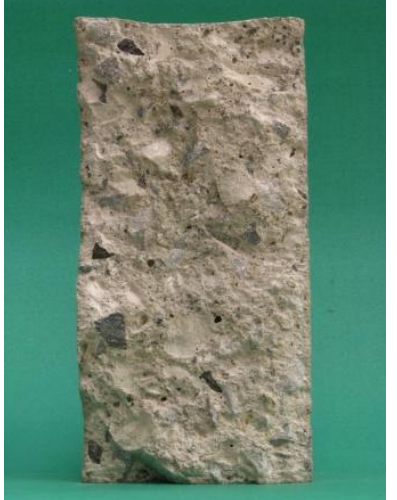 & 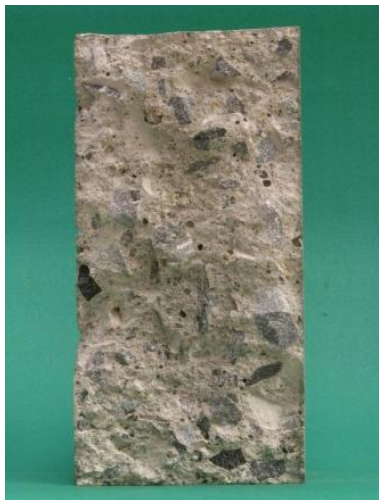 \\
\hline AE3: $\mathrm{cp} \mathrm{A25-Pm}=0,00 \mathrm{~mm}$ & AE3: $\mathrm{cp}$ A26- Pm = 0,00 mm & AE3: $c p$ B25- Pm = 0,00 mm & AE3: $\mathrm{cp}$ B26 $-\mathrm{Pm}=0,00 \mathrm{~mm}$ \\
\hline$x^{2} x^{2}+4$ & Sets & $\frac{1}{2}+\frac{1}{21}$ & 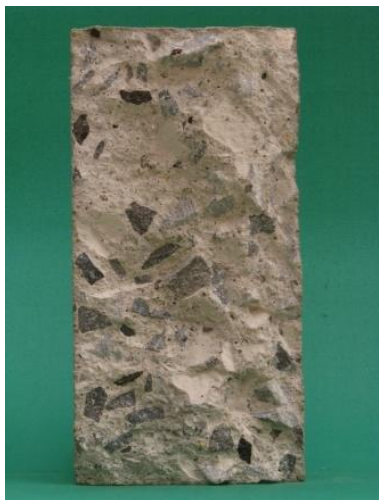 \\
\hline AE3: $\mathrm{cp}$ C25- $\mathrm{Pm}=0,00 \mathrm{~mm}$ & AE3: $\mathrm{cp}$ C26 $-\mathrm{Pm}=0,00 \mathrm{~mm}$ & AE3: $c p$ D25 $-\mathrm{Pm}=0,00 \mathrm{~mm}$ & AE3: $c p$ D26 - Pm = 0,00 mm \\
\hline 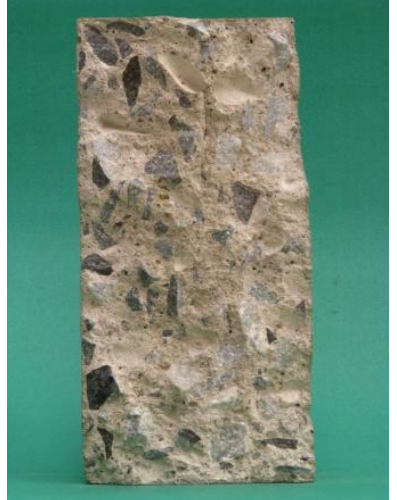 & 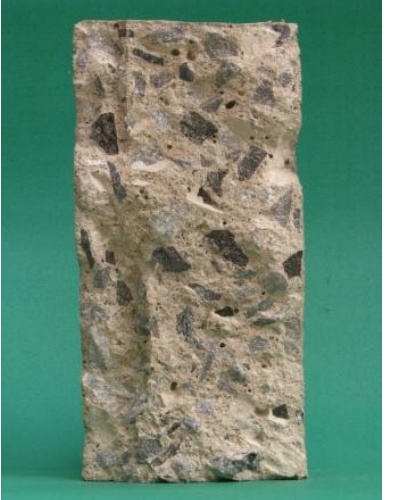 & 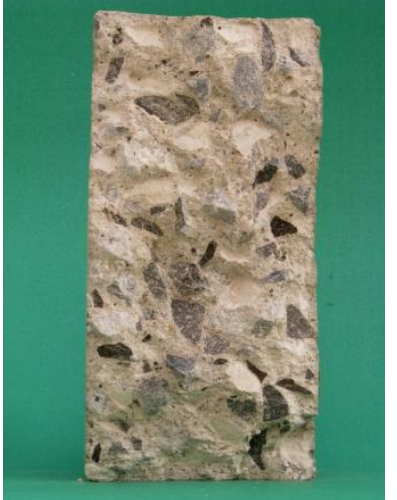 & 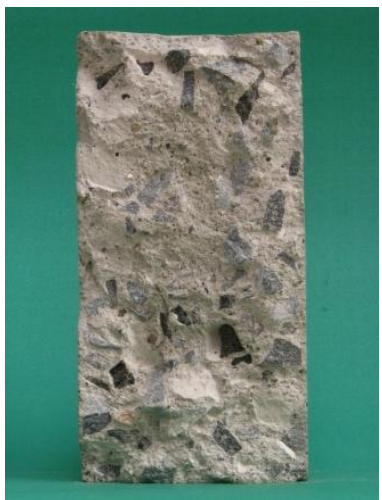 \\
\hline AE3: $c p$ E25-Pm = 0,00 mm & AE3: $\mathrm{cp}$ E26 - Pm = 0,00 mm & AE3: $\mathrm{cp} \mathrm{F25-Pm} \mathrm{=0,00} \mathrm{mm}$ & AE3: $\mathrm{cp} F 26-\mathrm{Pm}=0,00 \mathrm{~mm}$ \\
\hline
\end{tabular}


APÊNDICE C - CORPOS-DE-PROVA- ENSAIOS DE CARBONATAÇÃO (AE1, AE2, AE3 91D)

Data de moldagem dos corpos-de-prova: 13/08/2009

$\checkmark$ Idade de ensaio: 91 dias

$\checkmark$ (AE1) Corpos-de-prova 7 e 8 - expostos em câmara a $5 \%$ de $\mathrm{CO}_{2}$;

$\checkmark$ (AE2) Corpos-de-prova 19 e 20 - ciclagem secagem 24h em tanque com água;

$\checkmark$ (AE3) Corpos-de-prova 25 e 26 - ciclagem secagem contínua.

$\checkmark$ Ensaiados com fenolftaleína

$\mathrm{Pm}=$ profundidade de penetração em $\mathrm{mm}$.

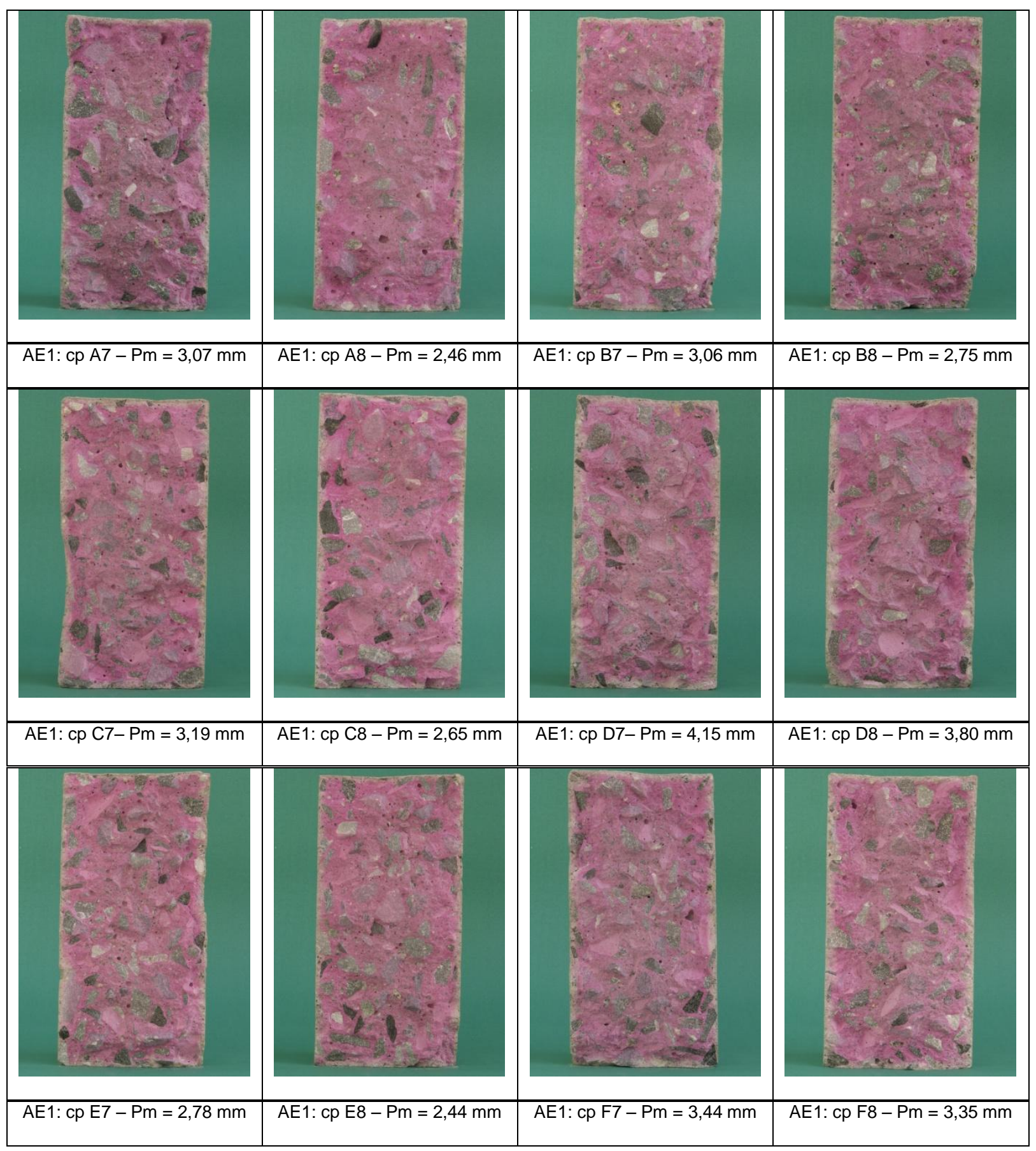




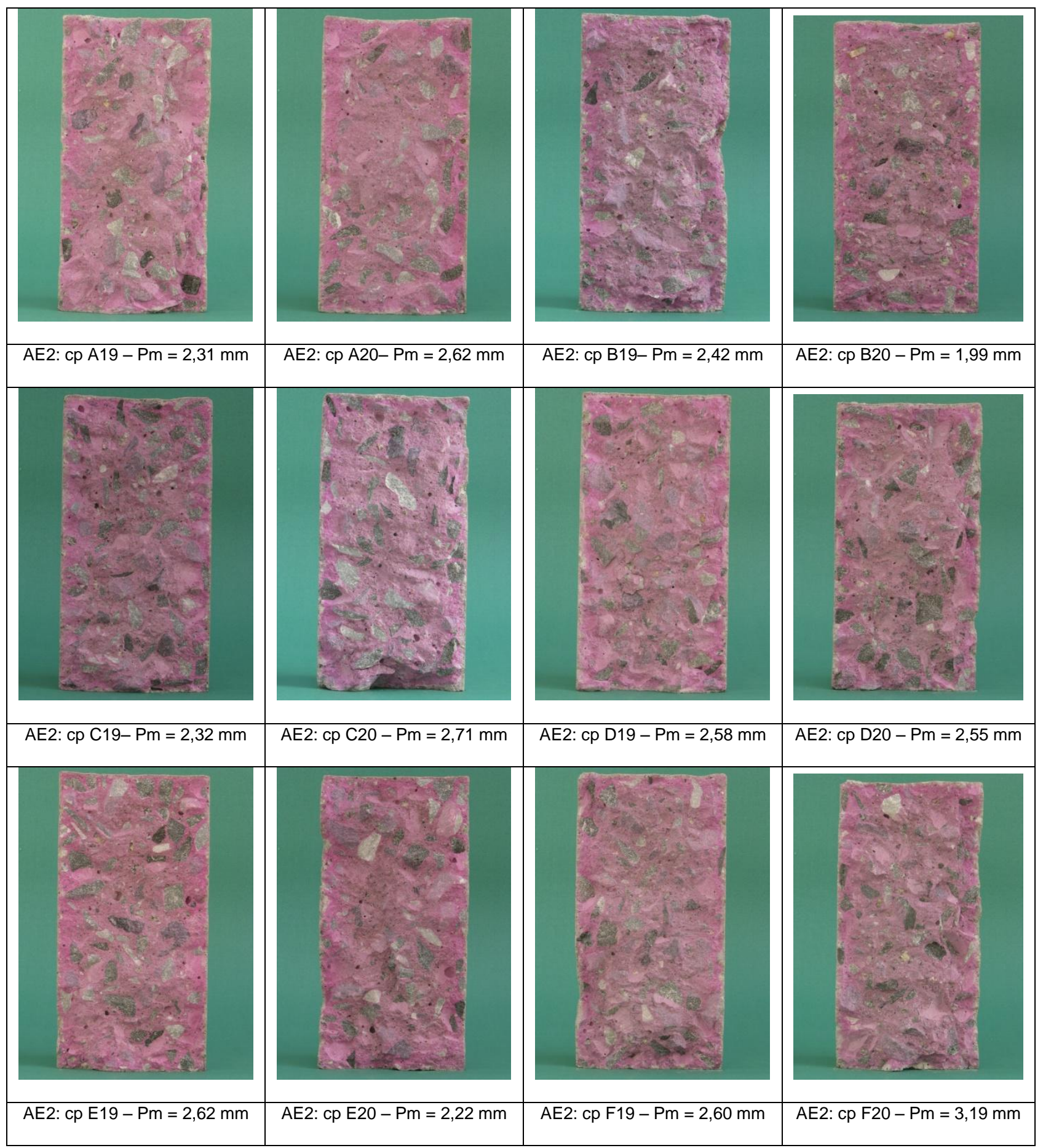




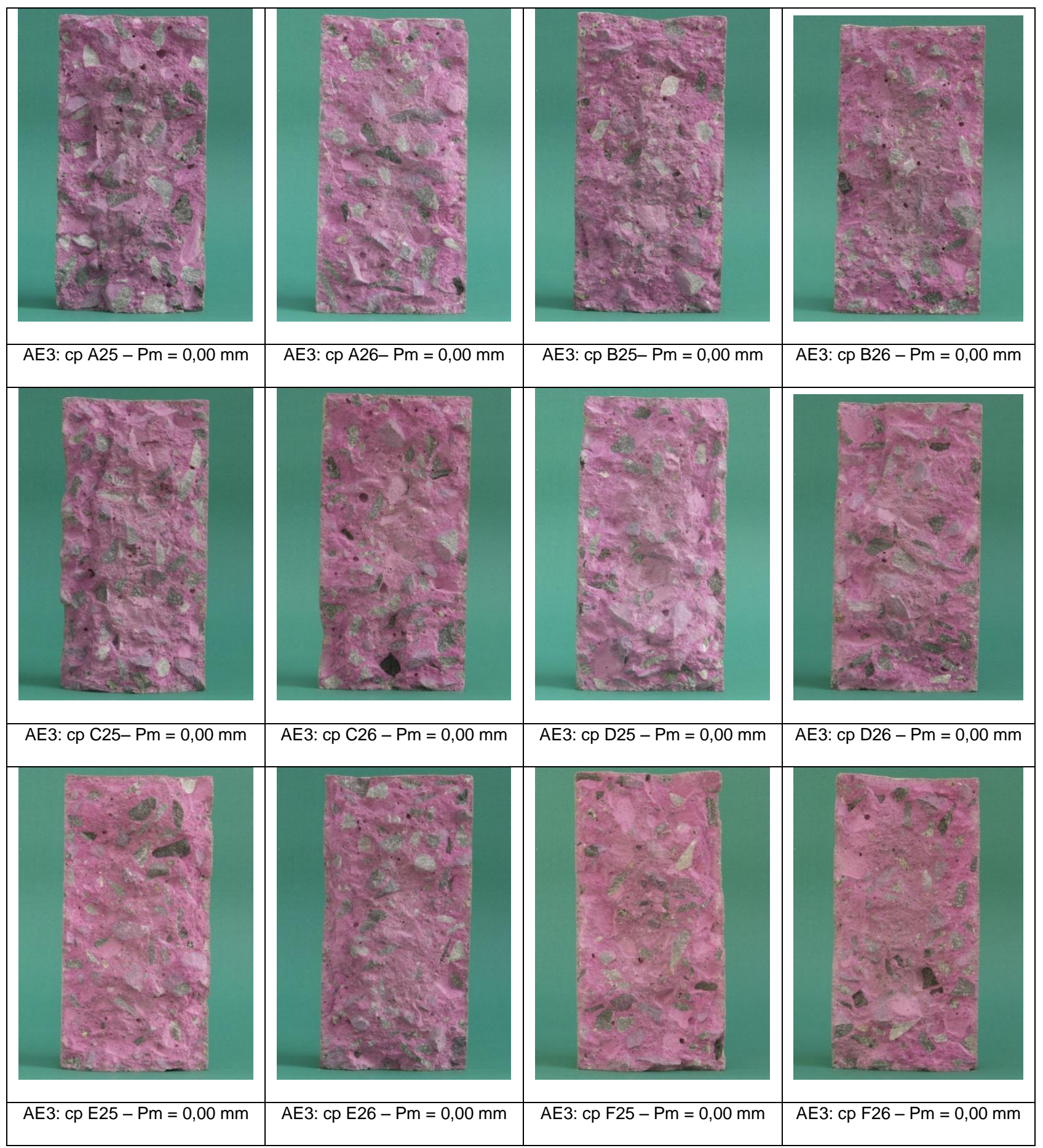


APÊNDICE C - CORPOS-DE-PROVA- ENSAIOS DE CARBONATAÇÃO (AE1, AE2, AE3 203D)

Data de moldagem dos corpos-de-prova: 13/08/2009

$\checkmark$ Idade de ensaio: 203 dias

$\checkmark$ (AE1) Corpos-de-prova 9 e 10 - expostos em câmara a $5 \%$ de $\mathrm{CO}_{2}$;

$\checkmark$ (AE2) Corpos-de-prova 21 e 22 - ciclagem secagem 24h em tanque com água;

$\checkmark$ (AE3) Corpos-de-prova 27 e 28 - ciclagem secagem contínua.

$\checkmark$ Ensaiados com fenolftaleína - Pm = profundidade de penetração em $\mathrm{mm}$.

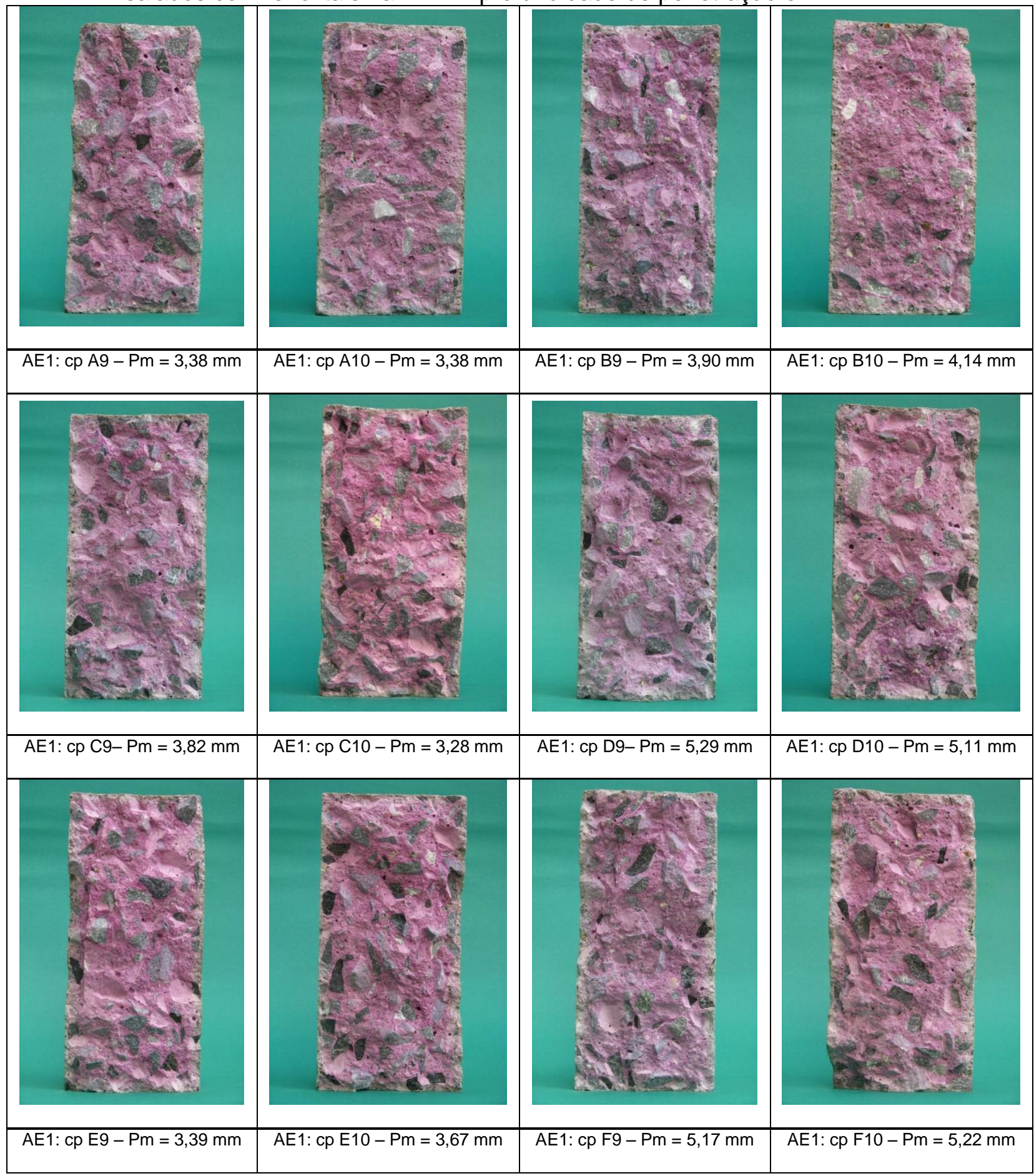




\begin{tabular}{|c|c|c|c|}
\hline 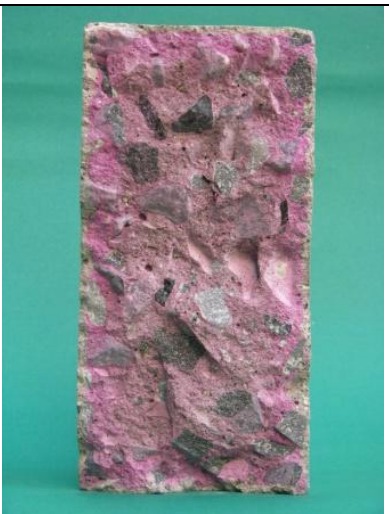 & 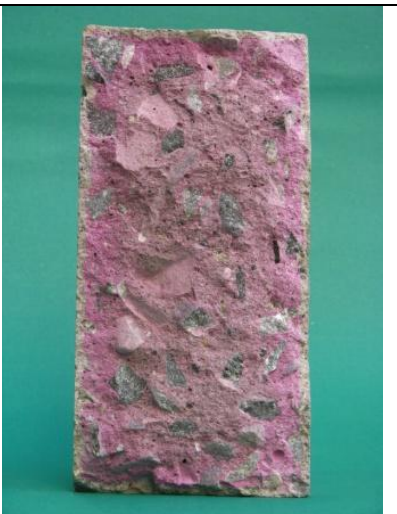 & 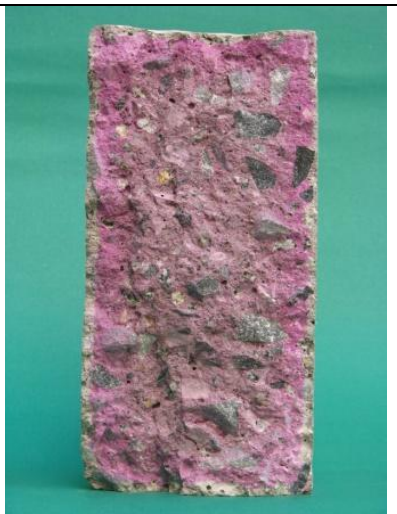 & 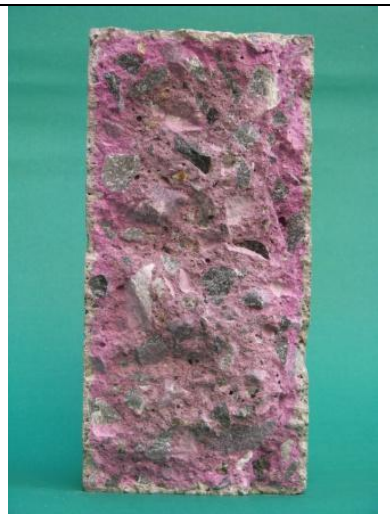 \\
\hline AE2: $\mathrm{cp} \mathrm{A21-Pm}=3,14 \mathrm{~mm}$ & AE2: $\mathrm{cp}$ A22- $\mathrm{Pm}=3,56 \mathrm{~mm}$ & AE2: $\mathrm{cp} \mathrm{B21-} \mathrm{Pm} \mathrm{=} \mathrm{4,37} \mathrm{mm}$ & AE2: $\mathrm{cp}$ B22 $-\mathrm{Pm}=3,53 \mathrm{~mm}$ \\
\hline 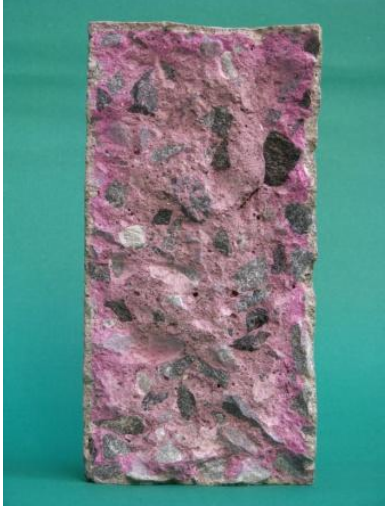 & 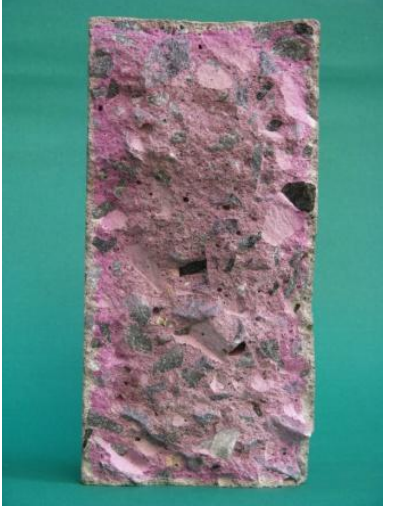 & 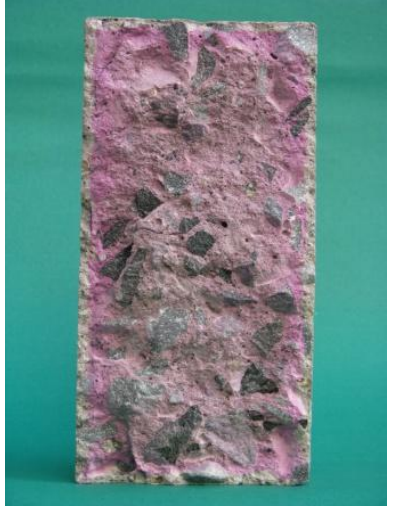 & 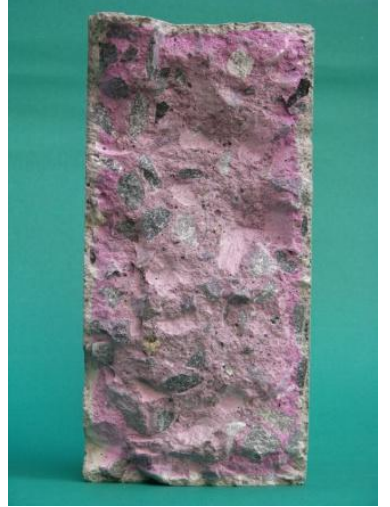 \\
\hline AE2: $c p$ C21 - Pm = 3,21 mm & 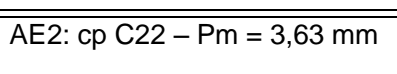 & AE2: cp D21 - Pm = 4,27 mm & AE2: $\mathrm{cp}$ D22 - Pm = 4,47 mm \\
\hline 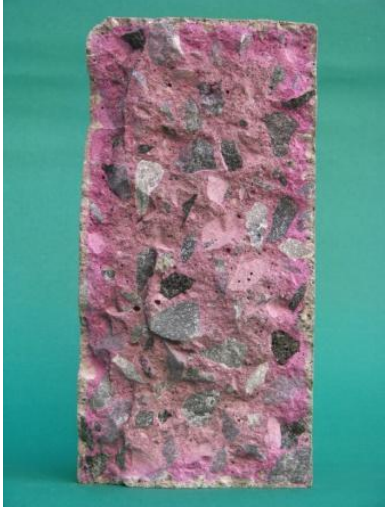 & 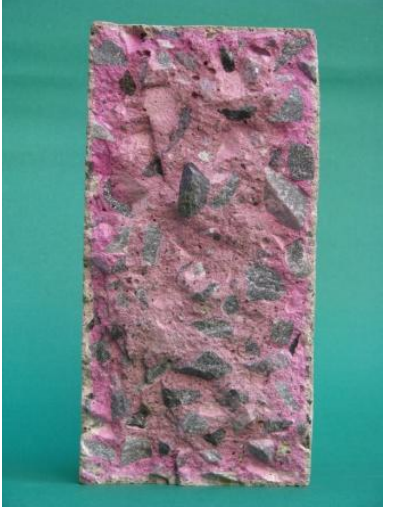 & 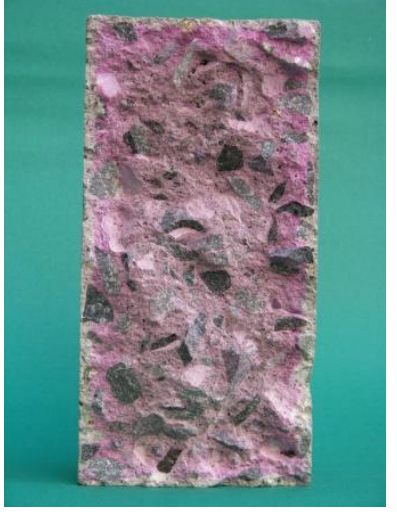 & 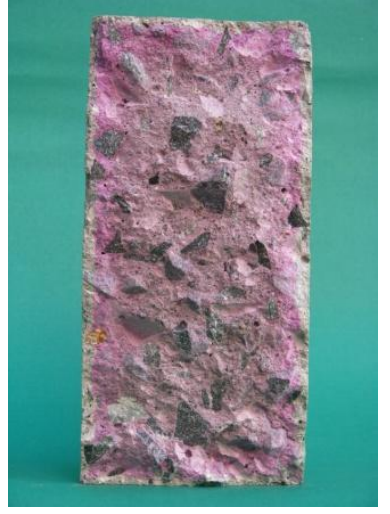 \\
\hline AE2: $\mathrm{cp} \mathrm{E} 21-\mathrm{Pm}=2,63 \mathrm{~mm}$ & AE2: cp E22 - Pm = 2,93 mm & 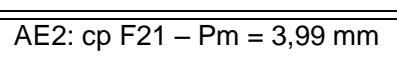 & AE2: $\mathrm{cp} \mathrm{F22} \mathrm{-} \mathrm{Pm} \mathrm{=} \mathrm{4,00} \mathrm{mm}$ \\
\hline
\end{tabular}




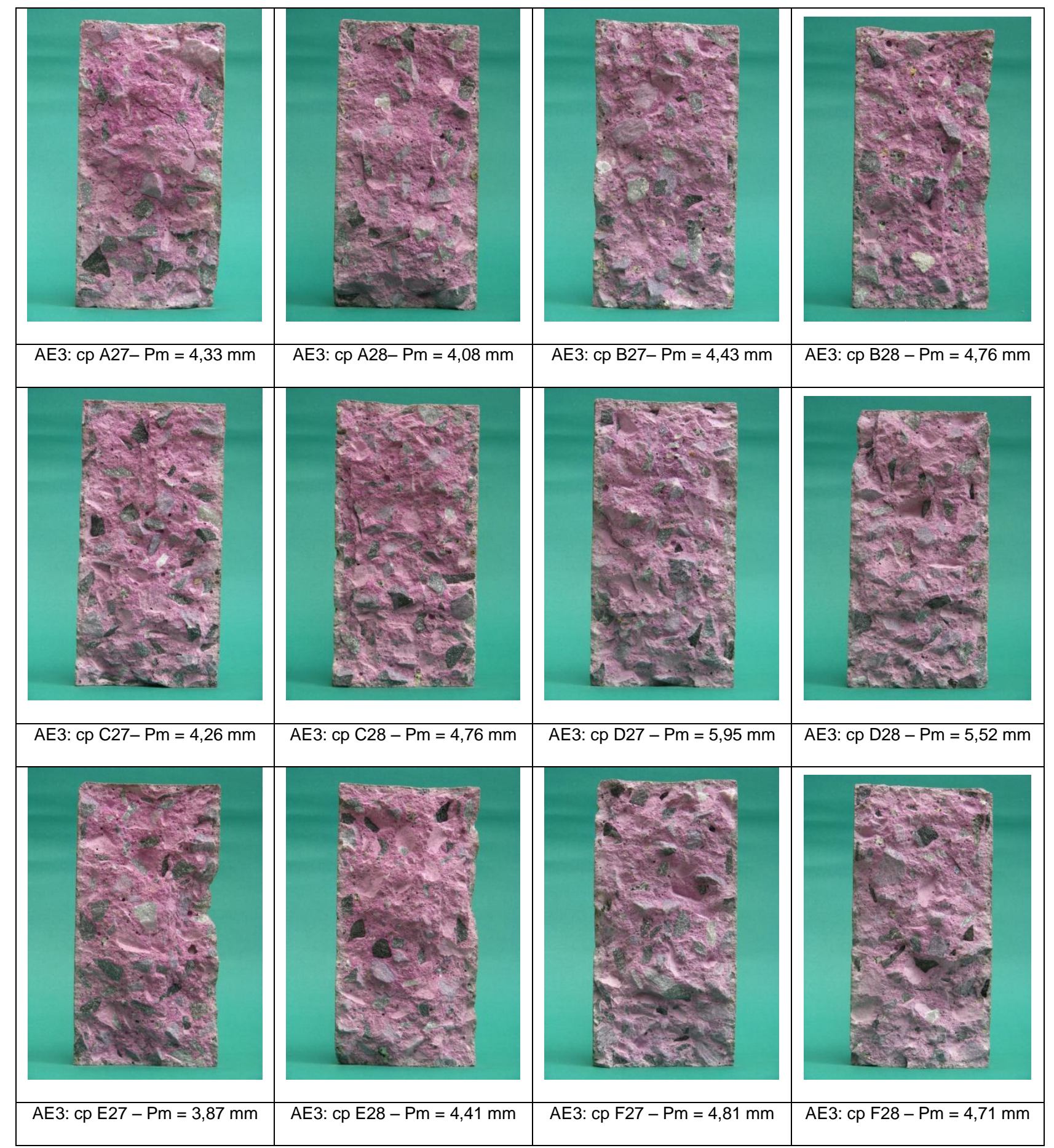


APÊNDICE C - CORPOS-DE-PROVA- ENSAIOS DE CARBONATAÇÃO (AE1 - 63D IMAGE J)

Data de moldagem dos corpos-de-prova: 13/08/2009

$\checkmark$ Idade de ensaio: 63 dias

$\checkmark$ (AE1) Corpos-de-prova 5 e 6 - expostos em câmara a $5 \%$ de $\mathrm{CO}_{2}$;

$\checkmark$ Ensaiados com fenolftaleína

$\checkmark$ Programa Image $\mathrm{J}-\mathrm{Pm}=$ profundidade de penetração em $\mathrm{mm}$.

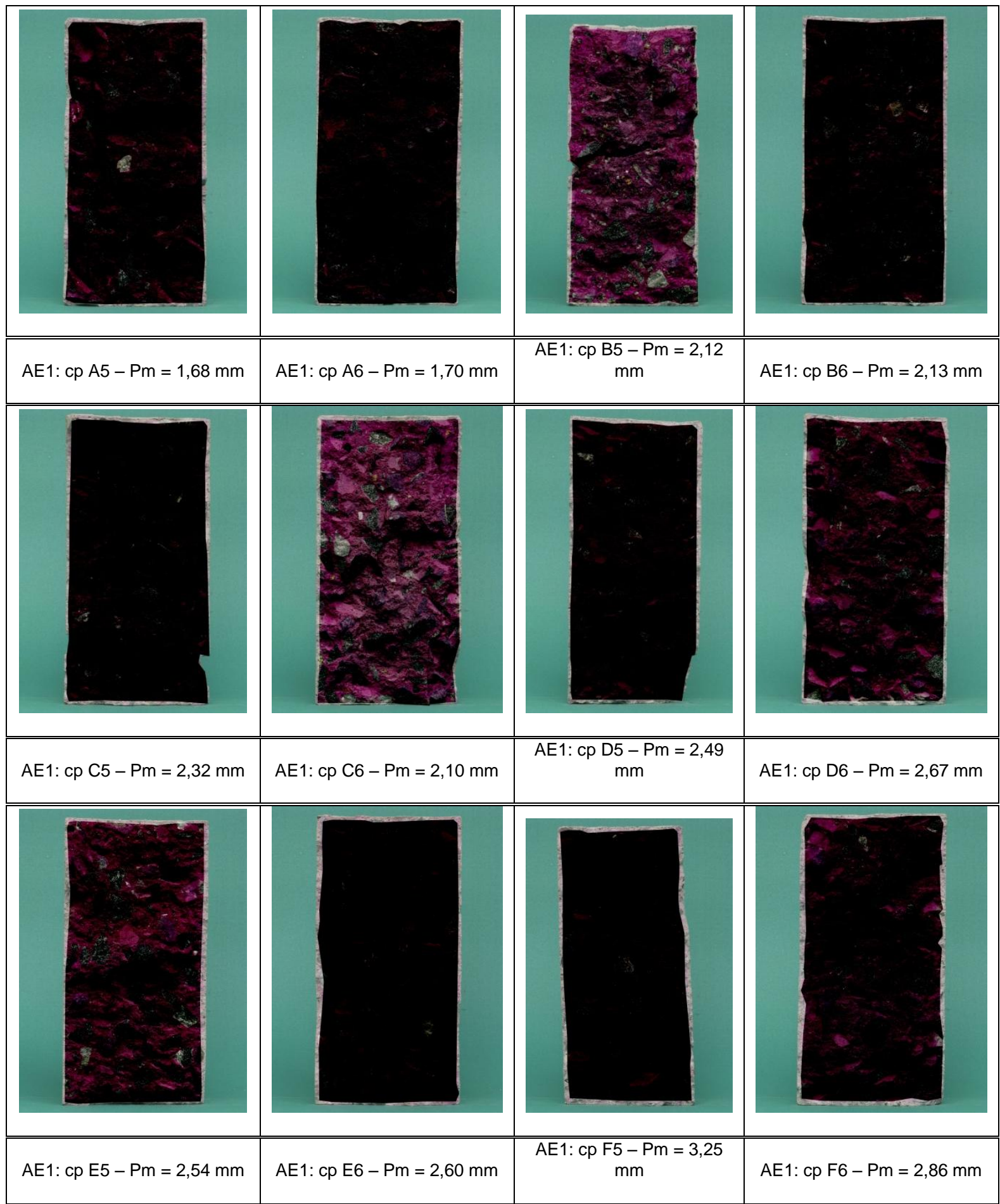


APÊNDICE C - CORPOS-DE-PROVA- ENSAIOS DE CARBONATAÇÃO (AE1, AE2 - 91D - IMAGE J)

Data de moldagem dos corpos-de-prova: 13/08/2009

$\checkmark$ Idade de ensaio: 91 dias

$\checkmark$ (AE1) Corpos-de-prova 7 e 8 - expostos em câmara a $5 \%$ de $\mathrm{CO}_{2}$;

$\checkmark$ (AE2) Corpos-de-prova 19 e 20 - com imersão em água;

$\checkmark$ Ensaiados com fenolftaleína

$\checkmark$ Programa ImageJ

$\mathrm{Pm}=$ profundidade de penetração em $\mathrm{mm}$.

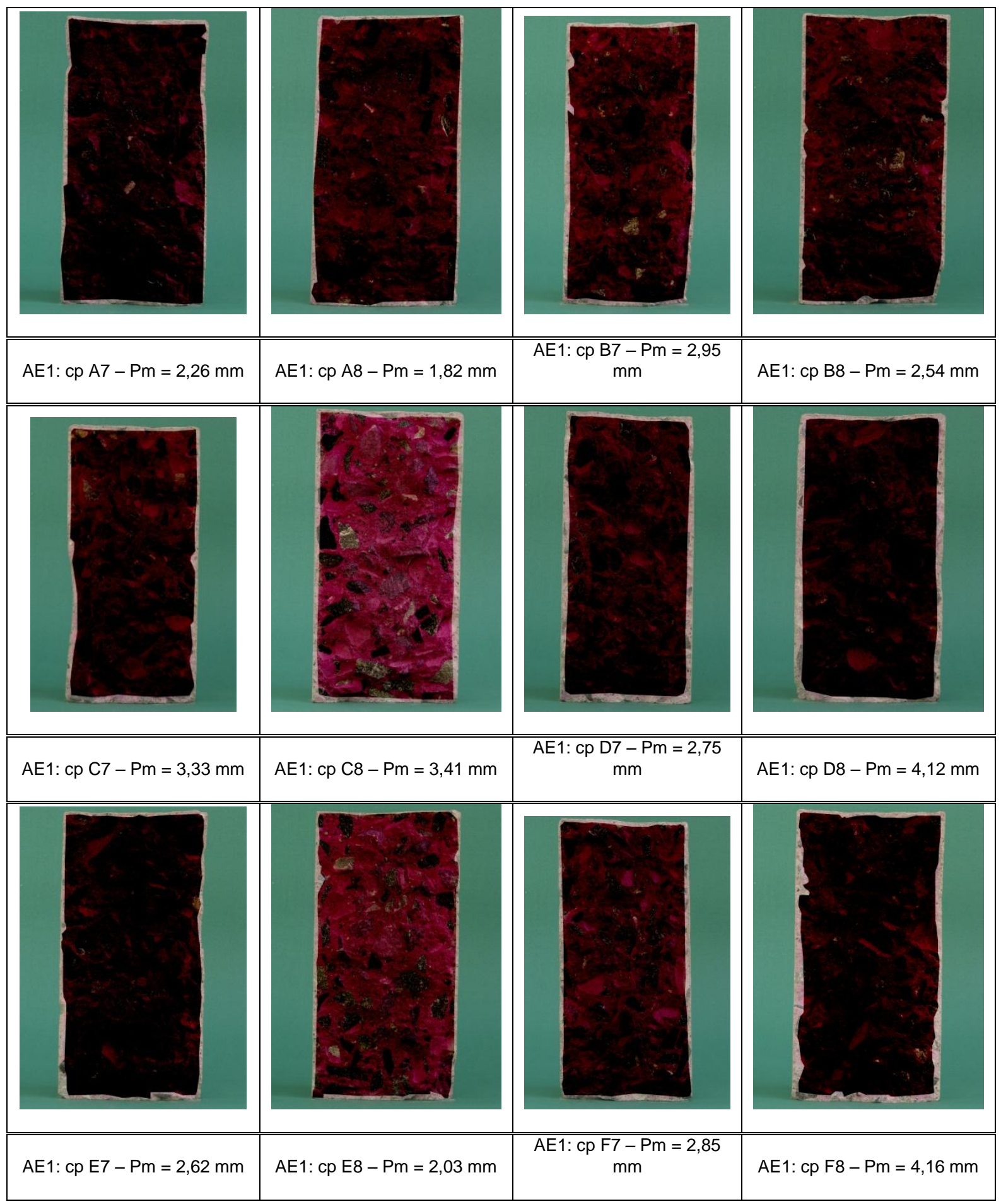




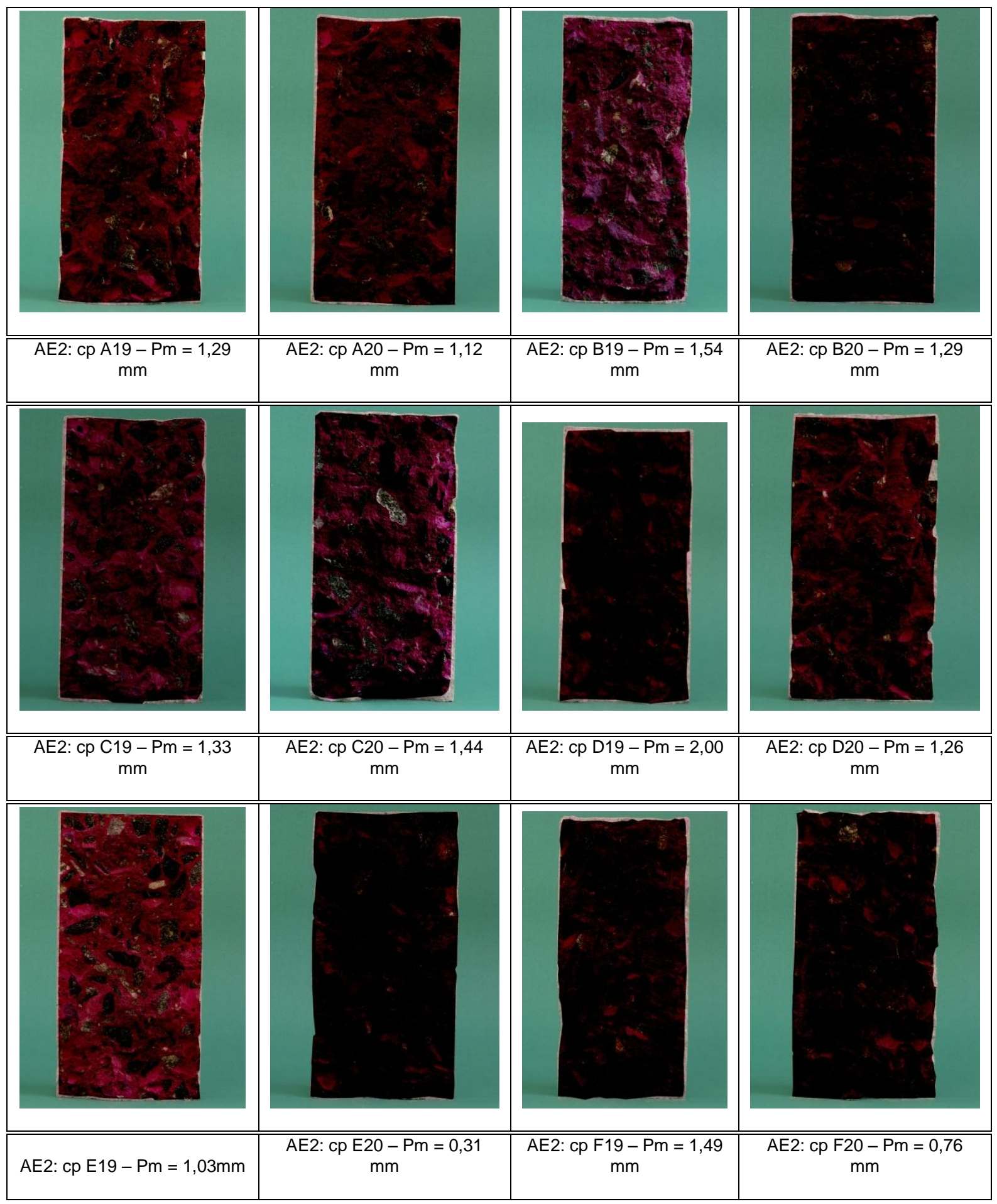


APÊNDICE C - CORPOS-DE-PROVA- ENSAIOS DE CARBONATAÇÃO (AE1, AE2, AE3 203D - IMAGE J)

Data de moldagem dos corpos-de-prova: 13/08/2009

$\checkmark$ Idade de ensaio: 203 dias

$\checkmark$ (AE1) Corpos-de-prova 9 e 10 - expostos em câmara a $5 \%$ de $\mathrm{CO}_{2}$;

$\checkmark$ (AE2) Corpos-de-prova 21 e 22 - com imersão em água;

$\checkmark$ (AE3) Corpos-de-prova 27 e 28 - secagem continua

$\checkmark$ Ensaiados com fenolftaleína

$\checkmark$ Programa Image

$\mathrm{Pm}=$ profundidade de penetração em $\mathrm{mm}$.

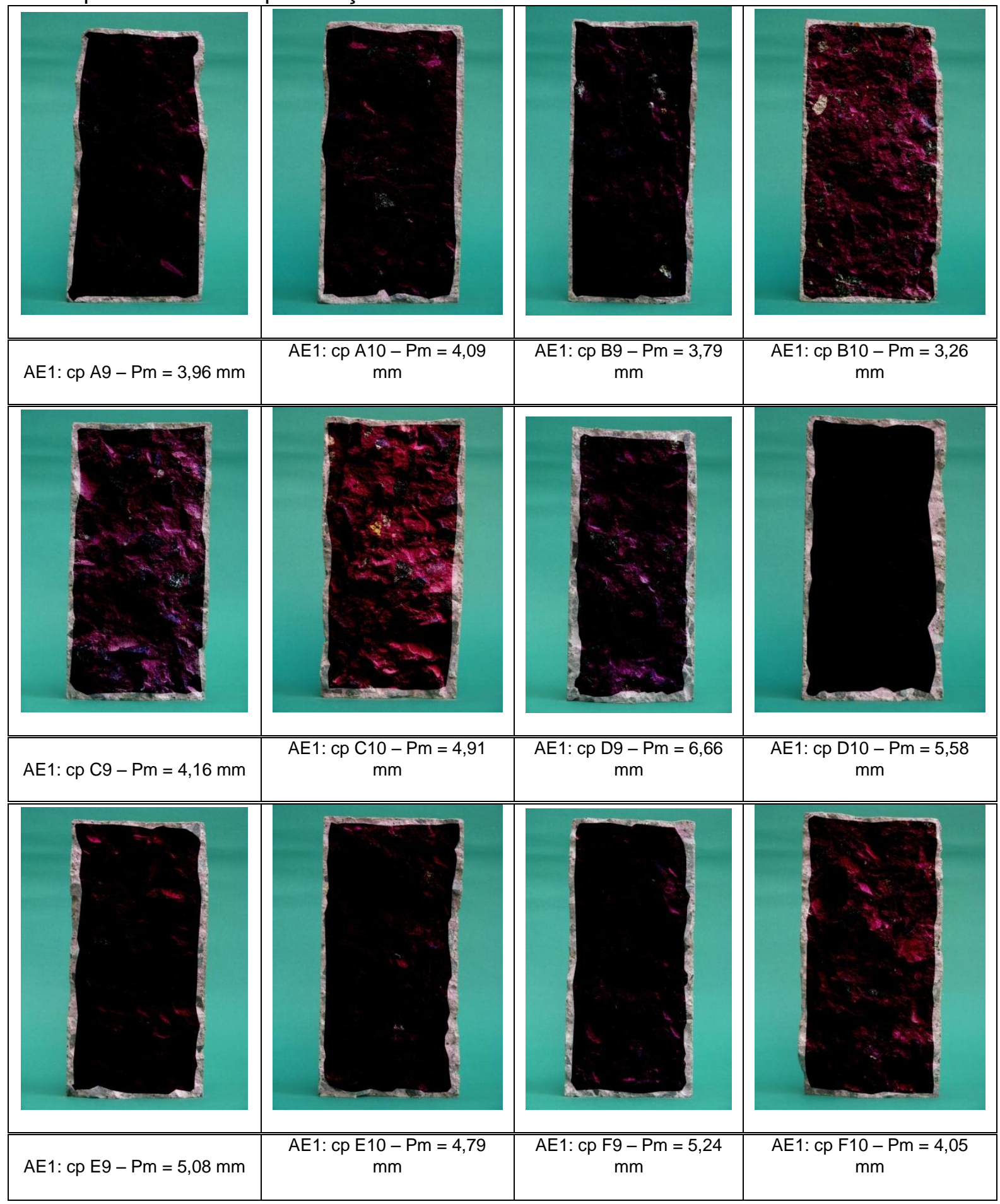




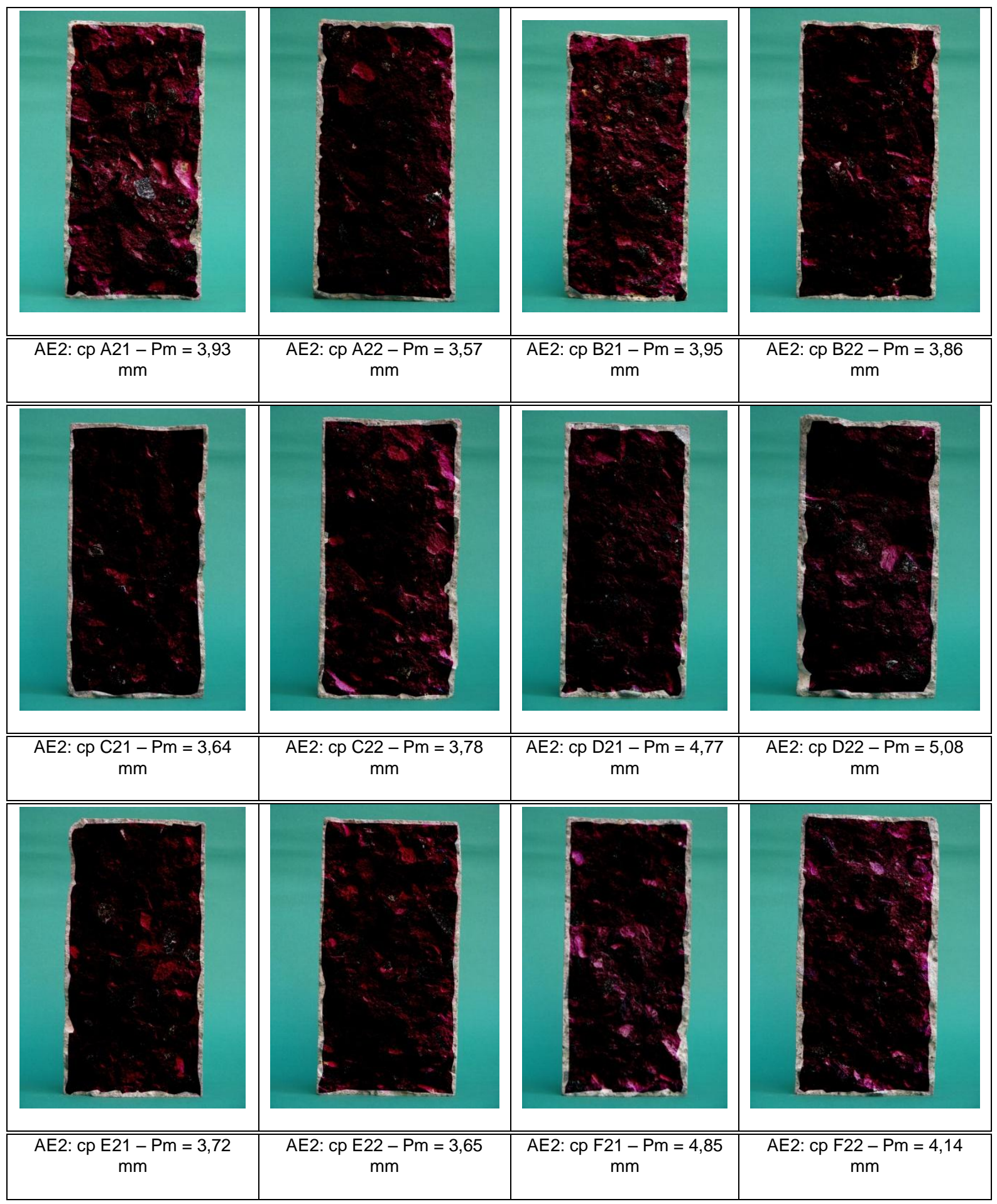




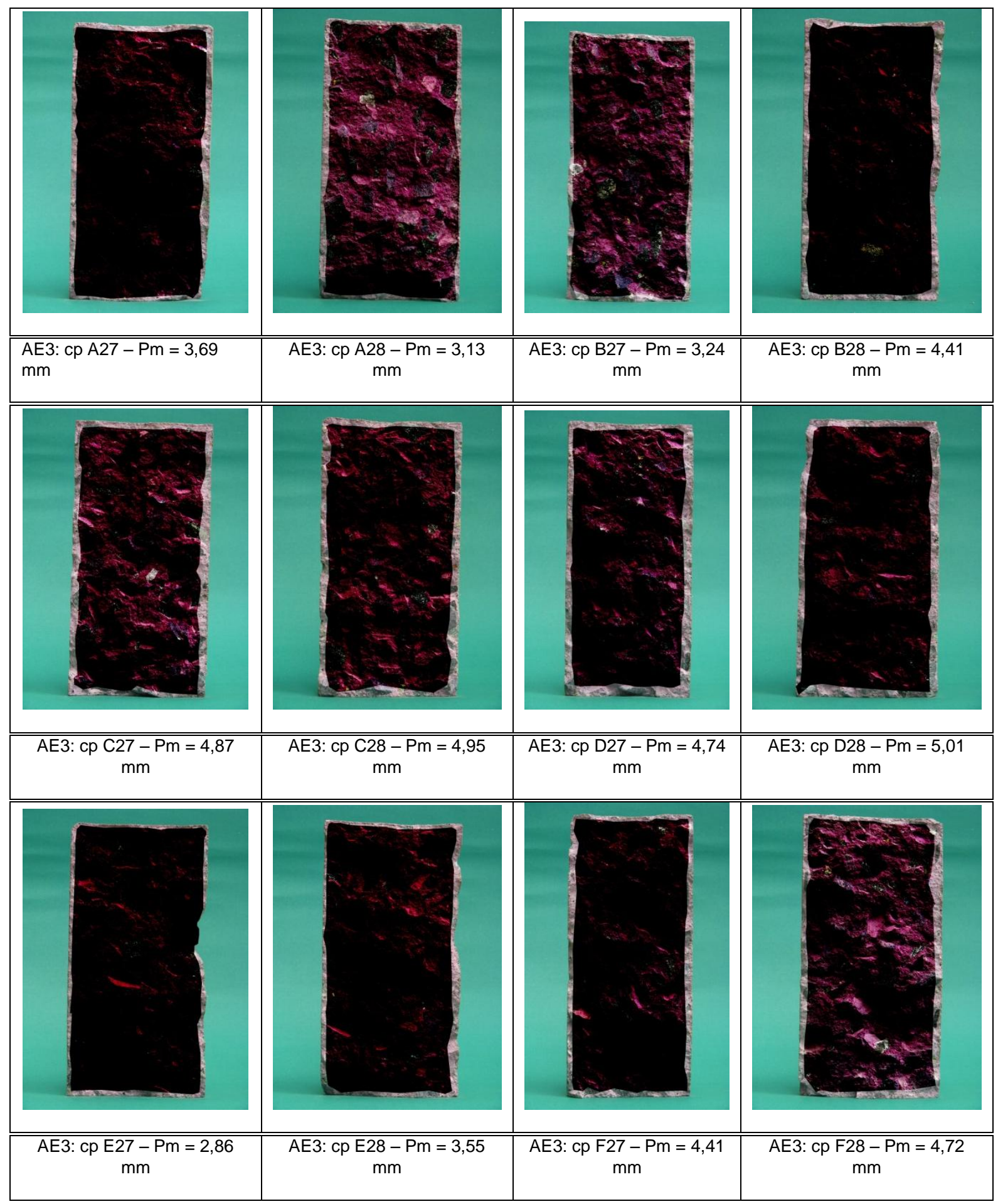


APÊNDICE C - CORPOS-DE-PROVA- ENSAIOS DE CARBONATAÇÃO (AE1, AE2, AE3 203D - LEICA QWIN)

Data de moldagem dos corpos-de-prova: 13/08/2009

$\checkmark$ Idade de ensaio: 203 dias

$\checkmark$ (AE1) Corpos-de-prova 9 e 10 - expostos em câmara a $5 \%$ de $\mathrm{CO}_{2}$;

$\checkmark$ (AE2) Corpos-de-prova 21 e 22 - com imersão em água;

$\checkmark$ (AE3) Corpos-de-prova 27 e 28 - secagem continua

$\checkmark$ Ensaiados com fenolftaleína

$\checkmark$ Programa LeicaQwin

$\mathrm{Pm}=$ profundidade de penetração em $\mathrm{mm}$.

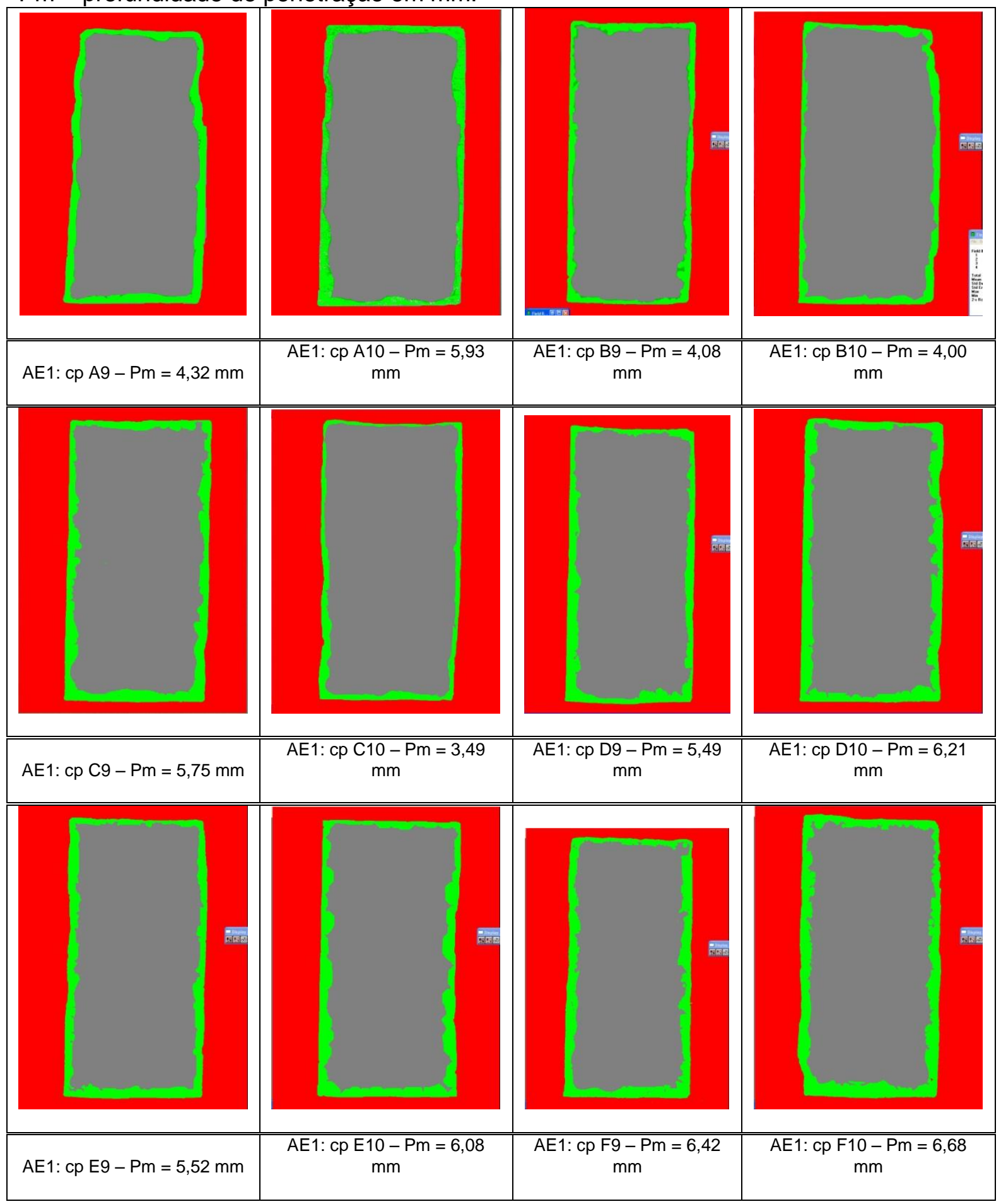




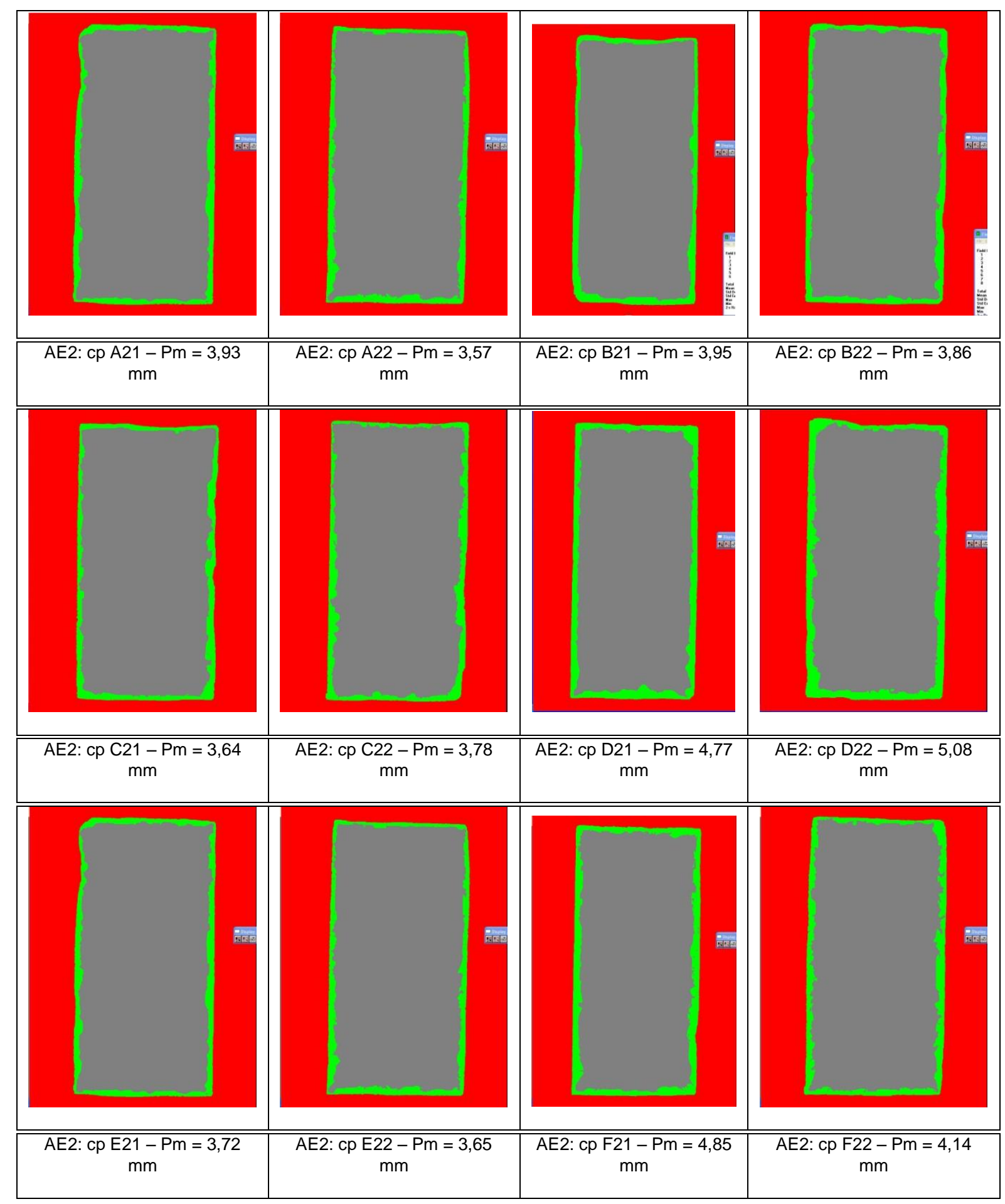




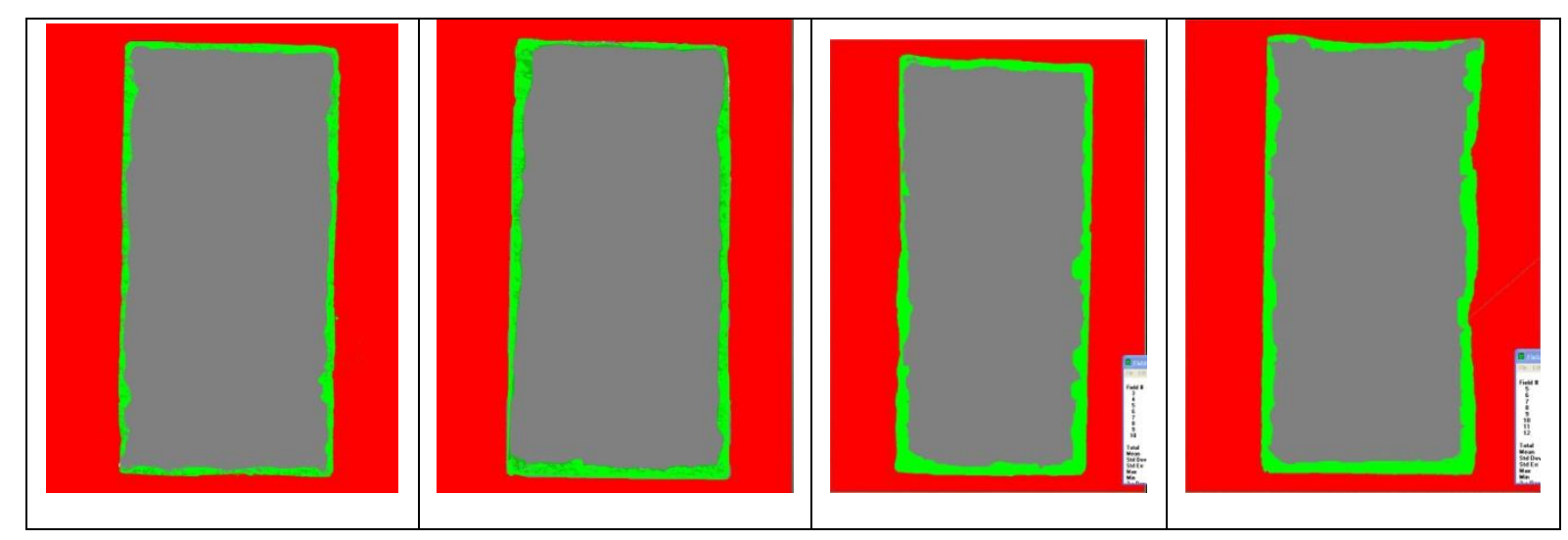

\begin{tabular}{|c|c|c|c|}
\hline AE3: $c p$ A27 $-\mathrm{Pm}=2,70 \mathrm{~mm}$ & $\begin{array}{c}\text { AE3: } \mathrm{cp} \mathrm{A28}-\mathrm{Pm}=2,29 \\
\mathrm{~mm}\end{array}$ & $\begin{array}{c}\mathrm{AE3}: \mathrm{cp} \mathrm{B} 27-\mathrm{Pm}=4,59 \\
\mathrm{~mm}\end{array}$ & $\begin{array}{c}\text { AE3: } \mathrm{cp} \mathrm{B28}-\mathrm{Pm}=4,83 \\
\mathrm{~mm}\end{array}$ \\
\hline
\end{tabular}

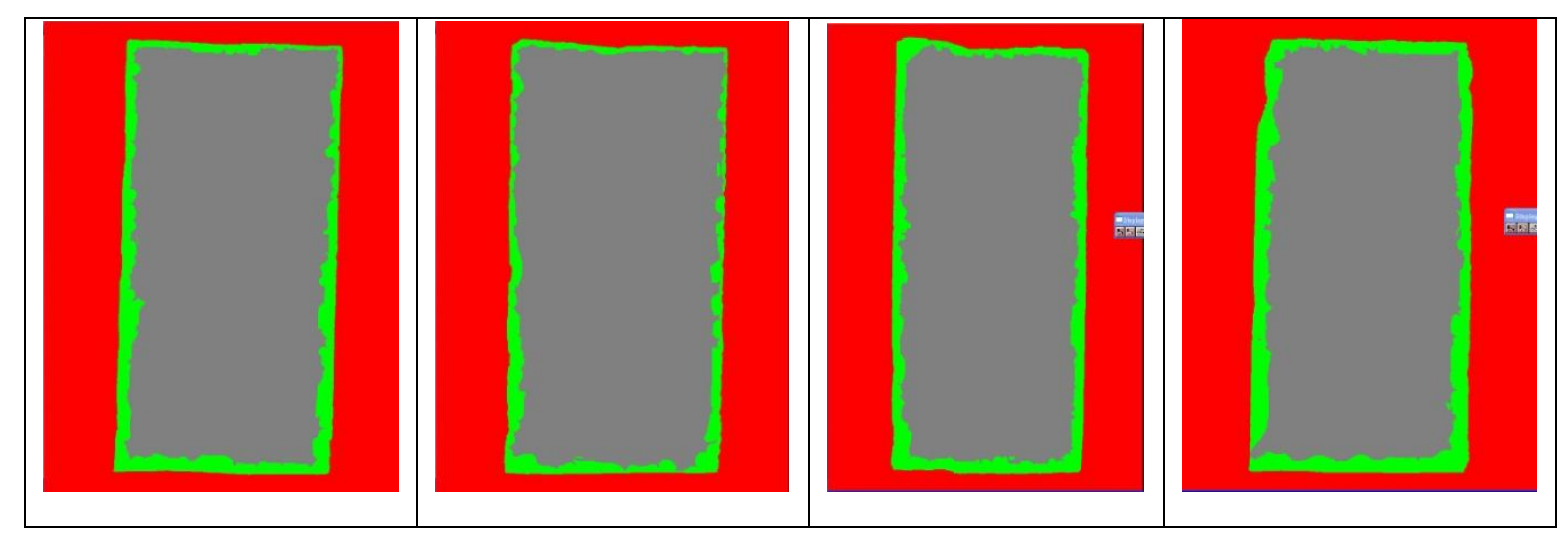

\begin{tabular}{|c|c|c|c|}
\hline $\begin{array}{c}\mathrm{AE} 3: \mathrm{cp} \mathrm{C27}-\mathrm{Pm}=4,85 \\
\mathrm{~mm}\end{array}$ & $\begin{array}{c}\mathrm{AE3}: \mathrm{cp} \mathrm{C28}-\mathrm{Pm}=3,59 \\
\mathrm{~mm}\end{array}$ & $\begin{array}{c}\mathrm{AE3}: \mathrm{cp} \mathrm{D27}-\mathrm{Pm}=6,96 \\
\mathrm{~mm}\end{array}$ & $\begin{array}{c}\mathrm{AE3}: \mathrm{cp} \mathrm{D28}-\mathrm{Pm}=6,05 \\
\mathrm{~mm}\end{array}$ \\
\hline
\end{tabular}

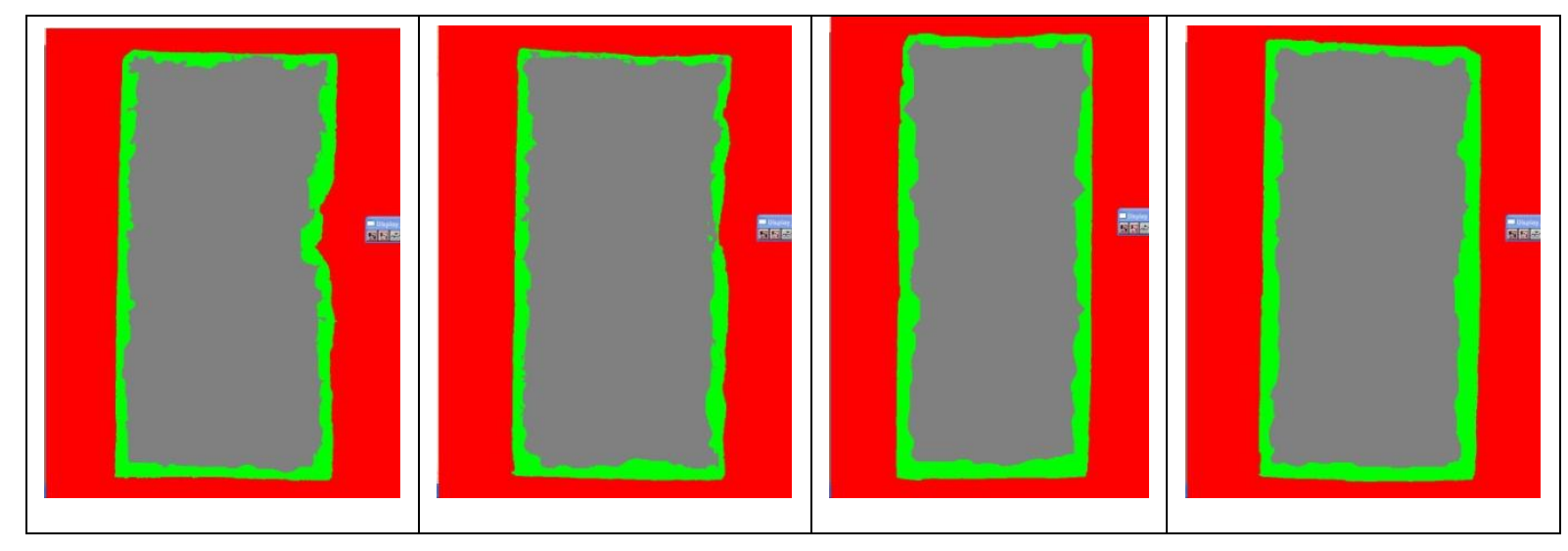

\begin{tabular}{|c|c|c|c|}
\hline $\begin{array}{c}\text { AE3: } c p \text { E27 }-\mathrm{Pm}=10,74 \\
\mathrm{~mm}\end{array}$ & $\begin{array}{c}\mathrm{AE} 3: \mathrm{cp} \mathrm{E28}-\mathrm{Pm}=5,18 \\
\mathrm{~mm}\end{array}$ & $\begin{array}{c}\mathrm{AE} 3: \mathrm{cp} \mathrm{F} 27-\mathrm{Pm}=6,63 \\
\mathrm{~mm}\end{array}$ & $\begin{array}{c}\text { AE3: } \mathrm{cp} \mathrm{F} 28-\mathrm{Pm}=6,62 \\
\mathrm{~mm}\end{array}$ \\
\hline
\end{tabular}


APÊNDICE D - TABELAS DE ANÁLISES DE FATOR DUPLO COM REPETIÇÃO

TABELA 129 - Resumo das análises de variância (ANOVA-2Fat) dos ensaios de resistência à tração por compressão diametral com a influência da mistura e dos tipos de ciclagem.

\begin{tabular}{|c|c|c|c|c|c|}
\hline $\begin{array}{l}\text { Propriedade / } \\
\text { Idade de ensaio }\end{array}$ & Interação & Resumo & \multicolumn{2}{|c|}{ Influenciou? } & P-Valor \\
\hline \multirow{3}{*}{$f_{\text {ct,sp } 8 \text { acel. }}$. } & \multirow{3}{*}{$\mathrm{CO}_{2}$ e $\mathrm{H}_{2} \mathrm{O}$} & MISTURA* (CAMINHÃ̃) & NÃOO & (Amostra) & 0,2946 \\
\hline & & CICLAGEM & NÃOO & (Colunas) & 0,4937 \\
\hline & & COMBINAÇÃOO DE FATORES & NÃO & (Interações) & 0,9018 \\
\hline \multirow{3}{*}{ 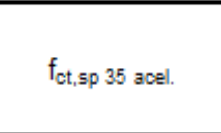 } & \multirow{3}{*}{$\mathrm{CO}_{2}$ e $\mathrm{H}_{2} \mathrm{O}$} & MISTURA $^{*}(\mathrm{CAMINHÃO})$ & NÃO & (Amostra) & 0,1504 \\
\hline & & CICLAGEM & NÃO & (Colunas) & 0,6867 \\
\hline & & COMBINAÇÃ̃O DE FATORES & NÃO & (Interaçỗes) & 0,0516 \\
\hline \multirow{3}{*}{$f_{c t, 5 p} 63$ acel. } & \multirow{3}{*}{$\mathrm{CO}_{2}$ e $\mathrm{H}_{2} \mathrm{O}$} & MISTURA $^{*}(\mathrm{CAMINHÃO})$ & NÃO & (Amostra) & 0,50894 \\
\hline & & CICLAGEM & NÃO & (Colunas) & 0,07723 \\
\hline & & COMBINAÇÃOO DE FATORES & NÃO & (Interações) & 0,16706 \\
\hline \multirow{12}{*}{$f_{\text {ct, sp } 91 \text { acel. }}$} & \multirow{3}{*}{ OS 3 JUNTOS } & MISTURA $^{*}$ (CAMINHÃO) & SIM & (Amostra) & $3,35592 \mathrm{E}-05$ \\
\hline & & \begin{tabular}{|l|} 
CICLAGEM \\
\end{tabular} & SIM & (Colunas) & $8,11548 \mathrm{E}-08$ \\
\hline & & COMBINAÇÃOO DE FATORES & NÃO & (Interações) & 0,0596 \\
\hline & \multirow{3}{*}{$\mathrm{SEC} \mathrm{E} \mathrm{CO} 2$} & MISTURA $^{*}$ (CAMINHÃO) & SIM & (Amostra) & 0,00336 \\
\hline & & CICLAGEM & NÃO & (Colunas) & 0,15663 \\
\hline & & COMBINAÇÃO DE FATORES & NÂO & (Interações) & 0,13826 \\
\hline & \multirow{3}{*}{$\mathrm{SEC} \mathrm{E} \mathrm{H}_{2} \mathrm{O}$} & MISTURA $^{*}(\mathrm{CAMINHẪO})$ & SIM & (Amostra) & 0,00215 \\
\hline & & CICLAGEM & SIM & (Colunas) & $1,42786 \mathrm{E}-05$ \\
\hline & & COMBINACCÃO DE FATORES & NÃO & (Interações) & 0,0680 \\
\hline & \multirow{3}{*}{$\mathrm{CO}_{2}$ e $\mathrm{H}_{2} \mathrm{O}$} & MISTURA $^{*}(\mathrm{CAMINHÃO})$ & SIM & (Amostra) & 0,00014 \\
\hline & & \begin{tabular}{|l} 
CICLAGEM \\
\end{tabular} & SIM & (Colunas) & $2,75654 \mathrm{E}-07$ \\
\hline & & \begin{tabular}{|l} 
COMBINACC̃̃O DE FATORES \\
\end{tabular} & NÃO & (Interações) & 0,16589 \\
\hline \multirow{12}{*}{$f_{c t, s p 203 \text { acsel. }}$} & \multirow{3}{*}{ OS 3 JUNTOS } & MISTURA* (CAMINHÃO) & NÃO & (Amostra) & 0,27227 \\
\hline & & CICLAGEM & SIM & (Colunas) & $6.62614 \mathrm{E}-05$ \\
\hline & & COMBINAÇÃOO DE FATORES & NÃO & (Interações) & 0,87816 \\
\hline & \multirow{3}{*}{$\mathrm{SEC} \mathrm{E} \mathrm{CO} 2$} & MISTURA* (CAMINHÃO) & NÃO & (Amostra) & 0,79541 \\
\hline & & MESMA CICLAGEM & SIM & (Colunas) & 0,03306 \\
\hline & & COMBINAÇÃO DE FATORES & NÃO & (Interações) & 0,78824 \\
\hline & \multirow{3}{*}{$\mathrm{SEC} \mathrm{E} \mathrm{H}_{2} \mathrm{O}$} & MISTURA $^{*}(\mathrm{CAMINHÃO})$ & NÃO & (Amostra) & 0,41572 \\
\hline & & CICLAGEM & SIM & (Colunas) & $6,0298 \mathrm{E}-05$ \\
\hline & & COMBINAÇÃ̃O DE FATORES & NÃO & (Interações) & 0,75105 \\
\hline & \multirow{3}{*}{$\mathrm{CO}_{2}$ e $\mathrm{H}_{2} \mathrm{O}$} & MISTURA $^{*}(\mathrm{CAMINHÃO})$ & NÃO & (Amostra) & 0,15491 \\
\hline & & CICLAGEM & SIM & (Colunas) & 0,00452 \\
\hline & & COMBINAÇÃO DE FATORES & NÃO & (Interações) & 0,80370 \\
\hline
\end{tabular}


TABELA 130 - Resumo das análises de variância (ANOVA) dos ensaios de absorção de água total com a influência da mistura e dos tipos de ciclagem para 2 fatores.

\begin{tabular}{|c|c|c|c|c|c|}
\hline $\begin{array}{c}\text { Propriedade / } \\
\text { Idade de ensaio }\end{array}$ & Interação & Resumo & \multicolumn{2}{|c|}{ Influenciou? } & P-Valor \\
\hline \multirow{3}{*}{ ABS 8 acel. } & \multirow{3}{*}{$\mathrm{CO}_{2}$ e $\mathrm{H}_{2} \mathrm{O}$} & MISTURA* (CAMINHÃO) & SIM & (Amostra) & 0,00045 \\
\hline & & CICLAGEM & NÃO & (Colunas) & 0,07646 \\
\hline & & COMBINAÇÃO DE FATORES & NÃO & (Interações) & 0,05044 \\
\hline \multirow{3}{*}{ ABS 35 acel. } & \multirow{3}{*}{$\mathrm{CO}_{2}$ e $\mathrm{H}_{2} \mathrm{O}$} & MISTURA $^{*}$ (CAMINHÃO) & SIM & (Amostra) & 0,00811 \\
\hline & & CICLAGEM & NÃO & (Colunas) & 0,87545 \\
\hline & & COMBINAÇÃO DE FATORES & NÃO & (Interações) & 0,53167 \\
\hline \multirow{3}{*}{ ABS 63 acel. } & \multirow{3}{*}{$\mathrm{CO}_{2}$ e $\mathrm{H}_{2} \mathrm{O}$} & MISTURA* (CAMINHÃO) & SIM & (Amostra) & 0,00037 \\
\hline & & CICLAGEM & NÃO & (Colunas) & 0,11988 \\
\hline & & COMBINAÇÃO DE FATORES & NÃO & (Interações) & 0,32089 \\
\hline \multirow{12}{*}{ ABS 91 acel. } & \multirow{3}{*}{ OS 3 JUNTOS } & MISTURA* (CAMINHÃO) & SIM & (Amostra) & 0,00015 \\
\hline & & CICLAGEM & SIM & (Colunas) & 0,03833 \\
\hline & & COMBINAÇÃO DE FATORES & NÃO & (Interações) & 0,27354 \\
\hline & \multirow{3}{*}{$\mathrm{SEC} \mathrm{E} \mathrm{CO} 2$} & MISTURA ${ }^{*}$ (CAMINHÃO) & SIM & (Amostra) & 0,00014 \\
\hline & & CICLAGEM & NÃO & (Colunas) & 0,11312 \\
\hline & & COMBINAÇÃO DE FATORES & NÅO & (Interações) & 0,17240 \\
\hline & \multirow{3}{*}{$\mathrm{SEC} \mathrm{E} \mathrm{H}_{2} \mathrm{O}$} & MISTURA* (CAMINHÃO) & SIM & (Amostra) & 0,01067 \\
\hline & & CICLAGEM & SIM & (Colunas) & 0,02648 \\
\hline & & COMBINAÇÃO DE FATORES & NÃO & (Interações) & 0,63509 \\
\hline & \multirow{3}{*}{$\mathrm{CO}_{2}$ e $\mathrm{H}_{2} \mathrm{O}$} & MISTURA* (CAMINHÃO) & SIM & (Amostra) & 0,00703 \\
\hline & & CICLAGEM & NÃO & (Colunas) & 0,19036 \\
\hline & & COMBINAÇÃO DE FATORES & NÃO & (Interações) & 0,18914 \\
\hline \multirow{12}{*}{ ABS 203 acel. } & \multirow{3}{*}{ OS 3 JUNTOS } & MISTURA* (CAMINHÃ̃) & SIM & (Amostra) & $5,11829 \mathrm{E}-06$ \\
\hline & & CICLAGEM & SIM & (Colunas) & 0,00115 \\
\hline & & COMBINAÇÃO DE FATORES & NÃO & (Interações) & 0,33334 \\
\hline & \multirow{3}{*}{$\mathrm{SEC} \mathrm{E} \mathrm{CO} 2$} & MISTURA* (CAMINHÃO) & SIM & (Amostra) & 0,00312 \\
\hline & & CICLAGEM & SIM & (Colunas) & 0,00073 \\
\hline & & COMBINAÇÃO DE FATORES & NÃO & (Interações) & 0,84948 \\
\hline & \multirow{3}{*}{$\mathrm{SEC} \mathrm{E} \mathrm{H}_{2} \mathrm{O}$} & MISTURA $^{*}$ (CAMINHÃO) & SIM & (Amostra) & 0,00024 \\
\hline & & CICLAGEM & SIM & (Colunas) & 0,03403 \\
\hline & & COMBINAÇÃO DE FATORES & NÃO & (Interações) & 0,18453 \\
\hline & \multirow{3}{*}{$\mathrm{CO}_{2}$ e $\mathrm{H}_{2} \mathrm{O}$} & MISTURA* (CAMINHÃO) & SIM & (Amostra) & 0,00013 \\
\hline & & CICLAGEM & SIM & (Colunas) & 0,05952 \\
\hline & & \begin{tabular}{|l} 
COMBINAÇÃO DE FATORES \\
\end{tabular} & NÃO & (Interaçôes) & 0,26621 \\
\hline
\end{tabular}


TABELA 131 - Resumo das análises de variância (ANOVA) dos ensaios de índice de vazios com a influência da mistura dos tipos de ciclagem para 2 fatores.

\begin{tabular}{|c|c|c|c|c|c|}
\hline \begin{tabular}{|c|} 
Propriedade I \\
Idade de ensaio
\end{tabular} & Interação & Resumo & \multicolumn{2}{|c|}{ Influenciou? } & P-Valor \\
\hline \multirow{3}{*}{ IV 8 acel. } & \multirow{3}{*}{$\mathrm{CO}_{2}$ e $\mathrm{H}_{2} \mathrm{O}$} & MISTURA* (CAMINHÃ̃O) & SIM & (Amostra) & 0,00068 \\
\hline & & CICLAGEM & NÃO & (Colunas) & 0,06843 \\
\hline & & COMBINAÇÃO DE FATORES & NẪO & (Interações) & 0,05311 \\
\hline \multirow{3}{*}{ IV 35 acel. } & \multirow{3}{*}{$\mathrm{CO}_{2}$ e $\mathrm{H}_{2} \mathrm{O}$} & MISTURA* (CAMINHÃO) & SIM & (Amostra) & 0,00561 \\
\hline & & CICLAGEM & NÃO & (Colunas) & 0,81745 \\
\hline & & COMBINAÇÃ̃O DE FATORES & NÃO & (Interações) & 0,34571 \\
\hline \multirow{3}{*}{ IV 63 acel. } & \multirow{3}{*}{$\mathrm{CO}_{2}$ e $\mathrm{H}_{2} \mathrm{O}$} & MISTURA $^{*}$ (CAMINHÃO) & SIM & (Amostra) & 0,00176 \\
\hline & & CICLAGEM & NẪO & (Colunas) & 0,12085 \\
\hline & & COMBINAÇÃO DE FATORES & NẪO & (Interações) & 0,33587 \\
\hline \multirow{12}{*}{ IV 91 acel. } & \multirow{3}{*}{ OS 3 JUNTOS } & MISTURA ${ }^{*}$ (CAMINHẪ) & SIM & (Amostra) & 0,00030 \\
\hline & & CICLAGEM & SIM & (Colunas) & 0,02374 \\
\hline & & COMBINAÇÃOO DE FATORES & NẪO & (Interações) & 0,29826 \\
\hline & \multirow{3}{*}{$\mathrm{SEC} \mathrm{E} \mathrm{CO} 2$} & MISTURA* ${ }^{*}$ (CAMINHÃO) & SIM & (Amostra) & 0,00018 \\
\hline & & CICLAGEM & NÃO & (Colunas) & 0,06362 \\
\hline & & COMBINAÇÃO DE FATORES & NÂOO & (Interações) & 0,13623 \\
\hline & \multirow{3}{*}{$\mathrm{SEC} \mathrm{E} \mathrm{H}_{2} \mathrm{O}$} & MISTURA* (CAMINHÃO) & SIM & (Amostra) & 0,01842 \\
\hline & & CICLAGEM & SIM & (Colunas) & 0,01642 \\
\hline & & COMBINAÇÃO DE FATORES & NÃO & (Interações) & 0,73358 \\
\hline & \multirow{3}{*}{$\mathrm{CO}_{2}$ e $\mathrm{H}_{2} \mathrm{O}$} & MISTURA* (CAMINHÃO) & SIM & (Amostra) & 0,01130 \\
\hline & & MESMA CICLAGEM & NÃO & (Colunas) & 0,19208 \\
\hline & & COMBINAÇÃOO DE FATORES & NÃO & (Interações) & 0,21276 \\
\hline \multirow{12}{*}{ IV 203 acel. } & \multirow{3}{*}{ OS 3 JUNTOS } & MISTURA* (CAMINHÃO) & SIM & (Amostra) & $1,24188 \mathrm{E}-06$ \\
\hline & & CICLAGEM & SIM & (Colunas) & 0,00078 \\
\hline & & COMBINAÇÃOO DE FATORES & NÃO & (Interações) & 0,26025 \\
\hline & \multirow{3}{*}{$\mathrm{SEC} \mathrm{E} \mathrm{CO} 2$} & MISTURA ${ }^{*}$ (CAMINHÃO) & SIM & (Amostra) & 0,00119 \\
\hline & & CICLAGEM & SIM & (Colunas) & 0,00051 \\
\hline & & COMBINAÇÃOO DE FATORES & NẪO & (Interações) & 0,80248 \\
\hline & \multirow{3}{*}{$\mathrm{SEC} \mathrm{E} \mathrm{H}_{2} \mathrm{O}$} & MISTURA* (CAMINHÃ̃) & SIM & (Amostra) & 0,00014 \\
\hline & & CICLAGEM & SIM & (Colunas) & 0,02541 \\
\hline & & COMBINAÇÃOO DE FATORES & NÄO & (Interações) & 0,14593 \\
\hline & \multirow{3}{*}{$\mathrm{CO}_{2}$ e $\mathrm{H}_{2} \mathrm{O}$} & MISTURA* (CAMINHÃO) & SIM & (Amostra) & $3,52105 \mathrm{E}-05$ \\
\hline & & CICLAGEM & NÂO & (Colunas) & 0,06238 \\
\hline & & COMBINAÇÃOO DE FATORES & NẪO & (Interações) & 0,23156 \\
\hline
\end{tabular}




\section{APÊNDICE E - TUTORIAL DOS SOFTWARES UTILIZADOS PARA MEDIDAS DE CARBONATAÇÃO}

\section{Tutorial Leica Qwin}

1. Mudar o tamanho do arquivo da imagem, caso as fotos não abram no programa devido à resolução muito grande:

a) acessar o Adobe;

b) na opção "image size", diminuir para $50 \%$ o primeiro e o segundo valor;

2. Abrir no programa (Leica Qwin) o arquivo convertido;

3. Para realizar a análise de imagem:

a) Para detectar as partes da análise, seguir para: /image/detect (detecta as partes de interesse na imagem: escolher fundo, depois centro);

b) Repetir esses passos para fundo e depois para o centro. Comece pelo fundo e quando tiver chegado ao último passo, voltar e concluir o centro.

Observação importante: Neste programa, é preciso ter cautela com o sistema binário, que são os locais onde ficam salvos os trabalhos a fazer. São cerca de 100 binários e se salvar em cima perde o anterior. Escolher então binário 1 no canto direito da janela detect (para o fundo), e binário 10 (para o centro);

c) Em /image/detect selecionar o local (com um pequeno retângulo para o centro ou um grande retângulo para o fundo - neste selecionar apenas a área verde). Verificar se obteve um bom preenchimento, caso contrário mexer no histograma das três cores até conseguir melhorar o preenchimento. $O$ fundo fica perfeito nesta etapa, o centro não fica bom, o ajuste deve ser manual;

d) Agora tratar a imagem com as ferramentas do Binary, que se encontram na aba. Edit é a ferramenta manual. Amend é a automática e identify ajuda a "limpar", logic é a que junta, invert separa os binários.

Observação: $O$ diferencial deste programa é a tecla $\mathrm{Ctrl}+\mathrm{B}$ e $\mathrm{Ctrl}+\mathrm{W}$, que mostram as máscaras do trabalho e a original. Note que se pressionar $\mathrm{Ctrl}+\mathrm{B}$ e não soltar, ou apertar $B$ rapidamente verá o seu trabalho ao mesmo tempo em que o original, isto ajuda muito a análise. Todas as ferramentas do Binary devem ser colocadas de entrada no binário que está trabalhando (binário 1).

e) No fundo um simples Edit (onde tem a sombra da foto), com a ferramenta draw é suficiente, habilite essa opção e salve no binario3. OBS: Casa seu detect não tenha sido bem feito para o fundo, utilize o ferramenta identify, entrada binário 1 saída binário 2 e habilite close, escolha o numero 10 ou mais caso não feche 0 figura de primeira;

f) Para o centro, na entrada binário 10, ir em identify, habilitar close >10 do modo que achar melhor, salvar em 11, na ferramenta Edit, utilizar draw ou eraser para terminar o contorno manual;

4. Obtido o fundo e centro, utilizar as operações lógicas do programa para selecionar o corpo-de-prova inteiro:

a) Edit/ logic: Escolher entrada 3 para A e saída 20, escolher INVERT_A.

5. Para isso, assim que acabar a operação logic, ir em Measure/measurefield, para medir a área.

6. Acabadas todas as medições, exportar os resultados:

a) Salvar a imagem do trabalho realizado pelo PrintScreen;

b) Salvar a planilha das áreas em: arquivo.dat ou copiar e colar direto no Excel. 


\section{Tutorial Imagej}

1. Baixar o software gratuitamente no site: http://rsbweb.nih.gov/ij/download.html;

2. Verificar a arquivo ideal para seu computador;

3. Pedir para instalar o arquivo e escolher o diretório;

4. Para realizar a análise de imagem:

a) Abrir o programa ImageJ;

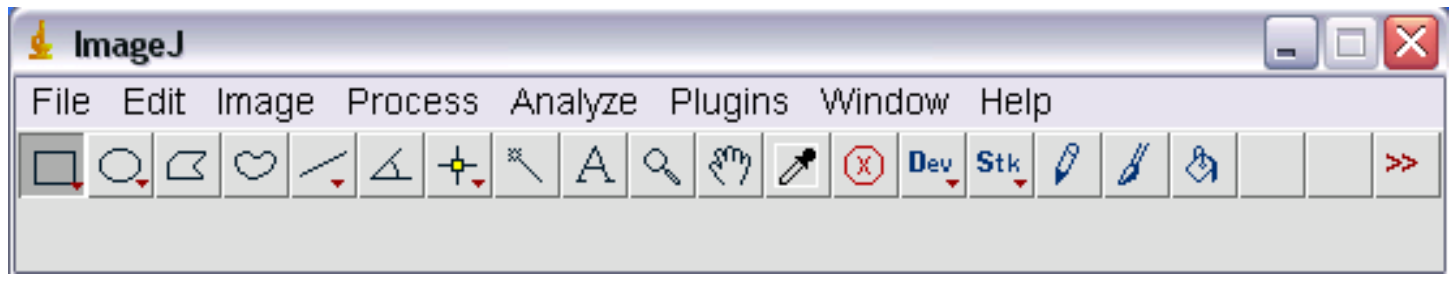

b) File/open/procurar diretório com a imagem a ser analisada. Abrir a imagem;

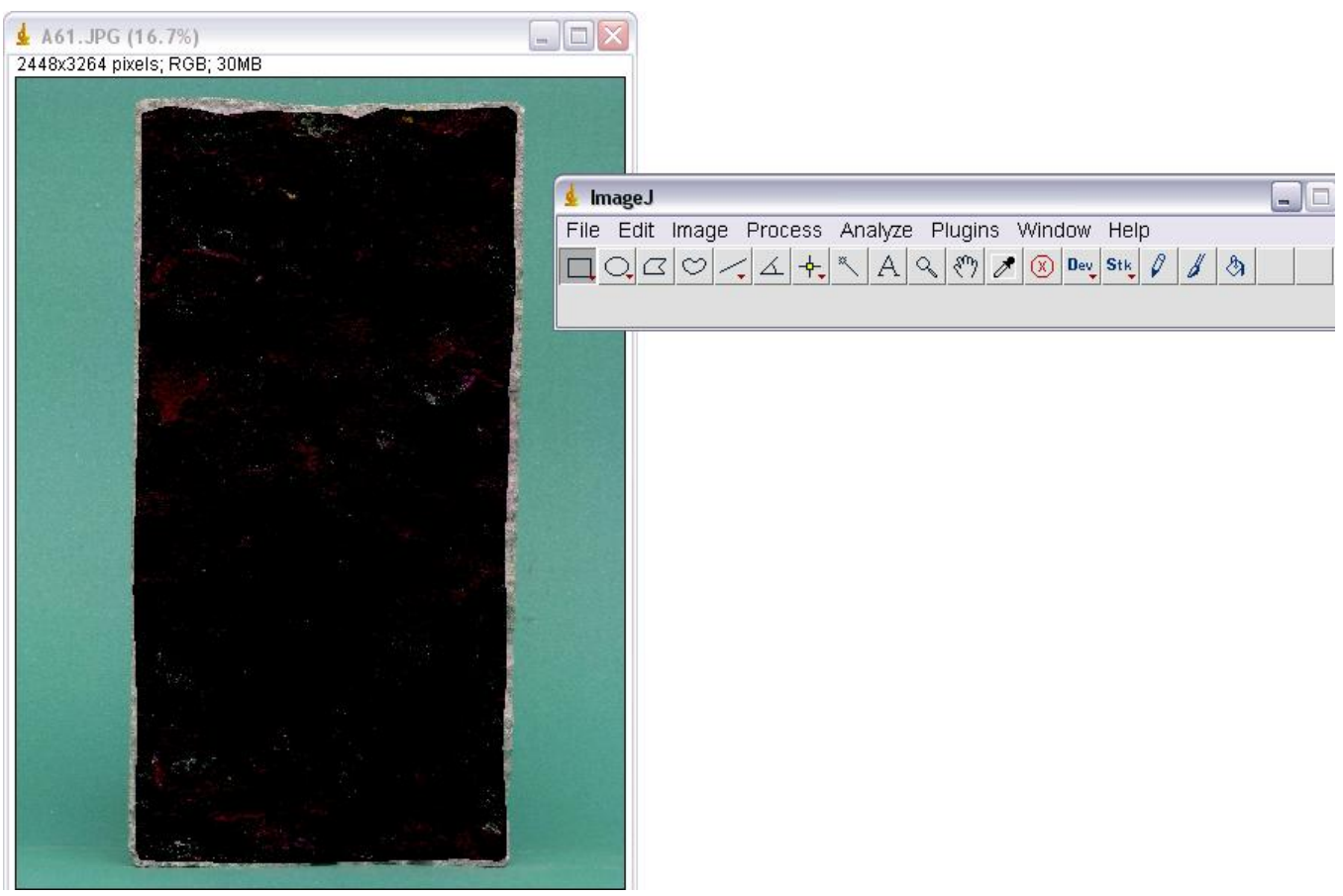

c) Agora ir para o menu Analyze /Set Measurements... Escolher todas as opções que gostaria de medir. (Área e perímetro);

d) Começar a medir a imagem, pela borda externa e depois a interna;

e) Repetir a rotina em todas as análises, para facilitar exportar depois ao Excel;

f) Há duas ferramentas para a medição, uma mais difícil $\bigcirc$ é a que risca e quando solta a tecla esquerda do mouse, a figura fecha. A outra forma de medir é por aproximação por um polígono; $\square$ é mais segura e fácil de fazer. Cada clique no mouse cria um vértice do polígono, quanto mais fizer melhor. Tomar cuidado para não clicar duas vezes no mesmo lugar pois então fechará o polígono. Caso erre um ponto com essa ferramenta você poderá corrigir o ponto quando acabar, mas cuidado para não clicar fora do ponto casa for arrumar, pois perderá o contorno.

g) Pedir ao programa medir o que fez, assim que acabar o primeiro contorno, através do comando Ctrl+M ou Analyze/Measure. Se fizer corretamente aparecerá: 


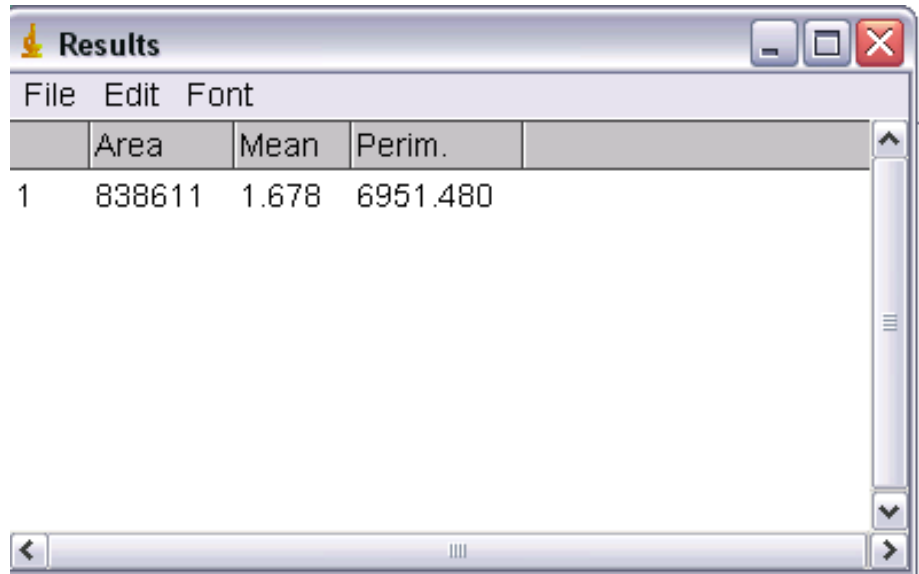

h) Repetir o processo para o contorno externo, assim saberá que o número ímpar é o contorno externo e o par o interno.

5. Para salvar a imagem que fez (o programa não salva diretamente):

a) Mudar o brilho interno ao contorno e salvar a imagem assim, para demonstrar a qualidade da medição;

6. Para isso, assim que acabar o contorno, apertar $\mathrm{Ctrl}+\mathrm{M}$ e abrir Image/adjust /brightness/Constrast e aumentar a primeiro ajuste ao máximo. Vá em File/Save (da janela ImageJ).

7. Acabadas todas as medições, exportar as resultados:

a) File/Save As (da janelaResults);

b) O programa já irá exportar para .xls; Coloque apenas o nome.

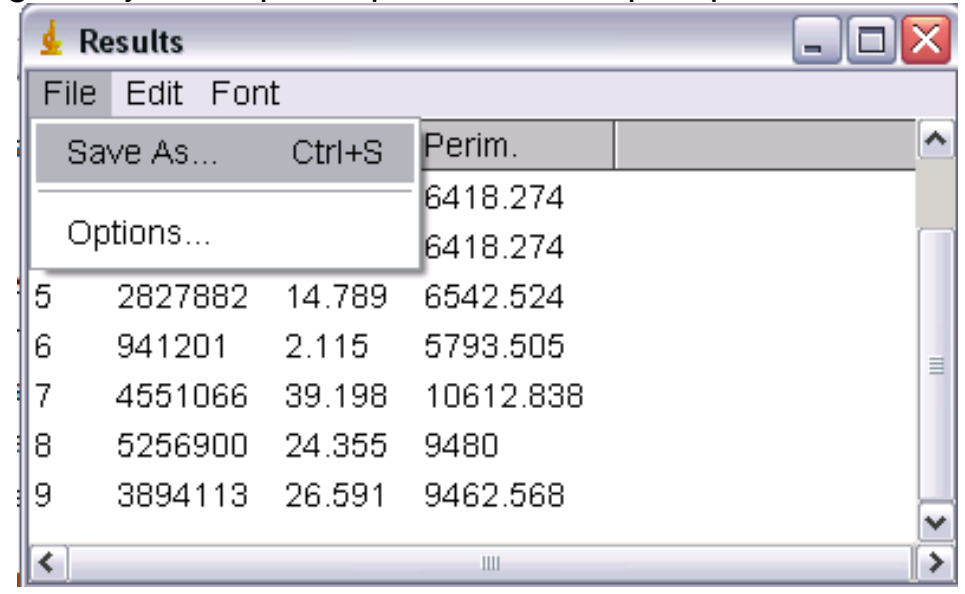


APÊNDICE F - MATRIZ DE CORRELAÇÕES 


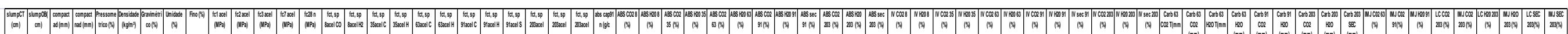

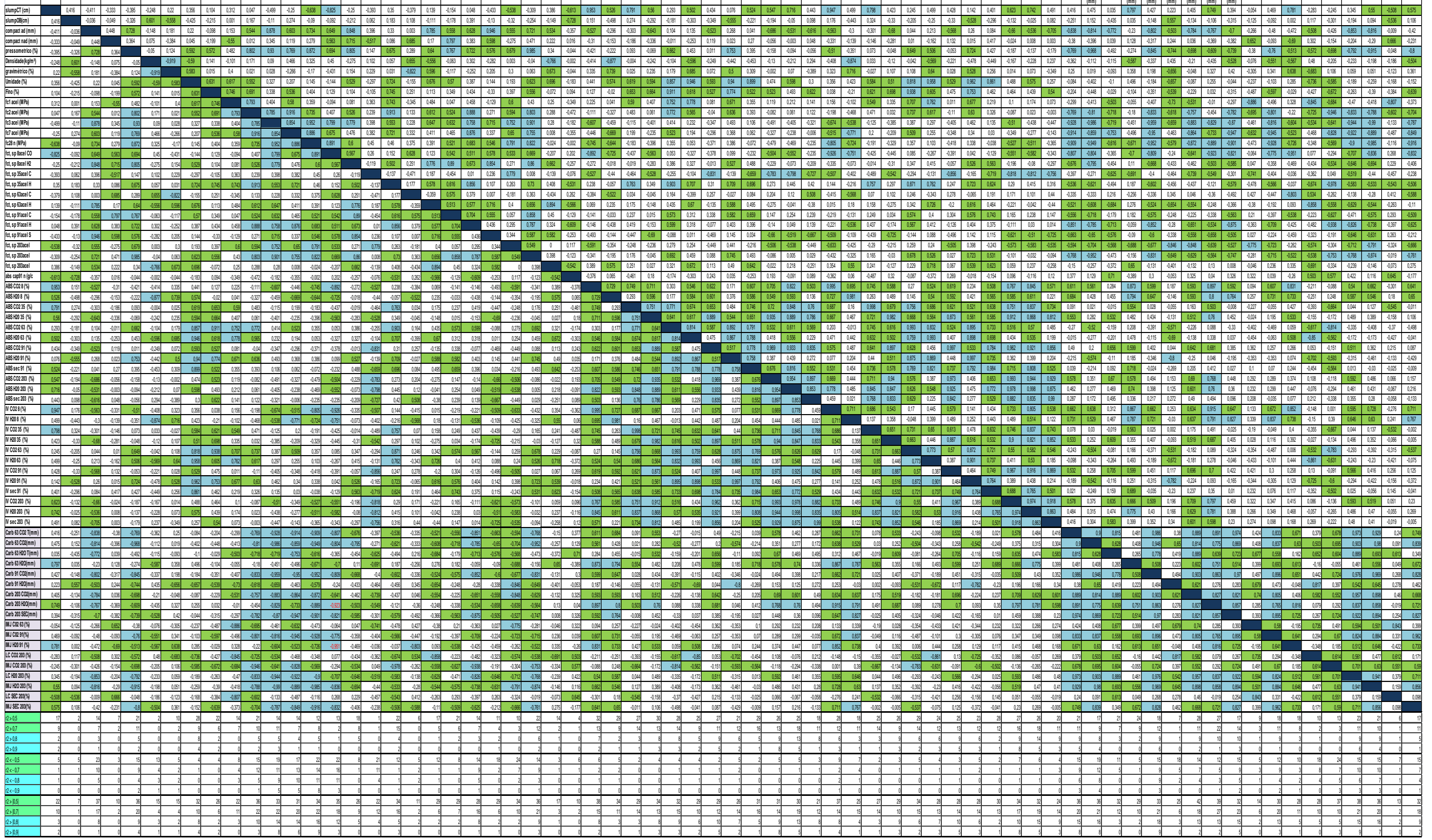

